\title{
Audit Committee Effectiveness in Victorian Local Government
}

\author{
Aquinas John Purcell \\ Bachelor of Business (Swinburne University) \\ Bachelor of Economics (Monash University) \\ Graduate Certificate in Fraud Investigation (La Trobe University) \\ Master of Business Administration (La Trobe University)
}

\author{
School of Law \\ Faculty of Business and Law \\ Victoria University
}

Submitted in fulfillment of the requirements of the degree of Doctor of Philosophy

November 2012 


\begin{abstract}
The tenets of local government are based on strong financial probity, adherence to independence principles to avoid conflict of interest and conformance to ethical principles.

This thesis addresses the issue of possible corruption and misconduct in local government, with particular reference to the role of the audit committee. The primary research question is: 'Do audit committees in Victorian local government function effectively?' The secondary research question is: 'Do the investigations into local government maladministration and malfeasance enhance governance and the audit committee's effectiveness?' Qualitative and quantitative data were collected to develop a model of audit committee effectiveness through a pilot survey, research questionnaire and interviews.
\end{abstract}

The research used a questionnaire based on a 'factorial design' to measure the perceptions, attitudes and perspectives of mayors, chief executives and chairs of the audit committee. The results were compared with perceptions of committee members of the Local Government and Shires Association of New South Wales and board members of the Municipal Association of Victoria as the representative bodies of local government in New South Wales and Victoria respectively.

The research established support from mayors, chief executives and chairs of audit committees for the primary research proposition, but no support for the secondary research proposition. There was a similarity of views in relation to: (1) inputs of an audit committee (charter, skills, activities, communications and induction and training); (2) the behavioural nuances of the rigour of: debate, trust and effective communications; and (3) the relationships with councillors and management. It was found that an audit committee's effectiveness was perceived to be limited by: (1) the ability to attract and retain skilled independent members; (2) the variability of expertise and the skills of the councillor audit committee members; (3) the level of continuing professional development for the councillor audit committee members; (4) the 'gaming' behaviours associated with manipulation of agendas, control of information and the omission of critical data from the audit committee; (5) power games associated with the appointment of councillor members to the audit committee; and (6) domination of the audit committee by one or two members or management.

The suggested way forward is to have an audit committee in local government which can provide the effective oversight of organisational governance processes with a specific focus on behavioural outcomes. 


\section{Student Declaration}

Student Number:

3793755

Family Name:

Purcell

Given Names:

Aquinas John

Principal Supervisor:

Emeritus Professor Ronald Francis

School of Law

Faculty of Business and Law, Victoria University

Melbourne, Australia

Second Supervisor:

Professor Colin Clark

Executive Dean

Faculty of Business and Law, Victoria University

Melbourne, Australia

Date:

Original Submission

4 August 2011

Revised

31 July 2012

Accepted

12 December 2012

This thesis was submitted in fulfillment of the requirements for the degree of Doctor of Philosophy at Victoria University, Melbourne, Australia.

\section{Doctor of Philosophy Declaration}

'I, Aquinas John Purcell, declare that the $\mathrm{PhD}$ thesis entitled, Audit Committee Effectiveness in Victorian Local Government, is no more than 100,000 words in length including quotes and exclusive of tables, figures, appendices, bibliography, references and footnotes.

This thesis contains no material that has been submitted previously, in whole or in part, for the award of any other academic degree or diploma. Except where otherwise indicated, this thesis is my own work'.

Signature

Original Submission

Revised

4 August 2011

Accepted

31July 2012

12 December 2012 


\section{Acknowledgements}

I was motivated to undertake this research by $\mathrm{Mr}$ John Bennie, chief executive officer, Greater Dandenong Council. From mid-2001 to late 2006, when John was chief executive officer, Manningham City Council, I was its internal auditor from late 2003 to mid-2007. John advocated for: (1) high standards of public sector integrity; (2) rigorous governance processes in local government; and (3) a strong and active audit committee. He was the catalyst for the reinvigoration of the audit committee and the internal audit processes at Manningham City Council and stands as a beacon for governance, probity and propriety in local government in Victoria.

My interest in the research would not have continued without the support of my Principal Supervisor, Emeritus Professor Ronald Francis, School of Law and my Co-Supervisor, Professor Colin Clark, Executive Dean, Faculty of Business and Law, Victoria University. Dr Andrea Diamond, former chief executive officer, Yarra City Council and current chief executive officer, Monash City Council and Dr Despina Whitefield, Senior Lecturer, School of Accounting and Finance, were appointed by Victoria University as my industry and research mentors. My supervisors were demanding, but never discouraging and my research has been further shaped by their theoretical contributions and humour. I cannot imagine a better supervisory team.

Special thanks are reserved for the mayors, councillors, chief executives and chairs of audit committees who willingly participated in the research and to Mr Geoff Rankin, former Chief Executive, CPA Australia who provided access to the members of CPA Australia with public sector audit committee experience. This revised thesis also acknowledges Mr Terry Richards, who proof read the original two volumes in July 2011 and Dr Diane Brown, who copy edited the revised thesis in June 2012.

This thesis is dedicated to: (1) my spouse, Ms Charlotte Chidell and my children, Elizabeth and Matthew; (2) Mr Gary Galvan; (3) Dr Colin and Mrs Ruth McKenzie; (4) Dr Duncan McKenzie; (5) Dr Ronald and Mrs Penny McKeran; (6) the late Dr Arthur Plant; and (7) the late Warrant Officer (Class 2), 'Jack’ Sheather (Royal Australian Infantry). These people have been influential mentors throughout my personal and professional life and I am grateful for their input into my intellectual and professional development. 


\section{List of Publications}

Purcell, A. J. 2012, 'Corruption and misconduct in local government in Australia: What we know, but have trouble understanding and explaining, IIA Australia Journal, Issue 01, March, pp. 35-40.

Purcell, A. J. (forthcoming), 'A Behavioural Perspective on Audit Committees in Victorian Local Government’ IIA Australia Journal. 


\section{TABLE OF CONTENTS}

Abstract

$\begin{array}{lll}\text { Student declaration } & \text { II }\end{array}$

Acknowledgements

$\begin{array}{ll}\text { List of publications } & \text { IV }\end{array}$

Table of contents $\quad$ V

List of cases $\quad$ XI

List of statutes $\quad$ XII

$\begin{array}{ll}\text { List of regulations } & \text { XIII }\end{array}$

$\begin{array}{ll}\text { List of figures } & \text { XIV }\end{array}$

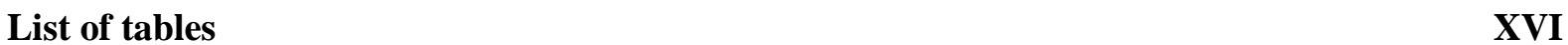

$\begin{array}{ll}\text { Abbreviations and conventions } & \text { XVIII }\end{array}$

1. CHAPTER ONE: INTRODUCTION 1

$\begin{array}{lll}\text { 1.1. Objectives } & 1\end{array}$

1.2. Local government in Australia $\quad 1$

1.2.1 Local government in Victoria 1

1.2.2 Audit committees in Victorian local government 2

1.3. Accountability 3

1.4. The research 3

1.5 Theoretical basis and constructs of the research 4

$\begin{array}{lll}\text { 1.6. } & \text { Sub-research questions } & 6\end{array}$

1.7 Assumptions and definitions associated with the research 9

$\begin{array}{lll}\text { 1.7.1 Integrity and honesty } & 10\end{array}$

$\begin{array}{ll}\text { 1.7.2 Effective governance } & 10\end{array}$

1.7.3 The dark side of leadership 10

1.7.4 Investigations into local government administration 10

1.7.5 Audit guidelines for local government 11

$1.8 \quad$ Limitations 11

1.8.1 No previous research into Victorian local government audit committees 11

1.8.2 Research bias 12 
2. CHAPTER TWO: GOVERNANCE

$2.1 \quad$ Corporate governance $\quad 16$

2.1.1. Context of corporate governance 16

$\begin{array}{ll}\text { 2.1.2 Historical perspective of governance literature } & 22\end{array}$

$\begin{array}{ll}2.1 .2 & \text { Corporate governance practice in Australia } \\ \end{array}$

$2.2 \quad$ Governance theories 30

2.2.1 Agency 31

$\begin{array}{lll}2.2 .2 & \text { Stewardship theory } & 34\end{array}$

2.2.3 Resource dependency theory 35

2.2.4 Behavioural theory 36

2.2.5 Other theories 37

$\begin{array}{lll}\text { 2.2.5.1 Decision making } & 37\end{array}$

$\begin{array}{lll}\text { 2.2.5.2 } & \text { Power and market control } & 37\end{array}$

2.3 Public sector governance $\quad 39$

2.3.1 Principles of public sector governance 39

2.3.2 Public sector governance in the Commonwealth of Australia 43

2.3.3 Public sector governance practice in Victoria, Australia 44

2.3.4 Other public sector organisations that support public sector governance 46

$2.4 \quad$ Governance in Victorian local government 47

$\begin{array}{lll}2.5 & \text { Summary } & 57\end{array}$

$3 \quad$ CHAPTER THREE: AUDIT COMMITTEES

3.1 Background to effectiveness of audit committees 58

3.2. Effectiveness of audit committees $\quad 62$

3.2.1 Review of the literature $\quad 62$

$\begin{array}{lll}3.2 .2 & \text { Context of the audit committee literature } & 68\end{array}$

$\begin{array}{lll}\text { 3.2.3 } & \text { Role of the audit committee } & 72\end{array}$

$\begin{array}{lll}3.2 .4 & \text { Recent audit committee literature } & 73\end{array}$

$\begin{array}{lll}3.2 .5 & \text { Audit committee literature in Australia } & 75\end{array}$

3.3. Application of governance theories to audit committees $\quad 76$

$\begin{array}{lll}\text { 3.3.1 Institutional theory } & 76\end{array}$

$\begin{array}{lll}3.3 .2 & \text { Resource dependency theory } & 79\end{array}$

$\begin{array}{lll}\text { 3.3.3 Managerial hegemony theory } & 80\end{array}$

$\begin{array}{lll}\text { 3.3.4 Behavioural theory } & 81\end{array}$

$\begin{array}{lll}3.4 & \text { Attributes of audit committee effectiveness } & \mathbf{8 3}\end{array}$

$\begin{array}{lll}3.4 .1 & \text { Composition } & 84\end{array}$

$\begin{array}{lll}3.4 .2 & \text { Authority } & 85\end{array}$

3.4.3 Resources 86

$\begin{array}{lll}3.4 .4 & \text { Diligence } & 87\end{array}$

\begin{tabular}{llr}
3.5 & Public sector audit committees & 88 \\
\hline
\end{tabular} 
$\begin{array}{lll}3.7 & \text { Measures of audit committee effectiveness } & 98\end{array}$

$\begin{array}{lll}3.8 & \text { Relevance of the literature } & 100\end{array}$

$\begin{array}{lll}3.9 & \text { Summary } & 102\end{array}$

4 CHAPTER FOUR: INQUIRIES INTO LOCAL GOVERNMENT 103

$\begin{array}{lll}4.1 & \text { Background } & 103\end{array}$

$\begin{array}{lll}4.2 & \text { Context of corruption and misconduct } & 106\end{array}$

$\begin{array}{lll}4.3 & \text { Literature review } & 116\end{array}$

$\begin{array}{lll}\text { 4.3.1 Corruption and politics } & 116\end{array}$

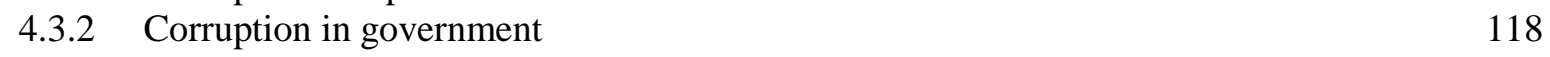

$\begin{array}{lll}\text { 4.3.3 Professional misconduct } & 119\end{array}$

4.3.4 Professional misconduct and professional ethics 124

\begin{tabular}{ll} 
4.3.5 & Bias in decision making \\
\hline
\end{tabular}

$\begin{array}{lll}\text { 4.3.6 Management of gifts } & 128\end{array}$

$\begin{array}{lll}4.4 & \text { Local government corruption and misconduct } & 129\end{array}$

4.4.1 Council governance and maladministration 130

4.4.2 Financial mismanagement 134

4.4.3 Corruption and misconduct by councillors and staff 134

$\begin{array}{lll}\text { 4.4.3.1 Victoria } & 134\end{array}$

4.4.3.2 New South Wales, Queensland and Western Australia 135

4.4.3.3 United Kingdom 138

$\begin{array}{lll}\text { 4.4.4 Breach of statutory powers } & 139\end{array}$

4.5 Some insights into unethical behaviours $\quad 142$

$\begin{array}{lll}\text { 4.6 A way forward? } & 143\end{array}$

$\begin{array}{lll}4.7 & \text { Summary } & 146\end{array}$

5 CHAPTER FIVE: METHODOLOGY 148

$\begin{array}{lll}\text { 5.1. Introduction } & 148\end{array}$

$\begin{array}{lll}\text { 5.1.1 Rationale for research } & 149\end{array}$

$\begin{array}{ll}\text { 5.1.2 Overview of research methodology } & 149\end{array}$

5.2. Methodology 151

$\begin{array}{lll}5.2 .1 & \text { Paradigms } & 151\end{array}$

$\begin{array}{lll}\text { 5.2.2 Justification of the paradigm } & 154\end{array}$

$\begin{array}{lll}5.2 .3 & \text { Phenomenology } & 155\end{array}$

$\begin{array}{lll}\text { 5.2.4 Naturalistic inquiry } & 156\end{array}$

$\begin{array}{lll}5.2 .5 & \text { Grounded theory } & 157\end{array}$

5.2.6 Rationale for selection of grounded theory 159

5.3. Methods $\quad 159$

5.3.1 Mixed methods $\quad 160$

5.3.2 Justification of the method 161

$\begin{array}{lll}\text { 5.3.3 } & \text { Research design } & 164\end{array}$

$\begin{array}{lll}\text { 5.3.4 Quantitative approach } & 166\end{array}$ 
$\begin{array}{lll}\text { 5.3.5 } & \text { Qualitative approach } & 167\end{array}$

$\begin{array}{lll}\text { 5.3.6 } & \text { Factorial design } & 167\end{array}$

$\begin{array}{lll}5.4 & \text { Pilot study } & 170\end{array}$

5.4.1 Response rate from the pilot survey 172

5.5 Confirmation of the research instrument - Questionnaire 174

5.6 Finalisation of the research instrument - Questionnaire 176

$\begin{array}{lll}5.7 & \text { Summary of results } & 178\end{array}$

$\begin{array}{lll}\text { 5.7.1 Results from the research } & 178\end{array}$

5.7.2 Early and late respondents 183

$\begin{array}{ll}\text { 5.7.3 Analysis of variances } & 186\end{array}$

$\begin{array}{lll}5.8 & \text { Summary } & 193\end{array}$

6. CHAPTER 6: RESEARCH FINDINGS 195

$\begin{array}{lll}\text { 6.1 Response rates from quantitative research } & 195\end{array}$

$\begin{array}{lll}\text { 6.2 } & \text { Acceptability of response rate } & 197\end{array}$

6.3 Demographic and firmographic analysis 199

6.3.1 Demographic analysis of respondents 199

6.3.2 Firmographic analysis of respondents 201

6.3.3 Differences between responses of metropolitan and rural councils 203

6.4 Detailed observations from quantitative research 203

6.4.1 Results - Establishment of the audit committee 203

6.4.2 Results - Forming an audit committee 207

6.4.2 Results - Knowledge and expertise of the audit committee 210

6.4.4 Results - Induction and training for the audit committee 213

6.4.5 Results - Managing the audit committee 216

6.4.6 Results - Risk assessment and financial reporting 221

$\begin{array}{lll}\text { 6.5 } & \text { Results from qualitative research } & 226\end{array}$

6.6 Detailed observations from qualitative research 226

6.6.1 Clarification of issues 226

$\begin{array}{ll}\text { 6.6.1.2 Induction and training } & 227\end{array}$

6.6.1.3 Managing the audit committee 229

6.6.1.4 Oversight of management of corruption and misconduct allegations 230

6.6.1.5 Risk assessment and financial reporting 231

6.6.1.6 Contributing reasons for response rates 233

6.6.2 Impact of ethical statements on audit committee outcomes 234

6.6.3 Influences on the audit committee 236

6.6.4 Inputs and outcomes for audit committees 237

$\begin{array}{lll}6.7 & \text { Summary } & 243\end{array}$

7 CHAPTER SEVEN: SUMMARY AND CONCLUSIONS 244

$\begin{array}{lll}7.1 & \text { Summary of findings } & 244\end{array}$ 
7.1.1 Quantitative research 244

7.1.2 Qualitative research 247

$\begin{array}{ll}\text { 7.1.3 Implications for audit committees } & 249\end{array}$

$\begin{array}{lll}7.2 & \text { How research questions are answered } & 252\end{array}$

$\begin{array}{lll}\text { 7.3 } & \text { Limitations of the research } & 254\end{array}$

7.4 What do these answers mean? 256

7.5 How does this relate to theory? 259

\begin{tabular}{ll}
7.6 & Suggestions for further research \\
\hline
\end{tabular}

$\begin{array}{lll}7.7 & \text { Conclusions and a way forward } & 270\end{array}$

$\begin{array}{ll}\text { REFERENCES } & 273\end{array}$

$\begin{array}{lr}\text { APPENDICES } & 304\end{array}$

APPENDIX 1 SUMMARY OF INVESTIGATION REPORTS INTO LOCAL GOVERNMENT

Appendix 1.1 Local government investigations, Victoria 304

Appendix 1.3 Local government investigations, New Zealand and the United Kingdom 316

$\begin{array}{ll}\text { APPENDIX } 2 \text { PILOT SURVEY } & 321\end{array}$

Appendix 3 Pilot survey response - Mr Wayne Cameron 326

APPENDIX 4 OBSERVATIONS FROM THE PILOT SURVEY 329

Appendix 4.1 Overview of local government audit committees 329

$\begin{array}{lll}\text { Appendix 4.2 } & \text { Mayors } & 332\end{array}$

$\begin{array}{lll}\text { Appendix } 4.3 \text { Councillors } & 333\end{array}$

Appendix 4.4 Chief executives 333

Appendix 4.5 Local government independent audit committee members 335

$\begin{array}{lll}\text { Appendix 4.6 External auditors } & 336\end{array}$

$\begin{array}{lll}\text { Appendix } 4.7 & \text { Other suggestions } & 338\end{array}$

APPENDIX 5 SURVEY OF AUDIT COMMITTEES - LOCAL GOVERNMENT

COUNCILS/SHIRES

APPENDIX 6 QUANTITATIVE RESULTS 353

$\begin{array}{lll}\text { Appendix 6.1 Total responses } & 353\end{array}$ 
Appendix 6.3 Responses - Local Government and Shires Association of New South Wales 355

Appendix 6.4 Responses - Mayors, Victorian Local Government

Appendix 6.5 Responses - Chief Executives, Victorian Local Government

Appendix 6.6 Responses - Chairs Audit Committees, Victorian Local Government

Appendix 6.7 Rankings of data from the Kruskal-Wallis Rank Test 


\section{LIST OF CASES}

\section{$\underline{\text { High Court of Australia }}$}

Brodie v Singleton Shire Council [2001] HCA 29

Giorgianni v R [1985] HCA 29

Ostrowski v Palmer [2004] HCA 30

Walden $v$ Hensler [1987] HCA 54

\section{Federal Court of Australia}

Australian Securities and Investments Commission v Healey [2011] FCA 717

\section{Supreme Court of New South Wales, Court of Appeal}

Daniels v Anderson (1995) 16 ACSR 607

Daniels v Anderson (1992) 7 ACSR 759

\section{Supreme Court of Victoria}

Burch v Shire of Yarra Ranges and Anor [2004] VSC 437

Bycon Pty Ltd v Moira Shire Council [1998] VSC 25

Winky Pop Pty Ltd \& Anor v Hobsons Bay City Council [2007] VSC 468

\section{United Kingdom}

Donoghue v Stevenson [1932] AC 562

Re City Equitable Fire Insurance Co Ltd [1925] Ch 407 


\section{LIST OF STATUTES}

\section{Commonwealth of Australia}

Australian Postal Corporation Act (1989)

Commonwealth Authorities and Companies Act (1997)

Corporations Act (2001)

Financial Management and Accountability Act (1997)

Local Government (Financial Assistance) Act (1995)

Trade Practices Act (1974)

Victoria Grants Commission Act (1976)

$\underline{\text { New South Wales, Australia }}$

Aboriginal Land Rights Act (1983)

Independent Commission Against Corruption Act (1988)

Local Government Act (1993)

Public Finance and Audit Act (1983)

Surveillance Devices Act (2007)

\section{Victoria, Australia}

Associations Incorporation Act (1981)

Audit Act (1994)

Building Act (1993)

City of Melbourne Act (2001)

Crimes Act (1958)

Financial Management Act (1994)

Freedom of Information Act (1982)

Local Government Amendment (Councillor Conduct and Other Matters) Act (2008)

Local Government Act (1989)

Local Government (Amendment) Act (1996)

Local Government (Further Amendments) Act (1996)

Local Government (Financial Assistance) Act (1995)

Monetary Units Act (2004)

Municipal Association of Victoria Act (1907)

Municipal Institutions Act (1854)

Ombudsman Act (1973)

Planning and Environment Act (1987)

Public Administration Act (2004)

Public Records Act (1973)

Victorian Constitution Act (1975)

Victoria Grants Commission Act (1976)

Whistleblowers Protection Act (2001)

\section{United States of America}

Sarbanes-Oxley Act (2002) 


\section{LIST OF REGULATIONS}

\section{$\underline{\text { Victoria, Australia }}$}

Audit (Public Bodies) Regulations (2005)

Financial Management (Amendment) Regulations (2006)

Financial Management Regulations (2004) 


\section{LIST OF FIGURES}

\section{Chapter 1}

Figure 1.1

Figure 1.2

Figure 1.3

\section{Chapter 2}

Figure 2.1

Figure 2.2

Figure 2.3

Figure 2.4

Figure 2.5

\section{Chapter 3}

Figure 3.1

Figure 3.2

Figure 3.3

Figure 3.4

Figure 3.5

Figure 3.6

Figure 3.7

Figure 3.8

\section{Chapter 4}

Figure 4.1

Figure 4.2

Figure 4.3

\section{Chapter 5}

Figure 5.1

Figure 5.2

Figure 5.3

Figure 5.4

Figure 5.5

Figure 5.6

Figure 5.7

Figure 5.8
Constructs of the research

4

$\begin{array}{ll}\text { Sub-research questions } & 7\end{array}$

Format and structure of the thesis 13

Governance framework 17

Comparison of differences between agency and stewardship 33 theories Stewardship propositions 35

Governance resources - Local government, Victoria 53

Governance resources - Municipal Association of Victoria 54

Select summary of themes in the audit committee literature 64

Audit committee effectiveness $\quad 70$

Recent audit committee literature $\quad 73$

Determinants of audit committee effectiveness 83

Summary of the literature $\quad 88$

Audit committees - Areas of focus 96

Principles of audit committee effectiveness $\quad 99$

Activities of the audit committee 100

Select contributors to the aetiology of fraud 107

Corruption risk factors 115

The continuum of behaviours 143

Research methodologies $\quad 150$

Labels associated with different paradigms 153

Four tests for quality research 163

Components of research design 166

Factorial design model 168

Survey questions and their replacements 177

Questions about the preparation of financial statements 177

'Yes' responses from questions A1-C5, D1-D12, 179

E1-E10

\section{Chapter 6}

Figure 6.1

Responses from the five groups to questions E1-E10

221

Response rates - Victorian metropolitan and rural regional 224 councils

Figure 6.2

33
54
5




\section{Chapter 7}

Figure 7.1

Figure 7.2

Figure 7.3

\section{Appendices}

Figure A7.1

Figure A7.2
Implications of findings from the meta-analysis research

A theory of audit committee effectiveness

265

Impact and consequences of behaviours

Affirmative responses D1-D12

368

Response rates - Victorian metropolitan and rural regional

370 


\section{LIST OF TABLES}

\section{Chapter 1}

Table $1.1 \quad$ Overview of select councils

\section{Chapter 4}

Table 4.1

Investigation reports into local government, 2000-2009

Table 4.2

Local government investigations in Victoria, New South Wales,

Queensland, Western Australia, New Zealand and the United Kingdom

\section{Chapter 5}

Table 5.1

Table 5.2

Table 5.3

Table 5.4

Table 5.5

Table 5.6

Table 5.7

Table 5.8

Table 5.9

Table 5.10

Table 5.11

\section{Chapter 6}

Table 6.1

Table 6.2

Table 6.3

Table 6.4

Table 6.5

Table 6.6

Table 6.7

Table 6.8

Table 6.9

Table 6.10
Pilot study sample and response rate

Summary of the research data 178

Low 'Yes' responses to individual questions 180

Differences between early and late respondents 184

Mayors of councils, student's t-test 185

Chief executive officers, student's $t$-test 186

Chairs of audit committees, student's t-test 186

Chi-square tests on select responses from mayors, chief 187

executives and chairs of audit committees

Rankings of the data from the Kruskal-Wallis Rank Test 190

Chi-square test and p values from the SPSS output for mayors, 192

chief executives and chairs of audit committees - Questions

A1-C5

Chi-square test and p-values from the SPSS output for mayors, D1-E10

Response rates from the research 196

Demography of respondents 200

Firmographic data 202

Establishment of the audit committee 205

Membership of the audit committee 206

Chairmanship of the audit committee 206

Mean responses, Questions A1-A5 208

Mean responses, Questions B1-B5 211

Mean responses, Questions C1-C5 214

Qualitative research - Clarification of issues from 227

quantitative research

\section{Chapter 7}

Table 7.1 Results from sub-research questions 


\section{$\underline{\text { Appendices }}$}

Table A7.1

Table A7.2

Table A7.3

Table A7.4

Table A7.5

Table A7.6

Table A7.7

Table A7.8

Table A7.9

Table A7.10

Table A7.11

Table A7.12

Table A7.13

Table A7.14

Table A7.15

Table A7.16

Table A7.17

Table A7.18

Table A7.19

Table A7.20

Table A8.1
Mean responses, Questions A1-A5

364

Standard deviation responses, Questions A -A5 364

Mean responses, Questions A1-A5 - Victorian metropolitan 364 and rural regional councils

Standard deviation responses, Questions A1-A5 - Victorian 365

metropolitan and rural regional councils

Mean responses, Questions B1-B5

365

Standard deviation responses, Questions B1-B5 365

Mean responses, Questions B1-B5 - Victorian metropolitan 366

and rural regional councils

Standard deviation responses, Questions B1-B5 - Victorian 366

metropolitan and rural regional councils

Mean responses, Questions C1-C5 366

Standard deviation responses, Questions C1- C5 367

Mean responses, Questions C1-C5 - Victorian metropolitan 367

and rural regional councils

Standard deviation responses, Questions C1-C5 - Victorian 367

metropolitan and rural regional councils

Mean responses, Questions D1-D12 369

Standard deviation responses, Questions D1-D12 369

Mean responses, Questions D1-D12 - Victorian metropolitan 371

and rural regional councils

Standard deviation responses, Questions D1-D12 - Victorian 371

metropolitan and rural regional councils

Mean responses, Questions E1-E10 372

Standard deviation responses, Questions E1-E10 372

Mean responses, Questions E1-E10 - Victorian metropolitan 372

and rural regional councils

Standard deviation responses, Questions E1-E10 - Victorian 373

metropolitan and rural regional councils

Outcomes from quantitative research 


\section{Abbreviations and Conventions}

The following syntax conventions have been observed.

i. $\quad$ chief executive or chief executives (lower case).

ii. CEO or CEOs. This is an acronym for chief executive officer and chief executive officers.

iii. chair (lower case) for example, chair of an audit committee.

iv. council (lower case).

v. The name of a council, for example, Baw Baw Shire Council and Stonnington City Council (title case).

vi. board (lower case) - can also be used interchangeably with the term, board of directors.

vii. board of directors (lower case).

viii. board of management (lower case). This term is used in the 'not-for-profit' sector and is the equivalent to board of directors for companies.

ix. director (lower case) - reserved for people who are directors of companies.

In local government in Victoria, the head of a functional group of activities is called a director, for example, Director of Infrastructure Services, Director of Corporate Services and Director of Community Services. 


\section{CHAPTER ONE: INTRODUCTION}

\subsection{Objectives}

Chapter One will describe Victorian local government and identify research areas. This chapter clarifies the two research questions developed from the theoretical constructs of the research as the prelude to the literature review in Chapters Two, Three and Four.

\subsection{Local government in Australia}

Local government is the third tier in the Australian federal system: the Commonwealth, six state and two territory governments; and then local government (Municipal Association of Victoria 2008a).

\subsubsection{Local government in Victoria}

The Victorian Constitution Act (1975) establishes the legal status of local government and its powers. The Local Government Act (1989) provides the framework for the establishment and operation of councils and is the major legislative instrument for Victorian councils. The Victoria Grants Commission Act (1976) provides the authority for the allocation of revenue from the Commonwealth Government to municipal councils in Victoria. The Local Government (Financial Assistance) Act (1995) details the provisions through which the Commonwealth Government provides grants to local government. ${ }^{1}$ The City of Melbourne Act (2001) only relates to the Melbourne City Council and provides the legislative provisions for the Melbourne City Council in addition to the requirements of the Local Government Act (1989).

Jones (1989) noted that the formation of municipalities in Victoria originated with the Municipal Institutions Act (1854) with restricted powers similar to English parish councils (p. 51). He explained that the Inquiry into Municipalities and Charitable Institutions in 1863 recommended to the Victorian Government that local government should not administer the broader responsibilities of education, police and justice. As a consequence, local government in Victoria has a narrow range of functions when compared, for example, to New Zealand and the United Kingdom.

\footnotetext{
1 'Financial Assistance Grants' included both general purpose grants and local road grants.
} 
There are seventy-nine municipal councils in Victoria, which represent approximately five million people in both metropolitan councils and rural shire councils with combined expenditures of approximately \$A4.74 billion (Municipal Association of Victoria 2008a, 2008g). Councils are made up of a number of elected councillors representing local constituents with the number of councillors varying. From the overview of selected councils (see table 1.1), the three metropolitan councils of Manningham, Whitehorse and Yarra had eight, nine and nine councillors respectively, as compared to rural city councils of Mildura, Swan Hill and Wangaratta with nine, nine and seven councillors respectively (Local Government Victoria 2008a, 2008b, 2008c, 2008g, 2008h, 2008i). This data was contrasted with rural shire councils (Moyne, Mansfield and Wellington) which had ten, five and seven councillors respectively (Local Government Victoria 2008d, 2008e, 2008f).

\section{Table 1.1 Overview of selected councils}

\begin{tabular}{|c|c|c|c|c|}
\hline Council & $\begin{array}{c}\text { Number of } \\
\text { councillors }\end{array}$ & $\begin{array}{c}\text { Council area } \\
\text { (square kms) }\end{array}$ & $\begin{array}{c}\text { Population } \\
\text { (Note 1) }\end{array}$ & $\begin{array}{c}\text { Recurrent income } \\
\text { \$A million } \\
\text { (Note 2) }\end{array}$ \\
\hline $\begin{array}{r}\text { Rural city councils } \\
\text { Mildura Rural City } \\
\text { Council }\end{array}$ & 9 & 22,082 & 52,507 & 32.73 \\
Swan Hill Rural City & 9 & 6,116 & 21,523 & 36.80 \\
Council & & 3,639 & 27,008 & 28.64 \\
Wangaratta City Council & 7 & 5,478 & 13.19 \\
\hline Rural shire councils & 10 & 3,892 & 7,263 & 50.96 \\
\hline $\begin{array}{c}\text { Moyne Shire Council } \\
\text { Mansfield Shire Council }\end{array}$ & 5 & 10,989 & 41,361 & 70.11 \\
Wellington Shire Council & 7 & 113 & 115,756 & 95.15 \\
\hline Metropolitan councils & 9 & 64 & 130,254 & 97.15 \\
\hline $\begin{array}{l}\text { Manningham City Council } \\
\text { Whitehorse City Council }\end{array}$ \\
Yarra City Council
\end{tabular}

\subsubsection{Audit committees in Victorian local government}

Section 139 of the Local Government Act (1989) specifies the requirement for local government councils in Victoria to appoint their own audit committee. The audit committee includes both councillors and independent members, with an independent member generally being the chair of the committee. The purpose of the audit committee is to assist council to establish and to maintain reliable systems of internal control. The committee can also enhance the internal auditor's independence to provide unfettered advice (Cameron 2008, 2004). 


\subsection{Accountability}

Accountability in local government has a broader dimension than in the private sector. In the private sector, accountability related to the management of the business entity for shareholder's interests, as prescribed by the Corporations Act (2001). In local government, accountability can be multifaceted as councils seek to achieve diverse social, political and financial goals for community benefit.

The accountability principles for local government are based on strong financial probity, propriety and adherence to conflict of interest principles. There are societal norms and expectations that local government is fully accountable for community resources in terms of propriety, probity, legality, financial diligence, efficiency and effectiveness. The ultimate sanction for a council is its dismissal and the appointment of an interim administrator until the next council elections, for example, Wollongong City Council in New South Wales in 2008 and Brimbank City Council in Victoria in 2009. These are discussed in Chapter Four.

\subsection{The research}

This thesis addresses governance issues associated with the effectiveness of audit committees within local government in Victoria, Australia.

The general research area is governance and the specific focus is on governance practices in local government. The primary research question is: 'Do audit committees in Victorian local government function effectively?' The secondary research question is: 'Do the investigations into local government maladministration and malfeasance enhance governance and the audit committee's effectiveness?'

This thesis extends the work of DeZoort, Hermanson, Archambeault and Reed (2002), Purcell (2005) and Wayne (2003) in relation to audit committees and addresses the gap in knowledge relating to the effectiveness of audit committees in the unique governance setting of Victorian local government. This thesis contends that audit committees, within the governance processes of local government, are the appropriate governance units to monitor the strategic and operational risks of councils, although each council is responsible for the management of governance. Ideally, the audit committee must have the commitment of its members, the support of councillors and the executive management team. The research used a questionnaire based on a 'factorial design' to measure the perceptions, attitudes and 
perspectives of mayors, chief executives and chairs of the audit committee. The results were compared with the perceptions of committee members of the Local Government and Shires Association of New South Wales and board members of the Municipal Association of Victoria as the representative bodies of local government in New South Wales and Victoria respectively.

\subsection{Theoretical basis and constructs of the research}

The theoretical framework for the research is represented in Figure 1.1, from ideas sourced from Sekaran ${ }^{2}$ (2003). The independent, moderating and dependent variables were developed from audit committee literature.

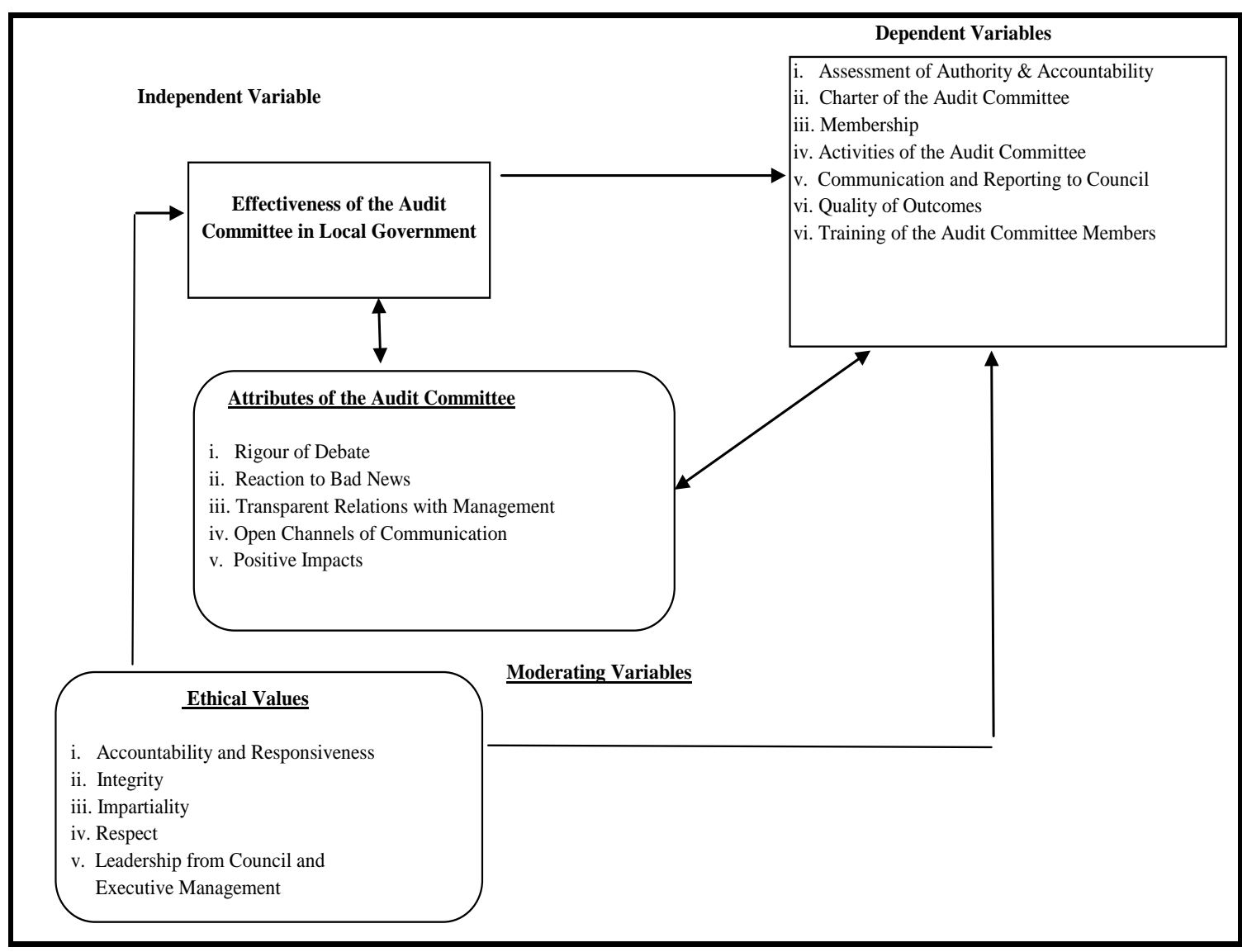

Figure 1.1

Constructs of the research

In relation to the 'composition of the audit committee', Krishnamoorthy, Wright and Cohen (2002a, 2002b) considered that financial expertise, independence and diligence were important attributes for successful audit committees. These were compared with Galvez

\footnotetext{
${ }^{2}$ Sekaran (2003) described how a theoretical framework was developed including 'dependent', 'independent' and 'moderating' variables. It also detailed when a null hypothesis would be accepted or rejected.
} 
(2003) who considered that a mix of audit members with the right skills, expertise and competencies were important attributes. As part of the 'authority of the audit committee', Kalbers and Fogarty (1993) noted that the effectiveness of the audit committee also required a 'supportive atmosphere from top management'. Hughes (2002) considered that in relation to the resources of the audit committee, one of the impediments of effectiveness related to resources and diligence. Rittenberg and Nair (1993) cited in DeZoort et al. (2002) noted that one of the keys to audit committee effectiveness related to background and training.

In relation to the 'diligence of the audit committee', Spangler and Braiotta (1990) argued that leadership and style of the audit committee chairperson were important. This was compared with McMullen and Raghunandan (1996) who argued that expertise in accounting, internal controls and auditing can be contributors to audit committee effectiveness, as well as the frequency of meetings. The pilot study identified the relevance of these measures and quantitative research tested them accordingly.

The independent variable is audit committee effectiveness in local government, explained by the six dependent variables of:

- $\quad$ assessment of authority and accountability;

- $\quad$ charter of the audit committee;

- $\quad$ membership;

- $\quad$ communication and reporting to council;

- $\quad$ quality of outcomes; and

- training.

The dependent variables represent the formal process, activities and the outcomes of the audit committee. They constitute what is seen or observed (Schein 1996, 1984). The moderating variables which can influence the independent variables are the attributes of the audit committee and ethical values. These include:

\footnotetext{
- $\quad$ rigour of debate;

- $\quad$ reaction to bad news;

- $\quad$ transparent relationships;

- $\quad$ open channels of communication; and

- $\quad$ positive impact.
}

The Victorian Public Sector Ethical Values (State Services Authority 2005) constitute the Victorian public sector values. Although it is not obligatory for Victorian local government to comply, nevertheless they represent values for councils to follow. These values include 
accountability and responsiveness, integrity, impartiality, respect and leadership. Hitt (1995) and Iles and Sutherland (2001) noted that the McKinsey 7S Theory from Waterman, Peters and Philips (1980) provided a system's view of the organisation, where each element is directed towards a common goal (Illes \& Sutherland 2001, pp. 28-9). From the McKinsey 7S Theory an effective audit committee has to have the formal structures, strategies and systems represented by dependent variables. The effectiveness of the audit committee is influenced by the moderating variables represented by the attributes of staffing, skills and style of the audit committee, within an ethical framework. This constitutes 'substance' rather than 'form' of the audit committee, represented by dependent variables.

Dailey, Dalton and Cannella (2003) noted that the majority of academic literature pertaining to corporate governance takes the perspective of rational and successful organisations which are inherently stable. They further noted that there was little academic research in relation to the issue of governance when an organisation was in crisis: financial or otherwise. In Chapter Four, the number of inquiries into local government over the past ten years within Australia shows that unethical behaviour can generally be symptomatic of a wider unethical organisational culture. Lagan (2005a, 2005b) and Lagan and Moran (2006) argued that unethical behaviour rarely flourishes in a vacuum and it was as much created and promoted by organisational culture that was allowed to emerge, compared to any predispositions of individuals.

\subsection{Sub-research questions}

The primary and secondary research questions are outlined in Section 1.4. The research questions were tested using qualitative and quantitative data in Chapter Six. They were validated by the following performance indicators.

Internal Performance Measures (Australian National Audit Office 2005)

i. Understanding by the audit committee of their responsibilities within a governance framework.

ii. $\quad$ Audit committee members with due skills and experience.

iii. The ability to act objectively and independently.

iv. Maintenance of effective relationships with council and management.

v. Timeliness of reporting from the audit committee to the council.

\section{External Performance Measures}

i. Quality of internal financial reporting (Auditor-General, Victoria 2008).

ii. Effectiveness of internal control (Auditor-General, Victoria 2008). 
iii. $\quad$ Financial viability of councils (Auditor-General, Victoria 2008).

iv. Annual community assessment of councils (Local government Victoria 2007a).

\section{Corruption and Misconduct Measures}

i. The audit committee had identified corruption as an inherent risk of the council.

ii. The audit committee was cognisant of the specific corruption risks applicable for councils (Independent Commission Against Corruption, 2009a).

iii. Arising from the corruption or misconduct investigations in other councils, the audit committee had benchmarked its activities against the internal control deficiencies in the investigator's report.

The research focused on the functions and responsibilities of audit committees as the premier governance units, notwithstanding that all audit committees in Victorian local government are advisory bodies to council and therefore not decision-making bodies. The research issues are detailed in Figure 1.1 and the sub-research questions are outlined in Figure 1.2.

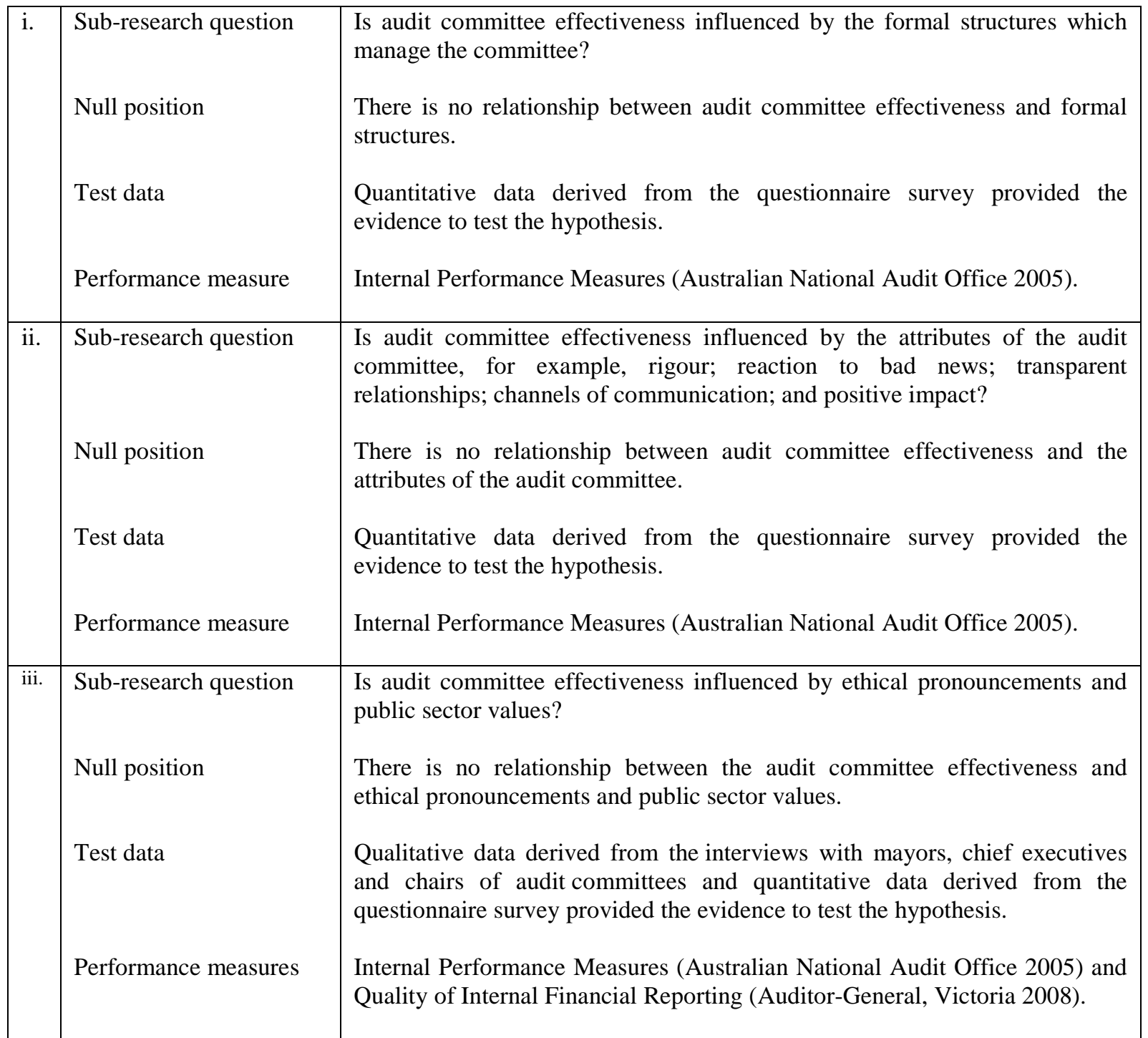




\begin{tabular}{|c|c|c|}
\hline iv. & Sub-research question & $\begin{array}{l}\text { Are audit committee members influenced by the views of mayors, chief } \\
\text { executives and chairs of audit committees? } \\
\text { There are no influential relationships between the audit committee members } \\
\text { and the mayors, chief executives and chairs of audit committees. } \\
\text { Qualitative data derived from the interviews with mayors, chief executives } \\
\text { and chairs of audit committees and quantitative data derived from the } \\
\text { questionnaire survey provided the evidence to test the hypothesis. } \\
\text { Internal Performance Measures (Australian National Audit Office 2005). }\end{array}$ \\
\hline v. & Sub-research question & $\begin{array}{l}\text { Are differences in opinions between the mayors, chief executives and chairs } \\
\text { of audit committees influenced by professional affiliations and experiences? } \\
\text { There are no relationships between professional affiliations, experiences } \\
\text { of the mayors, chief executives and chairs of audit committees. } \\
\text { Quantitative data derived from the questionnaire survey provided the } \\
\text { evidence to test the hypothesis. } \\
\text { Internal Performance Measures (Australian National Audit Office 2005). }\end{array}$ \\
\hline vi. & Sub-research question & $\begin{array}{l}\text { Are differences in opinions between the mayors, chief executives and chairs } \\
\text { of audit committees influenced by geographic location, for example, rural, } \\
\text { regional and the metropolitan areas? } \\
\text { There is no relationship between geographic location and the opinions } \\
\text { expressed by the mayors, chief executives and chairs of audit committees. } \\
\text { Quantitative data derived from the questionnaire survey provided the } \\
\text { evidence to test the hypothesis. } \\
\text { Internal Performance Measures (Australian National Audit Office 2005). }\end{array}$ \\
\hline
\end{tabular}

Figure 1.2

Sub-research questions

From the Constructs of the Research in Section 1.5, the research used 'grounded theory' sourced from Patton (2002, pp. 124-9). Although grounded theory was used, working hypotheses were developed to guide the research. The following two-tailed hypotheses were ideas sourced from Sekaran (2003, pp. 104-5); Siegel and Castellan (1988, pp. 6-8); and Wiersma and Jurs (2005, pp. 40-1). Two-tailed hypotheses were used, as there was no reason to suppose that the data would fall in any particular direction. Further, as there was no predetermined theory, the thesis was open to the prospect of the results falling in either direction.

Two sets of 'driving' and 'restraining' forces ${ }^{3}$ can operate on councillors and chief executive officers in the management of councils. On one hand, there can be the forces of rationality, openness, communication and confident self-analysis. On the other hand, there can be the

\footnotetext{
${ }^{3}$ Force field analysis (Lewin 1951) refers to 'driving' and 'restraining' forces which can initiate or restrain organisational change. The concept of 'forces' refers to people's perceptions of a particular issue and its influence (Iles \& Sutherland 2001, p. 43).
} 
political forces which can be more concerned with internal rivalries, Machiavellian machinations, empire protecting and selective communications. There can be a lack of will for organisational change, albeit incremental, rather than transformational (Gettler 2005b; Griffin \& O’Leary-Kelly 2004; Griffin, O’Leary-Kelly \& Collins 1998; Kets de Vries 2004a, 2004b, 2001; Punch 1996). Conflict between these forces can end with politically achievable outcomes becoming the norm. The thesis has noted the consequences for stakeholders within an organisation, whereby the leadership team engage in systematic misconduct and asks:

- What implications can be drawn?

- What conclusions can be inferred in relation to the practice of ethics and the values and culture of the organisation?

- What are the possibilities as a way forward?

This thesis contends that the introduction of an audit committee with behavioural insights may be a more constructive and feasible solution. Councils could use this behavioural model to enhance local government governance process and provide enhanced oversight of leaders and management processes within organisations where the leadership team engages in dishonesty or misconduct. It was hypothesised that any differences in attitudes of the five groups (mayors, chief executives, chairs of audit committees, board members of Municipal Association of Victoria and committee members of the Local Government and Shires Association of New South Wales) could be explained in the context of a power model ${ }^{4}$ and governance theories ${ }^{5}$ and the expectations that each group has, as well as the expectations each group has of other groups. It was contended that the perceptions and opinions of these groups may be influenced by the specific functions or roles that each group may act out (Reidy 2006).

\subsection{Assumptions and definitions associated with the research}

The research was contingent upon the following assumptions: integrity and honesty; effective governance practices; and the acknowledgement that negative organisational behaviours can exist. Investigations into local government corruption and maladministration therefore provided a context in which to question the effectiveness of governance processes.

\footnotetext{
${ }^{4}$ Dallas (1988) describes the firm in the power model as an 'institution within its own internal structure that seeks to decrease its uncertainty by increasing its own autonomy and discretion over its environment' (Dallas 1988, p. 30). Ziolkowski (2005) considered that these objectives can be 'pursued at the expense of profit, although subject to a profit restraint' (p. 378).

${ }^{5}$ In Chapters Two and Three there is a discussion of agency theory, institutional theory and resource dependency theory. Beasley, Carcello Hermanson and Neal (2009) called them the 'often but sometimes complementary theories with regard to corporate governance and audit committees' (p. 69).
} 


\subsubsection{Integrity and honesty}

Effective governance in local government relies upon councillors and staff acting in the public interest. Maladministration and corruption in local government can be caused by the misdeeds of councillors and the leadership team or other external parties, although the misdeeds of the leadership team may impact council and staff within council more dramatically (Schein 1984). The corporate sector provides some insights into these effects. Charles (2002) for example, noted that the common themes of various corporate collapses were often poor corporate governance, bad management and inadequate accounting practices.

\subsubsection{Effective governance}

Governance relates to a set of principles that provide an assurance that 'there is a clear direction, responsibility, and accountability for those directors and executives managing the organisation' (Department of Treasury 1997, p. 62). Effective organisational governance, under the auspices of the council and the council's audit committee can be the vehicle to monitor councillors and executive management and their mutual obligations toward honest stewardship.

\subsubsection{The dark side of leadership}

This thesis was not intended to be a treatise on organisational leadership theory and personality disorders which can pervade local government. However, the study does acknowledge some of the areas that the dark side of management can permeate or influence governance outcomes of councils. Amongst others this can include a range of behaviours from:

- $\quad$ abuse of power; nefarious conduct; and

- $\quad$ organisational dysfunctionality, where the councillors or members of the executive management team within a council engage in either systemic misconduct or low levels of corruption (Conger 1990; Gettler 2005b; Griffin \& O’Leary-Kelly 2004; Griffin et al.1998; Thomas \& Slade 2004).

\subsubsection{Investigations into local government administration}

Research outcomes were contextualised from conclusions of investigations into local government maladministration and malfeasance from the: 
- $\quad$ Victorian Inspector of Municipal Administration;

- $\quad$ Ombudsman, Victoria;

- $\quad$ Auditor-General, Victoria;

- $\quad$ Independent Commission against Corruption (New South Wales);

- $\quad$ Crime and Misconduct Commission (Queensland); and

- $\quad$ Corruption and Crime Commission (Western Australia).

\subsubsection{Audit guidelines for local government}

The Department of Infrastructure (2000) issued guidelines for the formation and management of audit committees in Victorian local government. The audit committee guidelines were revised and circulated to councils as a consultation draft in December 2009 (Department of Planning and Community Development 2009) and were promulgated as guidelines for local government in February 2011 (Department of Planning and Community Development 2011). This thesis acknowledges the 2011 guidelines, although audit committee guidelines (Department of Infrastructure 2000) were the relevant guidelines when the pilot study plus quantitative and qualitative research were undertaken in February to March 2009 and July 2010 to January 2011 respectively.

\subsection{Limitations}

The research was limited by:

- $\quad$ no previous research into local government audit committees and thus a smaller basis from which to work (Section 1.8.1);

- $\quad$ potential bias of the research (Section 1.8.2); and

- $\quad$ investigations into the allegations of local government maladministration, misconduct and corruption have been accepted as factual evidence of corruption or misconduct (Section 1.8.3).

\subsubsection{No previous research into Victorian local government audit committees}

No identifiable research of audit committees within Victorian or Australian local government was noted in the literature. ${ }^{6}$ Whilst this has been categorised as a limitation, it could equally be considered to be a positive, as this thesis has extended the academic knowledge into a

\footnotetext{
${ }^{6}$ The basis being six searches of the ProQuest Data Base using the terms 'audit committee', 'local government' and the 'names of the six Australian states'. A subsequent search of the Emerald Full Text Data Base, using the same search string failed to identify relevant literature. This was consistent with Van Der Hoek (2010) in relation to Dutch local government audit committees. A further review of the Australian Digital Thesis (Trove database in the National Library of Australia) identified forty-two theses in relation to audit committees although none of them related to local government.
} 
subject area that has not previously been analysed in depth. It was noted that audit committee literature often focused on financial reporting (Gendron, Bedard \& Gosselin 2004; Krishnamoorthy et al. 2002a) whereas audit committees in Victorian local government focus on risk, financial sustainability, performance outcomes, financial reporting and integrity (Banyule City Council 2008; Bayside 2011; Yarra City Council 2009). This research has a practical application and is relevant for local government entities in other states in Australia. As the research focused on public sector organisations, rather than corporate entities, it could also be further applied to government trading entities, although government trading entities adhere to the more stringent corporate governance requirements from the Corporations Act (2001).

\subsubsection{Research bias}

The research was specifically Victorian local government centric, although the research could be used for comparative analysis in other states in Australia, New Zealand and the United Kingdom. In undertaking any comparative analysis, some consideration of the different responsibilities and the accountabilities of local government in these countries could potentially influence the results.

\subsubsection{Investigations into local government administration}

Investigation reports of maladministration and misconduct in local government regarding councillors and council staff have been accepted as examples of corrupt behaviours, whilst acknowledging that only the judicial process can make a final determination of corruption and fraudulent misconduct. This thesis was the work and sole responsibility of the author, whilst every effort was made to overcome bias and any omissions, it should be recognised that some bias or omissions may have inadvertently occurred.

\subsection{Structure of the thesis}

Figure 1.3 is a diagrammatic representation of the thesis and provides an overview of the linkages between various topics and discusses an effective audit committee as the recommended way forward to contribute to management of governance within a council. 


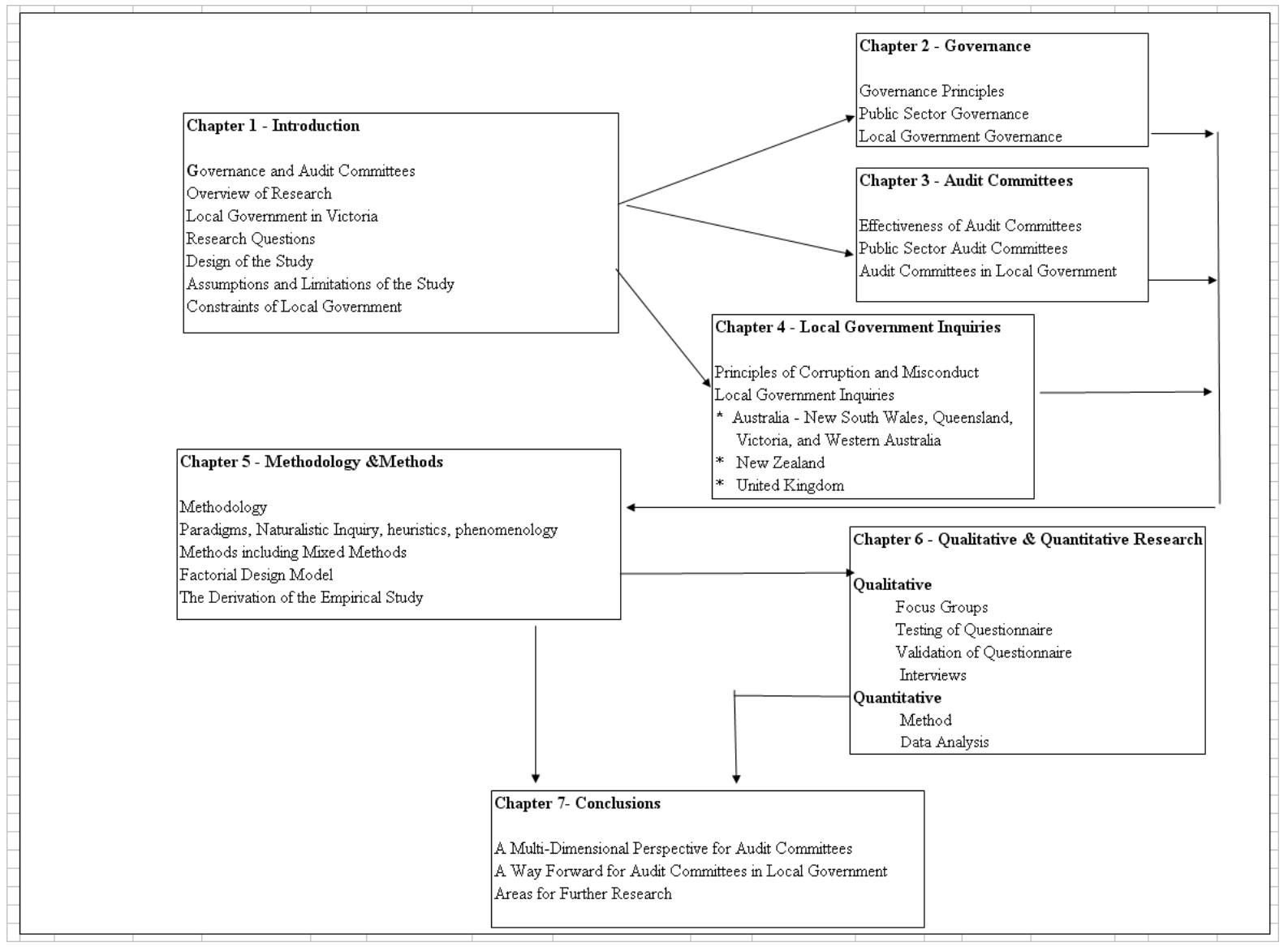

\section{Figure 1.3 Format and structure of the thesis}

The overview of Chapters Two to Seven follows:

Chapter Two notes that the Corporations Act (2001) is the principal legislation in Australia which governs the operations of companies including governance and financial reporting. Public sector governance extends the Corporations Act (2001) with additional stakeholder demands and societal expectations upon government bodies and government commercial enterprises.

Chapter Three reviews the literature pertaining to:

- $\quad$ general principles of audit committees;

- $\quad$ differences between private and public sector audit committees; and

- $\quad$ audit committees in local government.

The Australian regulatory environment provides a framework for governance and for audit committees to operate.

Chapter Four analyses the investigative reports into local government in Victoria, New South Wales, Queensland and Western Australia within the taxonomy of: 
- $\quad$ council maladministration;

- $\quad$ corrupt conduct;

- $\quad$ financial mismanagement;

- $\quad$ breaches of statutory powers; and

- $\quad$ unethical conduct by councillors and staff.

Chapter Five addresses the rationale for the derivation of the empirical study, which includes:

- $\quad$ the connection between the issues from the literature in Chapters Two and Three;

- $\quad$ the outcomes of corruption and misconduct in local government as evidenced in Chapter Four; and

- $\quad$ the need for empirical data to validate or disprove the two principal research questions.

Chapter Six describes qualitative and quantitative methods used to obtain data and interpret the significance of the results.

Chapter Seven synthesises the literature, summarises the results from qualitative and the quantitative research and identifies a contribution to new knowledge.

\subsection{Summary}

This chapter has introduced Victorian local government and the research questions. The principles of governance and audit committees are further developed in Chapters Two and Three. 


\section{CHAPTER TWO: GOVERNANCE}

Chapter Two will outline the principles of governance and their application to the public sector and Victorian local government. Audit committees, an integral part of the governance process, will be discussed in Chapter Three.

Farrar (2008) stated that 'corporatisation is part of a policy of commercialisation which in its turn is part of a policy of liberalisation or deregulation of the economy. It uses the private sector as the model of efficiency and aims to replicate as far as possible the corporate firm in the private sector' (p. 477). He distinguished between private and public entities in the areas of: (1) ownership; (2) markets in the private and public sector; (3) financing of public sector services; (4) provision of services based on the premise of 'public goods' and 'merit goods' (health and education); (5) different criteria of success; (6) profit verus achievement of economic goals; and (7) accountability to shareholders verus political accountability (pp. 476-447). In relation to public sector governance, Edwards (2002) noted the push by the Commonwealth Government to 'adopt private sector processes and structures within its agencies and use the phrase corporate governance' (p. 52). Edwards further argued that a 'common assumption is that the corporate form of governance can be readily adapted to improve on governance policy and implementation activities’ (2002, p. 52).

The literature review identified more articles relating to private sector governance than public sector governance, although the latter did have a number of better practice guides for public sector governance (Sections 2.1.1 and 2.3.1). This thesis has taken the position that public sector governance mirrors private sector governance and as a consequence, the review of private sector governance principles and practices provided an integrated framework for local government councils and audit committees to monitor the integrity and stewardship obligations of council and management.

Audit committees are an integral part of governance practices and this is why the following corporate governance issues are discussed: (1) the context of corporate governance (Section 2.1); (2) governance theories (Section 2.2); and (3) principles and practices of public sector governance (Sections 2.3 and 2.4 ).

In Section 2.1.1 corporate governance has been discussed from the perspective of:

- $\quad$ governance (Bolton 2006, Clarke \& Dean 2007, Khancel 2007, Shleifer \& Vishny 1997);

- $\quad$ control (Berle \& Means 1932);

- $\quad$ agency (Chi 2005; Jensen 1986); 
- $\quad$ quality of financial reporting (Brennan \& Solomon 2008);

- $\quad$ role of the chief executive (Jones 2005); and

- $\quad$ behavioural influences (Marnet 2008, 2007, 2005, 2004).

In Section 2.1.2 the historical perspective of the literature was addressed to take into account the changes in governance regulatory regimes post the Enron collapse in the United States of America and that of HIH Insurance in Australia.

\subsection{Corporate governance}

\subsubsection{Context of corporate governance}

The term 'corporate governance' has been extensively used since the 1980s although Berle and Means (1932) was the seminal work pertaining to the separation of rights and responsibilities of shareholders, directors and management.

Farrar (2008) stated that corporate governance had its origins in the Latin words, gubernare and gubernator, which referred to the steering of a ship and the French word 'gouvernance' which meant 'control and the state of being controlled'. He considered that these words provided a metaphor for governance, that is, the steering and controlling of a ship (Farrar 2008, p. 3). In general terms, corporate governance relates to a set of principles adopted by an organisation in order to provide an assurance that there is a clear direction, responsibility and accountability for those directors and executives managing the organisation. The Australian Treasury Corporate Law and Economic Reform (CLERP), Paper No 3 (Department of Treasury 1997) defined corporate governance as:

the term used to describe the rules and practices put in place within a company to manage information and economic incentive problems inherent in the separation of ownership from control in large enterprises (p. 62).

The governance principles which are universally applicable for all entities are due diligence, executive remuneration, conflict of interest and ethical practices. Due diligence, in a governance sense, generally means that directors are not held liable for the effects of their business judgements: even for judgements which are clear mistakes, with the exception being fraudulent misconduct.

Corporate governance provides the context for:

- $\quad$ ownership and the control of the organisation; 
- $\quad$ exercise of legitimate power within the organisation; and

- $\quad$ accountabilities and responsibilities of the company, to whom and for what.

The International Federation of Accountants (2008) stated that the governance framework comprised performance and conformance dimensions and together they represented the value creation, resource utilisation and accountability frameworks of an organisation (Figure 2.1). Conformance related to the provision of assurances to stakeholders, for example, control of resources and achievement of strategic and operational goals, whereas performance responsibilities focused on decision-making processes, risk appetite and effectiveness of decision making.

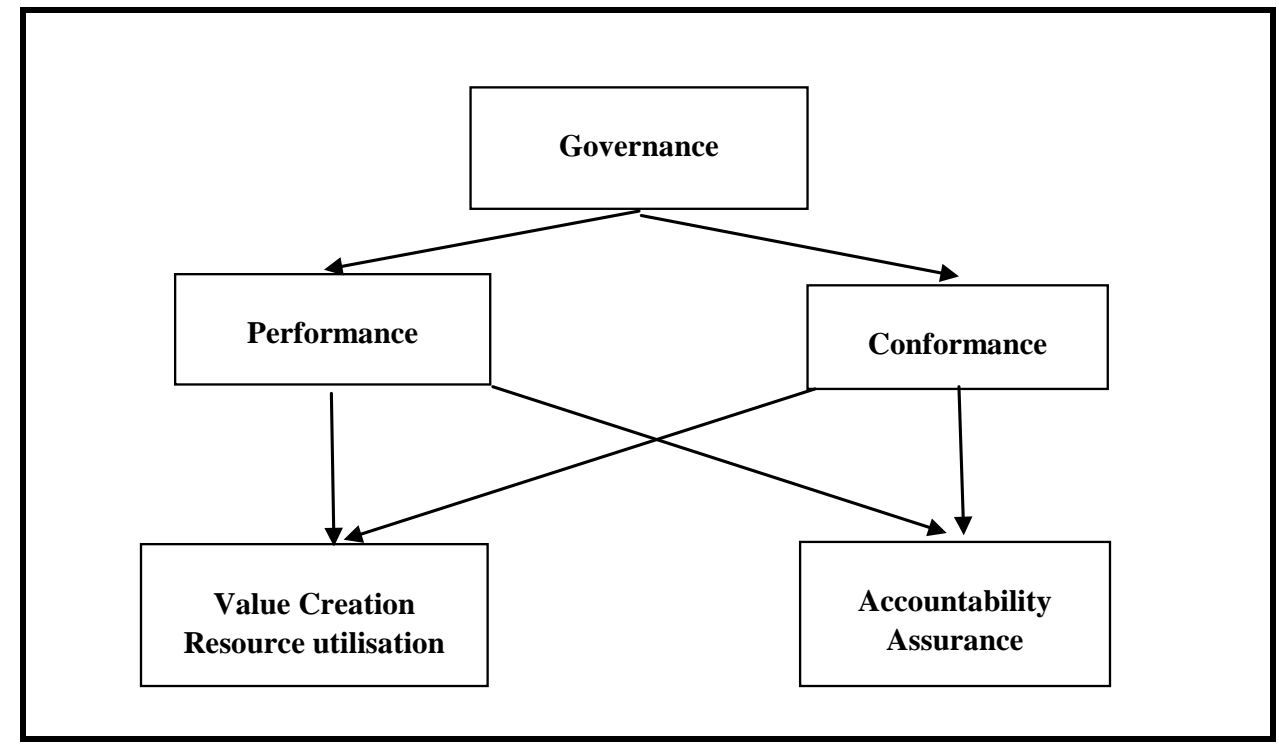

Figure 2.1 Governance framework

Source: $\quad$ International Federation of Accountants 2008, p. 8.

\section{i. The practice of corporate governance}

The review of corporate governance noted that the literature could be grouped into the following subject categories:

- $\quad$ 'board of directors';

- $\quad$ 'chief executives';

- 'accounting';

- $\quad$ 'executive compensation';

- $\quad$ 'business ethics'; and

- $\quad$ 'management'.

Whilst a detailed analysis of all the literature within these subject categories was outside the scope of this thesis, Brennan and Solomon (2008) considered that accounting and finance research had traditionally focused on corporate governance, as measures of accountability. 
A starting point for the synthesis of corporate governance literature was Berle and Means (1932) and their discussion of the evolution of control in a corporation. They stated that 'control lies in the hands of the individual or group who have the actual power to select the board of directors' (p. 69). They identified five types of controls, namely:

- $\quad$ control through complete ownership;

- majority control;

- $\quad$ control through legal devices without majority ownership;

- $\quad$ management control; and

- $\quad$ minority control (p. 70).

The first three controls are based on ownership and the latter two relate to a 'factual control rather than a legal base' (Berle \& Means 1932, p. 70). Management control occurs when ownership of a corporation is sufficiently sub-divided so that the management can become a self-perpetuating body, even though its ownership is negligible (Berle \& Means 1932, p. 88). Shleifer and Vishny (1997) defined corporate governance as 'the ways in which suppliers of finance to corporations assure themselves of getting a return on their investment' (p. 737). This was complemented by Clarke and Dean (2007) who considered that governance effectiveness requires an environment in which 'authority is exercised with absolute probity' (p. 64). Brennan and Solomon (2008) noted that the mechanisms of transparency within companies, particularly financial reporting, has been researched from the perspective of accountability of audit committees, internal audit and risk management as the conduits to provide assurances about the quality of financial reporting (p. 887). However, in the Australian context the notion of effective corporate governance generally goes beyond just accountability, covering development and use of infrastructure, creative solutions to problems, financial planning and strategic direction.

Carcello, Hermanson and Ye (2011) in their meta-analysis review of auditing and governance literature in the previous decade stated that:

At the most basic level, the thrust of the literature to date can be captured in one sentence, "Generally speaking, 'good' audit committee and board characteristics are associated with measures of 'good' accounting and auditing and with more effective internal controls". These associations tend to be driven by findings in Anglo-American settings, where most of the research has focused (p. 3).

These authors described the governance characteristics of 'good' audit committees and boards in terms of expertise and independence, with accounting outcomes being less accounting fraud, effective auditors and effective internal controls (Carcello et al. 2011, p. 3). 
Their observations were also confirmed during the analysis of the literature when similarities were observed in governance issues. For example:

- $\quad$ Monem (2011) summarising from Clarke and Dean (2007) stated that 'it requires director, executive and non-executive, to ask awkward questions and for the board chair to ensure a proper flow of information to the board of directors' (p. 345).

- $\quad$ Khancel (2007) considered that there was a relationship between the level of institutional ownership and the quality of governance within a firm.

- Bolton (2006) suggested that instead of considering one single measure of governance, one should consider multiple governance measures.

- $\quad$ Chi (2005) considered that the value of 'corporate governance lies in its ability to constrain agency conflicts' and examined the marginal value of the quality of corporate governance while 'controlling for the potential severity of agency conflicts' (pp. 1-3).

Chi (2005) argued that this was consistent with Jensen's (1986) hypothesis that higher governance quality increased a firm's value by constraining agency conflicts in investment decisions (p. 39). Tudway and Pascal (2006) in their corporate governance paper on shareholder value and societal expectations, concluded that there was a 'mismatch between economic and commercial criteria' for profit maximisation of an organisation and the societal expectations of a virtuous organisation, 'and the existing legal framework does little to help remedy these shortcomings' (p. 311). Khancel (2007) examined the indicators of good governance in companies in the United States of America from 1994 to 2003. He developed a corporate governance rating by using characteristics of the:

- $\quad$ board of directors (independence, board size, separation of the roles of chief executive and chairman);

- $\quad$ frequency of board meetings;

- $\quad$ financial competency of audit committee members;

- $\quad$ activities of the audit committee;

- $\quad$ reputation of auditors; and

- $\quad$ firm's attributes, for example, funding needs and growth opportunities, intangible assets, investment opportunities, financial performance and institutional ownership, as they related to governance.

He concluded that 'large firms with high investment opportunities, external financing needs and high intangible assets tend to have strong governance' (Khancel 2007, p. 756). Bolton (2006) however analysed the relationship between corporate governance and economic performance with a focus on management turnover, financial performance, corporate capital structures and corporate ownership structures and concluded there was:

consistent estimation of the relationship between corporate governance, and firm performance, by taking into account the inter-relationships among corporate 
governance, management turnover, corporate performance, corporate capital structure, and corporate ownership structure (Bolton 2006, pp. 105-6).

Bolton considered that better governance indicators, share ownership of board members and separation of the positions of chair of the board and chief executive were significant and 'correlated with better contemporaneous and subsequent operating performance' (2006, p.105). He further argued that poor financial performance within a company and the probability of executive management turnover positively correlated with share ownership of board members and with board independence. He explained that this would be expected, as directors have a greater incentive to monitor performance and actions of the firm.

Popescu (2006) in his analysis of executive compensation and the independence of directors as measures of the quality of corporate governance concluded that a 'firm's market value had the greatest and most consistent influence over the chief executive’s compensation' (p. 74.). He further argued that this finding was consistent with observations that the chief executive of a large company has a greater incentive to increase the firm's size. Ertugrul (2005) in his review of corporate governance metrics by governance research companies in the United States of America (e.g. Governance Metrics International, Institutional Shareholder Services and Standard \& Poors) and a firm's financial performance, concluded that the percentage of independent directors on board committees, director tenure, independent director ownership and level of a chief executive's remuneration were important determinants in the ratings. He concluded that there was no correlation between future financial performance and governance metrics (Ertugrul 2005, p. 37).

Jones (2005) in his doctoral thesis of governance practices in community service organisations concluded that, in relation to the adoption of governance practices, there were four factors which were important for the success of community organisations. These were:

- $\quad$ the role of the chief executive as the agent of the directors was crucial in assisting the board to meet its responsibilities under the Corporations Act (2001);

- $\quad$ organisations that focused on governance practices gave themselves a competitive advantage in tendering for services from government; and

- $\quad$ governments have encouraged the enhancement of governance practices in community organisations (Jones 2005, p. 179).

This has implications for governance practices in local government. Jones (2005), complemented by Baysinger and Hoskisson (1990), extended the work of Oviatt (1988) concerning the relationship between shareholders, management and organisational incentives and controls. These authors concluded that in organisations where agency relations existed 
and where there was a specific need for an agent to be controlled, attempts to regulate the strength of the agent's behaviours through financial controls may also affect the direction of that behaviour (Baysinger \& Hoskisson 1990, p. 85).

Marnet (2008, 2007, 2005, 2004) noted that some of the literature on corporate governance had focused on a quantifiable relationship between measures of corporate performance and solutions to agency problems such as independent directors, external audits, accounting standards and shareholders. For example, Bolton (2006); Chi (2005); Ertugrul (2005); and Fridman (2004); Kelly (2005); Khancel (2007) and Popescu (2006) identified important agency relationships between principal and agent, predicated upon rational economic behaviours. The contribution to governance literature by these authors is that it raised questions about the effectiveness of the conventional approach to monitoring and controlling the behaviours of managers. Marnet (2008) considered that whilst the research had identified some important aspects of the fundamental conflict and tensions between agent and principal, there were some questions as to the relevance of the research in monitoring and controlling managerial performance. He noted that 'numeric variables and models of rational behaviour have a poor record in the detection, prevention, and forecasting of earnings management, and accounting fraud' (Marnet 2008, p. 207). Marnet (2008) believed that the focus should be on managerial behaviours themselves, the behavioural traits of individuals not observing accepted societal norms, the tendency of regulators to concede or acquiesce towards corporate misdeeds and the 'socio-psychological effects of group decision-making on judgement and decision quality' (p. 9).

What is significant for this thesis is that effective corporate governance requires systems that are accountable (refer Chapter One), transparent, procedurally fair, participatory for stakeholders, responsive to the needs and the aspirations of the community.

\section{i. Clarification of 'governance principles'}

There have been several attempts by authoritative governance bodies to identify and explain corporate governance principles, with four seminal examples being:

- $\quad$ Financial Aspects of Corporate Governance (Cadbury1992);

- $\quad$ Organisation for Economic Development (OECD 2004);

- $\quad$ Principles of Corporate Governance, The King Report on Corporate Governance (King 2002); and

- $\quad$ Principles of Good Corporate Governance and Best Practice Recommendations (Australian Stock Exchange 2007). 
The Committee on the Financial Aspects of Corporate Governance issued its report in the United Kingdom in 1992 and addressed, for the first time, issues of accountability and financial reporting and provided the benchmark for governance. The OECD first issued the Principles of Corporate Governance in 1999. These were not a universal model of corporate governance applicable for all corporate entities, but rather the OECD recommended the adoption of a set of policy principles and guiding norms. The King Report (2002) identified seven principles of good corporate governance and in Australia, the Commonwealth Government through the Department of Treasury $(1999,1997)$ responded to global developments in governance and introduced the Corporate Law Economic Reform Program (CLERP) (Department of Treasury 2002, 1997). Within CLERP, it was contended that there was a specific governance framework for Australian corporations with four elements including:

- $\quad$ the legal regulatory environment;

- $\quad$ accounting standards;

- $\quad$ the listing rules of the Australian Stock Exchange; and

- $\quad$ voluntary codes of practice.

In analysing governance principles and practices it was appropriate to assess the cultural perspective of governance. In countries with a common law tradition, for example, Australia, Canada, New Zealand, the United Kingdom and the United States of America, the focus was on shareholders and the role of governance was to maximise outcomes for shareholders. In the civil law countries within Europe, the focus was on the interests of stakeholders to balance the interests of management, employees, creditors, customers and community. This was referred to as the 'insider model' of the corporation control (Psaros 2009, pp. 215-25). The differences between the 'insider model' and the 'outsider model' of corporate governance are: minimal separation between ownership and control, wider concept of the firm as an autonomous economic and social entity and wider board structures than under the ‘outsider’ model.

\subsubsection{Historical perspective of governance literature}

In reviewing governance literature it was important to reflect upon the date of the literature, as works prior to the late 1990s were written before the corporate collapses of Enron and WorldCom in the United States of America and Harris Scarfe, HIH Insurance and One.Tel in Australia. The failures of corporate governance processes, accounting manipulations and financial misconduct are not recent phenomenon, for example, the corporate governance 
failures in Australia between 1995 and 2005 of HIH Insurance Ltd, One.Tel Ltd and Harris Scarfe Ltd (Carson 2005; Economou 2005a, 2005b; Jimenez 2002; Lampe 2005; Main 2005a, 2005b, 2005c).

These corporate governance excesses and failures were an impetus for the improvement of governance standards in Australia. This drive was more than just ensuring they did not reoccur, but there was a general acknowledgment by the Commonwealth Government that improved corporate governance standards were important for community confidence and the future growth and development generated by the private sector.

The recent literature on corporate governance denoted a prescriptive approach to corporate governance, for example, Dalton and Dalton (2005); Daily and Dalton (2003); and Hall, Keane, McConnell and Becker (2005). A prescriptive approach does not consider that corporate governance needs to be tailored to the needs and complexities of the organisation, its outputs and the stakeholders to whom the organisation is accountable.

Durden and Pech (2006) argued that some governance changes, especially those that are prescriptive, can have unexpected negative consequences, even though they can achieve the goal of better corporate governance. These authors further noted the risks of the:

- $\quad$ board of directors usurping the executive management team and becoming directly involved in running the organisation;

- $\quad$ executives being distracted from the business objectives of the organisation and concentrating time and resources on the achievement of corporate governance compliance; and

- $\quad$ executive management team becoming risk adverse for fear of contravening corporate governance guidelines.

They suggested that a way forward was to focus on management, motivation, internal organisational culture and organisational design and flexibility, rather than burdening business with additional regulatory compliance (Durden \& Pech 2006). These views were complemented by Barrett (2000), who suggested that the corporate culture espoused and practised by the executive management team, was a better way forward than an overly prescriptive compliance culture. He noted the separation of powers in an organisation, where the board of directors 'deal with overall organisation policy, direction, culture' and 'provide the tone-at-the-top which is essential for corporate governance' (Barrett 2002, p. 2). Barrett distinguished the operational management of an organisation from the responsibilities of the board by indicating that executives manage the 'organisation by the virtue of the authority delegated to them by those who govern' (2002, p. 2). He suggested six general principles, 
which can enable effective governance to operate in an organisation. These included: (1) leadership; (2) commitment; (3) integrity; (4) accountability; (5) transparency; and (6) integration. He considered that for governance to be effective it required a committed leadership from directors and management.

The observations and conclusions of Barrett (2000) and Durden and Pech (2006) require a very supportive and honest management culture and not all organisations practise those values. It is possible that some chief executives may not want a strong governance structure, as they may perceive it to be a restriction on their ability to manage. However, effective governance is essentially a partnership between directors and management and should not be about ego. Barrett (2000) stated 'an indication of an agency's effectiveness is the way in which the organisation as a whole works together under the CEO's leadership' (p. 7). In relation to commitment, Barrett (2002) also noted that effective corporate governance was about more than having corporate structures in place, as they are the means, but not necessarily the ends in and of themselves.

The significance of the preceding discussion for this thesis is the increasing importance and heightened expectation of accountability for decision making including the actions of directors and management and their performance.

\subsubsection{Corporate governance practice in Australia}

Farrar (2008) described Australian corporate governance practices as the relationships between legal regulation (the Corporations Act, 2001); 'the case law decided by the courts'; the listing rules of the Australian Stock Exchange (ASX); the code of governance practices of the ASX (Corporate Governance Principles and Recommendations); business ethics; and the codes of conduct in place within organisational entities (Farrar 2008, p. 4). Farrar (2008) stated that 'all of these have some place in an analysis of corporate governance and create an increasing complex amalgam of law and self-regulation’ (p. 4).

\section{i. $\quad$ Corporations Act (2001)}

The standards of practice for directors and officers of corporations in Australia are prescribed in the Corporations Act (2001). The relevant sections for effective governance are detailed in Chapter 2D in the Corporations Act (2001). They include:

- $\quad$ duties and powers (Part 2D.1) including duties and disclosures; 
- $\quad$ restrictions on indemnities, insurance and termination payments (Part 2D.2);

- $\quad$ appointment, remuneration and cessation of directors (Part 2D.3);

- $\quad$ disqualification from managing corporations (Part 2D.6); and

- $\quad$ financial reports and audit (Part 2M).

The chief executive and chief financial officer under Section 295A certify to the directors of a listed company that: (1) the annual financial statements have been prepared in accordance with the Corporations Act (2001) and the accounting standards; and (2) the financial statements of the company represent a true and fair view. Section 1317AA of the Corporations Act (2001) also provided the framework for whistleblower disclosures from employees; officers of the company were to report breaches of the Corporations Act (2001) to the Australian Securities and Investments Commission (Australian Securities and Investments Commission n. d.).

\title{
ii. Duty of care
}

It is important to have an appreciation of duty of care (Daniels $v$ Anderson (1992) 7 ACSR 759 at 865; Daniels v Anderson (1995) 37 NSWLR 438 and Australian Securities and Investments Commission $v$ Healey [2011] FCA 717) as duty of care applies to local government.

The former duty of care by directors in Australian legal jurisdictions was expressed in $R e$ City Equitable Fire Insurance Co Ltd [1925] Ch 407).

\begin{abstract}
A director is not bound to give continuous attention to the affairs of his company. His duties are of an intermittent nature to be performed at periodic board meetings, and of meetings of any committee of the board upon which he happens to be placed. He is not, however, bound to attend all such meetings, though he ought to attend whenever, in the circumstances, he is reasonably able to do so (Re City Equitable Fire Insurance Co Ltd [1925] Ch 407 at 429, cited in Farrar 2008, p. 138).
\end{abstract}

In more recent times, the Australian Courts have inclined towards a more objective test which prescribed minimum standards for directors' responsibilities. Thus the standard of care required of a director, was the degree of care that a reasonable person doing the job in the company would exercise. This was demonstrated in Daniels v Anderson (1992) 7 ACSR 759, which determined an approach for duty of care, skill and diligence by directors. It was found that:

...Conventional wisdom held that a director need not exhibit, in the performance of duties, a greater degree of care, skill and diligence than may reasonably be expected from a person of his or her knowledge or experience (Re City Equitable 
Fire Insurance Co Ltd [1925] Ch 407 at 428); when the opportunity presented itself to reassess this approach it was declined: Byrne v Baker [1964] VR 443 at 450. More recent wisdom has suggested that it is of the essence of the responsibilities of directors that they take reasonable steps to place themselves in a position to guide and monitor the management of the company: cf Commonwealth Bank v Friedrich (1991) 5 ASCR 115 at 187. A director is obliged to obtain at least a general understanding of the business of the company and the effect that a changing economy may have on that business. Directors should bring an informed and independent judgment to bear on the various matters that come to the Board for decision (Daniels $v$ Anderson (1992) 7 ACSR 759 at 865).

The duty of directors was further refined in Daniels $v$ Anderson (1995) 37

NSWLR 438 where it was held that:

A person who accepts the office of director of a particular company undertakes the responsibility of ensuring that he or she understands the nature of the duty a director is called upon to perform. That duty will vary according to the size and business of the particular company and the experience or skills that the director held himself or herself ought to have in support of appointment to the office. None of this is novel. It turns upon the natural expectations and reliance placed by shareholders on the experience and skill of a particular director. The duty is a common law duty to take reasonable care owed severally by persons who are fiduciary agents bound not to exercise the powers conferred upon them for private purpose or for any purpose foreign to the power and placed, in the words of Ford and Austin, Ford's Principles of Corporations Law, 6th ed (1992), at 429, at the apex of the structure of direction and management. The duty includes that of acting collectively to manage the company (Daniels v Anderson (1995) 37 NSWLR 438, at 506).

Daniels $v$ Anderson and the appeals defined Australian corporate governance because it establised that there was not a single standard of care. Justice Owen in the HIH Royal Commission (2003) considered that good corporate governance should not be a 'one-sizefits-all' solution with accompanying heavy handed regulations. He considered that good governance naturally developed within companies by applying voluntary guidelines which can be used in circumstances which best fit their companies. He stated that:

for me, the key to good corporate governance lies in substance, not form. It is about the way the directors of a company create and develop a model to fit the circumstances of that company and then test it periodically for its practical effectiveness. It is about the directors taking control of a regime they have established and for which they are responsible. These concepts do not lend themselves easily to specification in something such as a code of best practice. One thing is clear, though. Whatever the model, the public must know about it and about how it is operating in practice. Disclosure should be a central feature of any corporate governance regime (HIH Royal Commission 2003, paragraph 6.6). 
In 2011 in the Australian Securities and Investments Commission v Healey [2011] FCA 717, generally known as the 'Centro case', Justice Middleton held that the defendant directors had breached their duty of care in relation to the presentation of financial statements.

14. A director is an essential component of corporate governance. Each director is placed at the apex of the structure of direction and management of a company. The higher the office held by a person, the greater the responsibility that falls upon him or her. The role of a director is significant as their actions may have a profound effect on the community, and not just shareholders, employees and creditors.

15. This proceeding involves taking responsibility for documents effectively signed-off by, approved, or adopted by the directors. What is required is that such documents, before they are adopted by the directors, be read, understood and focussed upon by each director with the knowledge each director has or should have by virtue of his or her position as a director. I do not consider this requirement overburdens a director, or as argued before me, would cause the boardrooms of Australia to empty overnight. Directors are generally well remunerated and hold positions of prestige, and the office of director will continue to attract competent, diligent and intelligent people (Australian Securities and Investments Commission v Healey [2011] FCA 717 (27 June 2011) at Para [14-15].

The relevance of the Daniels v Anderson and 'Centro' cases for this thesis and for Victorian local government is that they provide the precedent of how the courts will interpret duty of care for councillors, albeit that the Local Government Act (1989) is the principal enabling act. However, these cases directly impact upon the commercial subsidiaries of councils, for example Citywide the commercial subsidiary of Melbourne City Council and the joint ventures of Victorian councils, for example Community Chef, where councillors may not be the directors of subsidiary companies or joint venture companies; nevertheless they do have a duty of care to ask probing and insightful questions about the operations of councils' subsidiary companies and joint venture companies.

\section{iii. Corporate governance principles and recommendations of the Australian Stock Exchange}

The Australian Stock Exchange (2007) Principles of Good Corporate Governance and Best Practice Recommendations are recommended for listed companies in Australia and are considered to be best practice for Australian unlisted companies to achieve. The eight principles, revised from ten principles issued in 2003 by the Australian Stock Exchange (2003), are as follows:

- $\quad$ (Principle 1) lay solid foundations for management and oversight;

- $\quad$ (Principle 2) structure the board to add value;

- $\quad$ (Principle 3) promote ethical and responsible decision making; 
- $\quad$ (Principle 4) safeguard integrity in financial reporting;

- $\quad$ (Principle 5) make timely and balanced disclosures;

- $\quad$ (Principle 6) respect the rights of shareholders;

- $\quad$ (Principle 7) recognise and manage risk; and

- (Principle 8) remunerate fairly and responsibly.

The statements are aspirational but the reality within organisations can be quite different. It was noted that the structure of the board to add value (Principle 2) could be inconsistent in operation with ethical decision making (Principle 3), integrity in financial reporting (Principle Four), timely disclosure (Principle 5) and any other permutation of the principles.

The Australian Stock Exchange (2007) noted that it was important to distinguish between the principles and purpose of the recommendations, whereas the former established corporate governance standards and the latter suggested a possible framework for implementing the principles within an organisation. The governance recommendations in the Australian Stock Exchange (2007) are not mandatory for listed companies on the ASX although the ASX Corporate Governance Council supports companies to meet the spirit of the principles 'through whatever means they believe are most appropriate to their business' (Australian Stock Exchange 2007, p. 3). Under the ASX Listing Rule 4.10.3, companies are required, as part of the annual reporting process, to disclose the extent to which they have followed the recommendations in the reporting period.

The Australian Stock Exchange (2007) noted that good governance was not restricted to the adoption of these principles and recommendations. They considered it was important to disclose and explain governance practices considered by a company to be appropriate to its circumstances (Australian Stock Exchange 2007, p. 1). The Corporate Governance Principles and Recommendations are also used by unlisted companies to achieve better governance practices as far as they are relevant. For example, CPA Australia Ltd, an unlisted company in Australia, noted in its Annual Report that they complied with the Corporate Governance Principles and Recommendations as a guide to best practice corporate governance (CPA Australia 2007, p. 25).

\section{iv. Relevance for the public sector and local government}

This thesis notes that the principles and the practices of private sector governance are readily transferable to the public sector, for example, the Corporate Governance Principles and Recommendations of the Australian Stock Exchange (2007). However, public sector governance has a political representation dimension that cannot be under-estimated and 
accountability for outcomes. For example, the Commonwealth Government public sector and government enterprises are subject to the legal requirements of the:

- $\quad$ Commonwealth Authorities and Companies Act (1997);

- $\quad$ Financial Management and Accountability Act (1997);

- $\quad$ enabling Act under which the bodies or entities were incorporated, for example, Australia Post, the Australian Postal Corporation Act (1989); and

- governance arrangements for Australian government bodies (Department of Finance and Administration 2005).

Uhrig (2003) in his seminal review of corporate governance in Commonwealth statutory authorities concluded there was a lack of effective governance due in part to: (1) unclear boundaries in delegated powers to the statutory authority; (2) a lack of clarity in their relationship with the minister; and (3) a lack of accountability for the exercise of power. $\mathrm{He}$ considered that:

'lack of governance' arose 'primarily due to a hands-off attitude assumed by many when dealing with statutory authorities. This situation is often further complicated by the presence of a Board, particularly those where it is impractical for government to provide the full governing powers required to be effective' (Uhrig 2003, p. 5).

The Department of Finance and Administration (2005) detailed the governance arrangements that were to be followed in Commonwealth entities to ensure consistency of practice, whilst ensuring that the principles from the review by Uhrig (2003) were applied. The Department of Finance and Administration (2005) considered that there were a number of key factors which influenced governance arrangements in public bodies. These included:

- $\quad$ clarity of the purpose of the statutory body;

- $\quad$ financial management;

- $\quad$ effective relationships with the board of directors, including such issues as the size of the board, appointment process, tenure, development and performance;

- $\quad$ staff management processes; and

- $\quad$ independence (pp. 32-42).

These governance issues were also supported by Farrar (2008), who developed five principles of public sector governance, which were similar to the concepts proposed by Uhrig (2003) and the Department of Finance and Administration (2005) (pp. 470-77). In Victoria, all public sector entities are required to comply with the:

- $\quad$ Audit Act (1994);

- $\quad$ Financial Management Act (1994);

- $\quad$ Financial Management Regulations 2004; 
- $\quad$ Financial Management (Amendment) Regulations (2006); and

- $\quad$ Audit (Public Bodies) Regulations (2005).

The public sector also imposes stakeholder demands and societal expectations upon government bodies. For example, all Victorian public sector bodies, including local government, are expected to adhere to the principles of ethics and effective public sector governance (State Services Authority 2007a, 2006a and 2005). Governance within Victorian local government is prescribed in the Local Government Act (1989). Governance within local government is similar to corporate governance from the private sector, although local government has the political dimension of elected councillors. Local government has legislative and taxing powers and can be a provider of services. Local government can also have competing stakeholder demands which can range from: (1) expectations of the Commonwealth and state governments for delivery of services; (2) the 'needs' and 'wants' of constituents within the municipality; (3) users of council services; (4) motivations and personal agendas of individual councillors; and (5) councillors as part of a political bloc.

\subsection{Governance theories}

In any discussion of governance it was important to have an appreciation of governance theories in the literature.

Carcello et al. (2011) stated that 'most governance research is based on agency theory' although there are multiple theories, for example, resource theory, institutional theory and managerial hegemony theory (p. 19). The relevance of governance theories in this thesis it that it provides the starting point for the application of theories for audit committees discussed in Chapter Three. Some of these models included: (1) agency (Fama \& Jensen 1983; Jensen \& Meckling 1976); (2) behavioural (Leung \& Cooper 2003; Marnet 2008, 2007, 2005, 2004); (3) decision making (Pech \& Durden 2004); and (4) ethics (Francis \& Armstrong 2003; Lagan \& Moran 2006; Lagan 2005a, 2005b).

Traditionally, the research from agency theorists (Berle \& Means 1932; Fama \& Jensen 1983 and Jensen \& Meckling 1976) has focused on what Young and Thyil (2008) called the mechanisms and the rules designed to align the interests of owners and management. The regulatory approach to governance has an inbuilt predisposition to be prescriptive and to provide solutions to critical governance events after a crisis had occurred. Young and Thyil (2008) considered that one of the outcomes of prescriptive governance solutions was the 
focus on the 'what' and 'how', rather than the 'why' questions in relation to ineffective governance.

Leung and Cooper (2003) considered that a focus on a regulatory approach to governance had the effect of neglecting other possibilities or explanations. Durden and Pech (2006) argued, for example, that post-Enron governance changes, especially those that were prescriptive, can have unexpected negative consequences, even though they may potentially achieve the goal of better corporate governance. Whilst good corporate governance can have long-term beneficial effects, the organisation may raise its levels of protection against bad behaviour. However, the cost of increased and tighter governance can mean a loss in competitive advantage, such as flexibility in decision-making or added financial burdens which competitors may not necessarily share. Young and Thyil (2008) noted that the research in relation to governance has tended to focus on regulation and the 'burgeoning control industry surrounding accounting, auditing, and legal frameworks' (p. 94). Examples of quantitative governance research in Canada and the United States of America included: Bolton (2006); Popescu (2006); Chi (2005); Ertugrul (2005); Kelly (2005); and Fridman (2004).

\subsubsection{Agency}

Agency theory attempts to explain the relationship between the owners or 'principals' of a company and the 'agents', for example, the company's executive management team. In a 'principal-agent' relationship, the principal delegates to the agent, who are responsible for performing work on its behalf. Key assumptions from agency theory are that:

- $\quad$ individuals act in their own interest;

- $\quad$ where a conflict exists between the principal and an agent, the agent will act to maximise its own benefit; and

- $\quad$ an agent is in a unique position to further their own interest, at the expense of the principal, as the agent has access to and control of information.

Agency theory attempts to explain two specific problems, namely: (1) that the goals of the principal and agent are not in conflict; and (2) that the principal and the agent can reconcile their different tolerances for risk. It assumes that management is self-interested and does not bear the full wealth effects of its decisions. Daily, Dalton and Cannella (2003) noted that agency theory was one of the most widely discussed theoretical perspectives in governance research and Rogers (2006) Ziolkowski (2005) and Siladi (2006) included agency theory in their analysis. Donaldson and Davis (1991) noted that agency theory provides a mechanism 
to explain the concept of agency loss, which can occur when the returns to owners fall below what they would normally be, if the principals had exercised direct control over the corporation. In order to reduce agency loss, the principal provides various forms of financial incentive schemes for the agent, for example, the executive management team of a company align their financial interests with those of the shareholders (Donaldson \& Davis 1991, p. 50). Jensen and Meckling (1976) argued the theory of agency, in order to explain the existence of companies, owners and the alignment of self-interest of management. Fama and Jensen (1983) noted that it was common practice to:

...treat the separation of ownership and control in the modern corporation as raising two connected issues: whether managers have latitude in the attention in which they must pay to their owners' interests and, if they do, to what use they put their freedom (p. 301).

Davis, Schoorman and Donaldson (1997) in their analysis of stewardship theory identified eight factors which differentiated stewardship theory from agency theory. They noted the following differences between agency and stewardship theories (see Figure 2.2).

Kiel and Nicholson (2003) contextualised the development of agency theory by stating that Jensen and Meckling's explanation of agency relationships was widely adopted, due in part to the corporate excesses when the article was written. Kiel and Nicholson (2003) also noted that agency theory led organisations to conclude that boards should have a majority of independent directors and chief executive and chairman should be separate positions (Australian Stock Exchange 2007; OCED 2004; Cadbury 2002). In relation to the research of board composition practices and corporate performance in Australia, Kiel and Nicholson (2003) found there was a distinctive relationship between size of the company and board composition, with larger companies generally having more independent directors, interlocked boards and separation of chairman and chief executive officer. They noted that in relation to the merits of agency theory, stewardship theory, which holds that managers are essentially trustworthy individuals and therefore good stewards of the resource entrusted to them, did not provide a complete explanation of the relationship between governance and corporate performance, but rather elements of both agency and stewardship theories applied in different circumstances (Kiel \& Nicholson 2003, p. 201). 


\begin{tabular}{|c|c|c|}
\hline & Agency theory & Stewardship theory \\
\hline $\begin{array}{l}\text { Model of management } \\
\text { Behaviour }\end{array}$ & $\begin{array}{l}\text { Economic } \\
\text { Self-serving }\end{array}$ & $\begin{array}{l}\text { Self-actualising } \\
\text { Collective serving }\end{array}$ \\
\hline $\begin{array}{l}\text { Psychological mechanisms } \\
\text { Motivation }\end{array}$ & $\begin{array}{l}\text { Lower order/Economic needs } \\
\text { (Psychological, security And } \\
\text { economic) } \\
\text { Extrinsic }\end{array}$ & $\begin{array}{l}\text { Higher order needs } \\
\text { (Growth, achievement and self- } \\
\text { actualisation) } \\
\text { Intrinsic }\end{array}$ \\
\hline $\begin{array}{l}\text { Social comparison } \\
\text { identification } \\
\text { Power }\end{array}$ & $\begin{array}{l}\text { Other managers } \\
\text { Low value commitment } \\
\text { Institutional } \\
\text { (Legitimate, coercive, reward) }\end{array}$ & $\begin{array}{l}\text { Principal } \\
\text { High value commitment } \\
\text { Personal } \\
\text { (Expert, referent) }\end{array}$ \\
\hline \begin{tabular}{cc}
\multicolumn{2}{l}{ Situational mechanisms } \\
Management philosophy \\
- $\quad$ Risk orientation \\
- $\quad$ Time frame \\
- $\quad$ Objective \\
\end{tabular} & $\begin{array}{l}\text { Control oriented } \\
\text { Control mechanisms } \\
\text { Short term } \\
\text { Cost control } \\
\end{array}$ & $\begin{array}{l}\text { Involvement oriented } \\
\text { Trust } \\
\text { Long term } \\
\text { Performance enhancement } \\
\end{array}$ \\
\hline Cultural Differences & $\begin{array}{l}\text { Individualism } \\
\text { High power distance }\end{array}$ & $\begin{array}{l}\text { Collectivism } \\
\text { Low power distance }\end{array}$ \\
\hline
\end{tabular}

Figure 2.2 Comparison of differences between agency and stewardship theories Source: $\quad$ Davis et al. (1997), p. 37.

\section{i. $\quad$ Agency theory literature -2008 and 2009}

Recent research into the implications of agency theory for governance noted the following themes:

- $\quad$ performance and an integrated agency and resources dependency approach (Hillman \& Dalziel 2003); and

- $\quad$ agency conflicts (Dey 2008; Truong 2006).

Audretsch, Lehmann and Plummer (2009) examined agency theory in the context of entrepreneurial ventures, that is, where the entrepreneur had the dual role of providing managerial expertise and knowledge inputs to the venture. They concluded that the decision to provide equity ownership to managers of small high-tech new ventures was not entirely explained by agency theory. They considered that equity arrangements aligned the interests of the principal and the agent, as well as serving as a mechanism for leveraging the firm's resources (Audretsch et al. 2009, p. 163). Hillman and Dalziel (2003) in their analysis of the performance of the firm and directors used an integrated agency and resources dependency approach. They noted that researchers generally seek links between the performance of firms and directors, trying to frame it in the context of agency or resource dependency theories, rather than a combination of both. They argued that the combination of two theoretical views allowed the board to be viewed as both the monitor and the provider of resources and 
provided the following advantage of a 'more parsimonious understanding of board functions' (Hillman \& Dalziel 2003, p. 393).

Dey (2008) researched corporate governance and agency conflicts and concluded that there was a relationship between agency conflicts and governance mechanisms. She noted that firms with higher agency conflicts had governance structures in place, particularly related to the composition and functioning of the board of directors, audit committee and independence of the auditor (Dey 2008, p.1174). Truong (2006) on the other hand, researched the effectiveness of directors in mitigating agency conflicts between management and other stakeholders using a sample of the top five hundred companies in Australia. She noted that the corporate regulatory environment in Australia was different from other developed countries and concluded that firms with higher levels of managerial ownership used their resources more efficiently and that in turn, reduced agency costs (Truong 2006, p. 167).

\subsubsection{Stewardship theory}

Daily et al. (2003) noted that stewardship theory was also commonly discussed in relation to governance. Stewardship theory argued that directors and management can have interests that are isomorphic with those of shareholders and the interests of shareholders can also serve the interests of the managers. Davis et al. (1997) argued seven propositions in relation to stewardship theory, which are presented in Figure 2.3.

Davis et al. (1997) considered that the primary differences between the advocates of agency and stewardship theory lay in the assumptions of human nature, with people in agency theory being individualistic and utility maximisers, whereas in stewardship theory people were collective self-actualisers who achieved utility through organisational achievement (Davis et al. 1997 pp. 28-29). Whilst stewardship theorists do not consider that executives and directors are truly altruistic, they do recognise that there are situations where self-interest and the interests of the shareholders coincide (Daily et al. 2003). 


\begin{tabular}{|c|l|}
\hline Proposition 1 & $\begin{array}{l}\text { People who are motivated by higher order needs are more likely to become stewards in } \\
\text { the principal-steward relationship, than people who are not. }\end{array}$ \\
\hline Proposition 2 & $\begin{array}{l}\text { People who are motivated by intrinsic factors are more likely to become stewards than } \\
\text { those who are motivated by extrinsic factors. }\end{array}$ \\
\hline Proposition 3 & $\begin{array}{l}\text { People with high identification with the organisation are more likely to become stewards } \\
\text { in the principal-steward relationship, than people who are not. }\end{array}$ \\
\hline Proposition 4 & $\begin{array}{l}\text { People who are high in value commitment are more likely to become stewards in the } \\
\text { principal-steward relationship, than people who are not. }\end{array}$ \\
\hline Proposition 5 & $\begin{array}{l}\text { People who are more likely to use personal power as a basis for influencing others are } \\
\text { more likely to become stewards in the principal-steward relationship, than people who use } \\
\text { institutional power. }\end{array}$ \\
\hline Proposition 6 & $\begin{array}{l}\text { People who are more likely to be in an involvement-oriented situation are more likely to } \\
\text { become stewards in the principal-steward relationship, than people who are in a control- } \\
\text { oriented situation. }\end{array}$ \\
\hline Proposition 7 & $\begin{array}{l}\text { People in a collectivist culture are more likely to develop a principal-steward relationship } \\
\text { than people who are in an individualistic culture. }\end{array}$ \\
\hline
\end{tabular}

\section{Figure 2.3 Stewardship propositions}

Source: $\quad$ Adapted from Davis et al. (1997), pp. 29-36.

\subsubsection{Resource dependency theory}

The theory asserts that directors can provide access to resources needed by the organisation, for example, favourable lines of credit, if the director is also an executive of a financial institution and legal advice if the director is a partner of a law firm. Proponents of resource dependency theory included Dalton, Dailey, Johnson and Ellstrand (1999) and Hillman, Cannella and Paetzold (2000).

Resource dependency theory addressed the directors' contribution as 'the boundary spanners' of the organisation 'and its environment' (Daily et al. 2003, p. 372). In the context of resource theory, corporate boards were the mechanism for the management of external dependencies, reducing environmental uncertainty and 'co-opting important external' organisations (Pfeffer \& Salancik 1978, p.167; Pfeffer 1973, 1972). Dalton et al. (1999), in their analysis of directors and financial performance, noted that resource theory had been the primary foundation for the perspective that larger boards were associated with higher levels of financial performance, although researchers did not achieve a consensus that larger boards were associated with better performance (pp. 674-5). Whilst Dalton et al. (1999) asserted the relationship between board size and financial performance; there were a number of limitations which reduced universality and application. For example, the abovementioned analysis did not include board composition, capacity and competencies. Further, the analysis assumed positive values in relation to financial outcomes and board size. The analysis does not comment on whether financial performance was due to:

- $\quad$ access to company resources;

- $\quad$ interlocking of board directorships; 
- $\quad$ expertise and synergy of the board;

- $\quad$ monitoring and control by the board; or

- a combination of some or all of these elements, including the decision-making effects of government public policy and large institutional investment policy.

\subsubsection{Behavioural theory}

Behavioural theory argues that multiple factors can impact the governance of organisations and various participants including stakeholders (Cutting \& Kouzmin 2000; Leung \& Cooper 2003; Marnet 2008, 2007, 2005; Pech \& Durden 2004). These factors included: (1) power and self-interest; (2) decision making; (3) leadership; (4) organisational culture and values; and (5) group dynamics.

Marnet (2008, 2007) questioned the application of rationality in decision making within governance models and concluded that 'behavioural analysis appeared to explain some paradoxes on which the rational approach founders, or at best provides arduous explanations' (Marnet 2008, p. 207). A knowledge of such behaviours reflects an understanding of the composition of the board; decision-making structures; and networks within the board (Young \& Thyil 2008, p. 95). Cutting and Kouzmin (2000) considered that boards can fail to serve the company effectively due to apathy, ignorance and negligence of their fiduciary duties. They referred to the collapse of state banks in South Australia and Victoria in the 1980s as two examples of the board of directors not knowing what was going on. ${ }^{7}$ They suggested that an effective way forward would be for companies to implement:

(1) a modus operandi that consciously identified the relevant questions to foster constructive dialogue; (2) all major board decisions should go through additional validation and reflection process; (3) boards should pay particular attention to the level of understanding evident within the group, and ensure a process for openness and learning; and (4) boards should pay particular attention to foster corporate processes that are capable of creating new knowledge (Cutting \& Kouzmin 2000, p. 502).

Leung and Cooper (2003) writing in the period when the failures of HIH, One.Tel and Harris Scarfe in Australia were in the minds of regulators, community and media commentators, argued that corporate collapses were due to greed; incompetence; failure to understand the behaviours and dynamics of the board collectively; and behaviours and traits of individual board members. Pech and Durden (2004), in a similar vein to Cutting and Kouzmin (2000) and Marnet (2008), argued that the plethora of corporate failures had been caused in part by decision-making processes that destroyed the integrity of organisational learning through dysfunctional and corrupt conduct by managerial elite. They stated that 'organizations need

\footnotetext{
${ }^{7}$ A detailed analysis of the failure of Tricontinental Corporation Ltd, a subsidiary of the State Bank of Victoria and the State Bank of South
} Australia was discussed in Sykes (1994), pp. 437-520. 
to build a culture of knowledge sharing in which senior managers and, indeed all members of the organization, are connected to and remain connected to the collective consciousness' (Pech \& Durden 2004, p. 73).

\subsubsection{Other theories}

\subsubsection{Decision making}

Pech and Durden 2004 analysed the rationale for and organisational consequences of aberrant decision-making processes in terms of the continuum of knowledge management, namely information acquisition and use; and knowledge, insight and wisdom. They considered recent corporate failures can be partially explained in terms of managerial decision-making processes that have destroyed the integrity of the organisational learning experience through the corrupt and dysfunctional behaviour of their respective managerial elite (Pech \& Durden 2004, p. 65). These authors further argued that 'many organisations fail because of the weakness in the decision-making process', to the extent that leaders only receive filtered information and 'fracturing of the learning process can in extreme cases lead to corrupt practices on the part of the managerial elite' (Pech \& Durden 2004, pp. 65, 73). Gettler (2005a, 2005b); Kets de Vries (2004a, 1994, 1991, 1984a, 1984b) and Pech and Slade (2007) considered that some of the explanations for nefarious behaviours by executive management in organisations can include greed, narcissism, manipulation, exploitation and the 'complex nature of the corporate world for reinforcing pathological behaviours in the organisational context' (Pech \& Slade 2007, p. 254).

\subsubsection{Power and market control}

Other governance perspectives cited in the literature included: (1) power (Cutting \& Kouzmin 2002, 2001, 2000); and (2) market and control models (Jensen 2001; Sharma 1997).

Power

In relation to power, Cutting and Kouzmin (2002) discussed the essence of decision-making dynamics of board members. They noted the major shift away from 'managerialism' to 'politicism', which they described as networking and power relationships, especially in the Australian public sector, which impacted governance dynamics. They analysed the difference between the exercise of leadership, management and political power in organisations with a distinct emphasis on the governance responsibility of boards and power relationships 
between the board and the organisation. They considered that the governance orientation in the public sector within Australia had moved from a bureaucratic ordered management, to political networking and power relationships. They asserted that behavioural traits that can impede decision-making of the board included a proclivity for group thinking ${ }^{8}$ and too much commitment to a losing course of action. They also noted some academic analyses of successful companies were often based on a model of owner/manager, with the idea of a 'strong man' controlling the operations of the company. Cutting and Kouzmin considered this notion to be quite redundant, especially where companies have large numbers of individual shareholders and superannuation funds, greater complexity of organisations and competitive environments (2000, p. 501).

\section{Market control}

In relation to market control, Jensen (2001) noted that there were two major theories in relation to the purpose of an organisation, namely value maximisation and rival stakeholder theory. He considered that the concept of value maximisation was predicated upon 200 years of economic theory and described stakeholder theory as endeavouring to maximise total value distributed amongst all corporate stakeholders including employees, customers and local communities. He explained the appeal of stakeholder theory in the context of a broader public interest, but noted that chief executives who are forced to be accountable to different and conflicting constituencies can end up being accountable to none. He considered that a failing of stakeholder theory was that it can be a recipe for managerial confusion within a corporation.

Sharma (1997) however examined the principle of knowledge asymmetry in agency relationships in an environment where a company hired a professional service organisation and then restricted decision-making to perform knowledge intensive tasks. He considered that contracting staff were the agents within the context of agency theory, but their division of labour was knowledge. He stated that 'knowledge, power and social embeddedness are in short two distinctive attributes of professional work that did not lend themselves readily to the agency lens without modification of some of the basic assumptions' (Sharma 1997, p. 760). Sharma's contribution to academic knowledge related to the reconsideration of the

\footnotetext{
${ }^{8}$ Group think (Janis 1972, 1982) is a distortion of thinking which can render members of a group incapable of making sound decisions. He noted the following antecedent conditions can contribute to a group think: (1) group cohesiveness; (2) insulation of the group; (3) lack of impartial leadership; (4) lack of a norm of methodical processes; (5) homogeneity of the group; (6) high stress from external threats with a low hope of better solutions than the leader's; and (7) low esteem induced by recent failures which impacts the group's ability to make informed decisions. Janis (1983) and Manz \& Sims, (1982) expanded the concept of group think to encompass work groups and political groups. For example, jury decision making processes, (Mitchell \& Eckstein, 2009); disasters, (Burnett, Pollack \& Forsyth 2011); and corporate collapses in Australia (Gettler, 2005; Long 2008). Not all groups that fail, suffer from group think and organisations can make faulty decisions because their members lack the right skills and experience (Burnett et al. 2011).
} 
impact of traditional agency theory in new situations of labour hire companies undertaking work on behalf of a client company.

\subsection{Public sector governance}

\subsubsection{Principles of public sector governance}

The Australian National Audit Office in its analysis of processes and practices described public sector governance as 'how an organisation is managed, its corporate and other structures, its culture, and the way it deals with its stakeholders' (Australian National Audit Office 2003, p. 6). The distinguishing feature of governance in the public sector as compared to the private sector was the emphasis on accountability, stewardship and prudent decision making. Effective public sector governance focuses on the requirements of performance and compliance of the public sector body. The relevance of the concepts of organisational performance and conformance to this thesis is that the former related to delivery of services to the community, whilst the latter related to governance which conformed to legal requirements and community expectations of accountability, probity and transparency.

The Australian National Audit Office (2003) considered that effective governance was about giving equal weight to these principles rather than trading them off against each other. Governance in the public sector also takes into account the importance of leadership, ethics and performance culture. Governance principles within the Australian public sector have been influenced by the HIH Royal Commission (2003) and the subsequent strengthening of regulatory processes for banking and insurance sectors. Effective corporate and public sector governance is not an outcome of an overly prescriptive approach to governance. Justice Owen in the HIH Royal Commission (2003) stated that a:

danger with an overly prescriptive approach to systems and structures is that it may unwittingly encourage a superficial or 'tick the box' approach to the achievement of governance objectives (Section 6.12).

He further noted that:

systems and structures can provide an environment conducive to good corporate governance, but at the end of the day, it is the acts or omissions of the people charged with relevant responsibilities that will determine whether governance objectives are in fact achieved' (Section 6.12).

The three tiers of government within Australia: the Commonwealth, state and local, governments have specific accountabilities and responsibilities. For example: 
- $\quad$ make laws and regulations, for example, Corporations Act (2001) (Commonwealth); statutory planning (state); and municipal planning (local government level) subordinate to the statutory planing legislation of the state.

- $\quad$ collect company and personal tax (Commonwealth); land taxes (state); and rates (local government;

- $\quad$ fund or provide services, for example, community health services (Commonwealth); hospitals (state); planning and building regulations within local government subordinate to state legislation; Roads to Recovery (Commonwealth) for local government roads; and

- $\quad$ regulate and inspection services, for example, aged services (Commonwealth); health and children's services (state) and building inspection services by local government subordinate to state building regulations.

The public sector entity can also be an exclusive or monopolistic provider of services, which can lead to a gap, in the expectations of stakeholders, between service delivery and the demands of consumers and ratepayers, especially in the local government context. Examples are children's services (maternal and children's health) and library services, delivered by local government in Victoria, but these services are funded in part by the Victorian Government. Roads within a municipality can be funded by the abovementioned three tiers of government; for example, The Roads to Recovery Program funded by the Commonwealth with other funding from state or local governments.

Public sector governance can be complicated by the political process and competing demands of interest groups. Thus tension in the three tiers of government can be increasing demands by constituents for goods and services, coupled with competing pressures for financial and human resources, due in part to limitations imposed on the tax base. Constituents may demand higher levels of services, but generally do not want to pay higher levels of taxation to fund those services, which can lead to unresolved expectations and a degree of community tension, especially for local government.

The recurring themes in the literature on public sector governance were:

- $\quad$ public sector modernisation (Broadbent \& Laughlin 2005; Bryane \& Gross 2004; Cowell \& Martin 2003; Mador, Springdal \& Dixon 2008; Smith, Mathur \& Skelcher 2006; Woods 2004);

- $\quad$ modernisation in local government (Conley 2006; Harris 2005; Midwinter 2001); and

- $\quad$ modernisation of the National Health Service (Thompson \& Winter 2004; Goodwin 2002).

In relation to public sector governance, there was a plethora of material available from government departments and accounting bodies, for example:

- $\quad$ local government governance (CPA Australia 2005);

- good governance in local government (Chartered Institute of Public Finance and Accountancy 2006); 
- $\quad$ public sector governance (Australian National Audit Office 2003; Department of Finance and Administration 2005; Hong Kong Institute of Certified Public Accountants 2004; International Federation of Accountants 2001; Parliament, New South Wales 2006; Uhrig 2003); and

- $\quad$ conflict of interest (Controller and Auditor-General, New Zealand 2007a).

In the Victorian context, the literature on governance included:

- $\quad$ public sector governance (Parliament, Victoria 2006, 2005; State Services Authority 2007a);

- $\quad$ audit committee guidelines for local government (Department of Infrastructure 2000; Department of Planning and Community Development 2011, 2009);

- $\quad$ governance reviews (State Services Authority 2006a; 2006b, 2006c); and

- an ethics framework and a code of conduct for the public sector (State Services Authority 2005).

\section{i. Relevance of the literature for the Australian public sector}

Edwards (2002), Ryan, Williams, Charles and Waterhouse (2008) and Foster and Jonker (2005) discussed Australian public sector reforms in general and their impact on local government in Australia was analysed by Pullin and Haidar (2003) and Worthington and Dollery (2002). There was a degree of similar themes in the literature on Australian public sector reform, for example:

- $\quad$ Edwards (2002) considered that there was a lack of clarity as to the appropriate structures, processes and organisations to deliver services in collaboration with partners both inside and outside the public sector;

- $\quad$ Ryan et al. (2008) stated that the term, 'New Public Management', did not have a clear and precise definition, although it was associated with the principles of transformation of government agencies from bureaucratic process to market orientation, whilst at the same time maintaining public accountability and outcomes; and

- Worthing and Dollery (2002) considered that the evidence for the benefits of competitive tendering was mixed, but it was labour reform, particularly the introduction of fixed term contracts for senior officers, that allowed new managers from the private sector to transition into local government which had the potential for the most impact (Worthington \& Dollery 2002, pp. 501-510).

Edwards (2002) discussed the implications of governance, for public sector bodies, in the context of structural changes that had occurred in Australia. She noted that there had been a redefining of the role of government in the provision of public services and how they related to and interacted with the community. Ryan et al. (2008) examined organisational change in an Australian government agency post the 'New Public Management' reforms which had occurred within the three tiers of government. In their opinion, public sector reforms in Australia had placed emphasis on participation and empowerment of major stakeholders. Further, these authors considered that participation was illusory in what was effectively a 
top-down process. Their research concluded that whilst top-down change was effective for initiating and sustaining high level support for change, 'it does not permeate all levels of an organisation, and achieve sustained changes in day-to-day operations' (Ryan et al. 2008 p. 40). The implications of their research is that if a government body wants to effect change and in the Australian context of 'New Public Management', then a 'broader and deeper approach combining change from above, from the middle and from below, offers better prospects’ (Ryan et al. 2008 p. 40).

Foster and Jonker (2005) focused upon the management of stakeholder relationships. The significance of their research was how 'public sector values' operated in a context of more liberalised governance and public sector accountability. They concluded that 'organisations have to engage in a dialogic process within and beyond the boundaries of an organisation in order to engage significant stakeholders' that 'will lead to more communication and interactions, and finally the nexus of transactions’ (Foster \& Jonker 2005, p. 56).

\section{ii. Relevance of the literature for local government}

The academic literature pertaining to public sector governance that was relevant for Victorian local government was influenced by public sector modernisation and reforms in the United Kingdom including the modernisation agenda for local government. Modernisation of the public sector originated in the United Kingdom in 1999 in a parliamentary White Paper 'Modernising Government' (Parliament, United Kingdom 1999). The term 'modernisation agenda' in the United Kingdom was used by government until 2006 and included such local government measures as Best Value and Comprehensive Performance Assessment, to be replaced by the Comprehensive Area Assessment in 2009 (Audit-Commission, United Kingdom 2009a). The government had also initiated wide-scale public reform in 1998, which resulted in the establishment of Public Service Agreements (HM Treasury 1998a) to ensure the effectiveness of public services. The Civic Service Reform Program (HM Treasury 1998b) was also under the guidance of the Secretary of the Cabinet and Head of the Civil Service in 1998.

In Australia, Worthington and Dollery (2002) analysed trends within local government, particularly as a result of the initiatives of: (1) legislative reforms; (2) contracting out of services; (3) council amalgamations; (4) labour reforms; and (5) financial reforms instigated by state governments with strong Commonwealth encouragement. They noted that some chief executives had only stayed for one term in local government, which could suggest that 
labour reforms, as an outcome of structural and organisational changes in local government, may have been overstated.

Pullin and Haidar (2003) examined the concepts of 'managerial values' in local government within Australia. They noted that significant changes had occurred in local government ranging from increased autonomy to councils, fixed term senior management appointments and compulsory competitive tendering, which had occurred in the 1990s and council amalgamations. They considered that these events had changed perceptions and the relativity of what it was to be a local government officer providing advice to council or individual councillors. Their study concluded that council officers mixed their advice with the principles of neutrality and non-party partisan advice, with a greater emphasis on achieving outcomes (Pullin \& Haidar 2003, p. 297). They considered that neutrality did not mean that senior officers were politically neutral, but rather they were political party neutral in their dealings and advice to council. This was also discussed by Kloot and Martin (2000), who observed that senior officers were increasingly involved in the strategic processes of council and in the setting of organisational objectives and targets, notwithstanding that council and councillors were ultimately responsible for objectives and targets.

\subsubsection{Public sector governance in the Commonwealth of Australia}

A recurring theme in public sector governance was the need to balance: (1) public policy outcomes; (2) protection of the public interest; and (3) adherence to the democratic process of Parliament, including public sector ownership and the public interest. Edwards (2002) noted that a common assumption was that corporate governance principles and practices can be unilaterally adopted from the private sector to improve the development of government policy and implementation of services (p. 52). The Australian National Audit Office (2003) described corporate governance in the public sector in the following way:

\footnotetext{
It is about 'how an organisation is managed, its corporate and other structures, its culture, its policies and strategies and the way it deals with its various stakeholders'. It also 'encompasses the manner in which public sector organisations acquit their responsibilities of stewardship, by being open, accountable and prudent in decision-making, in providing policy advice, and in managing and delivering programs' (Australian National Audit Office 2003, p. $6)$.
}

The Australian National Audit Office (2003) considered that effective public sector governance was the outcome of performance and conformance. They defined performance to mean situations where an 'organisation uses its governance arrangements to contribute to the overall delivery of goods, services or programs' and conformance to mean 'an organisation 
[that] uses its governance arrangements to ensure it meets the requirements of the law' (Australian National Audit Office, 2003, p. 6).

In and of themselves, best practice governance arrangements do not guarantee or predict future success, but they set a constructive and positive environment and increase the probability of success. Of direct relevance to all board members of a statutory body or government enterprise was the vexed question of competing interests. In Australia, all public officers and directors must act in the best interests of the corporation. It is important for any individual selected as a director of a government entity to be aware of the distinction between the aspirations of a constituency and the obligations as a director to the organisation. Effective public sector governance can be enhanced when the elements of performance outcomes and regulatory conformance together with the internal organisational mechanisms of prudent risk management and a positive and ethical culture form part of a unified whole. Their success can be measured by how effectively these organisational elements are integrated and with the functionally being related to the strategic objective of the public sector entity.

Commercialisation of the public sector in Australia was part of the micro-economic reform agenda of the Commonwealth Government and state governments which took place over the past two decades. Objectives of reform programs were to promote competitive markets for goods and services, remove barriers to market entry and enhance competition under the Trade Practices Act (1974). These reforms have important implications for local government audit committees as councils find different ways to deliver services at a lower cost, for example, Community Chef in Victoria. The terms 'privatisation' and ‘commercialisation' in the Australian context mean the policies of corporatisation of public authorities, privatisation and other regulatory changes (Farrar 2008, p. 457). It has involved the retention of public ownership, but created an operating environment in public entities, which have replicated operating models in the private sector. Farrar (2008) noted that the privatisation of public assets had been generally less popular in Australia than in the United Kingdom and New Zealand, although major public assets had been privatised by successive Commonwealth Governments since the 1990s.

\subsubsection{Public sector governance practice in Victoria, Australia}

The Public Accounts and Estimates Committee (Parliament, Victoria 2005) reviewed the corporate governance processes in the Victorian public sector. They noted that governance of some public entities was 'complex, and required compliance with a wide range of legislation 
and policies and procedures' (Parliament, Victoria 2005, p. 39). It was also noted that some public sector agencies had conflicting objectives in trying to balance the objectives of government and the responsible Minister and the board of directors. They concluded that the process for appointments to boards was based upon formal requirements and was satisfactorily expressed in the enabling legislation for the particular agency or corporate entity. The Committee found that there was a degree of complexity in some governance arrangements which did not necessarily make accountability and transparency clear for stakeholders, particularly in the areas of: (1) functions and objectives of the government body; (2) role of the board and senior management; and (3) performance and service outcomes and future activities (Parliament, Victoria 2005, p. 161). They concluded that there was no 'across-the-board reporting by government entities on achieving the full range of government outcomes', which lagged 'behind' the 'United Kingdom and Canada' (Parliament, Victoria 2005, p. 14).

Effective governance in Victoria is supported by:

- $\quad$ Finance Management Compliance Framework (Department of Treasury and Finance, Victoria 2005a);

- $\quad$ Financial Reporting Directions (Department of Treasury and Finance, Victoria 2005b); and

- Behavioural Accountability Guidelines for public sector employees (Department of Treasury and Finance, Victoria 2002).

The State Services Authority in Victoria has the responsibility in the public sector for: (1) promotion of high standards of governance; (2) promotion of accountability and performance; (3) integration of government service delivery; and (4) reporting on service delivery outcomes and standards. The Public Sector Standards Commissioner appointed under the Public Administration Act (2004) has the responsibility to work with all public sector employees in the promotion of high standards of integrity and conduct. Amongst others, this has included the issuing of public sector codes of conduct, standards on employment principles and ethical standards and values (State Service Authority 2007a, 2007b, 2006a, 2006d, 2005).

The State Services Authority (2007a) details obligations, accountabilities and responsibilities of what it means to be a director of a public sector entity; defines the relationship between the Minister and the entity; and describes the expectations of compliance, accountability and operational practices. The Authority also produced the Director's Code of Conduct for observance by directors and board members in all public sector entities (State Services Authority 2006d), a governance manual for all directors, Welcome to the Board (State 
Services Authority 2006a) and codes of conduct for all public sector employees (State Services Authority 2007b, 2005).

The State Services Authority had also made provision for the sector-wide environment for ethical governance practices to be inculcated into the values and culture of the Victorian Public Sector (State Services Authority 2005). However, it is how those values are embedded, rather than espoused in government departments and public sector entities which is the fundamental issue. The Authority under the Public Administration Act (2004) has undertaken a number of public-sector-wide organisational reviews of services, governance standards and workforce practices. Recent reviews which have specifically examined governance practices included the:

- $\quad$ Governance Review of Alpine Resort Areas (State Service Authority 2009a);

- $\quad$ Review of the Cemetery Trusts (State Service Authority 2008a);

- $\quad$ Governance Arrangements within VicRoads (State Service Authority 2008b); and

- $\quad$ Review of the Rural Ambulance Service (State Service Authority 2006b, 2006c).

Governance reviews by the Public Accounts and Estimates Committee (Parliament, Victoria 2005) and the State Services Authority could be catalysts for the provision of consistent, competent and ongoing sector-wide changes to governance structures and practices within the Victorian public sector. This demonstrated that the state government, through the State Service Authority, considered these governance and effectiveness reviews to be important public policy matters, rather than just 'window-dressing' organisational problems, which can occur on some occasions in any politicised process, regardless of the tier of government.

\subsubsection{Other public sector organisations that support public sector governance}

Other bodies in Victoria which provide an independent assessment of financial and nonfinancial performance of government departments, corporatised organisations and local government include the Auditor-General and the Ombudsman. The Auditor-General's mandate is to provide an assurance to Parliament on accountability and performance of all departments, public sector corporate entities and statutory bodies. The Ombudsman in Victoria has the statutory authority to investigate any complaints about state government departments, statutory authorities and local government entities and is responsible directly to Parliament. The findings from select investigations are discussed in Chapter Four.

From the preceding discussion in this chapter the following has emerged as relevant for this research in this thesis: (1) the distinguishing feature of public sector governance (p. 38); (2) 
expectation gap in the public sector for services (p. 39); (3) influence of interest groups (p. 39); (4) modernisation principles (p. 40) and their influence on public policy (p. 40) and local government (p. 41).

\subsection{Governance in Victorian local government}

\section{i. Local government}

Effective governance in local government relies on the confidence of the community in their elected councillors, the council's chief executive officer and the senior officers of council. Governance provides a framework for local government to fulfill its mandate and achieve intended outcomes for stakeholders and community users of council services in an ethical, effective and economic manner. Some of the research into governance in local government examined:

- $\quad$ localised democratic processes (Geddes 2005; Valler, Wood \& North 2000);

- $\quad$ the modernisation agenda in the United Kingdom (Freeman, Littlewood \& Whitney 1996; Willis 2004; Wilson 2003b);

- $\quad$ community and local democracy (Woolmann 2006; Raco 2002; Painter \& Clarence 2001); and

- $\quad$ financial management (Downe, Grace, Kloot and Martin 2007; Martin \& Nutley 2008 and Ter Bogt 2008).

Other examples of Australian local government research included the impact of council mergers (Jones 2001); organisational learning in a changing environment (Kloot 1995); and leadership values (Dempsey 2006). Good governance in local government can be a catalyst for: (1) quality management of a council; (2) quality performance outcomes; (3) effective stewardship of public monies; (4) effective engagement with the community; and (5) quality outcomes for community and users of council services. There are numerous duties, functions and powers conferred on councils through such legislation as the Local Government Act (1989); the Building Act 1993; and the Planning and Environment Act (1987). Individual councillors cannot deal with the minutiae of council business. Councils delegate to their chief executive officers the authority to comply with legislation and implement strategies approved. In Victoria, councils cannot delegate the following powers:

- $\quad$ awarding contracts in excess of $\$ A 500,000$;

- $\quad$ purchasing land or disposal of land;

- $\quad$ making local laws;

- $\quad$ adoption of council plans and budgets; and

- $\quad$ declaring council rates. 
Effective governance in local government should thus be incontrovertible and perceived by the community and other stakeholders as representing integrity and trust.

\section{ii. Councillors}

The terms 'councillors' and 'governance' in the literature identified the following themes:

- $\quad$ councillor's role in the management of council business (Jones 1999; Issac-Henry \& Painter 1991; Pullin \& Haidar 2003);

- $\quad$ functional roles of councillors (Frere 2006; Martin 1997; Wilson (2003a); and

- $\quad$ leadership roles of the mayor (Elcock \& Fenwick 2007; Fenwick \& Elcock 2005; Tremaine 2000).

The literature generally related to councils in the United Kingdom and New Zealand although Jones (1999) was sourced from Australian local government experiences, with Frere (2006) and Pullin and Haidar (2003) pertaining to Victorian local government. Any assessment of the Victorian literature needs to be considered in the context that Sections 76B-81 of the Local Government Act (1989) prescribed behaviours expected of councillors, establishment of codes of conduct, declarations of conflict of interests and pecuniary interests.

\section{iii. Chief executives in local government}

In Victoria the chief executive of a municipality is a five-year appointment. This person is the council's 'chief administrative and local laws officer'. The literature identified the following themes of local government 'governance' and 'chief executives':

- $\quad$ leadership in voluntary organisations (Dartington 1996);

- $\quad$ strategic vision in local government (Asquith 1998; Issac-Henry \& Painter 1991);

- $\quad$ influences on management in Australian local government (Diamond 2007; Hoque 2005; Van Gramberg \& Teicher 2000); and

- $\quad$ relationship between the chair and the chief executive (Gaughan 2001).

The literature was generally from the United Kingdom. Hoque (2005) however related to Australia and Diamond (2007) and Van Gramberg and Teicher (2000) specifically related to Victorian local government. Van Gramberg and Teicher (2000) and Hoque (2005) reviewed the chief executive from the perspective of state governments that were reforming local government. Asquith (1998), Dartington (1996), Diamond (2007) and Issac-Henry and 
Painter (1991) examined the organisational impact of the chief executive within a single organisation.

In considering the relevance of the literature it was important to clarify both the perspective of the author and the historical period. Van Gramberg and Teicher (2000) noted that the reformist agenda in the 1990s for Victorian local government was to develop and 'marketize and managerialize relationships' within councils and to adopt a business-like culture (Van Gramberg \& Teicher 2000, p. 489). These authors identified the paradox of the rhetoric of the 'empowered new public manager' and the reality of intensified Victorian Government control and analysis of councils' activities.

However, Hoque (2005) in his analysis of the impacts of reforms in Australian local government noted the increased emphasis upon internal efficiencies and the shift from political accountability to managerial accountability in public sector delivery of services. Dartington (1996) discussed the struggles which can occur between the chair of the voluntary committee and the chief executive. He argued that unresolved conflicts can be the source of many difficulties and considered that one of the more problematic areas was varying influences of the chair and chief executive and the dynamics of their relationship. Gaughan (2001) in her analysis of the leadership in the National Health Service in the United Kingdom noted that for the organisation to operate successfully, an assessment or understanding of leadership styles between the chair of the board of directors and the chief executive was important. The observations of Dartington (1996) and Gaughan (2001) are pertinent for the relationship between the mayor and the chief executive in local government audit committees as they allude to underlying tensions.

Issac-Henry and Painter (1991) in their analysis of the management of systemic organisational change in local government argued that the leadership role of the chief executive was to provide coherent direction and articulate organisational values (p. 9). This view was supported by Asquith (1998), who noted that the success of a chief executive in local government, in gaining 'legitimacy for his/her organisational vision, can only be measured by the extent it is supported and owned by all individuals' within council (p. 263). Diamond (2007) in her analysis of gender as an enabler or hindrance for successes of a chief executive noted that the ability to positively engage with councillors was crucial for organisational success. This observation was also supported by Frere (2003). 


\section{iv. Local Government Act (1989)}

In November 2003, the Legislative Council of the Parliament of Victoria amended the Local Government Act (1989). The relevant reforms applicable to this thesis related to Part 4 Council Administration and Division 1A - Conduct and Interests in the Local Government Act (1989), namely the management of councillors and the mayor and their conduct whilst in office. Under the Local Government Act (1989):

- $\quad$ the mayor is required to take an oath of office (Section 63);

- the mayor undertakes duties in the best interests of the municipality and to exercise power impartially; and

- $\quad$ mayoral allowances are authorised in Section 74 of the Local Government Act (1989) and amounts are detailed in the Victorian Government Gazette (2008, p. 2787).

The capacity of councils to affect decisions on behalf of the community is prescribed in Section 82-93A of the Local Government Act (1989). All council decisions, except those in specific categories, must be made in open meetings. Section 89 requires the opening of meetings to the public.

Councils must not appoint (to the staff) any person who has been a councillor within two years after he/she ceases to hold that office (Section 102). If a council does so, the appointment will be voided. The Minister for Local Government has the power to suspend a council if the Minister identified a serious failure to provide effective local government or the council had acted unlawfully (Section 66A of the Local Government Act 1989). The ethical behaviour of councillors is prescribed in the Local Government Act (1989) in terms of:

\footnotetext{
- $\quad$ code of conduct;

- $\quad$ rules for conduct;

- $\quad$ conflict of interest;

- $\quad$ disclosure of gifts;

- $\quad$ confidentiality;

- $\quad$ transparent decision making; and

- $\quad$ code of conduct for council staff.
}

All councils are required to develop a Code of Conduct (Section 76C) and the Act requires the council's Code of Conduct to specify: (1) the rules for the conduct of councillors; (2) processes to be followed for the management of conflicts of interest; (3) processes to resolve disputation between councillors; and (4) 'caretaker' processes which will apply in an election period. 
Councillors are required to act honestly; use reasonable skill and care; not misuse their position; and not misuse information (Sections 76B-77). Prior to 2003, the Local Government Act (1989) did not adequately deal with the issue of non-pecuniary conflicts of interest. Previously, the Local Government Act (1989) required councillors and members of special council committees to declare their interests and abstain from voting (if they had pecuniary interests) and to be absent while the issue was discussed (Sections 86 and 87). The 2003 revision required councillors to declare any interests in matters being considered before council (or a special committee). If their interests were deemed pecuniary or conflicted with their public duty, a conflict of interest was declared and councillors abstained from voting (Sections 77A-79). To ensure clarity and adherence to the Local Government Act (1989) 'direct and indirect interests' are defined in Sections 77A and 77B. The Local Government Act (1989) further defined indirect interest by close association (Section 78); indirect interest by an indirect financial interest (Section 78A); indirect interest because of conflicting duties (Section 78B); indirect interest because of the receipt of an applicable gift (Section 78c); and indirect interest as a consequence of becoming an interested party (Section 78D).

Whilst the Local Government Act (1989) had attempted to define various circumstances where a conflict of interest could arise, it was generally not possible to define every circumstance where something could be deemed legitimate or illegitimate. Within Australian jurisprudence, the test of 'reasonableness' can often turn upon the interpretation of what a reasonable man (the man on the Clapham Omnibus) would view as reasonable (Donoghue $v$ Stevenson [1932] AC 562 in Vermeesch \& Lindgren 1978, p. 251). Whilst this definitional test arose from a tort case, it was important to note that 'where any person exercises a calling, the law requires him, in dealing with other people in the course of that dealing, to exhibit the degree and skill or competence, which is usually associated with its efficient discharge' (Vermeesch \& Lindgren 1978, p. 251). From a local government perspective, the test of reasonableness was not that the councillor or staff member believed something to be legitimate and reasonable. Rather, it was the more objective test, that there was sufficient reason in hindsight for the full council (in reviewing a councillor) and the chief executive officer (in reviewing a staff member) to believe that a conflict of interest did not arise.

Councils are required under Sections 76B and 95 of the Local Government Act (1989) to ensure that councillors and staff act in the community's interest. This should be borne in mind when considering what is 'reasonable', in relation to a conflict of interest. Under Section 95 of the Local Government Act (1989) all staff must act impartially, avoid conflicts 
of interest, be accountable for outcomes and provide a responsive service to the community and stakeholders.

Following the aforementioned dismissal of the Brimbank City Council by the state government in 2009 and the appointment of an administrator till council elections in November 2012, the Ombudsman, Victoria (2009a) recommended that the Local Government Act (1989) be amended to prohibit any persons being employed as electoral officers, ministerial and parliamentary advisors or be employed by a federal or state parliamentarian from becoming or continuing to serve as a councillor in Victoria. The Ombudsman, Victoria considered there was a direct conflict of duty in being an employee of a Commonwealth or state parliamentarian and a councillor at the same time.

The state government stated that the recommendation would be implemented (Municipal Association of Victoria 2009, p. 1). Dowling (2009) in his assessment of the governance issues in local government stated that the Ombudsman's Report of the Brimbank City Council had exposed councillors in that they were 'using local resources to do favours for parts of the community, often ethnic groups, who returned the favour by joining ALP local branches to help factional warlords and state and federal MPs' (p. 9). In the Victorian Parliament, Legislative Council member Inga Peulich stated in June 2009:

\begin{abstract}
Since the exposé of the Brimbank affair and of Labor's municipal rules, which require Labor-endorsed and Labor-supported councillors to caucus before council meetings - a practice that is clearly against the Local Government Act - and since the direction given by the Minister for Local Government, Mr Wynne, to councillors pertaining to their conduct and a requirement that they make decisions without bias, the lack of an effective complaints system operating in the sector and inadequate reporting and scrutiny of this sector have become serious matters for the government to address (Parliament, Victoria 2009, p. 3325).
\end{abstract}

The implications arising from councillors' misconduct are detailed in Section 4.3 in Chapter Four.

\title{
v. Audit committees
}

As noted in Chapter One audit committees have been mandated, since February 2004, as an extension of the governance process and the Auditor-General, Victoria is the external auditor of all local government councils and entities. In Chapter Three it is noted that a point of difference between local government in Victoria and New South Wales is the longevity of audit committees in Victoria as compared to the embryonic nature of audit committees in New South Wales. 


\section{vi. Resources to assist with the management of governance}

Local Government Victoria is a business unit within the Victorian Department of Planning and Community Development and works collaboratively with councils to ensure responsive and accountable governance outcomes. Local Government Victoria has provided advice and guidance in relation to governance, for example: (1) conflict of interest; (2) conduct of councillor and councils; (3) councillors' and mayors' entitlements and expenses; and (4) code of conduct for councils, councillors, council officers and the community to meet their obligations under the Local Government Act (1989) (Figure 2.4).

\begin{tabular}{|c|c|c|}
\hline Reference & Publication & Summary \\
\hline $\begin{array}{l}\text { Local Government } \\
\text { Victoria 2009a }\end{array}$ & $\begin{array}{l}\text { Conflict of Interest in Local } \\
\text { Government }\end{array}$ & $\begin{array}{l}\text { The Local Government Act (1989) was amended in } 2008 \\
\text { to include new conflict of interest rules for councils. The } \\
\text { new rules clearly define conflicts of interest. }\end{array}$ \\
\hline $\begin{array}{l}\text { Local Government } \\
\text { Victoria 2009b }\end{array}$ & Register of Interests Guide & $\begin{array}{l}\text { All councillors, members of council special committees } \\
\text { and nominated staff must disclose particular private } \\
\text { interests that have the potential to become conflicts of } \\
\text { interest. }\end{array}$ \\
\hline $\begin{array}{l}\text { Local Government } \\
\text { Victoria 2009c }\end{array}$ & $\begin{array}{l}\text { Guide to Councillor } \\
\text { Conduct Arrangements }\end{array}$ & $\begin{array}{l}\text { The Guide details the standards of conduct and } \\
\text { expectations for councillors. It provides an analysis of the } \\
\text { functions of Councillor Conduct Panels and the Victorian } \\
\text { Civil and Administrative Tribunal in dealing with } \\
\text { councillor misconduct. }\end{array}$ \\
\hline $\begin{array}{l}\text { Local Government } \\
\text { Victoria 2009d }\end{array}$ & $\begin{array}{l}\text { Mayor and Councillor } \\
\text { Entitlements Information } \\
\text { Guide }\end{array}$ & $\begin{array}{l}\text { The purpose of the Guide was to assist councils, council } \\
\text { staff and the community to understand the entitlements of } \\
\text { mayors and councillors in relation to expenses } \\
\text { reimbursement and the provision of facilities and } \\
\text { resources support. }\end{array}$ \\
\hline $\begin{array}{l}\text { Local Government } \\
\text { Victoria 2008j }\end{array}$ & $\begin{array}{l}\text { Ensuring Unbiased } \\
\text { Democratic Council } \\
\text { Decision Making: } \\
\text { Principles to Guide Good } \\
\text { Practice }\end{array}$ & $\begin{array}{l}\text { The purpose of the Guide was to assist councillors in } \\
\text { understanding the rule of bias as it relates to their role as } \\
\text { decision makers. } \\
\text { The Guide also provided advice on how to ensure that } \\
\text { councillors' actions are free from bias and offers } \\
\text { suggestions on steps which could be taken if bias was } \\
\text { relevant to a proposed decision. }\end{array}$ \\
\hline $\begin{array}{l}\text { Local Government } \\
\text { Victoria 2008k }\end{array}$ & $\begin{array}{l}\text { Recognition and Support: } \\
\text { The Victorian Government's } \\
\text { Policy Statement on Local } \\
\text { Government Mayoral and } \\
\text { Councillor Allowances and } \\
\text { Resources }\end{array}$ & $\begin{array}{l}\text { The Minister for Local Government, on } 8 \text { May 2007, } \\
\text { appointed a Local Government (Councillor Remuneration } \\
\text { Review) Panel to advise on remuneration of Victoria's } \\
\text { locally elected leaders through a review of current } \\
\text { allowances. And further, to provide advice and } \\
\text { recommendations to the Minister on allowances and } \\
\text { guidelines on the appropriate reimbursement of expenses } \\
\text { and provision of resources support for mayors and } \\
\text { councillors. }\end{array}$ \\
\hline $\begin{array}{l}\text { Local Government } \\
\text { Victoria 2007b }\end{array}$ & $\begin{array}{l}\text { Better Local Governance: } \\
\text { Consultation Paper }\end{array}$ & $\begin{array}{l}\text { This Paper discussed behavioural standards associated } \\
\text { with councillor's conduct as required under the Local } \\
\text { Government Act (1989). }\end{array}$ \\
\hline
\end{tabular}




\begin{tabular}{|l|l|l|}
\hline $\begin{array}{l}\text { Local Government } \\
\text { Victoria } 2004\end{array}$ & Model Code of Conduct & $\begin{array}{l}\text { This document was developed to assist councils and } \\
\text { councillors to meet their obligations under the Local } \\
\text { Government Act (1989). }\end{array}$ \\
\hline
\end{tabular}

\section{Figure 2.4 Governance resources - Local Government Victoria}

The Municipal Association of Victoria has provided governance policy advice to councils to improve the level of transparency, fairness and prudent decision making (Figure 2.5). The Local Government Professionals (LG Pro), as the peak organisational body for staff within Victorian local government, offers material and advice ranging from: (1) community consultation processes; (2) council planning; (3) community safety; (4) engineering services; (5) councillor support; and (6) family, youth and children’s services.

\begin{tabular}{|l|l|l|}
\hline \multicolumn{1}{|c|}{ Reference } & Publication & \multicolumn{1}{|c|}{ Summary } \\
\hline $\begin{array}{l}\text { Municipal Association } \\
\text { of Victoria 2008e }\end{array}$ & $\begin{array}{l}\text { Submission to the Better } \\
\text { Local Governance } \\
\text { Consultation Paper }\end{array}$ & $\begin{array}{l}\text { The Municipal Association of Victoria supported the } \\
\text { Local Government Consultation Paper: Reforms to } \\
\text { Support Councillor Conduct and Other Matters. Its } \\
\text { submission noted that a number of government proposals } \\
\text { introduced a greater level of prescription to local } \\
\text { government processes, which was contrary to } \\
\text { government policy. }\end{array}$ \\
\hline $\begin{array}{l}\text { Municipal Association } \\
\text { of Victoria 2008f }\end{array}$ & Citizen to Councillor & $\begin{array}{l}\text { The document provided a summary of council meetings } \\
\text { and meeting procedures including confidential } \\
\text { information and pecuniary interests. }\end{array}$ \\
\hline $\begin{array}{l}\text { Municipal Association } \\
\text { of Victoria 2007 }\end{array}$ & Councillor Misconduct \\
of Victoria 2005 & $\begin{array}{l}\text { The document provided Municipal Association of } \\
\text { Victoria views on councillor misconduct. }\end{array}$ \\
\hline $\begin{array}{l}\text { Municipal Association } \\
\text { of Victoria 2004a }\end{array}$ & $\begin{array}{l}\text { Gow to Develop a Code of } \\
\text { Governance Guide }\end{array}$ & $\begin{array}{l}\text { The purpose of this document was to assist councils to } \\
\text { meet their statutory obligation to develop and adopt a } \\
\text { code of conduct. }\end{array}$ \\
\hline $\begin{array}{l}\text { Municipal Association } \\
\text { of Victoria 2004b }\end{array}$ & $\begin{array}{l}\text { Citizen to Councillor, } \\
\text { Meeting Procedures }\end{array}$ & $\begin{array}{l}\text { The purpose of this document was to assist councils to } \\
\text { implement the code of conduct. } \\
\text { This document provided an overview of meeting and } \\
\text { council processes including the declaration of any } \\
\text { pecuniary interests. }\end{array}$ \\
\hline $\begin{array}{l}\text { Municipal Association } \\
\text { of Victoria 2004c }\end{array}$ & $\begin{array}{l}\text { Developing a Code of } \\
\text { Conduct Advisory Note }\end{array}$ & $\begin{array}{l}\text { This document provided an overview of meeting } \\
\text { procedures, including dealing with confidential } \\
\text { information and in situations where there was a pecuniary } \\
\text { interest in a matter before council. }\end{array}$ \\
\hline
\end{tabular}

\section{Figure 2.5 Governance resources - Municipal Association of Victoria}

\section{vii. Codes of conduct for Victorian local government councils}

Codes of conduct for council and councillors have been in place in local government since 1996 to meet the requirements of the Local Government Act (1989), for example, the Codes of Conduct of Manningham City Council and Whitehorse City Council (Manningham City 
Council 2006; Whitehorse City Council 2007). The most recent amendment was prescribed in November 2008 in the Local Government Amendment (Councillor Conduct and Other Matters) Act (2008), requiring councils to develop and approve a councillors' Code of Conduct by November 2009 and to review the councillors' Code of Conduct within twelve months after the election of the council.

Local Government Victoria (2004) produced a Model Code of Conduct which enabled councils to use the template, for example, Manningham City Council (2006) and Whitehorse City Council (2007). The Model Code of Conduct was not a directive from Local Government Victoria, as Section 76C of the Local Government Act (1989) prescribed the mandatory components to be included in the council's Code of Conduct and it was for each council to adopt a Code of Conduct that was appropriate to each council's circumstances.

\section{Duties of a councillor}

A council's Code of Conduct is required to include the full wording from Section 76BA of the Local Government Act (1989), namely:

A councillor must-

(1) Avoid conflicts between his or her public duties as a councillor and, his or her personal interests and obligations;

(2) Act honestly and avoid statements (whether oral or in writing) or actions that will or are likely to mislead or deceive a person;

(3) Treat all persons with respect and have due regard to the opinions, beliefs, rights and responsibilities of other councillors, council officers and other persons;

(4) Exercise reasonable care and diligence and submit himself or herself to the lawful scrutiny that is appropriate to his or her office;

(5) Endeavour to ensure that public resources are used prudently and solely in the public interest;

(6) Act lawfully and in accordance with the trust placed in him or her as an elected representative; and

(7) Support and promote these principles by leadership and example and act in a way that secures and preserves public confidence in the office of councillor.

Section 76D of the Local Government Act (1989) specifies the maximum penalty of up to 100 penalty units (\$A11,682 in the 2009-2010 financial year) under the Monetary Units Act (2004) for improper use of the position of councillor or the improper use of information acquired from the position of councillor. Section 81K of the Local Government Act (1989) also provided a range of penalties for a councillor convicted of misconduct, serious misconduct and gross misconduct. In instances of serious misconduct or gross misconduct by an individual councillor, Section $81 \mathrm{~K}$ (5) of the Local Government Act (1989) enables the 
Civil and Administrative Tribunal to direct that the councillor be ineligible to hold the office of mayor for the remainder of council's term.

\section{viii. Review of the Code of Conduct - Manningham and Whitehorse City Councils}

The councillor's reference manuals (Manningham City Council 2006 and Whitehorse Council 2007) mirrored the specific requirements of the Local Government Act (1989) in relation to Code of Conduct. Both reference manuals contained additional information including council policies in relation to:

- $\quad$ how to work with the community;

- $\quad$ obligations and responsibilities of being a councillor;

- $\quad$ management of official functions;

- $\quad$ management of petitions and joint letters;

- $\quad$ charters of major committees of council including the audit and risk committee; and

- $\quad$ council bylaws in relation to: reserves, roads, management of public places, environmental amenity and the enforcement of local laws.

The Whitehorse councillor's manual also contained information in relation to:

- $\quad$ demography of the municipality;

- $\quad$ administrative structure of council;

- $\quad$ councillor's support and policies and procedures;

- $\quad$ process for the setting of council's budget; and

- $\quad$ financial reporting.

Financial management of income and expenses is of paramount importance to councils. Publications produced by the Auditor-General, Victoria, CPA Australia and the Institute of Chartered Accountants may be seen to assist councillors in the discharge of their financial obligations including:

- $\quad$ Internal Financial Reporting in Local Government (Auditor-General, Victoria 2005c);

- Victorian City Council Model Budget 2009/2010 Guide (Institute of Chartered Accountants 2009); and

- $\quad$ Excellence in Governance for Local Government Manual (CPA Australia 2005).

The Municipal Association of Victoria also provided guidance materials for councillors in order for them to understand: (1) financial pressures on local government (Municipal Association of Victoria 2008b, 2008c 2008d); (2) intergovernmental agreements; (3) source of revenue and expenditure in councils; and (4) the preparation of budgetary submissions to the Victorian Government. 
The relevance of governance principles and practices for local government in this thesis are: (1) the balancing of social and regulatory objectives with the commercial imperative 'so that each can be pursued for its own sake' (Farrar, 2008 p. 470); (2) the authority of the council to give clear direction to management to accomplish commercial and social objectives; (3) performance monitoring and assessment; (4) rewards and sanctions; (5) implications of governance theories, (also refer to Section 3.3 pp. 76-83; and (6) duties of care by councillors and management.

\subsection{Summary}

This chapter has discussed corporate governance theories and practices in the private and public sectors. The purpose of effective corporate governance is to balance the interests of shareholders with the interests of stakeholders, the maximisation of wealth for private sector shareholders and wealth of the community for public sector bodies. This chapter noted the major point of difference between public and private sector governance under the Corporations Act (2001). There is also the added governance dimension relating to the management of public policy outcomes and the political process with differing stakeholder expectations. A public sector body can potentially have unfettered power, which needs to be counter-balanced by transparency, accountability and effective governance to ensure fairness and the effective management of physical, human and financial resources on behalf of the community.

In Chapter Three, the theory of audit committees in local government is developed. This chapter asserts that an effective audit committee within local government can be one of governance mechanisms to monitor risk within the organisational culture of council, notwithstanding that council and individual councillors are ultimately responsible for effective governance. 


\section{CHAPTER THREE: AUDIT COMMITTEES}

Chapter Three will outline the theories associated with effectiveness of audit committees, their application to public sector governance and Victorian local government.

Audit committee effectiveness is introduced in Section 3.1, Section 3.2 includes: (1) a literature review of audit committees (Section 3.2.1); (2) context of the audit committee literature (Section 3.2.2); (3) role of the audit committee (Section 3.2.3); (4) recent audit committee literature (Section 3.2.4) and audit committee literature in Australia (Section 3.2.5). In Section 3.3 management theories and their application to audit committees are discussed. These theories can provide interpretative lenses to assess audit committee practices and they are the prelude to discussion of the attributes of audit committee effectiveness in Section 3.4. Public sector audit committees are discussed in Section 3.5 followed by local government audit committees in Section 3.6. An alternative way of measuring audit committee effectiveness using the McKinsey 7S theory (Waterman et al. 1980) is discussed in Section 3.7. In Section 3.8 the context of the audit committee literature for this research is discussed. Section 3.9 summarises the chapter.

\subsection{Background to effectiveness of audit committees}

The effectiveness of audit committees as part of the governance process within organisations is a topical subject in the academic literature (Aiyesha 2005; Melendy 2005; Raghunandan \& Rama 2007; Turley \& Zaman 2007, 2004). This can be partially attributed to the reaction to corporate failures (Jubb 2000; Rogers 2006; Siladi 2006; Ziolkowski 2005). The corporate collapses, for example: Enron (Gini 2004; Hamilton 2004; Mullins 2004); WorldCom (Ahrens 2005; Gettler 2005a, 2005b; Hartley 2005); HIH Insurance (HIH Royal Commission 2003); and the National Safety Council (Sykes 1994; Parliament, Victoria 1991) were the catalyst for the plethora of investigative reports, legislation and changes in governance practices, for example: HIH Royal Commission (2003) and audit committees (Higgs 2002; Ramsey 2001; Smith 2003).

In this thesis 'effectiveness of the audit committee' has been defined to mean the functional relationship between the authority and composition of the audit committee and the specific measurement of outcomes or accomplishments. DeZoort et al. (2002) provided a workable definition of the effectiveness of an audit committee: 
An effective audit committee has qualified members with the authority and resources to protect stakeholders interests by ensuring reliable financial reporting, internal controls and risk management through diligent oversight efforts (p. 41).

DeZoort et al. (2002) stated that audit committees are formed to protect the interests of shareholders, as agency theory holds that management may not always act in the interests of the entity's owners. There is a limitation imposed on an audit committee to the extent that an audit committee only meets periodically and deals with complex, but limited second-hand information provided by management (DeZoort et al. 2002, p. 41). There is an expectation gap (AICPA 1978 generally known as the 'Cohen Commission'; Liggio 1974) and the audit expectation-performance gap (Porter 1993), which represented the gap between societal expectations and auditors' performance. The performance gap has two sub-categories, namely: the deficient standards gap (what can be expected from auditors' duties as defined by the law or professional standards) and the deficient performance gap (the expected standard of performance by auditors and perceived performance as expected and perceived by the public).

The effectiveness of the audit committee can be dependent on the 'goodwill' of management, but agency theory suggests that management may operate under different paradigms. Despite this limitation, stakeholders expect audit committees to provide effective oversight and protect their interests (DeZoort et al. 2002, p. 41).

\section{i. Influences in the literature}

Carcello et al. (2011) undertook a meta-analysis of governance and audit committee literature and noted the repetition of empirical findings equating 'good' governance with 'good' outcomes. They considered that recent corporate regulatory reforms had reduced previously reported variations in audit committee independence and financial reporting and publicly listed companies now had similar and stronger governance mechanisms. Their observations were also confirmed in the literature review in this thesis and implications for the research in Chapter Six are detailed in Section 3.8.

In undertaking the literature review, it was noted that only a small number of research articles specifically related to local government audit committees, although there were practice guides from accounting bodies and oversight agencies. As a consequence, it was decided to review the general literature on audit committees and look for relevant linkages for local 
government audit committees even though the Local Government Act (1989) and Corporations Act (2001) prescribed governance and audit committee practices.

\section{ii. Audit committees in the private sector}

In assessing the components which contribute to the effectiveness of the audit committee, it is important to differentiate between accountabilities and activities of the audit committee. The Sarbanes-Oxley Act (2002) was influential in international governance principles and practices, but was more prescriptive than: Australian CLERP 9 (Department of Treasury 2002); governance requirements of the Australian Stock Exchange (2007); guidance provided by the Australian National Audit Office (2003) for Commonwealth Government bodies and entities; and the State Services Authority (2007a) for Victorian public sector bodies.

As noted in Chapter One, the Sarbanes-Oxley Act (2002) has no relevance in Australian jurisprudence. This has been noted in this thesis because of its importance in American corporate life and its influence in recent American governance and audit committee empirical research.

A number of reviews, both within Australia and the United Kingdom, have recommended the strengthening of audit committees as part of the process of effective governance, for example:

- $\quad$ Report on the Role and Effectiveness of Non-Executive Directors, United Kingdom

(Higgs 2002);

- $\quad$ Report on Audit Committees: Combined Code Guidance (Smith 2003); and

- $\quad$ Report on the Principles of Good Corporate Governance and Best Practice Recommendations (Australian Stock Exchange 2007, 2003).

Higgs (2002) recommended incorporating a greater proportion of independent, betterinformed individuals as directors of boards and a greater transparency and accountability by boards for their actions. Conversely, Smith (2003) prescribed key elements of the role of the audit committee, with particular emphasis on reinforcement of external auditor's independence and maintaining the integrity of financial statements. Key proposals included provisions on the supply of non-audit services and increases in transparency and resources for the audit committee.

The Commonwealth Department of Treasury (2002) in the Report on Proposals for Reform Corporate Disclosure, recommended it be mandatory for the top five hundred companies to 
have an audit committee. The report also affirmed the conclusions of Ramsey (2001) by stating:

...that having an audit committee per se is not enough; it is essential that the audit committee has the necessary attributes to render it an effective corporate governance mechanism (Department of Treasury 2002, pp. 75-6).

Ramsey (2001) considered that:

- $\quad$ an effective audit committee should exist in both form and substance and be active;

- there is a functional relationship between the composition of the audit committee and effectiveness and independence are the most important of these factors; and

- $\quad$ members of the audit committee should be financially literate (pp. 85-9).

The Australian Stock Exchange $(2007,2003)$ in relation to 'good corporate governance and best practices' prescribed that all entities included in the S\&P/ASX All Ordinaries Index at the beginning of the financial year should have an audit committee and comply with recommendations of the ASX Governance Council as detailed in Principle $4 .^{9}$

\section{iii. Audit committees in the public sector}

The significance of the regulatory environment, both internationally and within Australia, was that it influenced public sector governance practices including audit committees. However, audit committee guidelines from the Department of Infrastructure (2000) and draft consultation guidelines from the Department of Planning and Community Development (2011, 2009) provided the framework under which local government audit committees operate within Victoria.

A limitation of a prescriptive regulatory approach to governance and audit committees can have unintended consequences, as compliance costs by audit committees are resource intensive. Also, the sovereign regulatory environment in which public sector entities operate was fundamental to understand the academic literature in relation to audit committees, as some observations and conclusions from one legal jurisdiction are not applicable to another.

Whilst corporate governance was an extensive area within the academic literature, the effectiveness of audit committees as a subset of public sector governance was limited. There

\footnotetext{
${ }^{9}$ Principle 4 related to the integrity of financial reporting and prescribed: (1) an audit committee should be established; (2) the structure of an audit committee; (3) the requirement for formal charters for audit committees; and (4) reporting from the audit committee to the board.
} 
was also a specific knowledge gap associated with the effectiveness of audit committees in local government in Australia and specifically in Victoria. However, there was considerable support and guidance for the operations of audit committees in the public sector, for example, Association of Government Accountants (2008); Cameron (2008, 2004); Chartered Institute of Public Finance and Accountancy (2004); Controller and Auditor-General, New Zealand (2008b); Department of Local Government (2008b); Department of Local Government and Regional Development (2006); HM Treasury (2007); Institute of Public Finance (2006) and National Audit Office (2007a, 2007). It was also noted that the effectiveness of audit committees in local government had been examined in both Wales and Scotland, by Davies (2009) and Crawford, Henry, McKendrick and Stein (2008) respectively, with West and Berman (2003) having undertaken a national survey of the effectiveness of local government audit committees in the United States of America (Section 3.6).

For public sector audit committees in Australia, the starting point for audit committee and governance practices is the Corporations Act, 2001 and Corporate Governance Principles and Recommendations (Australian Stock Exchange 2007), supplemented by public sector governance standards and ethos. For example, the Victorian Government has policies in relation to: (1) public sector governance (State Service Authority 2007a, 2006a, 2005; Public Sector Standards Commissioner 2006); (2) financial management (Local Government Victoria 2003); (3) audit committees in local government (Department of Infrastructure 2000; Department of Planning and Community Development 2011, 2009); and (4) a model code of conduct for councils (Local Government Victoria 2004; Ombudsman, Victoria 2008).

These policies were complemented by the perspectives of the Auditor-General, Victoria on local government audit committees (Cameron 2008, 2004; Pearson 2008). As noted in Chapter Two audit committees in Victorian local government became a requirement from 1 February 2004 as prescribed in Section 139 of the Local Government Act (1989).

\subsection{Effectiveness of audit committees}

\subsubsection{Review of the literature}

The review of audit committee literature identified a number of articles which had a compliance and regulatory perspective to audit committee effectiveness. This was particularly so for the American literature; for example, Carcello et al. (2011) grouped the 
outcomes from two hundred and fifty empirical research papers from 2003 to 2010 into categories of:

- $\quad$ governance and accounting outcomes, including fraudulent reporting and restatements;

- $\quad$ auditing including auditor selection, audit fees and auditor risk assessment;

- $\quad$ audit committee compensation;

- $\quad$ audit committee processes;

- $\quad$ audit committee judgements; and

- $\quad$ the impact of fraudulent accounting for directors (Carcello et al. pp. 6-9).

The primary purpose of an audit committee was to assist the directors by providing organisational oversight, which is independent of management. In relation to audit committee performance, there is not necessarily a clear-cut or precise understanding of what drives effectiveness and the 'compliance school' approach to audit committees often focuses on externally quantifiable data and the relationship to financial performance, for example, Agrawal and Chadha (2005), Bedard, Chtourou and Courtea (2004) and Klein (2002). The difficulty of using this approach is that available data, for example, the number of meetings attended by audit committee members and the tenure of audit committees, does not have a direct causal relationship with financial performance and outcomes of the organisation. The literature review identified 'associated relationships', rather than a nexus between financial performance and some attributes of the audit committee.

However, the 'performance approach' was essentially qualitative in nature and focused on what happens in audit committees and behaviours which contributed to effective audit committees, for example, Verschoor, Barrier and Rittenberg (2002) and Carcello and Neal (2000). The risk with the 'performance approach' is that it can be difficult to interpret and make comparisons with other organisations and as a consequence, to place a value on specific research outcomes. Also, qualitative data may have a self-reporting bias (Kolodinsky, Reynolds, Cannella, Timmons \& Bormberg 2009; Leroux, Rizzo \& Sickles 2010). Some 'key drivers' for an audit committee include: (1) survival and continuity of the business; (2) success in business; and (3) the ability of audit committee members to probe and question management (Sharma et al. 2009).

Compliance or a regulatory approach to audit committees in the literature was also affirmed by Bedard and Gendron (2009). Klein (2002) examined the relationship between audit committee characteristics and the earnings management of the firm. She concluded that there was: (1) an inverse relationship between audit committee independence and abnormal 
accruals; and (2) reductions in audit committee independence are accompanied by large increases in accruals. She concluded that boards which are structured to be independent of the chief executive were more effective in monitoring the financial accounting process. Other contributions to audit committee literature in relation to accounting statements and audit committee membership are detailed in Figure 3.1.

\begin{tabular}{|c|c|}
\hline $\begin{array}{l}\text { Accounting statements and } \\
\text { audit committees }\end{array}$ & $\begin{array}{l}\text { Bedard et al (2004) established that there was a negative association between } \\
\text { governance expertise and aggressive earnings management. Their conclusions } \\
\text { were a demonstration of an association and not necessarily a causal link } \\
\text { between the characteristics of the audit committee and earnings management. } \\
\text { Agrawal and Chadha (2005) considered that companies which had: (1) } \\
\text { independent boards; (2) independent audit committees; and (3) non audit } \\
\text { services were performed by accounting firms other than the statutory auditors, } \\
\text { were less likely to engage in the manipulation of earnings. } \\
\text { Carcello and Neal (2000) considered there was evidence of an inverse } \\
\text { relationship between corporate governance mechanisms, for example audit } \\
\text { committee composition and the likelihood of receiving a going-concern report. }\end{array}$ \\
\hline Audit committee membership & $\begin{array}{l}\text { Menon and Williams (1994) concluded that the formation of an audit } \\
\text { committee does not mean that the board of directors actually relies on the audit } \\
\text { committee to enhance its monitoring ability. } \\
\text { Verschoor et al. (2002) noted that audit committee members had discovered } \\
\text { that service on audit committees 'entails significant time and effort and } \\
\text { requires accountability when things go wrong' (Verschoor et al. 2002, p. 26). } \\
\text { They asserted that for audit committees to perform their increasing } \\
\text { responsibilities, as well as their traditional accounting duties, the audit } \\
\text { committee must be independent and possess financial knowledge (p. 30). } \\
\text { Spangler and Braiotta (1990) examined audit committee effectiveness in terms } \\
\text { of leadership styles of audit committee chairpersons. }\end{array}$ \\
\hline
\end{tabular}

\section{Figure 3.1 Selected summary of themes in the audit committee literature}

In more recent times, audit committees processes have been analysed by Beasley et al. 2009 and Gendron et al. 2004. Armitage (2011) and Magrane and Malthus (2010) discussed the creation of effective audit committees in the public sector in the United States of America and New Zealand respectively.

Given the volume of audit committee literature it was decided to selectively review the literature pertaining to 'audit committees' in relation to: (1) financial reporting; (2) governance; (3) financial experts; (4) independent experts; and (5) measures of effectiveness. 


\section{i. $\quad$ Financial reporting}

Bedard et al. (2004) examined whether there was a relationship between audit committee practices and the quality of financial reporting. They concluded that there was less likelihood of aggressive earnings management within a company, when there was: (1) the presence of a financial expert on the audit committee; (2) the audit committee was comprised of nonrelated directors; and (3) the audit committee had a clear mandate to oversee financial reporting processes (Bedard et al. 2004, p. 31). Agrawal and Chadha (2005) concluded that the probability of financial misstatement was lower in companies where audit committee members had financial expertise, but higher in family companies where the chief executive was a member of the founding family.

\section{ii. Governance}

Beasley et al. (2000) considered that 'fraud' and 'no-fraud' companies differed in terms of audit committee diligence and the existence of an effective internal audit function. The implications of the research for auditors and directors are that weak governance structures can provide the environment for fraudulent misconduct to continue unabated. Beasley et al. (2000) argued that 'any time governance structures are weak, auditors should evaluate the resulting impact on the audit' (p. 453). Carcello and Neal (2000) examined the relationship between the composition of financially distressed firms and their audit committees and the likelihood of those firms receiving a going-concern report. Similar to Bedard et al. (2004), Carcello and Neal (2000) considered their results were consistent with the audit committee affecting the audit reporting process, although they did note that they had only documented association and not causation (Carcello \& Neal 2000, p. 465).

\section{iii. Financial experts}

DeFond et al. (2005) concluded that there was a positive market reaction to the appointment of financial experts to audit committees as compared to non-accounting-related experts. They also found that there was a positive reaction in companies with strong governance structures, consistent with accounting expertise, 'possibly because strong governance helps channel the expertise towards enhancing shareholder value' (p. 154).

Engel (2005) reviewed the works of DeFond et al. (2005) and considered that their interpretation of the appointment of a financial expert to the audit improves corporate 
governance was too narrow. She considered that the market reaction was an expectation of 'value enhancement and not a direct measure of actual or ultimate improvements with the appointment' (Engel 2005, p. 203). She further questioned the veracity of the statement from DeFond et al. (2005) about positive market reaction and audit committee appointments and noted that alternative explanations had not been canvassed. Nevertheless, Engel concluded that the 'documented significant and positive average abnormal returns surrounding the announcements of accounting financial experts for firms with high corporate governance scores is an interesting and robust result' (2005, p. 204). Wild (1996) identified a relationship between the market's reaction to earnings' reports subsequent to the formation of an audit committee. Collier and Gregory (1999) noted that audit committees in companies in the United Kingdom were dependent upon the composition of the board of directors and audit committee activity was associated with the size of the company.

\section{iv. An independent expert}

Agrawal and Chadha (2005); Beasley et al. (2000); Bedard et al (2004); Carcello and Neal (2000); DeFond et al. (2005); Engel (2005); Klein (2002) and Wild (1996) found that an independent expert and a diligent audit committee were generally associated with higher quality financial reporting and auditing. However, Beasley et al. (2000) noted that these studies had not examined the processes by which the audit committee had contributed to improvements in financial reporting and auditing (p. 71). Menon and Williams (1994) noted that some companies may have an audit committee for 'image value', which was consistent with institutional theory. Their research concluded that reliance on the audit committee was a function of the composition of directors; with an increased proportion of outside directors on the board, companies were more likely to exclude officers from the audit committee; and audit committees were more active. They also found that frequency of audit committee meetings was related to size of the company.

Menon and Williams (1994) were writing well before corporate collapses in the United States of America, for example, Enron and WorldCom and the subsequent strengthening of corporate regulations. Their proposition of having an audit committee for 'image value' could, under the current regulatory environment of the twenty-first century, have the board of directors liable for breach of the Corporations Act (2001) in Australia or indeed a civil action for professional negligence. 


\section{v. 'Work of the Audit Committee'}

DeZoort (1997) examined the responsibilities of audit committees and the work they performed. His research concluded that some audit committee members believed they lacked the specific expertise in oversight areas of accounting, auditing and the law (DeZoort 1997, p. 210). This work predated the introduction of the Sarbanes-Oxley Act (2002) and consequentially some of his conclusions are now superseded by legislation. Governance and audit committee practices also need to be considered within a historical context, taking into account the impacts of corporate collapses in Australia, for example, $\mathrm{HIH}$ Insurance and Enron in the United States of America and the strengthening of legislative and listing rules including: the US Sarbanes-Oxley Act (2002); Principle 4.1 of the Corporate Governance Principles and Recommendations of the Australian Stock Exchange (2007); and requirement to form an audit committee in Victorian local government (Section 139 of the Local Government Act (1989)).

\section{vi. Measures of effectiveness}

These measures could easily be substituted from the relevant standards from the pronouncement of the Australian Stock Exchange (2007, 2003) and CLERP 9 from the Department of Treasury (2002). Braiotta and Zhou (2006) examined the effects of the Sarbanes-Oxley Act (2002) and the US Stock Exchange on audit committees. They concluded that companies aligned with an audit committee were more likely to be associated with large audit committees, higher directors' remuneration, higher audit committee independence and frequency of audit committee meetings (Braiotta \& Zhou 2006, p. 186).

Kalbers and Fogarty (1993) considered that the effectiveness of the audit committee was a function of type and extent of audit committee power. They stated that effectiveness consisted of three domains of oversight, namely: (1) financial reporting; (2) external auditors; and (3) internal control. In terms of organisational power, formal written authority coupled with observable support from the executive management team played an important role in audit committee power as it related to effectiveness (Kalbers \& Fogarty 1993, p. 24). They considered that audit committees 'need a strong organisational mandate, both through an adequate written charter and sufficient informal recognition by its constituents’ (p. 23).

Kalbers and Fogarty (1993) concluded that the effectiveness of the audit committee also required a 'supportive atmosphere from top management' but power from informal and 
formal sources, for example, audit charters, are inconsequential unless 'those with fortitude and ambition to enact these possibilities' operate the audit committee (1993, p. 22). They further stated that the expertise of audit committee members was important, but primarily for dealing with the complexities of financial reporting.

\subsubsection{Context of the audit committee literature}

\section{i. Regulatory regimes}

The audit committee literature had a strong North American flavour. It was noted that the United States of America had a more prescriptive corporate governance regime for the formation and continuity of audit committees, as compared with more voluntary corporate governance regimes in Australia, New Zealand, Spain, Singapore and the United Kingdom (Sharma, Naiker \& Lee 2009, p. 247). In these countries: (1) voluntary requirements for the formation of audit committees were needed; (2) the composition of the audit committee was recommended to be non-executive, as compared with the United States of America, where audit committee members should be independent; (3) the inclusion of a financial expert was recommended, but not necessarily an independent expert, except in the case of Singapore, where two experts were recommended, with a preference for independent status; and (4) financial literacy skills were recommended for audit committee members, except for New Zealand and Spain, where financial literacy skills were not prescribed (Sharma et al. 2009, p. 247).

\section{ii. Implications for local government}

An overt regulatory approach to governance and audit committee practices means that regulatory and compliance costs for audit committees can be an expensive utilisation of council resources. The more time taken up with compliance issues, the less time audit committees have to concentrate on the broader issues of: (1) current risks; (2) future council performance; and (3) identification and management of new risks. Audit committees also may struggle to get the balance right, with increased compliance and costs becoming selffulfilling prophecies. As a consequence, this can limit the audit committee's ability to focus upon operational performance and non-financial outcomes. 


\section{iii. Time period of the literature}

The review by McMullen and Raghunandan (1996) of audit committee effectiveness was written against the backdrop of the Reports from the Treadway Commission and the Public Oversight Board in the United States of America. They concluded that expertise in accounting, internal controls and auditing can be a key to audit committee effectiveness as well as the frequency of meetings. This was compared with Anonymous Author A (2002) in the CA Magazine, who noted that audit committees have been required in Canada since 1970. Anonymous Author A (2002) stated that in the wake of the Enron collapse in the United States of America, it was important for audit committees to demonstrate high standards of leadership, ethics and a commitment to performing their duties with integrity. McMullen and Raghunandan (1996) was compared with Anonymous Author B (2000), who stated that audit committees should remain 'at the oversight level' and would lose their effectiveness if they were required to review accounting compliance at a detailed level.

Lightle and Bushong (2000) discussed the effectiveness of audit committees as a consequence of the recommendations of the New York Stock Exchange and the National Association of Securities Dealers 'Blue Ribbon Committee on Improving Effectiveness of Corporate Audit Committees' (BRC). The BRC issued ten recommendations, which can be grouped into three themes that related to: (1) strengthening the independence of audit committees; (2) making audit committees more effective; and (3) improving accountabilities of the audit committee, auditors and management. Lightle and Bushong (2000) suggested the implementation of BRC recommendations in relation to effectiveness could be assisted through the implementation of a checklist for audit committee functions and for evaluating potential audit committee members. Krishnamoorthy et al. (2002a) commented on the effectiveness of BRC recommendations for audit committees. They concluded that in order for audit committees to be effective, they must have independence and financial competencies. It was also considered that it was 'important to look beyond the form (financial knowledge) of the audit committee and examine its substance (power, charge and will)' (Krishnamoorthy et al. 2002a, p. 57).

The implication from this is the need to go substantially beyond an audit committee checklist in order to measure effectiveness. A recent example of such a checklist approach was in the Australian National Office (2011) Public Sector Audit Committees, Independent Assurance and Advice, for Chief Executives and Boards, which provided a number of checklists to 
review financial statements, legal compliance, fraud control and internal audits. It also provided a number of self-assessment questions for audit committee members to reflect upon, which was consistent with other public sector publications, for example, the Department of Planning and Community Development (2011) for Victorian local government. Further contributions to the elements which contribute to audit committee effectiveness are noted in

Figure 3.2.

\begin{tabular}{|c|c|}
\hline $\begin{array}{l}\text { Krishnamoorthy et } \\
\text { al. (2002b) }\end{array}$ & $\begin{array}{l}\text { In an Australian survey of the quality of financial reporting quality, audit independence } \\
\text { and the effectiveness of audit committees, they concluded that in relation to audit } \\
\text { committee effectiveness, financial expertise, independence and diligence were important } \\
\text { attributes for a successful audit committee. }\end{array}$ \\
\hline Galvez (2003) & $\begin{array}{l}\text { It was concluded that an effective audit committee was a function of a good mix of audit } \\
\text { members with the right skills, expertise and competencies. }\end{array}$ \\
\hline $\begin{array}{l}\text { Richardson and } \\
\text { Baril (2003) }\end{array}$ & $\begin{array}{l}\text { They considered that the American corporate governance system depended on the } \\
\text { competence of audit committee members and ultimately hinged on independence. }\end{array}$ \\
\hline Hughes (2002) & $\begin{array}{l}\text { They stated that in the United Kingdom, there was a call for audit committees to challenge } \\
\text { management and auditors more effectively by asking the right questions. } \\
\text { This was an essential piece in the jigsaw of restoring confidence in companies, their } \\
\text { auditors and the integrity of the financial information (Hughes 2002, p. 37). }\end{array}$ \\
\hline
\end{tabular}

\section{Figure 3.2 Audit committee effectiveness}

From Figure 3.2, Krishnamoorthy et al. (2002b) stated that the effectiveness of the audit committee was a function of the 'tone ${ }^{10}$ set by the board of management. They noted that those organisations with ownership structures, which included independent directors, were more likely to have strong audit committees than medium-to-small companies with concentrated ownership. Consistent with the BRC Report, the survey identified independence and financial literacy/expertise as the major factors constituting an effective audit committee. Diligence (for example: active, interested and meeting frequently) and asking probing questions were considered to be important determinants of an effective audit committee. In relation to the question of diligence, Krishnamoorthy et al. (2002b) stated:

If audit committees have tough independent members, they will be more likely to question management and be an effective partner to the auditor in striving to establish a high quality financial reporting process (p. 10).

\footnotetext{
${ }^{10}$ COSO (2009) stated that the 'board's focus on effective risk oversight is critical to setting the tone and the culture towards effective risk management through strategy setting, formulating high-level objectives, and approving broad-based allocations' (p. 4).
} 
Galvez (2003) succinctly summarised the elements of an effective audit committee by stating that:

Translating the key principles of corporate governance from concepts to day-today implementation requires the commitment and dedication of competent and highly qualified individuals who are given the responsibility to be members of an audit committee. It cannot be overemphasized that the audit committee plays a pivotal role in the actual implementation of the corporate governance principles of fairness, accountability and transparency and in strengthening shareholder and investor trust and confidence (p.1).

Richardson and Baril (2003) considered that independence was a prerequisite for audit committee effectiveness and the legislative environment of the Sarbanes-Oxley Act (2002) reinforced that perspective. From the perspective of investors as stakeholders in an entity, independence 'in fact' and 'in appearance' was crucial. Richardson and Baril (2003) stated that:

Independence, in fact, requires that audit committee members' judgements are not tainted by their interests in management or in the auditor. Independence "in appearance" demands that a reasonable person with knowledge of the interests of the audit committee member would conclude that the member is objective (p. 35).

Hughes (2002) argued that the difficulty in achieving effective audit committees related to resources and diligence of the audit committee. This was complemented by similar findings from Kalbers and Fogarty (1993); Anonymous Author A (2002); Krishnamoorthy et al. (2002a, 2002b); and Galvez (2003) as previously noted. Hughes (2002) succinctly encapsulated the criterion for audit committee effectiveness by stating:

...however, in order really to be able to challenge management it [audit committee] must have the right resources. It is easy to forget that audit committees cannot provide effective oversight over the system of internal control and financial reporting unless they are independent of mind, knowledgeable and, crucially, in possession of relevant and reliable information (p. 37).

However, within the current Australian corporate regulatory environment, any open defiance or deliberate non-compliance with statutory obligations (e.g. the banking, finance and insurance sectors under the control of the Australian Prudential Regulation Authority (APRA) would be regarded as a statutory breach and would therefore be raised directly with the company's board as an issue of non-compliance. Wayne (2003) also revealed that the substance of the audit committee to achieve its obligations and outcomes was a functional relationship of the degree of trust in management and auditors (p. 87). Thus a higher level of cooperation and assistance from management and external auditors was axiomatic and directly proportional to levels of audit committee effectiveness. 


\subsubsection{Role of the audit committee}

Silver, Fleming and Riley (2008) considered that the audit committee needed to be cognisant of the potential for management fraud to occur through collusive company practices. They further recommended that diligent audit committees should enhance their understanding of the principles and processes underlying the preparation of accounting statements. Mohamed and Hussain (2005) reviewed the role of audit committees to enhance transparent corporate reporting. The authors noted that the most cited functions of an audit committee were to: (1) strengthen internal and external audit functions; (2) coordinate the work of auditors; (3) strengthen the positions of non-executive directors; and (4) assist the board to fulfil its legal obligations (p. 43). They argued that an audit committee can have limitations for example, it may encroach on management responsibilities and it can cause conflict within companies if the committee secretly communicates with external and internal auditors. The effectiveness of an audit committee, according to Mohamed and Hussain (2005), may be more apparent than real, as the power to appoint members sometimes rests with the chief executive, which can give rise to a conflict of interest. In these situations, there may be a tendency to 'rubber stamp' actions of the chief executive. Within the Australian context, directors and audit committee members have fiduciary obligations under the Corporations Act (2001) and stringent prudential reporting standards from APRA for audit committees in the banking, insurance and finance sectors. Mohamed and Hussain (2005) noted that some stakeholders have unrealistic expectations of the capabilities of audit committees, as the duties expected of them under legislation have broadened significantly (p. 42). However, these expectations can be reduced through the: (1) adoption of formal procedures and a charter for the audit committee; (2) consulting with management; and (3) conducting 'carefully planned, efficient and effective meetings' (Mohamed \& Hussain 2005, p. 43). Bromilow and Berlin (2005) provided an analysis of the issues that audit committees could consider in order to assess whether or not they have been effective for business. These included:

i. $\quad$ quality of financial reporting;

ii. risk management and internal control;

iii. compliance and ethics;

iv. oversight of management and internal audit;

v. relationships with external auditors;

vi. resources and investigations;

vii. composition of the audit committee;

viii. training;

ix. frequency of meetings; and

$\mathrm{x}$ roles and responsibilities of the audit committee. 
The contribution to the literature by Bromilow and Berlin (2005) is that they differentiated between the inputs to an audit committee (items vii to $\mathrm{x}$ ) and the framework to assess the quality of outcomes (items i to vi). In summary, the literature in relation to the role of the audit committee considered that an effective audit committee must comprise members who understood their obligations and accountabilities and were sufficiently skilled and experienced. Members needed to meet regularly in order to oversee such issues as financial reporting, the risk environment, managerial oversight and effective relationships with auditors. The knowledge and skills of audit committee members provides the attributes for the audit committee to operate effectively, whilst the actions of the audit committee (financial reporting, internal control and risk management), provides evidence to assess the credibility and diligence of the audit committee.

\subsubsection{Recent audit committee literature}

Although Carcello et al. (2011) noted the declining utility of certain research findings, the audit committee literature published in 2008 and 2009 was reviewed to ascertain whether any emerging themes emanated from the literature. Some examples are noted in Figure 3.3.

\begin{tabular}{|l|l|}
\hline $\begin{array}{l}\text { Bronson, Carcello, } \\
\text { (2009) }\end{array}$ & $\begin{array}{l}\text { They examined whether the requirements under the Sarbanes-Oxley Act (2002) } \\
\text { to have audit committee members in the United States of America independent } \\
\text { of management), was necessary to achieve the outcomes of improved audit } \\
\text { committee effectiveness. }\end{array}$ \\
\hline DeFond and Francis (2005) & $\begin{array}{l}\text { They concluded there was little evidence that fully independent audit } \\
\text { committees were associated with higher outcomes normally associated with } \\
\text { companies with effective governance practices (DeFond \& Francis 2005, p. 18). }\end{array}$ \\
\hline Klein (2002) & $\begin{array}{l}\text { She concluded that manipulation of earnings within a company was less likely } \\
\text { to occur if there were a higher number of independent directors on the audit } \\
\text { committee. }\end{array}$ \\
\hline Porter (2009) & $\begin{array}{l}\text { She considered that the 'audit committee has a pivotal and unifying role' to } \\
\text { oversee the work of internal and external auditors and review financial accounts } \\
\text { and other accountability reports before they are submitted to the board of } \\
\text { directors (Porter 2009, p. 178). }\end{array}$ \\
\hline Sharma et al. (2009) & $\begin{array}{l}\text { In relation to listed New Zealand companies, they concluded that: (1) audit } \\
\text { committees in high growth companies met less frequently, which was consistent } \\
\text { with the perspective that stringent internal monitoring was not conducive to } \\
\text { keeping pace with the rapid growth; (2) audit committees met more frequently } \\
\text { when management ownership was higher, which implied that the audit } \\
\text { committee was addressing some agency issues associated with managerial } \\
\text { power (p. 260). }\end{array}$ \\
\hline
\end{tabular}

Figure 3.3 Recent audit committee literature 
From Figure 3.3, Bronson et al. (2009) noted that previous research had primarily focused on the positive relationship between the audit committee and improved audit committee oversight without indicating how much independence was needed (p. 266). Bronson et al. (2009) concluded that for companies in financial stress, 'completely independent audit committees are associated with the highest level of audit committee effectiveness' (p. 266). They also noted that:

...wholly independent audit committees are (1) significantly positively associated with the likelihood that an audit firm issues a going-concern opinion to a financially distressed client and (2) negatively associated with the likelihood of auditor dismissal following the issuance of a going-concern opinion (Bronson et al. 2009, p. 266).

Carcello (2005) stated that the work by DeFond and Francis (2005) was an opinion on the state of financial reporting and auditing environment within the United States of America and the positioning of the influence that research 'has had, and could have on the issues affecting that environment' (p. 31). He noted that DeFond and Francis (2005) had questioned whether an audit committee entirely made up of independent members contributed to effectiveness. As previously mentioned, Klein (2002) concluded that there was no nexus between a fully independent audit committee and earnings management, but a move away from fully independent audit committee members increased the propensity for manipulation of financial earnings (p. 398). Porter (2009) examined the relationships between the audit committee, internal audit and external auditors, which she termed 'audit trinity' in order to secure and enhance corporate accountability. Her contribution to governance and audit committee literature related to her normative approach, appraising the values and norms which best fit the needs and expectations of stakeholders, for example, shareholders and creditors within a company.

Whilst Porter (2009) was much less prescriptive than Agrawal and Chadha (2005), Bedard, Chtourou and Courteau (2004) and Klein (2002), nevertheless her work loosely complemented them, as Porter provided a more generalised sociological interpretation of effective corporate governance and, in the context of this thesis, the audit committee. Sharma et al. (2009) examined the determinants of audit committee meeting frequency, using the context of voluntary corporate governance requirements in New Zealand. Their contribution to the literature related to the performance of audit committees in a non-prescriptive governance environment and they noted that research into audit committees in these environments was not widespread (Sharma et al 2009, p. 260). They further concluded that 
there was a negative association between the independence of the audit committee, the number of independent members and the frequency of meetings. This was consistent with the view that independent audit committee members provide a more objective monitoring of management (Sharma et al 2009, p. 261).

\subsubsection{Audit committee literature in Australia}

A review of the Australian literature on audit committees revealed similar themes to those observed in the American literature, although the influences of regulatory environments were different. Munro and Buckby (2008) reviewed developments in corporate governance and audit committees in Australia from 1974 to 2004. They noted that audit committees are:

...commonly viewed as monitoring mechanisms that enhance the audit attestation function of external financial reporting and external auditor independence by establishing a formal communication link between the board of directors, the internal monitoring system, and the internal and external auditors (p. 310).

\section{i. Formation of audit committees}

The contribution to the audit committee literature by Munro and Buckby (2008) related to the impact of the Australian Stock Exchange listing rules in relation to audit committee formation (as at 30 June 2004), which constituted the first full year of operation of the new rules. They noted improvements in relation to:

- $\quad$ audit committee formation;

- $\quad$ the increased number of audit committee members;

- $\quad$ the increased number of non-executive directors;

- $\quad$ the increase in financial expertise of audit committee members; and

- $\quad$ the increase in frequency of meetings.

Walker (2004) argued that within Australia there was a renewed enthusiasm for a stronger role for audit committees following the outcomes of corporate collapses in Australia and the United States of America. He considered that audit committees should review the structure and design of financial delegations and the adequacy of financial and operational performance information being provided to senior management and the board (Walker 2004, p. 157). His contribution to the literature was his assertion that given the number of corporate failures, it was reasonable to infer that boards had been given inadequate or misleading financial information. He considered that 'best practice' guidelines have not focused on this issue, but more on external reporting, which were adequately covered under the accounting 
standards. He suggested that management accounting and reporting to boards should also be covered under accounting standards (Walker 2004, p. 184).

\section{ii. Frequency of meetings and relationships with auditors}

Stewart and Munro (2007) examined the impact of audit committees, their frequency of meetings and the relationship with the external auditors. They stated that 'auditors' can 'perceive audit committees to be lacking in effectiveness and power and playing a passive role, rather than engaging in an active two-way exchange with auditors' (Stewart and Munro 2007, p. 53). It is contended that this view, which was supported by Cohen, Krishnamoorthy and Wright (2002) and Turley and Zaman (2004) would not be held to be true in the current regulatory and governance environment, given the degree of emphasis on audit committees and specifically the impact of the governance guidelines from the Australian Stock Exchange (2003 and 2007). Stewart and Munro (2007) concluded that the external auditors believed that 'the presence of the audit committee significantly reduces perceived audit risk and that the reduction in risk is influenced by meeting frequency and the audit partner's attendance at meetings' (p. 64).

\subsection{Application of governance theories to audit committees}

The literature in relation to audit committee effectiveness (DeZoort et al. 2002; Krishnamoorthy et al. 2002a, 2002b; Wayne 2003) has been examined from the perspectives of agency and institutional theory, with resource dependency theory and managerial hegemony theory also being influential. In a broad sense, the academic literature alluded to a relationship between 'company performance' and 'corporate misfeasance'. Effective governance assists the performance of any organisation however, the critical governance factors can relate to the diligence of the board of directors and the subcommittees of the board, for example, the audit committee and the level of transparency between the management and the directors of the board.

\subsubsection{Institutional theory}

In Chapter Two it was noted that institutional theory 'examines the processes and mechanisms by which structures, schemas, rules and routines become established as authoritative guidelines for social behavior' (Scott 2004, p. 409). The theory is a way of defining organisational structures and the social process through which these structures 
develop (DiMaggio \& Powell 1983; Meyer \& Rowan 1977). Institutional theory is set within the dynamics of an organisation and its institutional values, in addition to the ceremonial structures that people within this dynamic display.

DiMaggio and Powell (1983) argued that organisations adapt over time and become similar to other organisations. This institutionalised isomorphism had its origins through 'coercive', 'normative' and 'mimetic' practices. Coercive isomorphism was established from regulatory pressures for convergence within companies, for example, the compliance with Corporate Governance Principles and Recommendations of the Australian Stock Exchange (2007). Normative isomorphism comes about through socialisation, for example, following 'best practice guides' in relation to corporate governance and audit committees. Thus organisations can have a tendency to follow best practice guides, rather than questioning the relevance of alleged best practices and their specific application within the culture of the organisation. Mimetic isomorphism comes about from following the leader, regardless of whether the leader's practices are evidenced based. Best practice guides are illustrations of socialisation and normative practices and mimic governance practice without question.

\section{i. Relevance for audit committees}

The relevance of institutional theory for external stakeholders is that it confers a perception of trust and competency in the workings of the audit committee. In times of uncertainty or ambiguity, audit committee members can have a tendency to place a higher degree of emphasis on ceremony rather than monitoring under agency theory. Dillard, Rigsby and Goodman (2004) argued that institutional theory framework provided a useful insight into accounting practices in organisations, because these authors provided evidence:

...suggesting the importance of social culture and environment on the practice of accounting; the use of accounting practices as rationalizations in order to maintain appearances of legitimacy; and the possibility of decoupling these rationalizing accounting practices from the actual technical and administrative processes (p. 507).

This has broader implications for audit committees during an organisational crisis when there can be financial uncertainty including a lack of clarity in terms of cause, direction of change and long-term impact. Institutional theory implies a tendency to attract homogeneity into organisations (Tuttle \& Dillard 2007). Their review of isomorphism in accounting research in the United States of America had some parallels for audit committees. They noted that when 
a field of study becomes entrenched, there is a tendency to conform to norms and values. This conservative approach has the effect of producing similarity for similarity's sake, like normative and mimetic isomorphism.

Kalbers and Fogarty (1998) compared agency and institutional theory in an attempt to understand the effectiveness of an audit committee. They considered that the mere formation of an audit committee does not in itself achieve control of an organisation. They were unable to demonstrate a strong link however between audit committee effectiveness and agency factors and considered that effectiveness:

...emanates from sources close to the actual functioning of the audit committee. The formal empowerment of the audit committee appears to be designed for the consumption of external parties with some interest in the adherence to adequate forms of corporate control (p. 144).

Gendron et al. (2004) concluded that audit committees can fulfill both symbolic and substantive purposes. Their research concentrated on the following questions: (1) What matters are emphasised in audit committee meetings? (2) How do members evaluate them? and (3) How do members respond to management and external auditors during meetings? (p. 154). They concluded that practices which make the audit committee feel comfortable included the accuracy of financial statements and the quality of work performed by auditors. They also noted that the development of trust of external auditors was a fundamental aspect of work performance by the audit committee, although they did not make any assessment of reliance upon external auditors.

\section{ii. Implications for audit committees}

Implications of institutional theory for audit committees are the tendency for members to conform to the practices of audit committees in other organisations and, over time, display similar characteristics, for example, audit committees in Victorian local government.

Institutional theory also considers that audit committee members are more likely to come from similar backgrounds, which may be similar to management. DiMaggio and Powell (1983) and Powell and DiMaggio (1991) argued that institutions become similar over time through the process of isomorphism, as organisations adapt to those around them (Cohen, Krishnamoorthy \& Wright 2008; Dillard, Rigsby \& Goodman 2004; Gendron et al. 2004; Kalbers \& Fogarty 1998, 1993; Tuttle \& Dillard 2007). An example of this form of 
isomorphism is the legislative requirement to have an audit committee under the Local Government Act (1989), which results in councils in Victoria having audit committees, irrespective of external and internal environmental pressures. Thus the act of merely having an audit committee in name only is not measure effectiveness or contribution to council.

\subsubsection{Resource dependency theory}

Resource dependency theory (Boyd 1990; Pfeffer \& Salancik 1978) argues that shareholders and management rely upon the board of directors to: (1) access and manage scarce resources; and (2) set the strategy of the company with management. Under this theory, the role of the board is one of partnership as compared to monitoring under agency theory, and this formulates strategies and practices for the company. This perspective enhances the company's future due to the board of director's access to resources, networks and information. Cohen, Krishnamoorthy and Wright (2007) noted that none of the prior accounting studies had considered the duality of the board of directors performing simultaneous tasks of monitoring management, which is an agency perspective and actively setting corporate strategy, which is a resource dependency perspective (p. 92).

Their study evaluated where board roles were manipulated between strong and weak agency and resource dependency. They considered that the external auditor's internal control risk assessments were impacted by agency and resource dependency roles. There was a significant variance between the group, which assumed a strong board role for both variables and the group, which assumed a weaker board role. The study noted that audit planning increased when the board was considered to be weak and 'that auditors were willing to reduce their audit effort when the board is assessed as stronger on both dimensions' (Cohen et al. 2007, p. 93).

The implications from this research suggest that auditors do not focus on the monitoring role of the board of directors (as per agency theory), but generally bring to bear a more complex and sophisticated understanding of company operations, the director's roles, obligations and business risks (Cohen et al. 2007, p. 108). Cohen et al also stated that the implications 'are that researchers who limit their perspective to the monitoring role of the board, based strictly on agency theory, may lose some of the richness that alternative roles of governance provide' (2008, p. 185). 


\subsubsection{Managerial hegemony theory}

Managerial hegemony theory (Galbraith 1967; Kosnik 1987) argues that senior management appoint colleagues or contemporaries who will not impede the actions of management and will therefore be passive in governance processes. Under managerial hegemony theory, directors are dependent upon management for information and analysis of the company and the industry in which it participates. An outcome of this theory can mean a more symbolic compliance by the audit committee, rather than substantive oversight of management as would be the norm under agency theory. In conforming to managerial hegemony theory, the board of directors become limited to the ratification of management decisions and enhancement of executive compensation (Beatty \& Zajac 1994; Westphal \& Zajac 1994). Kosnik (1987) considered that in the context of hegemony theory, the board 'is ineffective in alleviating conflicts of interests between management and shareholders' (p. 166).

Westphal and Zajac (1994) examined long-term incentive plans as part of remuneration packages of chief executives between 1972 and1990. They noted that the use of such plans was particularly prevalent in companies with dominating or powerful chief executives or with poor financial performance. Beatty and Zajac (1994) provided an analysis of the relationship between the company's risk profile and its form of executive management compensation, ownership and governance mechanisms. They concluded that there was an inverse relationship between levels of risk profile and the degree of incentive remuneration. Core, Holthausen and Larcker (1999) examined entrenchment of management and noted that chief executives earned larger remuneration packages when governance structures were weak or ineffectual. They concluded that: (1) companies with weak governance structures have higher agency problems; (2) chief executives with higher agency problems obtain higher remuneration packages; and (3) companies with high levels of agency problems, perform worse financially (pp. 372-3).

\section{i. Relevance to the audit committee}

Cohen et al. (2008) in their analysis of managerial hegemony theory stated that the analysis by Westphal and Zajac (1994) and Beatty and Zajac (1994) were two examples of the lack of independent monitoring by the board of directors and impairment of the stewardship function respectively. Kosnik (1987) noted that both agency and managerial hegemony theories have some similarities, to the extent that: (1) both theories assume a prevalence of corporate control and issues associated with conflict of interest; and (2) managerial hegemony theory 
rejects directors as effective stewards of the company, whereas agency theory underscores their governance role.

\section{ii. Implications}

The implication of managerial hegemony theory (from the perspective of directors and the effectiveness of the audit committee) is that members of the audit committee will be compliant and less likely to ask probing questions of management. This also has implications for the external auditor in disputes with management pertaining to financial misstatements, as audit committee members have a propensity to side with management.

\subsubsection{Behavioural theory}

The research from a behavioural perspective recognises the interrelationship between the formal processes of an audit committee and the dimensions of informal relationships and power structures, for example: Beasley et al. (2009); Bedard and Gendron (2009); Brennan and Solomon (2008); Humphrey (2008); Turley and Zaman (2007).

Brennan and Solomon (2008) noted that accounting and finance research had traditionally focused on corporate governance, as measures of accountability. They also noted that the mechanisms of transparency within companies, particularly financial reporting, had been researched from the perspective of accountability of audit committees, internal audit and risk management as conduits to provide assurances about the quality of financial reporting (Brennan \& Solomon 2008, p. 887). However, in the Australian local government context, the notion of effective corporate governance generally goes beyond accountability: it covers the development and use of infrastructure, creative solutions to problems, financial planning and strategic direction.

\section{i. Relevance for audit committees}

The contribution to the literature of Beasley et al. (2009) was their review of audit committee oversight processes in relation to: (1) acceptance and due diligence to serve on an audit committee; (2) selection of audit committee nominees; (3) meeting processes; (4) oversight of financial reporting processes; (5) oversight of internal and external audit processes; and (6) benchmarking of audit committee processes (Beasley et al. 2009 pp. 77-78). These authors found that many audit committee members 'strive to provide effective monitoring of financial 
reporting and seek to avoid serving on ceremonial audit committees’ (Beasley et al. 2009, p. 66). However, they concluded that there was some evidence of both 'substantive monitoring and ceremonial action', which agency theory or institutional theory could not properly explain. They noted that whilst DeZoort et al. (2002) had described audit committee effectiveness in terms of: (1) composition; (2) authority; (3) resources; and (4) diligence, their 'interviews reveal that financial expertise (composition) is receiving a great deal of attention in the post-SOX environment' (Beasley et al. 2009, p. 112). Their research also highlighted the importance of the audit committee asserting authority, for example, the management of the internal audit program and external auditors having access to key internal and external stakeholders and spending sufficient time reviewing information presented to the audit committee (Beasley et al. 2009, p. 112).

Bedard and Gendron (2009) reviewed select audit committee literature between 1994 and 2008 to evaluate whether audit committees can deliver against increasing regulatory and societal expectations. The significance of their work related to the extension of audit committee effectiveness with regard to quality of financial reporting to what they called 'a perceptual perspective from the viewpoint of the actors involved' (Bedard \& Gendron 2009, p. 3). They noted that of the ninety-one papers produced, there were twenty papers which emphasised a psychological approach, with another five having a sociological perspective. These papers had been formulated from a psychological perspective and explored issues pertaining to expertise, credibility, negotiation, persuasion and accountability of the audit committee, whilst the papers formulated from a sociological perspective explored notions of power and organisational theory. Whilst the majority of papers (sixty-six out of ninety-one or 73\%) were from a legal or regulatory perspective and mostly from an agency perspective, it was relevant to note the emerging literature from sociological and psychological schools of thought, which could be used to explain or interpret behaviours of audit committee members and management attendees at audit committee meetings.

\section{ii. Implications for audit committees}

Turley and Zaman (2007) also noted the predominance of the agency approach to rationalise behaviours of audit committees. They considered that the empirical evidence of the nexus between financial reporting and audit committee variables, for example, frequency of meetings and financial expertise of members, was mixed. They concluded that the 'complexities of organisational settings, power relations around and within corporate entities 
and the nature of business as social systems are not properly represented in simple agency models' (Turley \& Zaman 2007, p. 767). Further, in addition to the formal process of audit committees, governance outcomes were significantly influenced by the informal processes which underpin an organisation and power relations. They noted that these dimensions can 'interact with each other in producing governance outcomes and it is difficult to isolate the effect of one from another' (Turley \& Zaman 2007, p. 785).

\subsection{Attributes of audit committee effectiveness}

DeZoort et al. (2002) provided an authoritative analysis of the successful components contributing to audit committee effectiveness, namely: (1) composition; (2) authority; (3) resources and; (4) diligence (illustrated in Figure 3.4). These factors are inputs and create an environment for the audit committee to be effective.

To support his assertions, DeZoort et al. (2002) discussed the work of Ridley and Roth (cited in Fabrizius 1998) who considered that five elements of audit committee effectiveness were: (1) independence; (2) training and resources; (3) regular meetings; (4) review of the assessment process; and (5) unrestricted access to auditors. DeZoort et al. (2002) also referred to Braiotta (1999) who identified the following contributors to audit committee effectiveness: (1) committee size; (2) proper delegation of responsibility; and (3) authority. Rittenberg and Nair (1993) considered that background and training were key to audit committee effectiveness which was similar to McMullen and Raghunandan (1996), who described the requirements of 'independence being informed and vigilance' as important characteristics of effectiveness.

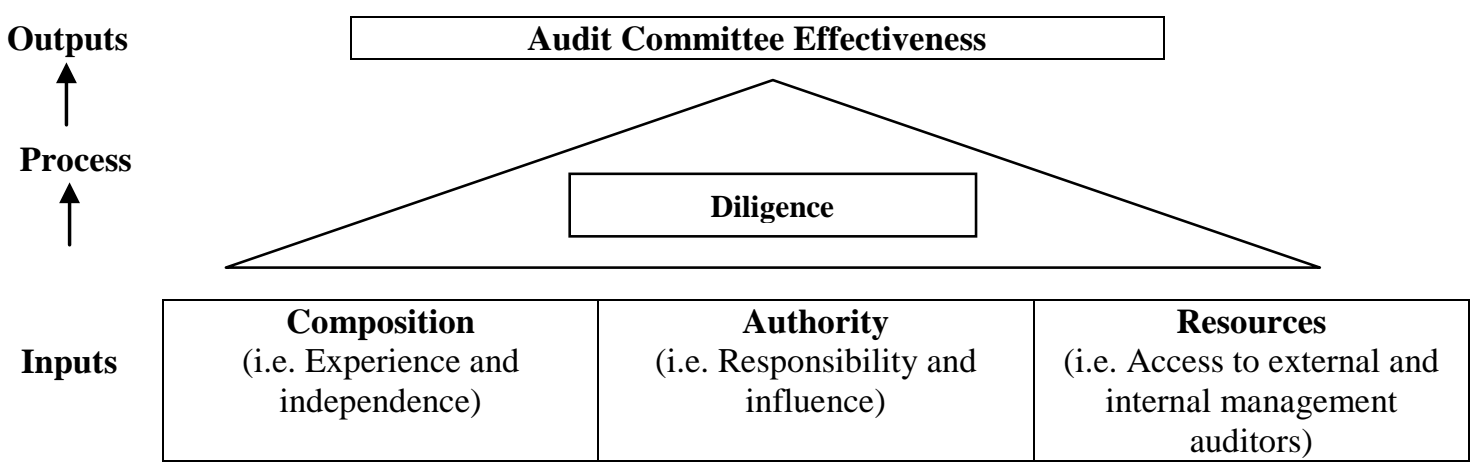

Figure 3.4 Determinants of audit committee effectiveness

Source: (DeZoort et al. 2002) 


\subsubsection{Composition}

A major facet in the literature was the notion of independence of audit committee members.

DeZoort et al. (2002) considered that audit committee independence was associated with the attributes of engaging higher quality external auditors; effective interaction with internal auditors; protecting external auditors from client pressure; and a reduced incidence of financial reporting problems. Audit committee expertise was perceived to be a critical component of audit committee effectiveness and this effectiveness was enhanced by interaction with internal auditors with support for both external and internal auditors in auditor-management disagreements (DeZoort et al. 2002, p. 51). This position was supported by Abbot and Parker (2000), Beasley and Salterio (2001), Carcello and Neal (2000) and Scarbrough, Rama and Raghunandan (1998).

Carcello and Neal (2000) examined the composition of the audit committee and its relationship with financial reporting by the external auditor. They concluded that their study provided evidence of a relationship between the composition of the audit committee and the going-concern reporting behaviours (p. 465). They also considered that the higher the number of directors who have an affiliation or association with the company, the lower the probability of receiving a going-concern report. They noted that auditors were less likely to modify the 'reports of distressed companies that have a greater percentage of affiliated directors on their audit committees’ (Carcello \& Neal 2000, p. 465).

The conclusions of DeZoort et al. (2002) in relation to the composition of audit committees were supported by Beasley and Salterio (2001), who undertook an analysis of company behaviours in Canada in relation to appointments to audit committees. They concluded that: (1) firms with larger numbers of independent members were likely to have larger boards; (2) were more likely to have separated the role of chief executive and chairman of the board; (3) independent audit committee members with financial expertise were more likely to be associated with companies with large boards; and (4) were less likely to be chaired by the chief executive or chairman of the board. This was complemented by Scarbrough et al. (1998), who noted that audit committees which comprised a higher number of independent directors were more likely to have stronger relationships with internal auditors. They concluded that audit committees with a higher number of independent members were likely 
to have more meetings with internal auditors and review the audit program and internal audit outcomes (Scarbrough et al. 1998, p. 61).

\subsubsection{Authority}

DeZoort et al. (2002) noted that audit committee responsibilities were diverse and authority was conditional upon written authorisation (audit committee charter) and management support (DeZoort et al. 2002 p. 58). DeZoort (1997) has also argued that audit committees represented the interests of stakeholders and the board in relation to financial reporting, auditing and elements of corporate governance (p. 208). His research related the understanding of the perceptions of audit committee members to their oversight responsibilities as exercised by them. Whilst the results of this survey have some public policy implications, in terms of adequacy of audit committees to accurately reflect upon their scope and coverage, it was noted that there has been significant regulatory reform of corporate governance and audit committees under the Sarbanes-Oxley Act (2002) in the United States of America and in Australia, due in part to the ASX Corporate Governance Principles and Recommendations (Australian Stock Exchange 2007, 2003).

Kalbers and Fogarty (1993) supported the conclusions of DeZoort et al. (2002) by examining the relationship between audit committee power and effectiveness. Kalbers and Fogarty (1993) considered that expertise of committee members was important, but primarily this expertise was for dealing with the complexities of financial reporting. Their study suggested that the types of power needed by audit committees to perform effectively were institutional support and actual authority (written and implied), coupled with diligence. They argued that the audit committee was an important link in the financial reporting process and that organisational displays of power were crucial for effectiveness. For example, an audit committee needs a strong mandate through its charter and recognition by stakeholders (management, external and internal auditors). Informal recognition can rely on an information support system, which includes support from executive management as well as timely and relevant reports from management and external and internal auditors. Misguided power relationships within the organisation can be problematic unless audit committees are operated by those with the skills and 'moral fortitude to use the rights and obligations of the audit committee’ (Kalbers \& Fogarty 1993, p. 45). 


\subsubsection{Resources}

DeZoort et al. (2002) considered that 'the overriding conclusion from the audit committee literature is that support from the external and internal audits is vital' (p. 59). They argued that quality external auditors were associated with increased committee support for the auditor in auditor-management disagreements and external auditors focus on audit committee effectiveness when assessing risk or accepting new clients. DeZoort et al. (2002) noted that the level of interaction with auditors was a proxy for the quality of information provided to audit committees, but this was not a perfect proxy (p. 59). His conclusions were also supported by Cohen and Hanno (2000); Cohen et al. (2002); DeZoort and Salterio (2001); and Raghunandan, Read and Rama (2001).

Cohen and Hanno (2000) reviewed the external auditor's consideration of corporate governance and management control within a company as part of the planning process. They found that higher levels of corporate governance and management control affected preplanning judgments, although there was a stronger effect for management control philosophy (Cohen and Hanno 2000, p. 143). These authors also reviewed the efficacy of the audit committee, vis-à-vis the board of directors, as they affect the audit process. They noted that one-third of respondents considered that the audit committee was less important than other governance mechanisms, which Cohen et al. (2002) attributed to the audit committee being 'limited to monitoring the financial reporting process, rather than the broader concerns of business strategies and risk’ (p. 585). This is an important link between governance (as discussed in Chapter Two) and audit committees.

It was noted that private and public sector audit committees have expanded the role of audit and risk management in Australia. If this survey was replicated in Australia in 2011 the response to this question would be substantially less. Cohen et al. (2002) noted that some audit partners considered that some audit committees can be ineffectual, because they 'are not powerful enough to resolve contentious issues with management’ (p. 586).

This argument was consistent with DeZoort and Salterio (2001) who 'examined audit committee members' experience and knowledge and the effects of their judgements in an auditor-management disagreement over an accounting policy choice' (p. 31). They concluded that higher numbers of independent directorships held by audit committee members, together with a high level of financial literacy, was positively associated with 
higher levels of support for the external auditor in auditor-management disputes (DeZoort \& Salterio 2001, p. 43). Raghunandan et al. (2001) examined whether there was an association between the composition of the audit committee and the audit committee's interaction with the internal auditors. The results indicated that audit committees which were comprised of all independent members, with at least one member having financial literacy skills, were more likely to: (1) have longer meetings with the chief internal auditor; (2) undertake private meetings with the internal auditors; and (3) review the internal audit work program and the results of internal audits (Raghunandan et al. 2001, p. 116).

\subsubsection{Diligence}

The literature clearly demonstrated the importance of having adequate audit committee meetings each year. Frequency of meetings was associated with a reduced incidence of financial reporting problems and greater external audit quality. The limitation of research into the diligence of the audit committee related to the fact that diligence cannot be observed and consequently indicators or proxies must be used. Whilst the frequency of meetings provided an indication of effort, the motivation and incentives for audit committee members were not analysed (DeZoort et al. 2002, p. 65). The position of DeZoort et al. (2002) was also supported by Abbot and Parker (2000), Beasley, Carcello, Hermanson and Lapides (2000) and Turpin and DeZoort (1998). Abbot and Parker (2000) examined the selection processes for the external auditor by the audit committee. They concluded that audit committees, which are independent and active, were more likely to appoint an external auditor with industry specific experience (Abbot \& Parker 2000, p. 63). DeZoort et al. (2002) was also complemented by Turpin and DeZoort (1998), who examined the characteristics of companies which voluntarily included a separate audit committee report in their annual report to shareholders. They concluded that whilst few companies had included a separate report, those that did were more likely to be: (1) large companies; (2) traded on a major stock exchange; and (3) have a greater number of independent directors than do companies that do not include a separate audit committee report in their annual report to shareholders (Turpin \& DeZoort 1998, p. 45).

Figure 3.5 synthesised some of the academic literature in relation to audit committee effectiveness using DeZoort's principles of determinants of audit committee effectiveness. 


\begin{tabular}{|c|c|}
\hline Audit committee effectiveness principles & Source \\
\hline $\begin{array}{l}\text { 1. Composition } \\
\text { - Financial expertise, independence and diligence were } \\
\text { important attributes for successful audit committees. } \\
\text { - Good mix of audit members with the right skills, } \\
\text { expertise and competencies. } \\
\text { - The competence and activities of audit committee } \\
\text { members and hinges ultimately on independence. }\end{array}$ & $\begin{array}{l}\text { Krishnamoorthy et al. (2002a). } \\
\text { Galvez (2003). } \\
\text { Richardson and Baril (2003). }\end{array}$ \\
\hline $\begin{array}{l}\text { 2. Authority } \\
\text { - Effectiveness of the audit committee also requires a } \\
\text { 'supportive atmosphere from top management'. } \\
\text { - For audit committees to be effective, they must have } \\
\text { independence and financial competencies. }\end{array}$ & $\begin{array}{l}\text { Kalbers and Fogarty (1993). } \\
\text { Krishnamoorthy et al. (2002a). }\end{array}$ \\
\hline $\begin{array}{l}\text { 3. Resources } \\
\text { - Difficulty for effective audit committees relates to } \\
\text { resources and the diligence of the audit committee. } \\
\text { - The elements of audit committee effectiveness are: } \\
\text { independence, training, resources, regular meetings, } \\
\text { review of the assessment process and unrestricted access } \\
\text { to auditors. } \\
\text { The key to audit committee effectiveness relates to } \\
\text { background and training. }\end{array}$ & $\begin{array}{l}\text { Hughes (2002). } \\
\text { Fabrizius (1998) cited in } \\
\text { DeZoort et al. (2002) p. } 42 . \\
\text { Rittenberg and Nair (1993) cited } \\
\text { in DeZoort et al. (2002 p. } 42 .\end{array}$ \\
\hline $\begin{array}{l}\text { 4. Diligence } \\
\text { - Leadership and style of the audit committee chairperson. } \\
\text { - Effectiveness consisted of three domains of oversight: } \\
\text { financial reporting, external auditors and internal } \\
\text { control. } \\
\text { - Expertise in accounting, internal controls and auditing } \\
\text { can be keys to audit committee effectiveness as well as } \\
\text { the frequency of meetings. } \\
\text { - Demonstrate high standards of leadership, ethics and a } \\
\text { commitment to performing their duties with integrity. }\end{array}$ & $\begin{array}{l}\text { Spangler and Braiotta (1990). } \\
\text { Kalbers and Fogarty (1993). } \\
\text { McMullen and Raghunandan } \\
\text { (1996). } \\
\text { Anonymous Author A, } 2002 .\end{array}$ \\
\hline
\end{tabular}

\section{Figure 3.5 Summary of the academic literature}

Another perspective developed in more detail in Section 3.7 related to organisational structures and values which bind or link activities and outcomes of an audit committee.

\subsection{Public sector audit committees}

In relation to audit committee effectiveness, the Higher Education Funding Council of England (2008) considered there was not a single measure of audit committee effectiveness that was universally applicable to all universities and it was up to each university to develop 
their own audit committee principles. The Higher Education Funding Council defined an effective audit committee as one that:

...successfully supports the governing body to fulfil its responsibility for adequate and effective risk management, control and governance and for the economy, efficiency and effectiveness of the institution's activities. This goes beyond simply meeting the criteria set out in the audit committee's own terms of reference (2008, p. 79).

As noted in Chapter Two, one of the distinguishing features of public sector governance as compared to governance in the private sector was the responsibility to protect the public interest. Public sector audit committees in Australia can have statutory compliance obligations as they are public bodies enacted under legislation. However, some entities can also have corporate responsibilities under the Corporations Act (2001); for example, City Wide is a corporate subsidiary of the Melbourne City Council and is therefore subject to the obligations of the Corporations Act (2001) and the City of Melbourne Act (2001). In this example, the directors and audit committee members of City Wide need to be cognisant of the obligations of both Acts, whilst simultaneously ensuring that their governance practices do not inadvertently contravene any obligations under the Local Government Act (1989) for the Melbourne City Council.

Edwards (2002) (Chapter Two of this thesis) discussed the perception that corporate governance principles and practices could be universally adopted from the private sector to improve the delivery of government services (p. 52). Whilst this was not necessarily true it was noted that the Corporate Governance Principles and Recommendations from the Australian Stock Exchange $(2007,2003)$ had contributed to the evolution of corporate governance practices in the private sector without being prescriptive. In addition to the ASX guidelines, there are a number of audit committee guides for the private sector, which contribute to the awareness of public sector audit committee roles and responsibilities. These include:

- $\quad$ A Guide for Effective Audit Committees (Hong Kong Society of Accountants 2002);

- 100 Best Practices for Audit Committees (Institut Francais des Administrateurs 2008);

- $\quad$ Audit Committee Effectiveness - What Works Best (Bromilow \& Berlin 2005);

- $\quad$ Good Practice for Meeting Market Expectations (PriceWaterhouseCoopers 2003); and

- $\quad$ Audit Committee Insights (KPMG 2009, 2008b, 2006). 
There are a number of international and Australian public sector audit committee publications which can act as an adjunct to the plethora of private sector audit committee guidance in the public domain, for example:

- $\quad$ Institute of Internal Auditors (2006);

- $\quad$ National Audit Office (2007a, 2007b);

- $\quad$ HM Treasury (2007);

- $\quad$ Controller and Auditor-General, New Zealand (2008b);

- $\quad$ Auditor-General, Manitoba (2006);

- $\quad$ Department of Treasury, Queensland (2008); and

- $\quad$ local governments within New South Wales (Department of Local Government 2008b) and Victoria (Pearson 2008).

These publications have both an international and an Australian perspective and act as a prompt for public sector audit committee members to think strategically and to consider what issues may impact their organisation. For example, the impact of the Global Financial Crisis in 2008 and 2009 and the implications for the continuity of companies, would also have been considered by public sector audit committees, albeit from the different perspective of its impact on constituents, reduced investment income, the future funding of services, the potential for reduced tax revenues and future provision of services.

\section{i. Audit committee guides}

The Hong Kong Society of Accountants (2002) considered that effective audit committees needed to: (1) clearly understand the responsibility of their oversight roles; (2) communicate independently with external and internal auditors; (3) assess the quality of information and judgements presented to the audit committee from management; and (4) ensure that audit committee members were suitably qualified and experienced (pp. 4-5). The Institut Francais des Administrateurs (2008) provides an example of a European perspective on the effectiveness of audit committees and confirmation that an audit committee should focus on: (1) quality of financial reporting; (2) risk management and internal control systems; and (3) effective relationships with external and internal auditors.

From an effectiveness perspective, KPMG (2008b) noted that respondents considered that the efficiency and effectiveness of audit committee meetings could be improved by better prioritisation of issues, followed by more time to discuss issues and ask questions, as compared to listening to presentations from management (p. 2). KMPG further noted that the opinions of Australian audit committee members generally corresponded to viewpoints of US 
and Canadian audit committee members, although audit committee members in Canada placed a higher emphasis on international financial reporting standards, information and data security (2008b, p. 22). KPMG (2006) also published an international survey of audit committee members including responses from Australia.

Whilst international surveys have the inherent limitation of reflecting differences of culture, linguistics and specific regulatory environment and jurisprudence, the survey did note a level of similarity in relation to audit committee effectiveness in terms of: (1) financial expertise incorporated into the audit committee: (2) quality of support from management and external auditors; (3) quality of reporting from management; and (4) an increased emphasis upon knowledge of audit committee members including induction programs.

In relation to public sector audit committees, the Institute of Internal Auditors (2006) stated that an audit committee can 'strengthen the independence, integrity and effectiveness of government audit activities by providing independent oversight of the internal and external audit plans and results' (p. 20). Audit committees can also manage the auditor's relationships with the entity (Institute of Internal Auditors 2006, p. 20). The Institute of Internal Auditors (2006) also detailed seven attributes of audit committee best practices, which in the main, mirrored the best practice guides for the private sector. In the United Kingdom, the National Audit Office (2007a and 2007b) provided a checklist for public sector audit committee members, largely based on the Audit Committee Handbook (HM Treasury 2007). It followed a principles based approach centred around: (1) the role of the audit committee; (2) membership; (3) objectivity and independence; (4) skills; and (5) scope of the audit committee and communications. These principles were not substantially different from private sector audit committee guidelines and publications, as previously discussed. Further, the Controller and Auditor-General, New Zealand (2008b) produced a useful practice guide for audit committees for public sector entities in New Zealand. The Controller and AuditorGeneral, New Zealand (2008b) advised that the guide was not meant to be a 'how to' manual, as it was the responsibility of each public sector entity to determine the most appropriate governance arrangements for its specific circumstances. In terms of assessment of the effectiveness of audit committees, the Controller and Auditor-General, New Zealand provided a number of questions centred on self-review (Controller and Auditor-General, New Zealand 2008b, pp. 69-74). Thus for the first time a public sector audit committee practice guide had defined a criterion upon which audit committees could make a quantitative or qualitative assessment of outcomes. The Controller and Auditor-General, New Zealand 
(2008b) further suggested that audit committees might wish to assess the improvement they make to: (1) policies and practices; (2) risk environment; (3) internal control environment; (4) accountability model for non-financial results; and (5) strengthening of internal assurance processes including organisational transparency (Controller and Auditor-General, New Zealand 2008b, p. 74). In Canada, the Auditor-General, Manitoba (2006), provided a discussion and analysis of best practice guidelines, which public sector bodies in Manitoba could follow in relation to responsibilities, relationships and structures. Similar to private sector best practice guidelines, the Auditor-General, Manitoba (2006) suggested that audit committees review their achievements against the following criteria: (1) structures; (2) oversight of financial reporting; (3) relationships with auditors; and (4) compliance and regulatory environment.

\section{ii. Audit committee guides - An Australian perspective}

In Australia, the Department of Treasury, Queensland (2008) provided audit committee guidelines that were mandated to apply to all public sector departments and statutory bodies in Queensland. In relation to the effectiveness of the audit committee, it was recommended that the audit committee assess its performance against the charter on an annual basis. The guidelines also provided a draft assessment questionnaire which could be used by Queensland public bodies to assess performance. The criterion was similar to the existing plethora of guidelines to assess effectiveness of audit committees in the private and public sectors, for example, Board Strategies (2002); Bromilow and Berlin (2005); Deloitte (2004, 2003); National Audit Office (2007a, 2007b and undated); and PriceWaterhouseCoopers (2003).

In Victoria, Pearson (2008) considered that the distinguishing feature of public sector governance was the public sector's focus on stewardship and accountabilities. He considered that public sector boards and audit committees in Victoria should look beyond the legislative compliance framework, for example, the Standing Directions of the Minister of Finance and the Financial Management Compliance Framework (Department of Treasury and Finance, Victoria 2005a, 2005b) and seek to strengthen audit committees. In relation to audit committees, Pearson (2008) considered that they needed to be: (1) independent; (2) limit the crossover between the roles of a finance committee and the audit and risk committee; and (3) ensure that audit committee members had adequate skills and breadth of experience directly relevant to the organisation. Pearson (2008) also considered that the more effective audit committees in the public sector maintained their independence, built networks with other 
audit committees for mutual support and constantly engaged with the external auditor and internal auditor on issues of substance. Pearson's (2008) contribution to the literature was his affirmation of the importance of audit committees. He also confirmed that the issues confronting audit committees in the public sector (e.g. independence, objectivity, quality of financial reporting and performance outcomes) were not substantially different from issues faced by audit committees in the private sector.

\subsection{Local government audit committees}

Effective governance and audit committees assist the performance and outcomes of local government councils. Amongst other things, audit committee effectiveness in local government can be contingent upon the: (1) diligence of the councillors; (2) diligence and expertise of independent members; and (3) level of transparency between management and members of council and subcommittees.

In the United Kingdom, Davies (2009) examined working relationships between audit committees and chief internal auditors in twenty-two councils in Wales in 2008, from the perspective of chief internal auditors. In relation to audit committee effectiveness, she concluded that an increased understanding of auditing and accounting matters helped the audit committee perform more effectively. She also noted that some respondents considered that the behaviours and personalities of members could influence effectiveness. She concluded that the relationship between the audit committee and the chief internal auditor inevitably depended 'on individual personalities, governance processes and the willingness' to adhere to the published guidelines for local government governance and audit committees (Davies 2009, p. 60). The Chartered Institute of Public Finance and Accountancy (2004) developed audit committee principles for local government authorities in Scotland. Whilst these principles were not mandatory, nevertheless they contained best practice observations which included: (1) structures plus terms of reference, membership, training, agenda papers and attendance by councillors and executive management; (2) assurance in relation to the control environment; (3) risk-related performance; and (4) financial and performance reporting. These best practices were similar to the private and public sector best practice guidelines as previously discussed. Crawford, Henry, McKendrick and Stein (2008) reviewed the effectiveness of audit committees from the perspective of the chair, chief financial officers and chief internal auditors in local government bodies in Scotland. They concluded that audit committees: (1) were effective in monitoring internal audits; (2) did not necessarily 
achieve the same levels of engagement with external auditors; (3) were not effective in monitoring organisational risk management; and (4) that party political issues were not influential (Crawford et al. 2008, pp. 212-3). In relation to risk management, the respondents noted that most audit committees had taken a narrow perceptive of risk management as pertaining to financial risks only, rather than organisational risks, including non-financial performance management issues.

Crawford et al. (2008) acknowledged that some responses could be coloured by individual relationships with councils and the developing experiences of some members. They also considered that it can be difficult to provide a meaningful sector wide perspective, because responses from each of the thirty-two councils that they surveyed can be filtered by differing levels of competencies, capabilities and capacities (Crawford et al. 2008). This limitation also applies to this research. West and Berman (2003) undertook a review of local government audit committees for cities which had large populations in the United States of America. They concluded that audit committees augmented financial accountability in local government, although 'despite legal and professional standards and recommended best practices, the use of audit committees in local government is uneven at best' (West \& Berman 2003, p. 354). Where audit committees did exist, there was significant variability in the range of activities they engaged in, although there was a degree of similarity in relation to financial reporting, external and internal auditors. Support for audit committees was strongest amongst the senior elected and appointed city officials and weakest among citizens, public managers and business elites (West \& Berman 2003, p. 355). Whilst the culture, jurisprudence and remit of local government audit committees in Scotland, Wales and the United States of America were substantially different, there were some similarities in audit committee functions in Victorian local government, for example, the oversight of council risks and financial reporting. It was noted that behaviours of audit committee members were implied in West and Berman (2003); Crawford et al. (2008); and Davies (2009) and there was a connection between these observations and findings from the research, as discussed in Chapters Five and Six.

\section{i. Audit committees in New South Wales local government}

The Department of Local Government (2008b) introduced formal requirements for internal audit and audit committees for all local government entities in New South Wales, Australia. These provide the oversight framework for council systems and internal control processes 
through the audit committee and partially address misconduct in local government in New South Wales, as investigated by the Independent Commission Against Corruption (see Chapter Four). The Department of Local Government (2008b) considered that the combination of an effective audit committee and internal audit function could provide the formal means by which councillors obtain assurance that council risk could be identified and managed (Department of Local Government 2008b, p. 5). The Department of Premier and Cabinet, New South Wales, advised that following a survey of internal audit functions in local government in 2009, only $46 \%$ of respondent councils reported having an audit committee. Of those, 95\% reported having a documented audit committee charter (Department of Premier and Cabinet, New South Wales 2010a). The guidelines from the Department of Local Government (2008b) were further revised in 2010 (Department of Premier and Cabinet, New South Wales 2010b) as a response to the survey in 2009, which established that:

- $\quad 61 \%$ of councils responded that they had an internal audit function;

- $\quad$ only $27 \%$ stated that they had all three components of an internal audit function: internal audit charter; audit committee with documented charter; and a documented internal audit plan;

- $\quad 39 \%$ councils advised that they did not have an internal audit function;

- $\quad 83 \%$ responded that they were planning to implement the function within the next six to eighteen months;

- $\quad$ only $6 \%$ indicated that at this stage they were not intending to implement an internal audit function; and

- $\quad 40 \%$ reported having a documented internal audit charter (Department of Premier and Cabinet, New South Wales 2010a).

\section{ii. Audit committees in Victorian local government}

As previously noted, audit committees were mandated in Victorian local government from 1 February 2004, although some councils, for example, Manningham and Whitehorse City Councils, had established audit committees before 2000 and developed audit committee policies and processes, which mirrored the audit committee and internal audit practice guidelines from the Department of Infrastructure (2000). In 2009, the audit committee guidelines were revised (Department of Planning and Community Development 2009) and reissued in 2011 (Department of Planning and Community Development 2011). Cameron (2008) considered that the four governance principles relevant for audit committees in local government were: (1) independence of audit committee members; (2) competence of audit committee members; (3) clarity of purpose of the audit committee; and (4) effective relationships. 
Cameron (2008) developed a local government audit committee taxonomy, which included attributes of effectiveness, namely: (1) membership and the appointment process; (2) functions of the audit committee; (3) meetings and agendas; (4) relationships and responsibilities; (5) oversight of the external audit process; and (6) reporting to council. PriceWaterhouseCoopers (2003) provided a synthesis of criteria to measure audit committee effectiveness. Similarly, Bromilow and Berlin (2005) developed a model of effectiveness, which comprised: (1) training needs of audit committee members; (2) communications and reporting from the audit committee; (3) an understanding of regulatory environments. This has implications for the audit committee's focus, namely: (1) financial reporting; (2) risk management and control; and (3) relationships with external and internal auditors (PriceWaterhouseCoopers 2003, p.5). PriceWaterhouseCoopers (2003) proposed that any evaluation of performance should focus on the performance of individual committee members, for example, business knowledge, expertise, objectivity, preparation for meetings and attendance and collective performance of the audit committee. The functions and activities that audit committees in Victorian local government can be involved in are represented in Figure 3.6. A review of audit committee charters from Darebin City Council (2009), Frankston City Council (undated a), Moreland City Council (undated) and Swan Hill City Council (2005) confirmed that these audit committees focused on: (1) financial reporting; (2) regulatory and legal compliance; and (3) risk management, using the services of their internal and external auditors. In Victoria, the external audits in local government are undertaken by accounting firms, as the agents of the Auditor-General, Victoria, with the Auditor-General, Victoria having the ultimate responsibility for certification of financial statements.

\begin{tabular}{|c|c|}
\hline \multicolumn{2}{|c|}{ Audit Committee - Areas of Focus } \\
\hline $\begin{array}{l}\text { Financial Reporting } \\
\qquad \begin{array}{l}\text { - Appropriateness of accounting policies } \\
\text { - Disclosure requirements } \\
\text { - True and fair view }\end{array}\end{array}$ & $\begin{array}{l}\text { Risk Management and Internal Control } \\
\text { - } \quad \text { Understanding of key risks } \\
\text { - } \quad \text { Effectiveness of controls } \\
\text { - } \quad \text { Fraud risk }\end{array}$ \\
\hline $\begin{array}{l}\text { External Audit } \\
\text { - } \quad \text { Appointment of the Auditors (Agent of } \\
\text { the Auditor-General, Victoria) } \\
\text { - Scope of work } \\
\text { - } \quad \text { Independence } \\
\text { - } \quad \text { Review of the performance of the Agent } \\
\text { of the Auditor-General, Victoria) }\end{array}$ & $\begin{array}{l}\text { Internal Audit } \\
\text { - } \text { Charter, authority and resources } \\
\text { - } \text { Scope of work } \\
\text { - } \text { Internal audit effectiveness } \\
\text { - Responses to internal audit } \\
\text { recommendations }\end{array}$ \\
\hline
\end{tabular}




\begin{tabular}{|c|c|c|}
\hline $\begin{array}{l}\text { Maintaining and Measuring } \\
\text { Effectiveness }\end{array}$ & Communication and Reporting & $\begin{array}{l}\text { Regulatory, Compliance and } \\
\text { Ethical Matters }\end{array}$ \\
\hline $\begin{array}{ll}\text { - } & \text { Training } \\
\text { - } & \text { Financial literacy } \\
\text { - } & \text { Annual performance } \\
& \text { evaluation }\end{array}$ & 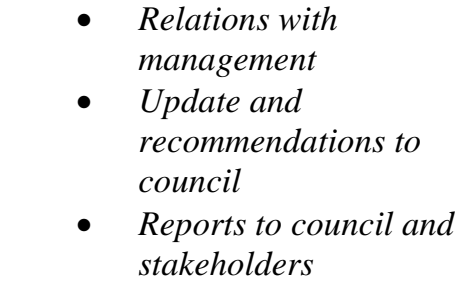 & $\begin{array}{l}\text { - } \quad \text { Effectiveness of } \\
\text { systems for ensuring } \\
\text { compliance with laws } \\
\text { and regulations } \\
\text { - Code of conduct } \\
\text { - Whistleblowers }\end{array}$ \\
\hline
\end{tabular}

Figure 3.6 Audit committee - Areas of focus

Source: Adapted from PriceWaterhouseCoopers (2003), p. 5.

\section{iii. Assessment of audit committee effectiveness against Victorian local government guidelines}

One of the distinguishing features of the audit committee guidelines (Department of Infrastructure, 2000; Department of Planning and Community Development 2009, 2011) was that they provided 'best practice' models for councils to aspire to, as compared to prescriptive audit committee measures to comply with. The behavioural consequence of prescriptive measures in audit committee guidelines was their propensity to become 'minimalist' in order for audit committee and members to comply as compared to using best practice models to inculcate audit committee practice, risk management and internal control into the culture and values of council. A review of 'audit committee effectiveness' was incorporated in the 2011 guidelines from the Department of Planning and Community Development (2011). The review concentrated upon the work of the audit committee, but did not include any measures on how to establish whether the audit committee had achieved any outcomes. For example, some objectives were:

- $\quad$ 'High standards of corporate governance';

- $\quad$ 'Compliance with applicable laws and regulations'; and

- $\quad$ 'Effective and efficient internal audit functions' (Department of Planning and Community Development 2011, pp. 46-7).

These 'aspirational goals' needed to be structured in such a way to uniformly measure outcomes; allow for comparisons between councils to be made; and identify those councils which may need some assistance to improve. For example, in relation to 'High standards of corporate governance', it may have been valuable to identify the eight principles of corporate governance (Australian Stock Exchange 2007) as the means by which the goal could be objectively measured. It was unclear how input costs were a measure of effectiveness in the Department of Planning and Community Development (2011) document because efficiency and effectiveness measures operate separately and do not interconnect. This would suggest 
that measures were misaligned. There were no behavioural questions about management of the audit committee. In this sense, the Department of Planning and Community Development (2011) had concentrated upon strategy, structures and systems from the McKinsey 7S Theory (Waterman et al. 1980) ${ }^{11}$ to support the audit committee, but had not considered:

- $\quad$ staffing (independent audit committee members, councillors and management);

- style (the way in which audit committee members and management achieve outcomes);

- $\quad$ skills (competencies, capabilities and capacities of audit committee members); and

- $\quad$ shared values (the organisational culture of the council).

The absence of behavioural questions was an important observation and constituted a weakness in the document.

Cameron (2004) in his analysis of local government audit committees from the perspective of the Auditor-General, Victoria, noted that some audit committees lacked the requisite financial skills; their role was too narrow and they did not meet frequently; and attendance by the external auditor varied enormously, with visits once a year or not at all. Cameron (2004) noted that the Auditor-General in early 2004 had requested his external agents to comment on the effectiveness of audit committees across local government. Whilst the best practice guidelines from the public and private sectors provide the information for an audit committee to operate, the behavioural attributes of a conducive and transparent environment for the audit committee to operate appeared to be assumed from the best practice guides, which is not necessarily the case for all audit committees (see Section 6.6.3).

\subsection{Measures of audit committee effectiveness}

In assessing the components which contribute to the effectiveness of the audit committee, it was important to differentiate between accountabilities of the audit committee and its activities. McKinsey's 7S Theory could thus be used as an alternative mechanism to assess audit committee effectiveness. This theory linked the behavioural theory of governance (Marnet 2008, 2007, 2005, 2004) and quantifiable relationships between measures of corporate performance and solutions to agency problems, for example, independent directors, external audits, accounting standards and shareholders (Bolton 2006; Chi 2005; Ertugrul

${ }^{11}$ McKinsey 75 Theory 'diagnoses the causes of organizational malaise' and formulates programs for improvement' (Waterman et al. 1980, p. 17). This theory describes the relationships between: (1) structure, strategy and systems of an organisational unit; (2) shared values of the organisational unit; and (3) skills, staff and style of the organisational unit (Iles \& Sutherland 2001, p. 27). 
2005; Fridman 2004; Kelly 2005; Popescu 2006). The significance and relevance of the McKinsey 7S Theory was that it placed an equal emphasis on organisational components (structure, strategy and systems) and the mechanisms (style, staff and skills) to undertake strategies and realise shared values of the organisation, which binds the organisation. Its significance was that it provided another interpretation to view the complexity, interdependence and relationships between accountabilities and outcomes of the audit committee. As noted, DeZoort et al. (2002) considered that audit committees are formed to protect the interests of shareholders, as agency theory holds that management may not always act in the interests of entity owners. Whilst the emphasis of the audit committee was on organisational risk, some audit committees focus on financial reporting and external audit relationships, without clearly focusing on measures and outcomes of organisational effectiveness.

The best practice guides from Deloitte (2004); the Institute of Internal Auditors (2003), KPMG (2003), the National Audit Office (2007a, 2007b) and audit committee questionnaires from Frankston City Council (undated b) and Moreland City Council (2003) were reviewed to ensure that practice guides and audit committee questionnaires contained material which complemented the academic research literature and to ascertain whether there were any issues that could be incorporated into the methodology and findings in Chapters Five and Six respectively. For the purposes of this thesis, 'accountabilities of the audit committee' has been defined as the strategy, structure and systems in place for the audit committee to discharge their responsibilities. These include the audit charter, meeting activities and diligence and training. The 'activities' of the audit committee and their outcomes relate to the assessment of business risk and control, assessment of the adequacy of financial reporting, assessment and supervision of external and internal auditors and regulatory compliance. Formal principles of effectiveness and activities of the audit committee are represented in Figures 3.7 and 3.8.

\begin{tabular}{|c|l|l|}
\hline \multicolumn{1}{|c|}{ Principles } & \multicolumn{1}{c|}{ Source of Information } \\
\hline 1. & Assessment of authority & $\begin{array}{l}\text { Frankston City Council (undated b); KPMG (2003); } \\
\text { Moreland City Council (2003); and National Audit Office (2007a, 2007b). }\end{array}$ \\
\hline 2. & Charter & $\begin{array}{l}\text { Frankston City Council (undated b); Moreland City Council (2003); } \\
\text { National Audit Office (2007a, 2007b); and Steinberg and Bromilow (2000). }\end{array}$ \\
\hline 3. & Membership & $\begin{array}{l}\text { Frankston City Council (undated b); Moreland City Council (2003); and } \\
\text { Steinberg and Bromilow (2000). }\end{array}$ \\
\hline the audit committee & $\begin{array}{l}\text { Deloitte (2004); Frankston City Council (undated b); KPMG (2003); } \\
\text { Moreland City Council (2003); National Audit Office (2007a, 2007b); and } \\
\text { Steinberg and Bromilow (2000). }\end{array}$ \\
\hline
\end{tabular}




\begin{tabular}{|l|l|l|}
\hline 5. & $\begin{array}{l}\text { Reporting from the audit } \\
\text { committee to council }\end{array}$ & $\begin{array}{l}\text { Deloitte (2004); Frankston City Council (undated b); and National Audit } \\
\text { Office (2007a, 2007b). }\end{array}$ \\
\hline 6. & Quality and training & $\begin{array}{l}\text { Deloitte (2004); Frankston City Council (undated b); KPMG (2003); } \\
\text { National Audit Office (2007a, 2007b); and Steinberg and Bromilow (2000). }\end{array}$ \\
\hline
\end{tabular}

\section{Figure 3.7 Principles of audit committee effectiveness}

\begin{tabular}{|c|c|c|}
\hline & Activities & Source of Information \\
\hline 1. & $\begin{array}{l}\text { Business risk and internal } \\
\text { control }\end{array}$ & $\begin{array}{l}\text { Deloitte (2004); Frankston City Council (undated b); National Audit Office } \\
\text { (2007a, 2007b); and Steinberg and Bromilow (2000). }\end{array}$ \\
\hline 2. & $\begin{array}{l}\text { Financial reporting - annual } \\
\text { financial statements }\end{array}$ & $\begin{array}{l}\text { Deloitte (2004); Frankston City Council (undated b); KPMG (2003); } \\
\text { National Audit Office (undated); and Steinberg and Bromilow (2000). }\end{array}$ \\
\hline 3. & $\begin{array}{l}\text { Oversight of external and } \\
\text { internal auditors }\end{array}$ & $\begin{array}{l}\text { Frankston City Council (undated b); KPMG (2003); Moreland City Council } \\
\text { (2003); National Audit Office (undated); and Steinberg and Bromilow } \\
\text { (2000). }\end{array}$ \\
\hline 4. & Regulatory compliance & Frankston City Council (undated b); and Steinberg and Bromilow (2000). \\
\hline 5. & $\begin{array}{l}\text { Compliance with code of } \\
\text { conduct }\end{array}$ & Frankston City Council (undated). \\
\hline
\end{tabular}

\section{Figure 3.8 Activities of the audit committee}

An example of an Audit Committee's Performance Evaluation Survey was contained in the Department of Planning and Community Development (2011) and Purcell (2004). These types of surveys can support governance principles of integrity and honesty and separate the governance process from obligations and responsibilities of the management team. They can assist local government councils to reinforce effective cultural practices, whilst at the same time not being restrictive or prescriptive (Barrett 2000; Durden \& Pech 2006). It was noted that whilst the Auditor-General, Victoria in 2004 had requested the review of audit committee effectiveness, neither the Auditor-General, Victoria or Local Government Victoria had provided a standard template for councils to follow. As a consequence, it was difficult to aggregate or analyse any sector-wide issues, as each council had interpreted and enacted the request differently. For example, the Whitehorse City Council had developed a model for the review of their audit committee in association with one of the 'Big Four' accounting firms (Whitehorse City Council 2004). These points gave rise to the empirical findings in Chapter Six.

\subsection{Relevance of the literature}

The pilot study and the research instrument in Chapter Five was based upon the literature in relation to governance and audit committees in chapters Two and Three as well as the 
investigation reports into local government in chapter Four. The following factors contributed to the framing of the research:

- Independence, financial expertise and diligence

- $\quad$ Skills and expertise

- $\quad$ Support from management

- $\quad$ Background and training of audit committee members

- $\quad$ Composition, authority and resources of the audit committee

- $\quad$ Leadership of the audit committee chair

- Weak governance was associated with the increased likelihood of adverse financial reporting

- $\quad$ The board and audit committee were the mechanisms for monitoring management's financial reporting behaviours

- $\quad$ Governance research was predominately based upon agency theory, but there are other theories

- $\quad$ Financial reporting, internal controls and financial Sustainability
Krishnamoorthy et al. (2002a, 2002b); Australian National Audit Office 2005).

Galvez (2003); Australian National Audit Office 2005).

Kalbers and Fogarty (1993).

DeZoort et al. (2002).

DeZoort et al. (2002).

Spangler and Braiotta (1990).

Carcello et al. (2011).

Beasley et al. (2009).

Cohen et al. (2008); Beasley et al. (2009); Marnet (2008).

Auditor-General, Victoria (2008).

So what does this all mean for this research? What emerges from the literature in this chapter are the following considerations which are influential in the local government audit committee research (Chapter six): (1) audit committees have become an important mechanism for strengthening corporate governance in both the private and public sectors; (2) the corporate law reforms in Australia and internationally (Chapter two) have the aim of improving accountability and the integrity of financial reporting and performance reporting; (3) audit committees can be viewed as a mechanism to enhance financial reporting, audit independence; and (4) can be a mechanism for the monitoring and the protecting the interests of the community as the agents of the councillors.

In relation to the questions 'are audit committee effective' and 'do they add value', the research as outlined in this chapter suggests that audit committees in local government can be effective by adding value to the oversight of the financial management process as well as providing oversight to risk management and fraud (Chapter six). This requires the independence of audit committee members (p. 84); the authority to act (p. 85); resources (p. 
86); and diligence (p. 87). Effectiveness can be influenced by the capabilities of the chair (Chapter six). Some of the recurring themes from the private and public sector audit committee literature influential in this research (Chapter six) are: (1) accountability and transparency; (2) the credibility of the members (qualifications, skills and experience (3) independence; and (4) the audit committee acting as an advisory body to the council.

\subsection{Summary}

In this chapter audit committee effectiveness as an integral part of the governance process was discussed. The discussion was an extension of governance processes in Chapter Two. The governance and audit committee issues discussed in Chapters Two and Three influenced the pilot study in Chapter Five and the research findings in Chapter Six.

The purpose of an audit committee as an extension of governance processes is to monitor financial and performance outcomes. Some of the issues for a local government audit committee can include the business continuity of council, risk management and performance outcomes. This can be coupled with the ability of audit committee members to probe and question management (Sharma et al. 2009). DeZoort et al. (2002) considered that 'composition, authority and resources' were input measures for audit committee effectiveness and this provided part of the framework for the pilot study and research findings in Chapters Five and Six.

The best practice guides from private and public sectors in Australia, Canada, France, New Zealand, the United Kingdom and the United States of America contained similar themes, notwithstanding specific regulatory environments and cultural nuances applicable for the intended audiences, whether they are in the private sector, public sector or local government.

Inquiries into misconduct, maladministration and corruption will be developed in Chapter Four. The outcomes from these inquiries are generally perceived by the community as a failure of strong governance processes within some local government councils. 


\section{CHAPTER FOUR: INQUIRIES INTO LOCAL GOVERNMENT}

This chapter documents, by way of illustration, the main thrust of the secondary research question from Section 1.4 in Chapter One, namely 'Do the investigations into local government maladministration and malfeasance enhance governance and the audit committee's effectiveness?' The chapter also provides some examples of corruption and misconduct and outlines the implications for public sector governance and audit committees within Victorian local government.

More specifically, the following issues are discussed: (1) the context of corruption and misconduct; (2) a literature review of corruption and misconduct; (3) corruption and misconduct as evidenced from local government inquiries and other investigating agencies; (4) possible explanations for corruption and misconduct behaviours; and (5) a way forward.

Corruption within local government can also be associated with the offering and the acceptance of bribes, albeit immaterial amounts (Independent Commission Against Corruption 2009a, 2009b). Receiving bribes and offering secret commissions are crimes under Commonwealth and State Acts, for example, Sections 176 and 177 of the Victorian Crimes Act (1958). The reasons as to why councillors or management of councils engage in misconduct or corrupt behaviours are multifarious and thus beyond the scope of this thesis. However, the consequences of such behaviours are more readily identifiable and these can include:

- $\quad$ criminal sanctions;

- $\quad$ loss of confidence in 'councillors' and 'local government'; and

- $\quad$ community perception of the erosion of ethical values and practices.

\subsection{Background}

From 1 January 2000 to 30 September 2009, there were twenty inquiries or investigations into Victorian councils by the: (1) Auditor-General, Victoria (three); (2) Local Government Victoria (eight); and (3) Ombudsman, Victoria (nine) (see Table 4.1). This thesis does not argue or consider that all councils in Victorian local government are corrupt or engage in systematic misconduct. Nevertheless, there are some inherent risks which audit committees in local government need to be aware of in their analysis of council's risk assessment. 
Whilst acknowledging the relevance of the issues from the investigations (Section 4.4) it was noted that a population of twenty inquiries (or investigations) in nearly ten years across all seventy-nine councils was a small number. Given the small number of investigations, a further sixty-four local government investigation reports were sourced from New South Wales, Queensland, Western Australia, New Zealand and the United Kingdom to provide a broader perspective on alleged instances of misconduct and corruption (Table 4.1). This number was reduced to forty-three reports, selected on the basis of: (1) Westminster style political processes in the different jurisdictions; (2) similarities in the ambit of council responsibilities; and (3) availability of reports to complement Victorian themes of: (1) council maladministration; (2) financial mismanagement; (3) corruption and misconduct by councillors and staff; and (4) breaches of statutory powers.

Table 4.1 Investigation reports into local government, 2000-2009

\begin{tabular}{|c|c|c|}
\hline State & Investigation Agency & Number \\
\hline Victoria & $\begin{array}{l}\text { - } \\
\text { - } \quad \begin{array}{l}\text { Localitor-General, Victoria } \\
\text { Planning and Community Development) }\end{array} \\
\text { Ombudsman, Victoria }\end{array}$ & $\begin{array}{c}3 \\
\text { (note } 1) \\
8 \\
9\end{array}$ \\
\hline New South Wales & $\begin{array}{ll}\text { - } & \text { Department of Local Government, New South } \\
\text { Wales } \\
\text { - }\end{array}$ & 10 \\
\hline Queensland & $\begin{array}{ll}\bullet & \text { Local Government, Queensland } \\
\bullet & \text { Crime and Misconduct Commission }\end{array}$ & $\begin{array}{c}1 \\
9 \\
\text { (note } 2)\end{array}$ \\
\hline Western Australia & 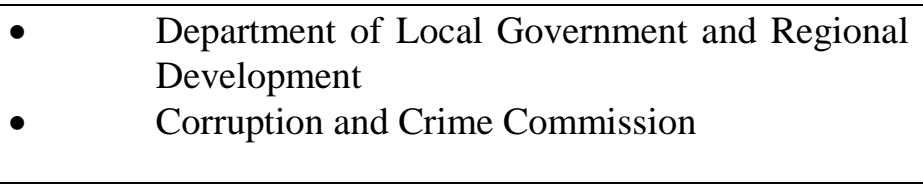 & $\begin{array}{c}4 \\
4 \\
(3)\end{array}$ \\
\hline New Zealand & Controller and Auditor-General, New Zealand & 6 \\
\hline United Kingdom & Audit Commission, United Kingdom & 17 \\
\hline & Total & 84 \\
\hline
\end{tabular}

Sources: $\quad$ Auditor-General, Victoria; Local Government Victoria; Ombudsman, Victoria; Department of Local Government; New South Wales, Independent Commission Against Corruption; New South Wales Local Government; Queensland, Crime and Misconduct Commission; Queensland, Department of Local Government and Regional Development; Corruption and Crime Commission, Western Australia; Controller and Auditor-General, New Zealand; and Audit Commission, United Kingdom.

Note 1: Reported number of investigation reports excluded consideration of financial performance.

Note 2: The Crime and Misconduct Commission was established in 1991. Since 2000, the Commission undertook nine investigations into local government.

Note 3: The Corruption and Crime Commission was established in 2004.

Whilst investigation reports from New Zealand, Queensland and the United Kingdom have been included, it was noted that local government in other international jurisdictions can have 
a different set of responsibilities to Victorian local government. For example, in New Zealand and the United Kingdom, local government was the second tier of government. Further, in the United Kingdom, local government is responsible for the management of community housing and primary and secondary education. In Victoria, this is the state government's responsibility. This does not suggest that all councils are corrupt, engage in systemic misconduct or that allegations undergo a judicial review process. For example, allegations into financial management practices in the Warrnambool City Council (AuditorGeneral, Victoria 2005d); allegations of misconduct in the Douglas Shire Council (Crime and Misconduct Commission 2006a); and mismanagement of funding for a proposed stadium by the Dunedin City Council and Otago Regional Council (Controller and Auditor-General, New Zealand 2007b). All of these allegations were found to be unsubstantiated.

The difference between corruption and fraud is explained by Transparency International (2012) in relation to corruption and the Auditing and Assurance Standards Board (2011) in relation to fraud. Transparency International (2012) stated that corruption is 'the abuse of entrusted power for private gain. It hurts every-one who depends on the integrity of people in a position of authority'. Fraud on the other hand is an 'intentional act by one or more individuals among management, those charged with governance, employees, or third parties, involving the use of deception to obtain an unjust or illegal advantage' (Auditing and Assurance Standards Board 2011 p. 10). Corruption and misconduct related to official corruption (Gerasimova 2008) and the occupational fraud categories of corrupt conduct, asset misappropriation and fraudulent statements (Association of Certified Fraud Examiners 2010). Gerasimova 2008 used the following corruption definition:

An individual or a group is guilty of corruption if they accept money, or money's worth, for doing something that he is under a duty to do anyway, that he is under a duty not to do, or to exercise a legitimate discretion for improper reason (McCullen 1961 cited in Seyf 2000 in Gerasimova 2008, pp. 223-4).

The Association of Certified Fraud Examiners (2010) and Wells (2007, 2004) categorised occupational fraud as 'corrupt conduct' (conflicts of interest, bribery, illegal gratuities and extortion), 'asset misappropriation' (cash and inventory) and 'fraudulent statements' (financial and non-financial, for example, false employment credentials). Gerasimova (2008) and Wells $(2007,2004)$ are further discussed in Section 4.4.3. In New South Wales, the Independent Commission Against Corruption (2008a) provided a definition of corruption and misconduct for the public service across New South Wales. This definition was relevant in 
other Australian states and included local government. The Commission defined corruption and misconduct as the:

...dishonest or partial behaviour, misuse of information, or breach of trust by a public sector employee, which if proved could amount to a crime or a disciplinary offence (Independent Commission Against Corruption 2008a, p.1).

The Commission further considered that corruption extended to the 'conduct of a person, which adversely affects, or could affect, the exercise of an official function by public officials’ (Independent Commission Against Corruption 2008a, p.1). Excluding the personal ramifications associated with an individual's corrupt behaviours or misconduct, the major implication for councils is that their integrity and reputation can be questioned and council operations, including the delivery of goods and services, can be impacted by either proven corruption or tainted by the perception of corruption. This can result in: (1) loss of reputation; (2) loss of public confidence; (3) direct financial loss; (4) wastage of scarce human and physical resources; and (5) adverse effects on staff morale. Sampford, Shadlock, Connors and Galtung (2006) argued that corruption had the propensity to undermine 'the fairness, stability, and efficiency of a society and its ability to deliver sustainable development to its members' (p. 1). They further considered that corruption and misconduct can be symptomatic of deeper distortions within society. Whilst bribery involved the physical movement of public funds and resources into private pockets, Sampford et al. (2006) considered it was more important to be aware that corrupt payments have the capacity to influence public policy choices and decisions by officials (p. 1). It was their view, that corruption and misconduct should be pursued, not because it was a moral issue, but because all members of society paid the price for corruption in one way or another.

\subsection{Context of corruption and misconduct}

\section{i. Select contributors to the aetiology of fraud}

Krambia-Kapardis (2001) used the term 'aetiology' of fraud to categorise the source or the origin of white-collar crime. Some of the literature had sociological and psychiatric origins (refer to the Models of Corruption and Misconduct in this section) although the Association of Fraud Examiners (2010) Wells (2007, 2004) and KPMG (2010, 2008a) provided current data in relation to the incidence of fraud. Some contributors to the aetiology of fraud are detailed in Figure 4.1. The exponents of an integrated perspective of fraud were KrambiaKapardis (2001) and Weisburd, Waring and Chayet (2001) who combined the theoretical 
criminological literature with an analysis of fraud data from the Major Fraud Group, Victoria Police in the period 1990 to October 1994 and a sample of cases prosecuted in seven federal judicial districts in the United States of America in 1976 and 1978 respectively.

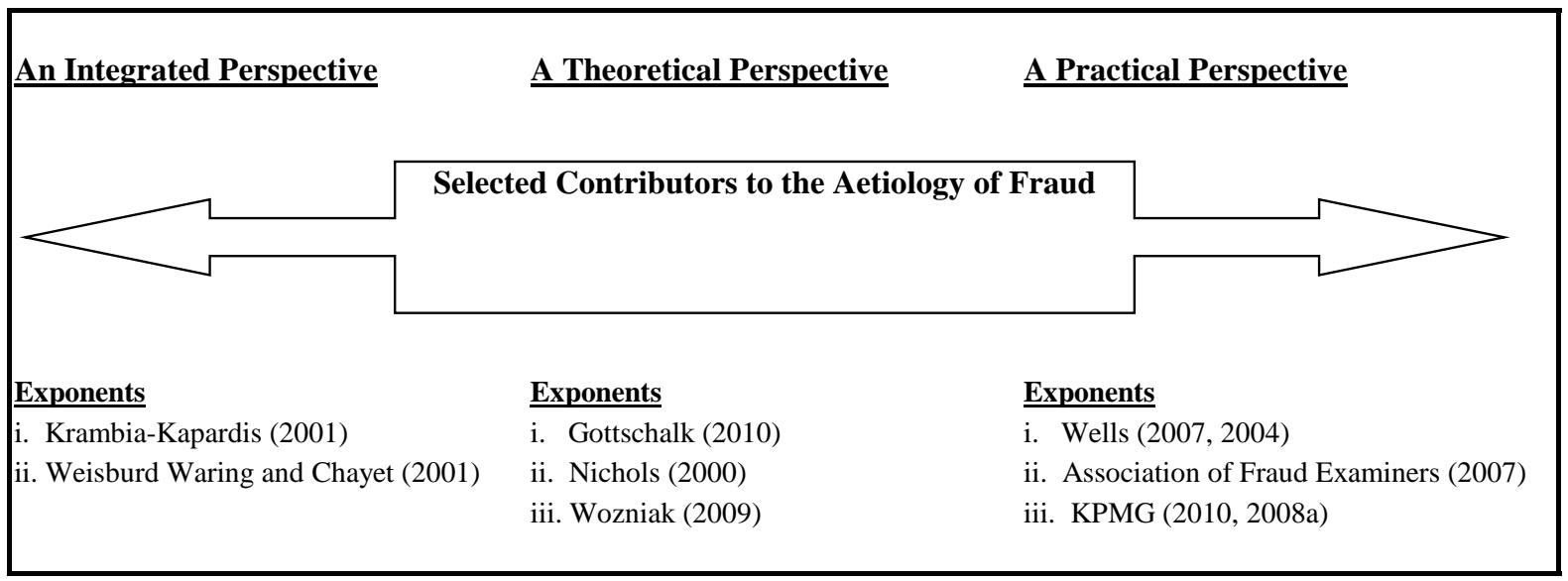

\section{Figure 4.1 Select contributors to the aetiology of fraud}

Krambia-Kapardis (2001) noted that criminal behaviour can be correlated with an offender's personality and situational factors and considered that these factors can be present in fraud offenders. She tested a model of fraud, which was a functional relationship between the fraud event and preconditions of opportunity, people in positions of financial trust and justification/rationalisation for offending. She examined fifty (from a total of one hundred and ninety-six) fraud cases from the Victoria Police from January 1990 to October 1994. She stated that 'major fraud offenders comprise a range of categories of offenders who perpetrate their crimes(s) under a broad range of circumstances, for a diversity of motives and use different modus operandi' (Krambia-Kapardis 2001, p. 106). Her contribution to the literature and the accounting profession was the importance of auditors undertaking a comprehensive fraud assessment risk of the companies they audit, based in part on 'red flags' and the relationship between 'different industries, different irregularities, different ways that alerted auditors and different audit procedures that appear to detect them' (Krambia-Kapardis 2001, p. 167). Weisburd et al. (2001) contradicted the notion that white collar offenders were generally one-off offenders and noted that offenders had 'multiple contacts in the criminal justice system' (p. 3). They concluded that repeat offenders presented a mixture of traits associated with deviance and conformity, but as they were white-collar criminals, they had characteristics associated with social stability and achievement. They categorised one group of offenders as opportunistic criminals, but noted that a second group reflected the stereotypical criminal, with high levels of deviance reflected from their childhood and adult lives. Weisburd et al. (2001) abandoned the: 
moralistic view of criminality that has drawn the public imagination and is reflected in much criminological theory. Criminals may often be just like others in the community. Their criminality may reveal little more than that they have committed a crime. This may be a less satisfying position for some than perspectives that attempt to distinguish offenders from non-offenders, but it is relevant to a large number of people who participate in crime (p. 145).

Gottschalk (2010), Nichols (2000) and Wozniak (2009) analysed criminological theories. Gottschalk (2010) provided a synthesis of the prevailing behavioural, organisational and managerial theories associated with criminality. This had some similarities to a metaanalysis, but was more a description of the literature than a critique. Nichols (2000) analysed similarities and differences between the perception of criminologists and management theorists in relation to white-collar crime. He noted that the two groups considered whitecollar crime to be serious and that both groups had placed an emphasis on white-collar crime over the past two decades. In relation to key differences between these groups, Nichols noted that:

- $\quad$ criminologists argue that white-collar crime is more serious than street crime, whilst managerial theorists are silent on the issue;

- managerial theorists consider that corporate behaviour and ethics have improved, whilst criminologists do not consider this to be the case; and

- criminologists consider that corporations are prone to violating the law, whilst managerial theorists consider that corporations are vulnerable (2000, p. 243).

Wozniak (2009) examined white-collar crime from the perspective of institutional structures. He argued that there was a tendency in the criminology literature to explain emerging patterns of crime by referring to dysfunctional families or individuals, rather than dysfunctional social structures. He considered that using a 'Millsian type of vantage point towards studies of crime helps to heighten an ability to observe criminal behaviours and unethical practices as embedded in a social environment in which people play social roles' (Wozniak 2009, p. 199).

From a fraud investigators' perspective of white-collar crime, Wells (2007) categorised fraud by topic and types of schemes. The Association of Fraud Examiners (2010) provided an American perspective on the incidence of white-collar crime, while KMPG (2010, 2008a) offered an Australian perspective. Their contribution to the literature was the currency of source material obtained from the periodic survey of businesses: annually for the Association of Fraud Examiners and biennially for KPMG. 


\section{ii. Models of corruption and misconduct}

Punch (1996) paraphrased Milton Friedman in the context of corruption and misconduct and stated that:

...the values for some companies at certain times are as follows: 'the only responsibility of business is to make profit - illegally if necessary'. And, 'the business of business is crime' (p. 247).

Punch (1996) noted that corruption can generally take the form of:

- $\quad$ informal rewards (perks, fiddles and discounts);

- work avoidance or the manipulation of the work situation (late to work, leisure time in the organisation's time);

- $\quad$ staff deviance against the organisation (stealing, absenteeism and neglect);

- $\quad$ staff deviance for the organisation (bending the rules, failure to observe health and safety in the interests of enhanced production);

- $\quad$ organisational deviance for the organisation (deception and cunning to achieve informal organisational goals); and

- managerial deviance against the organisation (senior management victimising the organisation in their own self-interest) (pp. 56-7).

He called the first four categories 'occupational deviances' and noted that deviance had been comprehensively discussed in the literature (Ditton 1977; Henry 1978). His analysis focused on the last two categories of 'organisational deviance', which was either for or against the organisation. Punch (1996) stated that 'influential people utilise their power or resources for ends which some other people define as illicit and then, not infrequently, employ that power or those resources, to protect themselves from the consequences of social control' (p. 57).

Misconduct and corrupt behaviours in local government can be perpetrated by councillors, the leadership team of council, the staff against council interests, external parties or a combination of these groups. The question of why this happens and in what circumstances can be imponderable and therefore potentially unanswerable. There can be multiple answers, each specific to the organisational environment in which the behaviours occurred.

Griffin and O’Leary-Kelly (2004) defined dysfunctional behaviour in organisations as:

motivated behaviour by an employee or group of employees that has negative consequences for an individual within the organization, another group of individuals within the organization, or the organisation itself (p. 4). 
They provided an all-encompassing definition of dysfunctional organisational conduct, which included alcohol and drug use, revenge by managers and staff, absenteeism, theft and workplace violence. Gettler (2005a, 2005b) applied the medical term 'psychoses' in a metaphoric sense to the dysfunctionality of organisations. Gettler (2005b) cited the work of Bion (1961) in relation to warning signs from dysfunctional groups and Finkelstein (2003), which Gettler (2005b) validated the work of Bion (1961). From Bion’s (1961) work Gettler (2005b) said that:

Using these criteria for healthy groups as a starting point, it is possible to work backwards and deduce that psychotic or dysfunctional groups will display certain warning signs:

- disorganisation of thought processes inside the organisation particularly from its leaders;

- individuals within the organisation who share a delusion;

- different components of the organisation lose or lack the capacity to communicate with each other, resulting in fragmentation;

- the organisation is unaware of its dysfunctional or disintegrating state; and

- significant deterioration in the organisation's capacity to deal with the external environment and its demands or, in some cases, ignorance of the external environment (p. 24).

Gettler (2005b) stated that Finkelstein (2003) validated the above patterns of destructive behaviour in his study of corporate collapses and stated that:

In every corporate collapse, Finkelstein found flawed mindsets that distorted a company's sense of reality, delusional attitudes that kept fuelling those perceptions, breakdowns in communication systems that were supposed to convey urgent information, and leadership qualities that kept executives from correcting their course (p. 25).

Clarke (2005) on the other hand stated that in Australia, the person who perpetrated a fraud may not necessarily be a sociopath and jumping to such conclusions cannot be substantiated without evidentiary based practice. Clarke (2005) noted that in one-third of all fraud cases, greed was the primary motivation for the offender (p. 115). O’Malley (2002) in his discussion of the criminologist, Sutherland (1961) noted that Sutherland had challenged the conventional perceptions that crime was a 'working class' phenomena. Sutherland considered that whitecollar crime was a crime albeit under different circumstances. O’Malley (2002) stated that Sutherland had argued that:

- individuals and organisations in business and professional sector commit substantial amounts of crime, possibly having as much impact as working class crime; and 
- their high social status, ability to evade detection and power to manipulate enforcement make white collar criminals' offending socially invisible - and criminology had failed to recognise this (p. 1).

O’Malley (2002) and Friedrichs (1996) affirmed the conclusions of Sutherland (1961), that is, psychobiological and pathological explanations for white-collar crime have generally been excluded by criminologists as an explanation for white-collar crime. O’Malley (2002) also noted that a relationship between criminality and the business cycle was also not valid or at best, an unconvincing argument. O’Malley (2002) argued 'those criminals are people whose environment provide an excess of definitions favourable to crime' (p. 2). This affirmed the argument of Clarke (2005) who stated that:

The corporate criminal psychopath's strategy can generally be summarised as follows. They enter the company, make connections with people they later use to cover up their behaviour, and then find a 'weak point' in the corporate system. This allows them to steal large amounts of money and escape detection for long periods of time (p. 114).

Friedrichs (1996) considered that:

White-collar crime is clearly a complex, multifaceted phenomenon. No single theory or explanation can comprehensively explain all forms of white-collar crime, much less all specific instances of white-collar crime (p. 240).

He observed that in trying to explain crime, one needs to be very clear about what the researcher is trying to explain. Is it 'criminality, crime or criminalization' that one is trying to explain (Friedrichs 1996, p. 240). The interpretations of O’Malley (2002), Friedrichs (1996) and Clarke (2005) accorded with Coleman (1994), who considered that the motivation and opportunity for white-collar crime to occur are 'separately interwoven, and any successful theory of white-collar crime must take that fact into account' (p. 361). Price (2000) supported the conclusions of Coleman (1994) in relation to ethical failures. He stated that in relation to ethical failures of leadership, 'we are often disposed to look for an explanation of the leader's behaviour, not an analysis of the moral status of what was done' (Price 2000, p. 177).

Applying some psychological theories to corrupt or dishonest organisations and disgraced leaders after the event was simple, yet it was generally impossible whilst an organisation was in the midst of a crisis (Clarke 2005; Gettler 2005b; Griffin \& O’Leary-Kelly 2004; Griffin et al. 1998; Kets de Vries 2001, 1991). Some staff within councils may have limited insights and may have observed various unrelated incidents, but these events and behaviours may not be in context. Even if some staff can clearly identify the issues, they may be powerless to 
influence or implement changes. Whilst it may be possible to generalise about some indicators of councils sliding into the corruption abyss, it is quite another thing to build a model that accurately predicts council corruption. However, the investigation reports of local government in New South Wales, Queensland, Victoria and Western Australia and New Zealand and the United Kingdom have been accepted as validating evidence of misconduct or corrupt behaviours (see Section 4.4).

The Institute of Internal Auditors and KPMG Fraud Survey (KPMG 2008a) used the term, 'red flags', which are a form of organisational indicators or 'early warning signs of possible fraud' (p. 20). Whilst the term has a specific meaning in forensic accounting (Grabosky \& Duffield 2001a, 2001b), organisational indicators of pathological behaviours by a manager or staff member within an organisation can also include behaviours which are manipulative, unethical, shallow and parasitic, as well as staff bullying and a desire for power and control (Clarke 2005 pp. 77-101). Krambia-Kapardis (2001) noted that one of the disadvantages of 'red flags' is that it focuses attention on specific cues and can limit an investigator from identifying or observing other factors (p. 51). Furthermore she considered that red flags were 'of doubtful usefulness if used on their own to detect fraud' (Krambia-Kapardis 2001, p. 147).

The KPMG Fraud Survey (KPMG 2008a) noted that 21\% of respondents indicated that the warning signs of possible fraudulent activity were ignored. Generally corruption and misconduct require two parties for a criminal act to be consummated; for example, bribery of a council officer requires the offer of the bribe from one party and acceptance by the second party in exchange for the latter party doing something for the benefit of the former. Equally, misconduct and corruption can occur when councillors use their positions to promote their own self-interests or the interests of other parties, for example, the Ballarat City Council (Inspector of Municipal Administration 2008) and usurping planning delegations and powers in the City of Greater Geelong (Inspector of Municipal Administration 2006; Ombudsman, Victoria 2007).

Punch (1996) considered that business was criminogenic and that understanding crime and business 'lies in recognising the structure that the business environment gives to misconduct, both in terms of opportunities, and how misconduct is managed' (p. 213). Punch (1996) also stated that in order to understand white-collar crime, 'it is essential to grasp that the business organization is the weapon, the means, the setting, the rationalization, the offender and the 
victim' (p. 214). He did not believe in a criminological model of fraud that explained the level of deviance and concluded that any attempts to explain fraud within such a model 'merely generates platitudinous generalizations'. From a societal perspective, corruption and misconduct required:

...deviation from the rules within a business organization requires agreement among managers to deviate, the selection of the suitable methods of implementing those decisions, the choice of strategies of defence and concealment, and the inducement for certain people to fill specific roles (Punch 1996, p. 245).

Gobert and Punch (2003) considered that there was no single variable theory of corruption and misconduct, but argued instead for a multi-causal explanation with contingent, situational factors playing an important role in individual cases. This will be further discussed in

Sections 4.4 and 4.5 .

The Independent Commission Against Corruption (1998) reviewed the literature pertaining to corruption and misconduct and stated that there are inherent risk factors which can: (1) enable or optimise corruption and misconduct; and (2) aid in the perpetration of the corruption and misconduct (p. 5). The recommendations from the Commission were for all government bodies, including local government, to focus on detective and preventative solutions for corruption (Figure 4.2).

From Figure 4.2, the three factors which can provide an environment for corruption and misconduct to occur include: (1) the nature of the work performed; (2) the working conditions of staff; and (3) individual histories of staff including any dependencies on alcohol, drugs and gambling. The inherent risk for staff in local government can increase, depending on a staff member's ability to exercise a delegation or discretionary power and their job responsibilities within council. In situations where there are potential delays in the provision of services, for example, a building approval or a food safety licence, there can be an increased opportunity for a bribe to be offered in order to short circuit the alleged bureaucratic 'red tape’ (Independent Commission Against Corruption 2009a; 2009b).

The Independent Commission Against Corruption (1998) noted that working conditions including low salaries can be a conditional factor for the susceptibility to corruption and misconduct. However, this should not be confused with the notions of 'need' and 'greed', which can be an individual's response to the temptation and the propensity for corrupt 
conduct to occur. The Independent Commission Against Corruption (1997) had previously suggested that staff who feel disgruntled or dissatisfied at work are more likely to commit workplace crime than others (Challinger 1994) as well as those who feel they are under work pressures. Other factors which contributed to corrupt behaviours included a dependence upon alcohol, illicit drugs and a predilection for gambling.

In order to moderate the inherent risks of corruption and misconduct, the Independent Commission Against Corruption (1998) suggested that some aspects of organisational culture can facilitate or impede corruption and misconduct. These included:

- $\quad$ unclear messages by the organisation about what constituted acceptable behaviours;

- $\quad$ attitudes of work colleagues towards corruption and misconduct;

- $\quad$ the example set by management;

- $\quad$ lack of reinforcement of ethical behaviours; and

- $\quad$ failure by staff to identify that behaviours associated with corruption and misconduct are wrong.

The Independent Commission Against Corruption (1998) suggested that effective remedies against corruption and misconduct included: (1) staff knowledge of organisational reporting mechanisms; (2) the history of the organisation in effectively dealing with reports of corruption; and (3) an individual's beliefs or values about corruption reporting.

So what does this mean for this research? Misconduct in local government can be a complex and multifaceted phenomenon, and no single theory or explanations can comprehensively explain all forms of misconduct or the aetiology of fraud. In explaining misconduct in local government we need to explain human behaviours in all their intricacies and varieties. Friedrichs (1996) stated that 'the ultimate complexity and diversity of white collar crime precludes the possibility of a single comprehensive theory of explanatory scheme' (p. 241). We need to recognise the different levels of theory for example Krambia-Kapardis (2001), Gottschalk (2010) Nichols (2000), and Wozniak (2009) with the fraud practitioners' perspective (Wells 2007; KPMG 2010, 2008a) as compared to the models of corruption and misconduct (Punch, 1996; Griffin \& O’Leary-Kelly, 2004; and Clarke 2005). Whilst greed may be a core motivation to explain misconduct, when the specific cases in local government are reviewed (Section 4.4) they can be analysed within the context of corruption and politics (Section 4.3.1); corruption in government (Section 4.3.2); professional misconduct (Section 4.3.3); ethics (Section 4.3.4); bias in decision making (Section 4.3.5) and the management of gifts (Section 4.3.6). 


\begin{tabular}{|c|c|c|}
\hline Factors which enable/optimise occurrence of corruption & Corruption risk factors & Factors which aid in the perpetuation of corruption \\
\hline $\begin{array}{l}\text { 1. Nature of the work performed } \\
\text { 1.1 Discretion exercised by position } \\
1.2 \text { Position in organisation } \\
1.3 \text { Service associated with delays } \\
\text { 2. Working conditions } \\
\text { 2.1 The disputed role of salary and its relationship to need } \\
\text { 2.2 Lack of benefits for remaining with employer } \\
\text { 2.3 Employee dissatisfaction } \\
2.4 \text { Work pressures } \\
\text { 3. Individual histories and dependencies } \\
\text { 3.1 Ethical decision making history } \\
\text { 3.2 Dependence on employer } \\
\text { 3.3 Dependence on alcohol, drugs and gambling }\end{array}$ & $\begin{array}{l}\text { 4. Organisational culture } \\
\text { 4.1 Unclear messages about what is acceptable } \\
\text { 4.2 Attitudes of colleagues } \\
\text { 4.3 Example set by management } \\
\text { 4.4 Lack of reinforcement of ethical behaviour } \\
\text { 4.5 Other workplace practices }\end{array}$ & $\begin{array}{l}\text { का Filure to identify the behaviour as wrong } \\
\text { 6. Organisational factors which affect taking action about corruption } \\
\text { 6.1 Reporting mechanisms } \\
\text { 6.2 Employee responsibility } \\
\text { 6.3 Organisation history in dealing with reports of corruption } \\
\text { 7. Other factors which affect taking action about corruption } \\
\text { 7.1 Individual beliefs } \\
\text { 7.2 Features of the wrongdoing }\end{array}$ \\
\hline
\end{tabular}

\section{Figure 4.2 Corruption risk factors}

Source: Independent Commission Against Corruption, 1998, p. 6. 


\subsection{Literature review}

The discussion of corruption to date has concentrated on governmental inputs. We now turn to the wider literature which identified the following themes: (1) corruption and politics (Berlinski 2009; Chang \& Golden 2006; Johnson 2008; Lederman, Loayza \& Soares, 2005); and (2) corruption in government (Collins, Uhlenbruck \& Rodriguez, 2009; Coxson 2009).

Much of the literature in relation to corruption and government was excluded from consideration as it generally related to corruption in the third world or other developing economies. Also, some literature had a specific emphasis on corruption perception indices, for example, the Transparency International (2011a) Corruption Perception Index, the Transparency International (2011b) Bribe Payers Index and the Transparency International (2011c) Global Corruption Barometer. A review of the literature for the terms 'corruption', 'Australia' and 'local government' did not identify any relevant references.

The literature pertaining to misconduct of public officers within government generally related to: (1) professional misconduct (Andreoli \& Lefkowitz 2009; Hodgkinson 1997; Karpoff, Lee \& Martin 2008; Oppler, Lyons, Ricks \& Oppler 2008; Perry 2001); and (2) professional misconduct and professional ethics (Burgess \& Mullen 2002; Jennings 2005; Simon 2005).

\subsubsection{Corruption and politics}

Whilst the literature in relation to corruption and politics had a strong international focus and perspective, nevertheless there were some parallels and lessons for local government in Australia. Berlinski (2009), for example, stated that:

corruption is the cancer of economics, with all that the metaphor implies — it is enigmatic, poorly understood, hydra-headed, deadly, and often hidden until it is too late (p. 81).

She lamented that corruption can be difficult to study because those associated with corruption are not unmotivated, 'and in the best cases, the data is buried and in the worst cases, the researchers are buried' (Berlinski 2009, p. 74). She argued that even if societies were unable to estimate the level of corruption, it remained as a lacuna in understanding corruption and the misery it brings. She considered that corruption was: (1) pervasive; (2) undermined economic, political and legal institutions which should be robust for society to work; and (3) created insecurity of property rights especially in developing countries. She 
considered that the conditions for corruption to thrive included a judiciary that does not properly enforce contractual obligations and dubious banking practices and a lack of regulatory oversight.

By way of parallel, Chang and Golden (2006) examined political corruption specifically from the perspective of electoral fraud. The relevance to this thesis was that electoral fraud, as perpetrated by the councillors of the local government municipality, has the propensity to create an unethical and illegal environment, which can permeate to the officers of council. As well as being illegal under the Local Government Act (1989) electoral fraud was a reputation risk for the audit committee to manage. Chang and Golden (2006) concluded from their research that corruption became less severe as elections were more open, whereas corruption increased where there was closed proportional representation and interference in the political processes. The outcomes from Brimbank City Council (Ombudsman, Victoria 2009a) and Greater Dandenong Council (Reilly 2009) provided a Victorian perspective to these findings. In both these councils, it was the internal political machinations, that is, the future vote buying and interference in political processes, both at council and state level, which was evident. The alleged inclusion of dummy candidates in the Whitehorse City Council election in 2005 was subsequently dismissed in the County Court in October 2010 (Bachelard 2009; Lowe 2010).

Johnson (2008) focused on the relationship between corruption and the democratic process and the ability to disentangle them. She noted that in some countries there were no quick fixes, because corruption was entangled 'in the political, social and economic landscape in which it operates' (Johnson 2008, p. 371). She considered that corruption cannot be addressed in isolation from these factors and that whilst corruption manifested itself in different ways in different countries, the general mainstay was that it had 'a corrosive and widespread effect on the quality of life of its citizenry' (Johnson 2008, p. 372). When one reflects upon the effects (on the citizens of the City of Port Phillip and the City of Ballarat) of investigations by the Ombudsman, Victoria and the Inspector of Municipal Administration (in relation to increased rates and charges to pay for the councillor's and management's largesse and misconduct), then Johnson's (2008) observations would appear to be prophetic. Lederman et al. (2005), similar to Chang and Golden (2006), used cross-country observations in relation to corruption, although Chang and Golden (2006) focused on elements of the electoral system, whereas Lederman et al. (2005) grounded their research in the determinants of corruption and the political institutions which increased accountability. They 
complemented Berlinski (2009) and Johnson (2008) and considered that the indicators of corruption were negatively correlated to economic outcomes and future prospects of growth and development. They argued that there was a link between political institutions and corruption, with political institutions (which determined the culture and values within a society) being instrumental in determining the incidence of corruption. They also noted that political structures and balance of power, including the electoral system and the level of electoral competitiveness, were important determinants and incentives 'for those in office to be honest, and to police and punish the misbehaviours of people inside and outside the government bureaucracy’ (Lederman et al. 2005, p. 27).

\subsubsection{Corruption in government}

The literature in relation to corruption in government also had a strong international perspective, although Coxson (2009) and Collins et al. (2009) provided some insights which were relevant for local government in Australia.

Coxson (2009), for example, examined corruption in local government in Armenia. His contribution to the literature related to the development of a corruption matrix, which could be applied to local government in any country. This matrix included:

- $\quad$ transparency of procurement;

- $\quad$ transparency of the lease and sale of assets;

- $\quad$ transparency of the ownership of entities bidding for local government contracts;

- $\quad$ formal quotations for procurements;

- $\quad$ internal audit; and

- $\quad$ internal control procedures.

In applying the matrix to local government in Victoria, it was considered that although there were processes for the transparency of procurement, sale of council land and assets and internal audit, as prescribed in the Local Government Act (1989), corruption and misconduct issues centred around the level of non-compliance with these processes. Collins et al.'s (2009) study was undertaken in India. The study concluded that corruption of government officials and politicians increased when companies had social ties with government including the propensity to engage in corrupt and illegal conduct and the payment of bribes. They also noted that companies were likely to rationalise this as the way that business was done and that this practice was necessary to remain competitive. The significance of their research was that it illustrated the importance of social and familial ties and perceptions of executives to continually engage in corrupt relationships with government officials. Collins et al. (2009) 
concluded that the rationalisation for companies to engage in corruption with government officials in order to reduce uncertainty for their companies was not supported by their research. However, they noted a correlation between the degree of social ties between executive management with politicians and government employees and corrupt conduct. They also noted that if managers of companies belonged to industry networks, for example, professional accounting and management bodies, they were less likely to engage in corrupt conduct, as compared with managers who did not belong to professional bodies.

The relevance of the study by Collins et al. (2009) was that it provided an alternative insight into the question of why corruption can occur, which can transcend different countries, industries and cultures. Taken together, the results of the research indicated that examining corruption from the perspectives of company management was an alternative way of examining corruption, as compared to examining corruption from the perspective of the efficacy of regulating measures. However, their research has a country and cultural bias and their conclusions may not necessarily translate into other cultures, specifically the local government sector in Australia, notwithstanding the risk of social ties with government could be universally applicable.

\subsubsection{Professional misconduct}

\section{i. Occupational fraud}

This subsection discusses occupational fraud and official corruption and misconduct.

Gerasimova (2008) discussed corruption in developing countries, although his analysis had some relevance for corruption and misconduct in local government. He noted the different forms of corruption, for example, bureaucratic corruption, where politicians take bribes and grand corruption where politicians misuse their powers for their own private gain. He considered that the consequences of bribery were that the provision of government services became more expensive and perverted democratic and rational decision-making processes (Gerasimova 2008, p. 230). This was particularly relevant to local government corruption cases identified in this chapter. The contribution to the literature of the Association of Fraud Examiners (2010) and Wells (2007, 2004) was the use of taxonomy of occupational fraud (corruption, asset misappropriation and fraudulent statements) to discuss fraud perpetrated against organisations by staff and management and external parties. Wells (2004) cited the 
Association of Fraud Examiners (1996) Report to the National on Occupational Fraud and Abuse by stating that:

The key is that the activity (1) is clandestine (2) violates the employee's fiduciary duties to the organisation (3) is committed for the purpose of direct or indirect financial benefit to the employee, and (4) costs the employing organization assets, revenues or reserves (cited in Wells 2004, p. 1.)

Wells (2004) noted the common law elements of a fraud, which have to be proven, namely: a material false statement, knowledge that the statement was false, the victim's reliance on the false statement and damages (p. 2). Grabosky and Duffield (2001a) considered that fraud, like all other crimes, was a function of the supply of motivated offenders, prospective victims and the absence of capable guardians. They categorised fraud into the organisational context in which it occurred, namely: (1) fraud committed by management; (2) fraud committed by employees; (3) fraud committed by direct interface (e.g. con games); and (4) fraud committed against individuals by electronic media (e.g. Nigerian advance fee scams). In relation to fraud in Australian businesses and government, KPMG (2010) noted that by dollar value, theft of cash was a major type of fraud perpetrated by management, followed cheque tampering by non-management staff and insurance fraud by external parties to an organisation (p. 7). Krambia-Kapardis (2001) noted that according to fraud victim studies, the cost of fraud had increased and opportunities for fraud to occur had increased due in part to social, technological and economic factors (pp. 15-6). She also stated that 'research into fraud was scarce' and 'very little was known about the types of crimes committed and the characteristics of those who commit such crimes’ (Krambia-Kapardis 2001, p. 17).

\section{ii. Corruption and misconduct}

Perry (2001) noted that one should be careful in trying to estimate the levels of corruption and misconduct in Australia, because the data pertaining to corruption and misconduct via the courts was 'quantitatively uncertain, and qualitatively an imperfect part of the totality' (p. 7). He considered that there were three sizeable bodies of corruption and misconduct, namely: (1) the body which had been uncovered and exposed; (2) the body that we are aware of, albeit, that it can be vague, uncertain and imprecise; and (3) the body of corruption and misconduct that no-one was aware of. Guesses as to levels of corruption and misconduct can include unreliable quantitative data and the 'rest can be rumours, memory, patterns of behaviour and lifestyle' (Perry 2001, p. 7). The research by Andreoli and Lefkowitz (2009) of employees working in the for-profit, not-for-profit and government sectors concluded that: 
...organizational factors but not personal characteristics were significant antecedents of misconduct and job satisfaction. Formal organizational compliance practices and ethical climate were independent predictors of misconduct, and compliance practices also moderated the relationship between ethical climate and misconduct, as well as between pressure to compromise ethical standards and misconduct (p. 309).

They noted that some of the previous empirical research into misconduct had inherent limitations, namely:

- $\quad$ most of the research was non-quantitative;

- many of the quantitative research had used students as compared to people working in the governmental and corporate sectors;

- $\quad$ the difficulty in obtaining measures of illegal activities unlikely to be observed by others; and

- $\quad$ corruption was not amendable to accurate self-reporting (p. 311).

The research by Andreoli and Lefkowitz (2009) research concluded that from the perspective of an individual's past history, self-reported misconduct or observations of misconduct in others was unrelated to: (1) the level of moral reasoning; (2) age, gender and ethnicity; (3) size and type of organisation; and (4) job status. They considered that organisations with ethical policies and practices and leaders setting a positive example of ethical behaviours contributed to the environment where misconduct could be predicted.

It appears that in addition to the positive effect of ethical compliance practices directly, it moderates the relationship between ethical climate and misconduct, as well as that between having been pressured to compromise one's standards and misconduct. Having a high level of compliance practices appears to have an attenuating effect on the relationship between ethical climate and misconduct (p. 325).

Hodgkinson (1997) examined the themes which he considered contributed to corruption and misconduct in the public sector in the United Kingdom. He noted that corruption and misconduct was under reported. This thesis acknowledges that the Audit-Commission in the United Kingdom, reports all corruption and misconduct investigations in health, education and local government with the National Audit Office, United Kingdom, reporting on other government departments and bodies. Hodgkinson (1997) considered that the 'marketised public sector' had inherent inbuilt tensions resulting from the move from a bureaucratic model to a functional rationality model of administrative action. As a consequence, there was a state of tension that "creates a hiatus in systems of control and accountability within which the opportunities and incentives for corruption abound' (1997, p. 33). These tensions in the 
public sector were also alluded to by Adcroft and Willis (2005); Willis (2004) and Wilson (2003b).

Hodgkinson's (1997) contribution to the literature was his succinct overview of the typology of corruption which included: legal, historical-cultural, public interest and market-centred approaches (pp. 18-28). He considered that the United Kingdom was not experiencing a rise in corruption, but rather a movement between 'primary' and 'secondary' corruption. Werlin (1994) used the word 'corruption' from Lowenstein (1989) 'as a violation of legal or formal norms of official conduct' (Werlin 1994, p. 553). He stated that:

The reason here emphasized is that primary corruption takes the form of excessive selfishness or partisanship without complete disregard for legal and formal norms of official conduct (p. 554).

To support his observation, Werlin (1994) cited The Economist (1993) which stated that 'unscrupulous contractors can make it worthwhile for a councillor or officer to bend the rules to put the business their way' (The Economist 1993, p. 14, cited in Werlin 1994, p. 554). He considered:

Secondary corruption, as explained earlier, arises out of the inadequacy of political software, particularly the distrust of government institutions. It is therefore a functional reaction to this inadequacy, much like fever is a response to a disease. At the same time it has a corrosive effect on political software (intensifying hostility towards government) (Werlin 1994, p. 554).

Hodgkinson (1997) considered that secondary corruption was 'more than simply an effect of a transformation within the polity, e.g., a temporary lack of respect or confidence in the constitution or a government, it is seen to have a "corrosive effect", which further undermines and already ailing system' (p. 23). Hodgkinson (1997) considered that in the United Kingdom in the 1990s, there was a period in the political system when government bodies and local government bodies changed. He stated that 'it has also created a context within which the regulative framework is largely unknown and unknowable. A culture of corruption is being nurtured due to this diminution of the democratic framework'. He considered that it is 'in this context that corruption appears to flourish, and take on a secondary character' (Hodgkinson 1997, p. 24).

He referred to this culture as primary corruption and considered that it was ironic that when corruption was discussed in official reports, that is, the media and the literature, corruption 
was conceptualised in terms which largely corresponded to the definition of primary corruption, when in reality it was 'secondary corruption'. He noted that corruption in the public sector was largely perceived from a legalistic and moralistic perspective, where corruption was perceived as a breach of probity and the breakdown of internal controls and political processes. He called this the 'rotten apple syndrome', in which corruption was seen as individualistic or opportunistic deviance.

Hodgkinson's next perspective was called the 'historic-cultural' approach, in which corruption was seen as something that happened in third world countries and was alien to the notion of corruption-free apolitical public service. His contribution to the literature was his argument that corruption should be examined in the context of systematic or structural explanations of corruption, which was similar to Punch (1996) and Gobert and Punch (2003). He examined the changes in the public sector in the 1990s in terms of organisational structures such as the change in the mode of service delivery and the marketisation of the public sector and considered that these were the major contributing rationale for corruption and misconduct to occur. This was similar to Punch (1996), who argued that organisations were the means and the victim, notwithstanding that it was an individual or a group of people who perpetrated corrupt conduct.

There can be a general perception that wrongdoers can often get away with corruption and misconduct. Karpoff et al. (2008) examined the consequences for managers who had engaged in the misrepresentation of financial statements in the United States of America. They examined the records of the Department of Justice and the Securities Exchange Commission for enforcement actions against individuals for financial misrepresentation from 1 January 1978 to 30 September 2006. They concluded that of the 'two thousand and six individuals identified, 93\% were terminated from jobs, with another 31\% being restricted from holding a position of a public officer, or director of a company' (Karpoff et al. 2008, p. 194). They noted that managers were more likely to be terminated if their misrepresentation of the financial accounts were 'particularly harmful to shareholders and when they faced strong governance controls' (Karpoff et al. 2008, p. 213). They considered that the notion of dishonest managers getting away with corruption or misconduct was not supported by the evidence with the regulators imposing both fines and criminal penalties. They noted that only forty of the seven hundred and eight enforcements had been undertaken under the provisions of the Sarbanes-Oxley Act (2002), which indicated that the Securities Exchange Commission and the Department of Justice and internal governance processes within companies were 
generally adept at applying sanctions against individuals who had misrepresented financial accounts.

Oppler et al. (2008) examined the relationship between the financial history of individuals and the propensity for counterproductive work behaviours, for example, bribery, theft of goods or information and their work related to recruitment and selection of employees. Their research tested the hypothesis that there was a relationship between applicants with a history of fiscal mismanagement and their level of susceptibility to bribes and theft, which they termed as 'counterproductive work behaviours'. The results indicated that of the $31 \%$ of employees who indicated they had a poor financial history, they also had a past history of 'counterproductive work behaviours'. This contrasted with only $18 \%$ of employees who did not have a poor financial history or 'counterproductive work behaviours'.

\subsubsection{Professional misconduct and professional ethics}

Breaches of professional conduct generally occur within self-regulated professional bodies which have a code of ethics, for example, the accountancy profession, the medical profession, psychologists and the legal profession. Simon (2005) and Jennings (2005) examined ethical behaviours in the legal profession, whilst Burgess and Mullen (2002) examined ethical misconduct amongst industrial hygienists in the United Kingdom.

Jennings's article was published after the ramifications of the Enron collapse and the implosion of Arthur Andersen in the United States of America. Jennings (2005) posed the question of why society was concerned with the distinction between ethical and legal positions in cases of malfeasance and nefarious conduct in the collapse of Arthur Andersen and Enron. Jennings (2005) noted that Arthur Andersen's conviction for the shredding of documents relating to Enron was overturned by the Supreme Court of the United States of America, although Jennings (2005) considered that the acquittal of the defendants 'was neither a finding of no wrongdoing, nor a licence to continue with the same activities' (p. 42). The Supreme Court of the United States of America reversed the conviction, from the lower court, as the prosecution had not shown that senior management of Arthur Andersen were aware that documents destroying in the Enron case was a violation of the law.

Jennings (2005) concluded by stating that the distinction between ethical and legal outcomes was that the 'laws and regulations cannot cover every possible situation' (p. 47). He 
considered that all employees and executives should adhere to an ethical standard of behaviours for the sake of the law and, in this instance, the survival of Arthur Andersen. In relation to Arthur Andersen, the philosophers Bentham and Kant would have disagreed. Bilz \& Darley (2004) stated that 'Bentham and Kant argued that justice forbids us from considering - at all - reasons for punishing that conflict with own preferred philosophy’ (p. 1217). Bentham believed that 'punishment can only be justified to the extent that it serves a particular goal - generally of wrongdoing', (Bilz \& Darley 2004, p. 1215). Kant on the other hand was a deonotologist whose proposition from the 'Critique of Pure Reason' was that all moral propositions should be treated as though one wished that they were a universal guide and this a duty (deontology). He considered that 'the rule of right and wrong must help us to the knowledge of what is right or wrong in all possible cases; otherwise, the idea of obligation or duty would be utterly null, for we cannot have any obligation to that which we cannot know' (Kant 2010, p. 289).

Squires, Smith, McDougall and Yeach (2003) and Gettler (2005a, 2005b) discussed the consequences of managerial misconduct in Arthur Andersen and the change in the culture of Arthur Andersen, who were auditors for Enron in the United States of America and HIH Insurance in Australia. The partners of the firm were encouraged to become more focused on revenue generation, than observing professional auditing standards and ethical standards. Gettler (2005b) noted that, 'in the end, one in ten partners were removed' (p. 5). He stated that 'the traditional values of integrity and speaking straight, of quality and honesty ahead of profitability were replaced by an emphasis on revenue generation (Gettler 2005b, p. 5). Squires et al. (2003) described the culture of Arthur Andersen as 'a firm that changed in a way that inadvertently created the seeds of its own destruction' (p. 22). Simon (2005) examined the notion that calculated ambiguity and deliberate ignorance were key themes from the Watergate and Enron scandals in the United States of America and that lawyers had sought to limit their professional responsibilities by the avoidance of knowledge and a clear articulation of ethical values. He stated that organisational cultures and what he called the 'ambivalent bureaucracy' were major contributors to the style and structure of businesses akin to Enron and Arthur Andersen. He defined 'ambivalent bureaucracy', as 'a strong and inevitable gulf between the two regimes of order, a formal one and an informal one' (Simon 2005, p. 12). In relation to legal professional ethics, he noted that Section 307 of the Sarbanes-Oxley Act (2002) required lawyers acting as corporate counsels within companies to report upwards to the chief executive, where they detected a material violation of the securities law or breach of fiduciary duty. If the chief executive did not take appropriate 
action, the corporate counsel was to report the matter to the audit committee or the board. He noted that the response of the Bar Association in the United States of America to this change was to oppose it, generally on the grounds that they did not want outside regulation imposed on them and this showed 'a visceral clinging to the prerogatives of ignorance and ambiguity' (Simon 2005, p. 30). Simon (2005) found this to be counter-productive to the interests of organisations and shareholders and further noted the contraction between ethical pronouncements of the legal profession and actual practice of ethical values in situations of wrongdoing within a company.

The contribution to the literature by Burgess and Mullen (2002) related to their study of misconduct amongst industrial hygienists and the antecedents for misconduct to occur. They examined nine activities in the United Kingdom, which were considered to be unethical conduct by the American Board of Industrial Hygiene and they asked participants in their survey if they had witnessed any of the same behaviours in the last five years amongst their colleagues in the United Kingdom. The research found that $51 \%$ of respondents had noted plagiarism in reports, $37 \%$ had noted a failure to protect confidential data and $23 \%$ had observed professional criticism of professional colleagues for self-interest and advancement. It was also reported that $25 \%$ of respondents had witnessed the fabrication of data. The reasons given for the behaviours included: (1) economic pressures; (2) workplace pressures that were organisational specific; and (3) a lack of training in ethics. The respondents considered that effectiveness of various approaches to prevent unethical behaviours included:

(1) development of ethics and professional codes; (2) ethics training; (3) legislation or the bylaws of professional bodies; and (4) societal expectations that professional bodies would require their members to adhere to ethical pronouncements and positions.

\subsubsection{Bias in decision making}

The Australian courts, over many years, have developed rules to ensure that decision makers at the three tiers of government act fairly and without bias in making decisions which affect the rights and interests of members of the community. In common law, this can be described as procedural fairness, which establishes that those who are affected by decisions will be treated with fairness, including an open mind, free of bias or any preconceived notions. Councillors are required to hold or form views on matters that come before them in council or in special committees. However, there is an expectation that councils and individual 
councillors will bring an open mind that is free from any perception of bias, notwithstanding that they have previously expressed a view.

In two legal cases, in 1998 and 2007, the Supreme Court of Victoria established that a council decision can be overturned if it was proven that a councillor or council, involved in decision making, had prejudged the matter and were not open to alternative viewpoints (Bycon Pty Ltd v Moira Shire Council [1998] VSC 25 and Winky Pop Pty Ltd \& Anor v Hobsons Bay City Council [2007] VSC 468). In the former case, the council was approached by a developer for a proposed supermarket, with one parcel of land ear-marked for development owned by council. The council negotiated the sale of the land to the developer without receiving any submissions from any other interested parties as required under Section 189 of the Local Government Act (1989). It was held that the submission process, as required under Section 189 of the Act, had been rendered illusory, by the prejudgement of council. Vincent J. stated that:

... I am satisfied on the balance of probabilities and on the basis of the largely undisputed history of the matter, that by the time that the necessity to comply with s.189 was recognised, the council was so committed to the development, that it is unrealistic to suggest that the subsequent formal compliance was anything other than mere ritual, designed to avoid a successful challenge being made to the proposed sale by the creation of an illusion that any submissions opposing the development had been seriously considered (Bycon Pty Ltd $v$ Moira Shire Council [1998] VSC 25 at para 55).

In Winky Pop Pty Ltd v Hobson Bay Council [2007] a councillor lodged a submission in relation to a proposed planning scheme amendment in a redevelopment area, which was subsequently referred to a review panel. The council subsequently considered the panel report and the first council motion was to prepare a revised version of the redevelopment strategy. This motion was defeated, with the councillor who had made the submission to the review panel voting with the majority to defeat it. The second motion was to prepare a revised development strategy, which effectively excluded the land owned by Winky Pop from the strategic redevelopment area. This motion succeeded, with the councillor who had appeared before the review panel again voting with the majority in support of the motion. Winky Pop challenged the validity of the two resolutions of the Hobson Bay City Council on the basis that the councillor, who had lodged a submission in relation to the development, was not entitled to vote on the motions and if he had not participated, the result would have been different. Kay J. held that: 
(3) Councillor Hemphill was affected by apparent bias in participating in, and voting on, those resolutions, in the sense that a fair minded and informed member of the public might entertain a reasonable apprehension that he might not have brought an impartial and unprejudiced mind to the resolution of the issues considered by the council on that day. Accordingly, the resolutions were so passed in breach of the rules of natural justice (Winky Pop Pty Ltd \& Anor v Hobsons Bay City Council [2007] VSC 468 at para 66).

Winky Pop Pty Ltd v Hobson Bay Council [2007] established the tests for valid decision making by councillors and councils. Kay J. noted that:

(1) In determining whether there was prejudgment on behalf of a councillor, it must be borne in mind that councils are democratically elected, and that councillors necessarily carry out political and legislative roles. Accordingly, a councillor is not necessarily disqualified from participating in a decision because the councillor, previously, has held and expressed views on the matter in question.

(2) The appropriate test, taking into account the political and legislative nature of the role of a councillor, is whether the councillor, on the matter in question, is open to persuasion, notwithstanding his or her previously held and expressed views on the subject. In other words, to establish that a councillor is disqualified from participating on a decision on the basis of prejudgment, it must be shown that the councillor's views were so demonstrably fixed that they were not open to being dislodged by reason or argument.

(3) It is not necessary to prove actual prejudgment on behalf of a councillor. It is sufficient if it is made to appear that a fair minded and informed member of the public might entertain a reasonable apprehension that the councillor was not open to persuasion on the matter in question, because of the councillor's previously held and expressed views on the matter, or because of the councillor's previous involvement in the issue in question (Winky Pop Pty Ltd \& Anor v Hobsons Bay City Council [2007] VSC 468 at para 44).

\subsubsection{Management of gifts}

Provision in the Local Government Act (1989) relating to the management of receipts of gifts was amended in 2003, 2008 and 2010. In 2003, the threshold for disclosure for receiving gifts was reduced from \$A2000 to \$A500. In 2008, the threshold was further reduced to \$A200 for all councillors, committee members and executive officers. In 2010, the amount was increased to \$A500 under Section 78C of the Act. It required all councillors, committee members and executive officers to declare gifts with a cumulative value of \$A500 or more, received from a person or persons in the five years preceding any decision, or the exercise of the power, duty or function (Local Government Victoria 2009a). Reasonable hospitality at an event or function where the mayor, councillors and staff members attend in an official capacity is considered to be legitimate, although the definition of 'reasonable' can be open to interpretation. The receipt of gifts and hospitality within local government can be problematic 
and contentious. It is understood that gifts to councillors and staff of councils have previously included low monetary value for goods and services from a variety of sources, as well as hospitality and invitations to sponsorship events such as the theatre and sporting events. Hospitality and the supply of beverages essentially involves the 'grooming' of councillors and executive officers in order to facilitate the favourable purchasing of goods and services or perhaps a favourable service from the council in future. The practice of grooming is specifically designed to facilitate familiarity and a level of personal indebtedness on the part of the councillors and managers receiving gifts or corporate hospitality. From the perspective of the supplier providing the gifts and hospitality, it was about 'relationship marketing'. However, the receipt of gifts can be challenging for a council from a reputation perspective in the eyes of stakeholders. In the public sector, the receipt of gifts and lavish hospitality is generally considered to be contrary to the principles of an open and transparent procurement process and principles of probity.

Codes of Conduct are generally in place in Australian state governments, for example Victoria, which prohibit the receipt of gifts and hospitality above a nominal amount, usually \$A50, although some public servants and agencies (e.g. Victorian Government Purchasing Board, Auditor-General, Victoria and the Ombudsman, Victoria) are prohibited from accepting any gifts or gratuities, as it would discredit their independence. Documented examples of some unethical and dishonest practices in councils have included attempted bribery, gifts of cash, in-kind gifts and hospitality (Independent Commission against Corruption 2009a, 2009b, 2008a, 2008b, 2007a, 2007b; Ombudsman, Victoria 2009c). Some lower level forms of financial misconduct are generally specific to the culture of a council, notwithstanding the ethical stance of a council that may be espoused, but not always practiced. A council's organisational culture can be both determined and modelled by councillors and executive management (Lagan \& Moran 2006). If councillors and executive management are unethical or dishonest, albeit at a low monetary level, it can set the tone and example for all other staff within council with regard to their relationships with suppliers and stakeholders.

\subsection{Local government corruption and misconduct}

Given the limited research into misconduct and corruption in local government, this thesis developed a taxonomy to interpret misconduct or corrupt conduct. As previously mentioned, forty-three investigation reports into local government from New South Wales, Queensland, 
Victoria, Western Australia, New Zealand and the United Kingdom were analysed using the taxonomy of: (1) council maladministration; (2) financial mismanagement; (3) corrupt or unethical conduct by councillors or staff; and (4) breach of statutory powers. The latter breach related generally to planning powers or inference by councillors in planning decisions, notwithstanding that a council was ultimately responsible for all planning decisions. The number of investigation reports are summarised in Table 4.2.

Table 4.2 Local government investigations in Victoria, New South Wales, Queensland, Western Australia, New Zealand and the United Kingdom

\begin{tabular}{|l|c|c|c|c|}
\hline \multicolumn{1}{|c|}{ Category } & Victoria & $\begin{array}{c}\text { New South Wales, } \\
\text { Queensland and } \\
\text { Western Australia }\end{array}$ & $\begin{array}{c}\text { New Zealand and the } \\
\text { United Kingdom }\end{array}$ & Subtotal \\
\hline $\begin{array}{l}\text { Council governance and } \\
\text { maladministration }\end{array}$ & 2 & 2 & 6 & 10 \\
\hline $\begin{array}{l}\text { Financial } \\
\text { mismanagement }\end{array}$ & 3 & 3 & 5 & 11 \\
\hline $\begin{array}{l}\text { Corrupt or unethical } \\
\text { conduct by councillors } \\
\text { or staff }\end{array}$ & 5 & 10 & 2 & 5 \\
\hline $\begin{array}{l}\text { Breach of statutory } \\
\text { powers }\end{array}$ & 4 & nil & 1 & 43 \\
\hline Totals & 14 & 15 & 14 & \\
\hline
\end{tabular}

Source: $\quad$ Investigation Reports summarised in Appendices 1.1.1, 1.1.2 and 1.1.3.

In relation to Victoria, investigations reports from the Auditor-General, Ombudsman, Victoria and the Inspector of Municipal Administration are summarised in Appendix 1.1. For local government in New South Wales, Queensland and Western Australia, investigation reports from the Independent Commission Against Corruption, Crime and Misconduct Commission, Corruption and Crime Commission and the Department of Local Government are summarised in Appendix 1.2. Investigation reports from New Zealand and the United Kingdom by the Audit-Commission, United Kingdom and the Controller and AuditorGeneral, New Zealand are summarised in Appendix 1.3.

\subsubsection{Council governance and maladministration}

Breaches of council governance processes or council maladministration related to ten of the forty-three investigations reports examined. There were two reports in Victoria (Appendix 
1.1) two in New South Wales, Queensland and Western Australia (Appendix 1.2) and in New Zealand and the United Kingdom (Appendix 1.3).

\section{i. $\quad$ Local government in Victoria}

As noted in Appendix.1.1, the two investigations in Victoria related to the dysfunctionality of council and the breakdown of relationships with councillors in Glen Eira City Council (Inspector of Municipal Administration 2005) and the misconduct of council officers in the Shire of Melton (Ombudsman, Victoria 2005). In the former investigation, the Inspector of Municipal Administration (2005) noted a total breakdown in relationships between councillors including their incapacity and unwillingness to pursue remedial action. He concluded that their conduct was characterised by hostile and acrimonious behaviours, including the denigration of councillor colleagues, which inhibited and retarded the decisionmaking capacity of council.

The maladministration of the Shire of Melton differed from the Glen Eira City Council, as it was caused in part by council officers, notwithstanding that councillors were ultimately responsible for the actions of officers. The Ombudsman, Victoria (2005) noted that the former chief executive: (1) breached the recruitment provisions of the Local Government Act (1989) by not advertising employment vacancies; (2) failed to maintain full and accurate council records in accordance with his statutory duties; and (3) purchased and disposed of assets without following due process as required in the Local Government Act (1989). The major criticism in the report related to council's mismanagement of the processes associated with attracting business and development into the shire. It was identified that the payment of incentives to businesses was poorly structured and managed and there had been a failure to obtain cost contributions from landholders in relation to road construction (of benefit to landholders) and obtain subdivision infrastructure cost contributions from developers.

\section{ii. Local government in New South Wales}

From investigations in New South Wales (Appendix 1.2) the outcomes of investigation into Brewarrina Shire Council was similar to the Shire of Melton. In this case, the Department of Local Government (2005) concluded there was a need to improve systems of internal control and polices and there were major difficulties in recruiting and retaining qualified staff. The investigation concluded that whilst there was no compelling evidence to dismiss council, it 
had a poor relationship with the Ngemba Community Working Party (part of the local Aboriginal community), which was caused in part by the Ngemba Community Working Party's inability to recognise the role of the local government council and its resource constraints. The investigation into the Broken Hill Council was similar to Glen Eira City Council in Victoria as: (1) councillors were unwilling or unable to exercise their responsibilities and accountabilities; (2) the mayor failed to demonstrate his capacity to fulfill his duties; and (3) relationships between councillors and staff had broken down.

\section{iii. Local government in the United Kingdom}

The three investigations in the United Kingdom (Appendix 1.3) related to: (1) unlawful payments and procedural deficiencies in the council's decision-making ability (Bude Stratton Town Council, Audit-Commission, United Kingdom 2007b); (2) conflict of interest (Chipping Campden Town Council, Audit-Commission, United Kingdom 2007d); and (3) termination of the chief executive of the council (Doncaster Metropolitan Borough Council, Audit-Commission, United Kingdom 2008a).

The Bude Stratton Town Council had established a subsidiary company, Bude-Stratton Heritage Trust, with a number of councillors being members of the Bude-Stratton Heritage Trust. It was concluded that the Bude-Stratton Town Council had exceeded its statutory powers by establishing a museum. When the Bude-Stratton Town Council resolved to provide a grant of£86,000, it did not adequately record its intention to do so in the council agenda and consequentially the payment was considered to be void. The two councillors who were members of the Bude-Stratton Heritage Trust had a conflict of interest, when both councillors participated in the council's decision to award a grant to the Trust.

The investigation of the Chipping Campden Town Council (Audit-Commission, United Kingdom 2007d) was similar to the Bude-Stratton Town Council, to the extent that it related to payments to the Peelers Trust, with two council members being members. The investigation concluded that councillors who were trustees had participated in discussions of grants at meetings of the Chipping Campden Town Council and had voted on the resolution to authorise payments after cheques had been issued. The Audit-Commission, United Kingdom concluded that this was a conflict of interest. The investigation of the Doncaster Metropolitan Borough Council (Audit-Commission, United Kingdom 2008a) concerned the termination of the chief executive officer. The report noted that the breakdown in the 
relationship between the mayor and the former chief executive officer were caused in part by tensions between councillors and the local Labor Party (Audit-Commission, United Kingdom 2008a, p. 6). The review concluded that: (1) the performance management system for the chief executive officer was not fully established; (2) there were weaknesses in the investigatory process; and (3) there was a breach of confidentiality in information by councillors about the case.

\section{iv. Local government in New Zealand}

The three investigation reports of local government in New Zealand (Appendix 1.3) related to: (1) funding and the management arrangements for proposed infrastructure assets Dunedin City Council and Otago Regional Council, (Controller and Auditor-General, New Zealand 2007b); Taupo District Council, (Controller and Auditor-General, New Zealand 2002); and (2) dysfunctionality at the West Coast Development Trust (Controller and AuditorGeneral, New Zealand 2008a).

The objectives of the investigation into funding for the proposed stadium by the Dunedin City Council and the Otago Regional Council were to provide assurances to the community that proposed funding arrangements with the Lake Taupo Development Trust were commercially sound. The investigation concluded that the allegations of misconduct were unfounded and that councils' funding arrangements were appropriate for preliminary stages of the project. The Controller and Auditor-General, New Zealand recommended that a formal and robust funding framework be established or both councils make a commitment to fund the construction phase.

The investigation of the Taupo District Council concerned the establishment of an interim board of the Lake Taupo Development Trust. The report noted that the appointment of councillors as trustees gave rise to a conflict of interest between being a councillor and a director of the Lake Taupo Development Trust. The other inquiry into the West Coast Development Trust noted that allegations of misconduct were unfounded and that other allegations were based on minor administrative or procedural errors or occasional errors of judgement. The major problem was that the Trust was dysfunctional at a governance level and trustees did not work together effectively. There was an atmosphere of suspicion and distrust, which manifested in hostility and accusations. The outcomes resonated with those from the Glen Eira City Council investigation (Inspector of Municipal Administration 2005). 


\subsubsection{Financial mismanagement}

The second most prevalent theme was financial mismanagement. Common themes from the Victorian investigations are summarised in Appendix 1.1 and include:

- financial mismanagement of the budgetary processes and financial reporting, for example, Surf Coast Shire Council (Inspector of Municipal Administration 2002);

- $\quad$ mismanagement of the sale of council assets, for example, the East Gippsland Shire Council (Auditor-General, Victoria 2005a); and

- mismanagement of procurement, including tendering arrangements as required under the Local Government Act (1989), for example, Warrnambool City Council (Auditor-General, Victoria 2005d).

From Appendix 1.2, the financial mismanagement in local government in New South Wales was similar, although two of the major inquiries related to financial mismanagement of large infrastructure projects, for example, the 'Oasis Project' and 'Woodward Park' in the Liverpool City Council (Department of Local Government, 2004a) and the mismanagement of the 'Glasshouse' project by the Port Macquarie-Hastings Council (Department of Local Government 2008a). The investigation into the Rylstone Shire Council (Department of Local Government 2004b) concluded that council were inadequate managers. The major difference which distinguished that investigation from investigations in Victoria was the level of negligence. Council was aware of its precarious financial position in 2002, but there was reluctance to address the issue. Financial mismanagement investigations from local government in the United Kingdom (Appendix 1.3) centred upon:

- $\quad$ mismanagement of procurement, including tendering arrangements, for example, City of Bradford Metropolitan District Council (Audit-Commission 2006b); Leicester City Council (Audit-Commission, United Kingdom 2007a); and Marlborough Town Council (AuditCommission, United Kingdom 2005);

- financial mismanagement of the council, for example, Epworth Town Council (AuditCommission, United Kingdom 2008b); and

- $\quad$ mismanagement of council's bank deposits in Iceland by the North East Lincolnshire Council (Audit-Commission, United Kingdom 2009b).

\subsubsection{Corruption and misconduct by councillors and staff}

\subsubsection{Victoria}

As summarised in Appendix 1.1, there were four investigations in Victoria in relation to corrupt conduct by councillors. Following the dismissal of the Brimbank Council in September 2009 (Ombudsman, Victoria 2009a; Inspector of Municipal Administration 2009) 
the Ombudsman, Victoria (2009c) investigated the abuse of power and conflict of interest by a building inspector at the Brimbank City Council. In this investigation, Peter Anastasi was assigned to investigate if there were non-compliant buildings on a property in the municipality. Anastasi formed the opinion that the buildings were non-compliant, but without informing the Brimbank City Council, he purchased the property before compliance with the building order. He further misused his position at the council to effect repairs to the property at the expense of a Buddhist community organisation that were the previous owners.

The Ombudsman, Victoria (2009c) concluded that Anastasi failed to notify his employer of the conflict of interest, between his duties as a building inspector and purchaser of the property (Ombudsman, Victoria, 2009c, p. 1). The Ombudsman, Victoria (2009c) further concluded that he destroyed the building complaint file pertaining to the property and recommended he be charged by the Victoria Police for destruction of evidence (Section 254 of the Crimes Act, 1958) and destruction of a public record (Section 19 of the Public Records Act, 1973). At the time of submitting this thesis, there has been no mention of any trial in The Age newspaper, nor was Peter Anastasi's name listed in the records of the Victorian Magistrates Court.

\subsubsection{New South Wales, Queensland and Western Australia}

There were nine investigation reports in New South Wales, Queensland and Western Australia, as summarised in Appendix 1.2. These reports were further grouped into a taxonomy of:

- $\quad$ attempted bribery (Ku-ring-gai Council, Independent Commission Against Corruption 2009b; and Warringah Council, Independent Commission Against Corruption 2009a);

- corrupt practices associated with procurement (Bankstown and Strathfield Councils, Independent Commission Against Corruption 2007b); and

- $\quad$ corrupt misconduct (Wollongong City Council, Independent Commission Against Corruption 2007a, 2008b, 2008c and 2008d); Smiths Beach Development, Corruption and Crime Commission 2009, 2008, 2007; Aboriginal Land Councils in New South Wales, Independent Commission Against Corruption 2005, 2000; and Douglas Shire Council, Crime and Misconduct Commission 2006a).

\section{i. Local government in New South Wales}

Investigation reports into Ku-ring-gai Council and Warringah Council related to attempted bribery, rather than misconduct of council officers. Investigations into Aboriginal Land Councils (Independent Commission Against Corruption 2005, 2000) concerned 
mismanagement and corruption associated with property dealings and management of complaints associated with maladministration, misuse of funds, favouritism, conflict of interest and irregularities in elections.

The investigation into Bankstown and Strathfield Councils (Independent Commission Against Corruption 2007b) concerned the conduct of Scott Freeman, a former council officer at both councils and contractor, Terence Stepto. It involved a false invoicing scheme between both men. Freeman arranged for Stepto to submit dummy quotes for work tenders. Freeman then placed forged quotes into the council's procurement files and used these quotes to demonstrate he had followed council's procurement procedures. During his employment at both councils, Freeman managed his own business which undertook work for a company called Admark. The Independent Commission Against Corruption established that Admark had not quoted for projects with either council, but was very successful in gaining a number of valuable contracts once Freeman was employed by these councils.

\section{$\underline{\text { Investigations into Wollongong City Council }}$}

The investigation of the systemic corruption at Wollongong City Council was unprecedented in local government in Australia and four separate reports were completed in 2007 and 2008. The first report related to bribery associated with the sale of a parcel of council land and the other three reports related to institutionalised corruption within council.

Report One - Allegations of Bribery, Independent Commission Against Corruption (2007a)

The Independent Commission Against Corruption report concluded that Mr Lou Tasich had offered Mr Coyte a \$A30,000 bribe to favourably treat his proposal to purchase and develop the Thomas Street Car Park. They also concluded that the conduct of the then general manager Mr Rod Oxley fell below the standard expected of a public officer to immediately report the allegation against Mr Coyte to the Independent Commission Against Corruption.

Reports Two, Three and Four - Corrupt Conduct, Independent Commission Against Corruption (2008b, 2008c, 2008d)

The three reports related to investigations into Wollongong City Council and concluded that: (1) Ms Beth Morgan, a former staff member of council and other current and former staff and councillors, had engaged in corrupt conduct in the management of development applications submitted by Messrs Frank Vellar, Glen Tabak and Michael Kollars; (2) the provision of 
confidential council information to Mr Vellar; and (3) relationships and dealings between $\mathrm{Mr}$ Vellar and current and former staff and councillors.

The second report (Independent Commission Against Corruption 2008c) related to the suspension of a development consent granted by council on 18 August 2005 for a proposed \$A100 million development known as 'Quattro'. The development was proposed by a company controlled by Mr Frank Vellar and the application for consent was assessed and approved by Ms Beth Morgan, who was a senior council officer at the time and had an undisclosed personal relationship with Mr Vellar. The Independent Commission Against Corruption concluded that both Morgan and Vellar had engaged in 'serious corrupt conduct' in connection with development consent for 'Quattro'.

The third report (Independent Commission Against Corruption 2008b) examined the corrupt behaviour of former Wollongong city councillors Zanotto, Jonovski, Esen and Gigliotti and how the behaviour of the former general manager, Mr Rod Oxley and former senior managers, Messrs Joe Scimone and John Gilbert contributed to council corruption.

\section{ii. $\quad$ Local government in Queensland}

The investigation of the Douglas Shire Council (Crime and Misconduct Commission 2006a) concerned the granting of the contract to operate the Daintree River ferry service, conflict of interest by the mayor and complaints against the chief executive. The investigation concluded that allegations of misconduct were without substance or could not be substantiated on the available evidence.

The second investigation report in Queensland related to the electoral fraud and bribery at council elections for the Gold Coast Council in 2004. The Crime and Misconduct Commission (2006b) concluded that:

- $\quad$ there were false and misleading statements from candidates with respect to other candidates or entities;

- $\quad$ there was the concealment of a fund for the election expenses of preferred candidates;

- $\quad$ false and misleading statements and electoral returns were made;

- $\quad$ there were inadequate declarations in relation to fundraising; and

- $\quad$ there were inadequate declarations between personal interests and the public duty to disclose interests. 


\section{iii. Local government in Western Australia}

The investigations into the Smith's Beach development in Western Australia (Corruption and Crime Commission 2007, 2008, 2009) related to: (1) land development; and (2) the nondisclosure of pecuniary interests by councillors who had an association with the development. In 1999, Canal Rocks Pty Ltd proposed a tourist and residential development on forty-five hectares adjacent to Smiths Beach. The Corruption and Crime Commission made a number of findings against public officials, but in the context of this thesis:

- $\quad$ one finding of misconduct against Ms Philippa Reid, Busselton Shire Council for failure to declare an interest affecting impartiality of her personal relationship with a lobbyist for the Canal Rocks Pty Ltd;

- $\quad$ four findings of misconduct against Ms Anne Ryan, Busselton Shire Council for failure to disclose gifts, source of campaign funds, declarations of financial interests and a declaration of financial interests in Canal Rocks Pty Ltd; and

- $\quad$ one finding of misconduct against Mr John Triplett, Busselton Shire Council for a failure to make a financial interest disclosure of his interest in Canal Rocks Pty Ltd, which had provided election funding to him.

A subsequent investigation in 2009 was an addendum to the Report on the investigation of the alleged public sector misconduct linked to the Smiths Beach Development at Yallingup (Corruption and Crime Commission 2007) and concerned the opinions and recommendations of the Corruption and Crime Commission in relation to Mr Mark Brabazon, a public officer of the Department of Conservation and Land Management. The Corruption and Crime Commission (2009) retracted and clarified a number of statements and opinions, concluding that there was no adverse opinion pertaining to Brabazon. There was an associated investigation into the conduct of Mr Stephen Lee, Mayor of the City of Cockburn, concerning allegations of election funding irregularities. It was concluded that:

- $\quad$ Mr Lee had engaged in misconduct in failing to disclose a company gift from Australand in the year ended 30 June 2005 and the concealment led to the conclusions that his decisionmaking ability was not impartial and honest;

- $\quad$ Mr Lee did not act out of naivety or inexperience and his conduct was deliberate and over a long period of time; and

- $\quad$ The funding was significant and the purpose of the concealment was to enable him to advance the interests of Australand at the Cockburn City Council.

\subsubsection{United Kingdom}

As summarised in Appendix.1.3, there were two investigations in the United Kingdom which concluded that fraud and misconduct had occurred. The first investigation by the AuditCommission, United Kingdom (2007c) into the City of Westminster Council, had its origins 
in the mid-1980s, when Dame Shirley Porter and others were involved in the sale of council houses in the City of Westminster in marginal wards with the aim of influencing voting outcomes. The report concluded that:

- $\quad$ the City of Westminster Council had delayed its recovery actions against former councillor, Dame Shirley Porter, allowing her to remove assets from the jurisdiction of the courts;

- $\quad$ the council lacked the will to pursue the debt; and

- $\quad$ the approach taken by council in the final mediation was flawed and the amount accepted from Dame Shirley Porter was inadequate.

The investigation by the Audit-Commission, United Kingdom (2009c) into Nottingham City Council identified corrupt conduct in the housing service. They concluded that from 2003 to 2005, the housing service did not operate in the public interest. They identified that a number of properties had been allocated to people associated with senior officers of the council, with some of these houses receiving significant repairs at public expense. These houses were subsequently sold to tenants at a significant discount under the 'right to buy' provisions.

\subsubsection{Breach of statutory powers}

\section{i. $\quad$ Local government in Victoria}

As summarised in Appendix 1.1, there were four local investigations in Victoria relating to breach of statutory powers. Three investigations related to breaches of statutory planning powers (Glenelg Shire Council, Auditor-General, Victoria 2005b; Moorabool Shire Council, Ombudsman, Victoria 2009b; and City of Greater Geelong, Ombudsman, Victoria 2007). The fourth investigation related to non-disclosure of sources of election funding by councillors at the City of Greater Geelong (Inspector of Municipal Administration 2006).

The Glenelg Shire Council investigation (Auditor-General, Victoria 2005b) identified mismanagement of statutory planning powers. The council had engaged an external statutory planning contractor and had not provided oversight to ensure effective management. The report noted that: (1) there was a failure to initiate amendments to council's planning scheme; (2) there was unwillingness by council to change planning processes when advised to do so;

(3) there were inappropriate practices by some councillors in dealing directly with the planning contractor and bypassing of other councillors and management. The Ombudsman, Victoria concluded that governance practices were not complied with, including the 
operations of the Councillor Planning and Strategy Forums. He further noted that there was a conflict of interest by councillors and they interfered in the day-to-day operations of council.

The inquiry into the City of Greater Geelong related to the processing of planning permits for development (Ombudsman, Victoria 2007). The investigation focused on whether planning applications were processed in accordance with the Planning and Environment Act (1987) and the adequacy of policies and procedures to ensure legal and reasonable outcomes from the processing of planning applications. The Ombudsman also examined planning delegations exercised by council officers and operations of the Councillor Hearing Panel. He concluded that operations of the Councillor Hearing Panel did not promote procedural fairness and needed to be more transparent. He recommended that council:

- $\quad$ review its delegations in relation to planning approvals;

- $\quad$ review operations of the Councillor Hearing Panel to ensure accountability and transparency; and

- $\quad$ review the councillors' Code of Conduct to ensure they do not interfere or pressure council officers in the exercise of delegated planning powers.

The Ombudsman, Victoria, was cognisant of the potential risk for a conflict of interest to occur where a councillor, acting on a planning complaint from a constituent or other stakeholder, became 'involved in the operational functions of the council to resolve the complaint’ (Ombudsman, Victoria 2007, p. 21).

The Inspector of Municipal Administration (2006) investigated the sources of election funding at the City of Greater Geelong. He concluded that six councillors received financial and campaign support during the council election, but did not disclose the support in accordance with Section 81 of the Local Government Act (1989). He noted that five councillors had received funds below the threshold for reporting under the Local Government Act (1989) but councillor David Saunderson had received funding in excess of the \$A500 threshold and did not disclose it. As previously discussed, the source of election funds and the associated potential for political influence were major issues in the investigations into: Gold City Council (Crime and Misconduct Commission 2006b); the Smith Beach development in Western Australia (Corruption and Crime Commission 2009, 2007); and misconduct of the mayor of the City of Cockburn (Corruption and Crime Commission 2008). 


\section{ii. $\quad$ Local government in New South Wales, Queensland and Western Australia}

Breaches of planning powers at the Wollongong City Council (Independent Commission Against Corruption 2008b, 2008c, 2008d, 2007a) and investigations into the Smith Beach development in Western Australia (Corruption and Crime Commission 2009, 2007) have been discussed in the context of corrupt conduct, notwithstanding that investigations were associated with planning, zoning and development in both instances.

\section{iii. Local government in the United Kingdom}

From Appendix 1.3, there was one investigation in the United Kingdom relating to the misuse of planning powers at the Restormel Borough Council (Audit-Commission, United Kingdom 2006a).

The investigation related to planning decisions associated with a retail development at Victoria Park between November 1990 and May 1997. The original report by the AuditCommission in 2000 focused on procedural failures in the planning department, which sustained a loss to council of $£ 1.9$ million. The council had previously received six linked applications for a development at the Victoria Park site between 1997 and 1998. As council had not determined the fifth planning application within the required time, an appeal was lodged with the Secretary of State for the sixth application. The investigation by the AuditCommission, United Kingdom (2006a) was a follow-up to an earlier investigation. The 2006 investigation focused on the alteration of conditions in planning applications, which allowed the developer to plan a retail village near the city of Roche. The Audit-Commission United Kingdom was also interested to ascertain whether the change to permit conditions was caused by deliberate misconduct of council officers. The Audit-Commission, United Kingdom was unable to conclude whether the changing of permit conditions was deliberate or otherwise. The Audit-Commission recommended that council continue to implement previous recommendations from the earlier 2000 investigation. These included:

- $\quad$ planning applications which are deemed to be contentious are to be managed by competent and experienced staff;

- $\quad$ sufficient physical and human resources to manage the workload from planning applications;

- $\quad$ external advice for specialist planning issues; and

- $\quad$ planning applications which follow a structured format to ensure that the council's decisions are legal, fair and transparent (Audit-Commission, United Kingdom 2006a pp. 12-14). 


\subsection{Some insights into unethical behaviours}

The analysis in Section 4.4 provided some examples where misconduct or corrupt behaviours had occurred in local government councils in Australia, New Zealand and the United Kingdom. The issue of why they occurred can have multiple explanations. For example, a council could have an over-controlling leader, staff with passive-aggressive personalities, staff with narcissistic or histrionic personality disorders or other behavioural traits. The practical solution to solving a myriad of organisational problems based on personality traits can be difficult, due in part to their complexity and potentially their interrelationship with other internal and external influences (Clarke 2005).

The literature on the behaviours of individuals within an organisation included concepts of:

- $\quad$ narcissism (Jones, Lasky, Russell-Gale \& Le Fevre; Kets de Vries 2001; Kets de Vries \& Miller 1987; Maccoby 2000);

- $\quad$ machiavellianism (Buttery \& Richter 2003; Christie \& Geis 1970; Macrosson \& Hemphill 2001 and Robbins 2003); and

- dysfunctional behaviours (Bion 1961; Clarke 2005; Coleman 1994; Finkelstein 2003; Friedrichs 1996; Gettler 2005a, 2005b; Griffin \& O’Leary-Kelly 2004; O’Malley 2002; Price 2000).

Other concepts included: (1) the dark side of leadership (Argyris 1990; Conger 1990; Kets de Vries 1997; Hogan \& Hogan 2001; Dijkstra, Van Dierendonck, Evers \& De Dreu 2005; Thomas \& Burns 2004;); and (2) toxicity of culture (Pech \& Slade 2004; Peterson \& Deal 1998; Cosner \& Peterson 2003; Frost \& Robinson, 1999). These concepts are relevant to this thesis because they can provide an interpretative lens to view the misconduct and corruption within local government.

The definitive text for the classification of personality disorders is the Diagnostic and Statistical Manual of Mental Disorders known as the DSM-IV-TR (American Psychiatric Association 2000, pp. 685-742). Whilst these conditions were outside the scope of the thesis, the context of 'mad' behaviours can be distinguished from individual psychological behaviour and those of organisations and personality disorders, which can range from antisocial, borderline, cyclothymic, histrionic, obsessive-compulsive and schizoid. There can be a continuum of behaviours in organisations, which can range from 'bad' to 'ethical and legal conduct' and from 'mad' to 'rational' behaviours (Figure 4.3). 


\section{Continuum of behaviours}

'Mad' - Non-Rational

Rational

\section{Continuum of behaviours}

\section{Figure 4.3 Continuum of behaviours}

The relevance of Figure 4.3 is the implication that it is difficult to position where the individual, the group or the organisation are on the continuum of these behaviours. Specific and relative positions on the continuum can change at any time, due in part to the dynamics of interrelationships. The relevance of emotions is that the literature suggested that emotions in the workplace can affect job performance in either a negative or positive way. Robbins (2003), for example, noted that employers seek to reduce negative emotions because they affect the workplace (p. 114). He considered that emotions can also enhance performance by increasing arousal levels and acting as motivators for increased performance. He also noted that the ability of people to manage their emotions in leadership and sales and customerinterface positions may be critical to their success (Robbins 2003, p. 114).

In relation to dysfunctional behaviours in organisations, it was noted that behaviours and emotions within an organisation can coexist on a number of levels, namely: (1) the individual; (2) the group; (3) the organisation; and (4) the market as well as compliance and stakeholder interactions (Robbins 2003). Griffin and O’Leary-Kelly (2004) considered that: (1) individual dysfunctional behaviours can relate to self-harm or substance abuse; and (2) group dysfunctional behaviours can relate to bullying, discrimination and harassment. Organisational dysfunctionality can relate to the toxicity of culture and low emotional intelligence on the part of the leader; however, a more important consequence of dysfunctionality is its impact upon followers in the organisation (Clarke 2005; Griffin \& O’Leary-Kelly 2004; Griffin, O’Leary-Kelly \& Collins 1998; Pech \& Slade 2004; Robbins 2003).

\subsection{A way forward?}

What emerges from the review of the investigative reports in this chapter is that explaining corruption and misconduct in local government can be difficult. To investigate them requires 
the trust of informants and the ability to have powerful insights with impeccable timing. All this is not possible without the support of councillors and the chief executive, who may or may not be disposed to someone analysing corruption and misconduct risks, particularly if they are not as 'white as snow' themselves.

Whilst agency reports are a determination of corruption or misconduct, there may have been some earlier anecdotal evidence or suspicions of wrongdoing, notwithstanding it may not have met the evidentiary hurdle for a successful criminal prosecution. Also, it can be difficult to identify corruption or misconduct when events are happening within various work groups and subcultures within council. What makes it challenging is that dysfunctionality and toxicity is embedded within the subcultures of councils. There can be resistance to change with all the strategies played out. In some cases, the council may be just suffering from bad management and since management can set the moral tone within council, it is not surprising when dysfunctional and misconduct behaviours abound within work groups. In other instances, a charismatic or bombastic chief executive can be in denial within council and these types of chief executive and councillors may not be necessarily enthusiastic about selfreflection upon their own stewardship or the health of their council.

As noted in Chapter Two Pech and Durden (2004) argued that organisations can fail because of weakness in the decision making processes and that leaders may only receive filtered information. They stated that the fracturing of decision making processes 'often results in dysfunctional and impoverished senior management decision processes, which can in extreme cases lead to corrupt and cannibalistic practices on the part of the managerial elite' (Pech and Durden (2004 p. 73). Kets de Vries (2004a, 1994, 1991, 1984a, 1984b), Gettler (2005a, 2005b) and Pech and Slade (2007) noted some of the explanations for executive financial misconduct included greed, narcissism, manipulation, exploitation and the 'complex nature of the corporate world for reinforcing pathological behaviours in the organisational context' (p. 1).

This thesis was cognisant of the dark side of behaviours (Conger, 1990; Thomas and Slade, 2004), which can manifest within individuals, within groups and totally within organisations. Whilst there can be multiple reasons for these behaviours, this thesis has noted the consequences of these behaviours, both upon the leaders of the council (councillors and executive management team); the stakeholders (community and employees of the council); and possible solutions to mitigate those behaviours. For an individual council, it may be 
easier to deny that dysfunctional behaviour occurs, rather than face the reality that organisational contexts can corrupt individuals (Appelbaum \& Shapiro 2006). As previously noted, Lagan (2005a, 2005b) argued that unethical behaviour was created and promoted by organisational culture, rather than individual predispositions. Organisational culture is a toneat-the-top $^{12}$ issue, because when one talks about business ethics, one is talking about institutional integrity, rather than individual morality. In relation to tone-at-the-top, Lagan (2005b) suggested that a way forward was to inculcate an ethical culture in the organisation, so that it was capable of being seen and found in 'every fibre of the organisation's being' (p. 10). This concept accords with Pech and Slade (2007) and was supported by Martins and Terblanche (2003). Argyris (1986) claimed organisations can communicate messages from leaders to followers in an ambiguous and inconsistent manner and that the inconsistency can become 'undiscussable'. The 'undiscussability of the message' can become an organisational norm and part of the socialisation of the staff.

How does the culture of an organisation reinforce the message that some things are not to be discussed? As an example, there may be a non-verbal message that is communicated and exchanged, when the leadership team of an organisation espouse the view that the organisation is ethical and adheres to high professional standards. Yet in reality, the organisation condones cronyism, nepotism and financial misconduct in the appointment of staff and management of resources. This paradoxical behaviour becomes inculcated as an organisational norm and as far as management is concerned, it is acceptable to employees. The series of mixed messages coming from management about ethical behaviour and actual misdeeds, only serve to reinforce a powerful but subtle message to staff and other stakeholders, that rhetoric from the leadership team does not match the espoused form. As a consequence, the level of trust between leaders and followers in the organisation is tarnished. The non-verbal message is the complete opposite to the formal message that has been stated. Hua (2003) explained that subordinates may perceive they are in a state of dependency and vulnerability and therefore the issue of trust between them and their supervisors is one of great importance.

Thus the problems evidenced in investigation reports in local government councils in New South Wales, New Zealand, Queensland, Victoria, Western Australia and the United Kingdom can be partially explained in the context of organisational dysfunctionality, toxicity

${ }^{12}$ COSO 2009, op.cit. 
of culture and ineffectual leadership. Should anyone therefore be surprised when employee surveys suggest there are problems of trust between staff and managers?

Corruption and misconduct within councils are usually investigated and reported by external investigating bodies, for example in Victoria, it could be the: (1) Auditor-General, Victoria; (2) Ombudsman, Victoria; (3) Inspector of Municipal Administration; or (4) Victoria Police. It also may require a whistleblower to provide an allegation of wrongdoing with sufficient initial evidence to warrant an investigation. The question of why it has waited until this stage, before council decides that various policies, procedures and practices require major revision, has multiple and differing explanations. One should also be cautious of 'confirmatory bias', that is, the situation where people confirm what they want to believe by selectively analysing the information that suits the position they wish to take (Kolodinsky et al. 2009; Leroux et al. 2010). The Ombudsman, Victoria, the Independent Commission Against Corruption and the Crime and Misconduct Commission all advocated a proactive, rather than reactive position towards misconduct and corruption. Roberts, Olsen and Brown (2009) in their analysis of whistleblowing programs in organisations recommended: (1) an organisational commitment to investigate and report wrongdoing; (2) the encouragement of reporting by staff of wrongdoing within their work groups; (3) effective review and analysis of whistle-blower allegations; and (4) an integrated organisational approach. They considered that there should be an organisational commitment to a misconduct program, which moves beyond the compliance of established procedures, to one where accountabilities and responsibilities of staff are inculcated into the culture of the organisation, which includes commitment of councillors and executive staff. Only then, will misconduct and corruption within local government be reduced in magnitude.

\subsection{Summary}

Chapter Four involved the discussion of the potential for corruption and misconduct to occur within local government and reviewed forty-three local government investigations from Victoria, New South Wales, Queensland, Western Australia, New Zealand and the United Kingdom to provide some context for the examination of the secondary research question (Chapter one and Chapter six). In some instances, the outcomes of these investigations could be attributed to the failure to adhere to general governance principles and lack of observance of the principles and conventions, as prescribed in local government acts of the various jurisdictions (Chapter Two). 
Corruption and misconduct was also discussed in the context of a literature review and possible explanations for corruption and misconduct behaviours. There are a number of inherent risks in local government, which fundamentally distinguish local government from corporate governance as discussed in Chapter Two. These included the: (1) propensity for bribery to occur within local government; (2) potential for conflict of interests to occur within local government; (3) potential for corruption and misconduct to be associated with the development of land and buildings and any consequential rezoning; and (4) power of political lobbyists. The literature review was discussed in the context of 'corruption and politics', 'corruption in government' and 'professional misconduct and professional ethics'. The investigation reports into corruption and misconduct were contextualised within a framework of: (1) maladministration by council officers; (2) corrupt conduct by councillors and council officers; (3) financial mismanagement by council officers; and (4) misuse of statutory powers by councillors. The question of why these wrongdoings occurred can have multiple explanations ranging on a continuum from unanswerable, to simple explanations of greed or dishonesty.

In Chapter Five the research method and the techniques are defined which employs a 'constructivist' and 'pragmatic' paradigm to incorporate a 'mixed methods' approach, initially weighted towards phenomenological interpretation (Mertens 2005; Patton 2002; Senge 1990). This is a qualitative and quantitative methodology, based on grounded theory, where theory is derived from the observed data (Partington 2000; Taylor \& Bogdan 1984; Turner 1983). 


\section{CHAPTER FIVE: METHODOLOGY}

\subsection{Introduction}

Chapter Five will outline the research methodology and methods which provide the context for quantitative and qualitative research discussed in Chapter Six. It describes the basis of the selection of methodology and the method to validate or disprove the research questions. This chapter addresses the rationale for the empirical study and links the literature reviews in chapters Two and Three and corruption and misconduct reports into local government in chapter Four.

The introduction (Section 5.1) outlines the rationale for the research and provides an overview of the research methodology. Methodology is described in Section 5.2 and includes: (1) paradigms; (2) justification of the paradigm; (3) phenomenology; (4) naturalistic inquiry; (5) grounded theory; and (6) rationale for the selection of grounded theory. The research methods are discussed in Section 5.3 and include: (1) mixed methods; (2) justification of the method; (3) research design; (4) quantitative approach; (5) qualitative approach; and (6) factorial design. The pilot study and finalisation of the research questionnaire are detailed in Sections 5.4, 5.5 and 5.6. The summary of the results from the research are described in Section 5.7.1, analysis of early and late respondents in Section 5.7.2 and the analysis of the variances in Section 5.7.3. The results of the pilot study are discussed in this chapter because it is an extension of the research methods and a guide to the results which follow in Section 5.7 and Chapter six respectively.

The terms 'methodology' and 'methods' can be used interchangeably within language, whereas from a research perspective, they have quite specific meanings. In the context of this thesis 'method', was the way of performing something, whereas methodology was a 'theory of knowledge and the activity of considering and reflecting upon and justifying the best methods’ (Wellington, Bathmaker \& Hunt 2005, p. 97). Wellington et al. (2005) stated that 'methods are the specific techniques for obtaining data that will provide the evidence base for the construction of that knowledge' (p. 97). 


\subsubsection{Rationale for research}

This section details the research rationale. Effective governance in local government relies on honesty and competence of elected councillors and the executive management team acting in the public interest. In working with audit committees, there can be a variety of negative and positive behaviours, some of which are consistent with agency; resource dependency; power; and institutional theories. For example, the management of a council withheld information from the audit committee, dominated members by manipulating the audit committee agenda and thwarted attempts to have an informed discussion of the entity's risks (Ombudsman, Victoria 2009d). During the qualitative research, some interviewees noted that a number of audit committee chairs did not consult with internal auditors about the risks within their entities, but conversed with management prior to the audit committee meeting, so that the meeting was a quick 'tick and flick' of the agenda and accompanying reports. Another example was where the chief executive of a council wanted to editorialise internal audit reports so that only positive news was reported to the audit and risk committee.

What are the consequences for integrity and competence, if integrity and competence within governance were only aspirational? What would be the consequences of ineffectual management, misconduct or unlawful actions, if this was a continuing reality for some councils rather than the exception? As noted in Chapter One, this thesis was not an exposition of the dark side of management (Conger 1990; Thomas \& Slade 2004) but it was noted that these behaviours can be pervasive and can influence councils' outcomes. This was consistent with Marnet's observations (2008, 2007, 2005, 2004) in relation to behavioural aspects of governance.

\subsubsection{Overview of research methodology}

This section details the paradigm selected for this research. In relation to the 'methodological paradigm wars', Patton (2002) noted that whilst controversy surrounding qualitative and quantitative research methodologies has generally subsided:

Not everyone has adopted a stance of methodological enlightenment and tolerance, namely that methodological orthodoxy, superiority, and purity should yield to methodological appropriateness, pragmatism, and mutual respect (p. 68). 
The 'constructivist' and 'pragmatic' paradigms in this thesis have been influenced from the principles of reflective learning and incorporate a 'mixed methods' approach with some influences from phenomenological interpretation (Mertens 2005; Patton 2002; Senge 1990). The 'pragmatic' paradigm is a mixed methods research model, distinguished from the quantitative research model and generally known as 'positivism' and 'transformative' research paradigms, which has as its ontology, 'multiple realities shaped by political, cultural, gender and disability values’ (Mertens 2005, p. 9). Taylor and Bogdan (1984) stated that a phenomenological perspective is central to qualitative research as the 'phenomenologist views human behaviour, what people say and do, as a product of how people define their world. The task of the phenomenologist and, for us, the qualitative methodologist, is to capture this process of interpretation' (1984 pp. 8-9). This is illustrated in Figure 5.1 and the differences between the two approaches are also noted.

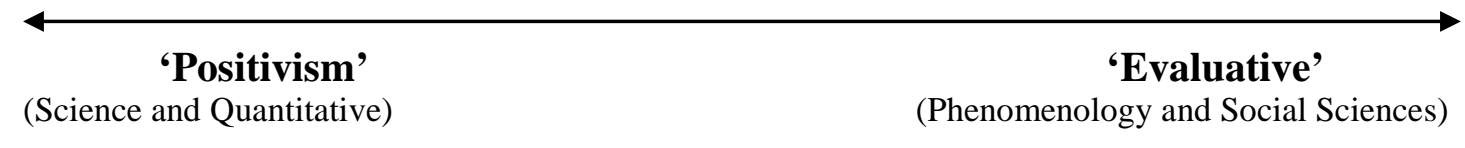

\section{Figure 5.1 Research methodologies}

This current research has been influenced by the phenomenological perspective to interpret what is measured from the quantitative research and links to a range of theoretical perspectives (Creswell 1998; Denzin \& Lincoln 2005; Lincoln 1990). Lincoln (1990) considered that in relation to qualitative research:

the phenomenologist looks in natural contexts for the ways in which individuals and groups make sense of their worlds. The collection of those intact realities and the interpretation of how those realities (or constructions), got constructed is the main point of the phenomenologically oriented inquirer (p. 290).

This was supported by Patton (2002), who described the power and outcomes of qualitative data, 'so that the person in search of qualitative methods will know what to look for and know when the real thing has been attained' (p. 28). Denzin and Lincoln (2005) described qualitative research as a topic of inquiry which 'crosscuts disciplines, fields and subject matters' (p. 2). They considered that the power of qualitative research is that it locates the researcher in the living world and consists of a set of interpretative practices which makes what is being observed, both visible and able to be interpreted.

This naturalistic approach allows the researcher to study phenomena in 'their natural settings and to attempt to make sense of, or interpret, phenomena in terms of meanings that people 
bring to them' (Denzin \& Lincoln 2005, p. 21). Denzin and Lincoln also considered that qualitative research generally follows three interconnected research processes, namely: (1) the researcher approaches the research setting with a set of ideas; (2) a framework (theory, ontology) which specifies a (3) set of questions (epistemology) which are examined in a specific way (methodology) (2005, p. 21). In relation to phenomenology, Patton (2002) asked 'What is the meaning, structure and essence of the lived experience of the phenomenon for his person or group of people?' (p. 104) He defined heuristic inquiry by asking: 'What is my experience of this phenomenon and the essential experience of others who also experience this phenomenon intensely?' (Patton 2002, p. 107). Creswell (1998), in relation to qualitative inquiry and research design, asked how the tradition of qualitative research shapes the design of a study. His contribution to the literature was that he: (1) succinctly linked the traditions of qualitative research with the parts of a research study; (2) prompted researchers to consider the differences between approaches to qualitative research and why they are using them; and (3) encouraged researchers to use alternative inquiry methods and procedures. Notwithstanding Creswell's contribution, it should be noted that not all grounded theory is qualitative.

In this thesis, grounded theory is applied where the theory is derived and based on observed data, as compared to hypothesis methodology, which broadly makes the theory fit the data (Partington 2000; Taylor \& Bogdan 1984; Turner 1983).

\subsection{Methodology}

The term 'methodology' applies to the overall theoretical approach to the research, as compared to the characteristics and practical applications of the specific research method selected for the research (Wellington et al. 2005, p. 98).

\subsubsection{Paradigms}

In this section the various paradigms in the literature are described, which provides the basis of the selected paradigm for the research in Section 5.2.2. The concept of a paradigm (Kuhn 1996) and the specific paradigm, in which this researcher operates, needs to be articulated, as the choice of paradigm influences the research and methodology (Guba \& Lincoln 2005, 1994). Guba and Lincoln (1994) defined a paradigm as: 
a set of basic beliefs that deals with ultimates or first principles. It represents a world view that defines, for its holders, the nature of the world, the individual's place in it, and the range of possible relationships to that world and its parts (p. 107).

This accorded with Mertens (2005), who stated that a paradigm 'is a way of looking at the world. It is comprised of certain philosophical assumptions that guide and direct thinking and actions' (p. 7). Kuhn (1996) indicated four factors which guide the development of a paradigm, namely: (1) 'paradigms could determine normal science without the intervention of discoverable rules' (p. 46); (2) concepts, laws and theories are the basis of initial investigations, but a new theory is announced with an application to some natural phenomena; (3) paradigms guide research though direct modelling; and (4) paradigms become a set of shared rules and assumptions (pp. 43-51). The merit of paradigm research is that it represents a frame of reference that provides new questions and new insights and thus is the basis of scientific progress.

Whilst the seminal work by Kuhn (1996) related to astronomy, his contribution was his insight into how discarding assumptions can lead to progress. This was complemented by Easterby-Smith, Thorpe and Lowe (1991) who stated three reasons for understanding philosophical issues relating to paradigms, namely: (1) clarifying the design of the research; (2) helping the researcher know which designs will work; and (3) helping the researcher use alternative methods outside of their past experience (Easterby-Smith et al. 1991, p.21). They further concluded that it was important to understand the philosophical and social levels of paradigms, as at the philosophical level, the definition by Guba and Lincoln (1994) was accurate, whereas at a social level, it can mean the guidelines for how the researcher undertakes their research (Easterby-Smith et al. 1991). Guba and Lincoln (1994) discussed the four research paradigms: 'positivism', 'postpositivism', 'critical theory' and 'constructivism' (p. 109) and highlighted the issues that can be in contention between different paradigms, namely: (1) inquiry aim; (2) nature of knowledge; (3) the way knowledge is accumulated; (4) rigour and validity; (5) values; and (6) ethics (p. 112). In their restatement of paradigms, Guba and Lincoln (2005) included another paradigm, the 'participatory cooperative paradigm', which they considered to be 'an excellent example, we might add of the hermeneutic elaboration, so embedded in our view of constructivism' (p. 192). Guba and Lincoln (1994) did not discuss the 'pragmatic paradigm', which Tashakkori and Teddlie (2003) attributed to Howe (1988). To be fair, trying to summarise or categorise all management research into a few paradigms could be considered a Herculean task. Figure 5.2 lists the labels commonly associated with different paradigms in the literature. 


\begin{tabular}{|c|c|c|c|}
\hline Positivism \& & Constructivist & Transformative & Pragmatic \\
Post Positivism & & & \\
\hline Experimental & Naturalistic & Critical Theory & Mixed Methods \\
Quasi- Experimental & Phenomenological & Neo Marxist & Mixed Models \\
Correlation & Hermeneutic & Participatory & \\
Causal Comparative & Ethnographic & Emancipatory & \\
Quantitative & Qualitative & & \\
\hline
\end{tabular}

\section{Figure 5.2 Labels associated with different paradigms}

Source: $\quad$ Mertens (2005), p. 8.

The 'positivism' and 'post positivism' paradigms are based on the notion of a single reality, that is, something is knowable through probability, with the researcher manipulating and observing the data in a dispassionate and objective manner. The methodologies commonly used are quantitative and include surveys and experiments. The ontology of the 'constructivist' paradigm argues there are multiple and socially constructed realities. The epistemology links the researcher and the participants, values are made explicit and findings are created. The methodologies commonly used are qualitative and can include interviews, observations and document reviews. The ontology of the 'transformative' paradigm is that there are multiple realities shaped by social, cultural, economic, gender and disability values. Mertens (2005) noted that the 'transformative' paradigm 'directly addresses the politics in research by confronting social oppression at whatever levels it occurs' (p. 17).

The 'pragmatic paradigm' from the seminal work of Howe (1988) was a counter to incompatibility arguments between qualitative and quantitative methods. Howe argued that both methods were compatible and researchers should use both methods and 'forge ahead with what works' (1988, p. 15). The ontology of the 'pragmatic' paradigm (Tashakkori \& Teddlie 2003) states 'what is useful determines what is true and the participants perform reality checks by determining increased clarity of understanding' (Mertens 2005, p. 9). Tashakkori and Teddlie (2003) stated that the major advantage of mixed methods research is that it enables the researcher to simultaneously answer confirmatory and exploratory questions and therefore verify and generate theory in the same study (p. 15).

Tashakkori and Teddlie (1998) considered that the 'pragmatic paradigm' supported the use of both qualitative and quantitative research methods in the same study, as the pragmatic researcher considers the research question to be more important than the method used or the paradigm which underlies the method. The 'pragmatic paradigm' also rejects the compulsory choice between positivism and constructivism with regard to logic and epistemology and 
embraces both points of view. Finally, the supporters of the 'pragmatic paradigm' avoid the use of the term ‘truth’ which has caused endless debate in the literature (Howe 1988).

The aim of this research is to accomplish two goals namely: (1) the demonstration that particular variables with have a predicated relationship with other variables in relation to audit committee effectiveness; and (2) to answer exploratory questions about how the relationships actually happen (Tashakkori and Teddlie 2003).

\subsubsection{Justification of the paradigm}

This section states the paradigm to be used and its justification. It identifies how it can be possible for research to be undertaken into audit committees in local government using the different perspectives of four paradigms.

The ontology of the 'positivism paradigm' considers that reality is real and that knowledge is knowable within probability. Accordingly, the audit committee featured within local government could be identified and quantified, although this would only provide one facet. A questionnaire survey does not necessarily allow the nuances and cultural values underlying the behaviours within council to be exposed, especially given the small population of mayors, chief executives and chairs of audit committees in seventy-eight of seventy-nine councils within Victoria, ${ }^{13}$ and the comparative data of thirteen board members of the Municipal Association of Victoria and thirty-six committee members of the Local Government and Shires Association of New South Wales

The ontology of the 'constructivist paradigm' considers multiple realities in that researchers should attempt to understand the complex world of lived experiences from the perspective of those who live them. Adoption of this 'lived experience' paradigm would require this researcher to work within a council and observe the governance practices and the audit committee and how they are both affected. This would provide significant insight into one specific council, but not other councils.

The 'transformational paradigm' considered that social realities are structured over time and the methodology within this paradigm could involve focus groups. The purpose of the focus groups could be to ascertain if there are audit committee structures in place within councils to

${ }^{13}$ The City of Greater Geelong Council as noted in Chapter One did not participate in the research. 
respond to governance practices as prescribed in the Local Government Act (1989). This approach could be possible, but would depend on sufficient mayors, chief executives and chairs of audit committees being available to provide data from these groups.

The selected paradigm is the 'pragmatic paradigm' and the method is both quantitative and qualitative with data being derived from surveys and interviews. This incorporated a 'mixed methods' approach, with the quantitative data providing the basis for the collection of the qualitative data in a sequential design. In a sequential mixed methods design, the conclusions from the first strand of the research led to the formation of questions, data collection and analysis for the second strand.

The qualitative inquiry of this research has considered phenomenological interpretation and heuristic inquiry (Mertens 2005; Patton 2002; Senge 1990). This study used naturalistic inquiry and grounded theory as the method (Guba 1978; Guba \& Lincoln 1981; Lincoln \& Guba 1989, 1986, 1985, 1982, 1981) to facilitate theory development and provide a framework for the testing of sub-research questions (Lincoln \& Guba 1986, p. 561).

The epistemological perspective adopted was as an 'outsider' looking in, observing reactions and emotions, as compared to an 'insider’ within local government (Blaikie 1993).

\subsubsection{Phenomenology}

Phenomenology can also refer to an inquiry paradigm (Lincoln 1990) as well as interpretative theory (Denzin \& Lincoln 2005), but in the main, a phenomenological approach to research uses its best endeavours to explore how 'people make sense of experience and transform experiences into consciousness' (Patton 2002, p. 104). To truly undertake phenomenological research, the researcher must interview subjects who have direct experience of the subject matter, that is, the subjects must have firsthand experience of knowledge as compared to second-hand experiences.

Lancy (1993) considered that the qualitative paradigm was ideal for phenomena that are complex or about which little is known with certainty. He considered that it 'is best employed in situations that have relatively confined temporal and physical boundaries' (p. 9). In Chapter One, the lack of research into audit committees in local government and in Victoria specifically was noted and thus naturalistic inquiry could be an effective research methodology. 
Heuristic inquiry is a branch of phenomenology and epistemology in which to answer the philosophical question of: 'What is my experience of this phenomenon and the essential experience of others who also experience this phenomenon intensely?' (Patton 2002, p. 107) The essential difference between heuristics and phenomenology is that heuristics include the experiences and insights of researchers as well as research subjects. Patton (2002) noted that heuristic inquiry focuses on intense relationships of both the researcher and the people who are the subject matter of the research and this combination of personal experience leads to an understanding of the meaning of the phenomenon. As a consequence, heuristic inquiry increases the propensity for unintended bias on the part of the researcher, to the extent that the researcher with lived experiences of the research area may impute or substitute their own views or conclusions subconsciously. As a consequence, heuristic inquiry was not utilised as a research methodology.

\subsubsection{Naturalistic inquiry}

Guba (1978) defined naturalistic inquiry as a discovery orientated approach that minimises the researcher's manipulation of the setting of the study and places no prior constraints on research outcomes. In naturalistic inquiry, the researcher lets the subject matter under investigation unfold without manipulation. Guba (1978) considered that there were eight differences between naturalistic inquiry and the more conventional scientific inquiry model. He explained these differences in the following way:

- $\quad$ philosophical base - he noted that naturalistic inquiry was generally sourced from phenomenology and in relation to the inquiry paradigm, he considered that in naturalistic inquiry the researcher is more interested in the description and understanding. Guba (1978) stated that 'as impressions are formed, he checks them out by various means, e.g., 'triangulation', testing one source against another until he is satisfied that his interpretation is valid' (p.13).

- $\quad$ purpose - the naturalistic inquirer has as his main objective 'the discovery of phenomena, whose empirical elaboration and testing would be worthwhile' (Guba 1978, p.13).

- $\quad$ stance - the naturalistic inquirer 'seeks a holistic view that will permit him to describe and understand phenomena as a whole or at least in ways that reflect their complexity' (Guba 1978, pp.13-14). He noted that in relation to the design of the study, the design can only be provided incompletely in advance, as to do so would place conditions on inputs and outcomes. 
- $\quad$ selection - Guba (1978) considered that the approach is one where the researcher does not manage the inquiry selection, but selects those elements or aspects which are critical for his purposes.

In relation to the reality of inquiry method, Guba (1978) considered that the conventional researcher is more concerned with an objective reality which exists and to which his methods can uncover. He considered that in naturalistic inquiry, the researcher must depend upon the perceptions of research subjects and that naturalists recognise that reality can be like an onion with many layers.

Guba (1978) noted that the point of difference was that the researcher recognised that values and attitudes were also part of the inquiry and that 'he needs to be as explicit about them as he can, both to avoid misleading persons who use his findings as well as deluding himself' (p. 16). Patton (2002) supported the work of Guba (1978) by stating that 'qualitative designs are naturalistic to the extent that the research takes place in real world settings and the researcher does not attempt to manipulate the phenomenon of interest' (p. 39). This was further supported by Guba and Lincoln (1981), who in their discussion of the advantages of naturalistic methods asked, 'How does one get at truth?' (p. 53). They argued that the naturalistic paradigm was an 'emergent' paradigm, although in context Guba and Lincoln were published in 1981 and that the naturalistic paradigm was best suited for socialbehavioural inquiry and certainly for responsive evaluation (Guba \& Lincoln 1981, p. 56). It was also important to note that 'truth' can have more than one definition, including verifiable hypotheses and phenomenological insights.

\subsubsection{Grounded theory}

Grounded theory is a research methodology attributed from the seminal work of Glaser and Strauss (1967) and restated in Glaser $(2007,1992,1978)$ where the investigator in grounded theory is the primary mechanism for data collection and analysis, characterised by inductive logic, as compared with deductive testing of a hypothesis. The theoretical perspectives of phenomenology, naturalistic inquiry and heuristics are based upon the notion of lived experiences and they 'direct us to particular aspects of human experience as deserving of attention in our attempt to make sense of the social world' (Patton 2002, p. 125).

Glaser (1992) stated that grounded theory is: (1) 'grounded systematically in the data and (2) it is neither forced nor reified' (p. 15). He considered it to be 'a general methodology of 
analysis with data collection that uses a systematically applied set of methods to generate an inductive theory about a substantive area' (Glaser 1992, p. 16). Charmaz (2006) noted that grounded theorists often 'begin their studies with certain guiding empirical interests to study and consistent with Blumer, general concepts that give a loose frame to these interests' (p. 16). He stated that 'grounded theorists evaluate the fit between their initial research interests and emerging data. We do not force preconceived ideas and theories directly upon our data' (Charmaz 2006, p. 17). Patton (2002) distinguished grounded theory from previously discussed theoretical perspectives, by stating that grounded theory 'focuses on the processes of generating theory rather than a particular theoretical content' and has as its fundamental question, 'What theory emerges from systematic comparative analysis and is grounded in fieldwork, so as to explain what has been and is observed?' (Patton 2002, p. 125)

Patton (2002) noted that grounded theory in the literature was generally discussed from the perspective that it places an 'emphasis on the inductive strategies of theory development in contrast to theory generated by logical deduction from a priori assumptions’ (p. 125). Jones (2009) considered that grounded theory as a methodology was a:

systemic process including sampling, coding, and memoing; it is based on data rather than impressions; and, while it can explore new subject matter, is a complete methodology rather than simply a starting point for further (presumably quantitative) research (p. 31).

Strauss and Corbin (1998) considered that grounded theories were likely to provide more powerful insights and understandings and provide a more useable guide to subsequent actions. In undertaking grounded theory, they considered that it was important to properly code the data in order to provide rigour and standardisation. Similarly, Merriam and Simpson (1995) noted that the development of grounded theory generally had four distinctive phases, namely: (1) collection of data; (2) analysis of data properties; (3) development of a hypothesis and checking of data; and (4) the development of a theory. Merriam and Simpson (1995) stated that grounded theory may be considered to be undisciplined and impressionistic, however they considered the constant comparison method for collecting data, if used properly, 'does allow for a very systematic and rigorous handling of data', although it can be dependent upon the sensitivity and analytical powers of the researcher (p. 117).

Conversely, Jones (2009) considered that the relevance of grounded theory as a methodological process, turns on the research question itself and 'how practitioners seek 
information' and 'how or why things are a certain way, which would indicate a qualitative approach would be most suitable' (p. 27). This was further supported by Charmaz (2006), who argued that a researcher should 'develop a theoretical sensitivity through theorising' in order to reach the fundamentals of the phenomena being reviewed and probe into the experiences and pose new questions about it (p. 135). Pergert (2009) referred to grounded theory as a 'methodology of learning by doing' and considered that some of the challenges of the approach included: (1) confusion arising from the sampling of data; (2) judging the point of saturation of data; and (3) development of the conceptual language for the new theory or theories.

From a practical perspective and for this research, the sampling and saturation of data was limited by the total number of prospective mayors, chief executives and mayors participating in the survey and board members of the Municipal Association of Victoria and the Local Government and Shires Association of New South Wales.

\subsubsection{Rationale for selection of grounded theory}

Grounded theory was selected for this research because it:

- $\quad$ was a methodology which has as its main objective the aim of theory building, as compared to theory testing;

- $\quad$ had a set of established guidelines for conducting the research and interpreting the data;

- $\quad$ was an interpretivist mode of inquiry, which had its 'roots in symbolic interactionism and as such gestures, expressions and actions are all considered primary to the experience' (Goulding 2002, p. 107);

- $\quad$ was a methodology which encouraged creativity and self-development;

- $\quad$ was renowned for its application in the study of human behaviour, which was an influential in this research; and

- $\quad$ was a credible methodology in the social sciences, but has not been used extensively for audit committees, particularly in local government. As such, it was an opportunity to use a legitimate methodology in a different field.

\subsection{Methods}

The term 'method' is generally understood to mean a way of doing something in agreement with a definite plan. Sections 5.3.1 - 5.3.6 defines the method for the research detailed in Chapter Six. 


\subsubsection{Mixed methods}

The choice of method for this research is mixed methods. Issues associated with the practical application of mixed methods are elaborated in the following sections: research design (Section 5.3.3), quantitative approach (Section 5.3.4), qualitative approach (Section 5.3.5) and factorial design (Section 5.3.6).

Morse (2003) defined the process for mixed methods as:

the incorporation of various qualitative and quantitative strategies within a single project that may have a qualitative and quantitative theoretical drive. The imported strategies are supplemental to the major or core method and serve to enlighten or provide clues that are followed up within the core method (p. 190).

Creswell, Plano Clark, Guttmann and Hanson (2003); Johnson and Onwuegbuzie (2004); Maxwell and Loomis (2003); and Tashakkori and Teddlie (2003) were generally in support of the definition by Morse (2003). Johnson and Onwuegbuzie (2004) stated that mixed methods 'was a class of research where the researcher mixes, or combines quantitative and qualitative research techniques, methods, approaches, concepts or language into a single study' (2004, p. 17). Tashakkori and Teddlie (2003) considered that most quantitative research seeks to confirm a hypothesis and to verify existing theories, whilst qualitative research, by definition, was exploratory and could involve the generation of new theories. They considered that when the two methods are mixed, it enables 'the researcher to simultaneously answer confirmatory and exploratory questions and therefore verify and generate theory in the same study’ (Tashakkori \& Teddlie 2003, p. 15). They also asserted that mixed methods provided the opportunity and environment conducive to providing stronger or more appropriate inferences from the research and to present a greater diversity of views. Tashakkori and Teddlie (2003) noted that mixed methods research studies use quantitative and qualitative data collection and analysis in either parallel or sequential phases.

This thesis has used a sequential design, described by Morse (2003) in the following shorthand as a 'QUAN $\rightarrow$ qual' study (p. 205). Morse (2003) considered that this sequencing was best used when 'quantitative study results are unexpected, unanticipated and qualitative study is conducted to ascertain the reasons for results or to find out what is going on' (p. 205). One could equally argue that qualitative precedes quantitative in the qual input and informs the QUAN questions to be put in a formal manner. Morse (2003) noted that in terms 
of the triangulation of results, the qualitative study provided an explanation for sections of the quantitative study. It was also noted that mixed methods explicitly have the merit of producing triangulated results, if they are congruent. Johnson and Onwuegbuzie (2004) listed some of the strengths of mixed method research as:

- $\quad$ words, pictures and narrative can be used to add meaning to numbers;

- $\quad$ numbers can be used to add precision to words, pictures and narrative;

- $\quad$ researchers can generate and test a grounded theory; and

- $\quad$ this approach can provide stronger evidence for a conclusion through

convergence and corroboration of findings (p. 21).

Conversely, they noted that some of the disadvantages of a mixed method approach included: (1) the researcher needed to understand different approaches and how to mix them appropriately; (2) methodological purists contend that one should always work within one paradigm; and (3) this approach can be more expensive and time consuming to collect and interpret data. Onwuegbuzie and Leech (2007) and Onwuegbuzie and Johnson (2006) discussed the validity of qualitative and mixed methods research. In relation to the validity of the latter, Onwuegbuzie and Johnson (2006) considered that with the overlap between qualitative and quantitative research, there can be difficulties in assessing the validity of the findings, if they are incongruent. They proposed a nine-point model of 'legitimation' derived from a combination of inferences from qualitative and quantitative components of mixed methods research (Onwuegbuzie \& Johnson 2006pp., pp. 56-60). They considered that researchers should keep these in mind when drawing inferences from their research. They further argued that as legitimation was 'analytical, social, aesthetic, emic, etic, political and ethical', researchers should be aware of multiple problems which can occur in mixed methods research (Onwuegbuzie \& Johnson 2006, p. 60).

The major advantage of using mixed methods can be in the 'quality of inferences that are made at the end of a series of phases or strands of the study' (Tashakkori \& Teddlie 2003, p. 35). Tashakkori and Teddlie (2003) differentiated between the terms 'inference' and 'results', with the latter being the outcomes of data collection and analysis. The former however referred to interpretation and expansion of results, noting of course that two different researchers could draw different inferences or conclusions from the same set of data.

\subsubsection{Justification of the method}

This section provides information about the justification of using mixed methods for this research. 
Teddlie and Tashakkori (2009) developed a typology of three components which can elicit various reasons for using mixed methods. This was complemented by Collins, Onwuegbuzie and Sutton (2006), who also developed a typology which provided a researcher with four rationales for using mixed methods and sixty-five processes that are applicable to the multiple steps within the processes of mixed methods (Collins et al. 2006pp., pp. 78-9. Teddlie and Tashakkori (2009) considered their rationale for using mixed methods including: (1) personal reasons; (2) advancement of knowledge; and (3) societal reasons to improve knowledge, society and institutions (pp. 111-15).

In relation to the 'personal reasons category' from Teddlie and Tashakkori (2009), the purpose of the research is to satisfy a curiosity of a phenomenon of interest, that is, audit committees in Victorian local government, as there has been no previously identified research. The second reason for using mixed methods is that it allows the ability to test new ideas and to develop causal explanations for actions associated with audit committees and to provide possible explanations for their behaviours or conduct. The quantitative studies provide the opportunity to elicit some causal explanations, using a Kruskal-Wallis Rank Test for non-parametric data, whilst the qualitative studies further the opportunity to study the causality and linkages from the quantitative research. As this research has used grounded theory and inductive logic, theories associated with the practices of Victorian audit committees begin to emerge. The final justification for using mixed methods by Teddie and Tashakkori (2009) relates to 'societal reasons'. Accountants have professional obligations under the Code of Ethics for Professional Accountants and this research conformed to the ethical pronouncement from the Accounting and Professional and Ethical Standards Board (2008). This research thus advances the practical knowledge of operations of Victorian local government audit committees.

The significance of Teddie and Tashakkori (2009) and Collins et al. (2006) to this research is that their work provided a sound justification and foundation for the: (1) mixing of methods in this research; (2) mixing phases of the data; and (3) allowing emphasis on the 'pragmatic paradigm' in order to give equal emphasis to both research components in this thesis. The typology by Collins et al. (2006) of the rationale and purposes for conducting mixed methods research comprised the following four categories: (1) participant enrichment; (2) instrument fidelity; (3) treatment integrity; and (4) significance enhancement. They defined these categories as: 
- $\quad$ participant enrichment - optimising the sample and ensuring that each participant is appropriate for inclusion;

- $\quad$ instrument fidelity - assessing the appropriateness and the utility of existing research instruments or create new instruments;

- treatment integrity - obtaining data that is trustworthy, credible, dependable, objective, valid (p. 77); and

- $\quad$ significance enhancement - expanding the interpretation of qualitative and quantitative data and clarifying why outcomes did or did not occur (p. 79).

The four tests Yin (1993) used to establish the quality of the research are summarised in Figure 5.3.

\begin{tabular}{|l|l|}
\hline \multicolumn{1}{|c|}{ Tests } & \multicolumn{1}{|c|}{ Descriptions } \\
\hline Construct validity & $\begin{array}{l}\text { Establishes the correct operational measures for } \\
\text { the concepts being studied. }\end{array}$ \\
\hline $\begin{array}{l}\text { Internal validity for causal and explanatory } \\
\text { studies }\end{array}$ & $\begin{array}{l}\text { Establishes a causal relationship, whereby certain } \\
\text { conditions are shown to lead to other conditions, } \\
\text { as distinguished from spurious relationships. }\end{array}$ \\
\hline External validity & $\begin{array}{l}\text { Establishes the domain to which the study's } \\
\text { findings can be generalised. }\end{array}$ \\
\hline Reliability & $\begin{array}{l}\text { Demonstrates the operations of a study, such as } \\
\text { the data collection processes can be repeated, } \\
\text { with the same results. }\end{array}$ \\
\hline
\end{tabular}

\section{Figure 5.3 Four tests for quality research}

Source: $\quad$ Adapted from Yin (1993), p. 33.

The quality and integrity of the research data conformed to the observations of Yin (2003) in relation to the propositions of: (1) construct validity; (2) internal validity; (3) external validity; and (4) reliability. This thesis adheres to construct validity which Yin (2003) defined as 'establishing correct operational measures for the concepts being studied' (p. 34). The most important step was to ensure that this process occurred in the exploratory stage of the research where considerable effort was applied to refining the concepts that were the subjects of the research. This involved the cross-checking of ideas with previous research in the literature and, as Yin (2003) noted, this helped keep the researcher on track as far as construct validity was concerned. The literature review and the testing of the quantitative research instrument provided support for the validation process. 
Another tool that can impact positively upon the construct validity is triangulation, which uses multiple sources to develop perspectives of the research problem. Yin (2003) stated that 'three tactics are available to increase construct validity when doing case studies' (p. 36). The first is the 'use of multiple sources of evidence in a manner encouraging convergent lines of inquiry' (Yin 2003 p. 36). The second tactic is to 'establish a chain of the evidence' and the third tactic is to have the participants review interpretations and conclusions from qualitative data (Yin 2003 p. 36). Yin (2003) described internal validity as the process of establishing 'causal relationships, whereby certain conditions are shown to lead to other conditions, as compared to spurious relationships’ (p. 34). This ensured there was support for any cause and effect relationships, that is, event ' $\mathrm{X}$ ' led to event ' $\mathrm{Y}$ '. This research is not looking for such causal relationships and, as a consequence, internal validity has not been utilised. Yin (2003) described external reliability as the ability to apply the findings of the research generally. Whilst the generality of the findings in this research can be confirmed in part from quantitative data from board members of the Municipal Association of Victoria and the Local Government and Shires Association of New South Wales, the principle of generalisation is never automatic and the ability to replicate the conclusions based on other local government councils elsewhere in Australia would be required. This was not a practical proposition for this thesis.

Yin (2003) argued that reliability related to the proposition that if a 'later investigator followed the same procedures as described by an earlier investigator and conducted the same case study all over again, the later investigator would arrive at the same findings and conclusions' (p. 37). Reliability places an emphasis on doing the same case study, not by replicating the results of one case study by doing another case study. The role of reliability is to minimise errors and biases in the study. To ensure the reliability and integrity in this research, the primary quantitative data was fully documented and the qualitative data collected in interviews was documented.

\subsubsection{Research design}

Wiersma and Jurs (2005) considered that the 'epistemology of research provides the underpinning of how research is conducted - how data is collected and analyzed and how conclusions are reached' (p. 202). Patton (2002) explored epistemology by asking 'How do we know what we know? (epistemological debates about the possibility and desirability of objectivity, subjectivity, causality, validity, general-izability’) p. 134. Lancy (1993) in his 
discussion of qualitative research considered that: (1) phenomena should be viewed holistically; and (2) the research operates in the natural setting, due to concern for context and to maintain an openness of what will be observed and collected. Wiersma and Jurs (2005) noted that researchers generally do their research in natural settings and do not intervene in the situation. Consequentially, research design requires some flexibility and a tolerance for adjustment as the research progresses. They noted that this is sometimes called a 'working design’ or ‘emergent design’ (Wiersma \& Jurs 2005, p. 203) with considerable overlap and integration (Figure 5.4).

The working design is the initial plan that begins the research, with some decisions made about issues to be researched, the length of time for research to be undertaken and variables to be considered (Figure 5.4). In chapter One, the primary and secondary research questions were formulated. Patton (2002) stated that:

Qualitative inquiry is particularly oriented toward exploration, discovery, and inductive logic. Inductive analysis begins with specific observations and builds toward general patterns (pp. 55-6).

As noted in Chapters One, Two and Three there was literature and best practice guidance on the public sector but little research on audit committees in local government, with no identifiable research on audit committees in Victorian local government. In relation to data collection, the researcher must gain access to the subjects, as discussed in the pilot study in Section 5.4. The researcher must decide whether to be an observer of the phenomena or a participant observer. In this research, it was about observations from the five participating groups, notwithstanding that the research was open to phenomenological interpretation. From Figure 5.4, data analysis was the process of 'categorisation, description and synthesis' (Wiersma \& Jurs 2005, p. 207). The research perspective used a 'funnel approach' (Wiersma \& Jurs 2005, p. 211) which begins with the researcher exploring possible avenues for research, sources of data and procedures for data collection. From the initial data collection, the sources of data are identified more specifically, 'thus providing increased focus on the phenomenon under study' (Wiersma \& Jurs 2005, p. 211) with data collection and interpretation becoming more focused and directed. 


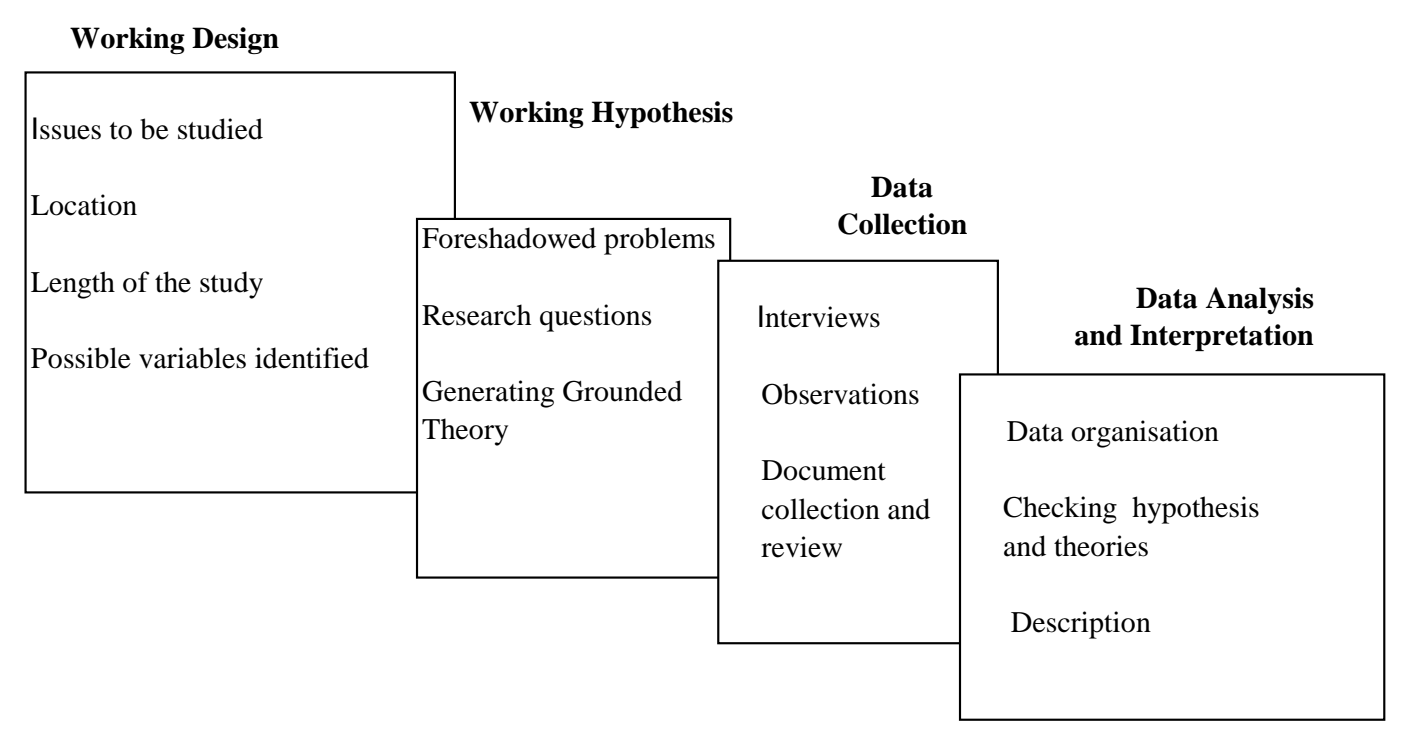

\section{Figure 5.4 Components of research design}

Source: Adapted from Wiersma and Jurs (2005), p. 208.

\subsubsection{Quantitative approach}

The research measured responses from mayors, chief executives and chairs of audit committees through the use of a questionnaire survey. They were asked to record their responses using a Likert 1 to 7 point scale ${ }^{14}$ in relation to: (1) assessment of authority; (2) audit committee charter; (3) membership; (4) activities of the audit committee; (5) communication and reporting; and (6) quality and training.

The differences in the backgrounds and attitudes of chief executives, mayors and chairs of audit committees can lead to creative tensions in power relations between them, given their varied backgrounds and experiences. The adage that 'knowledge is power' provides opportunities for some insights into creative tensions which can arise. A complication can arise, for example, if the mayor and councillors have political aspirations for federal and state governments. In these situations, councillors can pursue agendas or community issues which further their own political agendas, rather than the best interests of community or council. Sometimes these issues can be played out in the local media, in order to raise the profile of individual councillors. There can be other tensions in council, for example, if a group of councillors are aligned to one political party, which can see them voting as a block and not necessarily voting on the merits of the local issue.

Equally, chief executives and chairs of audit committees can have their own agendas such as business biases, opposite political views, community interests and normal human biases,

\footnotetext{
${ }^{14}$ The rationale for selection of the scale is discussed in Section 5.3.6.
} 
whether founded or not. Coupled with the positions of councillors, chief executives and chairs of the audit committee, this can give rise to variation in quantitative results and analysis.

\subsubsection{Qualitative approach}

The research considered that there may be some distinctive differences in attitudes, opinions and perceptions between mayors, chief executives and chairs of audit committees.

In Chapter Six, quantitative responses from all three groups were evaluated in the context of behaviours modelled at the audit committee. For example, the chairs of audit committees may express a need for adherence to strong governance standards and the mayors and chief executives may be more measured or neutral or there may be any number of combinations. Whilst it is acknowledged that this is potentially a simplistic example, this may corroborate some of the theories associated with: (1) agency; (2) resource dependency; (3) stewardship; and (4) power, which pertain to governance, as discussed in Chapters Two and Three. The research contribution to knowledge is the way in which the attitudes of the three distinctive groups are interpreted and evaluated.

As noted in Chapter One, the data from the research reflects a Victorian local government sector wide view, which constitutes the amalgam of responses from mayors, chairs and chief executives, rather than individual responses which are specific to one council. If the research data had been collected from the leadership group within local government, different responses could have been obtained. This would also have applied if non-executive managers with experience in governance in local government and individual councillors were analysed.

\subsubsection{Factorial design}

The research used a factorial design (Figure 5.5) to interpret results of the quantitative survey and to allow these results to be analysed as part of the qualitative evaluation process.

The significance of this approach is that it easily identified differences in data from the five groups, albeit geographic, demographic or occupational. It further allowed comparisons to be drawn, as well as the data being analysed by various combinations of groups or locations. 


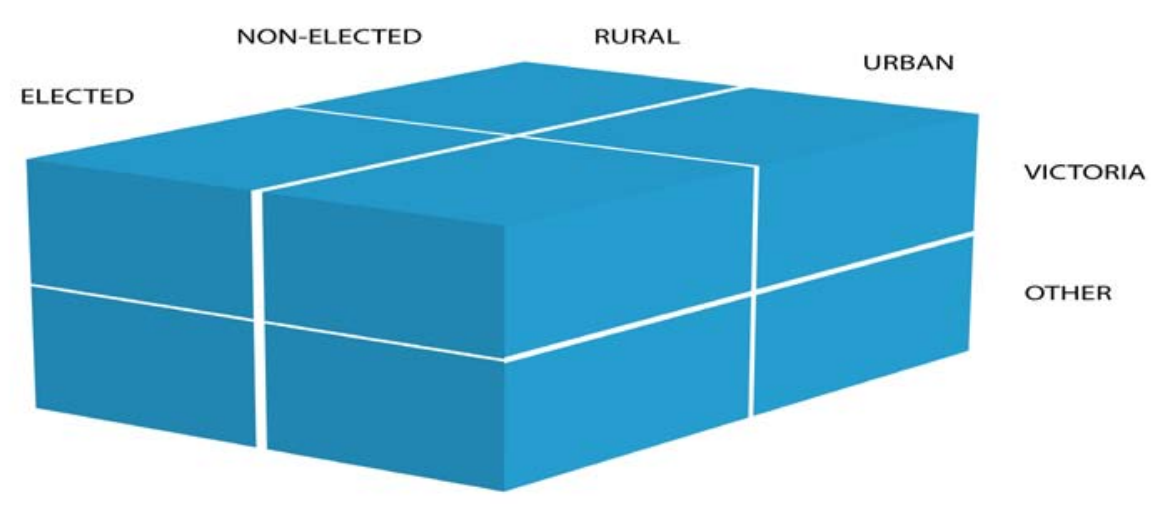

\section{Figure 5.5 Factorial design model}

\section{i. Qualitative method}

The quantitative data was analysed from qualitative discussions using a sample from the five groups. The following steps enhanced the validity of quantitative data:

i. Pilot Study ${ }^{15}$ - A group of selected mayors, chief executives, chairs of council audit committees, members of audit committees and external auditors of local government councils were asked to review the research instrument (questionnaire), to ensure that relevant issues had been addressed.

The group was selected from council information, for example, population size and revenue from Local Government Victoria; and from selected members of the public sector group from CPA Australia.

ii. The second step was to test the questionnaire with some of the respondents from the pilot study to ensure that the questionnaire addressed the substantive issues and was administratively easy to complete.

The quantitative responses from these groups were evaluated in the context of behaviours modelled at the audit committee. Following the quantitative research, interviews were held with a mayor, a councillor, two chief executives, two directors of corporate services, an auditor and three chairs of audit committees to explore the low response rate to some questions from the quantitative research and the relevance of research outcomes for a council and its audit committee (Section 6.6 in Chapter Six). The contribution of the research to academic knowledge was the way in which the attitudes and perceptions of these five distinct groups were interpreted and evaluated.

${ }^{15}$ Refer to the pilot study in Section 5.4 . 


\section{ii. Quantitative method}

The research measured responses from mayors, chief executives and chairs of audit committees through the use of a questionnaire survey. This was compared with responses from board members of the Municipal Association of Victoria and committee members of the Local Government and Shires Association of New South Wales for validation purposes only.

From a quantitative perspective, these groups were asked to respond using a Likert 7-point scale. The differences in backgrounds and attitudes of mayors, chief executives and chairs of audit committees were analysed from the perspective of their professional qualifications, experiences, occupations and geographic locations. The 7-point scale was selected for the following reasons (as compared to a 3-, 5- or 11-point scale):

- $\quad$ A 3- or 5-point scale could be used, if the researcher was using this information for reporting general observations only. A seven or eleven point scale allowed the researcher to report a mean and standard deviation and conduct analytics and modelling, based on responses;

- $\quad$ A 7- point scale provided the opportunity for more variance and Nunnally (1978) suggested that more scale points were better, although there were diminishing returns at 11 points.

- $\quad$ This research considered the neutral points (' 3 ' or ' 4 ') reduced the social desirability bias of a 7-point scale as compared to the neutral point of ' 3 ' in a 5-point scale. Using a 5-point scale with the neutral point of ' 3 ' increased the propensity to distort the results from this research.

These general observations were supported by Leung (2011) and Dawes (2008). Leung (2011) claimed that 'there is no agreement on the number of scale points to be used. Most studies use 4 to 7 points, while some may be extended to 10 or 11' (p. 412). She noted that Cummins and Gullone (2000) suggested that 'expanding beyond 5 or 7 points might increase the sensitivity without affecting reliability' and that Allen and Seaman (2007) 'proposed that 7 points could be shown to reach the upper limits of reliability' (Leung 2011 p. 413). Dawes (2008) complemented Leung (2011) and stated that '5- and 7-point scales produced the same mean as each other, once they were rescaled' and that 'a 10-point format tended to produce slightly lower relative means than either the 5- or 7-point scales (after the latter were rescaled)' (p. 61). In relation to the Likert Scale point, it was acknowledged that it had its orientation in one direction - ' 1 = improvement required' and '7 = no improvement required'. In order to increase the number of acceptable responses from the seventy nine mayors, chief 
executives and chairs of audit committees the questions in the research instrument were not randomised.

\section{iii. Data analysis}

The response rate of $36 \%$ of completed questionnaires provided the quantitative data. The response rate of $33 \%{ }^{16}$ from twelve board members (of the Municipal Association of Victoria) and $69 \%{ }^{17}$ from thirty-two committee members (of the Local Government and Shires Association of New South Wales), which had audit committees, provided data to compare and contrast results from councils.

The responses were analysed using the Excel statistical program (mean and standard deviation) and variances were analysed using the Kruskal-Wallis non-parametric one-way ANOVA test from the statistical package SPSS (Cooksey 2007). This compared and contrasted the results from mayors, chief executives and chairs of audit committees. The results obtained from quantitative data were used to formulate discussions with a select sample of mayors, chief executives and chairs of audit committees.

\subsection{Pilot study}

A pilot study was undertaken in April and May 2009 to 'gain additional information by which the major study could be improved' and to ascertain how the research could yield better results (Weirsma \& Jurs 2005, p. 490). As previously noted, the results of the pilot study are discussed because it is an extension of the methods and the quantitative and qualitative results that follow in Section 5.7 and Chapter Six respectively. The secondary objective was to ensure the: (1) appropriateness and relevance of proposed questions in relation to audit committee effectiveness; (2) proposed form of the questions; (3) sequencing of questions; (4) wording of questions; and (5) amount of personal data that could be requested from the respondents (Sekaran 2003, p. 238). The pilot study (Appendix 2) was undertaken in two parts including:

i. first sample of thirty-two people with audit committee expertise; and

ii. $\quad$ second sample of fifteen mayors and fifteen chief executives from: (1) four shire councils; (2) three regional cities; and (3) eight metropolitan councils based on population size and council revenue.

\footnotetext{
16 This is a low percentage and caution should be exercised in any inferences.

17 This is a low percentage and caution should be exercised in any inferences.
} 
The first sample included:

- $\quad$ current and former councillors of Victorian local government;

- $\quad$ a representative body of Victorian local government;

- $\quad$ members of local government audit committees;

- $\quad$ current and former chief executives of councils;

- $\quad$ senior public sector executives sourced via CPA Australia, who had specific local government audit committee expertise;

- $\quad$ two former auditor-generals, who had an oversight responsibility for local government; and

- $\quad$ external audit partners with direct experience within Victorian local government (Table 5.1).

The method of selection for the first sample was based upon contacts within local government, who provided suggestions and introductions. CPA Australia provided access to senior public servants and auditors, who undertook internal and external audits in local government, the latter being on behalf of the auditor-general. A further sample of fifteen mayors and fifteen chief executives from Victorian local government councils were asked to review the pilot survey, to ensure that from their perspective, the relevant issues had been addressed. The method of selection was based on revenue of the council with distribution of metropolitan and rural councils. Each of the people who responded to the pilot survey and the qualitative research (Chapter Six) were assigned a letter after their job title and a year corresponding to time when they were provided material or were interviewed. For example: Audit Partner B (2009). Further details of the respondents to the pilot survey and the qualitative research are contained in Appendix 2 and Appendix 8. The mayor of East Gippsland Shire Council declined to participate in the pilot study and was excluded from both subsequent quantitative and qualitative research (Urie 2009). The City of Greater Geelong advised that: '...council is of the view [that] responses to these questions should be coordinated through the Municipal Association of Victoria' (Brown 2009). The respondents were asked to comment on relevance and appropriateness of the issues canvassed in the pilot survey (Appendix 2), namely:

- $\quad$ understanding by the audit committee of its responsibilities within the local governance framework;

- $\quad$ how audit committee members apply their due skills and experience;

- $\quad$ the ability to act objectively and independently;

- $\quad$ maintenance of effective relationships with council and management;

- $\quad$ timeliness of reporting from the audit committee to the council;

- $\quad$ quality of internal financial reporting;

- $\quad$ impact of corruption and maladministration reports from other councils (including Victoria, New South Wales and Queensland);

- $\quad$ effectiveness of internal control in known 'trouble spots' within councils (e.g. planning and procurement); and

- $\quad$ financial viability of councils. 
The respondents were further asked whether: (1) any questions needed to be included or excluded from the quantitative research; and (2) what other specific questions should be asked. The observations of mayors, councillors, chief executives, audit committee members and external auditors are detailed in Appendix 4.

\subsubsection{Response rate from the pilot survey}

\section{i. $\quad$ First sample}

The response rate from the first sample was nineteen out of thirty-two participants (59\%) (Table 5.1). This rate was useful, as it provided some constructive data from which assertions could be drawn. However, within the six sub-categories of the sample, there were marked differences in response rates and differences in the emphasis of observations from respondents. The number of councillors sampled was nine, with a response rate of four (44\%). Seven independent audit committee members, serving on audit committees in Victorian local government, were also sampled with a response rate of four out of the seven (57\%). One of the respondents was a member of multiple audit committees in Victorian local government.

Three current chief executives and one former local government chief executive were sampled, with a response rate of three (75\%). One current mayor was selected in this sample, although it was acknowledged that a sample of one can skew observations and was insufficient to draw substantive conclusions. Fifteen mayors were subsequently included in the second sample, notwithstanding the low response rate from the second sample. A former Auditor-General, Victoria provided insights into Victorian local government audit committees and his comments are detailed in Appendix 3 with his permission (Cameron 2009). Four external audit partners with specific experience in external audits of Victorian local government provided insights about the workings of audit committees and their potential for operational difficulties (Appendix 4). In relation to the audit expectation gap noted in Chapter Three, Audit Partner B (2009) stated that:

...you may consider the question of defining what effectiveness actually means and to whom? An audit committee may be effective in the eyes of: (1) the chief executive and management; (2) councillors and ratepayers; (3) the state government (e.g. the Department of Planning and Community Development); (4) the Commonwealth Government; and (5) academia and professions. The real question is how to deal with the expectation gap, if any (Audit Partner B 2009). 
Table 5.1 Pilot study sample and response rate

First sample

Second sample

\begin{tabular}{|c|c|c|c|c|}
\hline & $\begin{array}{l}\text { Sample } \\
\text { Number }\end{array}$ & $\begin{array}{l}\text { Number of } \\
\text { Responses }\end{array}$ & $\begin{array}{l}\text { Sample } \\
\text { Number }\end{array}$ & $\begin{array}{l}\text { Number of } \\
\text { Responses }\end{array}$ \\
\hline Councillors & 9 & $\begin{array}{c}4 \\
(44.44 \%) \\
\end{array}$ & $\begin{array}{c}\mathrm{n} / \mathrm{a} \\
\text { (Note 4) }\end{array}$ & $\begin{array}{c}\mathrm{n} / \mathrm{a} \\
\text { (Note 4) }\end{array}$ \\
\hline $\begin{array}{lll}\text { Local government } & \text { independent } & \text { audit } \\
\text { committee members } & & \end{array}$ & 7 & $\begin{array}{c}4 \\
(57.14 \%)\end{array}$ & $\begin{array}{c}\mathrm{n} / \mathrm{a} \\
\text { (Note 4) }\end{array}$ & $\begin{array}{c}\mathrm{n} / \mathrm{a} \\
\text { (Note 4) }\end{array}$ \\
\hline $\begin{array}{l}\text { Current and former local government chief } \\
\text { executives }\end{array}$ & 4 & $\begin{array}{c}3 \\
(75 \%)\end{array}$ & 15 & $\begin{array}{c}7 \\
(46.66 \%) \\
\text { (Note 1) } \\
\end{array}$ \\
\hline Mayors & 1 & $\begin{array}{c}1 \\
(100 \%)\end{array}$ & 15 & $\begin{array}{c}4 \\
(26.66 \%) \\
\text { (Notes } 2 \text { and } 3)\end{array}$ \\
\hline Public sector specialists from CPA Australia & 7 & $\begin{array}{c}4 \\
(57.14 \%)\end{array}$ & $\begin{array}{c}\mathrm{n} / \mathrm{a} \\
\text { (Note 4) }\end{array}$ & $\begin{array}{c}\mathrm{n} / \mathrm{a} \\
\text { (Note 4) }\end{array}$ \\
\hline $\begin{array}{l}\text { External audit partners with specific } \\
\text { experience in local government }\end{array}$ & 4 & $\begin{array}{c}4 \\
(100 \%)\end{array}$ & $\begin{array}{c}\mathrm{n} / \mathrm{a} \\
(\text { Note 4) }\end{array}$ & $\begin{array}{c}\mathrm{n} / \mathrm{a} \\
\text { (Note 4) }\end{array}$ \\
\hline Total & 32 & $\begin{array}{c}19 \\
(59.38 \%)\end{array}$ & 30 & $\begin{array}{c}10 \\
(33.33 \%)\end{array}$ \\
\hline
\end{tabular}

Note 1: The response rate included a subsequent reply from the Director of Corporate Services from one municipality, to supplement the responses from the chief executive.

Note 2: The response also included a response where the mayor declined to participate in the pilot survey.

Note 3: The mayoral response rate included two acknowledgements that they would respond within 10 days, but they did not do so, despite subsequent follow-up.

Note 4: The second sample only contained a sample of current mayors and chief executives.

\section{ii. Second sample}

From Table 5.1 the response rate from the second sample of thirty participants was (33\%). This related to the two sub-categories of: (1) chief executives, a response rate of seven (47\%); and (2) mayors, a response rate of four (27\%), but with only one useful response. The low response rate from mayors was considered to be a potential precursor to a low response rate in the quantitative research. As such, follow-up actions were required to increase the level of responses in order to make meaningful comparisons between the three groups of mayors, chief executives and chairs of audit committees (Linder, Murphy \& Briers 2001; Lynn \& Clarke 2000). The disparity of responses from the mayoral and chief executive groups was of concern and the issue of non-respondent bias was considered (Miller \& Smith 1983). Whilst there could be many plausible explanations for the low response rate from the mayoral group, for example, lack of interest in the topic (Armstrong \& Overton 1977, p. 397), it also could include such methodological issues as: (1) 'making the task interesting and easy as possible'; 
(2) the length of the pilot survey; and (3) effective follow-up techniques (O’Rourke 1999, p. 108). The disparity of the response rate (between the higher response rate in the first sample and lower response rate in the second sample) can be potentially attributed to the personal relationship between the author and the first sample, notwithstanding the observations of Armstrong and Overton (1977) and O’Rourke (1999). This was supported by Pace (1939) who stated that:

whether or not a person will return the questionnaire and when they will return it depends on a favourable combination of all factors which influence questionnaire returns: interest; conscientiousness; habits of promptness; and time available (p. 391).

\subsection{Confirmation of the research instrument - Questionnaire}

Some of the respondents suggested that the following would enhance quantitative research:

- $\quad$ understanding of the role of the audit committee in local government (former Chief Executive A 2009; and Chief Executive B 2009 in Appendix 4);

- $\quad$ rigour, control and trust of the audit committee (Chief Executive C 2009 in Appendix 4);

- $\quad$ management of the audit committee including management interference (Chief Executive D 2009 in Appendix 4); and

- $\quad$ recruitment and retention of members (Chief Executive E 2009; and Chief Executive F 2009 in Appendix 4).

This formed the basis for the development of the Survey of Audit Committee Practices Local Government Councils and Shires (Appendix 5), which was to be used to survey the groups in the quantitative research. The Survey addressed the following issues:

i. $\quad$ the processes for the creation of an audit committee (seven questions);

ii. $\quad$ knowledge and expertise of the audit committee (five questions);

iii. induction and training for members of the audit committee (four questions);

iv. managing the work of the audit committee (fourteen questions); and

$v$ r. risk assessment, management reporting and outcomes of the audit committee (nine questions).

The reason for asking more questions about managing the work of the audit committee and outcomes (items iv and $v$ ) as compared to the creation of the audit committee, knowledge of members and induction and training (items $i$, ii and iii), was that the former focused on the management process to affect outcomes, whilst the latter were precursor attributes which must exist to contribute positively to the effectiveness of an audit committee. The survey was 
originally formulated as statements, as compared to questions, for example, Question A4 in Appendix 5 was drafted as: 'Committee members are appointed on the basis of agreed criteria with succession plans in place'. It was considered that the majority of these statements were ones that respondents could have a natural tendency to approve. This could potentially give rise to a mindset by respondents that evoked a disposition to agree with all statements. This was overcome by rewording and making the statements simple but interrogative, so that a respondent had to think about each question, for example, Question A4 from Appendix 5, 'Are audit committee members appointed on the basis of agreed criteria?

Against each question, respondents were asked:

i. Answer Yes / No / Not Applicable / Don't Know against the question, 'Is this current practice in your council/shire?'

ii. If respondents answered 'Yes', they were asked to numerically rate the current practice from ' 1 to 7 ', where ' 1 ' meant significant improvement required to current practice and ' 7 ' meant excellent processes were in place and no improvement needed.

iii. For those that answered 'No', respondents were asked the question, 'Should the audit committee do this in the future?'

iv. If respondents answered 'Not Applicable' to the question, 'Is this current practice in your council/shire?' they were asked not to rate the current practice numerically, but respond to the question, 'Should the audit committee do this in the future?'

Wayne (2003) provided the initial idea for including these questions in this research (2003, p. 46). The first question, 'Is this current practice in your council?' gives the opportunity for the respondent to reflect if this is a current practice in their councils/shires and 'gives them an opportunity to reflect about change and to indicate if they are aware, concerned or active in changing audit committee practices’ (Wayne 2010). Wayne (2010) in a private email stated that 'it also could indicate if audit committee members have been following better governance and audit committee practices'. The question, 'Should the audit committee do this in the future?' was asked to prompt responses which may indicate that respondents thought the practice should be introduced. It also allowed respondents to answer in the negative, for example, if they thought the process did not add any value such as the trade-off between outcomes and the resources required to implement audit committee practice. Wayne (2010) speculated that 'perhaps individual members of the audit committee could be pressured into accepting some audit committee practices or that the audit committee members did not believe that the practice was effective' (Wayne 2010). Wayne (2003) posed the further question, 'In your experience was this practised two years ago?' (p. 46). Wayne (2010) explained that when this question was posed in 2002, it was to gain insights into the reaction 
of the Canadian business community towards the implementation of the Sarbanes-Oxley Act (2002) in the United States of America. Wayne (2010) further stated that he was trying to elicit responses to the questions of:

Did the audit committee react only to today or has it been trying to improve over the past few years? Secondly, how close the person was to the detail of the committee. Thirdly, to determine if the member felt a need for progressive change but the committee did not favour or pursue it (Wayne 2010).

It was considered that this retrospective analysis was not relevant for this research. The draft survey was emailed in May 2010 to thirteen respondents from the pilot survey. It was requested that this group review the draft questionnaire and indicate where they considered any subject areas had been omitted or needed to be enhanced. An additional survey was also forwarded to a director of corporate services of a major shire council, as it was advised that this council executive had audit committee experience in providing administrative support and expertise for the shire’s audit committee (Corporate Services Director A 2009).

\subsection{Finalisation of the research instrument - Questionnaire}

Seven out of 14 responses were received (50\%). Their suggestions included the reformatting of some questions, the removal of others and the inclusion of new questions, described in Figure 5.6. The key point of difference between the draft questionnaire and revised questionnaire was the introduction of some demographic and organisational (also known as 'firmographic') questions, which allowed the responses to be further analysed by categories or positions held within the council/shire. These questions included:

- $\quad$ gender;

- $\quad$ years of experience with the audit committee;

- $\quad$ cumulative years of experience in local government;

- $\quad$ business occupation of the mayors, councillors and chairs of audit committees; and

- $\quad$ professional qualifications of chief executives (Appendix 5).

Where the chair of an audit committee was also the chair of an audit committee in another council or shire, the chair was asked to respond from the position of the first council to which he/she was appointed, but to note in the survey response the number of councils/shires where they were chair. One chief executive of a metropolitan council suggested that some specific questions should be asked about the preparation of financial and performance statements for council (Figure 5.7). 


\begin{tabular}{|l|l|}
\hline \multicolumn{1}{|c|}{ Original Questions } & \multicolumn{1}{|c|}{ Replacements } \\
\hline $\begin{array}{l}\text { Are the audit committee's terms of } \\
\text { reference approved by council? }\end{array}$ & $\begin{array}{l}\text { This question was removed and replaced by a series of } \\
\text { 'establishment questions' (Table 6.4) at the beginning of } \\
\text { the survey questionnaire, for example: }\end{array}$ \\
$\begin{array}{l}\text { Does your council/shire have an audit } \\
\text { committee? } \\
\text { Does the audit committee have a charter } \\
\text { approved by the council/shire? } \\
\text { Does the audit committee report to the } \\
\text { council/shire on a regular basis? }\end{array}$ \\
$\begin{array}{l}\text { Is there clarity by your council of its } \\
\text { (e.g. how the audit committee } \\
\text { supports the council to discharge its } \\
\text { accountabilities for governance and } \\
\text { risks?) }\end{array}$ & $\begin{array}{l}\text { This was replaced by: 'Is there clarity by the council/shire } \\
\text { of the expectations of the audit committee? }\end{array}$ \\
\hline $\begin{array}{l}\text { Are audit committee members } \\
\text { appointed on the basis of agreed } \\
\text { criteria with succession plans in } \\
\text { place? }\end{array}$ & $\begin{array}{l}\text { This was replaced by: 'Are audit committee members } \\
\text { appointed on the basis of agreed criteria for } \\
\text { membership?' }\end{array}$ \\
\hline
\end{tabular}

\section{Figure 5.6 Survey questions and their replacements}

- Do audit committees review the councils'shires' annual accounts, including the financial statements and certifications, to determine if anything is inconsistent with their knowledge, including such areas of liquidity, unusual transactions, infrastructure funding and impairment of assets?

- Does the audit committee review the external auditor's scope and audit plan to its satisfaction prior to the commencement of the audit?

- Does the audit committee review all unrecorded audit adjustments (if any reported) with management and the external auditors and understand why they were not recorded and reported?

\section{Figure 5.7 Questions about the preparation of financial statements}

The questionnaire was mailed to potential respondents as a paper-based questionnaire, as compared to electronically via the computer package 'Question Pro', due in part to the observations of Anseel, Lievens, Schollaert and Choragwicka (2010), who considered that online surveys, when compared with mail surveys may result in a lower response rate (Anseel et al. 2010, p. 337). This was also supported by Coverse, Wolfe, Huang and Oswald (2008) and Shih and Fan (2008), although from a researcher's perspective, there were cost savings with an electronic survey compared to a paper-based survey. Whilst online surveys can be attractive propositions for researchers, it was considered that for this research, personalised 
letters to the mayors, chief executives and councillors, using Victoria University's letterhead, could potentially enhance response rates, given that the research topic was also relevant to the sample being surveyed (Anseel et al. 2010, p. 337).

\subsection{Summary of results}

This section discusses the response rate from the research. The response rate from research is discussed in this section in order not to detract from the analysis of the quantitative and qualitative research in Chapter six. The analysis of responses to questions in the questionnaire is contained in Chapter Six. The research measured responses through the use of a questionnaire survey in the period 1 July 2010 to 31 August 2010 (Section 5.7.1). Respondents and non-respondents are discussed in Section 5.7.2 and responses were analysed using Excel (mean and standard deviation) and SPSS to measure variances using the KruskalWallis one-way ANOVA test for non-parametric data (Section 5.7.3) with results contrasted and compared between groups.

\subsubsection{Results from the research}

Results from the research are detailed in Appendices 6 and 7 and responses to each of the five sections are detailed in Table 5.2. The mean was generally skewed towards 'adequate processes in place and operating satisfactorily' for the audit committee, although some questions had ‘no' responses or were not answered (Table 5.3).

Table 5.2 Summary of research data

\begin{tabular}{|c|c|c|c|}
\hline Questions & $\begin{array}{c}\text { Average Number of } \\
\text { Respondents } \\
\text { (n) }\end{array}$ & Mean & Standard Deviation \\
\hline $\begin{array}{c}\text { Forming an Audit Committee } \\
\text { (5 questions) }\end{array}$ & 80 & 5.55 & 1.19 \\
\hline $\begin{array}{c}\text { Knowledge and Expertise } \\
\text { (5 questions) }\end{array}$ & 54 & 5.45 & 0.98 \\
\hline $\begin{array}{c}\text { Induction and Training } \\
\text { (5 questions) }\end{array}$ & 68 & 5.16 & 1.11 \\
\hline
\end{tabular}




\begin{tabular}{|l|c|c|c|}
\hline $\begin{array}{c}\text { Managing the Audit Committee } \\
\text { (12 questions) }\end{array}$ & 68 & 5.71 & 0.99 \\
\hline $\begin{array}{l}\text { Risk Assessment and Financial } \\
\text { Reporting (10 questions) }\end{array}$ & 69 & 5.54 & 1.13 \\
\hline
\end{tabular}

Notes: The mean and standard deviations in this table are responses from mayors, chief executives and chairs of audit committees from a Likert 1 to 7 point scale.

The responses from the five groups were analysed in detail in Chapter Six, although it was noted that some questions had 'Yes' responses for less than seventy-five of a potential eightynine respondents (Figure 5.8 and Table 5.2).
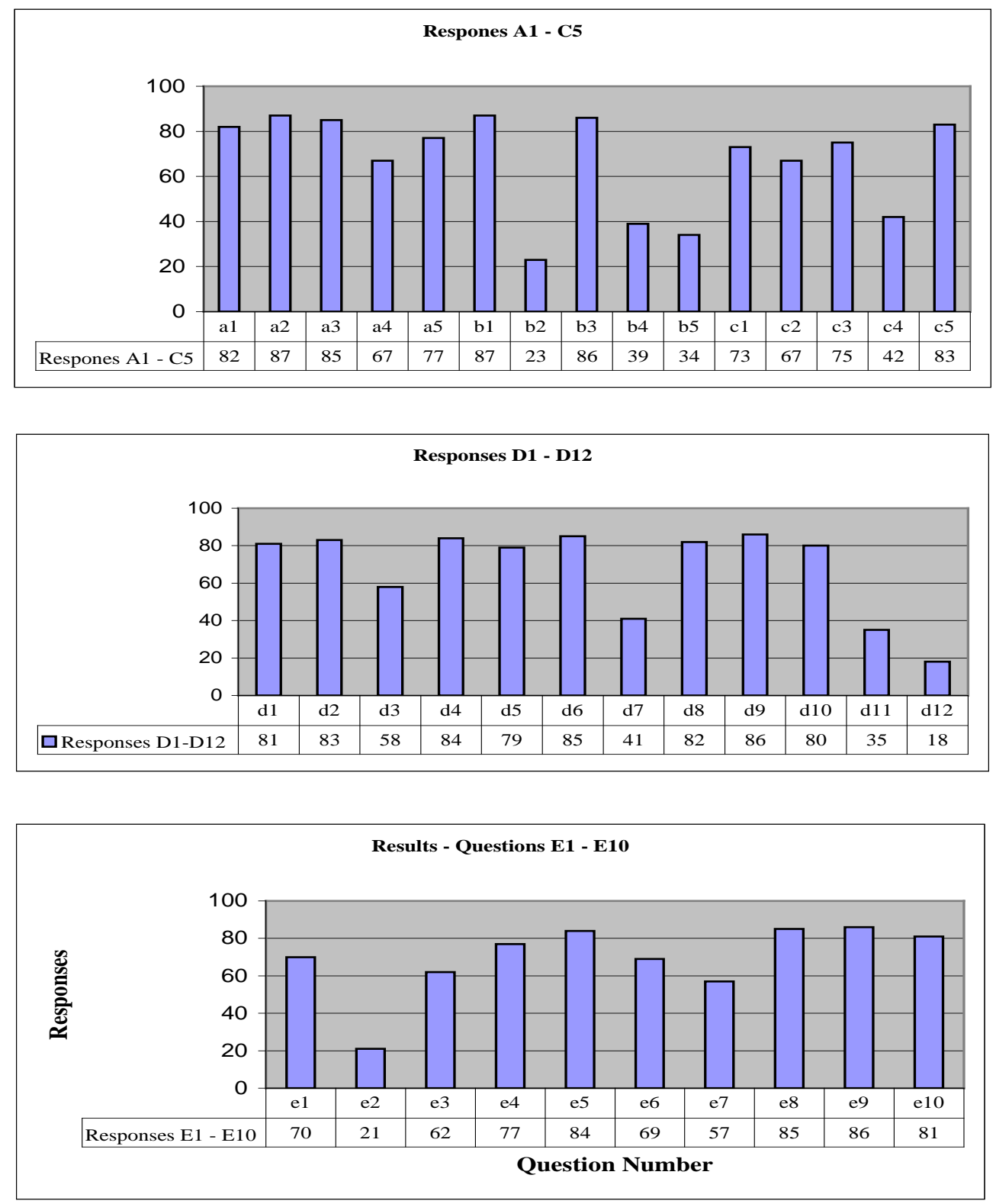

Figure 5.8 'Yes' Responses from Questions A1 - C5, D1 - D12, E1 - E10

Notes: This figure illustrates the total number of responses to each question (e.g. A1, 82 'Yes' responses). Source: Results from respondents - Appendix 6. 
Low response rates to some questions in Table 5.3 did not negatively impact upon the outcomes from the research on audit committees, for example, questions B2, B5 and E2. Question B2 (Is the audit committee dominated by an individual member?) had an affirmative response of twenty-three. It was expected that participants would confirm that this was not the case. Question B5 (Can the audit committee co-opt members for periods of less than a year to provide specialist skills?) had thirty-four responses. It was expected that audit committees would co-opt resources on a needs basis, so the low response was expected. Question E2 (Are there any risk categories of the council/shire which are not reviewed by the audit committee?) had twenty-one responses. The question was deliberately asked in the negative, so the response rate was both reasonable and acceptable.

For a competent audit committee, it was important that members had a holistic view of council risks. It was important that a council's audit committee was not dominated by one individual, regardless of whether they were a councillor, a member of management or an independent audit committee member.

\section{Table 5.3 Low 'Yes' responses to individual questions}

\begin{tabular}{|c|c|c|c|}
\hline Questions & $\begin{array}{l}\text { Number of } \\
\text { 'Yes' } \\
\text { Responses }\end{array}$ & Mean & $\begin{array}{l}\text { Standard } \\
\text { Deviation }\end{array}$ \\
\hline \multicolumn{4}{|l|}{ A. Forming an Audit Committee } \\
\hline $\begin{array}{l}\text { Question A4. } \\
\text { Does the audit committee review its charter annually and recommend } \\
\text { changes to your council/shire? }\end{array}$ & 67 & 5.64 & 1.04 \\
\hline \multicolumn{4}{|l|}{ B. Knowledge and Expertise } \\
\hline $\begin{array}{l}\text { Question B2. } \\
\text { Is the audit committee dominated by an individual member? }\end{array}$ & 23 & 5.16 & 1.07 \\
\hline $\begin{array}{l}\text { Question B4. } \\
\text { Does the audit committee review, at least annually, the skills base of its } \\
\text { members, to clarify if the audit committee has the requisite skills for } \\
\text { new and emerging risks of the council/shire? }\end{array}$ & 39 & 4.95 & 0.60 \\
\hline $\begin{array}{l}\text { Question B5. } \\
\text { Can the audit committee co-opt members for periods of less than a year } \\
\text { to provide specialist skills? }\end{array}$ & 34 & 5.20 & 1.17 \\
\hline \multicolumn{4}{|l|}{ C. Induction and Training } \\
\hline $\begin{array}{l}\text { Question C1. } \\
\text { Are new audit committee members provided with a relevant induction } \\
\text { program? }\end{array}$ & 73 & 4.81 & 1.26 \\
\hline $\begin{array}{l}\text { Question C2. } \\
\text { Are audit committee members assisted by the council/shire to } \\
\text { periodically update their knowledge of local government activities and } \\
\text { risks? }\end{array}$ & 67 & 4.81 & 1.04 \\
\hline $\begin{array}{l}\text { Question C4. } \\
\text { Does the audit committee periodically visit the council's/shire's sites } \\
\text { and receive briefings from key officers? }\end{array}$ & 42 & 4.96 & 1.11 \\
\hline
\end{tabular}




\begin{tabular}{|c|c|c|c|}
\hline D. Managing the Audit Committee & & & \\
\hline $\begin{array}{l}\text { Question D3. } \\
\text { Does the audit committee have any extraordinary sessions to consider } \\
\text { important issues? }\end{array}$ & 58 & 5.63 & 0.86 \\
\hline $\begin{array}{l}\text { Question D7. } \\
\text { Do audit committee members meet at least annually outside of the audit } \\
\text { committee with the council? }\end{array}$ & 41 & 5.12 & 1.18 \\
\hline $\begin{array}{l}\text { Question D11. } \\
\text { Does the audit committee directly receive communications from the } \\
\text { stakeholders of the council/shire regarding any allegations of } \\
\text { misconduct or corruption or matters of concern which they may have } \\
\text { with the council/shire? }\end{array}$ & 35 & 5.41 & 0.65 \\
\hline $\begin{array}{l}\text { Question D } 12 . \\
\text { Does the audit committee review all whistleblower allegations and } \\
\text { oversee their investigation? }\end{array}$ & 18 & 5.65 & 0.58 \\
\hline $\begin{array}{l}\text { Question E2. } \\
\text { Are there any risk categories of the council/shire which are not } \\
\text { reviewed by the audit committee? }\end{array}$ & 21 & 4.60 & 1.32 \\
\hline $\begin{array}{l}\text { Question E3. } \\
\text { Are local government investigation reports from other council/shires } \\
\text { reviewed against the current management practices and processes in } \\
\text { your council/shire? }\end{array}$ & 62 & 5.57 & 1.24 \\
\hline $\begin{array}{l}\text { Question E6. } \\
\text { Does the audit committee review the external auditor's scope and audit } \\
\text { plan to its satisfaction prior to the commencement of the audit? }\end{array}$ & 69 & 5.86 & 1.05 \\
\hline $\begin{array}{l}\text { Question E7. } \\
\text { Does the audit committee review all unrecorded audit adjustments (if } \\
\text { any reported) with management and the external auditors and } \\
\text { understand why they were not recorded and reported? }\end{array}$ & 57 & 5.57 & 0.68 \\
\hline
\end{tabular}

Notes: This table illustrates the total number of respondents to specific questions.

The mean and standard deviations in this table are the responses from mayors, chief executives and chairs of audit committees from a Likert 1 to 7 point scale.

Whilst the 'Yes' responses to the question, 'Can the audit committee co-opt members for periods of less than a year to provide specialist skills?' was only thirty-four of a possible eighty-nine respondents (38\%), those who answered 'No', indicated that, to date, there had not been a perceived need for this to occur. From an operational perspective, the ability to coopt resources could generally depend on the specific needs of an individual audit committee to respond to unusual circumstances, for example, the mismanagement of a major computer implementation. As such, this should be considered to be an enhancement to audit committee effectiveness, as compared to being negative.

In relation to question A4 in Table 5.3, some of the 'No' respondents indicated that their council generally reviewed the audit committee charter on a three-year cycle, which was the expiration date of the term of appointment of independent audit committee members.

The four questions in Table 5.3 relating to enhancement of 'skills' of audit committee members were B4, C1, C2 and C4. Questions B4 and C4 had an affirmative response rate of thirty-nine and forty-two respectively, which was unexpected. 
In relation to the skill base of audit committee members (question B4) some of the 'No' respondents indicated that the audit committee reviewed the skills base of members at the expiration of the term of appointment of independent audit committee members. Given the terms of appointment for audit committee members was twelve months for councillors and three years for independent members respectively, one respondent noted that the audit committee was in effect reviewing their skills base annually, albeit for councillors only. The low 'Yes' responses to visits to key sites and key briefings by council officers was unexpected, although it was acknowledged that councillors do receive briefings and site visits, as part of their induction and broader councillor functions. The 'Yes' responses to questions C1 and C2 in Table 5.3, concerning induction programs and updating of knowledge of local government risks were seventy-three and sixty-seven respectively. Whilst this was lower than expected, there are no consequences for the successful operations of audit committees.

There were fifty-eight respondents to question D3 and forty-one 'Yes' responses to question D7 in Table 5.3. An annual meeting with the council and audit committee is accepted practice in New South Wales (Department of Premier and Cabinet, New South Wales 2010b) and Victorian local government (Department of Infrastructure 2000) thus the low 'Yes' response rate was unexpected.

The management and oversight of misconduct and whistleblower allegations (questions D11 and D12 in Table 5.3), received thirty-five and eighteen 'Yes' responses. This was considered to be low, given the obligations imposed upon public officers under Section 11 of the Independent Commission Against Corruption Act (1988) for New South Wales local government and requirements of the Auditor-General, Victoria for the compilation of the annual representation letter for completion of annual financial and performance statements of Victorian local government. This requires the chief executive and principal accounting officer to 'certify' that there has not been any incidents in relation to theft, fraud or other financial misconduct in the financial year in which the council or shire is reporting.

Some 'No' responses suggested that whilst alleged misconduct was the responsibility of the local government council, the investigation of any alleged financial misconduct, including alleged councillor misconduct, would be under the auspices of other state government agencies. Respondents identified: the Auditor-General, Victoria; Auditor-General, New South Wales; Independent Commission Against Corruption, New South Wales Police; the 
Local Government Inspector; the Ombudsman, Victoria; or Victoria Police. One respondent noted that allegations of councillor misconduct in Victoria were investigated by the Local Government Inspector, Ombudsman, Victoria or Victoria Police, depending upon to whom the initial allegation was reported, as compared to the specific council. 'Yes' responses to question E6 (sixty-nine respondents) was anticipated. Some respondents stated that the Auditor-General, Victoria had the sole responsibility for the appointment of external audit firms, acting as his agent for the annual financial and performance statements of local government councils and that local government councils have no input into those appointments.

The low response to question E7 in Table 5.3 was unexpected, given that the review of the annual financial statements was the responsibility of the audit committee and audit committees in local government are expected to have members with financial skills and competencies (Department of Premier and Cabinet, New South Wales 2010b; Department of Infrastructure 2000).

\subsubsection{Early and late respondents}

Non response bias generally refers to research conditions, where opinions of those who did not respond are different from those who responded to the research questionnaire. Rogelberg, Conway, Sedererburg, Spitzmuller, Aziz and Knight (2003) discussed three general nonresponse methodologies, namely the: (1) archival approach; (2) intentions approach; and (3) wave approach. The first two approaches were not relevant to this research because the archival approach essentially compares the respondents and the population on variables in the data, whilst the intentions approach compares the differences between those who intended to respond and those who did respond.

This research has used a wave approach (Ellis, Endo \& Armer 1970), which compared early and late respondents, that is, those who respond to the first mailing of the questionnaire, with subsequent follow-up requests. Rogelberg et al. (2003) stated that 'late respondents cannot truly be considered to be non-respondents, as they did return the survey' (p. 1105); nevertheless, it is an accepted assumption that those who respond to follow-up requests are effectively a sample of non-respondents to the first request and represent that group. 


\section{i. Mean and standard deviations of early and late respondents}

In Table 5.4, the differences between the mean of early and late respondents for five groups are identified and reported. The mean and the standard deviations of the early 'Yes' responses were: (1) chief executives (5.77 and 0.87); (2) chairs of audit committees (6.06 and 0.85); (3) mayors (5.69 and 0.92); (4) committee members of the Local Government and Shires Association of New South Wales (5.75 and 0.34); and (5) board members of the Municipal Association of Victoria (5.02 and 0.34). This distribution was compared with the mean and standard deviation of late 'Yes' responses of chief executives (5.34 and 1.02); (2) chairs of audit committees (5.50 and 1.06); (3) mayors (5.35 and 0.11); (4) committee members of the Local Government and Shires Association of New South Wales (LGSANSW) (5.41 and 0.17); and (5) board members of the Municipal Association of Victoria (MAV) (4.35 and 1.42).

Table 5.4 Differences between mean of early and late respondents

\begin{tabular}{|c|c|c|c|c|c|}
\hline Research Groups & Mayors & $\begin{array}{c}\text { Chief } \\
\text { Executives }\end{array}$ & $\begin{array}{c}\text { Chairs, } \\
\text { Audit } \\
\text { Committee }\end{array}$ & $\begin{array}{c}\text { Lunicipal } \\
\text { Association of } \\
\text { Victoria }\end{array}$ & $\begin{array}{c}\text { Government } \\
\text { and Shires } \\
\text { Association of New } \\
\text { South Wales }\end{array}$ \\
\hline Mean (early respondents) & 5.69 & 5.77 & 6.06 & 5.02 & 5.75 \\
\hline Standard deviation & 0.82 & 0.87 & 0.85 & 0.34 & 0.34 \\
\hline Mean (late respondents) & 5.35 & 5.34 & 5.50 & 4.35 & 0.41 \\
\hline Standard deviation & 0.11 & 1.02 & 1.06 & 1.42 & 0.34 \\
\hline Differences between mean & 0.42 & 0.63 & 0.70 & 0.67 & 0.17 \\
\hline Differences between & 0.71 & 0.15 & -0.21 & -1.08 & \\
\hline standard deviation & & & & & \\
\hline
\end{tabular}

Notes: This table identifies the differences between mean and standard deviations of early and late respondents of mayors, chief executives, chairs of audit committees, board members of the MAV and committee members of the LGSANSW. The mean and the standard deviations in this table are responses from mayors, chief executives and the chairs of audit committees from a Likert 1 to 7 point scale.

The mean differences between early and late responses of chief executives, chairs of audit committees and mayors was $8 \%, 10 \%$ and $6 \%$ respectively and the standard deviation differences between early and late responses was 3\%, 3\% and 12\% respectively. The mean differences of committee members of the Local Government and Shires Association of New South Wales and board members of the Municipal Association of Victoria was 6\% and 13\%, respectively, although these two groups had low response rates of nine and four respectively and they have been included in Table 5.4 for completeness sake. From Table 5.4, minor 
differences were noted between the mean for early and late respondents. (Statistical differences were confirmed by the Student's $t$-test.) From this observation, it was concluded that non-respondents were similar to respondents and this gives some credence to the notion that the sample was less biased than one might otherwise conclude.

\section{ii. Student's t-test for early and late respondents}

The t-test analyses means with respect to variance and the test that analyses variances is the 'analysis of the variances'.

The Student's $t$-test (Student being a nom de plume of W. S. Gosset) was undertaken for early and late responses from mayors, chief executives and chairs of audit committees in Excel using the TTEST: Two-Sample Assuming Equal Variance (Tables 5.5, 5.6 and 5.7). Cooksey (2007) stated that 'the related groups t-test compares the observed difference between the sample means of the two conditions to an estimate of the variability of such mean differences in the population under the assumption that the condition means do not really differ' (p. 203). From the t-value, a p-value can be found from a Critical Values of Student's T Distribution (Siegel \& Castellan 1988, p. 322). If the calculated t-value is greater or equal to the critical value, the null hypothesis that there are no differences between the means would be rejected, as there are differences. Conversely, if the calculated t-value is less than or equal to the critical value, the null hypothesis that there are no differences between the means would be accepted. From Tables 5.5, 5.6 and 5.7 the calculated t-values were:

- $\quad$ Table 5.5, the t-value for the mayors was t (70) =1.78, $\mathrm{p}<0.05$;

- $\quad$ Table 5.6, the $\mathrm{t}$-value for chief executives was $\mathrm{t}(70)=2.03, \mathrm{p}<0.05$; and

- $\quad$ Table 5.7, the t-value for chairs of audit committees was t $(70)=3.93, \mathrm{p}<0.05$.

\section{Table 5.5 Mayors of councils, Student's $t$-test}

\begin{tabular}{|l|c|c|}
\hline Mean & 5.689352 & 5.346318843 \\
\hline Variance & 0.977764 & 0.349847939 \\
\hline Pooled variance & 0.663806 & \\
\hline Hypothesized mean difference & 0 & \\
\hline df & 70 & \\
\hline t Stat & 1.786288 & \\
\hline
\end{tabular}

Notes:

Note 1: The $t$ Stat shows the t-value from the data.

Conclusion - Accept that there is a statistical significance between the early and late respondents. 


\section{Table 5.6 Chief executive officers, Student's $t$-test}

\begin{tabular}{|l|c|c|}
\hline Mean & 5.774353 & 5.346318843 \\
\hline Variance & 1.246708 & 0.349847939 \\
\hline Pooled variance & 0.798278 & \\
\hline Hypothesized mean difference & 0 & \\
\hline df & 70 & \\
\hline t Stat & 2.032534 & \\
\hline
\end{tabular}

Notes:

Note 1: The $t$ Stat shows the t-value from the data.

Conclusion - Accept that there is a statistical significance between the early and late respondents.

\section{Table 5.7 Chairs of audit committees, Student's $t$-test}

\begin{tabular}{|l|c|r|}
\hline Mean & 6.067335 & 5.50154321 \\
\hline Variance & 0.344818 & 0.398004959 \\
\hline Pooled variance & 0.371412 & \\
\hline Hypothesized mean difference & 0 & \\
\hline df & 70 & \\
\hline t Stat & 3.938808 & \\
\hline
\end{tabular}

Notes:

Note 1: The $t$ Stat shows the t-value from the data.

Conclusion - Accept that there is a statistical significance between the early and late respondents.

From the table of Critical Values of Student's T Distribution (Siegel \& Castellan (1988, p. $322)$ it was noted that the tabulated t-value was $1.671(p<0.05)$, which indicated that the difference between the means was significant at that level of probability. The t-value for chief executive officers was 2.03 with 70 degrees of freedom (Table 5.6) and for chairs of audit committees it was 3.94 with 70 degrees of freedom (Table 5.7) respectively. Cooksey (2007) noted that it was easy to interpret the results. He stated that 'the conditions either differ or they do not' (p. 207). From the three tables above, it was identified that the t-value was above critical value of $1.671(\mathrm{p}<0.05)$, so the null hypothesis was rejected and differences were noted between early and late respondents.

\subsubsection{Analysis of variances}

The analysis of variances between groups was tested by way of a chi-square test and the Kruskal-Wallis Rank Test.

\section{i. Chi-square test}

Siegel and Castellan (1988) noted that a 'chi-square test for the one-sample goodness-of-fit should not be used if more than 20\% of the expected frequencies are less than 5 or when any expected frequency is less than 1' (p. 49). It was acknowledged that the Fisher Exact Test 
could have been used because of the small sample size, however it was decided to use the chi-square test as this test was more universally known. From Appendix 6 there were eight questions where there were sufficient 'Yes' and 'No' responses to be able to utilise the chisquare statistic, which is illustrated in Table 5.8. A chi-square test was undertaken using the following formula from Siegel and Castellan (1998, p. 112).

$$
\begin{aligned}
& \sum_{\text {Where }^{-1}} \frac{\sum_{\mathrm{ij}}=\text { actual frequency in the i-th row, j-th column }}{\mathrm{E}_{\mathrm{ij}}=\text { expected frequency in the i-th row, j-th column }} \\
& \mathrm{r}=\text { number or rows } \\
& \mathrm{C}=\text { number of columns }
\end{aligned}
$$

The null hypothesis was that responses were independent of the positions of mayor, chief executive and chair of the audit committee. In the chi-square test, a value was calculated with two degree of freedom. If the calculated value was equal to or greater to the critical value from the Table C Critical Values of the Chi-Square Distribution (Sigel \& Castellan 1998, p.

\begin{tabular}{|c|c|c|c|c|c|}
\hline Question Number & $\begin{array}{c}\text { Responses } \\
\text { Mayors }\end{array}$ & $\begin{array}{l}\text { Responses } \\
\text { Chief } \\
\text { Executives }\end{array}$ & $\begin{array}{c}\text { Responses } \\
\text { Chairs of } \\
\text { Audit } \\
\text { Committees }\end{array}$ & $\begin{array}{c}\text { Calculation } \\
\text { of the chi- } \\
\text { square } \\
\chi^{2}\end{array}$ & $\begin{array}{l}\text { Critical } \\
\text { Values of } \\
\text { the } X^{2} \\
\text { distribution } \\
\text { p>0.05 } \\
\text { (Note 1) }\end{array}$ \\
\hline $\begin{array}{l}\text { Question B4 } \\
\text { Does the audit committee review at least } \\
\text { annually the skill base of its members, to } \\
\text { clarify if the audit committee has the requisite } \\
\text { skills for the new and emerging risks of the } \\
\text { council/shire? }\end{array}$ & 7 & 10 & 17 & 0.0186 & 5.99 \\
\hline $\begin{array}{l}\text { Question B5 } \\
\text { Can the audit committee co-opt members for } \\
\text { periods of less than a year to provide } \\
\text { specialist skills? }\end{array}$ & 8 & 10 & 9 & 0.0745 & 5.99 \\
\hline $\begin{array}{l}\text { Question C4 } \\
\text { Does the audit committee periodically visit } \\
\text { the council's/shire's sites and receive } \\
\text { briefings from key officers? }\end{array}$ & 10 & 13 & 15 & 0.0000 & 5.99 \\
\hline $\begin{array}{l}\text { Question D3 } \\
\text { Does the audit committee have any } \\
\text { extraordinary sessions to consider important } \\
\text { issues? }\end{array}$ & 8 & 21 & 19 & 0.0526 & 5.99 \\
\hline
\end{tabular}
323) the null hypothesis was rejected. Conversely, if the calculated value was less than the critical value then the null hypothesis was accepted.

\section{Table 5.8 Chi-square tests on select responses for mayors, chief executives and chairs of audit committees}




\begin{tabular}{|c|c|c|c|c|c|}
\hline $\begin{array}{l}\text { Question D7 } \\
\text { Do the audit committee members meet at } \\
\text { least annually outside of the audit committee } \\
\text { with the council? }\end{array}$ & 6 & 16 & 16 & 0.0000 & 5.99 \\
\hline $\begin{array}{l}\text { Question D11 } \\
\text { Does the audit committee directly receive } \\
\text { communications from the stakeholders of the } \\
\text { council/shire regarding any allegations of } \\
\text { misconduct or corruption or matters of } \\
\text { concern which they may have with the } \\
\text { council/shire? }\end{array}$ & 9 & 14 & 10 & 0.0206 & 5.99 \\
\hline $\begin{array}{l}\text { Question E3 } \\
\text { Are local government investigation reports } \\
\text { from other council/shires reviewed against } \\
\text { the current management practices and } \\
\text { processes in your council/shire? }\end{array}$ & 10 & 22 & 20 & 0.0296 & 5.99 \\
\hline $\begin{array}{l}\text { Question E7 } \\
\text { Does the audit committee review all } \\
\text { unrecorded audit adjustments (if any } \\
\text { reported) with management and the external } \\
\text { auditors and understand why they were not } \\
\text { recorded and reported? }\end{array}$ & 11 & 22 & 20 & -0.0038 & 5.99 \\
\hline
\end{tabular}

Note 1: Value of $\mathrm{p}>.05$ sourced from Table C Critical Values of the Chi-Square Distribution, Sigel and Castellan (1998) p. 323

From Table 5.8, it was noted that the critical value of chi-square distribution was 5.99 at the p $<0.05$ level (Sigel \& Castellan 1998, p. 323) and that the values of $\chi_{2}$ in Table 5.8 were less than the critical value of chi-square distribution. It was concluded that as each of the calculated values were below the critical value, the null hypothesis should be accepted as there was no statistical significance between the three groups of respondents.

\section{ii. Kruskal-Wallis Rank Test}

Siegel and Castellan (1988) discussed the various tests which are available for testing nonparametric data, for example: (1) Cochran Q Test; (2) Friedman Two-Way Analysis by Ranks; (3) Page Test for ordered alternatives; and the (4) Kruskal-Wallis One-Way Analysis of Variances by Ranks (pp. 188-9 and pp. 206-12). Cooksey (2007) called it the Kruskal-Wallis Rank Test for Several Independent Groups. The Cochran Q Test enables a researcher to determine if the values in the sample 'exhibit significantly different frequencies of success than would be expected by chance', which is not the case in this research (Siegel \& Castellan 1988, p. 188). The Friedman Two-Way Analysis by Ranks tests the probability that 'related samples could have come from the same population with respect to mean rankings', which is not relevant for the sample of mayors, chief executives and chairs of audit committees (Siegel \& Castellan 1988, p. 188). The Page Test for Ordered Alternatives assumes the 'data is on an ordinal scale' and tests for 'groups that are ordered a priori with respects to their medians' 
(Siegel \& Castellan 1988, p. 189). The Kruskal-Wallis Rank Test is used when the variables are from different populations, which was the case in this research (Cooksey 2007, p. 232; Siegel \& Castellan 1988, p. 206).

Statistical analysis was performed using the SPSS Graduate Pack 15.0 for Windows. Hair, Black, Babin, Anderson and Tatham (2006) described an ANOVA as a test which is used to determine if the samples from two or more groups come from populations with equal means (Hair et al. 2006, p. 384). One of the standard tests for analysing variances between two groups is a $t$-test, whereas an ANOVA was used where there are two or more groups. In an ANOVA test, two independent estimates for the dependent variable are compared with the first, reflecting the general variability of respondents within the three groups for this research (mayors, chief executives and chairs of audit committees), with the second representing the differences between groups attributed to treatment effects (Hair et al. 2006, p. 391). Cooksey (2007) noted that a one-way ANOVA evaluated the size of the:

mean difference among the various groups by comparing the observed variability of these group means to the random variability that would be observed if the null hypothesis (i.e. no group difference in the population) were true (p. 213).

Cooksey (2007) noted that an ANOVA test will not detect group variables if the data does not approximate a normal distribution or if there were variables in dependent scores within each group, which should approximate the same homogeneity of group variables (Cooksey 2007, p. 216). Given that the data from this research was not normally distributed and there was a variability of the homogeneity of the variance assumption, Cooksey (2007) recommended that a Kruskal-Wallis Rank Test be used or that the data be rescaled or transformed to fit the ANOVA primary assumptions (Cooksey 2007).

The research used the Kruskal-Wallis Rank Test for non-parametric data for mayors, chief executives and chairs of audit committees only. The small number of responses from board members of the Municipal Association of Victoria and committee members of the Local Government and Shires Association of New South Wales were initially included in the testing, but they distorted the significance. The subsequent testing for significance excluded these respondents and only tested the levels of significance between mayors, chief executives and chairs of audit committees, as the prelude to the qualitative research in Chapter Six. A Kruskal-Wallis Rank Test, if significant, indicates if mayors, chief executives and chairs of audit committees differ in terms of average ranks and therefore in terms of Likert 1 to 7 
scores, which they used to rate 'improvement required' to 'no improvement required' from the research questionnaire. In simple terms, the Kruskal-Wallis Rank Test indicates that amongst the three groups, there is at least one significant difference (Cooksey 2006, p. 232).

\section{Output from tests performed in SPSS}

The SPSS output for the Kruskal-Wallis Rank Test provided the following three data sets:
- $\quad$ mean and standard deviation;
- $\quad$ ranking of data; and
- $\quad$ chi-square test and p-values.

\section{Mean and standard deviations from SPSS output}

Mean and standard deviations from SPSS output were not used, as they were calculated in

\section{Appendix 6.}

\section{Ranking of the data from SPSS output}

Cooksey (2007) noted that the Kruskal-Wallis Rank Test is conducted in three straightforward ways. The ratings for mayor, chief executive and chair of audit committee are ranked in order. A rank is then allocated to the groups of mayors, chief executives and chairs of audit committees and then an ANOVA is performed using the ranks of each group and their average rank scores are compared. The Kruskal-Wallis Rank Test evaluates the significance of the mean difference in the ranks. This is reflected in Table 5.9 for questions A1-A5 with rankings for questions B1-B5; C1-C5; D1- D12; and E1-E10 detailed in Appendix 6.

\section{Table 5.9 Rankings of data from the Kruskal-Wallis Rank Test}

\begin{tabular}{|c|c|c|c|}
\hline Ranks & Group & N & Mean Rank \\
\hline Question A1 & Mayors & 16 & 36.41 \\
& Chief Executives & 31 & 32.63 \\
& Chairs of Audit Committees & 23 & 36.74 \\
\hline Question A2 & Total & 70 & 37.66 \\
& Mayors & 16 & 37.73 \\
& Chief Executives & 34 & 24 \\
& Chairs of Audit Committees & 74 & \\
\hline
\end{tabular}




\begin{tabular}{|l|c|c|c|}
\hline Question A3 & Mayors & 15 & 42.57 \\
& Chief Executives & 34 & 37.31 \\
& Chairs of Audit Committees & 24 & 33.08 \\
\hline \multirow{2}{*}{ Question A4 } & Total & 73 & 26.53 \\
& Mayors & 15 & 29.48 \\
& Chief Executives & 25 & 33.42 \\
\hline Chairs of Audit Committees & 19 & 34.79 \\
& Total & 59 & 30.61 \\
& Mayors & 17 & 34.83 \\
\hline & Chief Executives & 28 & \\
\hline & Chairs of Audit Committees & 20 & $\mathbf{6 5}$ \\
\hline
\end{tabular}

Notes: The scores from the original units of measurement (Likert 1 to 7 scores) from mayors, chief executives and chairs of audit committees are ranked from 1 to 89 (total sample size) ignoring each respondent's membership in the groups defined by the grouping variable. The rank test ignores the grouping of mayors, chief executives and chairs of audit committees and puts back into the ranks an 'artificial mean'. An ANOVA was conducted using the ranks as data and the three groups are compared in terms of their average rank score. The Kruskal-Wallis Rank Test is based on the chi-square statistic and the outcome for the test conducted on the data from the mayor, chief executives and chairs of audit committees is a value for the chi-square statistic and associated p-value.

\section{Chi-square test and p-values from SPSS output}

In the SPSS output from the Kruskal-Wallis Rank Test, the rankings are based on the chisquare statistic with the outcome being a value for the chi-square statistic and associated pvalue of significance. The chi-square test evaluates whether two or more variables are 'independent', that is, not associated with each other, 'such that knowing the category of an observation on one variable tells us nothing about the category of the observation on the other variable (Cooksey 2007, p. 190). Cooksey (2007) noted that if the chi-square value was large enough, independence can be rejected and it can be concluded that the two variables are significantly associated. In the SPSS package, the term, 'Asymp Sig' is the p-value for the interpretation of significance (Tables 5.10 and 5.11). It was noted in both tables, that none of the p-values were significant. The key output in the Kruskal-Wallis Rank Test is the p-value which endeavours to answer the question: If the populations have the same median, what would be the chance that a random sample would result in the sum of the ranks as were observed in this data from the mayors, chief executives and chairs of audit committees? Table 5.10 is the test data from mayors, chief executives and chairs of audit committees for questions A1-A5, B1-B5 and C1-C5. The results showed that the responses to the survey questions, A3, B4, B5, C1, C2 and C5 in Appendix 7 all had scores greater than 'two' and Cooksey (2007) stated that larger chi-square values lead to a greater likelihood of significance (p. 190). 
Table 5.11 is the test data from mayors, chief executives and chairs of audit committees for questions D1-D12 and E1-E10 in Appendix 6. The responses to questions D4, D5, D7, D9, E1, E3 and E8 in Appendix 6 all had large chi-square values indicating a likelihood of significance. In Tables 5.10 and 5.11, the 'df' value is 2, which are the degrees of freedom, which generally denotes the number of variables in the final calculation. The variable in this research is the Likert 1 to 7 scales for each question and the ' $\mathrm{df}$ ' value of 2 is considered to be satisfactory for this research. The standard test of significance is where the p-value is equal to or less than the chosen value $(\mathrm{p}<0.05)$. In such circumstances one accepts the null hypothesis and confirms that no significant differences exist. In the two tables, the Kruskal-Wallis Rank Test indicated a probability of values less than $\mathrm{p}<0.05$, which accepts the null hypothesis that 'there is no difference between the groups'. For questions C5, D4 and D5 the chi-square values of 4.77, 6.04 and 7.79 were above $\chi^{2}$ and, as a consequence, a level of significance was noted.

Table 5.10 Chi-square test and p-values from SPSS output for mayors, chief executives and chairs of audit committees - Questions A1-C5

\begin{tabular}{|c|c|c|c|c|c|}
\hline \multicolumn{6}{|c|}{ Test Statistics } \\
\hline Test/Questions & A1 & A2 & A3 & A4 & A5 \\
\hline chi-square & 1.329 & .034 & 2.043 & 1.532 & .869 \\
\hline $\mathrm{df}$ & 2 & 2 & 2 & 2 & 2 \\
\hline 'p-value' & 0.514 & 0.983 & 0.360 & 0.465 & 0.648 \\
\hline Test/Questions & B1 & B2 & B3 & B4 & B5 \\
\hline chi-square & .321 & 1.318 & .107 & 2.079 & 4.319 \\
\hline $\mathrm{df}$ & 2 & 2 & 2 & 2 & 2 \\
\hline 'p-value' & 0.852 & 0.517 & 0.948 & 0.354 & 0.115 \\
\hline Test/Questions & C1 & C2 & C3 & C4 & C5 \\
\hline chi-square & 2.530 & 3.746 & 1.066 & 0.569 & 4.777 \\
\hline $\mathrm{df}$ & 2 & 2 & 2 & 2 & 2 \\
\hline 'p-value' & 0.282 & 0.154 & 0.587 & 0.752 & $.0092 * *$ \\
\hline
\end{tabular}


Table 5.11 Chi-square test and p-values from SPSS output for mayors, chief executives and chairs of audit committees - Questions D1-E10

\begin{tabular}{|c|c|c|c|c|c|c|c|c|c|c|c|c|}
\hline \multicolumn{13}{|c|}{ Test Statistics } \\
\hline Test/Questions & D1 & D2 & D3 & D4 & D5 & D6 & D7 & D8 & D9 & D10 & D11 & D12 \\
\hline chi-square & 1.935 & 1.515 & .529 & 6.046 & 7.798 & 1.573 & 3.646 & 0.012 & 3.576 & 0.004 & 0.803 & 0.894 \\
\hline $\mathrm{df}$ & 2 & 2 & 2 & 2 & 2 & 2 & 2 & 2 & 2 & 2 & 2 & 2 \\
\hline 'p-value' & 0.380 & 0.469 & 0.767 & $\begin{array}{c}.0490 \\
* *\end{array}$ & $\begin{array}{c}.020 \\
* *\end{array}$ & 0.455 & 0.162 & 0.994 & 0.167 & 0.998 & 0.669 & 0.639 \\
\hline
\end{tabular}

\begin{tabular}{|c|c|c|c|c|c|c|c|c|c|c|}
\hline \multicolumn{10}{|c|}{ Test Statistics } \\
\hline Test/Questions & E1 & E2 & E3 & E4 & E5 & E6 & E7 & E8 & E9 & E10 \\
\hline chi-square & 2.794 & 0.293 & 2.117 & 1.865 & 0.565 & 0.882 & 0.359 & 4.567 & 0.888 & 0.034 \\
\hline df & 2 & 2 & 2 & 2 & 2 & 2 & 2 & 2 & 2 & 2 \\
\hline 'p-value' & 0.247 & 0.864 & 0.347 & 0.394 & 0.754 & 0.643 & 0.836 & 0.102 & 0.641 & 0.983 \\
\hline
\end{tabular}

\section{Outcomes}

The outcomes from the Kruskal Wallis Rank Test were statistically significant and simply disclose that the three groups (mayors, chief executives and chairs of audit committees) differ in terms of average ranks. As previously noted, the Kruskal Wallis Rank Test does not disclose which of the three groups actually differ, but the test indicates that amongst the mayors, chief executives and chairs of audit committees, there is at least one significant difference (Cooksey (2007). The chi-square test identified that in questions C5, D4 and D5 there were significant differences between groups.

The data from the Kruskal-Wallis Rank Test formed the basis of questions for the qualitative research, notwithstanding that the factorial analysis in Chapter Six identified some differences between mean and standard deviations of three groups of respondents in Victorian metropolitan councils and Victorian rural and regional councils and shires.

\subsection{Summary}

In this methodology chapter, the research methods were described and an explanation for the selection of the pragmatic paradigm as the research methodology and mixed methods as the research method was provided. 
The chapter has outlined the preferred approach to theory and data collection including grounded theory as an approach to the collection of quantitative and qualitative data.

This chapter has provided the framework for the quantitative and qualitative research in Chapter Six and the conclusions in Chapter Seven respectively. 
Chapter Six will analyse the results from both quantitative and qualitative research to examine the two research questions in Chapter One.

The following results will be discussed: (1) response rates for quantitative research (Sections 6.1 and 6.3); (2) data analysis (Sections 6.4 and 6.5); (3) qualitative research (Section 6.6 and 6.7); and (4) outcomes from the research (Section 6.8). Quantitative responses provide the evidence to support or refute the sub-research questions (Section 1.6) in Chapter One and they are used to develop qualitative research with a sample of mayors, chief executives and chairs of audit committees (Section 6.5).

\subsection{Response rates from quantitative research}

Two hundred and eighty-two questionnaires were posted to: (1) seventy-eight Victorian metropolitan and shire councils; (2) twelve of thirteen board members of the Municipal Association of Victoria, as previously mentioned, one board member was from the council which declined to participate in the research; and (3) all thirty-six committee members of the Local Government and Shires Association of New South Wales. ${ }^{18}$ The latter representative organisations were followed up via emails and letters to increase the response rate.

As noted in Chapter Five the response rate to the research questionnaire was 36\% (eightynine usable responses from two hundred and fifty-four questionnaires) (Table 6.1).

The responses from mayors, chief executives and chairs of audit committees represented opinions from fifty-five Victorian councils or $71 \%$ of all councils and shires. From a factorial perspective, the response rates were: (1) mayoral group, 21\% of Melbourne metropolitan councils and $25 \%$ of rural and regional councils and shires; (2) chief executive group, $58 \%$ of Melbourne metropolitan councils and 35\% of rural and regional councils; and (3) chairs of audit committees, $48 \%$ of Melbourne metropolitan councils and 28\% of rural and regional councils and shires respectively.

\footnotetext{
${ }^{18}$ The thirty-six members of the Local Government and Shires Association of New South Wales represent one hundred and fifty-two general purpose councils and thirteen special purpose councils in New South Wales.
} 
Table 6.1 Response rates from research

\begin{tabular}{|c|c|c|c|c|}
\hline Research Groups (total) & $\begin{array}{c}\text { Number of } \\
\text { Surveys } \\
\text { Posted } \\
\end{array}$ & $\begin{array}{l}\text { Sample eligible } \\
\text { to respond (n) }\end{array}$ & $\begin{array}{l}\text { Number of } \\
\text { Usable } \\
\text { Responses } \\
\end{array}$ & $\begin{array}{c}\text { Response Rate } \\
\%\end{array}$ \\
\hline $\begin{array}{l}\text { Mayors } \\
\text { Metropolitan councils } \\
\text { Rural and regional councils and } \\
\text { shires }\end{array}$ & $\begin{array}{c}78 \\
\text { (Note 1) }\end{array}$ & $\begin{array}{c}73 \\
\text { (Note 3) } \\
29 \\
\\
44 \\
\end{array}$ & $\begin{array}{c}\mathbf{1 7} \\
6 \\
11 \\
\text { (Note 7) } \\
\end{array}$ & $\begin{array}{l}23.29 \% \\
20.69 \% \\
25.00 \% \\
\end{array}$ \\
\hline $\begin{array}{l}\text { Chief Executives } \\
\text { Metropolitan councils } \\
\text { Rural and regional councils and } \\
\text { shires }\end{array}$ & $\begin{array}{c}78 \\
\text { (Note 1) }\end{array}$ & $\begin{array}{c}77 \\
\text { (Note 4) } \\
31 \\
\\
46 \\
\end{array}$ & $\begin{array}{l}34 \\
18 \\
16\end{array}$ & $\begin{array}{l}\mathbf{4 4 . 1 6 \%} \\
58.06 \% \\
\\
34.78 \% \\
\end{array}$ \\
\hline $\begin{array}{l}\text { Chairs, Audit Committees } \\
\text { Metropolitan councils } \\
\text { Rural and regional councils and } \\
\text { shires }\end{array}$ & $\begin{array}{c}78 \\
\text { (Note 1) }\end{array}$ & $\begin{array}{c}70 \\
\text { (Note 5) } \\
27 \\
\\
43\end{array}$ & $\begin{array}{l}25 \\
13 \\
12\end{array}$ & $\begin{array}{l}35.71 \% \\
48.15 \% \\
27.91 \% \\
\end{array}$ \\
\hline Municipal Association Victoria & $\begin{array}{c}12 \\
\text { (Note 2) }\end{array}$ & 12 & 4 & $33.33 \%$ \\
\hline $\begin{array}{l}\text { Local Government and Shires } \\
\text { Association of New South Wales }\end{array}$ & 36 & $\begin{array}{c}13 \\
\text { (Note 6) }\end{array}$ & $\begin{array}{c}\mathbf{9} \\
\text { (Note 8) }\end{array}$ & $69.23 \%$ \\
\hline Total & 282 & 245 & 89 & $35.92 \%$ \\
\hline
\end{tabular}

Notes

Note 1: The calculation was 79 minus 1 council.

Note 2: The calculation was 13 minus 1 council.

Note 3: Of the 79 councils, three declined to participate.

The responses from City of Greater Bendigo and Kingston City Council were the composite views of the Council. These composite responses have only been added to the Chief Executive's responses. The calculation was 79 minus 6 councils.

Note 4: $\quad$ Of the 79 councils, Greater Geelong and North Grampians declined to participate. The calculation was 79 minus two councils.

Note 5: Two respondents were chairs of three and two metropolitan councils respectively. These have counted as two responses only. One person was the chair of one metropolitan council and two rural shire councils. This has been counted as one response only. The responses from City of Greater Bendigo and Kingston City Council were the composite views of the council. These composite responses have only been added to the chief executive's responses. Three councils declined to participate in the research. The calculation was 79 minus 9 councils.

Note 6: The 36 members of the Local Government and Shires Association represented 32 councils and shires in New South Wales. The research established that audit committees have only been established in 13 of the 32 councils and shires.

Note 7: $\quad$ One of the responses did not contain any ratings and the response was not used. The usable responses were 11 , although 12 responses were received.

Note 8: One response did not contain ratings and the response was not used. The usable responses were 9, although 18 responses were received with 8 respondents indicating that their council did not have an audit committee

Two responses from the chief executives of The City of Greater Bendigo and Kingston Council were the composite responses of the mayor, chief executive and chair of the audit committee respectively. Three audit committee chairs advised that they were the chairs of audit committees of six metropolitan councils and two shire councils respectively. This research has reported responses from Greater Bendigo and Kingston Council and the three chairs of audit committees as five responses (see column 3 in Table 6.1). 


\section{Response rate - Local Government and Shires Association of New South Wales}

The response rate was eighteen out of thirty-six (50\%) but this included eight respondents who stated that their council or shire did not have an audit committee and one response which was unusable (see notes 6 and 8 in Table 6.1).

The Division of Local Government, Department of Premier and Cabinet, New South Wales advised that only $46 \%$ of councils and shires in New South Wales had an audit committee, following a survey conducted by the Division of Local Government in October 2009 (Department of Premier and Cabinet, New South Wales 2010a). It was advised that audit committees in local government in New South Wales were recommended practice for councils and shires under Section 23A of the Local Government Act (1993) but were not a mandatory requirement. This was a substantial point of difference between audit committees in local government in New South Wales and Victoria, with the latter being compulsory under the Local Government Act (1989).

The websites of thirty-two councils and shires represented by the Local Government and Shires Association of New South Wales were searched electronically using the Boolean search phrase 'audit committee', to establish if the term was cited in council documents, for example, council agendas, council minutes and council policies. It was established that thirteen councils and shires had audit committees (41\%) compared to the $46 \%$ audit committee establishment rate, as advised by the Division of Local Government (see note 6 in Table 6.1). The usable response rate from the councils with audit committees was: (1) two metropolitan councils (2/7 - 29\%); and (2) seven rural and regional councils and shires (7/7 $100 \%)$.

\section{Response rates - Board members of the Municipal Association of Victoria}

The response rate from board members of the Municipal Association of Victoria was only four (33\%) despite two subsequent follow-ups by mail and email. This response rate is small in number and caution needs to be exercised in any extrapolation or inferences from the data.

\subsection{Acceptability of response rate}

The literature provided an estimate of the expected response rate from academic research that a researcher could obtain from material sourced via chief executives or other top positions in 
organisations (Anseel et al. 2010; Baruch 1999; Denison \& Mishra 1995). This allows a researcher to effectively follow-up to increase the response rate to an acceptable statistical power.

Baruch (1999) stated that there is no accepted norm 'as to what is or may be received as an acceptable, reasonable' response rate in academic studies and there can be a multitude of reasons for the non-respondent rate (p. 422). This can range from lack of interest in the research topic, a lack of relevance or being too busy to respond. Baruch (1999) also noted that the response rate for chief executives in research studies in the United States of America was generally lower than for other organisational sample groups. This finding was also supported by the response rate from chief executives by Denison and Mishra (1995) in their study of organisational culture and effectiveness. This study had a response rate of $21 \%$, which they considered to be adequate (Denison \& Mishra 1995, p. 217). Baruch (1999) undertook a comparative study of response rates in management and behavioural science academic journals for 1975, 1985 and 1995 and concluded that:

where the type of individual population was reported, the average RRs were as follows (SD in brackets) employees (e.g., rank and file) - 61.35 (18.4); professionals - 59.23 (18.2); managers - 61.79 (21.9); and top managers or representatives of the organizations - 36. (18.2) (p. 431). ${ }^{19}$

Baruch (1999) stated that when some of the major studies with high and low response rates were excluded, the response rates for top managers was reduced to $36 \%$ with a standard deviation of 13. This finding was complemented by Anseel et al. (2010) who analysed response rates in two thousand and thirty-seven surveys from twelve academic journals in psychology, management and marketing from 1995 to 2008. They concluded that the response rate for mailed surveys to top executives was 35\% with a standard deviation of 17.5\% (Anseel et al. 2010, p. 346), which compared favourably to the findings of $34 \%$ from the meta-analysis by Cycyota and Harrison (2006 p. 141) and 36\% and 35\% by Baruch and Holtom (2008) for organisational respondents in 2005 and 2000 (p. 1148).

As no previous academic research into audit committees in Victorian local government had been identified, it was difficult to comment upon the acceptability of the response rate. However, the response rate of $36 \%$ for this research was consistent with previously accepted response rates sourced from chief executives or leaders of organisations (Anseel et al. 2010;

\footnotetext{
${ }^{19}$ Baruch (1999) used the acronyms 'RRs' and 'SD' for response rates and standard deviations respectively.
} 
Baruch \& Holtom 2008; Cycyota \& Harrison 2006). Rogelberg and Stanton (2007) however argued against the notion of an acceptable response rate and stated that some surveys:

...often justify an obtained response rate on the basis that it is consistent with industry standards or what is typically found in given area of research. Although such descriptions do put a response rate into context, the fact that everyone else also achieves $30 \%, 40 \%$ or $50 \%$ response does not help to demonstrate that the research is free from nonresponse bias (pp. 197-8).

The responses from board members of the Municipal Association of Victoria (4 of 12) and committee members of the Local Government and Shires Association of New South Wales (9 of 13) were low in aggregate numbers, nevertheless they can be used to provide some general observations, as compared to specific inferences from the higher number of responses from mayors (17 of 73), chief executives (33 of 77) and chairs of audit committees (25 of 70) (see notes 2, 3, 4 and 6 in Table 6.1). It was noted however that small numbers do not necessarily distort. The sampling with respect to significance takes the small $n$ into account.

\subsection{Demographic and firmographic analysis}

Some responses from board members of the Municipal Association of Victoria and committee members of the Local Government and Shires Association of New South Wales had been completed by the chief executive of councils on behalf of councillors having memberships of the two representative bodies.

This accounted for the difference in the number of responses from chief executives in Table 6.1 (34 responses) and Table 6.2 (46 responses). The responses were accepted for the research, as it was beyond this researcher's power to influence the completion of the questionnaire by councillors, notwithstanding that questionnaires were personally addressed.

\subsubsection{Demographic analysis of respondents}

The respondents were almost equally divided between metropolitan and rural and regional councils with forty-three (48\%) from metropolitan councils in New South Wales and Victoria and forty-six (51\%) from rural shire and regional city councils (Table 6.1). The respondents were predominately male (84\%) (Table 6.2). The response rate from females was 16\%, with responses from four female mayors, one female councillor and fourteen female chief executives. Thirteen of seventeen responses from the mayoral group were male (76\%), all chairs of audit committees were male and thirty-seven of forty-six chief executives (80\%). 
Table 6.2 Demography of respondents

\begin{tabular}{|c|c|c|c|c|c|c|}
\hline Demographic Questions & Mayors & $\begin{array}{c}\text { Councillor } \\
\text { s }\end{array}$ & $\begin{array}{c}\text { Chairs, } \\
\text { Audit } \\
\text { Committee }\end{array}$ & $\begin{array}{c}\text { Chief } \\
\text { Executive } \\
s\end{array}$ & Total & $\begin{array}{c}\text { Percentag } \\
\text { e } \\
\%\end{array}$ \\
\hline \multicolumn{7}{|l|}{ Gender } \\
\hline \multirow{3}{*}{$\begin{array}{r}\text { Male } \\
\text { Female } \\
\text { Not specified } \\
\end{array}$} & 13 & 1 & 24 & 37 & 75 & $84.27 \%$ \\
\hline & 4 & 1 & 0 & 9 & 14 & $15.73 \%$ \\
\hline & 0 & 0 & 0 & 0 & 0 & 0 \\
\hline Subtotal & 17 & 2 & 24 & 46 & 89 & $100.00 \%$ \\
\hline \multicolumn{7}{|l|}{$\begin{array}{l}\text { Years of experience with the } \\
\text { audit committee }\end{array}$} \\
\hline \multirow{4}{*}{$\begin{array}{c}\text { 1-2 years } \\
\text { 3-4 years } \\
\text { 5-6 years } \\
\text { 7+ years }\end{array}$} & 4 & 0 & 4 & 8 & 16 & $17.98 \%$ \\
\hline & 3 & 1 & 5 & 12 & 21 & $23.60 \%$ \\
\hline & 5 & 0 & 4 & 4 & 13 & $14.61 \%$ \\
\hline & 5 & 1 & 11 & 20 & 37 & $41.57 \%$ \\
\hline Not specified & 0 & 0 & 0 & 2 & 2 & $2.25 \%$ \\
\hline Subtotal & 17 & 2 & 24 & 46 & 89 & $100.00 \%$ \\
\hline \multicolumn{7}{|l|}{$\begin{array}{l}\text { Cumulative years of experience } \\
\text { in local government }\end{array}$} \\
\hline 1-4 years & 3 & 0 & 5 & 4 & 12 & $13.48 \%$ \\
\hline 5-8 years & 7 & 0 & 4 & 1 & 12 & $13.48 \%$ \\
\hline $9-12$ years & 3 & 1 & 4 & 6 & 14 & $15.73 \%$ \\
\hline $13+$ years & 4 & 1 & 11 & 30 & 46 & $51.69 \%$ \\
\hline Not specified & 0 & 0 & 0 & 5 & 5 & $5.62 \%$ \\
\hline Subtotal & 17 & 2 & 24 & 46 & 89 & $100.00 \%$ \\
\hline
\end{tabular}

This gender imbalance was anticipated as 69\% of councillors were male from the 2006 Councillor Census (Municipal Association of Victoria, 2006, p. 3) and, in relation to chairs of audit committees, $57 \%$ of certified practising accountants in Australia were male (CPA Australia 2009, p. 16) and 66\% of chartered accountants in Australia were male (Institute of Chartered Accountants Australia 2010, p. 14). The Australian Local Government Women's Association (2009) stated that 'women still account for less than 30\% of councillors, only $20 \%$ of senior managers and only $5 \%$ of chief executives in local government' (p. 4). The AMP.Natsem Income and Wealth Report (2009) noted that 'women's educational attainment is reflected in their increasing presence in higher status occupations but they are also increasingly juggling the responsibilities of work with child rearing' (AMP.Natsem Income and Wealth Report 2009, p. 2). Diamond (2007), in her doctoral research into career development of local government chief executives, complemented the Australian Local Government Women's Association and noted the small number of female chief executives in Victorian local government (p. 107). Malkovic (2011) also complemented the Australian Local Government Women's Association (2009) and noted that Australian women comprise $55 \%$ of university graduates and nearly $50 \%$ of the workforce, but they were under- 
represented on boards. He summarised the debate in relation to quotas for women on boards, although this was outside the scope of the thesis.

The level of experience with audit committees and cumulative experience in local government was high, with $42 \%$ of respondents with more than seven years experience and $52 \%$ of respondents with more than thirteen years (Table 6.2). This was expected, given that respondents are mayors, councillors, chief executives and chairs of audit committees. In terms of experience and the familiarity with the workings of audit committees, $56 \%$ of respondents stated that they had greater than five to six years experience with audit committees.

It was noted that thirty-seven of eighty-nine respondents (42\%) indicated more than seven years experience. This corresponded with the: (1) mayoral group with ten of seventeen respondents (59\%) with more than five to six years; (2) fifteen of twenty-four chairs of audit committees (62\%); and (3) twenty-four of forty-six chief executives (52\%). In terms of experience in local government, sixty of eighty-nine respondents $(67 \%)$ had more than nine years experience, although this was skewed by chief executives, with six having nine to twelve years experience and thirty chief executives with more than thirteen years experience.

\subsubsection{Firmographic analysis of respondents}

Firmographic is a marketing term which generally refers to the characteristics of companies including size, industry, revenue and geographic locations ${ }^{20}$. From Table 6.3, twenty-nine (67\%) of the forty-three mayors and chairs of audit committees reported that they were employed outside council as 'managers and professionals'. This was anticipated, as the 2006 Councillor Census (Municipal Association of Victoria 2006, p. 3) noted that the largest occupational categories for councillors were 'manager', 'administrator' and 'professional'. Twenty-one (87\%) of twenty-four chairs of audit committees stated that their occupation outside council was 'managerial' or 'professional', with one respondent not providing any information. The remaining two chairs of audit committees were retired, but noted their previous occupations as school principal and pro vice-chancellor of a university respectively.

\footnotetext{
${ }^{20}$ What are being described are the characteristics of organisations similar to the use of demographic data for people. Consequently there is no need to differentiate between incorporated entities and public sector bodies in the use of the term 'firmographic'.
} 
Two mayors reported they were involved in agriculture and farming and two were retired. Four mayors in the 'other category' (Table 6.3) reported they were employed in: (1) dairy manufacturing; (2) disability and community services; (3) retail; and (4) as a company director respectively.

Table 6.3 Firmographic data

\begin{tabular}{|c|c|c|c|c|c|c|}
\hline Firmographic Questions & Mayors & Councillors & $\begin{array}{l}\text { Chairs, } \\
\text { Audit } \\
\text { Committee }\end{array}$ & $\begin{array}{c}\text { Chief } \\
\text { Executives }\end{array}$ & Total & $\%$ \\
\hline \multicolumn{7}{|l|}{$\begin{array}{l}\text { Occupations of mayors, councillors } \\
\text { and chairs, audit committees }\end{array}$} \\
\hline \multirow{2}{*}{$\begin{array}{r}\text { Agriculture and farming } \\
\text { Technical and trade }\end{array}$} & 2 & 2 & 0 & 0 & 4 & $9.30 \%$ \\
\hline & 1 & 0 & 0 & 0 & 1 & $2.33 \%$ \\
\hline \multirow{2}{*}{$\begin{array}{r}\text { Managerial/ Professional } \\
\text { Other (e.g. domestic duties, retired, or } \\
\text { unemployed) }\end{array}$} & 8 & 0 & 21 & & 29 & $67.44 \%$ \\
\hline & 2 & 0 & 2 & 0 & 4 & $9.30 \%$ \\
\hline \multirow{2}{*}{$\begin{array}{r}\text { Other (please specify) } \\
\text { Not specified }\end{array}$} & 4 & 0 & 0 & 0 & 4 & $9.30 \%$ \\
\hline & 0 & 0 & 1 & 0 & 1 & $2.33 \%$ \\
\hline Subtotal & 17 & 2 & 24 & 0 & 43 & $100.00 \%$ \\
\hline \multicolumn{7}{|l|}{ f chief } \\
\hline \multirow{5}{*}{$\begin{array}{r}\text { Accounting and finance } \\
\text { Community Services/Nursing/ } \\
\text { Social Work } \\
\text { Architecture/Building/Engineering } \\
\text { Other (please specify) } \\
\text { Not specified }\end{array}$} & 0 & 0 & 0 & 22 & 22 & $47.83 \%$ \\
\hline & 0 & 0 & 0 & 6 & 6 & $13.04 \%$ \\
\hline & 0 & 0 & 0 & 4 & 4 & $8.70 \%$ \\
\hline & 0 & 0 & 0 & 14 & 14 & $30.43 \%$ \\
\hline & 0 & 0 & 0 & & & \\
\hline Subtotal & & & & 46 & 46 & $100.00 \%$ \\
\hline
\end{tabular}

The chief executives in Table 6.3 reported that: (1) twenty-two (48\%) had accounting and finance qualifications; (2) six (13\%) had community, nursing or social work qualifications; (3) four (9\%) had architecture, building or engineering qualifications. Fourteen (30\%) reported other qualifications including: (1) law; (2) business administration; (3) economics; (4) human resources; and (5) sport and recreation respectively.

It was considered that results from this research had an under representation from chief executives with engineering qualifications, although they could have been part of the nonrespondent group or lacked interest in the research topic (Armstrong \& Overton 1977) or time available to contribute to the research (Pace 1939). The annual reports of twenty councils which did not respond to the research questionnaire were selected to ascertain if the number of chief executives with engineering qualifications differed from the research results. This review noted that three of twenty non-respondent chief executives (15\%) had engineering qualifications, which was twice the respondent rate from the research. In 2009, Local 
Government Professionals (LGP) reviewed the employment profile and skills of existing and future potential chief executives in Victorian local government. LGP identified that, 'half of the surveyed CEOs and potential CEOs had qualifications in the fields of business or management with three-quarters having postgraduate degrees - MBAs and similar' (Local Government Professionals 2009, p. 45). They also found that $47 \%$ of the existing chief executives in Victoria had business or management postgraduate qualifications and $10 \%$ had engineering qualifications. Whilst the lower representation of chief executives with engineering qualifications was noted from this research and the subsequent review of the annual reports from non-respondent chief executives was noted, the findings from this research in relation to the qualifications of chief executives was validated by the findings of Local Government Professionals (2009).

\subsubsection{Differences between responses of metropolitan and rural councils}

The differences in the demographic and firmographic data between respondents from the metropolitan and rural and regional councils and shires related to the occupational status of the mayors. The mayoral group had representation from the occupations of agriculture and farming', as well as dairy manufacturing, which was expected for rural and regional councils and shires. The occupational category, 'managerial and professional', was evenly distributed between mayors from rural and regional councils and shires and was similar for chairs of audit committees. The professional qualifications of chief executives were biased towards 'business, accounting and finance' qualifications from respondents in metropolitan and rural and regional councils and shires. The academic and professional qualifications of chief executives in metropolitan and rural and regional councils and shires were not significantly different.

\subsection{Detailed observations from quantitative research}

\subsubsection{Results - Establishment of the audit committee}

Eighty-nine respondents affirmed that their council or shire had an audit committee in accordance with the Victorian Local Government Act (1989) and recommended practice in New South Wales under Section 23 of the Local Government Act (1993) (Tables 6.4, 6.5 and 6.6). The respondents stated that the audit committee reported to council (question 5 in Table 6.4). Regular reporting for New South Wales councils was consistent with Section 3.10 of the Internal Audit Guidelines (Department of Premier and Cabinet, New South Wales 2010b, p. 
23) and Department of Local Government 2008b, p. 25) and best practice audit committee guidelines for Victorian local government (Department of Infrastructure 2000).

From Table 6.4, eighty-eight respondents indicated they were cognisant that the audit committee was an advisory committee with no executive powers. This question was included because the pilot study found that it could be a potential source of tension between the audit committee and the executive management team, especially if the audit committee usurped their roles.

Question 7 in Table 6.5 established that the membership of audit committees was almost evenly divided between a majority of independent members or an equal distribution between councillors and independent members for metropolitan councils of twenty-one and twenty respondents respectively.

Two Victorian councils stated that councillors constituted the majority of members, which was contrary to audit committee guidelines from the Department of Infrastructure (2000) stating that, 'the majority of committee members should be independent of the local government entity and management' (Department of Infrastructure 2000, p.7). The respondents from rural and regional councils stated that the majority were independent members, with twelve councils indicating an equal distribution between independent members and councillors.

One New South Wales council stated that management representatives were in the majority on the audit committee, which was inconsistent with the independent role of an audit committee (Department of Premier and Cabinet, New South Wales 2010b) and the Internal Audit Guidelines (Department of Local Government 2008b, p. 23). 
Table 6.4 Establishment of the audit committee

\begin{tabular}{|c|c|c|c|c|c|c|}
\hline Questions & Mayors & $\begin{array}{c}\text { Chief } \\
\text { Executives }\end{array}$ & $\begin{array}{c}\text { Chairs, } \\
\text { Audit } \\
\text { Committee }\end{array}$ & $\begin{array}{l}\text { Municipal } \\
\text { Association } \\
\text { of Victoria }\end{array}$ & $\begin{array}{c}\text { Local } \\
\text { Government } \\
\text { and Shires } \\
\text { Association of } \\
\text { New South } \\
\text { Wales } \\
\end{array}$ & Total \\
\hline \multirow{3}{*}{$\begin{array}{l}\text { Question 4: } \\
\text { Does the audit committee } \\
\text { have a charter approved } \\
\text { by the council/ shire? } \\
\text { Metropolitan councils } \\
\text { Rural and regional } \\
\text { councils }\end{array}$} & & & & & & \\
\hline & 6 & 18 & 13 & 4 & 2 & 43 \\
\hline & 11 & 16 & 12 & 0 & 7 & 46 \\
\hline Subtotal & 17 & 34 & 25 & 4 & 9 & 89 \\
\hline \multirow{2}{*}{$\begin{array}{l}\text { Question 5: } \\
\text { Does the audit committee } \\
\text { report to the council/shire } \\
\text { on a regular basis? } \\
\quad \text { Metropolitan councils }\end{array}$} & & & & & & \\
\hline & 6 & 18 & 13 & 4 & 2 & 43 \\
\hline $\begin{array}{r}\text { Rural and regional } \\
\text { councils }\end{array}$ & 11 & 16 & 12 & 0 & 6 & 45 \\
\hline Subtotal & 17 & 34 & 25 & 4 & 8 & 88 \\
\hline \multirow[t]{2}{*}{$\begin{array}{l}\text { Question 6: } \\
\text { Do audit committee } \\
\text { members understand that } \\
\text { the committee is only an } \\
\text { advisory body to the } \\
\text { council/shire? } \\
\quad \text { Metropolitan councils }\end{array}$} & & & & & & \\
\hline & 6 & 18 & 13 & 4 & 2 & 43 \\
\hline $\begin{array}{r}\text { Rural and regional } \\
\text { councils }\end{array}$ & 11 & 16 & 12 & 0 & 7 & 46 \\
\hline Subtotal & 17 & 34 & 25 & 4 & 9 & 89 \\
\hline
\end{tabular}

Question 8 in Table 6.6 confirmed that chairs of audit committees were predominately independent members in both metropolitan and rural and regional councils. It was established that five metropolitan and five rural and regional councils had a councillor as the chair of the audit committee, which was contrary to local government audit committee guidelines of New South Wales (Department of Local Government 2008b; Department of Premier and Cabinet 2010b) and Victoria (Department of Infrastructure 2000).

Two councils in New South Wales reported that a management representative was the chair of the audit committee, which was also contrary to audit committee guidelines from the Department of Local Government (2008b) and the Department of Premier and Cabinet, New South Wales (2010b). The Department of Local Government (2008b) stated that it was 'good practice for council staff not to be members' of the audit committee (Department of Local Government 2008b, p. 23). 
Table 6.5 Membership of the audit committee

\begin{tabular}{|c|c|c|c|c|c|c|}
\hline Questions & Mayors & $\begin{array}{l}\text { Chief } \\
\text { Executives }\end{array}$ & $\begin{array}{l}\text { Chairs, } \\
\text { Audit } \\
\text { Committee }\end{array}$ & $\begin{array}{l}\text { Municipal } \\
\text { Association } \\
\text { of Victoria }\end{array}$ & $\begin{array}{c}\text { Local } \\
\text { Government } \\
\text { and Shires } \\
\text { Association of New } \\
\text { South Wales } \\
\end{array}$ & Total \\
\hline \multicolumn{7}{|l|}{$\begin{array}{l}\text { Question 7: } \\
\text { The majority of the } \\
\text { members of the audit } \\
\text { committee are: } \\
\text { Metropolitan Councils }\end{array}$} \\
\hline Councillors & Nil & 1 & Nil & 1 & Nil & 2 \\
\hline Impendent members & 5 & 9 & 5 & 1 & 1 & 21 \\
\hline $\begin{array}{r}\text { Management } \\
\text { representatives }\end{array}$ & Nil & Nil & Nil & Nil & Nil & Nil \\
\hline $\begin{array}{r}\text { Equal representation } \\
\text { between councillors and } \\
\text { independent members }\end{array}$ & 1 & 8 & 8 & 2 & 1 & 20 \\
\hline Subtotal & 6 & 18 & 13 & 4 & 2 & 43 \\
\hline \multicolumn{7}{|l|}{$\begin{array}{l}\text { Rural and Regional } \\
\text { Councils }\end{array}$} \\
\hline Councillors & Nil & 1 & 1 & Nil & 2 & 4 \\
\hline Independent members & 7 & 11 & 9 & Nil & 2 & 29 \\
\hline $\begin{array}{r}\text { Management } \\
\text { representatives }\end{array}$ & Nil & Nil & Nil & Nil & 1 & 1 \\
\hline $\begin{array}{r}\text { Equal representation } \\
\text { between councillors and } \\
\text { Independent members } \\
\end{array}$ & 4 & 4 & 2 & Nil & 2 & 12 \\
\hline Subtotal & 11 & 16 & 12 & Nil & 7 & 46 \\
\hline Total & 17 & 34 & 25 & 4 & 9 & 89 \\
\hline
\end{tabular}

Table 6.6 Chairmanship of the audit committee

\begin{tabular}{|c|c|c|c|c|c|c|}
\hline Questions & Mayors & $\begin{array}{l}\text { Chief } \\
\text { Executives }\end{array}$ & $\begin{array}{l}\text { Chairs, } \\
\text { Audit } \\
\text { Committee }\end{array}$ & $\begin{array}{l}\text { Municipal } \\
\text { Association } \\
\text { of Victoria }\end{array}$ & $\begin{array}{c}\text { Local } \\
\text { Government } \\
\text { and Shires Association } \\
\text { of New South Wales }\end{array}$ & Total \\
\hline \multicolumn{7}{|l|}{$\begin{array}{l}\text { Question } 8 \\
\text { The chair of the audit } \\
\text { committee is: } \\
\text { Metropolitan Councils }\end{array}$} \\
\hline Councillor & 1 & 1 & Nil & 2 & 1 & 5 \\
\hline Independent member & 5 & 17 & 13 & 2 & Nil & 37 \\
\hline $\begin{array}{r}\text { Management } \\
\text { representative }\end{array}$ & Nil & Nil & Nil & Nil & 1 & 1 \\
\hline Subtotal & 6 & 18 & 13 & 4 & 2 & 43 \\
\hline \multicolumn{7}{|l|}{$\begin{array}{l}\text { Rural and Regional } \\
\text { Councils }\end{array}$} \\
\hline Councillor & 1 & 1 & 1 & Nil & 2 & 5 \\
\hline Independent member & 10 & 15 & 11 & Nil & 4 & 40 \\
\hline $\begin{array}{l}\text { Management } \\
\text { representative }\end{array}$ & Nil & Nil & Nil & Nil & 1 & 1 \\
\hline Subtotal & 11 & 16 & 12 & Nil & 7 & 46 \\
\hline Total & 17 & 34 & 25 & 4 & 9 & 89 \\
\hline
\end{tabular}




\section{Conclusions}

Respondents provided evidence to conclude that establishment processes for an audit committee were generally consistent with audit committee guidelines from New South Wales and Victoria with the following exceptions:

- $\quad$ two Victorian councils reported that councillors were the majority of audit committee members;

- $\quad$ one New South Wales council reported that management representatives were in the majority on the audit committee;

- $\quad$ four metropolitan and three rural and regional councils in Victoria had a councillor as the chair of the audit committee;

- $\quad$ one metropolitan and two rural and regional councils in New South Wales had a councillor as the chair of the audit committee; and

- two councils in New South Wales reported that a management representative was the chair of the audit committee.

\subsubsection{Results - Forming an audit committee}

\section{i. Background}

The Department of Infrastructure (2000), the Department of Local Government (2008b) and the Department of Premier and Cabinet, New South Wales (2010b) recommended that local government audit committees should be independent and objective. Each member of the audit committee should have an understanding of council or shire objectives and priorities and the role of the audit committee.

\section{ii. Observations}

The survey questions are contained in Appendix 5 and the responses to questions A1, A2 and A3 are contained in Appendix 6 and Tables A7.1-A7.4 in Appendix 7. These questions related to an agreed selection criteria for membership, clarity of councils' expectations of the audit committee and sufficiency of knowledge of operations and risks of local government. 


\section{Table 6.7 Mean responses, Questions A1-A5}

\begin{tabular}{|r|c|c|c|c|c|}
\hline \multicolumn{1}{|c|}{ Questions } & A1 & A2 & A3 & A4 & A5 \\
\hline Mayors & 5.75 & 5.31 & 5.93 & 5.6 & 5.82 \\
\hline Chief executives & 5.52 & 5.41 & 5.53 & 5.8 & 5.57 \\
\hline Chairs of audit committees & 5.83 & 5.29 & 5.42 & 6.16 & 5.85 \\
\hline Nocal Government and Shires Association of & & & & & \\
\hline Municipal Association of Victoria & 4.50 & 4.67 & 6.67 & 5.50 & 5.3 \\
\hline
\end{tabular}

Notes:

Note 1: The mean and standard deviations in this table are the responses from mayors, chief executives and chairs of audit committees from a Likert 1 to 7 point scale.

Note 2: $\quad$ Also refer to Tables A7.1-A7.4 in Appendix 7.

- The mean responses did not differ substantially between committee members of the Local Government and Shires Association of New South Wales (5.50, 5.33, 5.88) although board members of the Municipal Association of Victoria differed (4.50, $4.67,6.67)$, notwithstanding the low response rate of four.

- $\quad$ The standard deviation for mayors, chief executives chairs of audit committees and committee members of the Local Government and Shires Association of New South Wales generally ranged one standard deviation from the mean, indicating that respondents had similar views.

Questions A4 and A5 attracted response rates of sixty-seven and seventy-seven respectively.

- Whilst the mean and standard deviation for responses did not vary substantially for the five groups, some respondents indicated the audit committee charter was reviewed at a three-year interval, when the term of appointment of independent members expired.

- $\quad$ Other respondents stated that councils would generally not oppose audit committees seeking expert advice, but this would depend on the importance of the issue at hand. 


\section{iii. Differences between Victorian metropolitan and rural regional councils}

\section{Mayors (Table 6.7)}

- Metropolitan mayors considered that their audit committees had good processes in place and no improvement was required.

- $\quad$ The lower means from rural and regional mayors indicated that some improvement to audit committee processes were required.

- The standard deviation indicated a similarity in responses to questions A1-A5 from rural and regional mayors.

\section{Chief executives (Table 6.7)}

The chief executives in metropolitan and rural and regional councils all responded to questions A1, A2 and A3. There was a lower response to questions A4 and A5.

- $\quad$ The mean between the two groups differed, with rural and regional councils having a lower mean, indicating that some improvement in audit committee processes were required.

- $\quad$ The standard deviation of metropolitan councils indicated a consistency of observations from chief executives in metropolitan councils.

- $\quad$ The standard deviation for chief executives in rural and regional councils varied +1.36 from the standard deviation of 1.13 indicating a greater range of individual responses.

\section{Chairs of audit committees (Table 6.7)}

The response to questions A1-A4 from the chairs of audit committees from metropolitan councils was twelve to each question from thirteen respondents, with a lower response of ten for question A5. The response rate from chairs of audit committees of rural and regional councils to questions A1-A5 was eleven, twelve, twelve, seven and ten respectively.

- The mean differed between metropolitan and rural and regional councils, with the latter having a lower mean, indicating that an improvement in audit committee processes are required for rural and regional councils. 
- $\quad$ The standard deviation of metropolitan councils indicated consistency of observations from chairs of audit committees in metropolitan councils.

- $\quad$ The standard deviation for chairs of audit committees in rural and regional councils indicated a greater range of individual responses.

\section{iv. Conclusions}

The mean response from mayors, chief executives, chairs of audit committees and committee members of the Local Government and Shires Association of New South Wales indicated that:

- audit committee members were appointed in accordance with a predetermined appointment process;

- $\quad$ there was clarity from councils about the expectations of the audit committee; and

- $\quad$ the audit committee members had an understanding of the inherent risks associated with local government and the specific risks of the council/shire.

The mayors, chief executives and chairs of audit committees in rural and regional councils considered that improvements in the process to form an audit committee were required.

The reviewing of the audit committee charter at the time of the expiry of the independent member's appointment to the audit committee was considered to be reasonable, given that an audit committee generally only meets four to five times per year.

It was concluded that the 'forming of an audit committee' (Questions A1-A5) was consistent with best practice guidelines.

\subsubsection{Results - Knowledge and expertise of the audit committee}

\section{i. Background}

In order for the audit committee to function effectively, its members should have a mix of skills to perform committee functions. This section asked questions in relation to: (1) skills and expertise of audit committee members; (2) domination of the audit committee by an individual; (3) financial expertise; (4) review of the skills base of members; and (5) the ability to co-opt members to provide specialist skills. 


\section{ii. Observations}

Table 6.8 Mean responses, Questions B1-B5

\begin{tabular}{|r|c|c|c|c|c|}
\hline \multicolumn{1}{|c|}{ Questions } & B1 & B2 & B3 & B4 & B5 \\
\hline Mayors & 5.94 & 5.67 & 6.25 & 5.71 & 5.88 \\
\hline Chief executives & 5.76 & 4.57 & 6.15 & 5.00 & 4.80 \\
\hline Chairs of audit committees & 5.75 & 4.40 & 6.17 & 5.53 & 6.11 \\
\hline Nocal Government and Shires Association of & & & & & \\
\hline Municipal Association of Victoria & 5.56 & 6.00 & 6.67 & 5.00 & 4.00 \\
\hline
\end{tabular}

\section{Notes:}

Note 1: The mean and standard deviations in this table are the responses from mayors, chief executives and chairs of audit committees from a Likert 1 to7 point scale.

Note 2: $\quad$ Also refer to Tables A7.1-A7.4 in Appendix 7.

From Table 6.8 and Tables A7.5-A7.8 in Appendix 7:

- $\quad$ Question B2 in relation to domination of the audit committee by an individual had a low response rate of 16 from the 89 usable responses and care should be exercised in making inferences. The mean of chief executives and chairs of audit committees was lower than mayors. This suggests that chief executives and chairs of audit committees consider that this was an issue, although mayors did not. (This issue was discussed in the qualitative research.)

- The standard deviation for mayors, chief executives and the chairs of audit committees generally approximated one standard deviation from the mean, indicating that respondents had similar views.

- $\quad$ The standard deviation for committee members of the Local Government and Shires Association of New South Wales indicated a diversity of opinion. The standard deviation from board members of the Municipal Association of Victoria was higher, but no meaningful inference should be drawn, as there were only four respondents.

- Some of the 'No' respondents to the question concerning the skills base of audit committee members (question B4) noted that this was re-evaluated at the expiration of appointment terms of independent audit committee members. Some of the 'No' respondents (whether the audit committee could co-opt members to provide specialist 
skills) considered that it depended on the circumstances. If warranted, it would be considered by council.

\section{iii. Differences between Victorian metropolitan and rural regional councils}

\section{Mayors}

- With the exception of question B2, the mean between metropolitan and rural and regional mayors was generally in the range of $+-0.09-+-0.51$, indicating mayors considered that their audit committees had sufficient knowledge and expertise and no improvements were required.

\section{Chief executives}

- $\quad$ The mean differed between metropolitan rural and regional councils, indicating the potential for some improvement in audit committee processes.

- $\quad$ The standard deviation indicated a consistency of observations from chief executives in metropolitan councils. The standard deviation for chief executives in rural and regional councils indicated a greater range of responses.

\section{Chairs of audit committees}

- $\quad$ The mean between metropolitan and rural and regional councils, with the latter having a lower mean, with the exception of question B5, indicated that an improvement in audit committee processes were required for rural and regional councils.

- The standard deviation indicated a range of observations from chairs of audit committees in metropolitan councils. The standard deviation for chairs of audit committees in rural and regional councils indicated a narrow range of individual responses.

\section{iv. Conclusions}

- $\quad$ There was a difference of views in relation to audit committee members possessing relevant skills. The chief executives and chairs of audit committees considered some improvements were required, whilst mayors did not. 
- $\quad$ Rural and regional councils and shires indicated that improvements were required, whilst metropolitan councils did not consider improvements were required.

- $\quad$ Chief executives and chairs of audit committees indicated that 'domination of the audit committee by an individual' was an area where improvement was required.

- $\quad$ Audit committees had adequate financial skills to evaluate financial and management reporting.

It was concluded that audit committee members generally had a mix of skills to manage audit committee responsibilities and activities.

\subsubsection{Results - Induction and training for the audit committee}

\section{i. Background}

The Department of Infrastructure (2000) recommended that Victorian local government audit committees should provide an induction to new members including risk profile of council (Department of Infrastructure 2000, pp. 10, 24). Similarly, in New South Wales the Department of Local Government 2008b stated that new members 'receive relevant information and briefing on their appointment to assist them to meet their committee responsibilities' (p. 43).

\section{ii. Observations}

- From responses in Appendix 6 and Tables A7.9-A7.12 in Appendix 7 the mean responses of five groups was 5.16, with a standard deviation of 1.11, although some questions, for example, C1, C2 and C4 had a lower mean of 4.81, 4.81 and 4.96 respectively.

- $\quad$ This indicated that some respondents considered improvements in audit committee processes were needed. This position was supported by chairs of audit committees, board members of the Municipal Association of Victoria and committee members of the Local Government and Shires Association of New South Wales, which all had a lower mean. 


\begin{tabular}{|r|c|c|c|c|c|}
\hline \multicolumn{1}{|r|}{ Questions } & C1 & C2 & C3 & C4 & C5 \\
\hline Mayors & 5.08 & 5.00 & 5.54 & 5.10 & 6.07 \\
\hline Chief executives & 5.03 & 4.78 & 5.13 & 5.23 & 5.76 \\
\hline Chairs of audit committees & 4.42 & 5.36 & 5.23 & 5.47 & 6.26 \\
\hline New South Wales & 4.75 & 5.17 & 5.50 & 5.00 & 5.75 \\
\hline Municipal Association of Victoria & 4.75 & 3.75 & 6.00 & 4.00 & 5.00 \\
\hline
\end{tabular}

Notes:

Note 1: The mean and standard deviations in this table are the responses from mayors, chief executives and chairs of audit committees from a Likert 1 to 7 point scale.

Note 2: $\quad$ Also refer to Tables A7.1-A7.4 in Appendix 7.

- Generally, the chairs of audit committees had a lower mean than chief executives and mayoral groups. This could be attributed to the latter two groups having a greater operational familiarity of council as 'insiders', as compared to the independent role of the chairs as 'outsiders looking inwards' (Blaikie 1993).

- The mean from committee members of the Local Government and Shires Association of New South Wales and board members of the Municipal Association of Victoria were generally lower than the mean from mayors, chief executives and chairs of audit committees, with the exception of question C3. This indicated that these two groups considered that some improvements in audit processes were required.

- $\quad$ The standard deviation for mayors, chief executives and chairs of audit committees generally indicated that respondents had similar views. The committee members of the Local Government and Shires Association of New South Wales and board members of the Municipal Association of Victoria indicated a wider range of views, although these views came from a small sample.

- $\quad$ The mean from questions C3 and C5 indicated a general consistency of views from the three groups of mayors, chief executives and chairs of audit committees, in relation to the 'knowledge of the key risks of the council' and 'challenging of the management by the independent members'. The mean from committee members of the Local Government and Shires Association of New South Wales were consistently lower, indicating that respondents considered some improvements to the processes of 
the audit committee could be made. This was similar to board members of the Municipal Association of Victoria.

- $\quad$ From Table 6.9 the differences in the mean for question C2 were quite marked, with chief executives (4.78) and board members of the Municipal Association of Victoria (3.75) being a lower mean than mayors (5.00), chairs of audit committees (5.36) and committee members of the Local Government and Shires Association of New South Wales (5.17). This would suggest that chief executives and board members were less satisfied with their level of knowledge of key risks of council operations. The standard deviation indicated a general consistency of views.

- The mean for question C4 (inspections and briefings) was consistent for the five groups. Some respondents noted that councils did provide briefings to the audit committee, but in the main, did not offer site visits. Other respondents noted that councillors at their induction were taken on a bus tour of council facilities, so they were familiar with key assets and any inherent risks arising from them. They also received briefings on social and infrastructure needs of constituents and resources available from council and other tiers of government.

\section{iii. Differences between Victorian metropolitan and rural regional councils}

\section{Mayors}

- The mean of rural and regional mayors was lower than metropolitan councils, indicating that some improvement in induction and training was required. The mean ranges of metropolitan mayors were influenced by the lower rate of responses to questions in the survey than rural and regional mayors.

- $\quad$ The standard deviation for rural and regional mayors ranged from 0.99 to 1.20 , which indicated a similarity in responses to questions C1-C5.

\section{Chief executives}

- The mean of chief executives was markedly lower than metropolitan councils, indicating some improvement in induction and training was required. The standard 
deviation for rural and regional chief executives ranged from 1.80 to 2.35 indicating a larger range of opinions to questions C1-C5.

\section{Chairs of audit committees}

- The mean of rural and regional chairs of audit committees was generally lower than metropolitan councils, indicating some improvement in induction and training was required. The standard deviation for rural and regional chairs of audit committees ranged from 1.79 to 1.95 , indicating a similarity in responses to questions $\mathrm{C} 1-\mathrm{C} 5$, but a wider range of observations than for metropolitan councils.

\section{iv. Conclusions}

Improvements were required in the induction process and continuing training was needed for audit committee members in rural and regional councils.

\subsubsection{Results - Managing the audit committee}

\section{i. Background}

This section in the questionnaire covered four topics: (1) management of audit committee meetings (questions D1-D7); (2) management of debate (question D8); (3) interaction with external and internal auditors (question D9); and (4) anti-corruption processes, fraud and misconduct (questions D10, D11 and D12). These questions allowed the secondary research question to be assessed.

The Department of Infrastructure (2000) identified model processes for audit committees to manage their activities and these included: (1) the scheduling of meetings with pre-arranged dates; (2) structured agendas and supporting papers; (3) quorums; (4) minutes; and (5) progress reports on actions previously agreed (Department of Infrastructure 2000, p. 10). The Department of Local Government (2008b) and the Department of Premier and Cabinet, New South Wales (2010b) had similar processes in place for audit committees in New South Wales local government. 


\section{ii. Observations}

\section{Management of audit committee meetings (Questions D1-D7)}

- $\quad$ From survey questions in Appendix 5 and Tables A7.13-A7.16 in Appendix 7 the respondents considered that some improvements were warranted.

- Questions D3 and D7 had lower response rates of fifty-eight and forty-one respectively. One explanation for the low response rate to question D3 was that a higher affirmative response was dependent on the audit committee having extraordinary matters to discuss, outside of the normal audit committee cycle of quarterly meetings and the additional meeting for the review of financial statements. An annual meeting with council and the audit committee are accepted practices in New South Wales and Victorian local government, (Department of Premier and Cabinet, New South Wales 2010b; Department of Infrastructure 2000) and the low response rate to the question was therefore unexpected.

\section{Management of debate (Question D8)}

Some of the risks for an audit committee can be: (1) the propensity for group think; (2) domination of meetings by one or more individuals; and (3) management controlling the audit committee process and restricting information to the audit committee, for example, City of Port Phillip (Ombudsman, Victoria 2009d).

- $\quad$ The rigour of debate and questioning of management representatives was considered in question D8. The responses from the mayors, chief executives and the chairs of audit committees would suggest that the level of debate was rigorous within Victorian local government. This view was also shared by committee members of the Local Government and Shires Association of New South Wales, but did not include the views of the four board members of the Municipal Association of Victoria.

\section{Interaction with external and internal auditors (Question D9)}

The Department of Infrastructure (2000) recommended that audit committees 'meet periodically with key management staff, internal and external auditors and compliance staff to understand and discuss the organisation's control environment' (p. 14). This was similar to 
the Department of Local Government (2008b) and the Department of Premier and Cabinet, New South Wales (2010b) for the management of internal and external auditors (Department of Local Government 2008b, p. 25; Department of Premier and Cabinet, New South Wales 2010b, pp. 29-30).

- Question D9 had a response rate of eighty-six, a mean of 5.97 and a standard deviation of 1.15 (Appendix 6). This indicated that these groups were satisfied with the relationships between the audit committee and internal and external auditors. This result was mirrored in New South Wales and was shared by board members of the Municipal Association of Victoria. The lower mean and the wider standard deviation than from the New South Wales and Victorian councils suggested some disparate views, albeit that the response rate was garnered from a small sample.

\section{Management of corruption, fraud and misconduct (Questions D10, D11, D12)}

The review of corruption, fraud and misconduct processes in local government were considered in questions D10, D11 and D12. Question D10 related to the development of administrative process for the management of corruption and misconduct policies, whilst the latter two questions related to corruption or misconduct events. In Chapter Three, the inherent risks of local government were discussed and a corruption and misconduct taxonomy was developed. Victorian councils are required to provide public access to documents under the Freedom of Information Act (1982) and develop processes for the management of whistleblower disclosures under the Whistleblowers Protection Act (2001).

- $\quad$ The mean from mayors, chief executives and chairs of audit committees of Victorian councils was higher than the mean of committee members of the Local Government and Shires Association of New South Wales. The responses from board members of the Municipal Association of Victoria were low in comparison to their Victorian and New South Wales counterparts. The wider standard deviation also reflected a more diverse range of views.

- Questions D11 and D12 had low responses of thirty-five and eighteen respectively. This indicated that respondents overwhelmingly did not consider that the audit committee had the responsibility to receive any direct communications from stakeholders pertaining to allegations. There was only one response from committee 
members of the Local Government and Shires Association of New South Wales and the Municipal Association of Victoria to both questions and no inferences should be made. Some, who responded 'No', noted that allegations can be received directly by councils, as well as other investigatory bodies as noted in Chapter Four.

- $\quad$ The respondents indicated that there was little support for councils directly overseeing allegations of fraud and misconduct.

\section{iii. Differences between Victorian metropolitan and rural regional councils}

\section{Management of audit committee meetings (Questions D1-D7)}

- $\quad$ The mean of rural and regional mayors was generally lower than metropolitan councils, indicating that some improvements in the management of audit committees were required. The mean range of metropolitan mayors was influenced by a lower rate of responses to questions in the survey, as compared to the response rate from rural and regional mayors. The standard deviation for metropolitan mayors and rural and regional mayors indicated a similarity in responses to questions D1-D7.

- Whilst the mean of rural and regional chief executives was generally lower than metropolitan councils, nevertheless they were both ranked close to ' 6 ' on the Likert scale, indicating that chief executives did not generally consider that improvements in the administration of audit committees were warranted. The standard deviation for rural and regional chief executives indicated a greater range in responses to questions D1-D7, as compared to metropolitan chief executives.

- $\quad$ The mean of rural and regional chairs of audit committees was generally lower than metropolitan councils, indicating that some improvements in the management of audit committees were required.

\section{Management of debate (Question D8) and interaction with external and internal auditors (Question D9)}

- $\quad$ From Figure 7.2 and Tables A7.15 and A7.16 in Appendix 7, the narrow mean range indicated that all groups, namely: (1) metropolitan mayors; (2) rural and regional 
mayors; (3) metropolitan chief executives; (4) rural and regional chief executives; (5) metropolitan chairs of audit committees; and (6) rural and regional chairs of audit committees were satisfied with the level of debate at the audit committee and did not consider that improvements were required.

- The standard deviation for rural and regional mayors, chief executives and chairs of audit committees ranged more widely than for their counterparts in metropolitan councils. This indicated a more diverse range of opinions.

\section{Management of corruption, fraud and misconduct policies (Questions D10, D11 and D12)}

- $\quad$ The narrow mean range for metropolitan councils indicated they were satisfied with the establishment of anti-corruption and misconduct policies and did not consider that improvements were required. The standard deviation for rural and regional mayors, chief executives and chairs of audit committees ranged more widely than for their counterparts in metropolitan councils. This demonstrated a more diverse range of opinions.

\section{Process in place to manage allegations including whistleblower allegations}

- $\quad$ The response rate from questions D11 and D12 in relation to the management of whistleblower allegations were: (1) metropolitan mayors (3 and 1); (2) rural and regional mayors (6 and 2); (3) metropolitan chief executives (7 and no responses); (4) rural and regional chief executives (7 and 3); (5) metropolitan chairs of audit committees (7 and 5); and (6) rural and regional chairs of audit committees (3 and 5) (Figure A7.2 and Tables A7.15 and A7.16 in Appendix 7).

- Whilst the mean ranged from 4.33-7.00, with a narrow standard deviation, the low response from the six groups diminished the ability to make conclusive inferences.

\section{iv. Conclusions}

Administration and management of audit committee (questions D1-D8) interactions with external and internal auditors (question D9) and the management of anti-corruption and misconduct policies (question D10) were relatively well managed. 
The respondents to question D11 and D12 overwhelming indicated that the audit committee did not have the responsibility to receive any communications from stakeholders pertaining to allegations.

\subsubsection{Results - Risk assessment and financial reporting}

\section{i. Background}

This section of the research reviewed: (1) risk management (questions E1-E2); (2) issues arising from investigation reports (question E3); (3) annual financial statement process (questions E4-E7); (4) oversight of internal audit (questions E8 and E9); and (5) annual briefings from external and internal auditors (question E10) (Tables A7.17-A7.20 in Appendix 7).

Model processes for audit committees to manage risks and financial reporting were identified (Department of Infrastructure 2000, p. 12; Department of Local Government 2008b, pp. 259; and the Department of Premier and Cabinet, New South Wales 2010b, pp. 29-34).

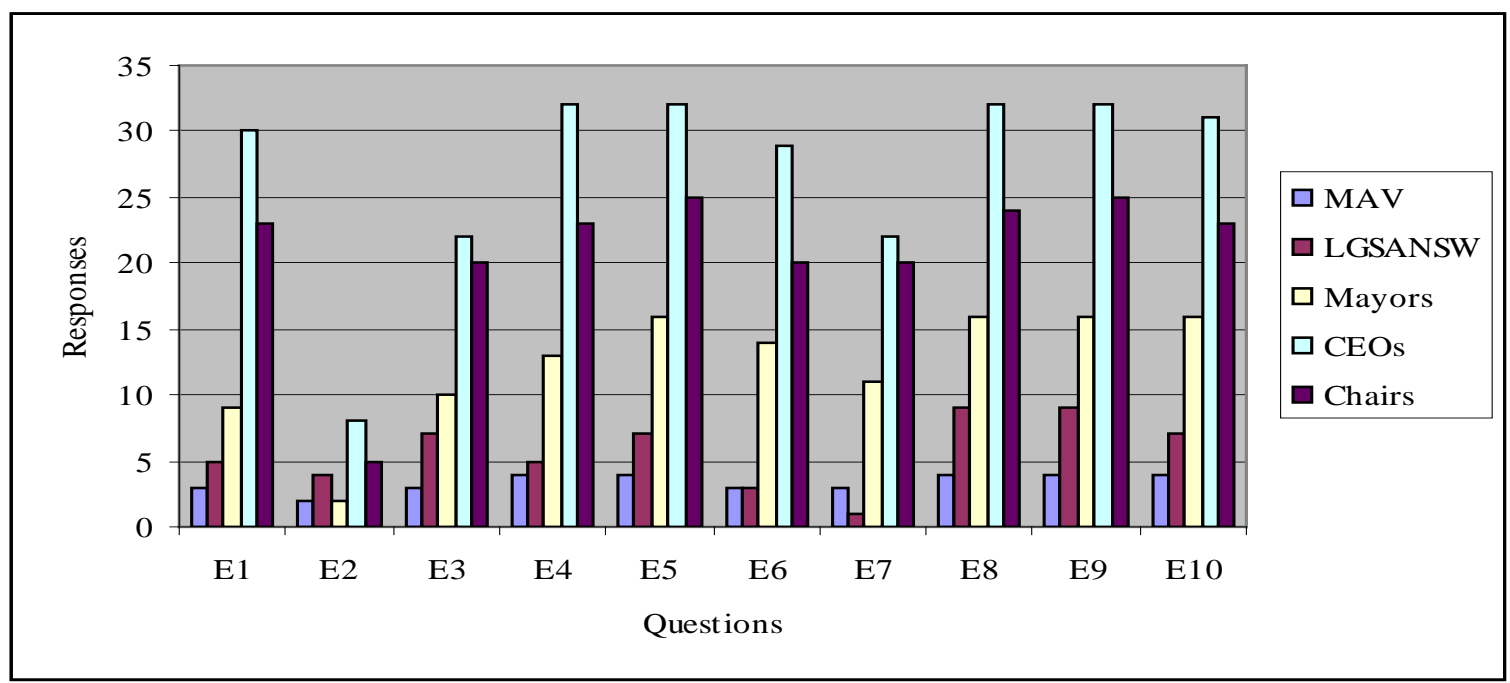

Figure 6.1 Responses from the five groups to questions E1-E10

Source: $\quad$ Results from respondents - Appendix 7

\section{ii. Observations}

\section{Risk management}

Questions E1 and E2 (Appendix 5) were asked because 'risk management is an essential part of effective governance' in local government, but strategy alone does not manage risk, which 
requires leadership and oversight from councillors and executive management to ensure successful outcomes (Department of Local Government 2008b, p. 26).

- $\quad$ There were seventy responses to question E1. The mean and standard deviations for Victorian councils were higher than the mean and standard deviations of committee members of the Local Government and Shires Association of New South Wales, albeit that the response rate was only five. A possible explanation of the differences between New South Wales and Victoria was that integrated risk management was a recent development in New South Wales councils (Department of Premier and Cabinet, New South Wales 2010b; Department of Local Government 2008b) compared to Victorian local government, where the oversight of risk management had been the responsibility of audit committees since 2000 (Department of Infrastructure 2000).

- The low response rate to question E2 was expected because the question was intentionally framed around the words, 'Are there risks which are not reviewed?' It was understood that councils in New South Wales and Victoria have processes in place for the audit committee to take a whole-of-council approach to risk, as compared to occupational health and safety risks, which have been relatively well managed in councils for some time, for example, Greater Dandenong, Holroyd City and Yarra City Councils (Greater Dandenong Council 2009, p. 25; Holroyd City Council 2009, p.17; Yarra City Council 2009, p. 25).

\section{Issues arising from investigation reports}

- $\quad$ Sixty-two respondents indicated that local government investigation reports from other council and shires were reviewed against existing management practices and processes in the council/shire. There were similar opinions between the five respondent groups to the issues from investigation reports as discussed in Chapter Four.

\section{Annual financial statement process}

The four questions about the management of financial accounts were E4, E5, E6 and E7 (Tables A7.17 and A7.18 in Appendix 7). 
- $\quad$ The Victorian councils (mayors, chief executives and chairs of audit committees) had similar opinions. The mean and standard deviations from board members of the Municipal Association of Victoria were lower than mayors, chief executives and chairs of audit committees and the difference in perspective to questions E4-E7 cannot be satisfactorily explained from the quantitative research.

- Some respondents to question E6 noted that the Auditor-General, Victoria was the external auditor of all Victorian councils and those councils had no input to the appointment process of the auditor's sub-contractors. In New South Wales, the councils and shires directly appoint their own external auditor (Ross 2010). The response rate from committee members from the Local Government and Shires Association to this question was only three, with a mean of 6.00 and a standard deviation of 0.82. A higher response rate from committee members of the Local Government and Shires Association would have been expected, given the external auditor appointment process by councils and shires. Given the embryonic nature of audit committee and internal audit processes in New South Wales local government, this could have partially contributed to the low response rate.

- Question E7 was framed around specific external auditing issues, which some mayoral and chief executive respondents may not have been familiar with, but it was considered that audit committee chairs, especially those independent members with professional accounting qualifications, would be conversant with external auditing terms and processes. Whilst the number of responses were: mayors (eleven); chief executives (twenty-two); and committee members of the Local Government and Shires Association of New South Wales (one); the low response of twenty from the audit committee chairs was unexpected and this was further considered in the qualitative research.

\section{Oversight and outcomes of internal audits}

The two questions in relation to oversight and outcomes were E8 and E9. The questions had a response rate of 85 and 86 with a mean of 5.81 and 5.66 respectively and standard deviations of 1.25 and 1.30 respectively. This indicated that mayors, chief executives and chairs of audit committees were satisfied with the processes for management of the internal audit. 


\section{Annual briefings from external and internal auditors}

- The annual briefing from external and internal auditors, albeit in an open session of the audit committee or 'in camera', was positively responded to with a response rate of eighty-one, a mean of 6.02 and a standard deviation of 1.07 (Tables A7.17 and A7.18 in Appendix 7).

- $\quad$ The mean and standard deviations from the Victorian councils: mayors $(6.38,0.70)$; chief executives $(6.23,1.01)$; and chairs of audit committees $(6.30,0.86)$ were consistent with the observations from committee members of the Local Government and Shires Association of New South Wales (6.43 and 0.49). This indicated that respondents were satisfied with the process for the annual briefing by external and internal auditors. The mean of 4.75 and the standard deviation of 2.28 from board members of the Municipal Association of Victoria was from four responses and some caution should be exercised in the interpreting the results.

\section{iii. Differences between Victorian metropolitan and rural regional councils}

The response rates of mayors, chief executives and chairs of audit committees from metropolitan and rural and regional councils are illustrated in Figure 6.2 and Tables A7.19 and $\mathbf{A 7 . 2 0}$ in Appendix 7.

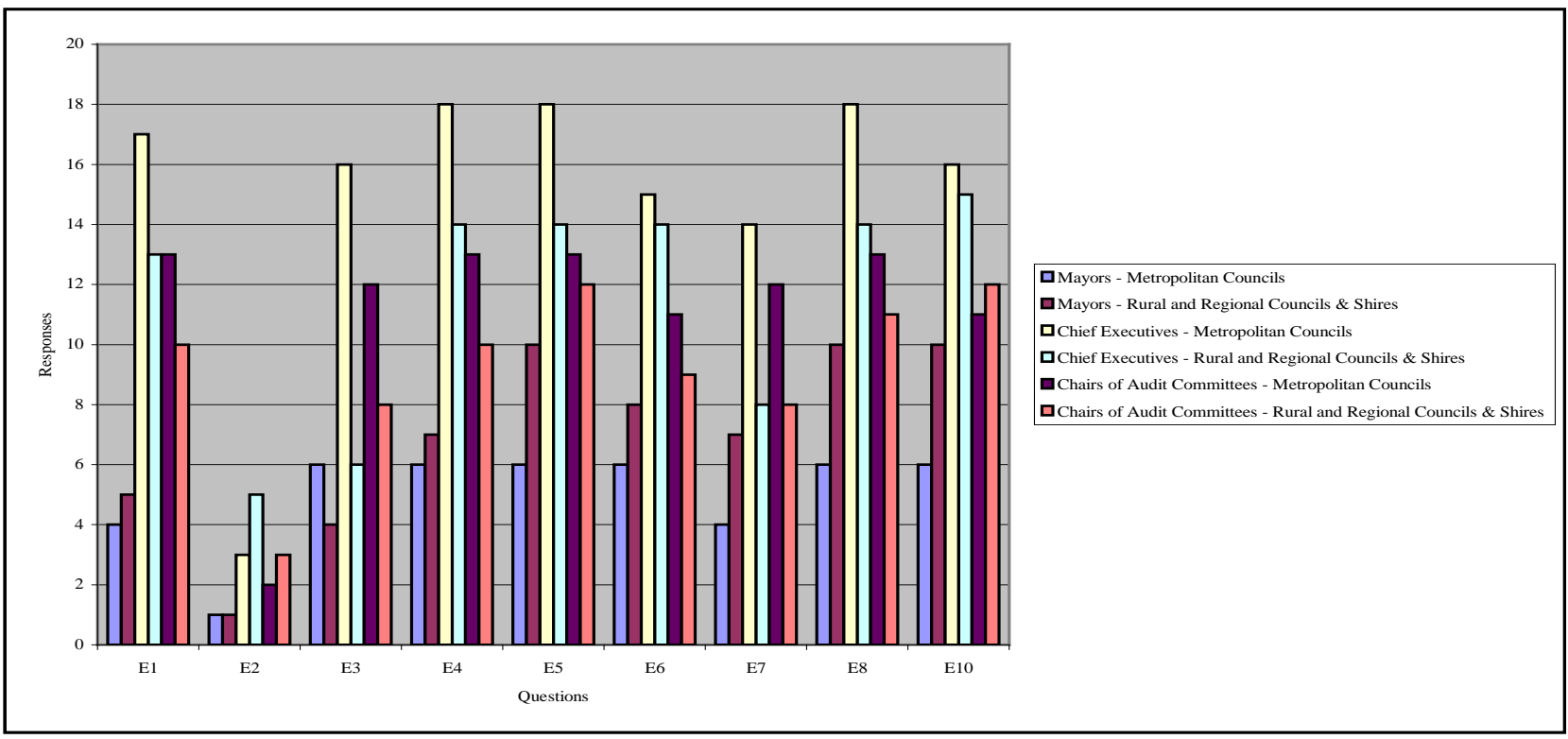

Figure 6.2 Response rates - Victorian metropolitan and rural regional councils Source: Results from respondents - Appendix A7.19 
- $\quad$ The mean of metropolitan mayors, chief executives and chairs of audit committees was generally higher than rural and regional councils and had lower standard deviations (Tables A7.19 and A7.20 in Appendix 7). This difference indicated that metropolitan mayors were more satisfied with the audit committee processes in place for: risk management (questions E1-E2); investigation reports (question E3); oversight of the financial statements process (questions E4-E7); oversight of internal audit (questions E8 and E9); and the annual briefing from external auditors (question E10).

- $\quad$ The difference for chief executive groups was equally marked: rural and regional chief executives had a lower mean to questions but nearly double the standard deviation of metropolitan chief executives. The same difference was noted for audit committee chairs in metropolitan councils, as compared with rural and regional councils.

- $\quad$ Question E2, was the exception for the two mayoral groups, as this question had only one response from a metropolitan mayor and one response from a rural and regional mayor, which accounted for the standard deviation of 0.00 . The differences in the mean and standard deviations of metropolitan and rural and regional councils were difficult to explain, given that all councils and shire audit committees: (1) operate in accordance with the requirements of the Local Government Act (1989); (2) were audited by the Auditor-General, Victoria; and (3) are expected to comply with the best practice audit committee guidelines (Department of Infrastructure 2000). occupational health and safety risks;

- $\quad$ audit committees reviewed the investigation reports from other councils to evaluate the findings with their own management processes;

- $\quad$ councils complied with standard accounting processes to manage the annual financial accounting statements;

- $\quad$ an internal audit process was in place for Victorian councils; and

- $\quad$ councils received an annual briefing from auditors.
} 


\subsection{Results from qualitative research}

The qualitative research was sourced from ten interviews with (1) two chief executives; (2) two directors of corporate services; (3) one auditor; (4) three chairs of audit committees; (5) one mayor; and one councillor (both of whom were members of audit committees from December 2010 to January 2011) from a sample of seventeen prospective interviewees who agreed to participate in qualitative research during the pilot study. (The participants have been de-identified in Appendix 8.)

The four board members from the Municipal Association of Victoria, who had contributed to the quantitative research, were invited to be interviewed (Table 6.1). One board member declined and no responses were received from the other board members, despite two followups by mail and email.

The participation rate was 48\% (10 of 21), with three interviewees sourced from rural and regional councils (one chief executive, one director of corporate services and one auditor), with seven interviewees from Melbourne metropolitan councils. Two chairs of audit committees from metropolitan councils had cross memberships with other metropolitan and rural councils (see note 5 in Table 6.1). One interviewee was the chair or independent member of three metropolitan and two rural councils respectively.

The interviewees were asked:

- $\quad$ two questions in relation to response rates from quantitative research (Table 6.7);

- $\quad$ one question in relation to ethics and codes of conduct for councillors and staff;

- $\quad$ one question in relation to influencing the audit committee; and

- $\quad$ four questions in relation to inputs and outcomes for audit committees (Appendix 8).

\subsection{Detailed observations from qualitative research}

\subsubsection{Clarification of issues}

The qualitative research sought to elicit reasons for the low response rate to some of the quantitative research questions and the significance of response rates for their audit committees (Table 6.10). The interviewees were asked:

- $\quad$ From your perspective, was the question a relevant issue for your council's audit committee? If yes, why? If no, why not? 
- What could be the contributing reasons for the low response rate to each of the questions and the accompanying low mean and standard deviations?

Table 6.10 Qualitative research - Clarification of issues

\begin{tabular}{|c|c|c|c|c|c|c|}
\hline & \multicolumn{2}{|c|}{$\begin{array}{l}\text { Mayor and } \\
\text { Councillor }\end{array}$} & \multicolumn{2}{|c|}{$\begin{array}{c}\text { Chief Executives and } \\
\text { Directors of Corporate } \\
\text { Services } \\
\end{array}$} & \multicolumn{2}{|c|}{$\begin{array}{c}\text { Chairs of Audit } \\
\text { Committees and } \\
\text { Auditor }\end{array}$} \\
\hline & Yes & No & Yes & No & Yes & No \\
\hline & \multicolumn{6}{|c|}{ Induction and Training } \\
\hline Question C2 & & & & & & \\
\hline $\begin{array}{l}\text { Are audit committee members assisted by } \\
\text { the council/shire to periodically update } \\
\text { their knowledge of local government } \\
\text { activities and risks? }\end{array}$ & 0 & 2 & 4 & 0 & 1 & 3 \\
\hline \multicolumn{7}{|l|}{ Question C4 } \\
\hline $\begin{array}{l}\text { Does the audit committee periodically visit } \\
\text { the council's/shire sites and receive } \\
\text { briefings from key officers? }\end{array}$ & 0 & 2 & 3 & 1 & 1 & 3 \\
\hline \multicolumn{7}{|l|}{ Question D3 } \\
\hline $\begin{array}{l}\text { Does the audit committee have any } \\
\text { extraordinary sessions to consider } \\
\text { important issues? }\end{array}$ & 0 & 2 & 1 & 3 & 1 & 3 \\
\hline & Yes & No & Yes & No & Yes & No \\
\hline \multicolumn{7}{|l|}{ Managing the Audit Committee } \\
\hline \multicolumn{7}{|l|}{ Question D7 } \\
\hline $\begin{array}{l}\text { Do audit committee members meet at least } \\
\text { annually outside of the audit committee } \\
\text { with council? }\end{array}$ & 0 & 2 & 1 & 3 & 2 & 2 \\
\hline \multicolumn{7}{|l|}{ Question D11 } \\
\hline $\begin{array}{l}\text { Does the audit committee directly receive } \\
\text { communications from stakeholders of the } \\
\text { council/shire, regarding any allegations of } \\
\text { misconduct or corruption or matters of } \\
\text { concern which they may have with the } \\
\text { council/shire? }\end{array}$ & & 2 & 1 & 3 & 0 & 4 \\
\hline \multicolumn{7}{|l|}{ Question D 12} \\
\hline $\begin{array}{l}\text { Does the audit committee review all } \\
\text { whistleblower allegations and oversee their } \\
\text { investigation? }\end{array}$ & & 2 & 1 & 3 & 0 & 4 \\
\hline \multicolumn{7}{|l|}{ Question E7 } \\
\hline $\begin{array}{l}\text { Does the audit committee review all } \\
\text { unrecorded audit adjustments (if any } \\
\text { reported) with management and external } \\
\text { auditors and understand why they were not } \\
\text { recorded and reported? }\end{array}$ & 1 & 1 & 3 & 1 & 1 & 3 \\
\hline
\end{tabular}

\subsubsection{Induction and training}

Question C2 had a response rate of 75\% (sixty-seven affirmative responses from the sample of eighty-nine) from the quantitative research, which meant that approximately $25 \%$ did not 
answer the question or did not consider it to be an issue. From Table 6.7, the chief executives and directors of corporate services considered that the updating of knowledge of local government activities and risks was relevant for their council's audit committee, but the chairs of audit committees and the councillor did not agree. Councillor A (2011) stated that:

there was an expectation that councillors on the audit committee should be conversant with the risks of the council and the local government sector and that he expected the independent members to be familiar with local government risks given their level of cross audit committee memberships.

This sentiment was also expressed by the chairs of two audit committees. They considered that one of the important sources of risk assessment knowledge came from the Municipal Association of Victoria's asset management program (STEP) and their cross memberships of audit committees (Audit Committee Chair A 2010; Audit Committee Chair C 2011).

Of the chairs who indicated that they needed less training, they were of the view that as qualified accountants, they were obliged to undertake continuous professional development as part of the membership obligations of CPA Australia and the Institute of Chartered Accountants in Australia and, as a consequence, less formal training and induction were required.

The implicit knowledge of risks, as compared to the explicit knowledge of risks was not supported by Audit Committee Chair B (2010), who considered that 'it was incumbent upon the council to ensure its members were informed of sector wide risks as identified by the Auditor-General, Victoria and the Municipal Association of Victoria' (Audit Committee Chair B 2010). The two chief executives and two directors of corporate services stated that the question was relevant for their audit committee and sector wide and specific council risks 'should be part of the induction for the members of the audit committee' (Chief Executive A 2011). Mayor A (2011) stated that this was not an issue for her council, as 'there was a culture of providing supplementary information to the councillors, but not necessarily the independent members' (Mayor A 2011). She further stated that 'if members of the committee wanted to do a specific training course, it would be funded accordingly’ (Mayor A 2011).

Question C4 had a response rate of 47\% (forty-two of eighty-nine respondents) from the quantitative research, which noted that chief executives and directors of corporate services considered site visits and briefings form officers to be an important issue for their councils, whilst the chairs of audit committees did not consider this to be important (Table 6.7). The 
mayor, chief executives and directors of corporate services stated that briefings to audit committees from key council officers were undertaken, but new infrastructure development site visits by independent audit committee members were not the norm (Chief Executive A 2011). Mayor A (2011) stated that 'councillors would be familiar with the infrastructure of the council, as they were provided with a tour as part of their induction' (Mayor A 2011).

Audit Committee Chair A (2010) stated that 'briefings and site visits were important issues', but 'it was a balancing act and dependent upon the council and the specifics of the site to be inspected'. He also considered that available time for independent members to visit sites could also be an impediment, but it was not insurmountable. Chief Executive B (2011) stated that 'whilst site visits had not been undertaken in the past, but given the upcoming major infrastructure development', within the municipality 'future site visits could be beneficial for the audit committee' (Chief Executive B 2011).

In summary, the chief executives and directors of corporate services stated that officers' briefings were commonplace for their audit committees, but site visits of infrastructure development were generally not undertaken.

\subsubsection{Managing the audit committee}

\section{Meetings of members outside of the audit committee}

In the quantitative research, questions D3 and D7 had response rates of $65 \%$ and $46 \%$ respectively. Most of the interviewees in the qualitative research (Table 6.7) considered that their council had no need to have extraordinary sessions of the audit committee, 'but would do so if needed' (Councillor A 2011). Corporate Services Director B (2011) stated that:

the audit committee meets six times a year, as opposed to four meetings a year in other councils, so that any issue of such magnitude which may warrant an extraordinary audit committee meeting in another council, would be dealt with in their six meeting cycle.

Mayor A (2011) indicated that the audit committee and council had held extraordinary meetings in 2009 and 2010 in order to be updated by the chief executive in relation to a criminal investigation and whistleblower allegation.

Most interviewees (Table 6.7) indicated that the chair of the audit committee meets annually with council, as compared to the full audit committee. Audit Committee Chair A (2010) 
stated that the practice at his council, was 'to have the minutes of the audit committee forwarded to the council after each meeting and to have the mayor as a member of the committee, so that, he/she was conversant with the issues being discussed at the audit committee’ (Audit Committee Chair A 2010). Councillor A (2011) suggested that an annual 'meeting of the independent members with council in the absence of management was important' (Councillor A 2011). Corporate Services Director B (2011) stated that his 'audit committee, provided a monthly report of issues from the audit committee' with 'the chair of the audit committee meeting annually with the council' (Corporate Services Director B 2011). Mayor A (2011) indicated that 'the chair of the audit committee did not meet annually with council, but the minutes of the audit committee were provided to councillors' (Mayor A 2011). She further stated that the 'councillors on the committee provided a verbal report at the next council meeting after the audit committee' (Mayor A 2011).

\subsubsection{Oversight of management of corruption and misconduct allegations}

The interviewees did not consider that audit committee had a role to play in the oversight of misconduct or whistleblower allegations or corrupt incidents (Table 6.7).

Councillor A (2011) considered that these matters were generally handled directly by the chief executive or independently by the Auditor-General, Victoria, the Ombudsman, Victoria, the Inspector of Municipal Administration or Victoria Police. Chief Executive A (2011) indicated that if there was an important issue, he would prepare a briefing paper for the audit committee, but would informally advise the chair before the paper was presented.

Audit Committee Chair A (2010) noted that the operational plan for the management of these types of incidents are detailed in the council's fraud and misconduct policy, although the audit committee 'would be part of the communication chain' albeit, 'not part of the management or investigative process' (Audit Committee Chair A 2010). He further stated that 'if the allegations related to the chief executive or a councillor, the audit committee chair may be a conduit to provide some oversight of the process' although 'any councillor's misconduct would normally be subject to the processes of a councillor conduct panel ${ }^{21}$ (Audit Committee Chair A 2010).

\footnotetext{
${ }^{21}$ Refer to sections 81A-81S of the Local Government Act (1989).
} 
Corporate Services Director A (2010) concurred with Chief Executive A (2011) and Councillor A (2011) in stating 'having a role for the audit committee in any investigative process had the potential to confuse the role of the audit committee as compared to providing oversight of the council's risk management processes' (Corporate Services Director A 2010). Corporate Services Director B (2011) discussed the inherent corruption and misconduct risks of councils, which can be hidden beneath the surface. He believed that a robust culture within council was one of the best ways of expressing a zero tolerance to any forms of misconduct. He also stated that at every audit committee three questions were always asked of the chief executive and auditors:

- $\quad$ Are there any matters that need to be brought to the attention of the audit committee?

- $\quad$ Has the work of the internal auditor been obstructed in any way? and

- $\quad$ Are there any conflicts of interest that anyone at the audit committee meeting is aware of? (Corporate Services Director B 2011).

He considered that the 'regular asking of these questions helped bring matters to the attention of the audit committee and provided a safe environment for any issues to be raised or addressed', although it was not the role of the audit committee to either investigate or manage the allegations (Corporate Services Director B 2011). Chief Executive B (2011) concurred with these observations, but noted there were some instances or events that would not be reported to the investigative agencies. In his council, when mission critical staff resigned from council or staff with substantial major financial or statutory delegations, he informed the audit committee at the next meeting. He stated that 'it was always a question of prudence, of where the line was drawn, between advising the audit committee and overburdening the audit committee' (Chief Executive B 2011). Mayor A (2011) indicated that her council had recently had a fraud investigation and whistleblower allegation of financial impropriety. In both instances, the council and the audit committee were informed of the investigations, which were managed by the Victoria Police and chief executive respectively.

\subsubsection{Risk assessment and financial reporting}

\section{i. Review of investigation reports}

Most interviewees (Table 6.7) stated that it was common practice for all councils to review the outcomes of investigations by the: (1) Ombudsman, Victoria; (2) Inspector of Municipal Administration; and (3) performance audit reports from the Auditor-General, Victoria and to compare their council's practices and internal controls with the recommendations. 
Some metropolitan audit committees reviewed the reports from the Independent Commission Against Corruption, albeit they had no legal effect for councils in Victoria, 'although the corruption and misconduct issues at the Wollongong Council ${ }^{22}$ were of such magnitude, that they had to be reviewed' (Audit Committee Chair A 2010). Corporate Services Director A (2010) stated that the 'audit committee did not review other council's investigative reports' but considered that it would be best practice, but her audit committee would consider it to be 'a nice to have, but not an important to have' (Corporate Services Director A 2010). Corporate Services Director A (2010) stated that 'it was important for the audit committee', but noted that there were 'some difficulties in attracting high calibre independent members, given the rural location of the council and that the positions were historically honorary' (Corporate Services Director A 2010).

\section{ii. Audit adjustments}

Question (E7) in relation to the review of unrecorded audit adjustments had a low response rate from the chairs of audit committees.

The councillor, chief executives and directors of corporate services considered this to be an issue for their councils, whereas the chairs of audit committees did not. Councillor A (2011) noted that all audit committees reviewed draft financial statements, but felt it could be an issue for his council, given the lack of trust in council which existed, which also manifested in the audit committee. He discussed the valuation of nursing home licences by management, which should have been treated as impaired, but were valued by management at \$A5 million, notwithstanding that the Commonwealth Government had changed the policy in relation to the trading of bed licences, making them valueless. The chief executives and directors of corporate services considered that any unrecorded audit adjustments could be a potential problem and if they occurred would reflect poorly on the council, especially if it was considered that the unrecorded adjustments were 'sharp' accounting practices. Chief Executive A (2011) stated that his council's audit committee had oversight of the annual accounts process and performance statements and that he 'would like to think that any material adjustments to the financial accounts would be reported to the audit committee, given the culture of his council' (Chief Executive A 2011). Audit Committee Chair C (2011) stated that:

${ }^{22}$ Refer to Independent Commission Against Corruption 2008b, 2008c, 2008d and 2007a. 
if there was a disagreement between the management and the external auditors (acting as agents of the Auditor-General, Victoria) on an issue of substance, but not necessarily material or a systems issue, then the independent audit committee members could provide advice to the chief executive and councillors.

The audit committee chairs were asked to comment on the possible reasons for the low response to this question by their metropolitan and rural contemporaries. The interviewees in the main were perplexed, given that all had extensive financial experience and professional accounting qualifications. In their opinion, questioning annual financial accounts and performance statements was within the purview of the audit committee and independent members had the technical competencies to contribute to the review. One chair surmised that the question was alluding to some potential manipulation of the accounts, whereas he had a high level of trust in his council that this would not occur, notwithstanding the potential for it to occur.

\subsubsection{Contributing reasons for response rates}

Interviewees were asked to give possible reasons for low response rates to questions from the quantitative research and their accompanying mean and standard deviations (Table 6.7). The quantitative research identified some differences between responses from metropolitan and rural councils.

Chief Executive A (2011), who was from a rural shire council, considered that some respondents may have 'lacked expertise or perhaps did not understand the subject matter and did not have a comprehensive level of understanding of governance matters and the connection with audit committees' (Chief Executive A 2011). This was complemented by the Corporate Services Director B (2011), who questioned the educational background and governance experience of some mayors and councillors as a possible impediment to response rates and the mean and range of standard deviations. This view was also supported by Audit Committee Chair B (2010), who considered that 'the level of expertise of audit committee members was an issue for rural councils and that some audit committees in rural councils were under resourced' (Audit Committee Chair B 2010). Corporate Services Director B (2011) stated that 'there could be a fear factor in completing surveys' (albeit they were contributing to academic research) and 'not understanding that the responses would remain anonymous' (Corporate Services Director B 2011). He also raised behavioural issues which can occur in a council, that is, "the mere mention of "audit committee" sometimes means that people are being judged’ (Corporate Services Director B 2011). Chief Executive B (2011) 
complemented the Corporate Services Director B (2011) by stating that the 'local government sector on the whole tended to be conservative in nature and to some extent prescriptive, given the services provided by council and not open minded to the possibilities of ideas from outside of local government' (Chief Executive B 2011). Auditor A (2011) suggested that a possible explanation to the low response rate 'was because the questions asked something which was not being done in the council or alternatively it was being done, so the response was no’ (Auditor A 2011).

Interviewees considered that when they reviewed the mean and standard deviations in Table 6.7, the former were generally quite positive, that is, in the range of 5.00-5.63 out of an upper score of 7.00 on the Likert scale. This indicated that respondents considered that audit committees had adequate processes in place. They also noted the range of standard deviations and particularly the differences between metropolitan and rural councils.

\subsubsection{Impact of ethical statements on audit committee outcomes}

Interviewees were asked 'Does the council's ethical statements or the council's codes of conduct contribute to an environment which mitigates the council's risks and as such, contributes towards the effectiveness of the council's audit committee. If yes, why? If no, why not?'

This question complemented questions D10, D11 and D12 from the quantitative research and provided evidence to support or repudiate the sub-research questions and Schwartz (2001) in relationship to codes of conduct and corporate behaviours. Schwartz (2001) considered that 'codes of conduct can be an important first step towards encouraging legal and ethical behaviour' (p. 260).

This question was supported by the mayor, chief executives, corporate services directors and chairs of audit committees. Mayor A (2011) stated that the 'council's code of conduct helped set the tone-at-the-top, which assisted councillors to guide behaviours, when the council had any acrimonious debates' (Mayor A 2011). Corporate Services Director A (2010) considered 'that ethical statements and public service values gave a framework to work towards and measure against' (Corporate Services Director A 2010). Corporate Services Director B (2011) stated that 'his council used a positive organisational culture, so that councillors and staff could make the appropriate ethical decisions' (Corporate Services Director B 2011). He used the example of an individual's ethical decision-making processes around the acceptance 
or non-acceptance of gifts, where the councillors and staff can make their own decisions, but needed to be cognisant that the acceptance of gifts could be construed as influencing their delegated powers. The chief executive had advised councillors and staff that he does not accept any gifts, no matter what their monetary value. Audit Committee Chair A (2010) stated that his council:

needed to have a workable ethical position and statement, which staff could understand, which would link the ethical pronouncements with the Crimes Act (1958) so that expected behaviours are clear and staff and councillors will know what is expected of them (Audit Committee Chair A 2010).

He further stated that it was the role of the audit committee 'to look for these signs and to ask the hard and sceptical questions and evaluate the responses' (Audit Committee Chair A 2010). This position was complemented by Audit Committee Chair C (2011) who suggested that the audit committee needed to review the: (1) relevance of induction processes for staff and councillors; (2) content of training for fraud, ethics and their frequency; (3) breaches of internal control or fraudulent misconduct; and (4) content of the annual representation letter by the chief executive as part of the annual accounts process. Audit Committee Chair C (2011) considered that there were good processes within his council for staff to follow, but he was unclear as to whether councillors were adhering to the same standards.

This was complemented by Councillor A (2010) who considered that the code of conduct for councillors and staff assisted the audit committee to view risks from an ethical perspective, notwithstanding that the council's code of conduct was 'broken regularly' by some councillors and, by implication, some staff. He used the example of factional infighting that had occurred within his council, including alleged councillor misconduct, allegations of bullying and assault and 'blogging' by one councillor, which he considered lacked balance and perspective.

In summary, the interviewees complemented the work of Schwartz (2001) as there were examples of code compliance, based on personal values and council loyalty. Councillor A (2010) provided specific examples of non-compliance, based upon Schwartz's (2001) principles of self-interest, the council environment and potential dissatisfaction (pp. 257-9). 


\subsubsection{Influences on the audit committee}

Interviewees were asked, 'Do you consider that audit committee members are influenced by the views of mayors, chief executives and chairs of audit committees? If yes, why? If no, why not?' This question was asked because there were only sixteen responses in the quantitative research. Three considered this was not an issue for their audit committee, five respondents indicated it was a potential risk and two indicated it was a specific issue for their audit committee. They discussed the potential for: (1) personality issues; (2) manipulation or management control of agendas and information; (3) negative dynamics associated with meetings; and (4) deference and referral by some councillors to independent members, especially on financial matters.

Audit Committee Chair A (2010) stated that domination of the audit committee can occur, albeit by an independent member, a councillor or the chief executive. He considered that audit committees needed to be confident in their role to support the council, the mayor and chief executive. Corporate Services Director B (2011) considered it to be an inherent risk. The way it was managed at the audit committee was to have full transparency, detailed minutes of discussions and a comprehensive management response to avoid misunderstandings at the next meeting.

Corporate Services Director A (2010) noted that there needed to be a focus on the transparency of issues before the audit committee, as compared to being side-tracked by personality issues. Chief Executive B (2011) stated that his audit committee had experienced an overbearing audit committee chair. He considered that 'the way to resolve it was for all members of the audit committee and management to understand their functions and the different roles each had to play' (Chief Executive B 2011). Chief Executive A (2011) considered audit committee dynamics was an 'issue that can be below the surface, but the way to stop it occurring, was to ensure that the audit committee members are confident in their roles and understood they are there to support the council' (Chief Executive A 2011). He considered that egoistic behaviours can occur, generally from one or two individuals, but that these behaviours 'can be used as a cue by other members of the audit committee, that it was acceptable behaviour' (Chief Executive A 2011).

Audit Committee Chair C (2011) noted that chief executives can dominate the audit committee, either positively or negatively. It was positive when the chief executive actively 
engaged with independent members to promote and contribute to effective governance and independent members, with their knowledge of local government risks, actively engaged in the process. It was negative when independent members felt the audit committee was just going through the motions (he called this 'tick-a-box') and the management team gave the impression they 'were bored and did not want to be there' (Audit Committee Chair C 2011).

This view differed from Councillor A (2011), who believed that management had manipulated agendas and withheld information from the audit committee, for example, full copies of internal audit reports. He considered that it could be difficult to get a full perspective on some issues because selective or incomplete information was provided. He indicated that this issue was not unique to the audit committee, but at council meetings as well. Auditor A (2011) noted that his council had experienced difficulties with the dominating personality of a particular audit committee member. He considered that he was aggressive, which degenerated into the audit committee meetings being a tussle between members and management. He noted that this member had the ability to plant the seeds of doubt, which was then used as a cue by other members to judge issues, when in reality they were not in a position to judge. He considered that this behaviour should have been addressed by the chief executive and as a consequence the behaviour had continued unchecked.

The interviewees were asked why this question had a low response in the quantitative research. In summary, their explanations ranged from: (1) embarrassment; (2) a denial that their council had a problem; and (3) the hope that the issue would go away. One interviewee commented that the personality related issues of his audit committee made him question the value of the audit committee for council and had made him lose respect for the individuals concerned and for council when the issue was not resolved. One chief executive further stated that his problem only went away when the independent member's term of appointment expired.

\subsubsection{Inputs and outcomes for audit committees}

Finally, interviewees were asked the following four questions: (1) What do you consider to be the contributing factors for a successful audit committee in local government? (2) What are the improvement opportunities for your council's audit committee? (3) What are the practices at your audit committee, which you consider are being managed well? (4) Is there anything else about your council's audit committee practices or processes, which you think are important or should be changed? 
These questions were meant to complement quantitative research in relation to: (1) the formation of the audit committee; (2) knowledge and expertise of the committee; (3) induction and training; (4) committee administration; and (5) risk management and financial reporting.

\section{i. What do you consider to be the contributing factors for a successful audit committee in local government?}

The interviewees generally held similar views in relation to: (1) inputs of an audit committee (e.g. charter, skills, activities, communications and induction and training); and (2) the behavioural nuances of the rigour of: debate, trust, effective communications and the relationships with councillors and management. The issues of: (1) the mix of skills for members; (2) the transparency of debate; and (3) a strong culture of trust and integrity were frequently raised.

Corporate Services Director B (2011) commented upon a workable audit committee charter, so that all parties were clear of their obligations and responsibilities. This was complemented by Audit Committee Chair C (2011), who considered 'the charter was an important foundation and in having this right, the structure and people management would follow' (Audit Committee Chair C 2011). He stated that one of the 'keys to success was openness and communication' (Audit Committee Chair C 2011). Chief Executive A (2011) suggested a positive commitment from staff to work with the committee and the need for a comprehensive risk assessment, so the committee could competently drive audit committee plans. Mayor A (2011) considered that 'competent and well-qualified independents were the key to the audit committee' (Mayor A 2011). She stated that independent members 'should be conversant with the localised issues, the financial accounting directives from the AuditorGeneral, Victoria and should be qualified accountants, as they have an obligation to undertake continuous professional development' (Mayor A 2011). Corporate Services Director A (2010) suggested an unambiguous audit charter, comprehensive induction for the members, positive communications processes and balancing the skill mix of members. Audit Committee Chair C (2011) raised the issue of resources and suggested that a poorly resourced internal audit function can impede the work of the committee. One Councillor (Councillor A 2010) referred to the possibility of the audit committee having its own budget so that it could obtain independent advice. Auditor A (2011) further discussed the issue of trust and tact of members, which was an extension of the behavioural issues noted in Chapters Two and

\section{Three.}




\section{ii. What are the practices at your audit committee, which you consider are being managed well?}

Interviewees generally held similar views in relation to management of the audit committee (structured agendas, timely discussion of issues, no late reports, positive culture and leadership) and the focus on outcomes (risk management, strong links between risk and the internal audit plan). Only one interviewee considered 'there were issues' at the audit committee (Councillor A 2011). Chief Executive B (2011) considered that one of the strengths of the audit committee was its 'structure, quality and expertise of independent members', as well as 'the management processes to ensure timely distribution of the agenda and accompanying papers' (Chief Executive B 2011). He stated that:

it was important to keep the faith with the audit committee and ensure that there were no late reports to the audit committee, either deliberately or inadvertently, to demonstrate that the management were supportive and committed to the audit committee process and its relationship to governance.

Corporate Services Director B (2011) reiterated the issue of council culture and how this contributed to the way in which councillors, management and independent members engaged with one another with a 'sense of mutual respect' (Corporate Services Director B (2011). Audit Committee Chair A (2010) considered that one of the strengths of his audit committee was leadership, with council members generally following the principles of effective governance and management, actively supporting the committee. Mayor A (2011) discussed the council's risk register, its periodic updating and actions plans, which helped focus the audit committee. She spoke enthusiastically about the relationship with internal auditors and how they assisted the audit committee to discharge its obligations. Corporate Services Director A (2010) also discussed the link between risk registers and the audit plan. She stated that 'the buy-in of committee members was important to assist in the outcomes of issues' (Corporate Services Director A 2010). Audit Committee Chair C (2011) also discussed risk management as an important facet of the success of the audit committee. Audit Committee Chair B (2010) discussed the tracking of internal audit recommendations and subsequent actions or inactions, as an important tool at his audit committee. Auditor A (2011) considered that the audit committee was well focused on strategic and operational risks of council. This meant that resources were concentrated on the 'real issues as opposed to the peripheral, which meant there was direction and substance for the council's internal control structures and compliance matters' (Auditor A 2011). 
Chief Executive A (2011) discussed risk management briefings which followed audit committee meetings. He noted that his independent members were retirees and they were keen to contribute their professional expertise in the areas of construction engineering, financial management and project management. He had organised a quarterly forum, where audit committee members acted as 'mentors', to provide constructive advice to the management team on issues where the independent members held professional expertise. Chief Executive A (2011) said the forums worked well, once 'the staff got over the hurdle, that it was constructive advice, it was not obligatory and it was free' (Chief Executive A 2011). He further stated that 'if council had to pay for the advice, it would cost thousands of dollars', but acknowledged that these workshops would not necessarily translate well to metropolitan councils because of time commitments of independent members or interest by council management, due in part to their access to resources (Chief Executive A 2011).

\section{iii. What are the improvement opportunities for your council's audit committee?}

Risk management, a comprehensive internal audit program and rigorous questioning by audit committee members were considered by interviewees to be important opportunities for their audit committees to improve.

Councillor A (2011) suggested that a comprehensive risk assessment, linked to a strong internal audit program, was needed at his council. He stated that he wanted 'to have more sceptical and independent thinking from the audit committee members and the asking of difficult questions to management' (Councillor A 2011). He indicated that some audit committee members were all too ready to accept management explanations, without querying the substance of management responses. He stated that the audit committee should have a budget of approximately $\$ A 30,000$ to engage consultants as required, as compared to management engaging consultants at the behest of the audit committee. Mayor A (2011) suggested a register of recommendations and actions from internal audit reports. This was complemented by Corporate Services Director B (2011), who stated that 'he was going to streamline the audit committee agenda using a traffic light system (colour codes of red, orange and green) in order that the audit committee can focus on the important matters (Corporate Services Director B 2011). Corporate Services Director A (2010) and Corporate Services Director B (2011) suggested that the audit committee charter may need to be revised, following the release of audit committee guidelines from the Department of Planning and Community Development in 2011. Both directors wanted to ensure that audit committee 
charters clearly articulated the responsibilities and accountabilities of members and management.

Mayor A (2011) considered that risk management was an issue and stated that from 2011, 'the risk manager will attend audit committee meetings to discuss the status of organisational risks and fraud management'. Risk management to drive the audit committee plan was also raised as 'an improvement opportunity’ by Audit Committee Chair C (2011), Chief Executive A (2011) and Corporate Services Director A (2010).

Audit Committee Chair C (2011) stated that he wanted to 'increase the frequency of discussions at the audit committee in relation to risks' and wanted 'an agreed meeting schedule for risks to be included on the audit committee agenda' (Audit Committee Chair C 2011). He wanted all members to be cognisant of the council's risks and the management processes to mitigate them. Corporate Services Director A (2010) stated that she wanted the audit committee 'to structure the internal audit program directly from the council's risk assessment' (Corporate Services Director A 2010). She stated that 'risk management was considered to be the responsibility of the corporate services directorate, as opposed to being a whole of organisation responsibility' (Corporate Services Director A 2010). She 'would like to have all members of the executive management team at the audit committee to demonstrate that organisational risks are owned by all members of the executive and not just the risk manager’ (Corporate Services Director A 2010).

Increased training for councillors of the audit committee was suggested by Chief Executive B (2011). He suggested that the course for company directors, available through the Australian Institute of Company Directors, could enhance their knowledge of governance practices and processes and had direct benefits for council and the audit committee. He acknowledged that to date, 'no councillor had requested to undertake the course or its equivalent and that councillors' commitments, as well as their full-time employment obligations could be limiting factors’ (Chief Executive B 2011).

\section{iv. Is there anything else about your council's audit committee practices or processes, which you think are important or should be changed?}

This final question sought to elicit information that had not been captured in other questions. The interviewees discussed: (1) behaviours of committee members; (2) risk management; (3) audit committee training; and (4) revision of the audit charter. 
Auditor A (2011) suggested that the chair should be an annual appointment, similar to the term of councillor appointments to the audit committee, which would 'inhibit the chair using the audit committee for his own personal agenda' (Auditor A 2011). He stated that the audit committee never meets separately with the internal auditor and therefore does not know if management are filtering information. He considered that 'some committee members were passive and it was obvious that they were reading the audit committee papers for the first time at the meeting' (Auditor A 2011). This passivity was also discussed by Audit Committee Chair C (2011) and Chief Executive B (2011). Chief Executive B (2011) stated that 'from a sector wide perspective, local government can be insular and as such suffers from a degree of tardiness and apathy' (Chief Executive B 2011). He would like to 'see some openmindedness, towards the relevance of governance models and practices from the corporate sector' (Chief Executive B 2011). He considered that 'blindly following best practice audit committee guidelines, whilst easy, was akin to following tradition without questioning', whereas he believed that 'one should reflect on tradition to inform practice' (Chief Executive B 2011).

Auditor A (2011) posed the rhetorical question, 'What value does the audit committee add to the council given the behaviours exhibited at the council?' (Auditor A 2011). Nevertheless, he considered that an effective audit committee does have a role to play in the oversight of risk management and the internal auditor and can add value to council as a 'sounding board', it was just that the committee were not performing these functions. Audit Committee Chair C (2011) continued the themes from Auditor A (2011) and stated that in his experience as a member of five audit committees, 'councillors and mayors should not be the chair of the audit committee, as some councillors and mayors can be engaged in tokenism and did not understand or take the time to understand, the role that an audit committee should play' (Audit Committee Chair C 2011). Mayor A (2011) stated that 'sometimes there can be a power play at the council, to see who is appointed to the committee' (Mayor A 2011). She explained that 'the audit committee appointment was seen as prestigious and powerful, given its access to information' (Mayor A 2011). Audit Committee Chair C (2011) considered the major risk for an audit committee was councillor members who displayed (through their behaviour) that they are not interested in governance and the audit and, consequently, the audit committee degenerates into tokenism.

Audit Committee Chair C (2011) stated the audit committee 'should provide a strong support base for the internal audit function, especially if it was internally resourced' and 'should be 
involved in the appointment process of the internal auditor and the allocation of internal audit resources on the basis of risks' (Audit Committee Chair C 2011). ${ }^{23}$ Corporate Services Director B (2011) stated that 'the biggest challenge for an audit committee was to deliver information at the right level, given the varying qualifications and professional experiences of councillors, managers and independent members' (Corporate Services Director B 2011). He considered that 'better induction training for councillors appointed to the committee was essential, to ensure that the council members were conversant with risk management and corporate governance processes'. He further stated that key to an effective audit committee was the 'relationships between councillor members, which would flow into the audit committee' (Corporate Services Director B 2011). He used the example of councillors from different political factions with opposing positions on issues, which can negatively impact on the audit committee, particularly if issues are decided on political grounds, as compared to the issue's merits.

Mayor A (2011) suggested that the audit committee's charter needed to be revised to incorporate fraud and corruption management, due to a recent fraud and misconduct incident. She also indicated that the audit committee charter would be reviewed when the audit committee guidelines from the Department of Planning and Community Development (2011) were issued. Corporate Services Director B (2011) also indicated that the audit committee charter for his council would also be reviewed for the same reasons.

\subsection{Summary}

In this chapter, the evidence from quantitative and qualitative research has been provided to corroborate or contradict the primary, sub-research and secondary research questions respectively.

The final chapter (Chapter Seven) synthesises the research in chapter Six and advances a theory of audit committee effectiveness within the context of governance and audit committee literature (Chapters Two and Four) and the risks of misconduct and corruption in chapter Three.

\footnotetext{
${ }^{23}$ Internal Auditing in Victorian local government was predominately provided by accounting firms under contract to council. In New South Wales, internal auditors are generally staff appointments.
} 


\section{CHAPTER SEVEN: $\quad$ SUMMARY AND CONCLUSIONS}

Chapter Seven will draw conclusions from the research in Chapters Six together with the literature in chapters Two, Three and Four and the methodology in chapter Five to address the primary and secondary research questions (Section 1.4) in chapter One.

Section 7.1 summarises the research findings from quantitative and qualitative research data. In Section 7.2, the research questions in Chapter One are answered. Limitations of the research are noted in Section 7.3 and Section 7.4 discusses the research findings by addressing the question: What do the answers mean? A revised theory of audit committee effectiveness is discussed in Section 7.5 and suggestions for future research are noted in

\section{Section 7.6.}

\subsection{Summary of findings}

\subsubsection{Quantitative research}

The general conclusions from this study are that audit committees in Victorian local government are operating in accordance with the Best Practice Guidelines, Local Government Entity, Audit Committees and Internal Audit from the Victorian Department of Infrastructure (2000) and in accordance with Section 139 of the Local Government Act (1983). Audit committees in New South Wales were in a state of 'embryonic development' and it was established that only $40 \%$ represented by committee members of the Local Government and Shires Association of New South Wales, ${ }^{24}$ had audit committees. As noted in Chapter Six, this was consistent with the findings by the Department of Premier and Cabinet, New South Wales that $46 \%$ of councils in New South Wales had audit committees (2010a, 2010b). Audit committee members were aware that their committees were only advisory committees to council and therefore did not have any executive powers.

The qualitative research in Chapter Six noted the potential for chairs to usurp their authority. This can be a source of tension between councillors, management and audit committee members. The membership was generally evenly divided between the majority of independent members or an equal distribution of councillors and independent members.

\footnotetext{
${ }^{24}$ The thirty-six members of the Local Government and Shires Association of New South Wales are the councillor representatives from thirty-two councils. The Association is the representative body of one hundred and fifty-two councils in New South Wales.
} 
There were two exceptions to this rule, with two councils in Victoria having a majority of councillors as audit committee members and one council in New South Wales, where management constituted the majority of audit committee members.

In Chapter Six it was established that audit committees reported to council. This complied with the reporting arrangements for councils in New South Wales and Victoria in accordance with Section 3.10 of the Internal Audit Guidelines (Department of Premier and Cabinet, New South Wales 2010b, p. 23; Department of Local Government 2008b, p. 25) and the best practice audit committee guidelines for Victorian local government (Department of Infrastructure, 2000).

In relation to 'Forming an Audit Committee' (questions A1-A5 in Appendix 5) it was found that audit committee members were: (1) appointed via a transparent process; (2) clear about council's expectations of the audit committee; and (3) understood the general risks of local government and specific risks of council. Councils and shires periodically updated their audit committee charter to reflect changed circumstances or expectations, whilst others updated their charters at the expiration of an independent member's appointment.

The mean and standard deviations of Likert scores 1 to 7 from the responses of mayors, chief executives and chairs of audit committees of metropolitan councils were higher than their counterparts in rural and regional councils. This indicated that metropolitan councils considered that their audit committees had adequate processes in place for their formation and that no improvements were required. Conversely, the mean from mayors, chief executives and chairs of audit committees of rural and regional councils were lower, indicating that these three groups considered that improvements were required. Lower standard deviations indicated more unanimity of agreement than it did about improvement opportunities. This was also reaffirmed during the qualitative research, as discussed in Chapter Six.

Questions B1-B5 (Appendix 5) related to 'Knowledge and Expertise' of audit committee members. The mean of metropolitan councils was generally higher and standard deviations lower than rural and regional councils. This indicated that an improvement in the knowledge and expertise of audit committee members was warranted for rural and regional councils. This was also confirmed during qualitative research, that is, that some councils experienced 
difficulties in attracting and retaining competent and experienced independent audit committee members.

In relation to 'Induction and Training' (questions C1-C5 in Appendix 5), the research indicated that an improvement in induction and training for new audit committee members in rural and regional councils was required. This was consistent with observations of attracting and retaining skilled audit committee members.

The chief executives and directors of corporate services considered that updating of knowledge of local government activities and risks was relevant for their council's audit committee, but chairs of audit committees and the councillors did not think it was relevant. The research noted the number of cross memberships by some chairs and committee members. This group considered they required less formal training and development on local government risks.

'Managing the Audit Committee' (questions D1-D12 in Appendix 5) enabled an assessment of the secondary research question, as outlined in Chapter One. In Chapter Six it addressed: (1) management of audit committee meetings (questions D1-D7); (2) management of debate (question D8); (3) interaction with external and internal auditors (question D9); and (4) three questions (D10, D11 and D12) pertaining to anti-corruption processes, fraud and misconduct.

The research concluded that administration and management of the audit committee (questions D1-D8); interaction with the external and internal auditors (question D9); and management of anti-corruption and misconduct policies (question D10) were well managed by audit committees. The responses to questions D11 and D12 established that audit committees considered they were not responsible for management of corruption and misconduct allegations and they provided enough evidence to confirm that the secondary research question was answered in the negative (Section 7.2). This was because the audit committee did not play a role in the management of any fraud or whistleblower investigations. These types of investigations are managed exclusively by the chief executive or an external agency, such as Victoria Police or the Ombudsman, Victoria, which was confirmed by Mayor A (2011) and Audit Committee Chair A (2010) whose councils had frauds perpetrated against them. However, audit committees do receive an assessment of internal control processes operating in their councils, following a reported investigation of another council by the Auditor-General, Victoria, Ombudsman, Victoria and the Inspector of 
Local Government. The reassessment of risks and internal controls does have the capacity to enhance governance practices, but what was required for this thesis was proof of a direct linkage between governance and audit committee inputs and outcomes.

In relation to 'Risk Assessment and Financial Reporting' (questions E1- E10 in Appendix 5), the Department of Infrastructure (2000), the Department of Local Government (2008b) and the Department of Premier and Cabinet, New South Wales (2010b) had established model processes for audit committees to manage risks and financial reporting.

In chapter Six, the mean of metropolitan mayors, chief executives and chairs of audit committees was generally higher than rural and regional councils and had lower standard deviations (Tables A7.19 and A7.20 in Appendix 7). This suggested that metropolitan mayors were more satisfied with audit committee processes in place for: risk management (questions E1-E2); investigation reports (question E3); oversight of financial statements (questions E4E7); oversight of internal audit (questions E8-E9); and the annual briefing from external auditors (question E10). This difference for the chief executive groups was similarly marked: rural and regional chief executives had a lower mean response to the questions, but they had nearly double the standard deviation of metropolitan chief executives. The same difference was noted for audit committee chairs in metropolitan councils, as compared with rural and regional councils.

In Chapter Six it was noted that some of differences in the responses between New South Wales and Victorian councils for risk management could be explained in the context that integrated risk management was a recent development in New South Wales (Department of Premier and Cabinet, New South Wales 2010b; Department of Local Government 2008b) as compared to Victorian local government, where the oversight of risk management by audit committees had been in place since 2000 (Department of Infrastructure 2000).

\subsubsection{Qualitative research}

The respondents to quantitative research and interviewees from qualitative research generally held similar views in relation to:

- $\quad$ inputs of an audit committee (e.g. charter; skills; activities; communications; induction and training); and

- $\quad$ behavioural nuances of the rigour of: debate; trust; effective communications; and 
relationships with councillors and management.

The issues of: (1) mix of skills for members; (2) transparency of debate; and (3) cultural issues of trust and integrity were frequently raised. The interviewees commented positively in relation to management of the audit committee (structured agendas, timely discussion of issues, no late reports, positive culture and leadership) and the focus on outcomes of the audit committee (risk management, strong links between risk and the internal audit plan).

It was found that the following factors can limit an audit committee's effectiveness:

- $\quad$ the ability to attract and retain skilled independent members, particularly for rural councils;

- $\quad$ varying degrees of expertise and skills of councillor audit committee members;

- $\quad$ the level of continuing professional development for councillor audit committee members;

- $\quad$ power and 'gaming' behaviours associated with manipulation of agendas, control of information and the omission of critical data from the audit committee;

- $\quad$ power games associated with appointments of councillor members to the audit committee; and

- $\quad$ domination of the audit committee by one or two members or management.

It was also noted that the chairs of audit committees, mayors and chief executives each play different roles at the audit committee and there are different expectations of each group and different expectations of the roles that each group will play (Reidy 2006). In Chapter Three and during the pilot study the issue of the audit expectation gap was raised. Whilst this was not pursued in this research, ${ }^{25}$ Auditor Partner C (2009) summarised the following limitations:

...a cynical view would be that the effectiveness of an audit committee is significantly impacted by the culture and attitude of the council to this function and who 'controls' the operation of the function. In many councils audit committees and associated internal audit is seen as a compliance function. Appointment of independent members of the audit committee is a means to avoid management letter points from Auditor-General, Victoria about not complying with best practice guidelines. In many cases, the internal audit agenda, which tends to be the major focus of many audit committees is set at the discretion of senior management, with little input or control by the audit committee members.

\footnotetext{
${ }^{25}$ This research related to the perceptions of audit committee participants (mayors, chief executives and chairs) as 'internal stakeholders', as compared to 'external stakeholders' who may rely upon publicly available documents such as the annual report and financial statements. In Section 7.6 this has been identified as an area for further research.
} 
Therefore at the extreme, some councils do not have an audit committee. Some have them, fund them in a minimalist way and treat them as a compliance function. Others have a more substantial function and they are used to achieve significant benefits to the council (Audit Partner C 2009).

Some interviewees supported a fixed term of appointment for the chair (i.e. 12 months with eligibility for reappointment) although this issue was raised because some interviewees considered that the appointment of some independent chairs had proven unsatisfactory. It was noted that the Baw Baw Shire Council, in its recruitment for independent audit committee members in May 2011, had specified that the appointment of the chair would be for a twelvemonth period, with the eligibility for reappointment (Baw Baw Shire Council, 2011).

\subsubsection{Implications for audit committees}

During the qualitative research and as noted in Chapter Four, an assessment of 'audit committee effectiveness' was incorporated in the 2011 guidelines from the Department of Planning and Community Development (2011). The review of effectiveness concentrated upon the work of the audit committee, but did not include any measures on how to establish whether the audit committee had achieved outcomes. For example, some of the objectives were: (1) 'high standards of corporate governance'; (2) 'compliance with applicable laws and regulations'; and (3) 'effective and efficient internal audit functions' (Department of Planning and Community Development 2011pp., pp. 46-7). These goals needed to be restructured in order to:

- $\quad$ uniformly measure outcomes;

- $\quad$ allow for comparisons between councils to be made; and

- $\quad$ identify those audit committees where improvement opportunities may be needed.

The review of governance and audit committees in Chapters Two and Three was heavily influenced by the literature with a private sector bias, although the public sector had produced governance and audit committee best practice guides. For example:

\section{Governance}

Governance research was predominately based upon agency theory, but there are other theories.

Weak governance was associated with the increased likelihood of adverse financial reporting.

The board and the audit committee are the mechanisms for the monitoring of management's financial reporting behaviours.
Beasley et al. (2009); Cohen et al. (2008); Marnet (2008).

Carcello et al. (2011);

Beasley et al. (2009); 


\section{$\underline{\text { Audit committees }}$}

Independence, financial expertise and diligence.

Skills and expertise.

Support from management.

Background and training.

Composition, authority and resources.

Leadership of the chair.
Australian National Audit Office (2005);

Krishnamoorthy et al. (2002a, 2002b)

Galvez (2003);

Australian National Audit Office (2005);

Kalbers and Fogarty (1993);

DeZoort et al. (2002);

DeZoort et al. (2002);

Spangler and Braiotta (1990);

Audit committee literature in Chapter Three noted the recurring themes of: financial reporting, governance structures, financial expertise, independent expertise, measures of effectiveness and the role of the audit committee. DeZoort et al. (2002) provided the following observations in relation to determinants for audit committee effectiveness:

- Authority Audit committee authority was conditional upon the written authority of the audit committee (audit committee charter) and management support (p. 58).

- Composition Audit committee expertise was perceived to be a critical component of audit committee effectiveness and this effectiveness was enhanced by an enhanced interaction with internal auditors with support for both the external and internal auditors in any auditormanagement disagreements (p. 51).

- Diligence Whilst the frequency of meetings provided an indication of effort, the motivation and incentives for audit committee members were not analysed (DeZoort et al. 2002, p. 65).

- Resources '.. the overriding conclusion from the audit committee literature is that support from the external and internal audits is vital' for audit committee effectiveness (DeZoort et al. 2002, p. 59).

In relation to diligence, the literature noted the importance of having an adequate number of audit committee meetings each year (Anonymous Author A 2002; Kalbers \& Fogarty 1993; McMullen \& Raghunandan 1996 and Spangler \& Braiotta 1990).

Figure 7.1 compared the findings from meta-analysis of the governance and audit committee literature to the findings from this qualitative and quantitative research. There was a level of consistency with the findings from Carcello et al. (2011) in relation to governance, auditing and this research. 


\begin{tabular}{|c|c|}
\hline Meta-Analysis Findings (Carcello et al. 2011 pp.17-18) & Research Observations \\
\hline $\begin{array}{l}\text { 'Weak governance is associated with an increased } \\
\text { likelihood of adverse reporting outcomes (in particular, } \\
\text { fraud and restatements)'. }\end{array}$ & $\begin{array}{l}\text { Victorian councils have well-documented processes in } \\
\text { relation to financial management. } \\
\text { Carcello et al. } 2011 \text { noted the relationship between weak } \\
\text { governance and financial misstatements. The governance } \\
\text { structures in Victorian local government are legislatively } \\
\text { prescribed and the Auditor-General, Victoria audits all } \\
\text { local government councils. } \\
\text { This was consistent with Carcello et al. (2011). }\end{array}$ \\
\hline $\begin{array}{l}\text { 'The board and the audit committee are the primary } \\
\text { mechanism for the internal monitoring of top } \\
\text { management's financial reporting behaviour'. }\end{array}$ & $\begin{array}{l}\text { Councils receive regular financial reports from } \\
\text { management. Local government audit committees receive } \\
\text { regular financial reports and provide a review of the } \\
\text { annual financial statements before they are approved by } \\
\text { council. } \\
\text { This was consistent with Carcello et al. (2011). }\end{array}$ \\
\hline $\begin{array}{l}\text { 'Audit changes/dismissals are less problematic in the } \\
\text { presence of good governance'. }\end{array}$ & $\begin{array}{l}\text { This is not applicable, as the Auditor-General, Victoria } \\
\text { audits all councils. }\end{array}$ \\
\hline $\begin{array}{l}\text { 'Stronger boards and audit committee are associated with } \\
\text { stronger auditing'. }\end{array}$ & This was consistent with Carcello et al. (2011). \\
\hline $\begin{array}{l}\text { 'A number of studies have demonstrated the importance of } \\
\text { audit committee accounting expertise and industry } \\
\text { experience'. }\end{array}$ & $\begin{array}{l}\text { In Section 6.3.2 the education and experience of audit } \\
\text { committee members was discussed. } \\
\text { This would confirm the observations from Carcello et al. } \\
\text { (2011). }\end{array}$ \\
\hline $\begin{array}{l}\text { 'Some audit committees appear to take their roles seriously, } \\
\text { while others appear to be primarily ceremonial in nature'. }\end{array}$ & $\begin{array}{l}\text { Audit Committees in Victorian local government were } \\
\text { mandated in } 2004 \text {. } \\
\text { The qualitative research would support the observation } \\
\text { from Carcello et al. (2011) in relation to audit committees } \\
\text { being diligent and serious in their duties. } \\
\text { There was no evidence to support the notion of } \\
\text { 'ceremonial' audit committees. }\end{array}$ \\
\hline
\end{tabular}

\section{Figure 7.1 Implications of the findings from meta-analysis for this research}

In chapter Three DeZoort et al. (2002) noted that an audit committee's ability to provide effective oversight was limited by the nature of the audit committee function as: (1) the audit committee only meets periodically; (2) deals with second-hand information supplied by management; and (3) the members of the audit committee may have no direct knowledge or experience of the organisation's operations and controls (DeZoort et al. 2002, p. 41). Despite, this limitation, DeZoort et al. (2002) noted stakeholder expectations that the audit committee would provide effective oversight of the organisation in order to protect the varied interests of shareholders and stakeholders. Mohamed and Hussain (2005) noted that an audit committee 
may encroach on management responsibilities. This can cause conflict within organisations if they secretly communicate with external and internal auditors. They also argued that the effectiveness of an audit committee may be more apparent than real, as the power to appoint members sometimes rests with the chief executive, which can give rise to a conflict of interest. This is an area of potential concern in local government, although interviews for independent members of the audit committee are conducted by a panel consisting of the chair of audit committee, mayor and chief executive and confirmed at the next council meeting, for example, Banyule, Bayside, Knox and Yarra City Councils.

\subsection{How research questions are answered}

\section{i. Primary research question}

The primary research question, 'Do audit committees in Victorian local government function effectively?' was supported by evidence from quantitative and qualitative research.

Audit committee effectiveness in local government was characterised by:

- $\quad$ the charter of the audit committee;

- $\quad$ periodic assessment of authority and accountability;

- $\quad$ membership;

- $\quad$ communication and reporting to council;

- $\quad$ quality of outcomes; and

- $\quad$ continuing professional development training.

This was evidenced by:

- $\quad$ an understanding by the audit committee of its accountabilities within a governance framework;

- $\quad$ audit committee members with the requisite skills and experience;

- the capacity and capabilities of audit committee members to act objectively and independently;

- $\quad$ the maintenance of structured relationships with council and executive management team;

- $\quad$ timeliness of reporting from the audit committee to council;

- $\quad$ rigour of debate; and

- $\quad$ transparency of relationships and communications. 


\section{ii. Secondary research question}

The secondary research question, 'Do the investigations into local government maladministration and malfeasance enhance governance and the audit committee's effectiveness?' was answered in the negative by the research, as reported in Chapter Six. Whilst Victorian councils were cognisant of their misconduct and corruption risks and had generally benchmarked their activities against the internal control deficiencies from the investigating agency's report, there was no support for an audit committee to actively participate in or oversee whistleblower or misconduct allegations. This could be considered to be one of the inhibitors to governance and audit committee effectiveness, based upon the principles of 'enablers' and 'stressors' from the model of change from Lewin (1951).

The research concluded that an audit committee could contribute to good governance outcomes for council by taking a leadership role for: (1) financial reporting; (2) risk management; and (3) internal control environment. In order for these outcomes to occur, it required councillors, management and independent audit committee members to demonstrate accountability, integrity, impartiality, respect and leadership.

\section{iii. Sub-research questions}

The outcomes from sub-research questions from Section 1.4 in Chapter One are detailed in Section 7.1 and summarised in Table 7.1

Table 7.1 Results from sub-research questions

\begin{tabular}{|c|c|c|}
\hline i. & $\begin{array}{r}\begin{array}{r}\text { Sub-research } \\
\text { question }\end{array} \\
\text { Null position } \\
\text { Outcomes }\end{array}$ & $\begin{array}{l}\text { Is Audit committee effectiveness influenced by the formal structures which manage the } \\
\text { committee? } \\
\text { There is no relationship between audit committee effectiveness and formal structures. } \\
\text { The formal structures of an audit committee support and contribute to effectiveness and the null } \\
\text { hypothesis is rejected. }\end{array}$ \\
\hline ii. & $\begin{array}{r}\text { Sub-research } \\
\text { question }\end{array}$ & $\begin{array}{l}\text { Is Audit committee effectiveness influenced by the attributes of the audit committee, for } \\
\text { example, rigour, reaction to bad news, transparent relationships, channels of communication } \\
\text { and positive impact? } \\
\text { There is no relationship between audit committee effectiveness and the attributes of the audit } \\
\text { committee. } \\
\text { The effectiveness of the audit committee is functionally dependent upon the attributes of the } \\
\text { audit committee and the null hypothesis is rejected. }\end{array}$ \\
\hline
\end{tabular}




\begin{tabular}{|c|c|c|}
\hline iii. & $\begin{array}{r}\begin{array}{r}\text { Sub-research } \\
\text { question }\end{array} \\
\text { Null position }\end{array}$ & $\begin{array}{l}\text { Is Audit committee effectiveness influenced by ethical pronouncements and public sector } \\
\text { values? } \\
\text { There is no relationship between the audit committee effectiveness and ethical pronouncements } \\
\text { and public sector values. } \\
\text { An ethical environment within the council contributes to outcomes of the audit committee and } \\
\text { thereby its effectiveness. The null hypothesis is rejected. }\end{array}$ \\
\hline iv. & $\begin{array}{r}\begin{array}{r}\text { Sub-research } \\
\text { question }\end{array} \\
\text { Null position }\end{array}$ & $\begin{array}{l}\text { Are audit committee members influenced by the views of mayors, chief executives and chairs } \\
\text { of audit committees? } \\
\text { There are no influential relationships between the audit committee members and the mayors, } \\
\text { chief executives and chairs of audit committees. } \\
\text { The audit committee members can be influenced by key stakeholders and the null hypothesis is } \\
\text { rejected. }\end{array}$ \\
\hline v. & $\begin{array}{r}\begin{array}{r}\text { Sub-research } \\
\text { question }\end{array} \\
\text { Null position }\end{array}$ & $\begin{array}{l}\text { Are Differences in opinions between mayors, chief executives and chairs of audit committees } \\
\text { influenced by professional affiliations and experiences? } \\
\text { There are no relationships between professional affiliations, experiences and the mayors, chief } \\
\text { executives and chairs of audit committees. } \\
\text { The different professional affiliations, experiences do influence outcomes from the audit } \\
\text { committee and the null hypothesis is rejected. }\end{array}$ \\
\hline vi. & $\begin{array}{r}\text { Sub-res } \\
q u\end{array}$ & $\begin{array}{l}\text { Are differences in opinions between mayors, chief executives and chairs of audit committees } \\
\text { influenced by geographic location, for example, rural, regional and metropolitan areas? } \\
\text { There is no relationship between geographic location and the opinions expressed by mayors, } \\
\text { chief executives and chairs of audit committees. } \\
\text { There were differences in the outcomes from quantitative research between metropolitan and } \\
\text { rural and the null hypothesis is rejected. }\end{array}$ \\
\hline
\end{tabular}

From the above table, the influences of key stakeholders were preconditions for audit committee effectiveness. In addition, formal structures and attributes of audit committees (e.g. rigour of debate) and transparency of relationships, an ethical framework and influences of key stakeholders were mechanisms for audit committee effectiveness. The differences from quantitative research between rural and metropolitan councils were discussed in Chapter Six.

\subsection{Limitations of the research}

The research had the following limitations and the arguments here acknowledge the methodological issues that can arise in such research.

i. The quantitative research had the limitations of a survey method, for example, it required the respondents to numerically plot on a 1 to 7 scale and interpret their observations to written questions. The same group of respondents could have different numeric interpretations, if asked to repeat the ratings. 
ii. The research asked individuals to make 'in context' individual decisions concerning ratings. It may be that respondents ordinarily participate in group 'in context' decisions, as compared to individual 'in context' decisions, as required by the quantitative research instrument.

iii. The respondents could not be randomly selected from their respective populations and, as a consequence, there is the potential for sampling bias. However, the respondents to quantitative and qualitative research could be defined as competent participants of audit committees and therefore it was considered that the results were generally applicable to Victorian local government audit committees.

iv. It was recognised that corruption and misconduct can take many forms, with the primary one being financial. In this thesis, a taxonomy of local government corruption and misconduct was developed, which included (1) maladministration; (2) financial mismanagement; (3) corrupt or unethical conduct; and (4) breaches of statutory powers, with an emphasis on statutory planning.

The limitations specific to this research were:

i. The research measured the perceptions of participants to a quantitative research instrument in July 2010 to August 2010 and their opinions and perceptions from qualitative research in December 2010 to January 2011. As governance and audit committee processes evolve over time, it was quite possible that if the same research instrument was used, the results would be different over time;

ii. The research considered the views and opinions of three groups, namely chairs of audit committees, mayors and chief executives. It was possible that if a research sample was drawn from an associated population, for example, audit committee members (independent members and councillors), that different research outcomes would be achieved; and

iii. The research examined local government audit committees and as such, the results are specific to this sector, although there could be some relevance to other public sector boards and utilities, for example, library boards and public sector water utilities. It was important to acknowledge the response rate of $36 \%$ from the 
quantitative research (Table 6.1 in Chapter Six) and follow-up steps were taken to remind participants to respond. One should also acknowledge early and late respondents as discussed in Section 5.7.2 in Chapter Five.

\subsection{What do these answers mean?}

Effectiveness of an audit committee can be an elusive term to define, although this research has described the attributes which contribute to the overall effectiveness of the audit committee. This is an important concept, because these attributes are the preconditions or foundations for effectiveness to occur, but without positive behavioural influences, they will not contribute to effectiveness. This is further discussed in Section 7.5.

In Chapter Three, effectiveness of an audit committee was described as a functional relationship between the authority, composition of the audit committee and specific measurement of outcomes or accomplishments of the audit committee and this was tested in Chapter Six. 'Effectiveness' can also mean the extent to which the audit committee is accomplishing what was intended by council. This 'in-practice' definition and operational attributes for effective audit committees were supported by audit committee guidelines from the Department of Planning and Community Development (2011) and Cameron (2008).

As noted in Chapter Three, Cameron (2008) considered that the four principles of governance relevant for audit committees in local government were: (1) independence of audit committee members; (2) competence of audit committee members; (3) clarity of purpose of the audit committee; and (4) effective relationships. Cameron (2008) also developed a local government audit committee taxonomy, which included the attributes of effectiveness, namely: (1) membership and the appointment process; (2) functions of the audit committee; (3) meetings and agendas; (4) relationships and responsibilities; (5) oversight of the external audit process; and (6) reporting to council.

DeZoort et al. (2002) stated that the four factors that contribute to effectiveness of an audit committee are: (1) composition; (2) authority; (3) resources; and (4) diligence. We might also add: (5) personalities of the incumbents; (6) transparency; and (7) the goodwill of council. They noted that audit committees are formed to protect the interests of shareholders, as agency theory holds that management may not always act in the interests of the entity's owners. The audit committee has the role of a 'watchdog' or guardian and reports to council. It has delegated powers from the council to scrutinise and hold management to account. An 
effective audit committee provides a level of assurance that council's physical and financial resources are used legitimately, prudently and economically. In assessing the components which contribute to the effectiveness of the audit committee, it was important to differentiate between the accountabilities of the audit committee and its activities. It was relevant to distinguish those authors who discuss organisational theory, for example, Robbins (2003) and organisational integration such as the management theorists, Follett and Barnard in Wren (2005) and those authors who comment on audit committee effectiveness on the basis of an outcome of process or the consequence of a regulatory framework (DeZoort et al. 2002).

There are a number of inherent limitations imposed on audit committees, for example, that they only meet periodically and deal with complex but selective information provided by management. Effectiveness and outcomes can be dependent on the 'goodwill' of management, although agency theory suggests that management may operate under different paradigms. Despite this limitation, stakeholders expect audit committees to provide effective oversight and protect their interests (DeZoort et al. 2002, p. 41). In relation to audit committee effectiveness, the Higher Education Funding Council for England (2008) recommended that, as part of an assessment of effectiveness, the following attributes should be considered, namely: (1) independence; (2) clearly established goals; (3) candour of members; (4) confidentiality; (5) trust relationships; (6) regular review of the assessment process; and (7) regular feedback.

Audit committee attributes from Cameron (2008) and the Higher Education Funding Council for England (2008) were consistent with the audit committee literature in Chapter Three. The literature noted that the actual method by which each council and each audit committee assesses effectiveness is a matter for each council and the audit committee to decide. It was noted that no single audit committee evaluation was recommended for Victorian councils to implement (Auditor-General, Victoria 2004; Cameron 2004; Department of Planning and Community Development 2011), which was consistent with the approach by the AuditorGeneral, Victoria in the review of audit committee effectiveness in 2004, as discussed in Chapter Four and noted by Purcell (2004).

In Chapter Three there is a review of the relationship between inputs to the audit committee, for example, the characteristics of members of the audit committee (independence, expertise and diligence) and outputs of financial reporting, for example, restatements of financial reports, fraud and going-concern reporting. Further examples included: (1) abnormal accruals (Bedard et al. 2004; Klein 2002); (2) financial restatements (Agrawal \& Chadha 
2005); (3) fraudulent financial reporting (Beasley et al. 2000); (4) going-concern reports (Carcello \& Neal (2000); (5) share price reactions (DeFond, Hann \& Hu 2005); and (6) financial expertise of audit committee members (Engel 2005).

The doctoral research by Wayne (2003) into effectiveness of Canadian audit committees was influential in this thesis. He stated that the primary purpose of an audit committee, from the perspective of legislators and regulators, was to ensure the integrity of financial reporting (Wayne 2003, p. 84). He developed an audit committee effectiveness matrix which applied the principles from: (1) agency theory; (2) institutional theory; (3) trust; and (4) scepticism. He applied the matrix to identify how an audit committee can fulfill its functional responsibilities and statutory obligations, based upon positioning of the audit committee in the four quadrants of the matrix, namely: (1) 'a paralysed audit committee'; (2) 'an institutional audit committee'; (3) 'a professional audit committee'; and (4) 'an agency audit committee'. His contribution to academic knowledge related to his assertion that the classification of the audit committee within the matrix was critical to understanding its impediments and conditions for effectiveness. He considered that the impediments of audit committee effectiveness related to:

- $\quad$ lack of technical resources;

- $\quad$ management interference;

- $\quad$ management dominating the audit committee;

- $\quad$ conflict between internal and external auditors; and

- the audit committee not being cognisant or accepting of the mandatory obligations as prescribed by regulators (Wayne 2003, p. 85).

Some of these conditions were also confirmed in this research. Wayne (2003) raised the concern that 'an audit committee does not accept or recognise some of the tasks as mandated by regulators', although this was not identified in this research (p. 85). Wayne (2003) measured the consequences of audit committee effectiveness, for example, a 'paralysed audit committee', whereas this thesis builds upon the preconditions for audit committee effectiveness (the attributes and dependent variables) from Figure 1.1 in Chapter One and suggests ways in which an audit committee can achieve effectiveness. Wayne's (2003) research was an ex-post analysis, whereas this thesis was an ex-ante analysis of effectiveness. The contribution of this thesis to academic knowledge is that it gives a level of credence to the behavioural influences identified by Kalbers and Fogarty (1998), Kets de Vries (1997), 
Marnet (2008, 2007, 2005, 2004) and Punch (1996) and their impact on audit committees as discussed in Chapter Four.

\subsection{How does this relate to theory?}

\section{i. Governance theories}

As noted in chapters Two and Three, the theories which resonate throughout the literature were agency theory (Fama \& Jensen 1983; Jensen \& Meckling 1976) and institutional theory (Scott 2004, 1987). In relation to governance in chapter Two and its implications for audit committees, agency theory postulates that audit committees are an independent monitor of management, whereas institutional theory establishes that audit committees can be ceremonial in nature, 'with a focus on providing symbolic legitimacy', but not necessarily 'vigilant monitoring' (Beasley et al. 2009, p. 66). Other theories which are also cited in the literature are behavioural, resource dependence and managerial hegemony. Whilst these theories are generally considered from the context of directors, they connect with the effectiveness of the audit committee from the perspective that audit committees can simultaneously perform the role of organisational monitors, agents of the board and facilitators from a resource dependency perspective.

In chapter Two and Three a focus on agency theory for governance and audit committees can translate into an understanding of the separation of roles between the audit committee and management. This can lead to an increased understanding of audit committees to perform the role of financial expert and be independent, transparent and enhance accountability. The separation of duties and responsibilities for financial reporting from an agency perspective can include such processes within councils to oversee management, given that financial incentives can have the propensity to conflict with the interests of stakeholders.

An exclusive resource dependency approach to audit committees in relation to the evaluation of internal controls within councils could lead the internal or external auditor to consider the council's processes in the establishment of effective policies and procedures to control risks. This approach is more of a partnering perspective, rather an adversarial role, which is implied under agency theory. During qualitative research, a chief executive of a large shire council stated that he used the audit committee as a sounding board, as well as getting independent members to provide mentoring and advice as applicable. 
A stakeholder's evaluation of an organisation using managerial hegemony theory would lead the stakeholder to be more sceptical, given that under this theory it was the council's management that was influential in the appointment of the audit committee. A stakeholder would need to understand the extent of personal relationships between councillors and management and the processes for nomination of new audit committee members or renomination of existing members. Stakeholders may wish to evaluate the efficacy of integrity policies within an organisation, for example: (1) conflict of interest; (2) whistleblowing; (3) management of gifts; and (4) consultation by employees outside of the organisation, in order to make an assessment of the corporate culture, which underpins effective internal control systems and accurate financial reporting.

From an agency and resource dependency perspective, both internal and external stakeholders would need to question whether directors with a narrow monitoring focus have the capacity and capabilities to evaluate strategic and operational plans and thus violate accounting principles for organisational continuity and going-concern. Using institutional theory, stakeholders would need to question the form and substance of governance structures within council. The implication arising from institutional theory is that a council can have the processes in place that are a 'tick-a-box' approach and stakeholders would need to establish if the internal control framework in the organisation was working consistently and was not overridden by management. The pilot study and qualitative research identified where management had overridden the audit committee by withholding information and audit reports.

\section{ii. Outcomes from this research in relation to governance theories}

This research concluded that when audit committee members were interviewed about audit committee processes, their responses were consistent with a range of governance theories, for example, Chief Executive A (2001) balanced the monitoring role of the audit committee under agency theory and assisting management under resource dependency theory.

Agency theory is a predominate theory in the audit committee literature, (ie: audit committee are in place to monitor management who may not act in the interests of the council), and the research in this thesis identified that some councils used an exclusive agency approach to audit committees. The qualitative research noted the commitment to good governance from the sample of mayors, councillors, audit committee chairs and management interviewed. This 
was consistent with stewardship theory 'which presumes that managers are honest, capable stewards of the company's resources (Beasley et al. 2009, p. 70). For example, Chief Executive B (2011) and Audit Committee Chair A (2010) indicated that advice was sought from individual audit committee members outside of meetings. This could indicate also indicate a resource dependency approach, although not as pronounced as that espoused by Chief Executive A (2011). In this example, it was more likely to be consistent with stewardship theory where the audit committee members contribute their skills and expertise to the council from a purely philanthropic perspective.

One councillor noted an institutional approach to the audit committee, (audit committee was primarily ceremonial and served as a symbol of effective oversight), although he was in the minority of councillors and audit committee members interviewed. It was further advised that this council had reverted to an agency approach for their audit committee following a council initiated review. The new independent audit committee members closely monitor management actions given their prior opportunistic behaviours. The research identified other examples of councils who just complied with the audit committee requirements of the Department of Planning and Community Development. This was an example of institutional theory where a council follows 'best practice' or mimics 'other organizations to enhance their legitimacy’ (Beasley et al. 2009, p. 69).

The research did not identify any audit committees conformed with managerial hegemony theory where the audit committee members were weak and under the control of the management. However some audit committee members were aware of instances where management had attempted to dominate the audit committee by controlling agendas and access to information. This could be considered to be the first step towards an audit committee environment where managerial hegemony theory would become the dominating modus operandi.

The research in this thesis supports the prevailing governance theories (agency, institutional, managerial hegemony, resource dependence \& stewardship) and notes the increasing importance of behavioural theory (Section 2.2.4) to explain the actions and outcomes of audit committees. These theories provide the interpretative lenses in which to assess the effectiveness of local government audit committees. 


\section{iii. A theory contributing to audit committee effectiveness}

The research in this thesis has used grounded theory (Glaser \& Strauss 1967), restated in Glaser (2007, 1992, 1978), where theory was characterised by inductive logic, as compared with deductive testing of a hypothesis (Chapter Five). Grounded theory collects the data and finds the best theoretical fit. As previously noted in Chapter five, Patton (2002) stated 'what theory emerges from systematic comparative analysis and is grounded in field work, so as to explain what has been and is observed?' (p.125).

What has emerged from this research was the influence of stewardship theory and behavioural theory which can contribute to or negatively impact audit committee effectiveness. The following contributes to audit committee effectiveness. It is based upon: (1) audit committee knowledge; (2) complements Bloom's taxonomy of learning; and (3) builds upon the notions of competencies, capacity and capabilities of audit committee members:

Audit committee effectiveness is based on an evolving process. This process depends upon the relationship between skills, competencies and capabilities of audit committee members. Audit committee effectiveness is influenced by the levels of trust and the behaviours exhibited at the audit committee.

This builds on existing behavioural and stewardship theories and was supported from the quantitative and qualitative research and the observations of Audit Partner C (2009); Chief Executive B (2011); Corporate Service Director B (2011); Corporate Service Director A (2010); Councillor A (2011); \& Mayor A (2011). It is represented in Figure 7.1 and allows a council to analyse an audit committee. The council can: (1) appraise the nature of the audit committee; (2) figuratively locate the audit committee within the competency matrix in Figure 7.2; and (3) take remedial steps to enhance skills, competencies and capabilities as required. Metaphorically speaking 'trust' and 'positive behaviours' are the 'two umbrellas', which can protect and enhance audit committee effectiveness.

At the top of Figure 7.2, there is recognition that council has a number of governance external influences which include the evolving nature of governance principles and practices, the regulatory environment of the Local Government Act (1989) and successive amendments and regulations and the oversight of the Auditor-General, Victoria, the Inspector of Local Government and the Ombudsman, Victoria. As discussed, the local government audit committee practice guide (Department of Planning and Community Development 2011) only 
focused on accountabilities and outcomes of the audit committee, for example, financial statements and internal controls and was silent about audit committee behaviours, which can constrain or inhibit audit committee effectiveness. As a consequence of these and other external influences, the council and management have to make some decisions in terms of resource allocation, which can impact upon governance practices and council risks. Using strategic human resources principles adapted from Boxall and Purcell (2000), the following questions can provide an interpretative lens in which resource allocation can be contextualised (Boxall \& Purcell 2000, p. 185).

i. What human and financial investments are critical to the council's performance?

ii. How are these choices being made and what processes are involved?

iii. What is the connection or alignment with other choices in the council?

iv. How can the council's practices become more effective to improve relative performance within local government?

At the next level are attributes and responsibilities of audit committees and these were represented in Figure 1.1 in Chapter One and tested in Chapter Six. Their outcomes are influenced by the principles of integrity, accountability and impartiality, as well as leadership from the audit committee and trust relationships between the council, the audit committee and management. Wayne (2003) explained audit committee effectiveness by populating audit committees on a matrix of trust and oversight to form his four perspectives of audit committee effectiveness (pp. 76-83). The limitation of this perspective is that it does not recognise that audit committees can evolve over time, due in part to: (1) a response to changes in legislation and regulations; (2) the emergence of new risks and their impact upon the council; (3) new members of the audit committee with different skills; and (4) changing management attitudes. The evidence in this thesis leads to the conclusion that audit committees are not static and evolve and grow in competence over time. As such, Bloom's (1956) taxonomy of learning, coupled with the principles of trust and audit committee behaviours, provides an alternative interpretative lens in which to contextualise audit committee effectiveness.

In thinking about audit committee effectiveness, the issues of competency, capability and capacity emerged during the research and especially the distinction between the audit committees in rural and regional councils as compared to metropolitan councils. Levels of competency can be viewed from two perspectives, namely: the level of complexity of the issues discussed at the audit committee and member's degree of skill in contributing to the audit committee. The research in relation to competency originates from the action verbs 
developed by Bloom with 'learning objectives beginning at knowledge and advancing to comprehension, application, synthesis and evaluation' (cited in Gebbie 2010, p. 210). In relation to an audit committee, inexperienced audit committee members could be considered to be 'novices', but may need support from more experienced audit committee members and management. A 'proficient' audit committee member would have higher level skills and competencies and an 'expert' audit committee member would perform his or her functions without any direction. The idea of using metaphors as a vehicle for discussion is not new, as Lakoff and Johnson (1980) showed that metaphors can be used in all 'types of analysis, because they are embedded in conversations and texts that both constitute and characterise so much of everyday life’ (Reidy 2006, p. 25).

Grant and Oswick (1996) considered that metaphors 'shape the way we think and the way we see' and they 'play a highly influential role in shaping organisational theory and analysis' (p.17). When assessing the skills of audit committee members, one could assess the level of: (1) primary skills; (2) range of skills; (3) maintenance of skills; and (4) competence. Primary skills could be held to mean, the assessment of the principal skills that are required for an audit committee member to satisfactorily perform in the role. The range of skills could be those skills above the minimum requirement for the audit committee member. The maintenance of skills could relate to the level of continuous professional development and competency could relate to the ability to perform the role of an audit committee member, after assessing primary skills, range of skills and level of skill maintenance.

There are two further factors which impact the capacity, competence and capabilities of an audit committee, namely, the level of trust and oversight relationships. The oversight relationship can range on a continuum from 'symbolic' to 'substantive' and reflect the level of maturity of relationships with the audit committee. It can also refer to the level of diligence of members, for example, preparing for the meeting by reading and reflecting upon the papers and following through on commitments and attendance at meetings. Herzberg, Mausner and Snyderman (1959) and Schein (1970) considered these to be 'hygiene factors', whereas the contribution to audit committee effectiveness comes from members sharing information, participating in discussions, asking relevant questions and translating their wider professional and personal experiences into a relevant context. The level of trust, namely the attributes of: integrity, loyalty, openness, consistency and competence (Robbins 2003, p. 336) contribute to audit committee effectiveness, which extends Schein's (1984) seminal work on the culture of visual artefacts and values and basic assumptions, which support the culture. 


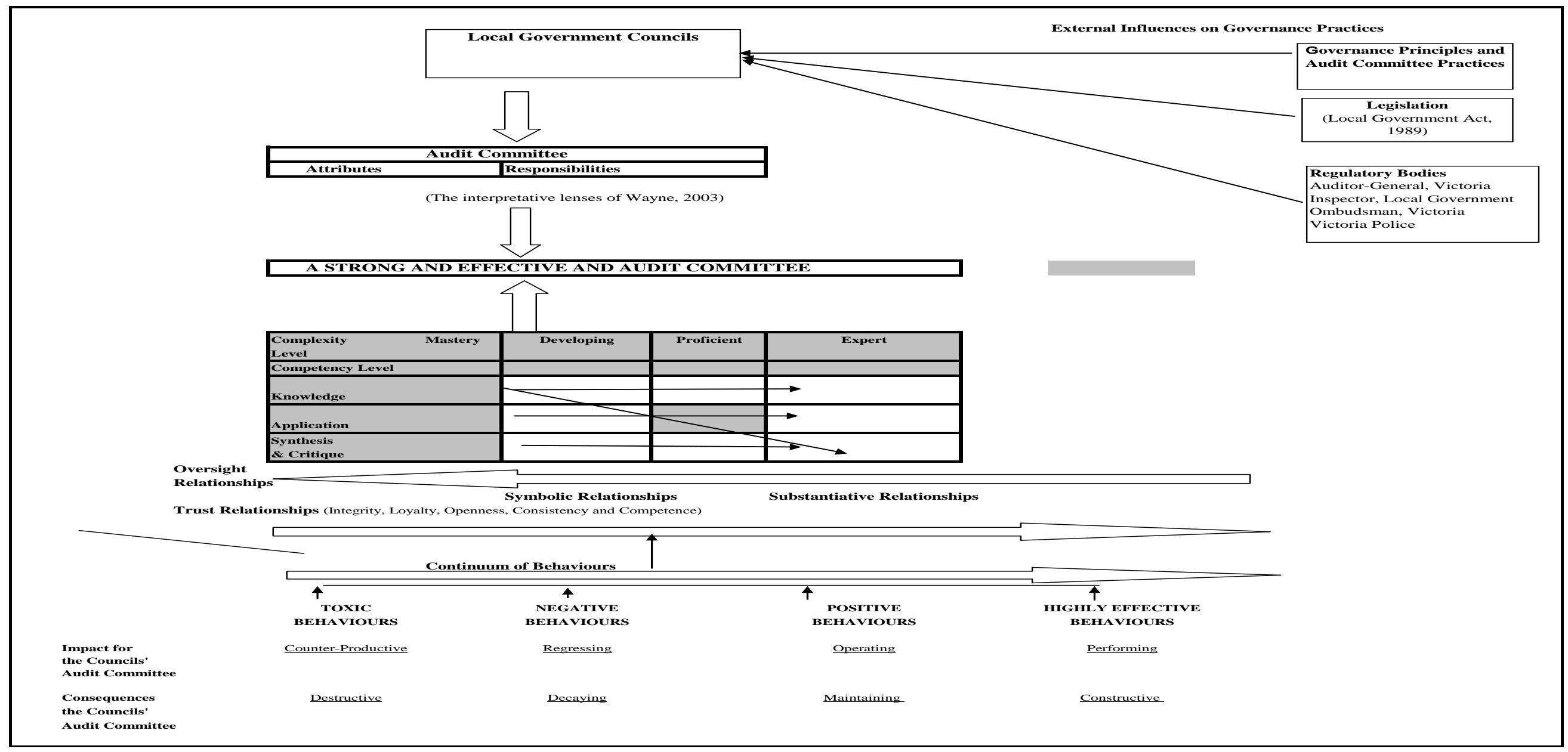

Figure 7.2 A theory of audit committee effectiveness

Adapted from Wayne (2003, p. 83) and Gebbie (2010, p. 211). 
In Chapter Two Leung and Cooper (2003), Pech and Durden (2004) and Marnet (2008) noted that organisations can also fail because of the lack of commercial acumen. In any analysis of 'environmental conditions' for potential corporate governance failures to occur, consideration needs to be given to how ethics, culture and values are embedded, espoused and practised within the organisation.

In analysing an organisation's culture it can be difficult to observe values and it would be rare indeed for a senior manager to warn of an impending problem, because they had noticed a problem with organisational values. It can be necessary to infer organisational values by reviewing organisational documents, for example, the Annual Report, as well as the organisation's strategies and policies. However, the identification of such values generally only represents the manifestation of espoused values of culture and focuses on what people say, rather than what they actually do.

To truly understand a culture and to ascertain an organisation's values and overt behaviour, it can be important to delve into the underlying assumptions which are typically implicit, rather than explicit, but which actually determine how a group within an organisation perceive, think and feel. The literature suggested that culture and values are 'observed', 'learned' and 'experienced' and they are reinforced by individuals, groups and organisational norms. The relevance of culture and values is that it allows some inferences to be drawn. Whilst it could be inferred that a strong, ethical organisational culture would generally abhor 'misconduct', that is not to say that all individuals necessarily share or enact those values.

The literature noted that the assumptions of rational behaviour and acting in the interests of the organisation do not necessarily apply where dishonest conduct is concerned (Griffin \& O’Leary-Kelly 2004; Griffin et al. 1998). Organisations can be replete with 'undiscussables', which are things that people do not want to talk about and they can range from hidden agendas to unethical and unlawful acts. On the balance of probabilities, most organisations may have at least one or some staff members engaged in some form of financial misconduct, ranging from simple theft, to more covert financial crimes of false documentation and misappropriation of funds and assets. What can be most worrying and what was already noticeable two decades ago was the greatest amount of dishonesty (measured through its destructive impact and the amounts stolen), which occurred at supervisory and executive 
levels (Jaspan 1988), thus reinforcing the notion of managerial hypocrisy and double standards.

Pech and Slade (2007) argued that the 'organisational tolerance for sociopathic managerial behaviour' could be the 'consequence of cultural and structural complexity' and suggested that the 'reduction of cultural and structural complexity may provide a partial solution' (p. 3). They contended that issues of culture could be amongst the major contributors to the problem and also provided subsequent solutions. Mumford, Gessner, Connelly, O’Connor and Clifton (1993) noted that when leaders defined problems in terms of their own needs, rather than the needs of their organisations, it can have disastrous consequences (pp. 116, 143). Gini (2004) in the analysis of the failure of the leadership of directors and executives within Enron, poignantly stated that the most simple and obvious explanation for the ignominy of Enron was greed, although ‘cowboy capitalistic behaviours' certainly contributed. Gini (2004) stated:

...hubris, money, greed, arrogance and reckless cowboy capitalism are really symptoms, or at best, only partial causes, for Enron's immoral and illegal pursuit of self-destruction. Enron's failure is really a result of a total breakdown of the "corporate structure", and "corporate culture" brought about by a failure of “corporate leadership” (p. 11).

Research by Mumford et al. (1993), Gini (2004), Price (2000) and Maccoby (2005) suggested that the failures of organisations may be intricately tied to a combination of their leadership and the cultures that leaders spawn. An example of this phenomenon was the National Aeronautics and Space Administration's investigation report, which summarised the organisational dysfunctionality that compounded the failures from Challenger and Columbia space missions by stating that, 'because ill-structured problems are less visible and therefore invite the normalisation of deviance, they may be the most risky of all' (National Aeronautics and Space Administration 2003, p. 203).

The literature indicated that the tone-at-the-top is the best way of creating an environment that demonstrated that misconduct is an anathema to the organisation (Institute of Internal Auditors 2005a, 2005b). The tone-at-the-top was essentially about demonstration by the organisational management of the values of trust, which includes integrity, competence, consistency, loyalty and openness (Bies 2004). Leaders can demonstrate their commitment through their individual conduct and their response to control failures. An ethics program can be successful when: (1) it was demonstrated and valued by staff at all levels within an 
organisation; and (2) the cultural environment empowers staff to raise ethical or reputation concerns to appropriate levels of management without any fear of retribution. In optimum practice organisations, the organisational culture should be such that it was possible to raise issues to senior management that they may not be aware of, in order that executive management can then respond positively and appropriately. Unfortunately, senior and executive management can often be the source of the problem and employees may not have the resilience or motivation to attempt to rectify such unpleasant matters. That does not make it moral, but rather a question of whether an individual can survive or whether an individual has the emotional resilience to take on the role of whistleblower and deal with the consequences.

Figure 7.2 shows the Continuum of Behaviours, which have been categorised as toxic, negative, positive and highly effective. These behaviours are dependent upon the levels of influence in the audit committee and recognise formal and informal power and influence relationships. For example, the behaviours of a charismatic chief executive or chair of the audit committee could have a high degree of influence and impact on the audit committee outcomes, affirmed by Auditor A (2011), Chief Executive B (2009) and Councillor A (2011). In another council, the chief executive sought to neuter the internal audit process, by marginalising the internal auditor, as the executive management did not want to allow 'uncomfortable truths' to be aired before the audit committee. Whilst this could be considered to be an exemplification of power theory, it also runs contrary to the notion of effective and transparent governance. Whilst there can be multiple reasons for doing so, the question that should be asked was: How was the management able to manipulate the council and persuade councillors on the audit committee that this was the best course of action for the council? Sometimes these situations can be contrived and involve a degree of managerial 'smoke and mirrors' including the selective presentation of information to the audit committee, for example, the City of Port Phillip (Ombudsman, Victoria 2009d).

A range of behaviours articulated at audit committees were identified from qualitative research. For example, under the category of toxic behaviours, there is dysfunctionality, which is similar to the 'paralysed audit committee' (Wayne 2003). Under the category of negative behaviours, there is narcissistic leadership, Machiavellianism and unhealthy group behaviours. Conflict and power and followership forces can be located between the categories of negative and positive behaviours. This recognises that these behaviours are not absolutely negative or absolutely positive. For example, if the behaviours in the audit 
committee were categorised as negative, this describes the impact as regressing and the consequences for the audit committee and council as decaying. The impact and the consequences for the audit committee of toxic, positive and highly effective behaviours from

Figure 7.2 are summarised in Figure 7.3.

\begin{tabular}{clll}
\multicolumn{1}{c}{ Behaviours } & Toxic & $\underline{\text { Positive }}$ & Highly Effective \\
Impact on audit committee/council & $\begin{array}{l}\text { Counter } \\
\text { operating }\end{array}$ & Performing & Productive \\
Consequences & Destructive & Maintaining & Constructive
\end{tabular}

\section{Figure 7.3 Impact and consequences of behaviours}

Further examples which can contribute to audit committee behaviours include: (1) the preexisting condition of bias; (2) the consequences of group think; (3) the escalation of commitment, where decision makers become committed to prior decisions; (4) strong aversion by some individuals not to lose an argument; and (5) reputation. Marnet (2004) eloquently described the loss of reputation that sometimes 'inevitably runs into a backward recursion problem, when the future benefit from being honest are dwarfed by the potential return from being dishonest' (p. 278). It has been assumed that councils and their audit committees would ideally like to position themselves in the categories of positive or highly effective behaviours. In order to move to these categories Pech and Slade (2004) noted the influence of culture and Martins and Terblanche (2003) noted behaviours that can encourage innovation including the processes for mistake handling, risk taking, support for change and conflict handling.

\subsection{Suggestions for further research}

Possible areas for future research include the following.

i. The research measured the perspectives of participants of local government audit committees. The same research instrument could be used, but limited to audit committee members only (councillors and independent members) with a comparison to the results from this research to ascertain if there were any differences.

ii. The regulators (Department of Planning and Community Development, Inspector of Local Government and Ombudsman, Victoria) and the agents of the external 
auditor of councils (Auditor-General, Victoria) could have a different perspectives on the effectiveness of local government audit committees. This could be compared to the results from this research to ascertain if there were any differences.

iii. The replication of research in other Australian local government councils, for example, Queensland and South Australia, with a comparison to the outcomes from this research to ascertain if there were any differences in outcomes.

iv. The replication of research with local government entities in other countries, for example, New Zealand and the United Kingdom, notwithstanding the differences in functions and responsibilities for local government in these two countries. The purpose would be to explain any differences.

v. A comparative study of larger state government entities, for example, library corporations and water authorities to ascertain if there any similarities or differences from the outcomes of this research.

vi. An analysis of the audit expectation gap between council constituents, audit committee members and management.

vii. An analysis of trust and behaviours articulated at audit committees, from the perspective of audit committee members, councillors and management. There could be some difficulty in sourcing data for this research, as respondents may be loath to report negative behaviours.

\subsection{Conclusions and a way forward}

Local government has an overarching party-political dimension unlike governance and management processes within the corporate sector. Whilst the corporate sector does not have political party representation, it does have a political dimension in the sense of hierarchies, power structures and elites. Councillors and constituents can potentially have different personal or single issue agendas, which can run contrary to the principles of sound financial management, effective administration and good governance. This means that the mayor and the chief executive need to carefully balance competing 'needs' and 'wants' of constituents, councillors and other stakeholders in equilibrium, with the need to manage the operations of 
council and deliver community service outcomes. As a consequence, this has implications for the audit committee and, specifically, independent members of the audit committee in the diligent discharge of their duties.

One of the implications from this research related to the power of culture and subcultures within a council, which can have the ability to hide more than culture reveals, for example, the investigation reports from Glen Eira Council (Inspector of Municipal Administration 2005), Ballarat Council (Inspector of Municipal Administration 2008) and the City of Port Phillip (Ombudsman, Victoria 2009d). This has implications for governance and effectiveness of audit committees. Lagan (2005a, 2005b) stated that in its simplest form organisational culture is a set of societal arrangements that needs to be consciously managed, rather than left to chance. Ethical and socially responsible core values need to be rooted in context and purpose of the council and be supported by governance systems, organisational recruitment and reward and recognition systems. The culture of a council can cast long shadows that may conceal unspoken and deeply pervasive irregularities, as identified in Chapter Four.

These shadows can become manipulated systems with council executives recruiting and promoting to their own likeness, including the in-house way of doing things, which may slowly and subtly come adrift from peer and industry norms. The creeping manner in which this pathological drift occurs may desensitise councillors and audit committee members to risk management and the severity and destructive nature of the working environment within council.

Lagan (2005b) argued that 'arrogance and self-satisfaction help blindside members to any growing chasm between how the organisation operates and what is seen as acceptable practice' (p. 10). She considered that this does not have to be the case, if councils accept that in the twenty-first century business ethics are set by society at large and by a broad base of stakeholders. Accommodating this paradigm allows a council to move beyond the context of 'tone setting' to recognition of the dynamic nature of organisational life and its interdependence within its wider societal context and the adaptive role this demands of its executives and council members. An active engagement with the organisational context is the social backdrop, which enables councils to ensure survival and prosperity in a changing environment. The suggested way forward is an effective audit committee that provides oversight of the council's governance process. Whilst one cannot legislate for integrity and 
honesty, the audit committee can be the monitoring mechanism and agent of council, although councillors cannot abrogate their duty of care. The presence of an effective and contributing audit committee makes a statement to the council and its stakeholders that all actions will be examined, that transparency is highly valued and that if self-interest were to conflict with council's expectations and societal norms, it will be exposed and will not be tolerated. It is axiomatic that the audit committee has to be successful in its task, otherwise the audit committee, as the agent of council, will be perceived as weak and ineffectual, which defeats the entire purpose of the exercise.

It was 'good' governance practice for organisations to measure the effectiveness of the audit committee on an annual basis and to use the information derived from an annual survey to constantly improve governance practices and to continue to monitor levels of exposure and risks within the organisation. These surveys could be used to support organisational governance principles of integrity and honesty and to separate the governance process from responsibilities of the management team. These types of surveys can assist councils to reinforce effective cultural practices, whilst at the same time not being restrictive or prescriptive (Barrett 2000; Durden \& Pech 2006). It also negates a corrupt council from listening or subverting positive actions by the audit committee and further provides a signal to the external auditor of organisational risks, for example, the Auditor-General, Victoria for Victorian councils. Stakeholders will always be more receptive to the creation of structured and credible systems which serve to remove temptation, rather than systems that attempt to bludgeon people into a state of compliance.

In closing, this thesis considers that a way forward is the establishment and reinforcement of a strong governance culture in local government and an effective audit committee. Whilst this research advocates the implementation of a more effective governance process through the audit committee, one must be cognisant of the power of individuals and groups within council to resist change. 


\section{References}

All website sources include the date the website was accessed at the end of the reference.

Abbot, L J. and Parker, S. 2000, 'Auditor selection and audit committee characteristics', Auditing: A Journal of Practice and Theory, Volume 19, Number 2, pp. 47-66.

Accounting and Professional and Ethical Standards Board, 2008, Code of Ethics for Professional Accountants, Melbourne, Australia, <http://www.apesb.org.au/Document/Issued_Standards/ Compiled\%20APES\%20110-\%20July\%2007.pdf> (29 January 2010).

Adcroft, A. and Willis, R. 2005, 'The (Un) intended outcome of public sector measurement', The International Journal of Public Sector Management, Volume 18, Number 5, pp. 386-400.

Agrawal, A. and Chadha, S. 2005, 'Corporate governance and accounting scandals', Journal of Law and Economics, Volume 48, Issue 2, pp. 371-406.

Ahrens, F. 2005, ‘Corporate cowboy at a low ebb’, The Age, March 19, Business p. 6.

AICPA, 1978, Commission on Auditors' Responsibilities: Report, Conclusions and Recommendations, AICPA, New York, United States of America

$<$ http://c0403731.cdn.cloudfiles.rackspacecloud.com/collection/papers/1970/1978_0101_CohenAuditors.pdf>(3 March 2012).

Aiyesha, D. 2005, Corporate Governance and Financial Reporting Credibility, PhD Thesis, Northwestern University, Illinois, United States of America.

Allen, E. Seaman C. 2007, 'Likert scales and data analysis, quality progress', Volume 40, Number 7, pp. 64-65, in Leung, S. 2011, 'A comparison of psychometric properties and normality in 4-, 5-, 6-, and 11- point likert scales’, Journal of Social Service Research, Volume 37, Issue 4, pp. 412-421.

Andreoli, N. and Lefkowitz, J. 2009, 'Individual and organizational antecedents of misconduct in organizations', Journal of Business Ethics, Volume 85, Number 3, pp. 309-332.

AMP.Natsem Income and Wealth Report, 2009, She Works Hard for her Money, Australian women and the gender divide, http://apo.org.au/sites/default/files/she_works_hard_for_money.pdf (8 February 2012).

Anonymous Author A, 2002, CA Magazine, 'Canada’s top corporate directors discuss best practices for audit committees’, Volume 135, Issue 9, p. 45-46.

Anonymous Author B, 2000, Financial Executive, 'audit committee effectiveness', ideas from the front line, January February, Volume 16, Issue 1, p. 56.

Anseel, F. Lievens, F. Schollaert, E. and Choragwicka, 2010, B. 'Response rates in organizational science, 1995-2008: A meta-analytic review and guideline for survey researchers', Journal of Business Psychology, Volume 25, Number 3, pp. 335-349.

Appelbaum, S. H. and Shapiro, B. T. 2006, 'Diagnosis and remedies for deviant workplace behaviors', Journal of American Academy of Business, September 9, pp. 14-20.

Argyris, C. 1990, Overcoming Organizational Defences, Allyn \& Bacon, Boston, United States of America.

Argyris, C. 1986, ‘Skilled incompetence’, Harvard Business Review, September-October, pp. 74-79.

American Psychiatric Association, 2000, Diagnostic and Statistical Manual of Mental Disorders, $4^{\text {th }}$ edition, Text Revision, Arlington, Virginia, United States of America.

Armitage, J. 2011, 'Creating effective public sector audit committees', Journal of Leadership, Accountability and Ethics, Volume 8, Number 3, pp. 96-102.

Armstrong, J. S. and Overton, T. S, 1977, 'Estimating nonresponse bias in mail surveys’, Journal of Marketing Research, Volume 14, Number 3, pp. 396-402.

Asquith, A. 1998, 'Non-elite employees perceptions of organizational change in English local government', The International Journal of Public Sector Management, Volume 11, Number 4, pp. 262-280.

Association of Fraud Examiners, 2010, Report to the Nations on Occupational Fraud and Abuse, $<$ http://www.acfe.com/uploadedFiles/ACFE_Website/Content/documents/rttn-2010.pdf>(12 February 2012). 
Association of Fraud Examiners, 1996, Report to the Nations on Occupational Fraud and Abuse, in Wells, J. T. 2004, Corporate Fraud Handbook, Prevention and Detection, Association of Fraud Examiners, Austin Texas, United States of America.

Association of Government Accountants, 2008, Characteristics of Effective Audit Committee in Federal, State and Local Government, CPAG Research Series: Report no. 17, November, <http://www.agacgfm.org/AGA/Documents/Research/CPAG_No17-1-.pdf> (17 January 2012)..

Auditing and Assurance Standards Board, 2011, The auditor's responsibilities relating to fraud in an audit of a financial report, Auditing Standard ASA 240, <http://www.auasb.gov.au/admin/file/content102/c3/Jun11_Compiled_ASA_240.pdf> (9 August 2012).

Audit-Commission, United Kingdom, 2009a, Comprehensive Area Assessment, London, United Kingdom, <http://www.audit-commission.gov.uk/localgov/audit/CAA/Pages/default.aspx> (4 August 2009).

Audit-Commission, United Kingdom, 2009b, North East Lincolnshire Council - Icelandic investments, London, United Kingdom,

$<$ http://www.audit-commission.gov.uk/localgov/audit/pir/Pages/nelincolnshirecouncilpir24jun2009.aspx> (7 September 2009).

Audit-Commission, United Kingdom, 2009c, Nottingham City Council - Housing Services, London, United Kingdom, <http://www.audit-commission.gov.uk/localgov/audit/pir/Pages/pir09nottingham.aspx> (7 September 2009).

Audit-Commission, United Kingdom, 2008a, Doncaster Metropolitan Borough Council - Governance, London, United Kingdom, <http://www.audit-commission.gov.uk/localgov/audit/pir/Pages/pir08doncaster.aspx> (7 September 2009).

Audit-Commission, United Kingdom, 2008b, Epworth Town Council - Financial Governance, London, United Kingdom, <http://www.audit-commission.gov.uk/localgov/audit/pir/Pages/pir08epworth.aspx> (7 September 2009).

Audit-Commission, United Kingdom, 2007a, Leicester City Council - Housing Repairs Contracts London, United Kingdom, <http://www.audit-commission.gov.uk/localgov/audit/pir/Pages/pir07leicester.aspx> (7 September 2009).

Audit-Commission, United Kingdom, 2007b, Bude Stratton Town Council - Unlawful Payments, London, United Kingdom, <http://www.audit-commission.gov.uk/localgov/audit/pir/Pages/pir07budestratton.aspx> (7 September 2009).

Audit-Commission, United Kingdom, 2007c, City of Westminster Council - Homes for Votes, London, United Kingdom, <http://www.audit-commission.gov.uk/localgov/audit/pir/Pages/pir07westminster.aspx> (7 September 2009).

Audit-Commission, United Kingdom, 2007d, Chipping Campden Town Council - Financial Governance, London, United Kingdom, <http://www.auditcommission.gov.uk/localgov/audit /pir/Pages/pir07chippingcampden.aspx > (7 September 2009).

Audit-Commission, United Kingdom, 2006a, Restormel Borough Council - Planning Decisions, London, United Kingdom, <http://www.audit-commission.gov.uk/localgov/audit/pir/Pages/pir06restormel.aspx> (7 September 2009).

Audit-Commission, United Kingdom, 2006b, City of Bradford Metropolitan District Council - Procurement Processes of an Asset Management Project, London, United Kingdom, $<$ http://www.audit-commission.gov.uk/localgov/audit/pir/Pages/pir06bradford.aspx> (7 September 2009).

Audit-Commission, United Kingdom, 2005, Marlborough Town Council - Procurement of Commemorative Brochure for Royal Charter Celebrations, London, United Kingdom, <http://www.audit-commission.gov.uk/localgov/audit/pir/Pages/marlboroughtowncouncilpir15March2009.aspx> (7 September 2009).

Auditor-General, Manitoba, 2006, Enhancing Audit Committee Practices In The Public Sector, Winnipeg, Manitoba, Canada, <http://www.oag.mb.ca/reports/PSAUDITPRAC_OCT06.pdf> (15 December 2009).

Auditor-General, Victoria, 2008, Local Government, Results of the 2006-2007 Audits, Melbourne, Victoria, Australia, <http://archive.audit.vic.gov.au/reports_mp_psa/psa23_LGA.pdf> (14 April 2008). 
Auditor-General Victoria, 2005a, East Gippsland Shire Council: Proposed sale of Lakes Entrance property, Melbourne, Victoria, Australia, <http://archive.audit.vic.gov.au/reports_par/agp108cv.html> (21 March 2008).

Auditor-General Victoria, 2005b, Community Planning Services in Glenelg Shire Council: 1998-2005, Melbourne, Victoria, Australia, http://archive.audit.vic.gov.au/reports_other/agpglenelgcv.html (21 March 2008).

Auditor-General Victoria, 2005c, Internal Financial Reporting in Local Government, Melbourne, Victoria, Australia, <http://download.audit.vic.gov.au/files/LG_Financial_GPG.pdf> (20 July 2009).

Auditor-General, Victoria, 2005d, Review of Warrnambool City Council Financial Management Practices, Results of Financial Statements for Agencies with other than 30 June 2005 Balances, Melbourne, Victoria, Australia, <http://www.audit.vic.gov.au/reports_pm_psa/psa1111html> (15 August 2006).

Auditor-General, Victoria, 2004, Report on Public Sector Agencies - Results of special reviews and financial statement audits for agencies with 2003 balance dates other than 30 June, $<$ http://www.audit.vic.gov.au/reports_mp_psa/psa0802.html>(18 June 2004)

Audretsch, D. B. Lehmann, E. E. and Plummer, L. A. 2009, 'Agency and governance in strategic entrepreneurship’, Entrepreneurship, Theory and Practice, January, pp. 149-166.

Australian Local Government Women's Association 2009, 50:50 Vision: A National Program for Gender Equity in Local Government, < http://www.algwa.net.au/files/T5TA4RM411/50_50_Vision.pdf> (12 February 2012).

Australian National Audit Office, 2011, Public Sector Audit Committees, Independent Assurance and Advice, for Chief Executives and Boards, Canberra, Australia, <http://www.anao.gov.au/ /media/Uploads/BPGs/2011/PublicSectorAuditCommitteeBPG.pdf> (21 January 2012).

Australian National Audit Office, 2005, Best Practice Guide, Public Sector Audit Committees, Canberra, Australia, <http://archive.audit.vic.gov.au/reports_mp_psa/psa23_LGA.pdf> (14 April 2008).

Australian National Audit Office, 2003, Public Sector Governance, Volume 1 and 2, Canberra, Australia, $<$ http://www.anao.gov.au/director/publications/betterpracguides.cfm> (18 December 2008).

Australian Securities and Investments Commission (undated), Whistle Blowing, $<$ http://www.asic.gov.au/asic/asic.nsf/byheadline/Whistleblowing?openDocument> (28 April 2009)

Australian Stock Exchange, 2007, Corporate Governance Principles and Recommendations, with 2010 Amendments, Second Edition, August, Sydney, Australia, $<$ http://www.asx.com.au/documents/about/cg_principles_recommendations_with_2010_amendments.pdf> 25 March 2011).

Australian Stock Exchange, 2003, Principles of Corporate Governance and Best Practice Recommendations Sydney, Australia, <http://www.asx.com.au/about/corporategovernance_aa2.shtm> (21 June 2004).

Bachelard, M. 2009, 'ALP staffer facing 42 counts of fraud', The Age, August 2, p. 9.

Banyule City Council, 2008, Audit Committee Charter, <http://www.banyule.vic.gov.au/Assets/Files/IR-AuditCharterFinalDec08.pdf> (21 February 2012).

Barrett, P. J. 2002, Achieving Best Practice Corporate Governance in the Public Sector, Australian National Audit Office, Canberra, ACT, Australia.

Barrett, P. J. 2000, Corporate Governance in an Environment of Devolved Authority, Australian National Audit Office, Canberra, ACT, Australia.

Baruch, Y. 1999, 'Response rate in academic studies - A comparative analysis', Human Relations, Volume 52, Number 4 pp. 421- 438.

Baruch, Y. and Holtom, B. C. 2008, 'Survey response rate levels and trends in organizational research’, Human Relations, Volume 61, Number 8, pp. 1139-1160

Baw Baw Shire Council, 2011, Independent Audit Committee Member, Expression of Interest Information, May, Warragul, Victoria, Australia. 
Bayside City Council, 2011 Audit Committee Charter, Sandringham, Victoria Australia.

Baysinger, B. and Hoskisson, R. E. 1990, 'The composition of board of directors and strategic control: Effects on corporate strategy’, Academy of Management Review, Volume 15, Issue 1, pp. 72-87.

Beasley, M. S. Carcello, J. V. Hermanson, D. R. and Neal T. L. 2009, 'The audit committee oversight process’, Contemporary Accounting Research, Volume 26, Number 1, pp. 65-122.

Beasley, M. S. Carcello, J. V. Hermanson, D. R. and Lapides, P. D. 2000, 'Fraudulent financial reporting: Consideration of industry traits and corporate governance mechanisms', Accounting Horizons, Volume 14, Number 4, pp. 441-454.

Beasley, M. S. and Salterio, S E. 2001, 'The relationship between board characteristics and voluntary improvements in audit committee composition and experience', Accounting Research, Volume 18, Number 4, pp. 539-570.

Beatty, R. P and Zajac, E, 1994, 'Managerial incentives, monitoring and risk bearing: A study of executive compensation, ownership and board structure in initial public offerings', Administrative Science Quarterly, Volume 39, Issue 2, pp. 313-335.

Bedard, J. and Gendron Y. 2009, 'Strengthening the Financial Report System: Can Audit Committees, Deliver?' <http://papers.ssrn.com/sol3/papers.cfm?abstract_id=1438150> (17 September 2009).

Bedard, J. Chtourou, S. M. and Courteau, L. 2004, 'The effect of audit committee expertise, independence, and activity on aggressive earnings management', Auditing: A Journal of Practice and Theory, Volume 23, Number 2, pp. 13-35.

Berle, A. A. and Means, G. C. 1932, The Modern Corporation and Private Property, The Macmillan Company, New York, United States of America.

Berlinski, C. 2009, ‘The dark side of corruption’, Policy Review, Issue 155, June/July, pp. 71-81.

Bies, S. S. 2004, 'Current issues in corporate governance: effective risk management', Vital Speeches of the Day, May 1, 70, 14 , pp. 424-429.

Bilz, K. Darley, J. M. 2004, 'What’s wrong with harmless theories of punishment', Chicago-Kent Law Review, Volume 79, Issue 4, pp. 1215-1252.

Bion, W. R. 1961, Experiences in Groups and Other Papers, Basic Books, New York, United States of America, in Gettler, L. 2005b, Organisations Behaving Badly, A Greek Tragedy of Corporate Pathology, John Wiley and Sons, Queensland, Australia.

Blaikie, N. 1993, Approaches to Social Enquiry, Polity Press, Cambridge, in Blunden, D. W. 2000, A Case Study of Two Subversive Counter Cultures - The Disconnected Landscapes of Pedagogy and the Bureaucracy, Unpublished Masters Thesis, RMIT University, Melbourne, Australia.

Bloom, K. S. 1956, Taxonomy of Educational Objectives, Handbook 1: The Cognitive Domain, David McKay Co Inc, New York, United States of America.

Board Strategies, 2002, 'Evaluating Audit Committee Performance', $<$ http://boardstrategies.com/boarddoctor/audit_evaluating.html> (15 December 2009).

Bolton, B. J. 2006, Corporate Governance and Firm Performance, Doctor of Philosophy, University of Colorado, Bolder, United States of America.

Boyd, B, 1990, 'Corporate linkages and organizational environment: A test of the resource dependency model', Strategic Management Journal, Volume 11, Issue 6, pp. 419-430.

Boxall, P. and Purcell, J. 2000, 'Strategic human resources management: Where have we come from and where should we be going?’ International Journal of Management Reviews, Volume 2, Issue 2, pp. 183-203.

Braiotta L. 1999, The Audit Committee Handbook, $3^{\text {rd }}$ edition, John Wiley \& Sons, New York, United States of America in DeZoort, F.T. Hermanson, D. R. Archambeault, D. S. Reed, S. A. 2002, 'Audit committee effectiveness: A synthesis of the empirical audit committee literature', Journal of Accounting Literature, Volume 21, pp. 38-75. 
Braiotta L. and Zhou, J. 2006, 'An exploratory study of the effects of the Sarbanes-Oxley Act, the SEC and the United States Stock Exchange (s) rules on audit committee alignment', Managerial and Auditing Journal, Volume 21, Number 2, pp. 166-190.

Brennan, N. M and Solomon, J. 2008, 'Corporate governance, accountability and mechanisms of accountability: An Overview’, Accounting, Auditing and Accountability Journal, Volume 21, Number 7, pp. 885-906.

Broadbent, J. and Laughlin, R. 2005, 'The role of PFI in the UK government's modernisation agenda', Financial Accountability \& Management, Volume 2, Issue 1, pp. 75-97.

Bromilow, C. L. and Berlin B. L. 2005, Audit Committee Effectiveness, What Works Best, Institute of Internal Auditors, 3rd edn, Altamonte Springs, Florida, United States of America.

Bronson, S. N. Carcello J. V. Hollingsworth C. W. and Neal, T. L. 2009, 'Are fully independent audit committees really necessary?’ Journal of Accounting and Public Policy, Volume 28, Issue 4, pp. 265-280.

Brown, J. 2009, Audit Committees in Local Government, City of Greater Geelong, Private Email, 2 March.

Bryane, M. and Gross R. 2004, 'Running business like a government in the new economy: Lessons for organizational design and corporate governance', Corporate Governance, Volume 4, Number 3 , pp. 32-46.

Burgess, G. L, Mullen, D. 2002, 'Observations of ethical misconduct among industrial hygienists in England', AIHA Journal, Volume 63, Issue, 2. pp. 151-155.

Burnette, J. L. Pollack, J. M. Forsythe, D. R. 2011, Leadership in extreme contexts: A groupthink analysis of the May 1996 Mount Everest disaster, Journal of Leadership Studies, Volume 4, Number 4, pp. 29-40.

Buttery, E. A. and Richter, E. M. 2003, 'On machiavellian management', Leadership and Organization Development Journal, Volume 24, Number 8, pp. 426-435.

Cadbury, A. 2002, The Financial Aspects of Corporate Governance, Gee Ltd, London, United Kingdom $<$ http://www.ecgi.org/codes/documents/cadbury.pdf> (13 April 2009).

Cameron, W. 2009, Research into Victorian Local Government Audit Committee Effectiveness, Private Email, 28 February.

Cameron, W. 2008, Effective Audit Committees in Local Government, Municipal Association of Victoria, Victoria, Australia,

<http://www.mav.asn.au/CA256C320013CB4B/Lookup/wrs08cameron/\$file/WayneCameron.pdf> (14 April 2010).

Cameron, W. 2004, Role of the Audit Committee in Local Government, Presentation to the Local

Government Audit Committee Chairs, Office of the Auditor-General, Victoria, Melbourne, Australia, $<$ http://www.audit.vic.gov.au/speeches/agspeeech_18html> (10 January 2008).

Carcello J. V. 2005, 'Discussion of audit research after Sarbanes-Oxley', Auditing a Journal of Practice and Theory, Volume 24, Issue 5, Supplement, pp. 31-40.

Carcello, J. V. Hermanson, D. R. \& Ye, Z. 2011, 'Corporate governance research in accounting and auditing: Insights, practice implications, and future research directions', Auditing: A Journal of Practice \& Theory, Volume 30, Number 3, pp. 1-31.

Carcello J. V. and Neal, T. L. 2000, ‘Audit committee composition and auditor reporting’, The Accounting Review, Volume 75, Number 4, pp. 453-467.

Carson, V. 2005, ‘HIH informant didn’t want to live in the gutter’, The Australian, 10 August $<$ http://0-global.factiva.com.alpha2.latrobe.edu.au/en/arch/display.asp> (19 August 2005).

Challinger, D. 1994, Feeling Good at Work - An Antidote to Workplace Crime, Australian Institute of Criminology Conference, Crime Against Business, 28 February - 2 March, Melbourne, Australia, in Independent Commission Against Corruption, 1997, Corruption and Related Matters, An Annotated Bibliography, Sydney, New South Wales, Australia, <http://www.icac.nsw.gov.au/files/pdf/pub2_6r.pdf> (23 August 2009). 
Charmaz, K. 2006, Constructing Grounded Theory: A Practical Guide through Qualitative Analysis, Sage Publications, London, United Kingdom.

Chang, E. C. C. and Golden, M. A. 2007, 'Electoral systems, district magnitude and corruption’, British Journal of Political Science, Volume 37, Issue 1, pp. 115-137.

Charles, E. 2002, ‘Bad company’ CPA Australia, August 2002, pp. 28-33.

Chartered Institute of Public Finance and Accountancy, 2006 Good governance in local government, <http://www.cipfa.org.uk/pt/download/good_gov_in_localgov_briefing.pdf> (17 January 2012).

Chartered Institute of Public Finance and Accountancy, 2004, Audit Committee Principles in Local Authorities in Scotland, <http://www.cipfa.org.uk/scotland/download/audit_committee_principles.pdf> (12 October 2009).

Chi, J. 2005, Conditional Tests of Corporate Governance Theories, Doctor of Philosophy, Texas A \& M University, College Station, Texas, United States of America.

Christie, R.G, and Geis, F.L. 1970, Studies in Machiavellianism, Academic Press, New York, New York State, United States of America, cited in Macrosson, W.D.K. and Hemphill, D. J. 2001, 'Machiavellianism in Belbin team roles', Journal of Managerial Psychology, Volume 16, Number 5, pp. 355-363.

Clarke, F. and Dean, G. 2007, Indecent Disclosure: Gilding the Corporate Lily, Cambridge University Press, Cambridge United Kingdom.

Clarke, J. 2005, Working with Monsters How to Identify and Protect Yourself from Workplace Psychopaths, Random House, Sydney, Australia.

Cohen, J. R. and Hanno D. M. 2000, 'Auditors' consideration of corporate governance and management control philosophy in preplanning and planning judgement's', Auditing: A Journal of Theory and Practice, Volume 19, Number 2, pp. 133-146.

Cohen, J. R. Krishnamoorthy, G. and Wright, A. M. 2008, 'Form versus substance: The implications for auditing practice and research of alternative perspectives on corporate governance', Auditing: A Journal of Practice and Theory, Volume 27, Number 2, pp. 181-198.

Cohen, J. R. Krishnamoorthy, G. and Wright, A. M. 2007, ‘The impact of roles of the board on auditors' risk assessments and program planning decisions', Auditing: A Journal of Practice and Theory, Volume 26, Number 1, pp. 91-112.

Cohen, J. R. Krishnamoorthy, G. and Wright, A. M. 2002, 'Corporate governance and the audit process', Contemporary Accounting Research, Volume 19, Number 4, pp. 573-594.

Coleman, J. W. 1994, The Criminal Elite: The Sociology of White-collar Crime, St Martins Press, New York, United States of America.

Collier, P. and Gregory, A. 1999, ‘Audit committee activity and agency costs', Journal of Accounting and Public Policy, Volume 18, Issue 4-5, pp. 311-332.

Collins, J. D. Uhlenbruck, K. Rodriguez, P. 2009, 'Why Firms engage in corruption: A top management perspective', Journal of Business Ethics, Volume 87, Issue 1, pp. 89-108.

Collins, K. M. T. Onwuegbuzie, A. J. and Sutton, I. L. 2006, 'A Model incorporating the rationale and purpose for conducting mixed methods research in special education and beyond', Learning Disabilities: A Contemporary Journal, Volume 4, Number 1, pp. 67-100.

Conger, J.1990, ‘The dark side of leadership’, Organisational Dynamics, Volume 19, Issue 2 pp. 44-56.

Conley, H. 2006, 'Modernisation or casualisation? Numerical flexibility in public services', Capital \& Class, Issue 89, pp. 31-57.

Controller and Auditor-General, New Zealand, 2008a, Inquiry into the West Coast Development Trust, Wellington, New Zealand, <http://www.oag.govt.nz/2008/west-coast/> (7 September 2009).

Controller and Auditor-General, New Zealand, 2008b, Audit Committees in the Public Sector, Wellington, New Zealand, <http://www.oag.govt.nz/2008/audit-committees/docs/audit-committees-public-sector.pdf> (12 October 2009). 
Controller and Auditor-General, New Zealand, 2007a, Managing Conflicts of Interest: Guidance for Public Entities, Wellington, New Zealand, <http://www.oag.govt.nz/2007/conflicts-public-entities/docs/oag-conflictspublic-entities.pdf $>$ (12 June 2009).

Controller and Auditor-General, New Zealand, 2007b, Inquiry into Dunedin City Council and Otago Regional Council's funding of the proposed stadium, Wellington, New Zealand, <http://www.oag.govt.nz/2007/dunedin-stadium/> (7 September 2009).

Controller and Auditor-General, New Zealand, 2002, Taupo District Council - Funding of the Interim Establishment Board and the Lake Taupo Development Trust, Wellington, New Zealand, <http://www.oag.govt.nz/2002/taupo/> (7 September 2009).

Converse, P.R. Wolfe, E.W. Huang, X. T. and Oswald, F. L. 2008, 'Response rates for mixed-mode surveys using mail and e-mail/web’, American Journal of Evaluation, Volume 29, Number 1, pp. 99-107.

Cooksey, R. M. 2007, Illustrating Statistical Procedures for Business, Behavioural \& Social Science Research, Tilde University Press, Prahran, Victoria, Australia.

Core, J. E. Holthausen, R. and Larcker, D. F. 1999, ‘Corporate governance, chief executive officer compensation and firm performance’, Journal of Financial Economics, Volume 51, Issue 3, pp. 371-406.

Corruption and Crime Commission, 2009, Supplementary Report on the Investigation of the alleged public sector misconduct linked to the Smiths Beach Development at Yallingup, Perth, Western Australia, Australia, <http://www.ccc.wa.gov.au/pdfs/CCC\%20-\%20Smith’s\%20Beach\%20Supplementary\%20Report.pdf> (7 September 2009).

Corruption and Crime Commission, 2008, Report on the Investigation of alleged misconduct concerning Mr Stephen Lee, Mayor of the City of Cockburn, Perth, Western Australia, Australia, $<$ http://www.ccc.wa.gov.au/pdfs/Report\%20on\%20the\%20Investigation\%20of\%20Alleged\%20Misconduct\% 20Concerning\%20Mr\%20Stephen\%20Lee,\%20Mayor\%20of\%20the\%20City\%20of\%20Cockburn.pdf> (7 September 2009).

Corruption and Crime Commission, 2007, Report on the Investigation of the alleged public sector misconduct linked to the Smiths Beach Development at Yallingup, Perth, Western Australia, Australia, $<$ http://www.ccc.wa.gov.au/pdfs/investigation-misconduct-smiths-beach.pdf> (7 September 2009).

Cosner, S., Peterson, K. 2003, ‘Building a Learning Community’, Leadership, May/June, pp. 12-15.

COSO, 2009, Strengthening Enterprise Risk Management for Strategic Advantage, <http://www.coso.org/documents/COSO_09_board_position_final102309PRINTandWEBFINAL_000.pdf> (10 February 2012)

Cowell, R. and Martin, S. 2003, 'The joy of joining up: Modes of integrating the local government modernisation agenda', Environment \& Planning C: Government \& Policy, Volume 21, Issue 2, pp. 159-180.

Coxson, S. L. 2009, ‘Assessment of Armenian local government corruption potential’, Public Administration and Development, Volume 29, Issue 3, pp. 193-203.

CPA Australia, 2009, Annual Report, Melbourne, Australia, $<$ http://www.cpaaustralia.com.au/cps/rde/xbcr/cpa-site/annual_report_2009.pdf> (11 September 2010).

CPA Australia, 2007, Annual Report, Melbourne, Australia, p. 25, $<$ http://www.cpaaustralia.com.au/cps/rde/xbcr/cpa-site/annual_report_2007(1).pdf> (11 September 2010).

CPA Australia, 2005, Excellence in Governance for Local Government Manual, Melbourne, Australia, $<$ https://www.cpaaustralia.com.au/cps/rde/xbcr/SID-3F57FECB-6B9A3C8D/cpa/excellence_gov.pdf> (12 June 2009).

Crawford, M. Henry, W. McKendrick, J. and Stein, W. M. 2008, 'Effectiveness of audit committees in local authorities: Views from key players', Public Money and Management, August, pp. 207-214.

Creswell, J. W. 1998, Qualitative Inquiry and Research Design: Choosing Among Five Traditions, Sage Publications. Thousand Oaks, California, United States of America. 
Creswell, J. W. Plano Clark, V. L. Guttmann, M. and Hanson, W. 2003, 'Advanced mixed methods research Designs', in Tashakkori, A. and Teddlie, C. (Eds), 2003, Handbook of Mixed Methods in Social and Behavioural Research, Sage Publications, Thousand Oaks, California, United States of America, pp. 209-240.

Crime and Misconduct Commission, 2006a, Investigation into the Allegations Affecting the Douglas Shire Council, October, Brisbane, Queensland, Australia, <http://www.cmc.qld.gov.au/data/portal/00000005/content/76 435001161924976712.pdf> (25 March 2008).

Crime and Misconduct Commission, 2006b, Independence, Influence and Integrity in Local Government: A CMC Inquiry into the 2004 Gold Coast Council Election, Brisbane, Queensland, Australia, <http://www.cmc.qld.gov.au/data/portal/00000005/content/90913001147153596715.pdf> (7 September 2009).

Cummins, R. A. Gullone, E. 2000, 'Why we should not use a 5-point Likert scales: The case for subjective quality-of-life measurement' in Proceedings of the Second International Conference on the Quality of Life in Cities pp., pp. 74-93 in Leung, S. 2011, 'A comparison of psychometric properties and normality in 4-, 5-, 6-, and 11- point Likert Scales’, Journal of Social Service Research, Volume 37, Issue 4, pp. 412-421.

Cutting, B. A. and Koumin, 2002, 'Evaluating corporate board culture and decision making', Corporate Governance, Volume 2, Number 2, pp. 27-45.

Cutting, B. A. and Koumin, 2001, 'formulating the metaphysics, of governance: explaining the dynamics of governance using a new JEWAL synthesis framework', Journal of Management Development, Volume 20, Number 6, pp. 526-564.

Cutting, B. A. and Koumin, 2000, 'The emerging patterns of power in corporate governance: Back to the future in improving corporate decision making', Journal of Managerial Psychology, Volume 15, Number 5, pp. 447-507.

Cycyota, C. S. and Harrison, D. A. 2006, 'What (not) to expect when surveying executives, A meta-analysis of top manager response rates and techniques over time', Organizational Research Methods, Volume 9, Number 2, pp. 133-160.

Dailey, C. M. and Dalton, D. R. 2003, 'Conflicts of interest: corporate governance pitfall', The Journal of Business Strategy, Volume 24, Issue 4, pp. 7-9.

Dailey, C. M. Dalton, D. R. and Cannella, A. A. 2003, 'Corporate governance: decades of dialogue and data’, Academy of Management Review, July, Volume 28, Number 3, pp. 371-383.

Dallas, L . L. 1988, Two models of corporate governance: Beyond Berle and Means', Journal of Law Reform, University of Michigan, Volume 22, Number 1, pp. 19-116.

Dalton, C. M. and Dalton, D. R. 2005, 'Corporate governance reforms: Profiling at its worst', The Journal of Business Strategy, Volume 26, Issue 4, pp. 7-10.

Dalton, D. R. Daily, C. M. Johnson, J. L. and Ellstrand A. I. 1999, 'Number of directors and financial performance: A meta-analysis', Academy of Management Journal, Volume 42, Number 6, pp. 674-686.

Darebin City Council, 2009, Audit Committee Charter, Preston, Victoria, Australia.

Dartington, T. 1996, 'Leadership and management: Oedipal struggles in voluntary organizations', Leadership \& Organization Development Journal, Volume 17, Number 6, pp. 12-16.

Davies, M. 2009, 'Effective working relationships between audit committees and internal audit - the cornerstone of corporate governance in local authorities, a Welsh perspective', Journal of Management and Governance, Volume 13, Issue 1-2, pp. 41-73.

Dawes, J. 2008 'Do data characteristics change according to the number of scale points used?' International Journal of Market Research, Volume 50 Issue 1, pp. 61-77.

Davis, J. H. Schooramn F. D. and Donaldson, L. 1997, 'Towards a stewardship theory of management', The Academy of Management Review, Volume 22, Number 1, pp. 20- 47.

DeFond, M. L and Francis, J. R. 2005, 'Audit research after Sarbanes-Oxley’, Auditing a Journal of Practice and Theory, Volume 24, Issue 5, Supplement, pp. 5-30. 
DeFond, M. L. Hann, R. and Hu, X. 2005, 'Does the market value financial expertise on audit committee of boards of directors’, Journal of Accounting Research, Volume 43, Number 2, pp. 153-193.

Deloitte, 2004, Audit Committees - Better Practice Guide, <http://www.deloitte.com/dtt/cda/doc/content/AC_better_practice\%281\%29.pdf> (21 June 2004).

Deloitte, 2003, Audit Committee, Resource Guide, $<$ http://www.deloitte.com/assets/DcomGlobal/Local\%20Assets/Documents/Audit\%20Cmte\%20Resource\%20Gui de(1).pdf> (15 December 2009).

Dempsey, K, 2006, Values in Leadership: Approaches of Victorian Local Government Managers, PhD Thesis, Victoria University, Victoria, Australia.

Denzin, N. K. and Lincoln, Y. S. (Eds), 2005, The Sage Handbook of Qualitative Research, Sage Publications, $3^{\text {rd }}$ edition, Thousand Oaks, California, United States of America.

Denison, D. R. and Mishra A. K. 1995, 'Toward a theory of oganizational culture and effectiveness', Organizational Science, Volume 6, Number 2, pp. 204-223.

Department of Finance and Administration, 2005, Governance Arrangements for Australian Government Bodies, Canberra, Australia.

$<$ http://www.finance.gov.au/financial-framework/governance/docs/Governance-Arrangements-for-AustralianGovernment-Bodies.pdf> (9 December 2009).

Department of Infrastructure, 2000, Best Practice Guidelines, Local Government Entity, Audit Committees and Internal Audit, Victoria, Australia, <http://www.localgovernment.vic.gov.au/web20/rwpgslib.nsf/GraphicFiles/ BestPractiseGuidelinesAudit/\$file/BestPractiseGuidelinesAudit.pdf> (20 June 2008).

Department of Local Government, 2008a, Port Macquarie-Hastings Council Public Inquiry, New South Wales, Australia, <http://www.dlg.nsw.gov.au/portmacquariehastings/> (21 March 2008).

Department of Local Government, 2008b, Internal Audit Guidelines, New South Wales, Australia, <http://www.dlg.nsw.gov.au/Files/Information/08-64\%20Internal\%20Audit\%20Guidelines. Pdf\#xml=http://www.dlg.nsw.gov.au/Scripts/dtSearch/dtisapi6.dll?cmd=getpdfhits\&DocId=1645\&Index=C\%3a \%5cdtSearch\%5cUserData\%5cAllDocuments\&HitCount=18\&hits $=1+2+3+46 \mathrm{e}+46 \mathrm{f}+470+49 \mathrm{~d} 2+49 \mathrm{~d} 3+49 \mathrm{~d} 4+49 \mathrm{da}$ $+49 d b+49 d c+49 f c+49 f d+49 f e+4 a 0 a+4 a 0 b+4 a 0 c+\& \cdot p d f>(12$ October 2009).

Department of Local Government, 2006, Broken Hill City Council Public Inquiry, New South Wales, Australia,<http://www.dlg.nsw.gov.au/dlg/dlghome/documents/Information/Broken_Hill_public_ inquiry_report.pdf> (21 March 2008).

Department of Local Government, 2005, Brewarrina Shire Council Public Inquiry, New South Wales, Australia,<http://www.dlg.nsw.gov.au/brewarrina/documents/Information/Brewarrina\%20Shire\%2 0Council\%20Public\%20Inquiry\%20Report.pdf> (21 March 2008).

Department of Local Government, 2004a, Liverpool City Council Public Inquiry, New South Wales, Australia,<http://www.dlg.nsw.gov.au/liverpool/documents/Information/Liverpool_Inquiry_ Volume_3.pdf $>$ (21 March 2008).

Department of Local Government, 2004b, Rylstone Shire Council Public Inquiry, New South Wales, Australia,<http://www.dlg.nsw.gov.au/rylstone/documents/Information/Rylstone_Shire_ Council_Public_Inquiry_Report.pdf> (21 March 2008).

Department of Local Government and Regional Development, 2006, Western Australia, Audit committees in local government. Their appointment, function and responsibilities, Perth, Western Australia, <http://dlg.wa.gov.au/OpenFile.ashx?Mode=446E37686749376A356D684D2B6E6D6D4D6E555273773D3D\&C ontentID=79435A65306B496D4E4E343D> (17 January 2012).

Department of Planning and Community Development, 2011, Audit Committees, A Guide to Good Practice for Local Government, January, Melbourne, Victoria, Australia.

Department of Planning and Community Development, 2009, Audit Committees, A Guide to Good Practice for Local Government, Consultation Draft, December, Melbourne, Victoria, Australia.

Department of Premier and Cabinet, New South Wales, 2010a, 'Audit Committees in NSW Local Government', Private Email, 26 July, Division of Local Government, Nowra, New South Wales, Australia. 
Department of Premier and Cabinet, New South Wales, 2010b, Internal Audit Guidelines, Division of Local

Government, Norwa, New South Wales, Australia,

$<$ http://www.dlg.nsw.gov.au/dlg/dlghome/documents/Information/Internal\%20Audit\%20Guidelines\%20-

\%20September\%202010.pdf> (16 September 2010).

Department of Treasury, 2002, CLERP Paper No. 9: Proposals for Reform - Corporate Disclosure Strengthening the Financial Reporting Framework, Canberra, ACT, Australia, $<$ http://www.treasury. Gov.au/documents/403/PDF/Clerp9.pdf> (24 June 2004).

Department of Treasury, 1999, Making Transparency Transparent: An Australian Assessment, Canberra, ACT, Australia, <http://www.treasury.gov.au/contentitem.asp?NavId=016\&ContentID=178> (29 April 2009).

Department of Treasury, 1997, CLERP Paper Number 3, Directors' Duties and Corporate Governance: Facilitating Innovation and Protecting Investors', Proposals for Reform, AGPS, Canberra, ACT, Australia $<$ http://www.treasury.gov.au/contentitem.asp?NavId=013\&ContentID=283> (10 August 2005).

Department of Treasury, Queensland, 2008, Audit Committee Guidelines, Improving Accountability and Performance, Brisbane, Australia, <http://www.treasury.qld.gov.au/office/knowledge/docs/improvingperformance/improving-performance.pdf> (15 December 2009).

Department of Treasury and Finance, Victoria, 2005a, Finance Management Compliance Framework, Victoria, Australia,<http://www.dtf.vic.gov.au/CA25713E0002EF43/WebObj/FINALFMframework_July2005/\$File/FINA L\%20FM\%20frameworkJuly2005.pdf> (12 June 2009).

Department of Treasury and Finance, Victoria, 2005b, Financial Reporting Directions, Victoria, Australia, $<$ http://www.dtf.vic.gov.au/CA25713E0002EF43/pages/bfm-financial-reporting-policy-financial-reportingdirections $>$ (12 June 2009).

Department of Treasury and Finance, Victoria, 2002, Behavioural Accountabilities Framework, Victoria, Australia, $<$ http://www.dtf.vic.gov.au/dtf/rwp323.nsf/0/3962477e75d97a1dca256ba70028f98d/\$FILE/BAF.pdf> (12 June 2009).

Dey, A. 2008,' Corporate Governance and Agency Conflicts', Journal of Accounting Research, Volume 46, Number 5, pp. 1143-1181.

DeZoort, F.T. 1997, ‘An investigation of audit committees’ oversight responsibilities’, Abacus, Volume 33, Number 2, pp. 208-227.

DeZoort, F.T. Hermanson, D. R. Archambeault, D. S. and Reed, S. A. 2002, 'Audit committee effectiveness: A synthesis of the empirical audit committee literature', Journal of Accounting Literature, Volume 21, p. 38-75.

DeZoort, F.T. and Salterio, S. E. 2001, 'The effects of corporate governance experience and financial reporting and audit knowledge and audit committee members' judgements', Auditing, A Journal of Theory and Practice, Volume 20, Number 2, pp. 31-47.

Diamond, A. 2007, The Career Development and Identity of Victorian Local Government Chief Executives: Is Gender a Factor? DBA Thesis, Victoria University, Australia.

Dijkstra, M. T. M. van Dierendonck, D. Evers A. and De Dreu C. K.W. 2005, 'Conflict and well-being at work: The moderating role of personality’, Journal of Managerial Psychology, Volume 120, Number 2, pp. 87-104.

Dillard, J. F. Rigsby, J. T. and Goodman, C. 2004, 'The making and the remaking of organization context, duality and the institutionalization process', Accounting Auditing and Accountability Journal, Volume 17, Number 4, pp. 506-542.

DiMaggio, P. J. and Powell, W. W. 1983, 'The iron cage revisited: institutional isomorphism and collective rationality in organisational fields', American Sociological Review, Volume 48, April, pp. 147-160.

Ditton, J, 1977, Part-Time Crime, Macmillan, London, United Kingdom cited in Punch, M. 1996, Dirty Business, Exploring Corporate Misconduct, Analysis and Cases, Sage Publications, London, United Kingdom.

Donaldson, L. and Davis, J. H. 1991, 'Stewardship theory or agency theory: CEO governance and shareholder returns', Australian Journal of Management, Volume 16, Number 1, pp. 49-65.

Dowling, J. 2009, ‘They’re rubbish’, The Age, July 7, p. 9. 
Downe, J. Grace, C. Martin, S. and Nutley, S. 2008, 'Best value audits in Scotland: Winning without scoring?' Public Money and Management, Volume 28, Issue 2, pp. 77-84.

Durden, C. H. and Pech, R. J. 2006, 'The increasing cost of corporate governance: decision speed-bumps for managers', Corporate Governance, Volume 6, Number 1, pp. 84-95.

Easterby-Smith, M. Thorpe R. and Lowe, A. 1991, Management Research: An Introduction, Sage Publications, London, United Kingdom.

Economou, A. 2005a, 'Former retail boss denies dishonesty’, The Advertiser, 10 February, $<$ http://0-global.factiva.com.alpha2.latrobe.edu.au/en/arch/display.asp> (19 August 2005).

Economou, A. 2005b, 'Retrial over 17 charges’, Herald-Sun, 7 April, <http://0-global.factiva.com.alpha2.latrobe.edu.au/en/arch/display.asp> (19 August 2005).

Edwards, M. 2002, 'Public sector governance - future issues for Australia', Australian Journal of Public Administration, Volume 61, Number 2, pp. 51-61.

Elcock, H. and Fenwick, J. 2007, 'Comparing Local Mayors', The International Journal of Public Sector Management, Volume 20, Number 3, pp. 226-238.

Ellis, R.A. Endo, CM, and Amer, J.M. 1970, 'The use of potential non-respondents for studying non-response bias', Pacific Sociological Review, Volume 13, Number 2, pp. 103-109.

Engel, E. 2005, 'Discussion of Does the market value financial expertise on audit committees of boards of director?' journal of accounting research, volume 43, number 2, pp. 195-204.

Ertugrul, M. 2005, Essays on Agency Problems and Corporate Governance, Doctor of Philosophy, University of Connecticut, Storrs, Connecticut, United States of America.

Fabrizius, M. P. 1998, 'Demystifying the audit committee', Director's Monthly, July in DeZoort, F.T. Hermanson, D. R. Archambeault, D. S. Reed, S. A. 2002, 'Audit committee effectiveness: A synthesis of the empirical audit committee literature’, Journal of Accounting Literature, Volume 21, pp. 38-75.

Fama, E. and Jensen, M. 1983, 'Separation of ownership and control', Journal of Law and Economics, Volume 26, Issue 2, pp. 301-325.

Farrar, J. 2008, Corporate Governance, Theories, Principles and Practice, Oxford University Press, South Melbourne, Victoria, Australia.

Fenwick, J. and Elcock, H. 2005, 'New development: The elected Mayor and local leadership', Public Money \& Management’, January, pp. 61-66.

Finkelstein, S. 2003, Why Smart Executives Fail and What You Can Learn from their Mistakes, Portfolio, New York, United States of America in Gettler, L. 2005b, Organisations Behaving Badly: A Greek Tragedy of Corporate Pathology, John Wiley and Sons, Queensland, Australia.

Foster, D. and Jonker, J. 2005, 'Stakeholder relationships: The dialogue of engagement', Corporate Governance, The International Journal of Effective Board Performance Volume 5, Number 5, pp. 51-57.

Francis, R. and Armstrong, A. 2003, 'Ethics as a risk management strategy: the Australian experience’, Journal of Business Ethics, Volume 45, Number 4, pp. 375-385.

Frankston City Council, undated a, Audit and Ethic Committee Charter, Frankston, Victoria, Australia, <http://www.frankston.vic.gov.au/library/scripts/objectifyMedia.aspx?file=pdf/294/76.pdf\&siteID=18\&str_title=A udit\%20and\%20Ethics\%20Committee\%20Charter.pdf> (1 April 2011).

Frankston City Council, undated b, Audit Committee Assessment, Frankston, Victoria, Australia.

Freeman, C. and Littlewood, S. and Whitney, D. 1996, 'Local government and emerging models of participation in the Local Agenda 21 process', Journal of Environmental Planning and Management, Volume 39, Issue 1, pp. 65-78.

Frere, M. 2006, Moving On: Women and Retirement from Victorian Local Government, Women's Participation in Local Government Coalition, Carlton, Victoria, Australia.

Fridman, J. J. 2004, Corporate Governance: A Practical and Effective Response to the Challenges Raised, Doctorate of Civil Law, McGill University, Montreal, Canada. 
Friedrichs, D. O. 1996, White-collar Crime in Contemporary Society, Wasworth Publishing Company, Belmont, United States of America.

Frost, P., Robinson, S. 1999, ‘The Toxic Handler, Organizational Hero and Casualty’, Harvard Business Review, July/August, pp. 97-106.

Galbraith, J. K. 1967, The new Industrial State, Hamilton, London, United Kingdom.

Galvez C. R. 2003, 'Providing oversight in challenging times’, Businessworld, April 7, p. 1.

Gaughan, A. C. 2001, 'Effective leadership behaviour: Leading the third way from a primary care group perspective’, Journal of Management in Medicine, Volume 15, Number 1, pp. 67-94.

Gebbie, K .M. 2010, 'The current status of nurses’ emergency preparedness: A commentary on the development of emergency preparedness and response competency', Collegian, Volume 17, Issue 4, pp. 209-211.

Geddes, M. 2005, 'Neoliberalism and local governance - cross national perspective and speculations', Policy Studies, September-December, Volume 26, Issue 3/4, pp. 359-377.

Gendron, Y. Bedard, J. Gosselin, M, 2004, 'Getting inside the black box: A field study of practices in effective audit committees’, Auditing: A Journal of Theory and Practice, Volume 23, Number 1, pp. 153-171.

Gerasimova, K 2008, 'Can corruption and economic crime be controlled in developing countries and if so, is it cost effective?’ Journal of Financial Crime, Volume 15, Number 2, pp. 223-233.

Gettler, L. 2005a, 'From bad timings to bad times’, The Sydney Morning Herald, 3 January.

Gettler, L. 2005b, Organisations Behaving Badly, A Greek Tragedy of Corporate Pathology, John Wiley \& Sons, Queensland, Australia.

Gini, A. 2004, 'Business, ethics and leadership in a post Enron era', Journal of Leadership and Organizational Studies, Volume 11, Number 1, pp. 9-15.

Glaser, B. G. 2007, Doing Formal Grounded Theory, Sociology Press, Mill Valley, California, United States of America.

Glaser, B. G. 1992, Basics of Grounded, Theory Analysis Sociology Press, Mill Valley, California, United States of America.

Glaser, B. G. 1978, Theoretical Sensitivity: Advances in Methodology of Grounded Theory, Sociology Press, Mill Valley, California, United States of America.

Glaser, B. G. and Strauss, A. L. 1967, The Discovery of Grounded Theory, Aldine, Chicago, United States of America, in Merriam, S. B. and Simpson, E. L. 1995, A Guide to Research for Educators and Trainers of Adults, $2^{\text {nd }}$ edition, Krieger Publishing Company, Malabar, Florida, United States of America.

Gobert, J. and Punch, M. 2003, Rethinking Corporate Crime, Butterworths Lexis Nexis, London, United Kingdom.

Goodwin, N. 2002, 'Creating an integrated public sector? Labour's plans for the modernisation of the English health care system’, International Journal of Integrated Care, Volume 2, Number 1, pp. 1-13.

Gottschalk, P. 2010, 'Theories of financial crime’, Journal of Financial Crime, Volume 17, Number 2, pp. 210-222.

Goulding, C. 2002, Grounded Theory: A Practical Guide for Management, Business and Market Researchers, Sage Publications, Thousand Oaks, California, United States of America.

Grabosky, P and Duffield, G. 2001a, 'Red Flags of Fraud', Trends \& Issues in Crime and Criminal Justice, Australian Institute of Criminology, Canberra, Australia, Number, 200, <http://www.aic.gov.au/documents/7/1/8/\{718579B2-A97B-4719-B2AD-01375403D4C4\}ti200.pdf> (16 October 2009).

Grabosky, P and Duffield, G. 2001b, 'The Psychology of Fraud’, Trends \& Issues in Crime and Criminal Justice, Australian Institute of Criminology, Canberra, Australia, Number, 199, <http://www.aic.gov.au/documents/8/2/D/\%7B82DFF3FE-8766-4087-A91B-688EDC200A3C\%7Dti199.pdf> (16 October 2009). 
Grant, D. and Oswick, C. 1996, Metaphors and Organisations, Sage Publications, London, United Kingdom.

Greater Dandenong City Council, 2009, Annual Report, Victoria, Australia, <http://www.greaterdandenong.com/Resources/SiteDocuments/sid1_20082009\%20AnnualReport\%20LowRes .pdf $>$ (30 September 2010).

Griffin, R. W. and O’Leary-Kelly, A. M. 2004, The Dark Side of Organizational Behaviour, Jossey-Bass, San Francisco, United States of America.

Griffin, R. W. O’Leary-Kelly, A. M. and Collins, J.M. 1998, 'Dysfunctional Work Behaviours in Organizations’, in Rousseau, D. M. and Cooper, C. (Eds), 1998, Trends in Organizational Behaviour, John Wiley \& Sons, London, pp. 65-82.

Guba, E. G. 1978, Toward a Methodology of Naturalistic Inquiry in Education Evaluation', UCLA Graduate School of Education, University of California, California, United States of America.

Guba, E. G. and Lincoln, Y. S. 2005, 'Paradigmatic Controversies, Contradictions and Emerging Confluences', in Denzin, N. K. and Lincoln, Y. S. (Eds), 2005, The Sage Handbook of Qualitative Research, Sage Publications, $3^{\text {rd }}$ edition, Thousand Oaks, California, United States of America.

Guba, E. G. and Lincoln, Y. S. 1994, ‘Competing Paradigms in Qualitative Research’ in Denzin, N. K. and Lincoln, Y. S. (Eds), 1994, The Sage Handbook of Qualitative Research, Sage Publications, $1^{\text {st }}$ edition, Thousand Oaks, California, United States of America.

Guba, E. G. and Lincoln, Y. S. 1981, Effective Evaluation, Improving The Usefulness Of Evaluation Results Through Responsive and Naturalistic Approaches, Jossey-Bass Publishers, San Francisco, California, United States of America.

Hair, J. F. Jnr, Black, W. C. Babin, B. J. Anderson, R. E. and Tatham , R. L. 2006, Multivariate Data Analysis, Pearson International Edition, Upper Saddle River, New Jersey, United States of America.

Hall, R. F. Keane T. P. McConnell, C. and Becker, S. 2005, 'The $21^{\text {st }}$ century board: structure, responsibility, assessment', Journal of Leadership and Organisational Studies, Volume 11, Issue 3, pp. 62-72.

Hamilton, S. 2004, 'Enron Unravelled', European Business Forum, Summer, Issue 18, pp. 66-71.

Harris, L. 2005, 'UK public sector reform and the "performance agenda” in UK local government: HRM challenges and dilemmas', Personnel Review, Volume 34, Issue 6, pp. 681-696.

Hartley, R. 2005, Business Ethics: Mistakes and Successes, $1^{\text {st }}$ edition, John Wiley and Sons, United States of America.

Henry, S. 1978, The Hidden Economy, Martin Robinson, Oxford, United Kingdom cited in Punch, M. 1996, Dirty Business, Exploring Corporate Misconduct, Analysis and Cases, Sage Publications, London, United Kingdom.

Herzberg, F. Mausner, B. and Snyderman, B. 1959, The Motivation to Work, John Wiley \& Sons, United States of America.

Higgs, D. 2002, Report on the Role and Effectiveness of Non-Executive Directors, Department of Trade and Industry, United Kingdom, <http://www.dti.gov.uk/cld/non_exec_review/pdfs/higgsreport.pdf > (17 June 2004).

Higher Education Funding Council for England, 2008, Handbook for Members of Audit Committees in Higher Education Institutions, London, United Kingdom, <http://www.hefce.ac.uk/pubs/hefce/2008/08_06/08_06.doc> (10 May 2010).

HIH Royal Commission, 2003, The Failure of HIH Insurance, Volume 1, April, Canberra, Australia.

Hillman, A. J. Cannella, A. A. and Paetzold, R. L. 2000, 'The resource dependence role of corporate directors: Strategic adaptation of board composition in response to environmental change', Journal of Management Review, Volume 37, Number 2, pp. 235-255.

Hillman, A. J. and Dalziel, T. 2003, 'Boards of directors and firm performance: Integrating agency and resource dependent perspectives', Academy of Management Review, Volume 28, Issue 3, pp. 383-396. 
Hitt, W. D. 1995, 'The learning organisation: Some reflections on organisational renewal', Leadership \& Organisational Development Journal, Volume 16, Number 8, 1995, pp. 17-25.

HM Treasury, 2007, Audit Committee Handbook, London, United Kingdom, <http://www.hm-treasury.gov.uk/d/auditcommitteehandbook140307.pdf> (12 October 2009).

HM Treasury, 1998a, Comprehensive Spending Review, London, United Kingdom, $<$ http://www.hm-treasury.gov.uk/d/460.pdf> (29 May 2009).

HM Treasury, 1998b, Public Services for the Future: Modernisation, Reform, Accountability, London, United Kingdom, <http://www.hm-treasury.gov.uk/d/13.pdf> (29 May 2009).

Hobsons Bay City Council, 2009, Ordinary Council Meeting Minutes, 10 February, Victoria, Australia, <http://www.hobsonsbay.vic.gov.au/Files/Minutes_10_February_2009.pdf> (14 April 2010).

Hodgkinson, P, 1997, 'The sociology of corruption, some issues and themes', Sociology, Volume 31, Number 1, pp. 17-35.

Hogan, R. and Hogan, J. 2001, ‘Assessing leadership: A View from the dark side’, International Journal of Selection and Assessment, Volume 9, Number 1/2, March/June, pp. 40-51.

Holroyd City Council, 2009, Annual Report, New South Wales, Australia, $<$ http://www.holroyd.nsw.gov.au/_data/assets/pdf_file/0020/18461/AnnualReport0809.pdf> (30 September 2010).

Hong Kong Institute of Certified Public Accountants, 2004, Corporate Governance for Public Sector Bodies: A Basic Framework, Hong Kong, <http://www.ifac.org/store/Details.tmpl?SID=9977171891360\&Cart=1244584773177498> (12 June 2009).

Hong Kong Society of Accountants, 2002, A guide for effective audit committees, Hong Kong, <http://app1.hkicpa.org.hk/publications/audit/audite.pdf> (15 December 2009).

Hoque, Z. 2005, 'Securing institutional legitimacy or organizational effectiveness? A case examining the impact of public sector reform initiatives in an Australian local authority', Journal of Public Sector Management, Volume 18, Issue 4, pp. 367-382.

Howe, K. R. 1988, ‘Against the quantitative-qualitative incompatibility thesis or dogmas die hard', Educational Researcher, Volume 17, Number 8, pp. 10-16.

Hua, W. 2003, 'Social exchange model of subordinate's trust in supervisors', paper presented at the Annual Meeting of the Academy of Management, August, Seattle, United States of America.

Hughes M. 2002, ‘Audit committees need right resources to take tough line', The Times, November 14, p. 37.

Humphrey, C. 2008, 'Auditing research: a review across the disciplinary divide', Accounting, Auditing and Accountability Journal, Volume 21, Number 2, pp. 170-203.

Iles V. and Sutherland K. 2001, Organisational Change - A Review for Health Care Managers, Professionals and Researchers, <http://www.sdo.lshtm.ac.uk/pdf/changemanagement_review.pdf> (15 April 2005)

Independent Commission Against Corruption, 2009a, Investigation into attempts to improperly influence Warringah Council Officers, Sydney, Australia,

$<$ https://www.icac.nsw.gov.au/files/pdf/Bauer_Report_for_web.pdf> (9 July 2009).

Independent Commission Against Corruption, 2009b, Attempts to improperly influence a Ku-ring-gai Council Officer, Sydney, Australia, <https://www.icac.nsw.gov.au/files/pdf/Capella_Investigation_Report_for_web.pdf> (9 July 2009).

Independent Commission Against Corruption, 2008a, Corruption Risk Management, Sydney, Australia, <http://www.icac.nsw.gov.au/files/pdf/Corruption_risk_management_web.pdf> (18 December 2008).

Independent Commission Against Corruption, 2008b, Report On Investigation into Corruption Allegations Affecting Wollongong City Council - Part 3, Sydney, New South Wales, Australia, $<$ http://www.icac.nsw.gov.au/files/pdf/Part_1pdf>21 March 2009). 
Independent Commission Against Corruption, 2008c, Report On Investigation into Corruption Allegations Affecting Wollongong City Council - Part 2, Sydney, New South Wales, Australia, $<$ http://www.icac.nsw.gov.au/files/pdf/Report_on_investigation_into_corruption_ allegations_affecting_Wollongong_City_Council__Part_2.pdf> (17 September 2009).

Independent Commission Against Corruption, 2008d, Report On Investigation into Corruption Allegations Affecting Wollongong City Council - Part 1, Sydney, New South Wales, Australia, $<$ http://www.icac.nsw.gov.au/files/pdf/Part_1.pdf> (17 September 2009).

Independent Commission Against Corruption, 2007a, Report on An Investigation into Allegations Of Bribery Relating To Wollongong City Council, Sydney, New South Wales, Australia, $<$ http://www.icac.nsw.gov.au/files/pdf/Berna_report_web.pdf> (21 March 2009).

Independent Commission Against Corruption, 2007b, Bankstown and Strathfield councils - Corrupt Manipulation of Contract Procurement Procedures, Sydney, New South Wales, Australia, <http://www.icac.nsw.gov.au/files/pdf/Torrens_report_web2.pdf> (21 March 2009).

Independent Commission Against Corruption, 2005, Report on investigation into Certain Transactions of Koompahtoo Local Aboriginal Land Council, Sydney, New South Wales, Australia, $<$ http://www.icac.nsw.gov.au/index.cfm?objectID=C81490DF-0E61-B5EA45824C54E99C95AB\&NavID=262BA41B-D0B7-4CD6-F955BD8CEE4CDF37> (25 March 2009).

Independent Commission Against Corruption, 2000, Report on investigation into Aboriginal Land Councils in New South Wales: Corruption Prevention and Research Volume, Sydney, New South Wales, Australia, $<$ http://www.icac.nsw.gov.au/index.cfm?objectID=E29C4880-0863-20F8A498F354C4D69376\&NavID=262BA41B-D0B7-4CD6-F955BD8CEE4CDF3> (25March 2008).

Independent Commission Against Corruption, 1998, Minimising Corruption: Some Lessons from the Literature, Sydney, New South Wales, Australia, <http://www.icac.nsw.gov.au/files/pdf/pub2_10r1.pdf>(13 August 2009).

Independent Commission Against Corruption, 1997, Corruption and Related Matters, An Annotated Bibliography, Sydney, New South Wales, Australia, <http://www.icac.nsw.gov.au/files/pdf/pub2_6r.pdf> (23 August 2009).

Inspector of Municipal Administration, 2009, Report on Brimbank Council, Government Victoria, Melbourne Victoria, Australia,

$<$ http://www.dvc.vic.gov.au/Web20/rwpgslib.nsf/GraphicFiles/Report+on+Brimbank+City+Council/\$file/Brimban k+City+Council+-+Report+2+-+Sept09.pdf> (15 September 2009).

Inspector of Municipal Administration, 2008, Investigation into Ballarat City Council, September, Local Government Victoria, Melbourne Victoria, Australia, $<$ http://www.dvc.vic.gov.au/Web20/rwpgslib.nsf/GraphicFiles/Investigation+into+Ballarat+City+Council+pdf/\$f ile/Investigation+into+Ballarat+City+Council+-+Sept+08.pdf> (20 December 2008).

Inspector of Municipal Administration, 2006, Report on Investigation into Greater Geelong City Council, 25 May 2006, Local Government Victoria, Melbourne Victoria, Australia, <http://www.localgovernment.vic.gov.au/web20/rwpgslib.nsf/GraphicFiles/Investigation GeelongCityCouncil/\$file/InvestigationGeelongCityCouncil.pdf> (21 March 2008).

Inspector of Municipal Administration, 2005, Report of Investigation into Glen Eira City Council, July, Local Government Victoria, Melbourne Victoria, Australia,

$<$ http://www.localgovernment.vic.gov.au/web20/rwpgslib.nsf/GraphicFiles/Geln+Eira+City+Council+Part+A+no +1/\$file/2005+July+-+Glen+Eira+City+Council+Pt+A+no+1.pdf> (21March 2008).

Inspector of Municipal Administration, 2002, Investigation into Surf Coast Shire Council Report, Melbourne, Victoria, Australia,

$<$ http://www.dvc.vic.gov.au/web20/rwpgslib.nsf/GraphicFiles/Surf+Coast+Review+

Report+Oct+02+no+9/\$file/Surf+Coast+Review+Report+-+Oct+2002+no+9.pdf > (21 March 2008).

Institut Francais des Administrateurs, 2008, 100 Bonnes Pratiques Pour Guider le Comité d'Audit, Paris, France, <www.leclubdesjuristes.com/.../IFA\%20les\%20comites\%20d\%20audit\%20100\%20bonnes\%20pratiques.pd.> 15 December 2009).

Institute of Chartered Accountants in Australia, 2010, Annual Report, Sydney, Australia, $<$ http://www.charteredaccountants.com.au/files/documents/BC_Annual_Report_Full_2010.pdf> (29 October 2010). 
Institute of Chartered Accountants in Australia, 2009, Victorian City Council Model Budget 2009/2010 Guide, $7^{\text {th }}$ edition, Sydney, Australia, <http://www.charteredaccountants.com.au/files/documents/ModelBudget FULLVERSIONyearend30June2010.pdf> (20 July 2009).

Institute of Internal Auditors, 2006, The Role of Auditing in Public Sector Governance, Altamonte Springs, Florida, United States of America,

$<$ http://www.theiia.org/guidance/additional-resources/corporate-governance/index.cfm?i=6711> (15 December 2009).

Institute of Internal Auditors, 2005a, 'Meeting new audit committee challenges', Tone at the Top, September, pp. 1-4 <http://www.theiia.org/?doc_id=739> (13 October 2005).

Institute of Internal Auditors, 2005b, 'A call for character and integrity', Tone at the Top, June, pp. 1-4, $<$ http://www.theiia.org/?doc_id=739> (13 October 2005).

Institute of Internal Auditors, 2003, Audit committees: are you in compliance?’ Tone at the Top, March, 17, <http://www.theiia.org/iia/publications/newsletters/ToneAtTheTop/MAR03TAT.pdf> (17 June 2004).

Institute of Public Finance, 2006, A toolkit for local authority audit committees, $<$ http://www.tisonline.net/internalaudit/content/A_Toolkit_for_Local_Authority_Audit_Committees_2006.pdf > (17 January 2012).

International Federation of Accountants, 2008, Evaluating and Improving Governance in Organizations, Exposure Draft, June, New York, United States of America, $<$ http://www.ifac.org/Guidance/EXD-Details.php?EDID=0115> (8 April 2009).

International Federation of Accountants, 2001, Governance in the Public Sector, A Governing Body Perspective, New York, United States of America, $<$ http://www.ifac.org/store/Details.tmpl?SID=9977171891360\&Cart=1244584773177498> (12 June 2009).

Issac-Henry, K, and Painter, C, 1991, 'Organisational response to environmental turbulence: The management of change in English local government', The International Journal of Public Management, Volume 4, Number 4, pp. 5-20.

Janis, I. L. 1972, Victims of groupthink, Houghton Mifflin, Boston, United States of America.

Janis, I. L. 1982, Stress, attitudes and decisions, Praeger Publications, New York, United States of America.

Janis, I. L. 1983, Groupthink, $2^{\text {nd }}$ edition, Houghton Mifflin, Boston, United States of America.

Jaspan, N. 1988, 'White collar fraud - a management perspective', CPA Journal, November, Volume 58, Number 11, pp. 12-20.

Jennings, M. M. 2005, 'The legal vs ethical distinction and why we care', Corporate Finance Review, Volume 10 Number 2, pp. 42-47.

Jensen, M. C. 2001, 'Value Maximization, Stakeholder Theory, and the Corporate Objective Function', in Chew, D. and Gillan, S. (Eds), 2005, Corporate Governance at the Cross Roads: A Book of Readings, McGraw-Hill/Irwin, New York, New York State, United States of America, pp. 7-20.

Jensen, M.C. 1986, ‘Agency costs of free cash flow, corporate finance, and takeovers', American Economic Review, Volume 76, Number 2, pp. 323-329.

Jensen, M. C. and Meckling W. H. 1976, 'Theory of the firm: Managerial Behavior, Agency Costs and Ownership Structure', Journal of Financial Economics, Volume 3, Number 4, pp. 305-360.

Jimenez, C. 2002, 'Harris Scarfe CFO guilty of dishonesty’, The Australian, 20 April $<$ http://0-global.factiva.com.alpha2.latrobe.edu.au/en/arch/display.asp> (19 August 2005).

Jones, B. M. 2001, Narrative Identity in Transition: The Lived Experience of an Organisational Merger in Local Government, PhD Thesis, Swinburne University of Technology, Victoria, Australia.

Jones, C. R. 2005, Best Practice Features and Practices Guiding Community Service Organisations, DBA Thesis, Southern Cross University, New South Wales, Australia.

Jones, J. W, 2009, 'Selection of grounded theory as an appropriate research methodology for a dissertation: One student’s perspective’, The Grounded Theory Review, Volume 8, Number 2, pp. 23- 34.

Jones, M. A. 1989, Managing Local Government, Leadership for the $21^{\text {st }}$ Century, Hargreen Publishing Company, West Melbourne, Australia. 
Jones, M. A. 1981, Local Government and the People, Challenges for the Eighties, Hargreen Publishing Company, West Melbourne, Australia.

Jones, R. 1999, 'Implementing decentralised reform in local government: Leadership lessons from the Australian experience', The International Journal of Public Sector Management, Volume 12, Number 1, pp. 63-76.

Jones, R. Lasky B. Russell-Gale, H. and le Fevre, m. 2004, 'Leadership and the development of dominant and countercultures: A narcissistic perspective', Leadership and Organizational Development Journal, Volume 25, Number 2, pp. 216-233.

Johnson, R. A. 2008, 'Disentangling corruption and democracy', The Journal of Social, Political and Economic Studies, Volume 33, Number 3, pp. 371-379.

Johnson, R. B and Onwuegbuzie, A. J. 2004, 'Mixed methods research: A research paradigm whose time has come’, Educational Researcher, Volume 33, Number 7, pp. 14-26.

Jubb, C. A. 2000, Choosing an Auditor: Corporate Governance, Interpersonal Associations and Investor Confidence, $\mathrm{PhD}$ Thesis, University of Melbourne, Victoria, Australia.

Kalbers, L. P. and Fogarty, T. J. 1998, 'Organizational and economic explanations of audit committee oversight’, Journal of Managerial Issues, Volume 10, Number 2, pp. 129-151.

Kalbers, L. P. and Fogarty, T. J. 1993, 'Audit committee effectiveness: An empirical investigation of the contribution of power’, Auditing, Sarasota, Spring, Volume 12, Issue 1, pp. 24-50.

Kant, I. 2010, The Critique of Pure Reason, $2^{\text {nd }}$ edition, translated by Meiklejohn, J. M. D. Electronic Classics Series, The Pennsylvania State University, Pennsylvania, United States of America, $<$ http://www2.hn.psu.edu/faculty/jmanis/kant/Critique-Pure-Reason6x9.pdf> (13 August 2012).

Karpoff, J. M. Lee, D. S. and Martin, G. S. 2008, ‘Consequences to managers for financial misrepresentation’, Journal of Financial Economics, Volume 88, Number 2, pp. 193-215.

Kelly, C. 2005, Corporate Governance Mechanisms and Small Cap Firm Performance, Evidence for Canada, Master of Science in Administration Thesis, Concordia University, Montreal, Canada.

Kets de Vries, M. 2004a, 'Organizations on the couch: A clinical perspective on organizational dynamics', European Management Journal, Volume 22, Number 2, pp. 183-200.

Kets de Vries, M. 2004b, 'Cultural approaches to management', Management Decision, Volume 42, Number 7, pp. 925-931.

Kets de Vries, M. 2001, The Leadership Mystique, Prentice-Hall, London, United Kingdom.

Kets de Vries, M. 1997, The dark side of leadership what drives people to become leaders? The Antidote, Issue 6, pp. 11-13.

Kets de Vries, M. 1994, ‘The leadership mystique’, Academy of Management Executive, Volume 8, Number 3, pp. 73-92.

Kets de Vries, M. 1991, Organizations on the Couch, Clinical Perspective on Organizational Behavior and Change, Jossey-Bass, San Francisco, California, United States of America.

Kets de Vries, M. and Miller D. 1987, Inside the Troubled Organization, Unstable at the Top, New American Library, New York, United States of America.

Kets de Vries, M. 1984a, The Irrational Executive, Psychoanalytic Explanations in Management, International Universities Press, Madison Connecticut, United States of America.

Kets de Vries, M. 1984b, 'Neurotic and organisational pathology', Strategic Management Journal, Volume 5, Number 1, pp. 35-55.

Khancel, I. 2007, 'Corporate governance: measurement and determinant analysis’, Managerial Auditing Journal, Volume 22, Number 8, pp. 740-760.

Kiel, G. C. and Nicholson, G. J. 2003, 'Board composition and corporate performance: how the Australian experience informs contrasting theories of corporate governance', Corporate Governance: An International Review, Volume 11, Issue 3, pp. 189-205. 
King, M.E. 2002, Executive Summary, Committee on Corporate Governance, Parktown, South Africa, <http://www.ecseonline.com/PDF/King\%20Committee\%20on\%20Corporate\%20Governance\%20\%20Executive\% 20Summary\%20of\%20the\%20King\%20Report\%202002.pdf> (13 April 2009).

Klein, A. 2002, 'Audit committee, board of director characteristics and earning management', Journal of Accounting and Economics, Volume 33, Number 3, pp. 375-401.

Kloot, L. 1995, Management Control Systems and Organisational Learning in a changing environment: An Investigation in an Industry undergoing Coercive Environment Change, $\mathrm{PhD}$ Thesis, Swinburne University of Technology, Victoria, Australia.

Kloot, L. and Martin, J. 2007, 'Research and evaluation: Public sector change, organisational culture and financial information: A study of local government', Australian Journal of Public Administration, December, Volume 66, Issue 4, pp. 485-506.

Kloot, L. and Martin, J. 2000, 'Strategic performance management: A balanced approach to performance management issues in local government', Management Accounting Research', Volume 1, Number 2, pp. 1-22.

Kolodinsky, J. Reynolds, T. W. Cannella, M. Timmons, D. Bromberg, D. 2009, 'US Consumer Demand for Restaurant Calorie Information: Targeting Demographic and Behavioural Segments in Labelling Initiatives', American Journal of Health Promotion,' Volume 24, Number 1, pp. 11-14.

Kosnik, R. D. 1987, 'Greenmail: A study of board performance in corporate governance', Administrative Science Quarterly, Volume 32, Issue 2, pp. 163-185.

KPMG, 2010, Fraud and Misconduct Survey 2010,

$<$ http://www.kpmg.com/AU/en/IssuesAndInsights/ArticlesPublications/Fraud-Survey/Documents/Fraud-andMisconduct-Survey-2010.pdf $>$ (12 February 2012).

KPMG, 2009, Highlights from the $5^{\text {th }}$ Annual Audit Committee Issues Conference, $<$ http://www.kpmg.com/aci/docs/issuesconference/2009AuditCommitteeIssuesConfHighlights.pdf> (15 December 2009).

KPMG, 2008a, Fraud Survey 2008, <http://www.kpmg.com.au/Portals/0/Fraud\%20Survey\%202008.pdf> (22 August 2009).

KPMG, 2008b, Audit Committee Insights, A Survey of Australian Audit Committees, $<$ Audit Committee Insights, A Survey of Australian Audit Committees> (15 December 2009)

KPMG, 2006, Agents of Change, A Survey of Australian Audit Committees and Comparison with International Experience, <http://www.kpmg.com.au/aci/pubs.htm> (15 December 2007).

KPMG, 2003, An Approach to Effective Audit Committee Self Evaluation, $<$ http://www.kpmg.com/aci/docs/selfevaluation.pdf $>$ (17 June 2004)

Krambia-Kapardis, M. 2001, Enhancing the Auditor’s Fraud Detection Ability: An Interdisciplinary Approach, Peter Lang Publishing, Frankfurt, Germany.

Krishnamoorthy, G. Wright, A. and Cohen, J. 2002a, ‘Auditors’ views on audit committees and financial reporting quality’, CPA Journal, The New York State Society of CPA, Volume 72, Number 10, pp. 56-57.

Krishnamoorthy G. Wright A. and Cohen J. 2002b, 'Audit committee effectiveness and financial reporting quality: Implications for auditor independence’, Australian Accounting Review, Volume 12, Issue 28, pp. 3-13.

Kuhn, T. S. 1996, The Structure of Scientific Revolutions, $3^{\text {rd }}$ edition, University of Chicago Press, Chicago, Illinois, United States of America.

Lagan, A. 2005a, A View from the Top, Business Ethics and Leadership, KPMG, $<$ http://www.kpmg.com.au/Portals/0/rasbas_view-from-the-top200510.pdf> (13 February 2005).

Lagan, A. 2005b, 'Boards must put backbone into their tone at the top', The Age, 10 November, p. 10.

Lagan, A. and Moran B. 2006, 3D Ethics, Implementing Workplace Values, Content Management Pty Ltd, Maleny, Queensland, Australia.

Lakoff, G. and Johnson, M. 1980, Metaphors we Live by, The University of Chicago Press, Chicago, Illinois, United States of America. 
Lampe, A. 2005, 'Judge takes One.Tel report apart', The Age, 12 July $<$ http://0-global.factiva.com.alpha2.latrobe.edu.au/en/arch/display.asp> (19 August 2005).

Lancy, D F. 1993, Qualitative Research in Education: An Introduction to the Major Traditions, Longman, New York, United States of America.

Lederman, D. Loayza, N. V. and Soares, R. R, 2005, 'Accountability and corruption: Political institutions matter', Economics and Politics, Volume 17, Number 1, pp. 1-35.

Leroux, J. Rizzo, J. A. Sickles R. 2010, 'The role of self-reporting bias in health, mental health and labor force participation: A descriptive analysis’, Empirical Economics, published online 29 December 2010 < http://www.springerlink.com/content/843x86124367370j/>(15 March 2012).

Leung, S. 2011, 'A comparison of psychometric properties and normality in 4-, 5-, 6-, and 11- point Likert scales', Journal of Social Service Research, Volume 37, Issue 4, pp. 412-421.

Leung, P. and Cooper, B. J. 2003, 'The mad hatter's corporate tea party', Managerial Auditing Journal, Volume 18, Number 6/7, pp. 505-516.

Lewin, K. 1951, Field Theory in Social Sciences, Harper Row, New York, United Sates of America.

Liggio, C. 1974, 'The expectation gap: The accountants Waterloo?' Journal of Contemporary Business, Volume 3, Number 3, pp. 27-44.

Lightle, S. S. Bushong, J. G. 2000, 'The role of internal audit in the effort to improve audit committee effectiveness’, Ohio CPA Journal, October-December Volume 59, Issue 4, pp. 39-43.

Lincoln, Y.S. 1990, ‘Towards a Categorical Imperative for Qualitative Research', in Eisner, E.W. and Peshkin, A. (Eds), 1990, Qualitative Inquiry in Education: The Continuing Debate, Teachers College Press, New York, United States of America.

Lincoln, Y. S Guba, E. G. 1989, Fourth Generation Evaluation, Sage Publications, Newbury Park, California, United States of America.

Lincoln, Y. S Guba, E. G. 1986, 'Research, evaluation and policy analysis: Heuristics for disciplined inquiry', Policy Studies Review, Volume 5, Number 3, pp. 546-565.

Lincoln, Y. S Guba, E. G. 1985, Naturalistic Inquiry, Sage Publications, Newbury Park, California, United States of America.

Lincoln, Y. S Guba, E. G. 1982, 'Epistemological and methodological bases of naturalistic inquiry', Educational Technology Research and Development, Volume 30, Number 4, pp. 233-252.

Lincoln, Y. S Guba, E. G. 1981, Effective Evaluation, Jossey-Bass, San Francisco, United States of America.

Linder, J. R. Murphy T. H. and Briers, G. E. 2001, 'Handling nonresponse in social science research', Journal of Agricultural Education, Volume 42, Number 4, pp. 43-53.

Livingston, P. 2003, 'Financial experts on audit committees-an overdue implementation', Financial Executive, January February, Volume 19, Issue 1, pp. 6-7.

Local Government Professionals, 2009, 2008 CEO Development Project, South Melbourne, Victoria, Australia.

Local Government Victoria, 2009a, Conflict of Interest in Local Government: A Guide, Melbourne, Victoria, Australia

<http://www.dvc.vic.gov.au/Web20/rwpgslib.nsf/GraphicFiles/Conflict+of+Interest+in+Local+Government +PDF/\$file/Conflict+of+Interest+in+Local+Government.pdf> (8 May 2009).

Local Government Victoria, 2009b, Register of Interests Guide, Melbourne, Victoria, Australia, <http://www.dvc.vic.gov.au/Web20/rwpgslib.nsf/GraphicFiles/Register+of+Interests+Guide/\$file/2009+Register+ of+Interests+Guide.pdf $>$ (July 2009).

Local Government Victoria, 2009c, Guide to Councillor Conduct Arrangements, Melbourne, Victoria, Australia, <http://www.dvc.vic.gov.au/Web20/rwpgslib.nsf/GraphicFiles/2009+Guide+to+Councillor+Conduct+ Arrangements+PDF/\$file/2009+Guide+to+Councillor+Conduct+Arrangements.pdf> (9 July 2009).

Local Government Victoria, 2009d, The Mayor and Councillor Entitlements Information Guide, Melbourne, Victoria, Australia,

$<$ http://www.dvc.vic.gov.au/Web20/rwpgslib.nsf/GraphicFiles/Mayor+and+Councillor+Entitlements +Information+Guide+March+2009/\$file/2008+Mayor+Cllrs+Entitlement+-+Info+Guide+-+Nov+08+.doc> (9 July 2009). 
Local Government Victoria, 2008a, Mildura Rural City Council, <http://www.localgovernment.vic.gov.au/web20/dvclgv.nsf/AllDocs/27EC5AE7DF0CFECCCA2571610027AEC 2?OpenDocument) <21 August 2008).

Local Government Victoria, 2008b, Swan Hill Rural City Council, <http://www.localgovernment.vic.gov.au/web20/dvclgv.nsf/allDocs/RWP73AB08D7FA CCAF58CA2571960029BB5C?OpenDocument> (21 August 2008).

Local Government Victoria, 2008c Wangarratta City Council, <http://www.localgovernment.vic.gov.au/web20/dvclgv.nsf/AllDocs/367CF7C1FC8F1DA2CA2571680033E1A4? OpenDocument> (21 August 2008).

Local Government Victoria, 2008d, Moyne Shire Council, <http://www.localgovernment.vic.gov.au/web20/dvclgv.nsf/AllDocs/B0E7AE8B90C8FEE4CA25716800318E6A ?OpenDocument> (21 August 2008).

Local Government Victoria, 2008e, Mansfield Shire Council, <http://www.localgovernment.vic.gov.au/web20/dvclgv.nsf/AllDocs/E66CE60796EA20A7CA25716100270782? OpenDocument> (21 August 2008).

Local Government Victoria, 2008f, Wellington Shire Council, $<$ http://www.localgovernment.vic.gov.au/web20/dvclgv.nsf/AllDocs/375F0E565EC35FB1CA257168003486C7? OpenDocument>21 August 2008).

Local Government Victoria, 2008g, Manningham City Council, $<$ http://www.localgovernment.vic.gov.au/Web20/dvclgv.nsf/allDocs/RWPD78BB9B63F381A47CA2571610026E A73?OpenDocument> (21 August 2008).

Local Government Victoria, 2008h, Whitehorse City Council, <http://www.localgovernment.vic.gov.au/web20/dvclgv.nsf/AllDocs/C9F67AF6283ED9BDCA25716800351FBC ?OpenDocument> (21 August 2008).

Local Government Victoria, 2008i, Yarra City Council, <http://www.localgovernment.vic.gov.au/web20/dvclgv.nsf/AllDocs/F2CE1D8AF98A0FDDCA2571680035BD95 ?OpenDocument> (21 August 2008).

Local Government Victoria, 2008j, Ensuring Unbiased Democratic Council Decision Making: Principles to Guide Good Practice, Melbourne, Victoria, Australia, $<$ http://www.dvc.vic.gov.au/Web20/rwpgslib.nsf/GraphicFiles/Ensuring+Unbiased+Democratic+Council+ Decision+Making:+Principles+to+Guide+Good+Practice+ $(\mathrm{PDF}+234 \mathrm{~kb}) /$ file/Ensuring+Unbiased+Democratic+ Council+Decision+Making+-+Sept+08.pdf> (9 July 2009).

Local Government Victoria, 2008k, Recognition and Support: The Victorian Government's Policy Statement on Local Government Mayoral and Councillor Allowances and Resources, Melbourne, Victoria, Australia, $<$ http://www.dvc.vic.gov.au/Web20/rwpgslib.nsf/GraphicFiles/Policy+Statement+-

+Recognition+and+Support/\$file/2008+Policy+Statement+-+Recognition+and+Support.pdf> (9 July 2009).

Local Government Victoria, 2007a, Local Government Community Satisfaction Survey, Melbourne, Victoria, Australia, <http://www.localgovernment.vic.gov.au/Web20/rwpgslib.nsf/GraphicFiles/2007_ LG_Satisfaction_Survey_State_Wide/\$file/20-09-07+2007+LG+Community+Satisfaction+Survey. Pdf> (14 April 2007).

Local Government Victoria, 2007b, Better Local Governance Consultation Paper, Melbourne, Victoria, Australia, <http://www.dvc.vic.gov.au/Web20/rwpgslib.nsf/GraphicFiles/Better+Local+Governance+ PDF/\$file/Better+Local+Government+-+Consultation+Paper+.pdf> (9 July 2009).

Local Government Victoria, 2004, Model Code of Conduct for Victorian Councils, Melbourne, Victoria, Australia, <http://www.localgovernment.vic.gov.au/web20/rwpgslib.nsf/GraphicFiles/Model+Code+of+ Conduct+or+Victorian+Councils.pdf/\$file/Model+Code+of+Conduct+for+Victorian+Councils.pdf $>$ (20 June 2008).

Local Government Victoria, 2003, Sustaining Local Assets, Melbourne, Victoria, Australia, $<$ http://www.localgovernment.vic.gov.au/web20/rwpgslib.nsf/GraphicFiles/OP+Sustaining+Local+Asset+Dec +0 3+no+3/\$file/OP+Sustaining+Local+Asset+-+Dec+2003+no+3.pdf> (20 June 2008).

Long, S. 2008, The perverse organisation and its deadly sins, Karnac Books Ltd, London, United Kigdom. 
Lowe, A. 2010, 'Fraud Charges dismissed: Ex Mayor has no case to answer', The Age, 12 October, $<$ http://www.theage.com.au/victoria/fraud-claims-dismissed-ex-mayor-has-no-case-to-answer-2010101216gsg.html> (12 October 2010).

Lowenstein, D. H. 1989, 'Legal Efforts to Define Political Bribery’, in A. J. Heidenheimer, M. Johnson and V. T. LeVine (eds) Political Corruption A Handbook, New Brunswick, NJ: Transaction Books cited in Werlin, H. 1994, 'Revisiting corruption: With a new definition', International Review of Administrative Sciences, Volume 60, Number 4, pp. 547-558.

Lynn, P. and Clarke, P. 2002, 'Separating refusal bias and non-contact bias: Evidence from UK national surveys’, The Statistician, Volume 51, Number 3, pp. 319-333.

Maccoby, M. 2005, ‘Creating moral organisations’, Research Technology Management, January/February, Volume 48, Number 1, pp. 59-60.

Maccoby, M. 2000, 'Narcissistic leaders: The incredible pros, the inevitable cons’, Harvard Business Review, January-February, pp. 69-77.

Macrosson, W.D.K. and Hemphill, D. J. 2001, ‘Machiavellianism in Belbin team roles', Journal of Managerial Psychology, Volume 16, Number 5, pp. 355-363.

Mador, M. Springdal, K. and Dixon, S. 2008, 'Quasi-privatisation and corporate governance: A process perspective’, Corporate Governance, Volume 8, Number 5, pp. 595-606.

Magrane, J. and Malthus, S. 2010, 'Audit committee effectiveness: A public sector case study’, Managerial Auditing Journal, Volume 25, Number 5, pp. 427-443.

Main, A. 2005a, 'Far cry from boardroom to correction centre', Australian Financial Review, 13 May $<$ http://0-global.factiva.com.alpha2.latrobe.edu.au/en/arch/display.asp> (19 August 2005).

Main, A. 2005b, 'HIH ex-director shown door', Australian Financial Review, 29 July <http://0-global.factiva.com.alpha2.latrobe.edu.au/en/arch/display.asp> (19 August 2005).

Main, A. 2005c, 'Shortfall spelt out, court told', Australian Financial Review, 9 August <http://0-global.factiva.com.alpha2.latrobe.edu.au/en/arch/display.asp> (19 August 2005).

Malkovic, T. 2011, ‘Gender agenda’, Charter, September, pp. 16-18.

Manz, C. \& Sims, H. P. 1982, The potential for groupthink in autonomous workgrops, Human Relations, Volume 35, Number 9, pp. 773-784.

Manningham City Council, 2006, Councillor’s Reference Manual, Doncaster, Victoria, Australia.

Marnet, O. 2008, Behaviour and Rationality in Corporate Governance, Routledge (Taylor and Francis Group), Abingdon, United Kingdom.

Marnet, O. 2007, 'History repeats itself: The failure of rational choice models in corporate governance', Critical Perspectives on Accounting, Spring 2007, Vol. 18, No 2, pp. 191-210.

Marnet, O. 2005, 'Behaviour and rationally in corporate governance', Journal of Economic Issues, September 2005, Vol. 39, No. 3, pp. 613-632.

Marnet, O. 2004, 'Behavioural aspects of corporate governance', Advances in Financial Economics, October 2004, Vol. 9, pp. 265-286.

Martin, S. 1997, 'Leadership, learning and local democracy: Political dimensions of the strategic management of change', The International Journal of Public Sector Management, Volume 10, Number 7, pp. 534-536.

Martins, E. C. and Terblanche, F. 2003, 'Building organizational culture that stimulates creativity and innovation’, European Journal of Management, Volume 6, Issue 1, pp. 64-74.

Maxwell, J. A and Loomis, D. M. 2003, 'Mixed methods design: An alternative approach', in Tashakkori, A. and Teddlie, C. (Eds), 2003, Handbook of Mixed Methods in Social and Behavioural Research, Sage Publications, Thousand Oaks, California, United States of America, pp. 189-208.

McMullen, D. A. and Raghunandan, K. 1996, ‘Enhancing audit committee effectiveness’, Journal of Accountancy, Volume 182, Issue. 2, pp. 79-82. 
Melendy, S. 2005, The Role of Compliance Committees in Corporate Governance, PhD Thesis, State University of New York, Buffalo, New York, United States of America.

Menon, K and Williams, J. D. 1994, 'The use of audit committees for monitoring', Journal of Accounting and Public Policy, Volume 13, Issue 2, pp. 121-139.

Merriam, S. B. and Simpson, E. L. 1995, A Guide to Research for Educators and Trainers of Adults, $2^{\text {nd }}$ edition, Krieger Publishing Company, Malabar, Florida, United States of America.

Mertens, D. M. 2005, Research and Evaluation in Education and Psychology, $2^{\text {nd }}$ Edition, Sage Publications, Thousand Oaks, California, United States of America.

Meyer, J. W. and Rowan, B. 1977, 'Institutionalized organizations: Formal structure as myth and ceremony', American Journal of Sociology, Volume 83, Number 2, pp. 340-363.

Midwinter, A.2001,' New Labour and the modernisation of British local government: A critique', Financial Accountability \& Management, Volume 17, Issue 4, pp. 311-321.

Miller, L. E. and Smith, K. L. 1983, 'Handling nonresponse issues', Journal of Extension, Volume 21, Number 5, pp. 45-50.

Mitchell, D. H. \& Eckstein, D. Jury dynamics and decision-making: A prescription for groupthink, International Journal of Academic Research, Volume 1, Number 1, pp. 163-169.

Mohamed, E. and Hussain, M. M. 2005, 'The role of the audit committees in enhancing a transparent corporate Reporting', Humanomics, Volume 21, Number 1 / 2, pp. 30-47.

Monem, R. 2011, 'The One.Tel collapse: lessons for corporate governance', Australian Accounting Review, Volume 21, Number 4pp., pp. 340-351.

Moreland City Council, 2003, Audit Committee Members Questionnaire, Victoria, Australia.

Moreland City Council, undated, Terms of Reference of the Audit Committee,, Victoria, Australia. $<$ http://www.moreland.vic.gov.au/mccwr/meetings/committees/terms-of-reference/terms\%20of\%20reference\%20\%20special\%20-\%20audit\%20committee.doc> (1 April 2011).

Mornington Shire Council, 2008, Minutes and Recommendations from the Audit Committee, 18 June, pp. 1-50, Victoria, Australia, <http://www.mornpen.vic.gov.au/Files/Governance_Minutes/081806am.pdf> (14 April 2010).

Morse, J. M. 2003, ‘Principles of Mixed Methods and Multimethod Design’, in Tashakkori, A. and Teddlie, C. (Eds), 2003, Handbook of Mixed Methods in Social and Behavioural Research, Sage Publications, Thousand Oaks, California, United States of America, pp. 189-208.

Mullins, J. 2004, 'Houston, we have a problem', IIA Educator, October, <http://www.theiia.org/newsletter/indix.cfm?news_id=212> (22 June 2005).

Mumford, M. D. Gessner, T. L. Connelly, M. S. O’Connor, and J. A. Clifton, T. C. 1993, 'Leadership and destructive acts: Individual and situational influences', Leadership Quarterly, Volume 4, Issue 2, pp. 115-147.

Municipal Association of Victoria, 2009, Ban on Councillors Working as Political Advisers, Victoria, Australia, <http://www.mav.asn.au/CA256C320013CB4B/Lookup/mbrbriefcrspoladv/\$file/Members\%20Brief\%20\%20Ban\%20on\%20councillors\%20working\%20as\%20political\%20advisers\%20-\%20July\%202009.pdf> (9 July 2009).

Municipal Association of Victoria, 2008a, Council Information, 13 November, Victoria, Australia, <http://www.mav.asn.au/CA256C2B000B597A/page/Council+Information-

About+Local+Government?OpenDocument $\& 1=20$-Council+Information $~ \& 2=05$ -

About+Local+Government $\& 3=\sim>(18$ December 2008).

Municipal Association of Victoria, 2008b, Local Government Finances Workshop, 29 April, Victoria, Australia, <http://www.mav.asn.au/CA256C320013CB4B/Lookup/LG_Finances_Event/\$file/MAV_LG_finances_Intro.pdf> (20 December 2008).

Municipal Association of Victoria, 2008c, Submission to the Commonwealth Review of Taxation, October, Victoria, Australia,<http://www.mav.asn.au/CA256C320013CB4B/Lookup/submissioncwealtht axreview08/\$file/MAVSubmissionCommonwealthTaxationReviewOctober2008.pdf> (18 December 2008). 
Municipal Association of Victoria, 2008d, Funding Structures of LG, Victoria, Australia, <http://www.mav.asn.au/CA256C320013CB4B/Lookup/handouts_small/\$file/Cost_Pressures.pdf> (18 December 2008).

Municipal Association of Victoria, 2008e, Submission to the Better Local Governance Consultation Paper, Victoria, Australia, <http://www.mav.asn.au/CA256C320013CB4B/Lookup/blgsubmission/\$file/MAV_ SubmissionBetterLocalGovernance.pdf> (9 July 2009).

Municipal Association of Victoria, 2008f, Citizen to Councillor, Victoria, Australia, <http://www.mav.asn.au/CA256C320013CB4B/Lookup/c2c/\$file/Citizen2Councillor.pdf> (9 July 2009).

Municipal Association of Victoria, 2008g, Victorian Local Government Snapshot, Victoria, Australia, <http://www.mav.asn.au/CA256C320013CB4B/Lookup/LG\%5fSnapshot/\$file/FS\%20\%2d\%20\%20LG\% 20Snapshot\%202008.pdf> (14 October 2009).

Municipal Association of Victoria, 2007, Councillor Misconduct, Victoria, Australia, <http://www.mav.asn.au/CA256C320013CB4B/Lookup/crmisconduct/\$file/CrMisconductApr07.pdf> (9 July 2009).

Municipal Association of Victoria, 2006, 2006 Councillor Census, Victoria, Australia, <http://www.mav.asn.au/CA256C320013CB4B/Lookup/MAV_Councillor_Census_Report_2006/\$file/MAV\%20 Councillor\%20Census\%20Report\%202006.pdf> (20 December 2008).

Municipal Association of Victoria, 2005, How to Develop a Code of Governance Guide, Victoria, Australia, <http://www.mav.asn.au/CA256C320013CB4B/Lookup/GGAG_Code_Gov/\$file/GGAG\%20Code\%20of\%20Con duct.pdf> (9 July 2009)

Municipal Association of Victoria, 2004a, Good Guidance Guide , Victoria, Australia, <http://www.mav.asn.au/CA256C320013CB4B/Lookup/GG_guide04/\$file/GGGuide2004.pdf> (9 July 2009).

Municipal Association of Victoria, 2004b, Citizen to Councillor, Meeting Procedures, Victoria, Australia, <http://www.mav.asn.au/CA256C320013CB4B/Lookup/MeetingProcedures04/\$file/Meeting_pro04.pdf> (9 July 2009).

Municipal Association of Victoria, 2004c, Developing a Code of Conduct Advisory Note, Victoria, Australia, <http://www.mav.asn.au/CA256C320013CB4B/Lookup/PrACTicalitiesl25/\$file/Practicialities\%20L25.pdf> (9 July 2009).

Munro, L. and Buckby, S. 2008, 'Audit committee regulation in Australia: how far have we come’, Australian Accounting Review, Volume 18, Issue 4, pp. 310-323.

National Aeronautics and Space Administration, 2003, Report of the Columbia Accident Investigation Board, Volume 1, August <http://www.nasa.gov/columbia/caib/PDFS/Vol1/02.PDF> (20 August 2005).

National Audit Office, 2007a, United Kingdom, Audit Committee, Self-Assessment Checklist, London, United Kingdom, <http://www.nao.org.uk/practice_areas/FMAG/Self_Assessment_Checklist.pdf> (21 June 2008).

National Audit Office, 2007b, United Kingdom, Helping your Audit Committee to add Value, London, United Kingdom, <http://www.nao.org.uk/practice_areas/FMAG/Adding_Value.pdf> (21 June 2008).

National Audit Office (undated), United Kingdom, Audit Committee, Self-Assessment Checklist, London, United Kingdom, <http://www.nao.org.uk/guidance/checklists/auditcommittee_ckecklist.pdf> (17 June 2004).

Nichols, L T. 2000, 'Constructing white-collar crime: claims in criminology and management education', Business and Society Review, Volume 105, Number 2, pp. 221-246.

Nunnally, J. C. 1978, Psychometric theory, McGraw-Hill, New York, United States of America.

OECD, 2004, Principles of Corporate Governance, Paris, France, <http://www.oecd.org/dataoecd/32/18/31557724.pdf> (13 April 2009).

O’Malley, P. 2002, Criminology and Fraud, Fraud Investigation Course, La Trobe University, Bundoora, Victoria, Australia.

Ombudsman, Victoria, 2009a, Investigation into the alleged improper conduct of Councillors at Brimbank Council, Melbourne, Victoria, Australia, <http://www.ombudsman.vic.gov.au/resources/documents /Investigation_into_the_alleged_improper_conduct_of_councillors_at_Brimbank_City_Council_P1-P1991.pdf> (8 May 2009). 
Ombudsman, Victoria, 2009b, Investigation into corporate governance at Moorabool Shire Council, Melbourne, Victoria, Australia, <http://www.ombudsman.vic.gov.au/resources/documents/Corporate_Governance _at_Moorabool_Shire_for_web.pdf> (8 May 2009).

Ombudsman, Victoria, 2009c, Conflict of Interest and Abuse of Power by a Building Inspector at Brimbank City Council, Melbourne, Victoria, Australia, <http://www.ombudsman.vic.gov.au/resources/documents/ Conflict_of_Interest_and_Abuse_of_Power_by_a_Building_Inspector_at_Brimbank_City_Council.pdf $>$ (14 June 2009).

Ombudsman, Victoria, 2009d, A Report of Investigations in the City of Port Phillip, Melbourne, Victoria, Australia, <http://www.ombudsman.vic.gov.au/resources/documents/A_report_ of_investigations_into_the_City_of_Port_Phillip.pdf> (13 August 2009).

Ombudsman, Victoria, 2008, Conflict of Interest in Local Government, Melbourne, Victoria, Australia, $<$ http://www.ombudsman.vic.gov.au/resources/documents/Conflict_of_interest_in_local_ government_March_2008.pdf> (21 March 2008).

Ombudsman, Victoria, 2007, Own Motion Investigation into the Policies and Procedures of the Planning Department at the City of Greater Geelong, Melbourne, Victoria, Australia, $<$ http://www.ombudsman.vic.gov.au/resources/documents/Own_motion_investigation_ into_the_policies_and_procedures_of_the_planning_department_at_the_CGG.pdf> (21 March 2008).

Ombudsman, Victoria, 2005, Investigation into the Conduct of Council Officers in the Administration of the Shire of Melton, Victoria, Australia, $<$ http://www.ombudsman.vic.gov.au/resources/documents/Investigation_into_the_ conduct_of_council_officers_in_the_administration_of_the_Shire_of_Melton.pdf $>$ (6 September 2009).

Onwegbuzie, A. J. and Johnson, R. B. 2006, ‘The validity issue in mixed research’, Research in Schools, Volume 13, Number 1, pp. 48-63.

Onwegbuzie, A. J. and Leech, N. L. 2007, ‘validity and qualitative research: an oxymoron’, Quality \& Quantity, Volume 41, Number 2, pp. 233-249.

Oppler, E. S. Lyons, B. D. Ricks, D. A. and Oppler, S. H. 2008, 'The relationship between financial history and counterproductive work behavior’, International Journal of Selection and Assessment, Volume 16, Number 4, pp. 416-420.

O’Rourke, T. W. 1999, 'The importance of an adequate survey response rate and ways to improve it', American Journal of Health Studies, Volume 15, Number 2, pp. 107-109.

Oviatt, B. M. 1988, 'Agency and transaction cost perspectives on the manager-shareholder relationship: Incentives for congruent interests', Academy of Management Review, Volume 13, Issue 3, pp. 214-225, cited in Baysinger, B. and Hoskisson, R. E. 1990, 'The composition of board of directors and strategic control: Effects on corporate strategy', Academy of Management Review, Volume 15, Issue 1, pp. 72-87.

Pace, C. R. 1939, 'Factors influencing questionnaire returns from former university students', Journal of Applied Psychology, Volume 23, Number 3, pp. 388-397.

Painter, C. and Clarence, W. E. 2001, 'UK local action zones and changing urban governance', Urban Studies, July, Volume 38, Issue 8, pp. 1215-1232.

Parliament, New South Wales, 2006, Report on Corporate Governance, Follow-Up Review of Performance Audit Report on Corporate Governance, Public Bodies Review Committee, <http://www.parliament.nsw.gov.au/Prod/parlment/committee.nsf/0/ff94efbceaae1ae6ca2571f000263830/\$FILE/ Final\%20Corporate\%20Governance.pdf> (12 June 2009).

Parliament, Victoria, 2009, Planning and Community Development Report 2007-08, Hansard, Legislative Council, 25 June,

$<$ http://tex.parliament.vic.gov.au/bin/texhtmlt?form=VicHansard.dumpall\&db=daily\&dodraft=1\&speech= 17605\&activity=Statements+on+Reports\&title=Planning+and+Community+Development:+report+200708\&date1=25\&date2=June \&date3=2009\&query=true\%0a\%09and+\%28+data+contains+'PEULICH'+\%29\%0a\% 09and+\%28+members+contains+'PEULICH'+\%29\%0a\%09and+\%28+hdate.hdate_2+contains+'June'+\%29\%0a \%09and+\%28+hdate.hdate_1+=+25+\%29\%0a\%09and+\%28+house+contains+'COUNCIL'+\%29\%0a > (9 July 2009).

Parliament, Victoria, 2006, Victorian Government Response to Public Accounts and Estimates Committee Report on Corporate Governance in the Victorian Public Sector, Public Accounts and Estimates Committee, <http://www.parliament.vic.gov.au/paec/inquiries/publicgovernance/ VicGov-Response_CorporateGovernancePublicSector_2005-11-22.pdf.>(14 June 2009). 
Parliament, Victoria, 2005, Report on the Inquiry into Corporate Governance in the Victorian Public Sector, Public Accounts and Estimates Committee,

$<$ http://www.parliament.vic.gov.au/paec/inquiries/publicgovernance/PAEC-Report-

63_CorporateGovernancePublicSector_2005-05-17.doc> (21 May 2009).

Parliament, United Kingdom, 1999, Modernising Government, White Paper, March, <http://www.archive.official-documents.co.uk/document/cm43/4310/4310.htm> (25 May 2009).

Partington, D. 2000, 'Building grounded theories of management Action', British Journal of Management, Volume 11pp., pp. 91-102.

Patton, M. B. 2002, Qualitative Research \& Evaluation Methods, $3^{\text {rd }}$ edition, Sage Publications, Thousand Oaks, California. United States of America.

Pearson, D. 2008, Role of Public Sector Audit Committees, An Auditor-Generals Perspective, AuditorGeneral Victoria, Melbourne, Victoria, Australia, <http://download.audit.vic.gov.au/files/speeches/20080213_Deloittes_Audit_Commmittees_Meeting.pdf> (1 January, 2010).

Pech, R. J. Durden, G. 2004, 'Where the decisions-makers went wrong: From capital to cannibalism', Corporate Governance, The International Journal of Business in Society,Volume 4, Number 1, pp. 65-75.

Pech, R.J. and Slade, B.W. 2007, 'organisational sociopaths: rarely challenged, often promoted. why?' Society and Business Review, Volume 2, Issue 3, pp. 254-269.

Pech, R. J. Slade, B. W. 2004, 'Memetic engineering: A framework for organisational diagnosis and development', The Leadership and Organization Development Journal, Volume 25, Number 5, pp. 452-465.

Pergert, P. 2009, 'Methodological learning-by-doing: Challenges, lessons learned and rewards', The Grounded Theory Review, Volume 8, Number 2, pp. 65-75.

Perry, P. J. 2001, Political Corruption in Australia: A Very Wicked Place, Ashgate Publishing Company, Aldershot, Hampshire, United Kingdom.

Peterson, K. D., Deal, T. E. 1998, 'How leaders influence the culture of schools’, Educational Leadership, Volume 56, Issue 1, pp. 28-30.

Pfeffer, J. and Salancik, G. R. 1978, The External Control of Organizations: A Resource-Dependence Perspective, Harper Row, New York, United States of America.

Pfeffer, J. 1973, 'Size, Composition, and Function of Hospital Boards of Directors: The Organization and its Environment', Administrative Science Quarterly, Volume 18, Number 3, pp. 349-364.

Pfeffer, J. 1972, 'Size, Composition, and Function of Corporate Boards of Directors: The Organization and its Environment’, Administrative Science Quarterly, Volume 17, Number 2, pp. 218-229.

Popescu, R. 2006, Quantifying Corporate Governance: Executive Employee Compensation and Independence of Directors as a measure of the Quality of Corporate Governance, Master of Science in Telecommunications, University of Colorado, Bolder, United States of America.

Porter, B. A. 2009, 'The audit trinity: The key to securing corporate accountability', Managerial Auditing Journal, Volume 24, Number 2, pp. 156-182.

Porter, B. A. 1993, 'An empirical study of audit expectation-performance gap', Accounting and Business Research, Volume 24, Issue 93, pp. 49-68.

Powell, W. W. and DiMaggio, P. J. 1991, The New Institutionalism in Organizational Analysis, The University of Chicago Press, Chicago, United States of America.

Price, T. L. 2000, 'Explaining ethical failures of leadership', The Leadership and Organization Development Journal, Volume 21, Number 4, pp. 177-184.

PriceWaterhouseCoopers, 2003, Audit Committees, Good Practice for Meeting Market Expectations, $2^{\text {nd }}$ edition, $<$ http://www.pwcglobal.com/extweb/pwcpublications.nsf/4bd5f76b48e282738525662b00739e22/253e1c17db806b 13802569a10036c92d/\$FILE/Audit_Committees_2nd_Ed.pdf> (28 June 2004). 
Psaros, J. 2009, Australian Corporate Governance: A Review and Analysis of Key Issues, Pearson Education Australia, Frenchs Forest, New South Wales, Australia.

Public Sector Standard Commissioner, 2006, Victorian Public Entity Directors' Codes of Conduct, Melbourne, Victoria, Australia, <http://www.ssa.vic.gov.au/CA2571410025903D/WebObj/Directors CodeGuidanceNotes/\$File/DirectorsCodeGuidanceNotes.pdf> (20 June 2008).

Pullen, L. and Haidar, A. 2003, 'Managerial values in local government Victoria, Australia', The International Journal of Public Sector Management, Volume 16, Number 4, pp. 286-302.

Punch, M. 1996, Dirty Business, Exploring Corporate Misconduct, Analysis and Cases, Sage Publications, London, United Kingdom.

Purcell, A. J. 2005, The Boss is Mad and Bad! A Discussion of the Organisational Implications, Minor Thesis, Graduate School of Management, La Trobe University, Bundoora, Australia.

Purcell, A. J. 2004, Survey to Measure the Effectiveness of the Audit Committee, unpublished paper, Manningham City Council, Doncaster, Victoria, Australia.

Raco, M. 2002, 'The social relations of organisational activity and the new local governance in the UK', Urban Studies, March, Volume 39, Issue, 3, pp. 437-456.

Raghunandan, K. and Rama, D. V. 2007, 'Determinants of audit committee diligence', Accounting Horizons, Volume 21, Issue 3, pp. 265-280.

Raghunandan, K. and Read, W. J. Rama, D. 2001, 'Audit committee composition, "gray directors” and interaction with internal auditing’, Accounting Horizons, Volume 15, Number 2, pp. 105-118.

Ramsey I. 2001, 'Independence of Australian Company Auditors, Review of Current Australian Requirements and Proposals for Reform, October, <http://cclsr.law.unimelb.edu.au/research-papers/audit-indreport/audit-ind.html> (17 June 2004).

Reidy, J. M. 2006, Learning to Work, Melbourne University Press, Carlton, Victoria, Australia.

Reilly, T. 2009, 'The Mayor, the MP, the council, and the catfight', Sunday Age, p. 9.

Richardson, R. C. Baril, C. P. 2003, ’Can your audit committee withstand the market’s scrutiny of independence?', Financial Executive, January-February, Volume 19, Issue 1, pp. 35-38.

Rittenberg, L. E. and Nair, R. D. 1993, Improving the Effectiveness of Audit Committees, Montvale, New Jersey, Institute of Management Accountants in DeZoort, F.T. Hermanson, D. R. Archambeault, D. S. Reed, S. A. 2002, 'Audit committee effectiveness: A synthesis of the empirical audit committee literature', Journal of Accounting Literature, Volume 21, pp. 38-75.

Robbins S. P. 2003, Organizational Behavior, $10^{\text {th }}$ edition, Pearson Education, New Jersey, United States of America.

Roberts, P. Olsen J. and Brown, A. J. 2009, Whistling While they Work: Toward Best Practice Whistleblowing Programs in Public Sector Organisations, Draft Report, July, Griffith University, Queensland, Australia, <http://www.griffith.edu.au/centre/slrc/whistleblowing/pdf/whistling-july09-full-report.pdf> (1 September 2009).

Rogelberg, S. G. Conway, J. M. Sedererburg, M. E. Spitzmuller, C. Aziz, S. and Knight, W. E. 2003, 'Profiling active and passive nonrespondents to an organizational survey', Journal of Applied Psychology, Volume 88, Number 6, pp. 1104-1114.

Rogelberg, S. G. and Stanton, J. M. 2007, 'Introduction: Understanding and dealing with organizational survey nonresponse’, Organizational Research Methods, Volume 10, Number 2, pp. 195-209.

Rogers, M. 2006, Contingent Corporate Governance: A Challenge to Universal Theories of Board Structure, PhD Thesis, University of New South Wales, New South Wales, Australia.

Ross, P. 2010, Management of External Audits in New South Wales Local Government, School of Accounting, University of Western Sydney, New South Wales, Australia, Private Conversation, 21 September, 2010

Ryan, N. Williams, T. Charles, M and Waterhouse, J. 2008, 'Top-down organizational change in an Australian government agency', The International Journal of Public Sector Management, Volume 21, Number 1, pp. 26-44. 
Sampford, C. Shadlock, A. Connors, C. and Galtung, F. (Eds ), 2006, Measuring Corruption, Ashgate Publishing Company, Aldershot, Hampshire, United Kingdom.

Scarbrough, P. D. Rama, D. V. and Raghunandan, K. 1998, 'Audit committee composition and interaction with internal auditing', Accounting Horizons, Volume 12, Number 1, pp. 51-62.

Schein, E. 1996, 'Three cultures of management: The key to organisational learning', Sloan Management Review, Fall, Volume 38, Issue 1, pp. 9-20.

Schein, E. 1984, ‘Coming to a new awareness of organizational culture’, Sloan Management Review, Volume 25, Number 2, pp. pp. 3-16.

Schein, E. 1970, Organisational Psychology, Prentice Hall, Englewood Cliffs, New Jersey, United States of America.

Schwartz, M. 2001, 'The Nature of the Relationship between Corporate Codes of Ethics and Behaviour', Journal of Business Ethics, Volume 32, Issue 3, pp. 247-262.

Scott, W. R. 2004, Institutional Theory in Ritzer G. (Eds), 2004, Encyclopedia of Social Theory, Sage Publications, Thousand Oaks, California, United States of America, pp. 409-415, $<$ http://0-sage-ereference.com.library.vu.edu.al/social theory/Article_n155html?searchquery> (22 September 2009).

Scott, W. R. 1987, 'The adolescence of institutional theory’, Administrative Science Quarterly, Volume 32, Number 4, pp. 493-511.

Sekaran, U. 2003, Research Methods for Business, A Skill Building Approach, $4^{\text {th }}$ edition, John Wiley \& Sons, New Jersey, United States of America.

Senge, P. M. 1990, The Fifth Discipline: The Art and Practice of the Learning Organization, Doubleday, New York, United States of America.

Seyf, A. 2000, Corruption and Development, Division of Economics Working Paper N2000.7, Staffordshire University, Stafford, United Kingdom, in Gerasimova, K 2008, 'Can corruption and economic crime be controlled in developing countries and if so, is it cost effective?', Journal of Financial Crime, Volume 15, Number 2, pp. 223-233.

Sharma, A. 1997, 'Professional as agent: knowledge asymmetry in agency exchange', Academy of Management Review, Volume 22, Number 3, pp. 758-798.

Sharma, V. Naiker, V. and Lee, B. 2009, 'Determinants of audit committee meeting frequency: evidence from a voluntary governance system’, Accounting Horizons, Volume. 23, Issue 3, pp. 245-263.

Shih, T. H. and Fan, X. T. 2008, 'Comparing response rates from web and mail surveys: A meta-analysis', Field Methods, Volume 20, Number 3, pp. 249-271.

Shleifer, A. and Vishny, R. W. 1997, 'A survey of corporate governance’, The Journal of Finance, Volume 52, Number 2, pp. 737-783.

Siegel, S. and Castellan, N. J. 1988, Nonparametric Statistics for the Behavioral Sciences, $2^{\text {nd }}$ edition, McGraw Hill, New York, United States of America.

Siladi, B. 2006, The Role of Non-Executive Directors in Corporate Governance: An Evaluation, Masters Thesis, Swinburne University of Technology, Victoria Australia.

Silver, S. E. Fleming, A. S. and Riley, R. A. 2008, 'Preventing and detecting collusive management fraud', The CPA Journal, Volume 78, Number 10, pp. 46-48.

Simon, W. H. 2005, 'Wrongs of ignorance and ambiguity: Lawyer responsibility for collective misconduct', Yale Journal on Regulation, Volume, 22, Number 1, pp. 1-35.

Smith, M. Mathur, N. and Skelcher, C. 2006, 'Corporate governance in a collaborative environment: What happens when government, business and civil society work together?’, Corporate Governance: An International Review, Volume 14, Number 3, pp. 159-171.

Smith, R. Sir, 2003, Audit Committees: Combined Code Guidance, Financial Reporting Council, United Kingdom <http://www.frc.org.uk/images/uploaded/documents/acreport.pdf> (21 June 2004). 
Spangler, W. D. and Braiotta, L. Jr. 1990, 'Leadership and corporate audit committee effectiveness', Group \& Organization Studies, June, Volume 15, Issue. 2, pp. 134-158.

Squires, S. E. Smith, C. J. McDougall, L. Yeack, W. R. 2003, Inside Arthur Andersen: Shifting Values and Unexpected Consequences, Financial Times, Prentice Hall, Upper Saddle River, New Jersey, United States of America.

State Services Authority, 2009a, Review of the Alpine Resort Areas, Victoria, Australia, $<$ http://www.ssa.vic.gov.au/CA2571410025903D/WebObj/alpine_final/\$File/alpine_final.pdf> (15 June 2009).

State Services Authority, 2008a, Review of the Cemetery Trusts, Victoria, Australia, <http://www.ssa.vic.gov.au/CA2571410025903D/WebObj/CemeteryTrust_Final/\$File/CemeteryTrust_Final.pdf> (15 June 2009).

State Services Authority, 2008b, Review of the Governance and Operational Capability of VicRoads, Victoria, Australia,

<http://www.ssa.vic.gov.au/CA2571410025903D/WebObj/Review_VicRoads_2009/\$File/Review_VicRoads_ 2009.pdf> (15 June 2009.

State Services Authority, 2007a, The Good Practice Guide on Governance for Victorian Government Entities, Melbourne, Victoria, Australia <http://www.ssa.vic.gov.au/domino/Web_Notes/SSA/ssagpg.nsf> (20 June 2008).

State Services Authority, 2007b, Code of Conduct for Victorian Public Sector Employees (Number 1)

Melbourne, Victoria, Australia,

<http://www.ssa.vic.gov.au/CA2571410025903D/WebObj/CodeofConduct2007/\$File/CodeofConduct2007.pdf> (12 June 2009).

State Services Authority, 2006a, Welcome to the Board, Melbourne, Victoria, Australia, <http://www.ssa.vic.gov.au/CA2571410025903D/WebObj/WelcometotheBoard/\$File/WelcometotheBoard. Pdf $>$ (20 June 2008).

State Services Authority, 2006b, Review of the Governance and Effectiveness of Rural Ambulance Victoria, Interim Report, 14 July, Melbourne, Victoria, Australia, <http://www.ssa.vic.gov.au/CA2571410025903D/WebObj/RACInterim/\$File/RACInterim.pdf> (21 March 2008).

State Services Authority, 2006c, Review of the Governance and Effectiveness of Rural Ambulance Victoria, Final Report, Melbourne, Victoria, Australia, <http://www.ssa.vic.gov.au/CA2571410025903D/WebObj/RACFinal/\$File/RAC Final.pdf> (21 March 2008).

State Services Authority, 2006d, Victorian Public Entity, Directors’ Code of Conduct, Melbourne, Victoria, Australia,

<http://www.ssa.vic.gov.au/CA2571410025903D/WebObj/DirectorsCodeGuidanceNotes/\$File/DirectorsCode GuidanceNotes.pdf> (12 June 2009).

State Services Authority, 2005, An Ethics Framework for applying the Victorian Public Sector Values, Principles, Codes and Standards, Melbourne, Victoria, Australia, <http://www.ssa.vic.gov.au/CA2571410025903D/WebObj/EthicsFramework/\$File/EthicsFramework.pdf> (21March 2008).

Steinberg, R. M. and Bromilow C. L. 2000, Audit Committee Effectiveness - What Work Best, PriceWaterhouseCoopers \& Institute of Internal Auditors, $2^{\text {nd }}$ edition, The Institute of Internal Auditors Research Foundation, Florida, United States of America.

Stewart, J. and Munro, L 2007, 'The impact of audit committee existence and audit committee meeting frequency on the external audit: Perceptions of Australian auditors', International Journal of Auditing, Volume 11, Issue 1pp., pp. 51-69.

Strauss, A. and Corbin, J. 1988, Basics of Qualitative Research, Techniques and Procedures for Developing Grounded Theory, Sage Publications, Thousand Oaks, California, United States of America.

Sutherland, E. 1961, White-collar Crime, Holt, Rinehart \& Winston, New York, cited in O’Malley, P. 2002, Criminology and Fraud, Fraud Investigation Course, La Trobe University, Bundoora, Victoria, Australia.

Sykes, T. 1994, The Bold Riders - Behind Australia's Corporate Collapses, Allen \& Unwin, St Leonards, New South Wales, Australia. 
Swan Hill Rural City Council, 2005, Audit Committee Charter, Swan Hill, Victoria, Australia $<$ http://www.swanhill.vic.gov.au/council/meetings/images/Audit_Committee_Charter1.pdf> (6 January 2010).

Tashakkori, A. and Teddlie, C. 2003, Handbook of Mixed Methods in Social and Behavioural Research, Sage Publications, Thousand Oaks, California, United States of America.

Tashakkori, A. and Teddlie, C. 1998, Mixed Methodology: Combining Qualitative and Quantitative Approaches, Thousand Oaks, California, United States of America.

Taylor, S. J. and Bogdan, R. 1984, Introduction to Qualitative Research Methods, $2^{\text {nd }}$ edition John Wiley \& Sons, New York, United States of America.

Teddlie, C. and Tashakkori, A. 2009, Foundations of Mixed Methods Research, Sage, Publications, Thousand Oaks, California, United States of America.

Ter Bogt, H. J. 2008, 'Recent and future management changes in local government: Continuing focus on rationality and efficiency?’, Financial Accountability and Management, February, Volume 24, Issue 1, pp. 31-58.

The Economist, 1993 (30 ${ }^{\text {th }}$ January), p. 14 in Werlin, H. 1994, 'Revisiting Corruption: With a new definition', International Review of Administrative Sciences, Volume 60, Number 4, pp. 547-558.

Thomas, K. and Burns, J. 2004, 'The Dark Side and Leader-Follower Relationships', $18^{\text {th }}$ Annual Conference - Australian and New Zealand Academy of Management, December.

Thomas, K. and Slade B. 2004, 'Revisiting the Dark Side of Leadership in the Light of Management Theory: A Leadership Concept Paper', $18^{\text {th }}$ Annual Conference - Australian and New Zealand Academy of Management, <http://www.business.otago.ac.nz/mgmt/ANZAM2004/CD/Papers/abstract386.htm>(27 June 2011).

Thompson S. and Winter R, 2004, 'Can direct patient referral help the NHS modernisation agenda?' Professional Nurse, February; Volume 19, Number 6, pp. 324-327.

Transparency International (2012) What is corruption?, <http://www.transparency.org/whatwedo?gclid=CMmQoarv27ECFaRMpgod_T4A0w> (9 August 2012).

Transparency International (2011a), Corruption Perception Index, <http://cpi.transparency.org/cpi2011/> (20 July 2012).

Transparency International (2011b), Bribe Payers Index, <http://bpi.transparency.org/bpi2011/> (20 July 2012).

Transparency International (2011c), Global Corruption Barometer, <http://gcb.transparency.org/gcb201011/> (20 July 2012).

Tremaine, M. 2000, 'Women Mayors say what it takes to lead: Setting theory against the lived experience', Women in Management Review, Volume 15, Number 5/5, pp. 246-252.

Truong, T, 2006, 'corporate boards, ownership and agency costs, evidence from Australia', The Business Review, Volume 5, Number 2, pp. 163-167.

Tudway, R. and Pascal A. 2006, 'Corporate governance, shareholder value and societal expectations', Corporate Governance, Volume 6, Number 3, pp. 305-316.

Turley, S. and Zaman, M. 2007, 'Audit committee effectiveness: informal process and behavioural effects', Accounting, Auditing and Accountability Journal, Volume 20, Number 5, pp. 765-788.

Turley, S. and Zaman, M. 2004, 'The corporate effects of audit committees', Journal of Management and Governance, Volume 8, Number 3, pp. 305-332.

Turner, B. A. 1983, 'The use of grounded theory for the qualitative analysis of organizational behaviour', Journal of Management Studies, Volume 20, Number 3, pp. 333-348.

Turpin, R. A. and DeZoort, F. T. 1998, 'Characteristics of firms that include and audit committee report in their annual report', International Journal of Auditing, Volume 2, March, pp. 35-48.

Tuttle, B. and Dillard, J. 2007, 'Beyond competition: Institutional isomorphism in U. S. accounting research', Accounting Horizons, Volume 21, Number 4, pp. 387-409.

Uhrig, J. 2003, Review of Corporate Governance of Statutory Authorities and Office Holders, Parliament House, Canberra, Australia. 
Urie, M, 2009, 'Effectiveness of Audit Committees in Local Government', East Gippsland Shire Council, Private Letter, 19 February.

Valler, D. Wood, A. and North, P. 2000, 'Local governance and local business interests: A critical review', Progress in Human Geography, Volume 24, Issue 3, pp., pp. 409-428.

Van der Hoek, M. P. 2010, 'Dutch local accounting committees: A committee chair’s experience', Journal of Public Budgeting, Accounting and Financial Management, Volume 22, Number 4, pp. 561-577.

Van Gramberg, B. and Teicher, J. 2000, 'Managerialism in local government - Victoria, Australia', The International Journal of Public Sector Management, Volume 13, Number 5, pp. 476-492.

Vermeesch, R. B. and Lindgren K. E. 1978, Business Law of Australia, Butterworths, $3^{\text {rd }}$ edition, Melbourne, Australia.

Verschoor, C. C. Barrier, M. and Rittenbeg, L. E. 2002, 'Reflections on the audit committee’s role', The Internal Auditor, April, Volume 59, Number 2, pp. 26-35.

Victorian Government Gazette, 2008, Local Government Councillor and Mayoral Allowances, G 48, 27 November, pp. 2787-2790.

Walker, R. G. 2004, ‘Gaps in guidelines on audit committees’, Abacus, Volume 40, Number 2, pp. 157-192.

Waterman, R. H. Jr, Peters, T. J. and Philips, J. R, 1980, ‘Structure is not organisation’, Business Horizons, Volume 23, Number 3, pp. 14-26.

Wayne, P.F. 2010, An Investigation of the Determinants of Audit Committee Effectiveness, Private Email, 17 May.

Wayne, P.F. 2003, An Investigation of the Determinants of Audit Committee Effectiveness, PhD Thesis, York University, Toronto, Canada.

Wellington, J. Bathmaker, A.M. and Hunt, C. 2005, Succeeding with your Doctorate, Sage Publications. Thousand Oaks, California, United States of America.

Wells, J. T. 2007, Encyclopedia of Fraud, Association of Fraud Examiners, $3^{\text {rd }}$ Edition, Austin Texas, United States of America.

Wells, J. T. 2004, Corporate Fraud Handbook, Prevention and Detection, Association of Fraud Examiners, Austin Texas, United States of America.

West, J. P. and Berman, E. M. 2003, ‘Audit committees and accountability in local government: A national survey', International Journal of Public Administration, Volume 25, Issue 4, pp. 329-362.

Westphal, J and Zajac, 1994, 'Substance and symbolism in CEO’s long term-term incentive plans', Administrative Science Quarterly, Volume 39, Issue 3, pp. 367-390.

Werlin, H. 1994, 'Revisiting corruption: With a new definition', International Review of Administrative Sciences, Volume 60, Number 4, pp. 547-558.

West, J. P. and Berman, E. M. 2003, 'Audit committees and accountability in local government: A national survey’, International Journal of Public Administration, Volume 26, Number 4, pp. 329-362.

Wiersma, W. and Jurs S.G. 2005, Research Methods in Education, $8^{\text {th }}$ edition, Pearson Education, New York, United States of America.

Weisburd D. Waring E. Chayet, E. F. 2001, White-Collar Crime and Criminal Careers, Cambridge University Press, Cambridge, United Kingdom.

Whitehorse City Council, 2007, Councillor Reference Manual, Nunawading, Victoria, Australia.

Whitehorse City Council, 2004, Evaluation Template for White City Council Audit Advisory Committee, Nunawading, Victoria, Australia.

Wild, J. J. 1996, 'The audit committee and earnings quality', Journal of Accounting, Auditing and Finance, Volume 11, Issue 2, pp. 247-277. 
Willis, J. 2004, 'The third way, welfare, work and local governance reform', Environment and Planning A, Volume 36, Number 4, pp. 571-578.

Wilson, D. 2003a, 'Exploring the working life of a female politician’, Women in Management Review, Volume 18, Number 8, pp. 389-397.

Wilson, D. 2003b, ‘Unravelling control freakery: Redefining central-local government relations’, British Journal of Politics and International Relations, August, Volume 5, Issue 3, pp. 317-346.

Woods, G. 2004, 'Going deep: adapting the modernising leadership agenda', Management in Education, Volume 18, Issue 4, pp. 28-32.

Woolmann, H. 2006, 'The fall and rise of the local community: a comparative and historical perspective', Urban Studies, July, Volume 43, Issue 8, pp. 1419-1438.

Worthington, A. C. and Dollery, B. E. 2002, 'An analysis of recent trends in Australian local government, The International Journal of Public Sector Management, Volume 15, Number 6, pp. 496-515.

Wozniak J. F. 2009, 'C. Wright Mills and higher immorality: Implications for corporate crime, ethics, and peacemaking criminology’, Crime, Law and Social Change, Volume 51, Number 1, pp. 189-203.

Wren, D. A. 2005, The History of Management Thought, $5^{\text {th }}$ edition, John Wiley \& Sons, United States of America.

Yarra City Council, 2009, Annual Report, Victoria, Australia, $<$ http://www.yarracity.vic.gov.au/Your-Council/Annual-report/> (30 September 2010).

Yarra City Council, 2009, Audit Committee Charter, Victoria, Australia <http://www.yarracity.vic.gov.au/DownloadDocument.ashx?DocumentID=949>(17 April 2012).

Yin, R. K. 2003, Case Study Research Design and Methods, Sage Publications, Thousand Oaks, California, United States of America.

Yin, R. K. 1993, Case Study Research Design and Methods, Sage Publications, Newbury Park, California, United States of America.

Young, S. and Thyil, V. 2008, 'A Holistic Model of Corporate Governance: A New Research Framework', Corporate Governance, Volume 8, Number 1, pp. 94-108.

Ziolkowski, R. 2005, A Re-examination of Corporate Governance: Concepts, Models, Theories and Future Directions, PhD Thesis, University of Canberra, Australian Capital Territory, Australia. 
Appendices

\section{Appendix 1 Summary of investigation reports into local government}

The purpose of Appendix 9.1 was to summarise the investigations into local government, namely: (1) Victoria (Section 9.1.1); (2) New South Wales, Queensland and Western Australia (Section 9.1.2); and (3) New Zealand and the United Kingdom (Section 9.1.3).

\section{Appendix 1.1 Local government investigations, Victoria}

\begin{tabular}{|c|c|c|}
\hline Name of Report & Reference & Summary of Investigation \\
\hline \multicolumn{3}{|l|}{ Council Governance Maladministration } \\
\hline $\begin{array}{l}\text { Report of Investigation into Glen Eira City } \\
\text { Council. }\end{array}$ & Inspector of Municipal Administration (2005). & $\begin{array}{l}\text { The council failed to provide effective governance, due to a breakdown in the } \\
\text { relationships with councillors and their incapacity and unwillingness to purse remedial } \\
\text { action. Their conduct was characterised by hostile, acrimonious behaviours including } \\
\text { denigration of colleagues, which inhibited the decision making capacity of the council. }\end{array}$ \\
\hline $\begin{array}{l}\text { Investigation into the Conduct of Council } \\
\text { Officers in the Administration of the Shire of } \\
\text { Melton. }\end{array}$ & Ombudsman, Victoria (2005). & $\begin{array}{l}\text { The investigation concluded that: } \\
\text { - } \\
\text { the former chief executive breached the recruitment provisions of the Local } \\
\text { - } \\
\text { there was a failure to maintain full and accurate records of the council; } \\
\text { the purchase and the disposal of assets were undertaken without following } \\
\text { due process; } \\
\text { the failure to obtain cost contributions from land-holders in relation to road } \\
\text { construction; } \\
\text { the failure to obtain sub-division infrastructure cost contributions from } \\
\text { developers; and } \\
\text { the payment of incentives to businesses were poorly structured and } \\
\text { managed. }\end{array}$ \\
\hline
\end{tabular}




\begin{tabular}{|c|c|c|}
\hline Name of Report & Reference & Summary of Investigation \\
\hline \multicolumn{3}{|l|}{ Financial Mismanagement } \\
\hline $\begin{array}{l}\text { East Gippsland Shire Council: Proposed sale } \\
\text { of Lakes Entrance property. }\end{array}$ & Auditor-General Victoria (2005a). & $\begin{array}{l}\text { The investigation related to the management of the council's processes associated with } \\
\text { a sale of a council property. The investigation concluded that: } \\
\text { - } \\
\text { there was an inadequate process for the sale of the property in accordance } \\
\text { with the Local Government Act (1989); } \\
\text { inadequate due diligence on the prospective purchasers of the property; } \\
\text { poorly conducted tender process, which was further compromised by the } \\
\text { mayor; and } \\
\text { lack of transparency in community consultation. }\end{array}$ \\
\hline Investigation into Surf Coast Shire Council. & Inspector of Municipal Administration (2002). & $\begin{array}{l}\text { The investigation concluded that the council: } \\
\text { was not in a sound financial position in terms of liquidity and debt liability; } \\
\text { there was an over reliance on rates and charges, borrowing and assets sales } \\
\text { for funding; } \\
\text { there was a loss of } \$ 1.98 \text { million from 'Surflink'(a trading enterprise of the } \\
\text { Council); } \\
\text { there was insufficient funds for infrastructure and capital works; and } \\
\text { the council budgeted on an annual basis, rather than preparing a forward } \\
\text { plan of financial and non-financial resources. }\end{array}$ \\
\hline $\begin{array}{l}\text { Review of Warrnambool City Council } \\
\text { Financial Management Practices }\end{array}$ & Auditor-General, Victoria (2005d). & $\begin{array}{l}\text { The investigation related to a number of allegations into the financial practices of the } \\
\text { council. Whilst the majority of the allegations were found to be unsubstantiated or were } \\
\text { unable to be substantiated due to a lack of evidence, it was noted that there was: } \\
\text { - } \\
\text { non-compliance with the tendering requirements of the Local Government } \\
\text { Act (1989) in relation to the Koroit Street Toilet Block and the funding of } \\
\text { long service leave; } \\
\text { non-compliance with procurement policies for four capital projects; } \\
\text { inadequate management reporting of the 'Fun } 4 \text { Kids' festivals in } 2002 \text { and } \\
\text { 2003; and } \\
\text { insufficient recurrent revenue funds to cover the operations of the council. }\end{array}$ \\
\hline
\end{tabular}




\begin{tabular}{|c|c|c|}
\hline Name of Report & Reference & Summary of Investigation \\
\hline $\begin{array}{l}\text { Unethical or Corrupt Conduct by } \\
\text { Councillors or Staff }\end{array}$ & & \\
\hline Investigation into Ballarat City Council. & Inspector of Municipal Administration (2008). & $\begin{array}{l}\text { This investigation related to alleged misconduct by councillors and breaches of the } \\
\text { Local Government Act (1989) by the chief executive. }\end{array}$ \\
\hline $\begin{array}{l}\text { Investigation into the alleged improper } \\
\text { conduct of Councillors at Brimbank Council. } \\
\text { Report on Brimbank City Council. }\end{array}$ & $\begin{array}{l}\text { Ombudsman, Victoria (2009a). } \\
\text { Inspector of Municipal Administration (2009). }\end{array}$ & $\begin{array}{l}\text { This investigation concluded that: } \\
\text { persons external to the council had undue influence over some councillors; } \\
\text { conflict of interest was not managed effectively; } \\
\text { there was improper use of powers by the councillors; } \\
\text { there was a culture of bullying and intimidation; } \\
\text { - } \quad \text { there was some misuse of council's funds and resources; } \\
\text { improper use of electoral information for political purposes; and } \\
\text { Onisuse of council information in leaking to the media. } \\
\text { Council. }\end{array}$ \\
\hline $\begin{array}{l}\text { A Report of Investigations in the City of Port } \\
\text { Phillip. }\end{array}$ & Ombudsman, Victoria (2009d). & $\begin{array}{l}\text { This investigation related to the failure of the chief executive to adhere to procurement } \\
\text { processes as required under the Local Government Act (1989). } \\
\text { The investigation also identified inappropriate and collusive procurement practices } \\
\text { associated with building maintenance contracts. }\end{array}$ \\
\hline
\end{tabular}




\begin{tabular}{|c|c|c|}
\hline Name of Report & Reference & Summary of Investigation \\
\hline \multicolumn{3}{|l|}{ Breaches of Statutory Powers } \\
\hline $\begin{array}{l}\text { Community Planning Services in Glenelg } \\
\text { Shire Council: 1998-2005. }\end{array}$ & Auditor-General Victoria (2005b). & $\begin{array}{l}\text { This investigation related to the mismanagement of the statutory planning powers of the } \\
\text { council, by an external planning contractor without appropriate oversight by the council } \\
\text { to ensure effective management. The report concluded that there was: } \\
\text { - a failure to initiate amendments to the council's planning scheme to ensure } \\
\text { effectiveness; } \\
\text { an unwillingness by the council to change planning processes when advised to } \\
\text { do so; } \\
\text { - inappropriate practices of some councillors dealing directly with the planning } \\
\text { contractor and the by-passing other councillors and management; and } \\
\text { a failure to maintain adequate documentation of the assessment and planning } \\
\text { decisions. }\end{array}$ \\
\hline $\begin{array}{l}\text { Report on Investigation into Greater Geelong } \\
\text { City Council. }\end{array}$ & Inspector of Municipal Administration (2006). & $\begin{array}{l}\text { Six councillors received financial support and campaign support, during the council } \\
\text { elections and did not disclose the support in accordance with Section } 81 \text { of the Local } \\
\text { Government Act (1989). } \\
\text { The report concluded that five councillors had received funds below the threshold for } \\
\text { reporting under the Local Government Act (1989) but Councillor David Saunderson } \\
\text { had received funding in excess of the } \$ 500 \text { threshold and did not disclose it. }\end{array}$ \\
\hline $\begin{array}{l}\text { Investigation into corporate governance at } \\
\text { Moorabool Shire Council. }\end{array}$ & Ombudsman, Victoria (2009b). & $\begin{array}{l}\text { It was established that: } \\
\text { - governance practices were not complied with, including the operations of } \\
\text { councillor planning and strategy forums; } \\
\text { the council's Code of Conduct for councillors was not signed, } \\
\text { notwithstanding that a motion was carried at formal council meeting; and } \\
\text { there was a conflict of interest by councillors and they interfered in the day to } \\
\text { day operations of the council. }\end{array}$ \\
\hline
\end{tabular}




\begin{tabular}{|l|l|l|}
\hline \multicolumn{1}{|c|}{ Name of Report } & \multicolumn{1}{|c|}{ Reference } & \multicolumn{1}{c|}{ Summary of Investigation } \\
\hline $\begin{array}{l}\text { Own Motion Investigation into the Policies } \\
\text { and Procedures of the Planning Department } \\
\text { at the City of Greater Geelong. }\end{array}$ & Ombudsman, Victoria (2007). & $\begin{array}{l}\text { The review of the planning process at the Council concluded that: } \\
\text { a planning register was not maintained in the prescribed form in accordance } \\
\text { with the Planning and Environment Act (1987); } \\
\text { the council should review its internal referral process and streamline its } \\
\text { practices; } \\
\text { the council should implement procedures for the advertising of planning } \\
\text { applications; } \\
\text { the council should ensure that councillors understand their obligations under } \\
\text { the Code of Conduct and define the parameters for the direct contact with } \\
\text { staff in relation to planning matters. }\end{array}$ \\
& &
\end{tabular}




\begin{tabular}{|c|c|c|}
\hline Name of Report & Reference & Summary of Investigation \\
\hline \multicolumn{3}{|l|}{ Council Governance or Maladministration } \\
\hline $\begin{array}{l}\text { New South Wales } \\
\text { Brewarrina Shire Council Public Inquiry. }\end{array}$ & Department of Local Government (2005). & $\begin{array}{l}\text { The investigation concluded that: } \\
\text { - the council had a poor relationship with the Ngemba Community Working Party, } \\
\text { caused in part by the Ngemba Community Working Party’s inability to recognise } \\
\text { the role of the council and its resource constraints; } \\
\text { - there was a need to improve systems of internal control and policies; and } \\
\text { There were difficulties in recruiting and retaining qualified staff. } \\
\text { The investigation further concluded that there was no evidence to dismiss the council. }\end{array}$ \\
\hline $\begin{array}{l}\text { New South Wales } \\
\text { Broken Hill City Council Public Inquiry. }\end{array}$ & Department of Local Government (2006). & $\begin{array}{l}\text { The investigation recommended that the council be dismissed because: } \\
\text { - the relationships between councillors and staff had broken down; } \\
\text { - there were inappropriate interactions between some councillors and staff; } \\
\text { - } \quad \text { accountabilities; and }\end{array}$ \\
\hline \multicolumn{3}{|l|}{ Financial Mismanagement } \\
\hline $\begin{array}{l}\text { New South Wales } \\
\text { Port Macquarie-Hastings Council Public } \\
\text { Inquiry. }\end{array}$ & Department of Local Government (2008a). & $\begin{array}{l}\text { The investigation related to the management of the infrastructure project known as 'The } \\
\text { Glasshouse'. } \\
\text { The report recommended that the council be dismissed on the grounds that: } \\
\text { - they failed to manage the project and its costs; } \\
\text { - } \quad \text { failed to impose financial controls on the project; } \\
\text { - } \text { rere not their responsibility; } \\
\text { - provided misleading and incorrect information; and } \\
\text { - improperly used a support group to campaign against critics, rather than adopt a } \\
\text { proper consultation policies and process. }\end{array}$ \\
\hline
\end{tabular}




\begin{tabular}{|c|c|c|}
\hline Name of Report & Reference & Summary of Investigation \\
\hline $\begin{array}{l}\text { New South Wales } \\
\text { Liverpool City Council Public Inquiry. }\end{array}$ & Department of Local Government (2004a). & $\begin{array}{l}\text { This investigation related in part to the mismanagement of the infrastructure project known } \\
\text { as the 'Oasis Project' and 'Woodward Park'. The investigation concluded that: } \\
\text { - the council suffered a direct loss of } \$ 15 \text { million with a further contingent loss of } \$ 7 \\
\text { million; } \\
\text { the council's losses were caused by negligence of the council and the general } \\
\text { manager; } \\
\text { - probity issues were mismanaged on the Woodward Project; } \\
\text { the council misrepresented the advice given by its legal advisors and shopped for } \\
\text { advice to suit their own position; } \\
\text { the councillors failed to discharge their responsibilities under the Local } \\
\text { Government Act (1993) in relation to transparency of government, management of } \\
\text { council owned lands, tendering and delegations; and } \\
\text { the council was ignorant of commercial risks and displayed hopeless optimistic } \\
\text { faith in their commercial partners. }\end{array}$ \\
\hline $\begin{array}{l}\text { New South Wales } \\
\text { Rylstone Shire Council Public Inquiry. }\end{array}$ & Department of Local Government (2004b). & $\begin{array}{l}\text { The investigation recommended that the council be dismissed on the grounds that: } \\
\text { - the council were not prudent financial managers; } \\
\text { council was aware of the financial position in } 2002 \text { and there was reluctance to } \\
\text { address the issue; and } \\
\text { council did not exercise due diligence and compliance with the Local Government } \\
\text { Act (1993) in relation to the council's restructure and employment practices. }\end{array}$ \\
\hline
\end{tabular}




\begin{tabular}{|c|c|c|}
\hline Name of Report & Reference & Summary of Investigation \\
\hline $\begin{array}{l}\text { Unethical or Corrupt Conduct by } \\
\text { Councillors or Staff }\end{array}$ & & \\
\hline $\begin{array}{l}\text { New South Wales } \\
\text { Attempts to improperly influence a Ku-ring- } \\
\text { gai Council Officer. }\end{array}$ & $\begin{array}{l}\text { Independent Commission Against Corruption } \\
\text { (2009b). }\end{array}$ & $\begin{array}{l}\text { It was concluded that Ms Diana Huang and Mr Wing Mak have engaged in corrupt conduct } \\
\text { by giving corrupt benefits to an employee of Ku-ring-gai Council, in return for receiving } \\
\text { improper assistance with obtaining approval of plans submitted in connection with a } \\
\text { property development. }\end{array}$ \\
\hline $\begin{array}{l}\text { New South Wales } \\
\text { Bankstown and Strathfield Councils - } \\
\text { Corrupt } \\
\text { Manipulation of Contract Procurement } \\
\text { Procedures. }\end{array}$ & $\begin{array}{l}\text { Independent Commission Against Corruption } \\
\text { (2007b). }\end{array}$ & $\begin{array}{l}\text { The Independent Commission Against Corruption investigated the conduct of Mr Scott } \\
\text { Freeman, a then council officer and contractor Mr Terence Stepto in relation to contract } \\
\text { procurement procedures at Bankstown and Strathfield councils. } \\
\text { It was found that both Mr Freeman and Mr Stepto had engaged in corrupt conduct. }\end{array}$ \\
\hline $\begin{array}{l}\text { New South Wales } \\
\text { Investigation into attempts to improperly } \\
\text { influence } \\
\text { Warringah Council Officers. }\end{array}$ & $\begin{array}{l}\text { Independent Commission Against Corruption } \\
\text { (2009a). }\end{array}$ & $\begin{array}{l}\text { It was concluded that two business owners Jin Hua Chen and Yu Ling Sun had engaged in } \\
\text { corrupt conduct by offering cash bribes to two Warringah Council staff members in order to } \\
\text { facilitate council building inspection approval of their business premises. }\end{array}$ \\
\hline $\begin{array}{l}\text { New South Wales } \\
\text { Report on Investigation into Allegations of } \\
\text { Bribery Relating to Wollongong City } \\
\text { Council. }\end{array}$ & $\begin{array}{l}\text { Independent Commission Against Corruption } \\
\text { (2007a). }\end{array}$ & $\begin{array}{l}\text { This investigation concerned an allegation that allegations that a developer, Mr Lou Tasich } \\
\text { attempted to bribe Wollongong City Council’s Manager Commercial Projects and Property, } \\
\text { Mr Peter Coyte, by offering Mr Coyte } \$ 30,000 \text { to favourably treat Mr Tasich’s proposal to } \\
\text { purchase and develop a Council property known as the Thomas Street Car Park. } \\
\text { The Independent Commission Against Corruption concluded that Mr Lou Tasich had offered } \\
\text { Mr Coyte a } \$ 30,000 \text { bribe to favourably treat his proposal to purchase and develop a Council } \\
\text { property known as the Thomas Street Car Park. }\end{array}$ \\
\hline
\end{tabular}




\begin{tabular}{|c|c|c|}
\hline Name of Report & Reference & Summary of Investigation \\
\hline $\begin{array}{l}\text { New South Wales } \\
\text { Report on the Investigation into Corruption } \\
\text { Allegations affecting Wollongong City } \\
\text { Council - Part } 3 .\end{array}$ & $\begin{array}{l}\text { Independent Commission Against Corruption } \\
\text { (2008b). }\end{array}$ & $\begin{array}{l}\text { The Independent Commission Against Corruption made corrupt conduct findings against Ms } \\
\text { Morgan; Mr Vellar; a developer, Bulent Tabak; three of Ms Morgan's superiors at Council, } \\
\text { former General Manager Rod Oxley and former senior managers, Joe Scimone and John } \\
\text { Gilbert; and former Councillors Valerio Zanotto, Kiril Jonovski, Zeki Esen and Frank } \\
\text { Gigliotti. }\end{array}$ \\
\hline $\begin{array}{l}\text { Report on the Investigation into Corruption } \\
\text { Allegations affecting Wollongong City } \\
\text { Council - Part } 2 .\end{array}$ & $\begin{array}{l}\text { Independent Commission Against Corruption } \\
\text { (2008c). }\end{array}$ & $\begin{array}{l}\text { The Independent Commission Against Corruption investigated allegations that former and } \\
\text { current officials of Wollongong City Council and developers had engaged in corrupt conduct } \\
\text { in relation to the assessment of development applications and a range of other matters. } \\
\text { They recommended that consideration be given to the suspension of the development } \\
\text { consent granted by the Council on } 18 \text { August } 2005 \text { for a proposed } \$ 100 \text { million development } \\
\text { known as 'Quattro' because of serious corrupt conduct by Ms Beth Morgan, a former } \\
\text { member of staff of the Council and Mr Franco Vellar, who controlled the company } \\
\text { proposing the development. }\end{array}$ \\
\hline $\begin{array}{l}\text { Report on the Investigation into Corruption } \\
\text { Allegations affecting Wollongong City } \\
\text { Council - Part } 1 .\end{array}$ & $\begin{array}{l}\text { Independent Commission Against Corruption } \\
\text { (2008d). }\end{array}$ & $\begin{array}{l}\text { The Independent Commission Against Corruption recommended to the state government of } \\
\text { New South Wales, that the Council be dismissed on the grounds of systemic corruption } \\
\text { within the council. }\end{array}$ \\
\hline
\end{tabular}




\begin{tabular}{|c|c|c|}
\hline Name of Report & Reference & Summary of Investigation \\
\hline $\begin{array}{l}\text { Western Australia } \\
\text { Report on the Investigation of the alleged } \\
\text { public sector misconduct linked to the Smiths } \\
\text { Beach Development at Yallingup. }\end{array}$ & Corruption and Crime Commission (2007). & $\begin{array}{l}\text { In 1999, Canal Rocks Pty Ltd proposed a tourist and residential development. } \\
\text { The significance of this report is that it concerned the actions of the lobbyist, Mr Brian } \\
\text { Burke, who was a former Premier of the Western Australian government. } \\
\text { The Corruption and Crime Commission concluded that: } \\
\text { - inadequate disclosure of the true sources of donations in the local government } \\
\text { elections had been made; } \\
\text { inadequate declaration of interests and conflict of interest in council decision- } \\
\text { making processes had been made; } \\
\text { - extensive lobbying; and } \\
\text { there were external influences on the decisions made by public officials. } \\
\text { The findings which were relevant to this thesis included: } \\
\text { - One finding of misconduct against Ms Philippa Reid, Busselton Shire Council for } \\
\text { failure to declare an interest of her personal relationship with a lobbyist for the } \\
\text { Canal Rocks Pty Ltd; } \\
\text { Four findings of misconduct against Ms Anne Ryan, Busselton Shire Council for } \\
\text { failure to disclose gifts, source of campaign funds, declarations of financial } \\
\text { interests and a declaration of financial interests in Canal Rocks Pty Ltd; and } \\
\text { One finding of misconduct against Mr John Triplett, Busselton Shire Council for a } \\
\text { failure to make a financial interest disclosure of his interest in Canal Rocks Pty Ltd } \\
\text { which had provided election funding for him. }\end{array}$ \\
\hline $\begin{array}{l}\text { Western Australia } \\
\text { Supplementary Report on the Investigation of } \\
\text { the alleged public sector misconduct linked } \\
\text { to the Smiths Beach Development at } \\
\text { Yallingup. }\end{array}$ & Corruption and Crime Commission (2009). & $\begin{array}{l}\text { This report was an addendum to the Report on the Investigation of the alleged public sector } \\
\text { misconduct linked to the Smiths Beach Development at Yallingup and concerned the } \\
\text { opinions and the recommendations of the Corruption and Crime Commission in relation to } \\
\text { Mr Mark Brabazon, a public officer of the Department of Conservation and Land } \\
\text { Management. } \\
\text { The Commission retracted and clarified a number of statements and opinions and concluded } \\
\text { that there were no adverse findings for Mr Mark Brabazon. }\end{array}$ \\
\hline
\end{tabular}




\begin{tabular}{|c|c|c|}
\hline Name of Report & Reference & Summary of Investigation \\
\hline $\begin{array}{l}\text { Western Australia } \\
\text { Report on the Investigation of alleged } \\
\text { misconduct concerning Mr Stephen Lee, } \\
\text { Mayor of the City of Cockburn. }\end{array}$ & Corruption and Crime Commission (2008). & $\begin{array}{l}\text { The Corruption and Crime Commission investigated allegations of election funding } \\
\text { irregularities by Mr Stephen Lee, Mayor of the City of Cockburn. The Commission } \\
\text { concluded that: } \\
\text { - Mr Lee had engaged in misconduct in failing to disclose a gift from Australand in } \\
\text { the year ended } 30 \text { June } 2005 \text { and the concealment led to the conclusions that his } \\
\text { decision-making ability was not impartial and honest; } \\
\text { - Mr Lee did act out of naivety or inexperience and his conduct was deliberate and } \\
\text { over a long period of time; and } \\
\text { The funding was significant and the purpose of the concealment was to enable him } \\
\text { to advance the interests of Australand at the Cockburn City Council. } \\
\text { The investigation concluded that Mr Lee had engaged in a further four acts of misconduct } \\
\text { and recommended that he be dismissed from the Cockburn City Council for official } \\
\text { misconduct. }\end{array}$ \\
\hline $\begin{array}{l}\text { New South Wales } \\
\text { Report on investigation into Certain } \\
\text { Transactions of Koompahtoo Local } \\
\text { Aboriginal Land Council. }\end{array}$ & $\begin{array}{l}\text { Independent Commission Against Corruption } \\
\text { (2005). }\end{array}$ & $\begin{array}{l}\text { The Independent Commission Against Corruption investigated the conduct of certain } \\
\text { officers of the Koompahtoo Local Aboriginal Land Council in relation to certain property } \\
\text { dealings, which took place between approximately } 1997 \text { and } 2002 \text {. } \\
\text { The report made corrupt conduct findings in relation to eight persons and prosecution } \\
\text { recommendations in relation to six persons. }\end{array}$ \\
\hline $\begin{array}{l}\text { New South Wales } \\
\text { Report on investigation into Aboriginal Land } \\
\text { Councils in New South Wales. }\end{array}$ & $\begin{array}{l}\text { Independent Commission Against Corruption } \\
\text { (2000). }\end{array}$ & $\begin{array}{l}\text { The objectives of the review were to identify any corrupt practices and system inadequacies } \\
\text { within the aboriginal land council system and to recommend changes which would } \\
\text { discourage corrupt conduct in the future. } \\
\text { The most common complaints concerned maladministration, misuse of funds, favouritism, } \\
\text { conflict of interest and irregularities in elections. }\end{array}$ \\
\hline
\end{tabular}




\begin{tabular}{|c|c|c|}
\hline Name of Report & Reference & Summary of Investigation \\
\hline $\begin{array}{l}\text { Queensland } \\
\text { Investigation into the Allegations Affecting } \\
\text { the Douglas Shire Council. }\end{array}$ & Crime and Misconduct Commission (2006a). & $\begin{array}{l}\text { This investigation concerned in part, the granting of the contract to operate the Daintree } \\
\text { River ferry service, conflict of interest by the mayor and complaints against the chief } \\
\text { executive. } \\
\text { The investigation concluded that the allegations of misconduct were without substance or } \\
\text { could not be substantiated on the available evidence. }\end{array}$ \\
\hline $\begin{array}{l}\text { Queensland } \\
\text { Independence, Influence and Integrity in } \\
\text { Local Government: A CMC Inquiry into the } \\
2004 \text { Gold Coast Council Election. }\end{array}$ & Crime and Misconduct Commission (2006b). & $\begin{array}{l}\text { This investigation related to electoral fraud and bribery in the elections for the council in } \\
2004 . \\
\text { The investigation concluded that: } \\
\text { - there were false and misleading statements from candidates with respect to other } \\
\text { candidates or entities; } \\
\text { - there was a concealment of a fund for the election expenses of preferred } \\
\text { candidates; } \\
\text { - there were false and misleading statements and electoral returns were made; } \\
\text { - there were inadequate declarations in relation to fundraising; and } \\
\text { disclose interests. }\end{array}$ \\
\hline
\end{tabular}




\section{Appendix 1.3 Local government investigations, New Zealand and the United Kingdom}

\begin{tabular}{|c|c|c|}
\hline Name of Report & Reference & Summary of Investigation \\
\hline Council Governance or Maladministration & & \\
\hline $\begin{array}{l}\text { United Kingdom } \\
\text { Bude Stratton Town Council - Unlawful } \\
\text { Payments. }\end{array}$ & Audit-Commission, United Kingdom (2007b). & $\begin{array}{l}\text { The council established a subsidiary company Bude-Stratton Heritage Trust. The } \\
\text { expenditure by the Council was unlawful because: } \\
\text { the council exceeded its statutory powers in granting monies to a museum; } \\
\text { there were procedural deficiencies in decision making; and } \\
\text { - } \\
\text { decisions were made with the involvement of councillors who were members of } \\
\text { the museum, which was an undeclared conflict of interest in the decision- } \\
\text { making processes. }\end{array}$ \\
\hline $\begin{array}{l}\text { United Kingdom } \\
\text { Chipping Campden Town Council - } \\
\text { Financial Governance. }\end{array}$ & Audit-Commission, United Kingdom (2007d). & $\begin{array}{l}\text { The council paid an annual grant of 20,000 pounds to the Peelers Trust for four financial } \\
\text { years from } 31 \text { March } 2002 \text { to } 31 \text { March 2005. It was established that the payments on } 6 \text { May } \\
2003 \text { and } 7 \text { May } 2004 \text { were unlawful because: } \\
\text { - } \quad \text { the council had failed to authorise the expenditure; and } \\
\text { the Chapping Campden councillors who were the trustees to the Peelers Trust, } \\
\text { had participated in discussions of the grants and voted on the resolution to } \\
\text { authorise the payments, after the cheques had been issued. }\end{array}$ \\
\hline $\begin{array}{l}\text { United Kingdom } \\
\text { Doncaster Metropolitan Borough Council - } \\
\text { Governance. }\end{array}$ & Audit-Commission, United Kingdom (2008a) & $\begin{array}{l}\text { This investigation report related to the termination of the chief executive officer at the } \\
\text { council. The report noted that the breakdown in the relationship between the mayor and the } \\
\text { former chief executive officer were caused by tensions between councillors and the local } \\
\text { Labor Party (Audit-Commission, United Kingdom, 2008a, p. 6). } \\
\text { The review concluded that: } \\
\text { the performance management system for the chief executive officer was not fully } \\
\text { established; } \\
\text { there were weaknesses in the investigatory process; } \\
\text { there was a breach of confidentiality in information by councillors about the } \\
\text { case; and } \\
\text { the cost of legal advice exceeded the original estimate. }\end{array}$ \\
\hline
\end{tabular}




\begin{tabular}{|c|c|c|}
\hline Name of Report & Reference & Summary of Investigation \\
\hline $\begin{array}{l}\text { New Zealand } \\
\text { Inquiry into Dunedin City Council and Otago } \\
\text { Regional Council's funding of the proposed } \\
\text { stadium. }\end{array}$ & $\begin{array}{l}\text { Controller and Auditor-General, New Zealand } \\
\text { (2007b). }\end{array}$ & $\begin{array}{l}\text { The purpose of the inquiry was to review the Councils' funding arrangements with the Trust. } \\
\text { It was concluded that: } \\
\text { the councils' funding arrangements were appropriate for this stage of the project; } \\
\text { and } \\
\text { a formal and robust funding framework will need to be put in place should either } \\
\text { or both of the councils make a firm commitment to fund the construction phase } \\
\text { of the project. }\end{array}$ \\
\hline $\begin{array}{l}\text { New Zealand } \\
\text { Inquiry into the West Coast Development } \\
\text { Trust. }\end{array}$ & $\begin{array}{l}\text { Controller and Auditor-General, New Zealand } \\
\text { (2008a). }\end{array}$ & $\begin{array}{l}\text { The review of the West Coast Development Trust concluded that the allegations of } \\
\text { misconduct were unfounded. } \\
\text { The investigation concluded that the Trust was dysfunctional at a governance level and that } \\
\text { the trustees did not work together effectively. There was an atmosphere of suspicion and } \\
\text { distrust, which manifested itself in hostility and accusations. }\end{array}$ \\
\hline $\begin{array}{l}\text { New Zealand } \\
\text { Taupo District Council - Funding of the } \\
\text { Interim Establishment Board and the Lake } \\
\text { Taupo Development Trust. }\end{array}$ & $\begin{array}{l}\text { Controller and Auditor-General, New Zealand } \\
\text { (2002). }\end{array}$ & $\begin{array}{l}\text { The investigation concerned the establishment of the Lake Taupo Development Trust. The } \\
\text { entity had been created in connection with a proposal to establish a university and } \\
\text { technology park in Taupo. } \\
\text { The report noted that the appointment of councillors as the trustee of the external } \\
\text { organisation gave rise to a conflict of interest between being a councillor and director of the } \\
\text { external body. In this particular instance, the appointment of the councillors was not in } \\
\text { accordance with council's existing policies and procedures. }\end{array}$ \\
\hline
\end{tabular}




\begin{tabular}{|c|c|c|}
\hline Name of Report & Reference & Summary of Investigation \\
\hline Financial Mismanagement & & \\
\hline $\begin{array}{l}\text { United Kingdom } \\
\text { City of Bradford Metropolitan District } \\
\text { Council - Procurement Processes of an Asset } \\
\text { Management Project. }\end{array}$ & Audit-Commission, United Kingdom (2006b). & $\begin{array}{l}\text { In December 2001, the Council approved a project for the delivery of asset and facilities } \\
\text { management (known as the Asset Management Project). The investigation considered there } \\
\text { were weaknesses in the: } \\
\text { - } \\
\text { program management (identification of benefits and affordability); } \\
\text { project structure and project management; } \\
\text { - } \quad \text { procurement documentation; } \\
\text { - } \quad \text { evaluation of bids. }\end{array}$ \\
\hline $\begin{array}{l}\text { United Kingdom } \\
\text { Epworth Town Council - Financial } \\
\text { Governance. }\end{array}$ & Audit-Commission, United Kingdom (2008b) & $\begin{array}{l}\text { This investigation related to the mismanagement of the town clerk who had failed to } \\
\text { discharge his financial delegations in a responsible manner. The review concluded that: } \\
\text { - the council failed to implement appropriate record management systems, which } \\
\text { put the council at increased financial and reputational risks; and } \\
\text { the town clerk failed to ensure that proper statutory records relating to burials } \\
\text { were maintained, resulting in the sale of one burial site to the estates of two } \\
\text { deceased people. }\end{array}$ \\
\hline $\begin{array}{l}\text { United Kingdom } \\
\text { Leicester City Council - Housing Repairs } \\
\text { Contracts. }\end{array}$ & Audit-Commission, United Kingdom (2007a) & $\begin{array}{l}\text { This investigation related to the procurement of housing repairs and improvement contracts. } \\
\text { It was established that: } \\
\text { contracts had been tendered and awarded in breach of European Union rules; } \\
\text { - } \\
\text { there was inadequate evidence that repairs had been carried out to a sufficient } \\
\text { standard or quality; } \\
\text { one contractor was paid for work not performed; and } \\
\text { tender decisions were not transparent, making it difficult to demonstrate value } \\
\text { for money. }\end{array}$ \\
\hline
\end{tabular}




\begin{tabular}{|c|c|c|}
\hline Name of Report & Reference & Summary of Investigation \\
\hline $\begin{array}{l}\text { United Kingdom } \\
\text { Marlborough Town Council - Procurement } \\
\text { of Commemorative Brochure for Royal } \\
\text { Charter Celebrations. }\end{array}$ & Audit-Commission, United Kingdom (2005). & $\begin{array}{l}\text { The Council did not follow its own policies and procedures in relation to the procurement of } \\
\text { a commemorative brochure for the } 800^{\text {th }} \text { anniversary of the granting of the Royal Charter to } \\
\text { the Marlborough Town Council. The contract was awarded: } \\
\text { - } \\
\text { without being subjective to a competitive tender; } \\
\text { no orders were placed for the design or the printing; and } \\
\text { the first company went into liquidation and the work was passed to a director of } \\
\text { the first company, again without a competitive tender process. }\end{array}$ \\
\hline $\begin{array}{l}\text { United Kingdom } \\
\text { North East Lincolnshire Council - Icelandic } \\
\text { investments. }\end{array}$ & Audit-Commission, United Kingdom (2009b). & $\begin{array}{l}\text { The council officers did not adhere to the council's investment strategy resulting in money } \\
\text { being invested with Icelandic Banks in 2008, when it was it was advised not to do so. } \\
\text { Officers did not follow proper internal control processes and these were routinely avoided. } \\
\text { The report concluded that the two Council financial officers were in breach of their statutory } \\
\text { and fiduciary duties. }\end{array}$ \\
\hline
\end{tabular}




\begin{tabular}{|c|c|c|}
\hline Name of Report & Reference & Summary of Investigation \\
\hline \multicolumn{3}{|l|}{$\begin{array}{l}\text { Unethical or Corrupt Conduct by Councillors } \\
\text { or Staff }\end{array}$} \\
\hline $\begin{array}{l}\text { United Kingdom } \\
\text { City of Westminster Council - Homes for Votes. }\end{array}$ & Audit-Commission, United Kingdom (2007c). & $\begin{array}{l}\text { This case had its origins in the mid 1980s when Dame Shirley Porter and others were involved in the } \\
\text { sale of council houses in Westminster, with the aim of influencing voting outcomes. } \\
\text { This report concerned the council's actions in: } \\
\text { taking too long to pursue the debt from Dame Shirley Porter, and allowing her to remove } \\
\text { assets from the jurisdiction of the Courts; } \\
\text { the council lacked the will to pursue the debt; and } \\
\text { the approach taken by the council in the final mediation was flawed and the amount } \\
\text { accepted was inadequate. }\end{array}$ \\
\hline $\begin{array}{l}\text { United Kingdom } \\
\text { Nottingham City Council - Housing Services. }\end{array}$ & Audit-Commission, United Kingdom (2009c). & $\begin{array}{l}\text { The investigation concluded that in the period } 2003-2005 \text {, the Housing Service did not operate in the } \\
\text { public interest. } \\
\text { A number of properties were allocated to people associated with senior officers. Some of these houses } \\
\text { also received significant repairs at the public expense and the houses were subsequently sold to these } \\
\text { tenants at a significant discount under the 'right to buy' provisions. }\end{array}$ \\
\hline \multicolumn{3}{|l|}{ Breaches of Statutory Powers } \\
\hline $\begin{array}{l}\text { United Kingdom } \\
\text { Restormel Borough Council - Planning Decisions. }\end{array}$ & Audit-Commission, United Kingdom (2006a). & 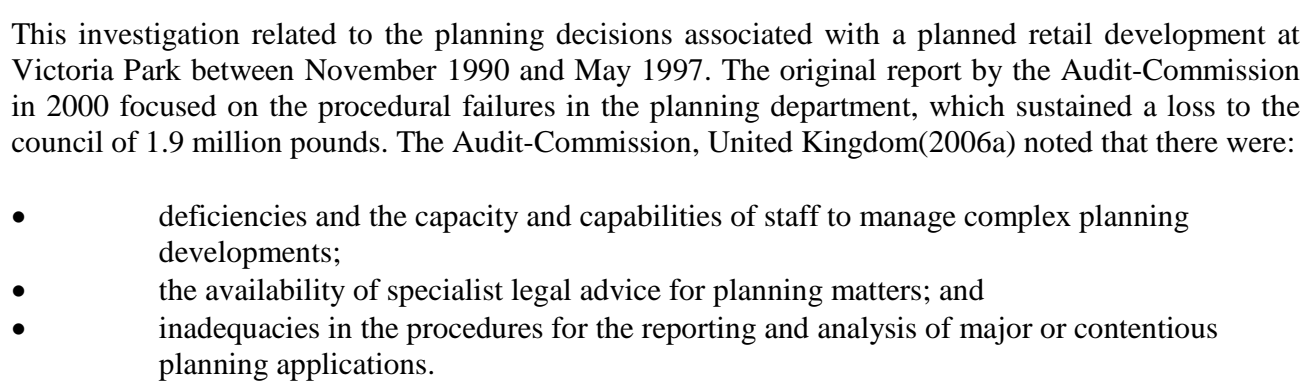 \\
\hline
\end{tabular}




\section{Appendix 2 Pilot survey}

The purpose of Appendix 2 is to detail the issues examined in the pilot survey.

\section{i. Issues canvassed}

Issue 1 Understanding by the Audit Committee of their responsibilities within the local government governance framework

Types of questions include:

How do they keep current with the knowledge of their accountabilities and responsibilities?

What are the areas that are focused on?

What other areas should be included?

What induction training is provided and updated?

What is the period of time of the updates?

\section{Issue 2 How Audit Committee Members apply their due skills and experience}

Types of questions include:

What are the relevant skills required to be on an audit committee?

How does a council ensure that the skills are current?

What training does the council provide and what is its frequency?

How does an individual audit committee member ensure their skills are current?

What periodic training does a committee member do?

\section{Issue 3 The ability to act objectively and independently}

Types of questions include:

How is independence and objectivity exercised?

What are the contentious issues within local government for audit committee members?

How are these issues addressed by the chief executive and the mayor?

How is conflict of interest managed?

\section{Issue 4 Maintenance of effective relationships with Council and Management}

Types of questions include:

What is the formal reporting mechanism from the audit committee to the council?

How is it managed?

How is negative news conveyed to council?

Does the audit committee meet with the council in the absence of the executive management team on a periodic basis?

(If so, what is the time period?)

Issue 5 Timeliness of Reporting from the Audit Committee to the Council

Types of questions include:

What is the frequency of formal reporting to the council by the audit committee?

Does the chair of the audit committee address the council periodically?

\section{Issue 6 Quality of Internal Financial Reporting}

Types of questions include:

Does a representative of the Auditor-General, Victoria address the audit committee on an annual basis?

Does the audit committee meet with the external auditor to discuss the interim and final financial audits?

What issues are raised and how are they managed? 


\section{Issue 7 Impact of Corruption and Maladministration Reports from other Councils (including Victoria, NSW and Qld)}

Types of questions include:

What issues have been raised at the audit committee?

How relevant are those issues for the operations of the council and the audit committee?

How effective are the internal controls and the management processes within the council to stop those events from occurring within the council?

Does the internal auditor and the external auditor address these know 'trouble spots'.

\section{Issue 8 Effectiveness of Internal Control in known 'trouble spots' within Councils (ie: Planning and Procurement)}

Types of questions include:

What are the trouble spots within the council?

Are they addressed in the annual internal audit program?

Does the audit committee require the relevant line manager to address the audit committee on how these issues are controlled, monitored and reported?

\section{Issue 9 Financial Viability of Councils}

Types of Questions include:

What are the viability issues for the council?

(ie: over-reliance on rates, inadequacy of tax base, changing demography, ageing infrastructure)

How often does the audit committee address these issues?

How can the audit committee assist the council to address the issues?

What strategies are put in place to manage these issues and how effective are the strategies?

Suggested areas for inclusion in or deletion from the research

Suggested questions which could be asked? 


\section{ii. Sources for the pilot survey}

\begin{tabular}{|l|l|}
\hline \multicolumn{1}{|c|}{ Name of Pilot Survey Respondent } & \multicolumn{1}{|c|}{ Overview of the Council or Organisation } \\
\hline Govesentative Bodies of Local & $\begin{array}{l}\text { Contractor, Finance and Insurance 2009. } \\
\text { This municipal representative body was established to promote } \\
\text { the effective carrying out of municipal government throughout } \\
\text { Victoria, Australia and to watch over and protect the interests, } \\
\text { rights and privileges of municipal bodies. }\end{array}$ \\
\hline Mayors & $\begin{array}{l}\text { This council was located in the outer northern suburbs of } \\
\text { Melbourne. Demographically, over half of the residents are from } \\
\text { non-English speaking backgrounds. }\end{array}$ \\
\hline Mayor B 2009. & $\begin{array}{l}\text { This council was located in the inner east of Melbourne and } \\
\text { features a mixture of residential, industrial and commercial } \\
\text { activity. }\end{array}$ \\
\hline Councillor B 2009. & $\begin{array}{l}\text { This metropolitan council was located 12 kilometres east of the } \\
\text { Melbourne central business district. }\end{array}$ \\
\hline Councillor A 2009. & $\begin{array}{l}\text { This metropolitan council was located south east of Melbourne's } \\
\text { central business district. It was culturally diverse, with 37\% of its } \\
\text { residents coming from more than 30 countries. }\end{array}$ \\
\hline As above. \\
\hline
\end{tabular}




\begin{tabular}{|c|c|}
\hline $\begin{array}{c}\text { Name of Pilot Survey Respondent } \\
\text { Current and Former Chief Fxecutive }\end{array}$ & Overview of the Council or Organisation \\
\hline $\begin{array}{l}\text { Current and Former Chief Executive } \\
\text { Officers \& Corporate Services Director }\end{array}$ & \\
\hline Former Chief Executive A 2009. & $\begin{array}{l}\text { This council was located in Melbourne's inner and middle- } \\
\text { eastern suburbs, approximately five kilometres east of the central } \\
\text { business district. }\end{array}$ \\
\hline Chief Executive B 2009. & $\begin{array}{l}\text { This council was located to the south east of Melbourne and was } \\
\text { the second largest retail and commercial centre in the } \\
\text { metropolitan area. }\end{array}$ \\
\hline Chief Executive C 2009. & $\begin{array}{l}\text { This council was located close to Melbourne's central business } \\
\text { district and major retail areas. Land use was predominantly } \\
\text { residential with associated retail and services. }\end{array}$ \\
\hline Chief Executive D 2009. & $\begin{array}{l}\text { This council was located in the inner east of Melbourne and } \\
\text { features a mixture of residential, industrial and commercial } \\
\text { activity. }\end{array}$ \\
\hline Chief Executive E 2009. & $\begin{array}{l}\text { The council was situated in the outer eastern metropolitan area. It } \\
\text { was a large municipality that has passed through a period of } \\
\text { rapid housing and business development. }\end{array}$ \\
\hline Chief Executive F 2009. & $\begin{array}{l}\text { This rural shire council was located approximately } 130 \\
\text { kilometres south-east of Melbourne and was predominantly a } \\
\text { coastal municipality with major industries being tourism and } \\
\text { agriculture. }\end{array}$ \\
\hline Corporate Services Director A 2009. & $\begin{array}{l}\text { This council was located in the inner east of Melbourne and } \\
\text { features a mixture of residential, industrial and commercial } \\
\text { activity. The main industries include beverage and malt } \\
\text { manufacturing, clothing manufacturing, machinery and } \\
\text { equipment wholesaling. }\end{array}$ \\
\hline \multicolumn{2}{|l|}{$\begin{array}{l}\text { Local Government Independent Audit } \\
\text { Committee Members }\end{array}$} \\
\hline Audit Committee Member A 2009. & $\begin{array}{l}\text { This audit committee member currently serves on two local } \\
\text { government audit committee. He previously served as chair on } \\
\text { another three local government audit committees. He has } \\
\text { extensive private sector audit and risk experience and was an } \\
\text { acknowledged expert in the areas of information technology } \\
\text { auditing. }\end{array}$ \\
\hline
\end{tabular}




\begin{tabular}{|c|c|}
\hline Name of Pilot Survey Respondent & Overview of the Council or Organisation \\
\hline Audit Committee Member B 2009. & $\begin{array}{l}\text { This audit committee member was a chartered accountant was: (1) } \\
\text { the Chair of a state government department's audit committee; (2) } \\
\text { an independent member of the audit committees of another state } \\
\text { government department; and } \\
\text { government council. }\end{array}$ \\
\hline Audit Committee Member C 2009. & $\begin{array}{l}\text { This audit committee member concurrently serves on six local } \\
\text { government audit committees. } \\
\text { He has extensive public sector audit and risk experience. }\end{array}$ \\
\hline Current and Former Audit Partners & \\
\hline Audit Partner A 2009. & $\begin{array}{l}\text { This partner was a chartered accountant and was a member of the } \\
\text { fifth largest accounting firm internationally, with a global turnover } \\
\text { of over US } \$ 4 \text { billion and has more than } 28,000 \text { staff. }\end{array}$ \\
\hline Audit Partner B 2009. & $\begin{array}{l}\text { This partner was a chartered accountant with extensive public } \\
\text { sector internal and external audit experience. } \\
\text { He was also an independent member of a local government audit } \\
\text { committee in the western metropolitan area of Melbourne and was } \\
\text { a consultant to other local government councils. }\end{array}$ \\
\hline Audit Partner C 2009. & $\begin{array}{l}\text { This audit partner had an association with external audits of local } \\
\text { government since } 1994 \text {. } \\
\text { He was well known in auditing circles for his public sector } \\
\text { auditing knowledge and expertise. }\end{array}$ \\
\hline Former Audit Partner D 2009. & $\begin{array}{l}\text { This member was an audit partner of a 'Big } 4 \text { ' accounting firm in } \\
\text { Melbourne, before moving to a second tier firm. } \\
\text { He has extensive internal audit experience in the private and public } \\
\text { sectors and was an expert in the areas of fraud, probity and internal } \\
\text { audit. }\end{array}$ \\
\hline
\end{tabular}




\title{
Appendix 3 Pilot survey response - Mr Wayne Cameron
}

\author{
Former Auditor-General, Victoria (28 February 2009) \\ Reprinted with his permission.
}

\section{Issue 1. How do members keep up to date?}

Practice can vary between different local government councils regarding how members are briefed about their roles and kept up to date. Some councils provide good briefings to new members, followed by appropriate papers about the role, the organisation. Others do not. In most cases briefing on appointment occurs but there may not be much subsequent briefings on say an annual basis.

The Municipal Association of Victoria may also provide training. For instance in 2008, I did a road show across Victoria on the role of audit committees. In most cases, the turn-out was pretty good, but in some there was no representation by the local government at all. About 140 members attended these May/June seminars, held at each of the main towns throughout Victoria.

\section{Issue 2. How Audit Committees apply skills and experience.}

In most cases committee membership is influenced by a range of skills that a council wishes to apply to the task. Members are drawn from council and local identities with legal or finance background. I did not encounter any with members with risk management backgrounds.

\section{Issue 3. Ability to act objectively and independently.}

An important aspect of audit committees in local government, as is the case across the public sector, is that by definition, an audit committee is an advisory committee of Council. They do not have any executive authority to do so and run the risk that they cut across the primary responsibilities either of the chief executive officer or the council or both. Having said that, most audit committees have a charter, which is reviewed annually by the committee and approved by council. That charter sets out clearly the expectations and powers of the audit committee.

The most contentious issues relate to the quality of the relationship of the committee with council, the chief executive officer and with staff. Because of the role of the committee and the nature of its interests, the risk exists that it becomes too involved in administration and undermines the primary responsibilities of the chief executive officer or staff accordingly. I am convinced that is the reason why most chief executive officers attend all audit committee. They want to make sure that if directions are to be given, for instance to staff, that it is them that makes them, not the audit committee.

Where, on rare occasions, a major issue arises for instance suspected fraud, the committee of course has an interest to see that appropriate investigation occurs and that if procedural or control weaknesses led to that occurrence appropriate remedial action is promptly taken. But the committee's role is to oversee that investigative work and to brief council accordingly. It is for council to decide what action should be taken, just as it is for the chief executive officer to act decisively. The most constructive and healthy arrangement is when timely briefings occur between the audit committee, the chief executive officer and the mayor or council.

How the audit committee relates to the work of the internal auditor is a further case in point. It's for the audit committee to be satisfied about the scope coverage and competency of internal audit, but it's the chief executive officer who will act on the internal audit recommendations and is answerable to council for actions taken. Of course in a day to day sense the chief financial officer will act on their own initiative to recommendations by the internal auditor, but they will be guided by the expressed priorities of the audit committee and/or the chief executive officer. Conflict will only arise if the values of either audit committee or the chief executive officer are not common.

Conflict of interest is managed variously by councils. Some manage it around the council and through the chief executive officer where a councillor or an external party is concerned. In purchasing examples the matter may be managed through a combination of the purchasing function and the chief financial officer or the chief executive officer. I have not seen many instances where matters of potential conflict of interest are referred to audit committee as a matter of standard practice. And I am not sure that they should be unless the audit 
committee has a risk management oversight role, in which case the role is one of systems monitoring rather than resolution. Resolution responsibilities lie with those who have executive responsibility for managing potential conflict risks.

\section{Issue 4. Maintenance of effective relationships}

Reporting arrangements to council vary. Some of the best provide regular written reports to council, sometimes done annually only with copies of audit committee minutes included in papers to councillors after audit committee meetings. Others have arrangements where the audit committee chair briefs council once a year. Others see the audit committee chair briefing the mayor annual or on an as needed basis.

Briefings to the chief executive officer are usually achieved by the chief executive officer attending all audit committee meetings - not something that I would have thought all that essential so long as the audit committee chair briefs the chief executive officer informally after each meeting on any matters. Negative news would typically be conveyed to council by the chief executive officer or mayor. Very rarely would the audit committee convey such news in preference to either the mayor or chief executive officer. Don't forget that in most cases the audit committee chair is not a councillor and therefore is not a member of council. Thus they only attend by mayoral invitation. In some cases the councillor on the audit committee will provide the briefing to council. But in my view this undermines the role of the audit committee chair, particularly if it's a serious matter. Audit committee meetings with council with executive management team absent, I haven't heard about, unless it's a particularly extreme situation. Audit committee meetings with the auditors and with executive management team excluded are difficult enough and still remain questioned by some chief executive officers and mayors. Despite my explaining to them the need for it.

\section{Issue 5. Timely reporting to Council.}

See my comments in 4 above.

\section{Issue 6. Quality of Internal Financial Reporting.}

In most, but not all, the auditor is provided an opportunity to brief the audit committee - around the time of the annual attest audit. Often before the audit starts and at the conclusion of the audit. In some cases the auditor does not see the other agenda items and this from my experience is a bit frustrating since it denies the auditor any chance of judging the effectiveness of the audit committee and of ascertaining whether the committee has any concerns that the auditor should be aware of.

On the matter of interim audits - there are very few interim audits in local government. Most local government audits are too small to justify a full interim audit approach. Where there are interim audits they tend to focus on control effectiveness and allow discussion with the committee on the effectiveness of the control environment. But the reality is that audits are still very much substantively driven and thus discussions around control effectiveness are limited. Most issues raised by auditors at the audit committee are around accounting policy matters and accounting treatments. This would make a good study area. For example, look at the nature of matters brought to audit committee for discussion. It's my feeling that for small to medium sized audits across Australia that most matters raised by the external audits relate to the financial statement items rather than the quality of the control environment per se.

\section{Issue 7. Impact of Corruption and Maladministration Reports.}

It's my experience that most audit committees are well tuned to reports that could assist them in the discharge of their duties. Typical sources of such reports can be those you ask about but they also include matters that feature in the Auditor-Generals Reports to Parliament- both from the results of financial audits, special reviews and performance audits.

Most audit committees will ask the chief financial officer or the internal auditor to comment or report on such matters at the next meeting. If the response requires any further action then either the chief financial officer Director of Corporate Services or the internal auditor will be tasked with an activity to investigate and report back. The risk is of course that the audit committee receives the positive assurances and things are not as well as expected. Hence it is good strategy for the audit committee to ask for the external auditors comment. Only in a small number of instances do audit committees ask the external auditor to investigate matters addressed in other external reports. Usually they tend to get assurance form their own staff or the internal auditor. 


\section{Issue 8. Effective Internal Controls.}

Increasingly audit committees are targeting the work of the internal auditor to focus on the areas of high risk. This focus is often preceded by annual assessments or risk analyses prepared by risk managers in the organisation or the internal auditor. As part of my road show to Victorian councils last year I suggested that the audit committee ask each senior manager in the organisation to brief them on the 'trouble areas', the areas that kept them awake at night - as part of the overall risk assessment process. This suggestion was made to try and get beyond the financial perspective of the risks to the organisation and to gain buy in by senior line managers to the annual discussion about areas needing further attention. It's my experience that although the process of risk assessment can be useful, it's not an adequate substitute for the exercise of judgment by senior players such as the members of the audit committee, senior management and the chief executive officer in identifying areas of intuitively high risk. As you say in your questionnaire, traditionally purchasing, payroll, miscellaneous revue raising activities and town planning approval administration are typically areas where one can simply never gain too much reassurance about the adequacy of controls.

Incidentally one of the most effective controls is often overlooked in this setting is that of budget setting and monitoring. There is no way that serious maladministration can continue undetected if budgets are set and monitored intelligently. If they are it's my contention that the budget setting process was not performing its function effectively. I continue to be amazed that significant fraud can occur without some detrimental and observable effect on the overall financial position of the entity. Yet we read about it more often than we should. Other areas that typically get attention - and they should - are around IT security. However they often do not include adequately sophisticated penetration testing. Tests are often designed by accountants using the Canadian industry standards rather than skilled IT personnel. More could be done in this area.

\section{Issue 9. Financial Viability.}

This area is often only addressed by audit committee $s$ in the context of their consideration of the financial statements prior to their 'sign off' to council. It's usually the role of the finance committee to concern itself about the financial state of the council. Having said that I do detect a reduction in the number of councils that have a dedicated finance committee. If that is the case then one would expect that council would be explicit about who is to monitor the finances of council - council itself or some other committee of council. It is my view that it's not the role of the audit committee to consider such matters in a fundamental fashion. It is either council as a whole acting as the budget and finance committee for a designated committee. As I said earlier the audit committee is an advisory committee. It is not a section 86 committee under the Local Government Act. It has no other role than to advise Council. Its membership of a majority of external members (ie they are not councillors and are not therefore responsible for the governance of the council) makes it impossible for them to make anything happen for this reason.

\section{Further suggestions:}

Victoria has much more prescribed audit committee arrangements for local government than other states. There exists ongoing debate about the level of that prescription. A key question is therefore around what elements of that prescription are being challenged and why. For instance there has been a long standing debate about whether members of the audit committee should be independent of council. Some argue that the advice that was taken by government in 1999 that led to the current policy overlooked the fact that by definition councillors (ie those charged with governance) are independent and that therefore the audit committee should be populated with councillors. Others argue that this would risk not having the requisite range of skills and experience around the audit committee table.

A related question is around whether the presence of a more prescribed regime in Victoria has led to any change in the incidence of maladministration or corruption. I have already alluded to the importance of budgetary control and monitoring performance against budget. It would be interesting to see if there exists a gap in oversight of this important activity if in fact what I hear is true that there are now fewer councils with dedicated finance committees. 


\section{Appendix 4 Observations from the pilot survey}

The observations and comments from participants in the pilot survey were provided on the condition of anonymity as outlined in the information provided to the participants in the research.

\section{Appendix 4.1 Overview of local government audit committees}

A number of the respondents provided some broad sector-wide observations about the operations of audit committees in Victorian local government. The most pertinent observations came from: (1) Cameron (2009); (2) a current councillor and a former board member of the Municipal Association of Victoria; (3) a former chief executive; and (4) a current chief executive.

A representative body of local government in Victoria stated that in its view:

'....the project was timely and that it is known the Municipal Association of Victoria is keen on promoting the importance of audit committees in local government and the benefits accruing to councils if these committees are properly formed and operating effectively.

The Municipal Association of Victoria has particular interest in understanding whether a council sees the benefits of having an audit committee and what they may be. In addition, do audit committees in local government look at purely financial matters or do they take a broader perspective around total organisational risk?' (Contractor, Finance and Insurance 2009).

Cameron (2009) stated that:

'Victoria has greater prescribed audit committee arrangements for local government than other Australian States. There exists an ongoing debate about the level of that prescription.

A key question is therefore around what elements of that prescription are being challenged and why. For instance there has been a long standing debate about whether members of the audit committee should be independent of council.

Some argue that the advice that was taken by the Victorian Government in 1999 that led to the current policy overlooked the fact that by definition councillors (ie those charged with governance) are independent and therefore the audit committee should be populated with councillors. Others argue that this would risk not having the requisite range of skills and experience around the audit committee table' (Cameron 2009). 
Cameron (2009) also referred to the presentation for the Municipal Association of Victoria concerning effective audit committees in local government (Cameron 2008). He considered that the 'four main principles of good governance supporting an audit committee were: (1) independence; (2) competence; (3) clarity of purpose; and (4) open and effective relationships between the audit committee and the council' (Cameron, 2008, p. 4). It was noted that the presentation by Cameron (2008) was discussed at the audit committee of Mornington Shire Council and the council meeting of the Hobsons Bay City Council in 2008 and 2009 respectively (Mornington Shire Council 2008, p. 49; and Hobsons Bay City Council 2009, Item 7.1.1).

A councillor and a former board member of the Municipal Association of Victoria stated that:

'....in relation to your pilot study, I don't know if it is beyond the scope of what you plan to cover, but I think it would be particularly interesting to review the role played by audit committees in New South Wales compared to Victoria.

Whilst I don't know if it can be substantiated, Victorian councils have often claimed to be less 'prone to corruption' than their New South Wales counterparts because of claimed superior administrative and legal controls, the separation of elected members from management decisions and a generally better local government governance culture.

As I said, I don't know how much of this is spin and how much is substance, but I think it would be interesting to examine the different approaches to audit committees in the two states and whether the approach in New South Wales can in any way be said to be inferior and to have resulted in New South Wales local government having had more publicly discovered instances of corruption than in Victoria,' (Councillor A 2009).

Whilst these comments were informative, it was considered to be beyond the scope of this thesis, although they could form the basis of some further research.

A former chief executive of a large Melbourne metropolitan council made the following observations:

'...the composition of local government audit committees needs attention. There has been a past attempt to apply private sector thinking. Unfortunately, that work and its recommendations (supported by some peak bodies) have failed to recognise the importance of the role of elected councillors on audit committees as the clear equivalent of independent non-executive directors of private sector boards. 
The extent of the role of audit committees is too often inappropriately limited to review of financial systems and transactions. Modern audit committees of local governments should have a wider ranging brief similar to developments in the private sector and include responsibilities for audit of risk management, governance systems and statutory compliance' ( Former Chief Executive Officer A 2009).

A Director of Corporate Services at an inner metropolitan council commented about the expectations and the clarity of the specific role of the audit committee. He noted that there can be a risk for some independent chairs of audit committees to usurp their role or accountabilities, notwithstanding that the audit committee is only an advisory committee to the council and only councillors can have the legal responsibilities and the accountabilities to govern and to manage the affairs of the municipality. This accorded with a current chief executive of large outer Melbourne metropolitan council who considered that:

'... an audit committee may have some understanding of what 'they' think they should do, but their 'client' is council and the council should clarify its expectations. In addition, it is important that this reverse accountability apply that council understands that it too has a responsibility to give guidance to its audit committee about matters on council's agenda; that it does not for instance want it to be a 'finance committee'; that it will allow the audit committee to operate with autonomy and within best practice principles, but expects some or certain particular outcomes.

I often fear that too many councillors breathe easy when they have an audit committee in the belief that their own accountability has been transferred - but we know that this is not the case and councils must be clearer on their roles with audit committees' (Chief Executive Officer B 2009).

In relation to the maintenance of effective relationships between the audit committee and the council, Cameron (2009) stated that:

'... a briefing to the chief executive officer can be achieved in practice by the chief executive officer attending all audit committee meetings, not something that I would have thought all that was essential, so long as the audit committee chair briefs the chief executive officer informally after each meeting on any matters that need that step.

Negative news would typically be conveyed to council by the chief executive officer or mayor. Vary rarely would the audit committee convey such news in preference to either the mayor or chief executive officer. Don't forget that in most cases the audit committee chair is not a councillor and therefore is not a member of council. Thus they only attend by mayoral invitation. In some cases the councillor on the audit committee will provide the briefing to council. But in my view, that undermines the role of the audit committee chair, particularly if it's a serious matter' (Cameron 2009). 
He further considered that in relation to the impact of corrupt practices or maladministration in local government that it was his experience that:

'...most audit committees are well tuned to reports that could assist them in the discharge of their duties. Typical sources of such reports feature in the AuditorGeneral's Reports to Parliament, both from the results of financial audits, special reviews and performance audits.

Most audit committees will ask the chief financial officer or the internal auditor to comment or report on such matters at the next meeting. If the response requires any further action then either the chief financial officer, director of corporate services or the internal auditor will be tasked with an activity to investigate and report back.

The risk is of course that the audit committee receives the positive assurances and things are not as well as expected. Hence it is good strategy for the audit committees to ask for the external auditors comment. Only in a small number of instances do audit committees ask the external auditor to investigate matters addressed in other external reports. Usually they tend to get assurance from their own staff or the internal auditor' (Cameron 2009).

\section{Appendix 4.2 Mayors}

The response rate from the mayors was low and definitive conclusions from this sub-group could not be made. One mayor indicated that the municipality had recently had a falseinvoicing fraud perpetrated by a staff member. She stated that she was comforted by the way in which the chair of the audit committee provided some oversight of the investigation process with the investigation directly managed by the chief executive and investigated by the Victoria Police (Mayor A, 2009).

Another mayor indicated 'that it was worth noting that I have been council for five months and our audit committee has only met once,' (Mayor B 2009). She further alluded to the issue of the control of information by the management and noted that the audit committee needed to trust that the management was transparent and demonstrated integrity in providing full information and not doctored information. 


\section{Appendix 4.3 Councillors}

A former mayor of a Melbourne metropolitan council suggested that further analysis could be made of:

'... (1) the scope of the audit committee; (2) the mix of skills from external representatives; (3) the turnover of the committee members; (4) the selfassessment of the committee's performance; and (5) the chair of the audit committee addressing the council periodically' ( Councillor B 2009).

Another councillor of a Melbourne metropolitan council suggested that further consideration could be made of:

'... (1) the audit committee charter, for example, who prepares it; (2) performance management and reporting, for example, what is the role of the audit committee in monitoring performance reporting over and beyond the Local Government Act; (3) Local Government Act statutory reports, for example, compliance with Best Value obligations in the Local Government Act, performance reporting generally; (4) who does the audit committee report to; the councillors or the chief executive? (5) how detailed are reports or the minutes of the audit committee? (6) is there an independent evaluation of audit committee effectiveness? (7) the audit committee and their individual professional responsibilities; and (8) culture of transparency in council decision-making' ( Councillor C 2009).

\section{Appendix 4.4 Chief executives}

The response from current and former chief executives was divided into two categories namely: (1) general observations; and (2) specific observations.

\section{i. General observations}

A chief executive from a Melbourne metropolitan council stated that the effectiveness of an audit committee depended: (1) on the rigour of its members; and (2) on the ability of independent members to 'educate' councillor members (Chief Executive C 2009). He further indicated that he considered that the secondary research question was not well expressed. He considered that investigations into corruption and maladministration were not there to enhance the audit committee's effectiveness, but moreover, the audit committee was there to enhance the council's effectiveness. This author partially agrees with the comments, although, the recommendations of corruption and maladministration reports from councils by 
the Ombudsman, Victoria and the Auditor-General, Victoria, do provide some benchingmarking material for each council to assess its own performance.

Whilst the corruption and maladministration reports in themselves do not directly contribute to the governance of a council, they do however enhance the governance and administration processes for the particular council in question and do provide an authoritative source for other councils to reassess their internal control environment and processes. For example, at Manningham City Council in the period 2003-2007, the former chief executive required that the recommendations from all local government investigation reports be benched-marked against the management processes and the organisational internal controls. This was reported to the audit committee, with the relevant manager, for example, Manager, Statutory Planning, being required to provide both a written assessment and a verbal presentation to the audit committee.

Chief Executive D (2009) stated that,' it would be useful to get some different perspectives on how the audit committee was managed'. She suggested that one should consider the processes to support the management of the agenda and how the council may use this to curtail debate and focus on particular areas (Chief Executive D 2009).

Chief Executive E (2009) stated that:

'...audit committees form a very important component of councils' overall governance framework and yet I do not believe sufficient attention has been given to date to their functioning. The only additional matter you may care to consider is how the membership of an audit committee is recruited by a council.

My understanding is that there is a very wide range of methodologies and approaches utilised in the recruitment of members to audit committees and this no doubt has a significant impact on the functioning of audit committees across the sector' ( Chief Executive E 2009).

This was an insightful observation, as another chief executive from a rural shire council stated that finding and retaining professionally qualified and experienced audit committee members residing in rural areas was problematic for the council and could be problematic for other shire councils and rural city councils in general ( Chief Executive F 2009). 


\section{ii. Specific observations}

A corporate services director stated that the audit committee required:

'... (1) a comprehensive induction for new members; (2) stability of tenure for the independent members of the audit committee; (3) a clear and unambiguous audit committee charter which defined accountabilities and responsibilities; and (4) should focus on the key risks of the council and effectiveness of processes to manage those risks' (Corporate Services Director A 2009).

A chief executive from a shire council concurred with the observations from the corporate services director and confirmed that the induction of audit committee members was crucial for them to understand the workings and the nuances of council operations and the external pressures upon local government. He stated that the relationship between the audit committee and the council requires trust, in order that issues from the audit committee can be considered open-mindedly and objectively by the council (Chief Executive F 2009). This was also supported by Chief Executive B (2009) who stated that:

'...this raises in my mind, how the council would respond, react or address 'barriers and obstacles'. Remember at a former council, you would be aware that they established a process that offset the fact that a councillor was always chair of the audit committee and that if any independent member had a problem that is they felt gagged or compromised, that they could report directly to the full council. So how would the audit committee respond if management of the council put unreasonable obstacles or expectations in the way?' (Chief Executive B 2009).

\section{Appendix 4.5 Local government independent audit committee members}

One independent audit committee member stated that an important issue that could be considered was 'what measures are needed to increase the effectiveness of audit committees' (Audit Committee Member A 2009). In relation to the context of governance in local government he considered that:

'...At the moment it is rather 'tick the boxes', rather than understanding the context. It is important to identify what substance governance takes in local government entities, as opposed to going through the motions of complying with the form. I have severe doubts as to the value of form activities, particularly as to how they add value to a local government entity's ratepayers and other stakeholders' (Audit Committee Member A 2009).

Audit Committee Member B (2009) stated that: 
'...the big issue not addressed in the pilot survey is the structure of the audit committees, which I suspect vary widely and, even more importantly, the way both the elected councillors and the council officers react to the committee.

I am not sure a questionnaire can be devised to draw that particular information out’ (Audit Committee Member B 2009).

This issue of trust and the relationships between the audit committee and the council were canvassed by a number of councillors and chief executives. Whilst the above observations came from two audit committee members who were accountants, it was significant to note the differing observations of a legal practitioner who was the chair of an audit committee of a Melbourne metropolitan council. He suggested that it was important to differentiate between those councils who want the audit committee to be the 'quasi finance committee' of the council and concentrate its time and resources on accounting related matters, whereas in his experience, it was more appropriate that audit committees focus on organisational risks and sector-wide risks.

This observation accorded with the audit committee best practice guides as discussed in Chapter Four and the observations from a chief executive of a Melbourne metropolitan council, who considered that the management of the council's finances is a fundamental obligation of all councillors and not exclusively the purview of a council subcommittee or a quasi-finance and audit committee (Australian National Audit Office 2005; Cameron 2008, HM Treasury 2007; KPMG 2008b; PriceWaterhouseCoopers 2003). An audit committee member, who is currently a member of six local government audit committees, suggested the following enhancements to this research:

(1) an additional question may relate to previous audit committee and governance experience at council and/or other places; (2) does the reporting of the activities of the audit committee to council meet council's expectations?; (3) in relation to performance ratios of the council what ratios does the audit committee monitor and over what time period do these ratios relate? (Audit Committee Member C 2009)

\section{Appendix 4.6 External auditors}

Four audit partners with extensive external and internal audit experience in local government provided the following observations. Whilst two of the observations were general in nature, the remaining two observations were particularly insightful. One audit partner indicated that: 
...there are some clear issues on local government audit committees and the rotation of councillors and the independents and who chairs the meetings are a few that spring to mind. Composition can also be an issue with a bias towards financials (Audit Partner A 2009).

Audit Partner C (2009) suggested that the attributes of effectiveness can be assessed by looking at things such as:

(1) the size of the budget to support audit committee and internal audit; (2) who establishes the agenda of the audit committee; (3) what is on the agenda; (4) how long meetings run for; (5) how often they meet; and (6) whether the audit committee works to an annual program that is aligned to the audit committee charter (Audit Partner C 2009).

Another former accounting partner considered that it was fundamental to be clear as to the purpose of the audit committee and its responsibilities and accountabilities. For example, was the audit committee only responsible for the review of financial controls and operations or was the audit committee have a broader remit of reviewing a council’s risks.

He suggested that the audit committee needed to establish clear and unambiguous channels of communication to identify the organisational wide risks and the expectations from the key players within council, namely the mayor, councillors, chief executive, directors of service functions within the council and the external stakeholders including, Local Government Victoria and the Auditor-General, Victoria. He further stated:

$\ldots$ is the audit committee the driver of what they want to achieve or is the audit committee told what they want to hear (Former Audit Partner D 2009).

It was noted that some of these observations were consistent with the behavioural theory of governance, as expressed by Marnet (2008, 2007 and 2005) and supported by Cutting and Kouzmin (2000); Leung and Cooper (2003); and Pech and Durden (2004). Marnet (2008 and 2007) questioned the application of the rationality in decision making within all governance models and concluded that 'behavioural analysis of governance practices appears to explain some of these paradoxes on which the rational approach to governance founders, or at best, provides very arduous explanations’ (Marnet 2008, p. 207). 


\section{Appendix 4.7 Other suggestions}

Some of the suggestions for enhancement from the pilot survey included the observations from Cameron (2009):

.... a related question is around whether the presence of a more prescribed regime in Victoria has led to any change in the incidence of maladministration or corruption (Cameron 2009).

This was consistent to the observations from a current councillor of a Melbourne suburban council and a former board member of the Municipal Association of Victoria (Councillor A 2009) and would tentatively be supported by findings of the investigations in Victoria (Table

3.1 in Chapter Three). Cameron (2009) stated:

...I have already alluded to the importance of budgetary control and monitoring performance against budget. It would be interesting to see if there exists a gap in oversight of this important activity if in fact what I hear is true that there are now fewer councils with dedicated finance committees (Cameron 2009).

Another independent member of an audit committee suggested that further questions could be asked in relation: (1) composition and the membership of the audit committee; (2) the process for the setting of the audit committee agenda; (3) the processes to manage agenda and followup activities; and (4) the adequacy of the audit committee papers (Audit Committee Member C 2009). Specifically, it was suggested that the research should ascertain:

\section{i. Membership of the audit committee}

- What is the membership of the committee?

- How many councillors and independent members comprise the audit committee?

- Does the mayor attend the meeting as a member or observer?

- Do any other councillors attend the meetings as observers? and

- Who chairs the meeting?

\section{ii. Committee's agenda}

- How is the agenda established? and

- What if any is the relationship between the agenda and the audit committee charter.

\section{iii. Audit committee papers}

- Are the committee papers complete, timely and easy to comprehend? and

- Does the audit committee source material and reports from other professional entities to help them fulfill their responsibilities? 
He noted that the pilot survey did not include any questions pertaining to risk management, internal audit, continuous improvement, audit committee charter and sustainability reporting (other than some reference to financial viability). These observations were noted, but it considered that the quantitative research questionnaire should ideally be around twenty to twenty-five questions and as a consequence it would not be possible to include all the suggestions from the participants. 


\section{Survey of Audit Committees - Local Government Councils/Shires}

An audit committee can be part of the council's/shire's governance structure and inculcated into the culture of the council/shire.

Audit committees are supported by the governance 'building blocks' of: (1) composition and structure; (2) delegated accountabilities and responsibilities from the council/shire; and (3) an understanding of current and emerging issues within the council/shire and local government generally.

This Survey of Audit Committees asks some questions framed around: (1) the role of the audit committee: (2) the charter of the audit committee; (3) audit committee membership and processes; (4) training and development of audit committee members; and (5) communications and reporting.

\section{Background Questions}

It would be appreciated if you could tick the following boxes:

Question

\begin{tabular}{|c|c|c|c|c|c|c|}
\hline 1. & Please indicate if you are: & $\begin{array}{l}\text { Member of the } \\
\text { Management Committee of } \\
\text { the Municipal Association } \\
\text { of Victoria } \\
\text { (Please Tick) }\end{array}$ & $\begin{array}{c}\text { Office Bearer or } \\
\text { Committee Member of } \\
\text { the Local Government } \\
\text { and Shires Association } \\
\text { of New South Wales } \\
\text { (Please Tick) }\end{array}$ & $\begin{array}{l}\text { Chief Executive of a Victorian } \\
\text { Council/Shire } \\
\text { (Please Tick) }\end{array}$ & $\begin{array}{l}\text { Chair of the } \\
\text { Audit } \\
\text { Committee of a } \\
\text { Victorian } \\
\text { Council/Shire } \\
\text { (Please Tick) }\end{array}$ & $\begin{array}{l}\text { Mayor of a } \\
\text { Victorian } \\
\text { Council/Shire } \\
\text { (Please Tick) }\end{array}$ \\
\hline 2. & Is your council/shire: & Metropolitan & Regional City Council & Rural Shire Council & & \\
\hline
\end{tabular}

Please answer 'yes' or 'no' to the following

\begin{tabular}{|c|c|c|c|c|}
\hline 3. & $\begin{array}{l}\text { Does your council/shire have an audit } \\
\text { committee? }\end{array}$ & Yes & No & $\begin{array}{l}\text { If 'No', please discontinue answering the } \\
\text { survey and return the survey. }\end{array}$ \\
\hline 4. & $\begin{array}{l}\text { Does the audit committee have a charter } \\
\text { approved by the council/shire? }\end{array}$ & Yes & No & \\
\hline 5. & $\begin{array}{l}\text { Does the audit committee report to the } \\
\text { council/shire on a regular basis? }\end{array}$ & Yes & No & \\
\hline
\end{tabular}




\begin{tabular}{|c|l|c|c|}
\hline 6. & $\begin{array}{l}\text { Do audit committee members understand } \\
\text { that the committee is only an advisory body } \\
\text { to the council/shire? }\end{array}$ & Yes & No \\
\hline
\end{tabular}

\begin{tabular}{|c|l|c|c|c|}
\hline 7. & $\begin{array}{l}\text { Are the majority of the members of the audit } \\
\text { committee }\end{array}$ & Councillors? & $\begin{array}{c}\text { Independent audit } \\
\text { committee members? }\end{array}$ & Management representatives? \\
\hline 8. & Is the chair of the audit committee a: & Councillor? & $\begin{array}{c}\text { Independent audit } \\
\text { committee member? }\end{array}$ & Management representative? \\
\hline
\end{tabular}

\section{Instructions for Completion of the Survey Questions}

1. The Survey asks each Mayor/Councillor/Chief Executive/Chair of the Audit Committee to answer Yes / No / Not Applicable/Don't Know against the statement, 'is this the current practice in your council/shire?'

2. If you answer ' $\underline{\text { Yes, }}$ you are asked to numerically rate the current practice from ' 1 to 7 ', where ' 1 ' means significant improvement required to current practices and ' 7 ' means excellent processes are in place and no improvement required

3. If you answered 'No', please do not numerically rate the 'current practice in your council/shire'.

4. For those that answered 'No', please also respond to the question, 'should the audit committee do this in the future?'

5. If you answered 'Not Applicable' to the statement 'is this the current practice in your council/shire', do not numerically rate the current practice, but respond to the question, 'should the audit committee do this in the future?' 


\section{VICTORIA UNIVERSITY

\begin{tabular}{|c|c|c|c|c|}
\hline Number & Questions & $\begin{array}{l}\text { In your experience is this } \\
\text { the current practice in your } \\
\text { council/shire? } \\
\text { Please indicate Yes/No/ } \\
\text { Not Applicable/ }\end{array}$ & $\begin{array}{l}\text { If you answered 'YES', please rate the current } \\
\text { practice in your council/shire. } \\
1 \text { indicates significant improvement required to } \\
\text { current practices. } \\
7 \text { indicates excellent processes are in place and } \\
\text { no improvement needed. } \\
\begin{array}{l}\text { Improvement } \\
\text { Required }\end{array} \\
\begin{array}{l}\text { No improvement } \\
\text { Required }\end{array}\end{array}$ & $\begin{array}{l}\text { If you answered 'NO', should the audit } \\
\text { committee do this in the future? } \\
\text { Please indicate Yes/No/Not Applicable }\end{array}$ \\
\hline $\begin{array}{l}\text { A. Formin } \\
\text { The audit c } \\
\text { committee. }\end{array}$ & $\begin{array}{l}\text { an Audit Committee } \\
\text { nmittee should be independent and objective. }\end{array}$ & ch member of the audit commi & e should have an understanding of the council's r & priorities and of the role of the audit \\
\hline 1. & $\begin{array}{l}\text { Are audit committee members appointed on } \\
\text { the basis of agreed criteria for membership? }\end{array}$ & & & \\
\hline 2. & $\begin{array}{l}\text { Is there clarity by the council/shire of the } \\
\text { expectations of the audit committee? }\end{array}$ & & & \\
\hline 3. & $\begin{array}{l}\text { Do audit committee members have } \\
\text { sufficient knowledge of local government } \\
\text { and the operations and risks of your } \\
\text { council/shire? }\end{array}$ & & & \\
\hline 4. & $\begin{array}{l}\text { Does the audit committee review its charter } \\
\text { annually and recommend changes to your } \\
\text { council/shire? }\end{array}$ & & & \\
\hline
\end{tabular}




\section{VICTORIA ANEW UNIVERSITY THOUGHT}

\begin{tabular}{|c|c|c|c|c|}
\hline Number & Questions & $\begin{array}{l}\text { In your experience is this } \\
\text { the current practice in your } \\
\text { council/shire? } \\
\text { Please indicate Yes/No/ } \\
\text { Not Applicable/ } \\
\text { Don't Know }\end{array}$ & $\begin{array}{l}\text { If you answered 'YES', please rate the current } \\
\text { practice in your council/shire. } \\
1 \text { indicates significant improvement required to } \\
\text { current practices. } \\
7 \text { indicates excellent processes are in place and } \\
\text { no improvement needed. } \\
\begin{array}{l}\text { Improvement } \\
\text { Required }\end{array}\end{array}$ & $\begin{array}{l}\text { If you answered 'NO', should the audit } \\
\text { committee do this in the future? } \\
\text { Please indicate Yes/No/Not Applicable }\end{array}$ \\
\hline 5. & $\begin{array}{l}\text { Are resources available to the audit } \\
\text { committee to take independent advice when } \\
\text { the audit committee reasonably believes it } \\
\text { is necessary to do so? }\end{array}$ & & & \\
\hline \multicolumn{5}{|c|}{$\begin{array}{l}\text { B. Knowledge and Expertise of the Audit Committee } \\
\text { The audit committee should have a mix of skills to perform its functions. }\end{array}$} \\
\hline 1. & $\begin{array}{l}\text { Do audit committee members have the } \\
\text { skills and expertise to meet the objectives } \\
\text { of the audit committee charter? }\end{array}$ & & & \\
\hline 2. & $\begin{array}{l}\text { Is the audit committee dominated by an } \\
\text { individual member? }\end{array}$ & & & \\
\hline 3. & $\begin{array}{l}\text { Does at least one member of the audit } \\
\text { committee have financial qualifications } \\
\text { and skills to engage with financial and } \\
\text { management reporting? }\end{array}$ & & & \\
\hline
\end{tabular}




\section{VICTORIA UNIVERSITY

\begin{tabular}{|c|c|c|c|c|}
\hline Number & Questions & $\begin{array}{l}\text { In your experience is this the } \\
\text { current practice in your } \\
\text { council/shire? } \\
\text { Please indicate Yes/No/ } \\
\text { Not Applicable/ } \\
\text { Don't Know }\end{array}$ & $\begin{array}{l}\text { If you answered 'YES', please rate the } \\
\text { current practice in your council/shire. } \\
1 \text { indicates significant improvement required } \\
\text { to current practices. } \\
7 \text { indicates excellent processes are in place and } \\
\text { no improvement needed. } \\
\begin{array}{l}\text { Improvement } \\
\text { Required }\end{array} \\
\text { Required }\end{array}$ & $\begin{array}{l}\text { If you answered 'NO', should the audit } \\
\text { committee do this in the future? } \\
\text { Please indicate Yes/No/Not Applicable }\end{array}$ \\
\hline 4. & $\begin{array}{l}\text { Does the audit committee review at least } \\
\text { annually the skill base of its members, to } \\
\text { clarify if the audit committee has the } \\
\text { requisite skills for the new and emerging } \\
\text { risks of the council/shire? }\end{array}$ & & & \\
\hline 5. & $\begin{array}{l}\text { Can the audit committee co-opt members } \\
\text { for periods of less than a year to provide } \\
\text { specialist skills? }\end{array}$ & & & \\
\hline \multicolumn{5}{|c|}{$\begin{array}{l}\text { C. Induction and Training } \\
\text { The audit committee should provide an induction program to new members, including a review of the risk profile of the council/shire. It should also consider some periodic training for existing } \\
\text { members. }\end{array}$} \\
\hline 1. & $\begin{array}{l}\text { Are new audit committee members } \\
\text { provided with a relevant induction } \\
\text { program? }\end{array}$ & & & \\
\hline
\end{tabular}




\begin{tabular}{|c|c|c|c|c|}
\hline Number & Questions & $\begin{array}{l}\text { In your experience is this the } \\
\text { current practice in your } \\
\text { council/shire? } \\
\text { Please indicate Yes/No/ } \\
\text { Not Applicable/ } \\
\text { Don't Know }\end{array}$ & $\begin{array}{l}\text { If you answered 'YES', please rate the current } \\
\text { practice in your council/shire. } \\
1 \text { indicates significant improvement required to } \\
\text { current practices. } \\
7 \text { indicates excellent processes are in place and no } \\
\text { improvement needed. }\end{array}$ & $\begin{array}{l}\text { If you answered 'NO', should the audit } \\
\text { committee do this in the future? } \\
\text { Please indicate Yes/No/Not Applicable }\end{array}$ \\
\hline 2. & $\begin{array}{l}\text { Are audit committee members assisted } \\
\text { by the council/shire to periodically } \\
\text { update their knowledge of local } \\
\text { government activities and risks? }\end{array}$ & & & \\
\hline 3. & $\begin{array}{l}\text { Does the audit committee ensure that } \\
\text { new members have knowledge of the } \\
\text { key business risks of the council/shire? }\end{array}$ & & & \\
\hline 4. & $\begin{array}{l}\text { Does the audit committee periodically } \\
\text { visit the council's/shire's sites and } \\
\text { receive briefings from key officers? }\end{array}$ & & & \\
\hline 5. & $\begin{array}{l}\text { Do independent members of the audit } \\
\text { committee challenge line management } \\
\text { and the external/internal auditors on } \\
\text { critical and sensitive issues? }\end{array}$ & & & \\
\hline
\end{tabular}




\section{VICTORIA ANEW UNIVERSITY THOUGH}

\begin{tabular}{|c|c|c|c|c|}
\hline Number & Questions & $\begin{array}{l}\text { In your experience is this } \\
\text { the current practice in } \\
\text { your council/shire? } \\
\text { Please indicate Yes/No/ } \\
\text { Not Applicable/ } \\
\text { Don't Know }\end{array}$ & $\begin{array}{l}\text { If you answered 'YES', please rate the current } \\
\text { practice in your council/shire. } \\
1 \text { indicates significant improvement required to } \\
\text { current practices. } \\
7 \text { indicates excellent processes are in place and } \\
\text { no improvement needed. } \\
\begin{array}{l}\text { Improvement } \\
\text { Required }\end{array} \\
\text { No improvement } \\
\text { Required }\end{array}$ & $\begin{array}{l}\text { If you answered 'NO', should the audit committee } \\
\text { do this in the future? } \\
\text { Please indicate Yes/No/Not Applicable }\end{array}$ \\
\hline \multicolumn{5}{|c|}{$\begin{array}{l}\text { D. Managing the Audit Committee } \\
\text { This section relates to the administrative processes for the audit committee to operate. }\end{array}$} \\
\hline 1. & $\begin{array}{l}\text { Are all audit committee members required } \\
\text { at every meeting to disclose a conflict of } \\
\text { interest with any items on the agenda of the } \\
\text { meeting? }\end{array}$ & & & \\
\hline 2. & $\begin{array}{l}\text { Does the audit committee have an annual } \\
\text { calendar and agenda to ensure that the audit } \\
\text { committee achieves its responsibilities? }\end{array}$ & & & \\
\hline 3. & $\begin{array}{l}\text { Does the audit committee have any } \\
\text { extraordinary sessions to consider } \\
\text { important issues? }\end{array}$ & & & \\
\hline
\end{tabular}




\section{VICTORIA UNIVERSITY

\begin{tabular}{|c|c|c|c|c|}
\hline Number & Questions & $\begin{array}{c}\text { In your experience is } \\
\text { this the current practice } \\
\text { in your council/shire? } \\
\text { Please indicate Yes/No/ } \\
\text { Not Applicable/ } \\
\text { Don't Know }\end{array}$ & $\begin{array}{l}\text { If you answered 'YES', please rate the current } \\
\text { practice in your council/shire. } \\
1 \text { indicates significant improvement required to } \\
\text { current practices. } \\
7 \text { indicates excellent processes are in place and no } \\
\text { improvement needed. } \\
\begin{array}{l}\text { Improvement } \\
\text { Required }\end{array} \\
\text { Nequired } \\
\text { No improvement } \\
\text { Required }\end{array}$ & $\begin{array}{l}\text { If you answered 'NO', should the audit committee } \\
\text { do this in the future? } \\
\text { Please indicate Yes/No/Not Applicable }\end{array}$ \\
\hline 4. & $\begin{array}{l}\text { Can members of the audit committee place } \\
\text { items on the audit committee agenda? }\end{array}$ & & & \\
\hline 5. & $\begin{array}{l}\text { Are the agenda and supporting papers } \\
\text { distributed at least seven days in advance to } \\
\text { allow audit committee members to study } \\
\text { the papers and understand the information? }\end{array}$ & & & \\
\hline 6. & $\begin{array}{l}\text { Does the chair of the audit committee } \\
\text { ensure that all 'action points' from the } \\
\text { committee meetings are resolved? }\end{array}$ & & & \\
\hline 7. & $\begin{array}{l}\text { Do the audit committee members meet at } \\
\text { least annually outside of the audit } \\
\text { committee with the council? }\end{array}$ & & & \\
\hline 8. & $\begin{array}{l}\text { Do the independent audit committee } \\
\text { members strike a balance between } \\
\text { challenge and respect for the positions of } \\
\text { the councillors and the senior management } \\
\text { team? }\end{array}$ & & & \\
\hline
\end{tabular}




\section{VICTORIA UNIVERSITY

\begin{tabular}{|c|c|c|c|c|}
\hline Number & Questions & $\begin{array}{c}\text { In your experience is } \\
\text { this the current } \\
\text { practice in your } \\
\text { council/shire? } \\
\text { Please indicate } \\
\text { Yes/No/ } \\
\text { Not Applicable/ } \\
\text { Don't Know }\end{array}$ & $\begin{array}{l}\text { If you answered 'YES', please rate the current } \\
\text { practice in your council/shire. } \\
1 \text { indicates significant improvement required to } \\
\text { current practices. } \\
7 \text { indicates excellent processes are in place and no } \\
\text { improvement needed. } \\
\begin{array}{l}\mathbf{1} \\
\text { Improvement } \\
\text { Required }\end{array}\end{array}$ & $\begin{array}{l}\text { If you answered 'NO', should the audit committee } \\
\text { do this in the future? } \\
\text { Please indicate Yes/No/Not Applicable }\end{array}$ \\
\hline 9. & $\begin{array}{l}\text { Does the audit committee meet regularly with } \\
\text { the external and internal auditors? }\end{array}$ & & & \\
\hline 10. & $\begin{array}{l}\text { Does the audit committee periodically review } \\
\text { the anti-fraud and corruption policies and } \\
\text { procedures that are in place in the } \\
\text { council/shire? }\end{array}$ & & & \\
\hline 11. & $\begin{array}{l}\text { Does the audit committee directly receive } \\
\text { communications from the stakeholders of the } \\
\text { council/shire regarding any allegations of } \\
\text { misconduct or corruption or matters of concern } \\
\text { which they may have with the council/shire? }\end{array}$ & & & \\
\hline 12. & $\begin{array}{l}\text { Does the audit committee review all } \\
\text { whistleblower allegations and oversee their } \\
\text { investigation? }\end{array}$ & & & \\
\hline
\end{tabular}




\section{VICTORIA

\begin{tabular}{|c|c|c|c|c|c|}
\hline Number & Questions & $\begin{array}{c}\text { In your experience is } \\
\text { this the current } \\
\text { practice in your } \\
\text { council/shire? } \\
\text { Please indicate } \\
\text { Yes/No/ } \\
\text { Not Applicable/ } \\
\text { Don't Know }\end{array}$ & $\begin{array}{l}\text { If you answered ' } \\
\text { practice i } \\
1 \text { indicates significa } \\
\text { current practices. } \\
7 \text { indicates excellen } \\
\text { improvement neede } \\
1 \quad 2 \\
\text { Improvement } \\
\text { Required }\end{array}$ & $\begin{array}{l}\text {, please rate the current } \\
\text { ur council/shire. } \\
\text { nprovement required to } \\
\text { cesses are in place and no } \\
\underset{4}{\text { No improvement }} \\
\text { Required }\end{array}$ & $\begin{array}{l}\text { If you answered 'NO', should the audit committee } \\
\text { do this in the future? } \\
\text { Please indicate Yes/No/Not Applicable }\end{array}$ \\
\hline
\end{tabular}

E. Risk Assessment and Financial Reporting

This relates to the risk framework and control environment within the council/shire. It also relates the financial and non-financial performance of the council/shire.

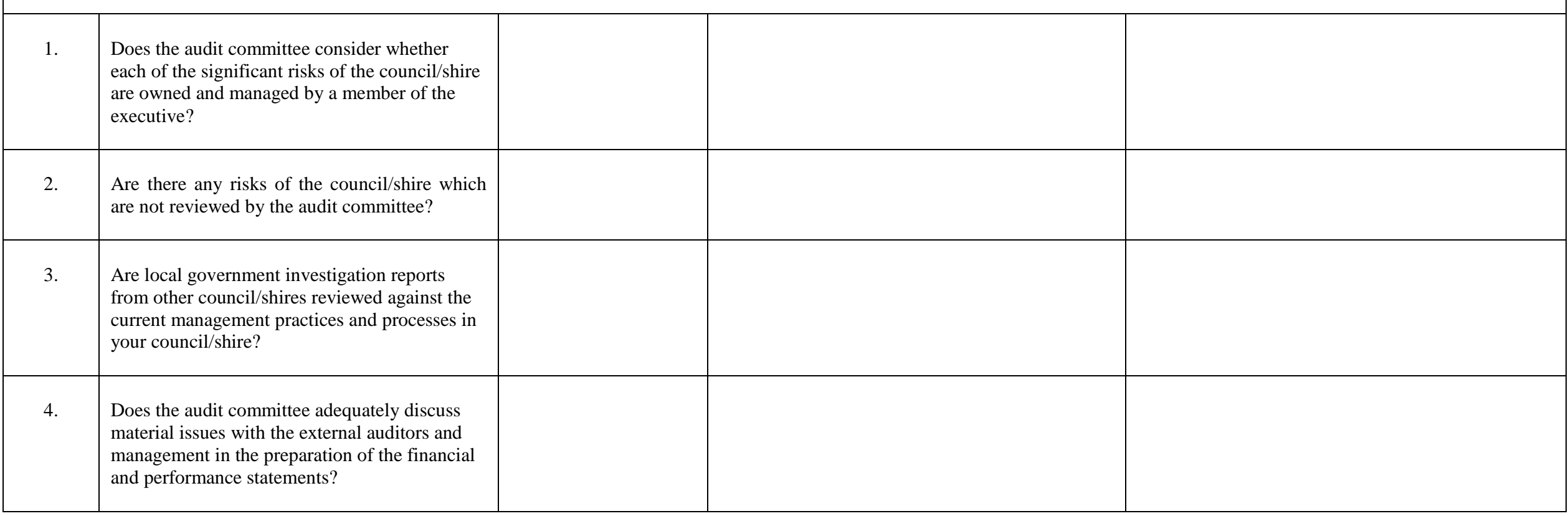




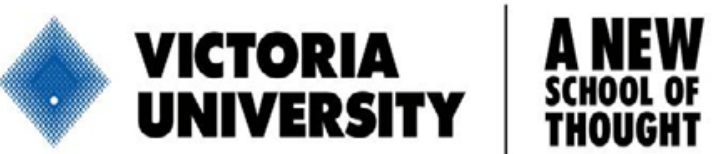

\begin{tabular}{|c|c|c|c|c|}
\hline Number & Questions & $\begin{array}{l}\text { In your experience is this the } \\
\text { current practice in your } \\
\text { council/shire? } \\
\text { Please indicate Yes/No/ } \\
\text { Not Applicable/ } \\
\text { Don't Know }\end{array}$ & $\begin{array}{l}\text { If you answered 'YES', please rate the current } \\
\text { practice in your council/shire. } \\
1 \text { indicates significant improvement required to current } \\
\text { practices. } \\
\begin{array}{l}\text { indicates excellent processes are in place and no } \\
\text { improvement needed. }\end{array} \\
\begin{array}{l}\text { Improvement } \\
\text { Required }\end{array} \\
\begin{array}{l}\mathbf{1} \\
\text { No improvement } \\
\text { Required }\end{array}\end{array}$ & $\begin{array}{c}\text { If you answered 'NO', should the } \\
\text { audit committee do this in the future? } \\
\text { Please indicate Yes/No/Not } \\
\text { Applicable }\end{array}$ \\
\hline 5. & $\begin{array}{l}\text { Does the audit committee review the } \\
\text { council's/shire's annual accounts, including } \\
\text { the financial statements and certifications, to } \\
\text { determine if anything is inconsistent with } \\
\text { their knowledge, including such areas as } \\
\text { liquidity, unusual transactions, infrastructure } \\
\text { funding and impairment of assets? }\end{array}$ & & & \\
\hline 6. & $\begin{array}{l}\text { Does the audit committee review the } \\
\text { external auditor's scope and audit plan to its } \\
\text { satisfaction prior to the commencement of } \\
\text { the audit? }\end{array}$ & & & \\
\hline 7. & $\begin{array}{l}\text { Does the audit committee review all } \\
\text { unrecorded audit adjustments (if any } \\
\text { reported) with management and the external } \\
\text { auditors and understand why they were not } \\
\text { recorded and reported? }\end{array}$ & & & \\
\hline 8. & $\begin{array}{l}\text { Does the audit committee review the internal } \\
\text { auditor's charter, work plans and the } \\
\text { outcomes from the internal audit reports? }\end{array}$ & & & \\
\hline
\end{tabular}




\section{VICTORIA ANEW UNIVERSITY SCHOOL OF}

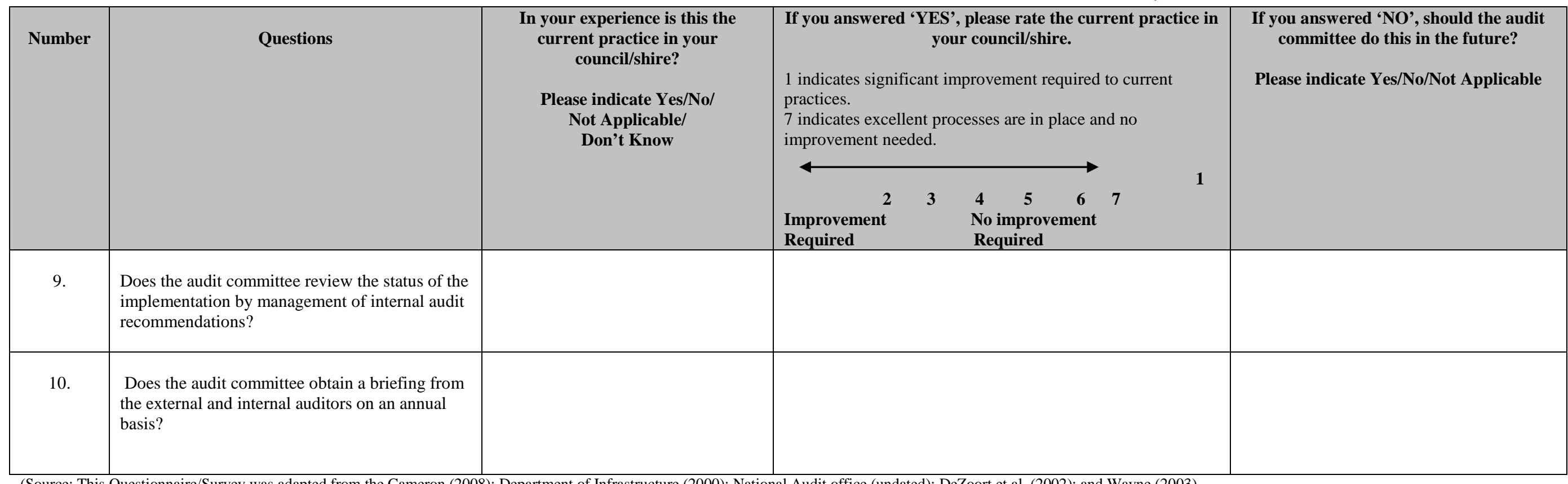


Please tick the appropriate box.

VICTORIA ANEW

UNIVERSITY THOUGH

\begin{tabular}{|c|c|c|c|c|c|}
\hline 1. & In responding to this survey, are you: & Mayor? & Councillor? & Chair of the Audit Committee? & Chief Executive? \\
\hline 2. & Your gender is: & Female? & Male? & & \\
\hline 3. & $\begin{array}{l}\text { Your years of experience on the audit committee } \\
\text { of the council/shire are: }\end{array}$ & $1-2$ years? & 3-4 years? & $5-6$ years? & $7+$ years \\
\hline 4. & $\begin{array}{l}\text { The cumulative number of years of experience } \\
\text { you have in local government are: }\end{array}$ & $1-4$ years? & $5-8$ years? & 9-12 years? & $13+$ years \\
\hline 5. & $\begin{array}{l}\text { (Mayors, Councillors \& Chairs, Audit } \\
\text { Committees only) } \\
\text { What is your main business occupation outside } \\
\text { of council: }\end{array}$ & Agriculture and Farming? & Technical and Trade? & Managerial/Professional? & $\begin{array}{l}\text { Other (ie: } \\
\text { Domestic Duties, } \\
\text { Retired, or } \\
\text { Unemployed? }\end{array}$ \\
\hline 6. & $\begin{array}{l}\text { (For Chief Executives only) } \\
\text { What is your major area of professional } \\
\text { qualifications: }\end{array}$ & Accounting and Finance? & $\begin{array}{c}\text { Community } \\
\text { Services/Nursing/Social } \\
\text { Work? }\end{array}$ & Architecture/Building/Engineering? & $\begin{array}{l}\text { Other (please } \\
\text { specify) }\end{array}$ \\
\hline
\end{tabular}




\section{Appendix 6 Quantitative results}

\section{Appendix 6.1 Total responses}

\begin{tabular}{|c|c|c|c|c|c|c|c|}
\hline Question & Count & Mean & Std & Question & Count & Mean & Std \\
\hline a1 & 82 & 5.42 & 1.35 & $\mathrm{~d} 1$ & 81 & 6.64 & 0.56 \\
\hline a2 & 87 & 5.20 & 1.27 & d2 & 83 & 5.73 & 1.23 \\
\hline a3 & 85 & 5.88 & 1.16 & d3 & 58 & 5.63 & 0.86 \\
\hline a4 & 67 & 5.64 & 1.04 & $\mathrm{~d} 4$ & 84 & 5.46 & 1.15 \\
\hline a5 & 77 & 5.59 & 1.14 & d5 & 79 & 5.94 & 1.10 \\
\hline Subtotal & 80 & \multicolumn{2}{|l|}{5.55} & d6 & 85 & 5.66 & 1.13 \\
\hline & & & & d7 & 41 & 5.12 & 1.18 \\
\hline b1 & 87 & 5.60 & 1.31 & d8 & 82 & 5.81 & 1.08 \\
\hline b2 & 16 & 5.16 & 1.07 & d9 & 86 & 5.97 & 1.15 \\
\hline b3 & 86 & 6.33 & 0.74 & $\mathrm{~d} 10$ & 80 & 5.47 & 1.24 \\
\hline b4 & 39 & 4.95 & 0.60 & $\mathrm{~d} 11$ & 35 & 5.41 & 0.65 \\
\hline b5 & 34 & 5.20 & 1.17 & $\mathrm{~d} 12$ & 18 & 5.65 & 0.58 \\
\hline Subtotal & 52 & \multicolumn{2}{|l|}{5.45} & Subtotal & 68 & 5.71 & 0.99 \\
\hline c1 & 73 & 4.81 & 1.26 & e1 & 70 & 5.28 & 0.97 \\
\hline c2 & 67 & 4.81 & 1.04 & e2 & 21 & 4.60 & 1.32 \\
\hline c3 & 75 & 5.48 & 0.83 & e3 & 62 & 5.57 & 1.24 \\
\hline c4 & 42 & 4.96 & 1.11 & e4 & 77 & 5.65 & 1.16 \\
\hline c5 & 83 & 5.77 & 1.28 & e5 & 84 & 5.39 & 1.25 \\
\hline Subtotal & 68 & 5.16 & 1.11 & e6 & 69 & 5.86 & 1.05 \\
\hline & & & & e7 & 57 & 5.57 & 0.68 \\
\hline & & & & e8 & 85 & 5.81 & 1.25 \\
\hline & & & & e9 & 86 & 5.66 & 1.30 \\
\hline & & & & $\mathrm{e} 10$ & 81 & 6.02 & 1.07 \\
\hline & & & & Subtotal & 69 & 5.54 & 1.13 \\
\hline
\end{tabular}

Notes: The mean and standard deviations in this table are the responses from mayors, chief executives and chairs of audit committees from a Likert 1 to 7 scale. 


\section{Appendix 6.2 Responses - Municipal Association of Victoria}

\begin{tabular}{|c|c|c|c|c|c|c|c|}
\hline Question & Count & Mean & Std & Question & Count & Mean & Std \\
\hline a1 & 4 & 4.50 & 2.18 & $\mathrm{~d} 1$ & 3 & 6.67 & 0.47 \\
\hline $\mathrm{a} 2$ & 4 & 4.67 & 1.66 & d2 & 4 & 4.50 & 2.18 \\
\hline a3 & 4 & 6.67 & 1.87 & d3 & 3 & 4.67 & 0.47 \\
\hline $\mathrm{a} 4$ & 2 & 5.50 & 0.50 & $\mathrm{~d} 4$ & 4 & 3.50 & 1.66 \\
\hline a5 & 4 & 5.33 & 1.87 & d5 & 4 & 4.50 & 2.06 \\
\hline Subtotal & 4 & 5.33 & 1.62 & d6 & 4 & 4.00 & 1.87 \\
\hline & & & & d7 & 2 & 3.50 & 2.50 \\
\hline b1 & 4 & 5.00 & 2.35 & d8 & 4 & 4.50 & 2.06 \\
\hline b2 & 1 & 6.00 & 0.00 & d9 & 4 & 5.00 & 2.35 \\
\hline b3 & 3 & 6.67 & 0.47 & d10 & 4 & 4.50 & 2.06 \\
\hline b4 & 3 & 5.00 & 0.00 & d11 & 1 & 5.00 & 0.00 \\
\hline b5 & 2 & 4.00 & 1.00 & $\mathrm{~d} 12$ & 1 & 4.00 & 0.00 \\
\hline Subtotal & 3 & 5.33 & 0.76 & Subtotal & 3 & 4.53 & 1.47 \\
\hline
\end{tabular}

\begin{tabular}{|c|l|l|l|}
\hline c1 & 4 & 4.75 & 1.09 \\
c2 & 4 & 3.75 & 1.30 \\
c3 & 3 & 6.00 & 0.00 \\
c4 & 2 & 4.00 & 1.00 \\
c5 & 4 & 5.00 & 2.45 \\
\hline Subtotal & 3 & 4.70 & 1.17 \\
\hline
\end{tabular}

\begin{tabular}{|c|l|l|l|}
\hline e1 & 3 & 5.00 & 0.82 \\
e2 & 2 & 4.00 & 1.00 \\
e3 & 3 & 6.00 & 0.82 \\
e4 & 4 & 4.25 & 2.05 \\
e5 & 4 & 4.25 & 1.92 \\
e6 & 3 & 5.67 & 0.94 \\
e7 & 3 & 5.33 & 0.47 \\
e8 & 4 & 4.75 & 2.28 \\
e9 & 4 & 4.50 & 2.06 \\
e10 & 4 & 4.75 & 2.28 \\
\hline Subtotal & 3 & 4.85 & 1.46 \\
\hline
\end{tabular}

Notes: The mean and standard deviations in this table are the responses from mayors, chief executives and chairs of audit committees from a Likert 1 to 7 scale. 


\section{Appendix 6.3 Responses - Local Government and Shires Association of New South Wales}

\begin{tabular}{|c|c|c|c|c|c|c|c|}
\hline Question & Count & Mean & Std & Question & Count & Mean & Std \\
\hline a1 & 8 & 5.50 & 1.41 & $\mathrm{~d} 1$ & 7 & 6.43 & 0.73 \\
\hline a2 & 9 & 5.33 & 1.05 & d2 & 8 & 5.50 & 1.41 \\
\hline a3 & 8 & 5.88 & 0.93 & d3 & 7 & 6.00 & 0.93 \\
\hline a4 & 6 & 5.17 & 1.21 & $\mathrm{~d} 4$ & 9 & 6.22 & 0.79 \\
\hline a5 & 8 & 5.38 & 1.11 & d5 & 9 & 6.22 & 0.79 \\
\hline Subtotal & 8 & 5.45 & 1.14 & d6 & 9 & 6.22 & 1.03 \\
\hline & & & & d7 & 1 & 5.00 & 0.00 \\
\hline b1 & 9 & 5.56 & 1.50 & d8 & 7 & 6.14 & 0.83 \\
\hline b2 & nil & nil & nil & d9 & 8 & 6.13 & 1.05 \\
\hline b3 & 9 & 6.44 & 0.50 & d10 & 6 & 5.33 & 1.37 \\
\hline b4 & 2 & 3.50 & 0.50 & d11 & 1 & 5.00 & 0.00 \\
\hline b5 & 5 & 5.20 & 1.17 & d12 & 1 & 7.00 & 0.00 \\
\hline Subtotal & 6 & 5.18 & 0.92 & Subtotal & 6 & & \\
\hline
\end{tabular}

\begin{tabular}{|c|l|l|l|}
\hline c1 & 8 & 4.75 & 1.56 \\
c2 & 6 & 5.17 & 0.69 \\
c3 & 6 & 5.50 & 1.12 \\
c4 & 2 & 5.00 & 1.00 \\
c5 & 8 & 5.75 & 1.30 \\
\hline Subtotal & 6 & $\mathbf{5 . 2 3}$ & $\mathbf{1 . 1 3}$ \\
\hline
\end{tabular}

\begin{tabular}{|c|l|l|l|}
\hline e1 & 5 & 4.60 & 1.02 \\
e2 & 4 & 3.50 & 1.12 \\
e3 & 7 & 5.43 & 1.68 \\
e4 & 5 & 6.00 & 0.63 \\
e5 & 7 & 4.86 & 1.64 \\
e6 & 3 & 6.00 & 0.82 \\
e7 & 1 & 5.00 & 0.00 \\
e8 & 9 & 6.11 & 0.99 \\
e9 & 9 & 5.44 & 1.57 \\
e10 & 7 & 6.43 & 0.49 \\
\hline Subtotal & 6 & & \\
\hline
\end{tabular}

Notes: The mean and standard deviations in this table are the responses from mayors, chief executives and chairs of audit committees from a Likert 1 to 7 scale. 


\section{Appendix 6.4 Responses - Mayors, Victorian Local Government}

\begin{tabular}{|c|c|c|c|c|c|c|c|}
\hline Question & Count & Mean & Std & Question & Count & Mean & Std \\
\hline a1 & 16 & 5.75 & 0.90 & $\mathrm{~d} 1$ & 15 & 6.80 & 0.40 \\
\hline a2 & 16 & 5.31 & 1.21 & d2 & 16 & 6.38 & 0.86 \\
\hline a3 & 15 & 5.93 & 0.77 & d3 & 8 & 5.75 & 0.97 \\
\hline a4 & 15 & 5.60 & 1.31 & $\mathrm{~d} 4$ & 15 & 5.53 & 1.31 \\
\hline a5 & 17 & 5.82 & 0.86 & d5 & 16 & 6.69 & 0.46 \\
\hline Subtotal & 16 & 5.68 & 1.01 & d6 & 16 & 5.94 & 0.83 \\
\hline & & & & d7 & 6 & 5.17 & 1.07 \\
\hline b1 & 17 & 5.94 & 0.80 & d8 & 17 & 6.12 & 0.83 \\
\hline b2 & 3 & 5.67 & 1.25 & d9 & 17 & 6.24 & 0.73 \\
\hline b3 & 16 & 6.25 & 0.83 & $\mathrm{~d} 10$ & 16 & 5.88 & 0.78 \\
\hline b4 & 7 & 5.71 & 0.70 & d11 & 9 & 5.78 & 1.13 \\
\hline b5 & 8 & 5.88 & 1.05 & $\mathrm{~d} 12$ & 3 & 6.00 & 0.82 \\
\hline Subtotal & 10 & 5.89 & 0.93 & Subtotal & 13 & 6.02 & 0.85 \\
\hline
\end{tabular}

\begin{tabular}{|c|l|l|l|}
\hline c1 & 13 & 5.08 & 1.07 \\
c2 & 12 & 5.00 & 0.91 \\
c3 & 13 & 5.54 & 1.15 \\
c4 & 10 & 5.10 & 1.04 \\
c5 & 15 & 6.07 & 0.85 \\
\hline Subtotal & 13 & 5.36 & 1.01 \\
\hline
\end{tabular}

\begin{tabular}{|c|c|c|c|}
\hline e1 & 9 & 5.89 & 0.74 \\
e2 & 2 & 5.50 & 1.50 \\
e3 & 10 & 5.30 & 1.00 \\
e4 & 13 & 6.08 & 1.07 \\
e5 & 16 & 5.81 & 1.01 \\
e6 & 14 & 5.79 & 1.08 \\
e7 & 11 & 5.73 & 0.96 \\
e8 & 16 & 5.69 & 1.04 \\
e9 & 16 & 6.06 & 1.03 \\
e10 & 16 & 6.38 & 0.70 \\
\hline Subtotal & 12 & 5.82 & 1.01 \\
\hline
\end{tabular}

Notes: The mean and standard deviations in this table are the responses from mayors, chief executives and chairs of audit committees from a Likert 1 to 7 scale. 


\section{Appendix 6.5 Responses - Chief Executives, Victorian Local Government}

\begin{tabular}{|c|c|c|c|c|c|c|c|}
\hline Question & Count & Mean & Std & Question & Count & Mean & Std \\
\hline a1 & 31 & 5.52 & 1.10 & $\mathrm{~d} 1$ & 33 & 6.52 & 0.78 \\
\hline a2 & 34 & 5.41 & 0.97 & d2 & 32 & 6.19 & 0.68 \\
\hline a3 & 34 & 5.53 & 1.24 & d3 & 21 & 5.76 & 0.92 \\
\hline $\mathrm{a} 4$ & 25 & 5.80 & 1.26 & $\mathrm{~d} 4$ & 32 & 5.69 & 1.13 \\
\hline a5 & 28 & 5.57 & 1.08 & d5 & 28 & 6.04 & 0.82 \\
\hline Subtotal & 30 & 5.57 & 1.13 & d6 & 32 & 6.03 & 0.85 \\
\hline & & & & d7 & 16 & 6.00 & 0.79 \\
\hline b1 & 33 & 5.76 & 0.89 & d8 & 31 & 6.16 & 0.81 \\
\hline b2 & 7 & 4.57 & 1.18 & d9 & 33 & 6.00 & 1.04 \\
\hline b3 & 34 & 6.15 & 1.03 & d10 & 31 & 5.84 & 0.92 \\
\hline b4 & 10 & 5.00 & 1.00 & $\mathrm{~d} 11$ & 14 & 5.86 & 0.91 \\
\hline b5 & 10 & 4.80 & 1.54 & $\mathrm{~d} 12$ & 3 & 5.33 & 0.94 \\
\hline Subtotal & 19 & 5.26 & 1.13 & Subtotal & 26 & 5.95 & 0.88 \\
\hline
\end{tabular}

\begin{tabular}{|c|l|l|l|}
\hline c1 & 29 & 5.03 & 1.07 \\
c2 & 23 & 4.78 & 1.18 \\
c3 & 31 & 5.13 & 0.91 \\
c4 & 13 & 5.23 & 1.37 \\
c5 & 33 & 5.76 & 0.89 \\
\hline Subtotal & 26 & 5.19 & 1.08 \\
\hline
\end{tabular}

\begin{tabular}{|c|c|c|c|}
\hline e1 & 30 & 5.30 & 1.10 \\
e2 & 8 & 5.00 & 1.32 \\
e3 & 22 & 5.82 & 1.11 \\
e4 & 32 & 5.78 & 1.08 \\
e5 & 32 & 6.06 & 0.83 \\
e6 & 29 & 5.79 & 1.30 \\
e7 & 22 & 5.86 & 1.10 \\
e8 & 32 & 6.19 & 1.01 \\
e9 & 32 & 6.25 & 0.90 \\
e10 & 31 & 6.23 & 1.01 \\
\hline Subtotal & 27 & 5.83 & 1.08 \\
\hline
\end{tabular}

Notes: The mean and standard deviations in this table are the responses from mayors, chief executives and chairs of audit committees from a Likert 1 to 7 scale. 


\section{Appendix 6.6 Responses - Chairs Audit Committees, Victorian Local Government}

\begin{tabular}{|c|c|c|c|}
\hline Question & Count & Mean & Std \\
\hline a1 & 23 & 5.83 & 1.13 \\
a2 & 24 & 5.29 & 1.46 \\
a3 & 24 & 5.42 & 1.00 \\
a4 & 19 & 6.16 & 0.93 \\
a5 & 20 & 5.85 & 0.79 \\
\hline Subtotal & 22 & 5.71 & 1.06 \\
\hline
\end{tabular}

\begin{tabular}{|c|c|cc|}
\hline Question & Count & Mean & Std \\
\hline d1 & 23 & 6.78 & 0.41 \\
d2 & 23 & 6.09 & 1.02 \\
d3 & 19 & 5.95 & 1.00 \\
d4 & 24 & 6.33 & 0.85 \\
d5 & 22 & 6.27 & 1.35 \\
d6 & 24 & 6.13 & 1.05 \\
d7 & 16 & 5.94 & 1.56 \\
d8 & 23 & 6.13 & 0.85 \\
d9 & 24 & 6.50 & 0.58 \\
d10 & 23 & 5.78 & 1.06 \\
d11 & 10 & 5.40 & 1.20 \\
d12 & 10 & 5.90 & 1.14 \\
\hline Subtotal & 20 & 6.10 & 1.01 \\
\hline
\end{tabular}

\begin{tabular}{|c|l|l|l|}
\hline c1 & 19 & 4.42 & 1.53 \\
c2 & 22 & 5.36 & 1.11 \\
c3 & 22 & 5.23 & 1.00 \\
c4 & 15 & 5.47 & 1.15 \\
c5 & 23 & 6.26 & 0.90 \\
\hline Subtotal & 20 & 5.35 & 1.14 \\
\hline
\end{tabular}

\begin{tabular}{|c|c|cc|}
\hline e1 & 23 & 5.61 & 1.17 \\
e2 & 5 & 5.00 & 1.67 \\
e3 & 20 & 5.30 & 1.58 \\
e4 & 23 & 6.13 & 0.99 \\
e5 & 25 & 5.96 & 0.87 \\
e6 & 20 & 6.05 & 1.12 \\
e7 & 20 & 5.95 & 0.86 \\
e8 & 24 & 6.33 & 0.90 \\
e9 & 25 & 6.04 & 0.92 \\
e10 & 23 & 6.30 & 0.86 \\
\hline Subtotal & 21 & 5.87 & 1.09 \\
\hline
\end{tabular}

Notes: The mean and standard deviations in this table are the responses from mayors, chief executives and chairs of audit committees from a Likert 1 to 7 scale. 


\section{Appendix 6.7 Rankings of data from the Kruskal-Wallis Rank Test}

\section{i. $\quad$ Test results for questions B1 to B5}

\begin{tabular}{|c|c|c|c|}
\hline \multicolumn{4}{|c|}{ Ranks } \\
\hline Question & Group & $\mathbf{N}$ & Mean Rank \\
\hline \multirow[t]{4}{*}{ B1 } & Mayors & 17 & 39.91 \\
\hline & Chief Executives & 33 & 36.53 \\
\hline & $\begin{array}{c}\text { Chairs of Audit } \\
\text { Committees }\end{array}$ & 24 & 37.13 \\
\hline & Total & 74 & \\
\hline \multirow[t]{4}{*}{ B2 } & Mayors & 3 & 10.50 \\
\hline & Chief Executives & 7 & 7.07 \\
\hline & $\begin{array}{c}\text { Chairs of Audit } \\
\text { Committees }\end{array}$ & 5 & 7.80 \\
\hline & Total & 15 & \\
\hline \multirow[t]{4}{*}{ B3 } & Mayors & 16 & 38.47 \\
\hline & Chief Executives & 34 & 37.76 \\
\hline & $\begin{array}{c}\text { Chairs of Audit } \\
\text { Committees }\end{array}$ & 24 & 36.48 \\
\hline & Total & 74 & \\
\hline \multirow[t]{4}{*}{ B4 } & Mayors & 7 & 20.36 \\
\hline & Chief Executives & 10 & 14.15 \\
\hline & $\begin{array}{c}\text { Chairs of Audit } \\
\text { Committees }\end{array}$ & 17 & \\
\hline & Total & 34 & \\
\hline \multirow[t]{4}{*}{ B5 } & Mayors & 8 & 15.44 \\
\hline & Chief Executives & 10 & 10.10 \\
\hline & $\begin{array}{l}\text { Chairs of Audit } \\
\text { Committees }\end{array}$ & 9 & 17.06 \\
\hline & Total & 27 & \\
\hline
\end{tabular}




\section{ii. Test results for questions $\mathbf{C 1}$ to $\mathbf{C 5}$}

\begin{tabular}{|c|c|c|c|}
\hline \multicolumn{4}{|c|}{ Ranks } \\
\hline Questions & Group & $\mathbf{N}$ & Mean Rank \\
\hline \multirow[t]{4}{*}{ C1 } & Mayors & 13 & 33.96 \\
\hline & Chief Executives & 29 & 33.09 \\
\hline & $\begin{array}{l}\text { Chairs of Audit } \\
\text { Committees }\end{array}$ & 19 & 25.79 \\
\hline & Total & 61 & \\
\hline \multirow[t]{4}{*}{$\mathrm{C} 2$} & Mayors & 12 & 28.08 \\
\hline & Chief Executives & 23 & 24.74 \\
\hline & $\begin{array}{l}\text { Chairs of Audit } \\
\text { Committees }\end{array}$ & 22 & 33.95 \\
\hline & Total & 57 & \\
\hline \multirow[t]{4}{*}{$\mathrm{C} 3$} & Mayors & 13 & 37.62 \\
\hline & Chief Executives & 31 & 31.44 \\
\hline & $\begin{array}{c}\text { Chairs of Audit } \\
\text { Committees }\end{array}$ & 22 & 33.98 \\
\hline & Total & 66 & \\
\hline \multirow[t]{4}{*}{$\mathrm{C} 4$} & Mayors & 10 & 17.55 \\
\hline & Chief Executives & 13 & 19.46 \\
\hline & $\begin{array}{l}\text { Chairs of Audit } \\
\text { Committees }\end{array}$ & 15 & 20.83 \\
\hline & Total & 38 & \\
\hline \multirow[t]{4}{*}{ C5 } & Mayors & 15 & 37.63 \\
\hline & Chief Executives & 33 & 30.86 \\
\hline & $\begin{array}{l}\text { Chairs of Audit } \\
\text { Committees }\end{array}$ & 23 & 42.30 \\
\hline & Total & 71 & \\
\hline
\end{tabular}

\section{iii. Test results for questions D1 to D12}

\begin{tabular}{|c|c|c|c|}
\hline \multicolumn{3}{|c|}{ Ranks } & Mean Rank \\
\hline \multirow{2}{*}{ Questions } & Group & N & 38.80 \\
\hline D1 & Mayors & 15 & 33.18 \\
& Chief Executives & 33 & 38.22 \\
& Chairs of Audit & 23 & \\
\cline { 2 - 4 } & Committees & 71 & \\
\hline
\end{tabular}




\begin{tabular}{|c|c|c|c|}
\hline Questions & Group & $\mathbf{N}$ & Mean Rank \\
\hline \multirow[t]{4}{*}{ D2 } & Mayors & 16 & 41.13 \\
\hline & Chief Executives & 32 & 34.27 \\
\hline & $\begin{array}{c}\text { Chairs of Audit } \\
\text { Committees }\end{array}$ & 23 & 34.85 \\
\hline & Total & 71 & \\
\hline \multirow[t]{4}{*}{ D3 } & Mayors & 8 & 23.38 \\
\hline & Chief Executives & 21 & 23.36 \\
\hline & $\begin{array}{l}\text { Chairs of Audit } \\
\text { Committees }\end{array}$ & 19 & 26.24 \\
\hline & Total & 48 & \\
\hline \multirow[t]{4}{*}{ D4 } & Mayors & 15 & 31.07 \\
\hline & Chief Executives & 32 & 32.30 \\
\hline & $\begin{array}{c}\text { Chairs of Audit } \\
\text { Committees }\end{array}$ & 24 & 44.02 \\
\hline & Total & 71 & \\
\hline \multirow[t]{4}{*}{ D5 } & Mayors & 16 & 40.41 \\
\hline & Chief Executives & 28 & 26.68 \\
\hline & $\begin{array}{c}\text { Chairs of Audit } \\
\text { Committees }\end{array}$ & 22 & 37.16 \\
\hline & Total & 66 & \\
\hline \multirow[t]{4}{*}{ D6 } & Mayors & 16 & 32.66 \\
\hline & Chief Executives & 32 & 35.63 \\
\hline & $\begin{array}{l}\text { Chairs of Audit } \\
\text { Committees }\end{array}$ & 24 & 40.23 \\
\hline & Total & 72 & \\
\hline \multirow[t]{4}{*}{ D7 } & Mayors & 6 & 12.50 \\
\hline & Chief Executives & 16 & 19.44 \\
\hline & $\begin{array}{c}\text { Chairs of Audit } \\
\text { Committees }\end{array}$ & 16 & 22.19 \\
\hline & Total & 38 & \\
\hline \multirow[t]{4}{*}{ D8 } & Mayors & 17 & 35.62 \\
\hline & Chief Executives & 31 & 36.24 \\
\hline & $\begin{array}{l}\text { Chairs of Audit } \\
\text { Committees }\end{array}$ & 23 & 35.96 \\
\hline & Total & 71 & \\
\hline \multirow[t]{4}{*}{ D9 } & Mayors & 17 & 36.65 \\
\hline & Chief Executives & 33 & 33.58 \\
\hline & $\begin{array}{l}\text { Chairs of Audit } \\
\text { Committees }\end{array}$ & 24 & 43.50 \\
\hline & Total & 74 & \\
\hline
\end{tabular}




\begin{tabular}{|c|c|c|c|}
\hline Questions & Group & $\mathbf{N}$ & Mean Rank \\
\hline \multirow[t]{4}{*}{ D10 } & Mayors & 16 & 35.63 \\
\hline & Chief Executives & 31 & 35.34 \\
\hline & $\begin{array}{l}\text { Chairs of Audit } \\
\text { Committees }\end{array}$ & 23 & 35.63 \\
\hline & Total & 70 & \\
\hline \multirow[t]{4}{*}{$\bar{D} 11$} & Mayors & 9 & 17.83 \\
\hline & Chief Executives & 14 & 18.04 \\
\hline & $\begin{array}{l}\text { Chairs of Audit } \\
\text { Committees }\end{array}$ & 10 & 14.80 \\
\hline & Total & 33 & \\
\hline \multirow[t]{4}{*}{ D12 } & Mayors & 3 & 8.83 \\
\hline & Chief Executives & 3 & 6.33 \\
\hline & $\begin{array}{c}\text { Chairs of Audit } \\
\text { Committees }\end{array}$ & 10 & 9.05 \\
\hline & Total & 16 & \\
\hline
\end{tabular}

\section{iv. Test results for questions E1 to E10}

\begin{tabular}{|c|c|c|c|}
\hline \multicolumn{4}{|c|}{ Ranks } \\
\hline Questions & Group & $\mathbf{N}$ & Mean Rank \\
\hline \multirow[t]{4}{*}{ E1 } & Mayors & 9 & 37.22 \\
\hline & Chief Executives & 30 & 27.83 \\
\hline & $\begin{array}{l}\text { Chairs of Audit } \\
\text { Committees }\end{array}$ & 23 & 34.04 \\
\hline & Total & 62 & \\
\hline \multirow[t]{4}{*}{ E2 } & Mayors & 2 & 9.50 \\
\hline & Chief Executives & 8 & 7.69 \\
\hline & $\begin{array}{l}\text { Chairs of Audit } \\
\text { Committees }\end{array}$ & 5 & 7.90 \\
\hline & Total & 15 & \\
\hline \multirow[t]{4}{*}{ E3 } & Mayors & 10 & 21.95 \\
\hline & Chief Executives & 22 & 29.66 \\
\hline & $\begin{array}{l}\text { Chairs of Audit } \\
\text { Committees }\end{array}$ & 20 & 25.30 \\
\hline & Total & 52 & \\
\hline
\end{tabular}




\begin{tabular}{|c|c|c|c|}
\hline Questions & Group & $\mathbf{N}$ & Mean Rank \\
\hline \multirow[t]{4}{*}{ E4 } & Mayors & 13 & 37.15 \\
\hline & Chief Executives & 32 & 31.20 \\
\hline & $\begin{array}{l}\text { Chairs of Audit } \\
\text { Committees }\end{array}$ & 23 & 37.59 \\
\hline & Total & 68 & \\
\hline \multirow[t]{4}{*}{ E5 } & Mayors & 16 & 34.09 \\
\hline & Chief Executives & 32 & 38.67 \\
\hline & $\begin{array}{l}\text { Chairs of Audit } \\
\text { Committees }\end{array}$ & 25 & 36.72 \\
\hline & Total & 73 & \\
\hline \multirow[t]{4}{*}{ E6 } & Mayors & 14 & 29.71 \\
\hline & Chief Executives & 29 & 31.09 \\
\hline & $\begin{array}{l}\text { Chairs of Audit } \\
\text { Committees }\end{array}$ & 20 & 34.93 \\
\hline & Total & 63 & \\
\hline \multirow[t]{4}{*}{ E7 } & Mayors & 11 & 24.77 \\
\hline & Chief Executives & 22 & 27.30 \\
\hline & $\begin{array}{l}\text { Chairs of Audit } \\
\text { Committees }\end{array}$ & 20 & \\
\hline & Total & 53 & \\
\hline \multirow[t]{4}{*}{ E8 } & Mayors & 16 & 27.63 \\
\hline & Chief Executives & 32 & 37.75 \\
\hline & $\begin{array}{l}\text { Chairs of Audit } \\
\text { Committees }\end{array}$ & 24 & 40.75 \\
\hline & Total & 72 & \\
\hline \multirow[t]{4}{*}{ E9 } & Mayors & 16 & 36.06 \\
\hline & Chief Executives & 32 & 39.39 \\
\hline & $\begin{array}{c}\text { Chairs of Audit } \\
\text { Committees }\end{array}$ & 25 & 34.54 \\
\hline & Total & 73 & \\
\hline \multirow[t]{4}{*}{ E10 } & Mayors & 16 & 36.06 \\
\hline & Chief Executives & 31 & 35.06 \\
\hline & $\begin{array}{l}\text { Chairs of Audit } \\
\text { Committees }\end{array}$ & 23 & 35.70 \\
\hline & Total & 70 & \\
\hline
\end{tabular}




\section{Appendix 7 Mean and standard deviations from the research}

Table A7.1

Mean responses, questions A1-A5

\begin{tabular}{|r|c|c|c|c|c|}
\hline \multicolumn{1}{|c|}{ Questions } & A1 & A2 & A3 & A4 & A5 \\
\hline Mayors & 5.75 & 5.31 & 5.93 & 5.6 & 5.82 \\
\hline Chief Executives & 5.52 & 5.41 & 5.53 & 5.8 & 5.57 \\
\hline Chairs of Audit Committees & 5.83 & 5.29 & 5.42 & 6.16 & 5.85 \\
\hline New South Wales & 5.50 & 5.33 & 5.88 & 5.17 & 5.38 \\
\hline Municipal Association of Victoria & 4.50 & 4.67 & 6.67 & 5.50 & 5.3 \\
\hline
\end{tabular}

Notes: The mean and standard deviations in this table are the responses from mayors, chief executives and chairs of audit committees from a Likert 1 to 7 scale.

Table A7.2

Standard deviation responses, questions A1-A5

\begin{tabular}{|r|c|c|c|c|c|}
\hline \multicolumn{1}{|c|}{ Questions } & A1 & A2 & A3 & A4 & A5 \\
\hline Mayors & 0.90 & 1.21 & 0.77 & 1.31 & 0.86 \\
\hline Chief Executives & 1.10 & 0.97 & 1.24 & 1.26 & 1.08 \\
\hline Chairs of Audit Committees & 1.13 & 1.46 & 1.00 & 0.93 & 0.79 \\
\hline New South Wales & 1.41 & 1.05 & 0.93 & 1.21 & 1.11 \\
\hline Municipal Association of Victoria & 2.18 & 1.66 & 1.87 & 0.50 & 1.87 \\
\hline
\end{tabular}

Notes: The mean and standard deviations in this table are the responses from mayors, chief executives and chairs of audit committees from a Likert 1 to 7 scale.

Table A7.3

\section{Mean responses, questions A1-A5 - Victorian metropolitan and rural regional councils}

\begin{tabular}{|l|c|c|c|c|c|}
\hline Questions & A1 & A2 & A3 & A4 & A5 \\
\hline Mayors - Metropolitan Councils & & & & & \\
Mayors - Rural and Regional Councils and Shires & 6.00 & 5.00 & 6.50 & 5.83 & 6.00 \\
\hline & 5.60 & 5.50 & 5.56 & 5.44 & 5.73 \\
\hline & & & & & \\
Chief Executives - Metropolitan Councils & 6.00 & 5.89 & 6.06 & 6.00 & 5.86 \\
Chief Executives - Rural and Regional Councils and Shires & 4.93 & 4.88 & 4.94 & 5.55 & 5.29 \\
\hline Chairs of Audit Committees - Metropolitan Councils & & & & & \\
Chairs of Audit Committees - Rural and Regional Councils and Shires & 6.17 & 5.83 & 6.00 & 6.25 & 5.90 \\
& & & 4.83 & 6.00 & 5.80 \\
\hline
\end{tabular}

Notes: The mean and standard deviations in this table are the responses from mayors, chief executives and chairs of audit committees from a Likert 1 to 7 scale. 
Table A7.4

Standard deviation responses, questions A1-A5

- Victorian metropolitan and rural regional councils

\begin{tabular}{|l|c|c|c|c|c|}
\hline Questions & A1 & A2 & A3 & A4 & A5 \\
\hline Mayors - Metropolitan Councils & & & & & \\
Mayors - Rural and Regional Councils and Shires & 1.00 & 1.41 & 0.50 & 1.34 & 0.82 \\
& 0.80 & 1.02 & 0.68 & 1.26 & 0.86 \\
\hline Chief Executives - Metropolitan Councils & & & & & \\
Chief Executives - Rural and Regional Councils and Shires & 0.91 & 0.81 & 0.70 & 1.20 & 0.91 \\
\hline & 2.36 & 2.38 & 2.49 & 2.14 & 2.01 \\
\hline Chairs of Audit Committees - Metropolitan Councils & & & & & \\
Chairs of Audit Committees - Rural and Regional Councils and Shires & 1.87 & 2.05 & 1.82 & 1.91 & 1.56 \\
\hline
\end{tabular}

Notes: The mean and standard deviations in this table are the responses from mayors, chief executives and chairs of audit committees from a Likert 1 to 7 scale.

Table A7.5

Mean responses, questions B1-B5

\begin{tabular}{|r|c|c|c|c|c|}
\hline \multicolumn{1}{|c|}{ Questions } & B1 & B2 & B3 & B4 & B5 \\
\hline Mayors & 5.94 & 5.67 & 6.25 & 5.71 & 5.88 \\
\hline Chief Executives & 5.76 & 4.57 & 6.15 & 5.00 & 4.80 \\
\hline Chairs of Audit Committees & 5.75 & 4.40 & 6.17 & 5.53 & 6.11 \\
\hline Nocal Government and Shires Association of & & & & & \\
\hline Municipal Association of Victoria & 5.56 & 6.00 & 6.67 & 5.00 & 4.00 \\
\hline
\end{tabular}

Notes: The mean and standard deviations in this table are the responses from mayors, chief executives and chairs of audit committees from a Likert 1 to 7 scale.

Table A7.6

Standard deviation responses, questions B1-B5

\begin{tabular}{|r|c|c|c|c|c|}
\hline \multicolumn{1}{|c|}{ Questions } & B1 & B2 & B3 & B4 & B5 \\
\hline Mayors & 0.80 & 1.25 & 0.83 & 0.70 & 1.05 \\
\hline Chief Executives & 0.89 & 1.18 & 1.03 & 1.00 & 1.54 \\
\hline Chairs of Audit Committees & 1.01 & 1.85 & 0.85 & 0.78 & 1.10 \\
\hline New South Wales & 1.50 & nil & 0.50 & 0.50 & 1.17 \\
\hline Municipal Association of Victoria & 2.35 & 0.00 & 0.47 & 0.00 & 1.00 \\
\hline
\end{tabular}

Notes: The mean and standard deviations in this table are the responses from mayors, chief executives and chairs of audit committees from a Likert 1 to 7 scale. 
Table A7.7

Mean responses, questions B1-B5 - Victorian metropolitan and rural regional councils

\begin{tabular}{|l|c|c|c|c|c|}
\hline \multicolumn{1}{|c|}{ Questions } & B1 & B2 & B3 & B4 & B5 \\
\hline Mayors - Metropolitan Councils & 6.00 & 6.50 & 6.60 & 5.50 & 5.50 \\
Mayors - Rural and Regional Councils and Shires & 5.91 & 4.00 & 6.09 & 5.80 & 6.00 \\
\hline Chief Executives - Metropolitan Councils & 5.78 & 4.80 & 6.50 & 5.33 & 4.25 \\
Chief Executives - Rural and Regional Councils and Shires & 5.73 & 4.00 & 5.75 & 4.50 & 5.17 \\
\hline Chairs of Audit Committees - Metropolitan Councils & 5.85 & 4.50 & 6.54 & 6.00 & 5.50 \\
Chairs of Audit Committees - Rural and Regional Councils and Shires & 5.64 & 4.00 & 5.73 & 5.00 & 6.60 \\
\hline
\end{tabular}

Notes: The mean and standard deviations in this table are the responses from mayors, chief executives and chairs of audit committees from a Likert 1 to 7 scale.

Table A7.8

Standard deviation responses, questions B1-B5 - Victorian metropolitan and rural regional councils

\begin{tabular}{|l|c|c|c|c|c|}
\hline \multicolumn{1}{|c|}{ Questions } & B1 & B2 & B3 & B4 & B5 \\
\hline Mayors - Metropolitan Councils & 0.82 & 0.50 & 0.49 & 0.50 & 0.50 \\
Mayors - Rural and Regional Councils and Shires & 0.79 & 0.00 & 0.90 & 0.75 & 1.15 \\
\hline Chief Executives - Metropolitan Councils & 0.85 & 1.17 & 0.76 & 0.75 & 1.92 \\
Chief Executives - Rural and Regional Councils and Shires & 2.35 & 1.44 & 2.35 & 1.48 & 1.56 \\
\hline Chairs of Audit Committees - Metropolitan Councils & 1.23 & 2.06 & 0.63 & 0.67 & 1.12 \\
Chairs of Audit Committees - Rural and Regional Councils and Shires & 1.90 & 1.66 & 1.87 & 1.52 & 1.72 \\
\hline
\end{tabular}

Notes: The mean and standard deviations in this table are the responses from mayors, chief executives and chairs of audit committees from a Likert 1 to 7 scale.

Table A7.9

Mean responses, questions $\mathrm{C} 1-\mathrm{C} 5$

\begin{tabular}{|r|c|c|c|c|c|}
\hline \multicolumn{1}{|c|}{ Questions } & C1 & C2 & C3 & C4 & C5 \\
\hline Mayors & 5.08 & 5.00 & 5.54 & 5.10 & 6.07 \\
\hline Chief Executives & 5.03 & 4.78 & 5.13 & 5.23 & 5.76 \\
\hline Local Government and Shires Association of \\
New South Wales & 4.75 & 5.17 & 5.50 & 5.00 & 5.75 \\
\hline Municipal Association of Victoria & 4.75 & 3.75 & 6.00 & 4.00 & 5.00 \\
\hline
\end{tabular}

Notes: The mean and standard deviations in this table are the responses from mayors, chief executives and chairs of audit committees from a Likert 1 to 7 scale. 
Table A7.10 Standard deviation responses, questions C1-C5

\begin{tabular}{|r|c|c|c|c|c|}
\hline \multicolumn{1}{|c|}{ Questions } & C1 & C2 & C3 & C4 & C5 \\
\hline Mayors & 1.07 & 0.91 & 1.15 & 1.04 & 0.85 \\
\hline Chief Executives & 1.07 & 1.18 & 0.91 & 1.37 & 0.89 \\
\hline $\begin{array}{r}\text { Local Government and Shires Association } \\
\text { of New South Wales }\end{array}$ & 1.16 & 0.69 & 1.12 & 1.00 & 1.30 \\
\hline Municipal Association of Victoria & 1.09 & 1.30 & 0.00 & 1.00 & 2.45 \\
\hline
\end{tabular}

Notes: The mean and standard deviations in this table are the responses from mayors, chief executives and chairs of audit committees from a Likert 1 to 7 scale.

Table A7.11 Mean responses, questions C1-C5 - Victorian metropolitan and rural regional councils

\begin{tabular}{|l|l|l|l|l|l|}
\hline \multicolumn{1}{|c|}{ Questions } & C1 & C2 & C3 & C4 & C5 \\
\hline Mayors - Metropolitan Councils & 5.50 & 4.80 & 6.00 & 6.00 & 6.50 \\
\hline Mayors - Rural and Regional Councils and Shires & 4.89 & 5.14 & 5.40 & 4.88 & 5.78 \\
\hline Chief Executives - Metropolitan Councils & 5.43 & 5.55 & 5.67 & 5.78 & 6.00 \\
\hline Chief Executives - Rural and Regional Councils and Shires & 4.67 & 4.08 & 4.63 & 4.00 & 5.47 \\
\hline Chairs of Audit Committees - Metropolitan Councils & 4.80 & 5.42 & 5.50 & 5.50 & 6.62 \\
\hline Chairs of Audit Committees - Rural and Regional Councils and Shires & 4.00 & 5.30 & 4.90 & 5.40 & 5.80 \\
\hline
\end{tabular}

Notes: The mean and standard deviations in this table are the responses from mayors, chief executives and chairs of audit committees from a Likert 1 to 7 scale.

Table A7.12 Standard deviation responses, questions C1-C5 - Victorian metropolitan and rural regional councils

\begin{tabular}{|l|c|c|c|c|c|}
\hline \multicolumn{1}{|c|}{ Questions } & C1 & C2 & C3 & C4 & C5 \\
\hline Mayors - Metropolitan Councils & 0.50 & 0.75 & 0.82 & 0.00 & 0.50 \\
\hline Mayors - Rural and Regional Councils and Shires & 1.20 & 0.99 & 1.20 & 1.05 & 0.92 \\
\hline Chief Executives - Metropolitan Councils & 1.12 & 1.16 & 0.70 & 0.92 & 0.88 \\
\hline Chief Executives - Rural and Regional Councils and Shires & 2.00 & 1.80 & 2.04 & 1.89 & 2.35 \\
\hline Chairs of Audit Committees - Metropolitan Councils & 1.60 & 1.11 & 0.96 & 1.28 & 0.74 \\
\hline Chairs of Audit Committees - Rural and Regional Councils and Shires & 1.95 & 1.89 & 1.85 & 1.79 & 1.91 \\
\hline
\end{tabular}

Notes: The mean and standard deviations in this table are the responses from mayors, chief executives and chairs of audit committees from a Likert 1 to 7 scale. 
Figure A7.1 Affirmative responses, questions D1-D12

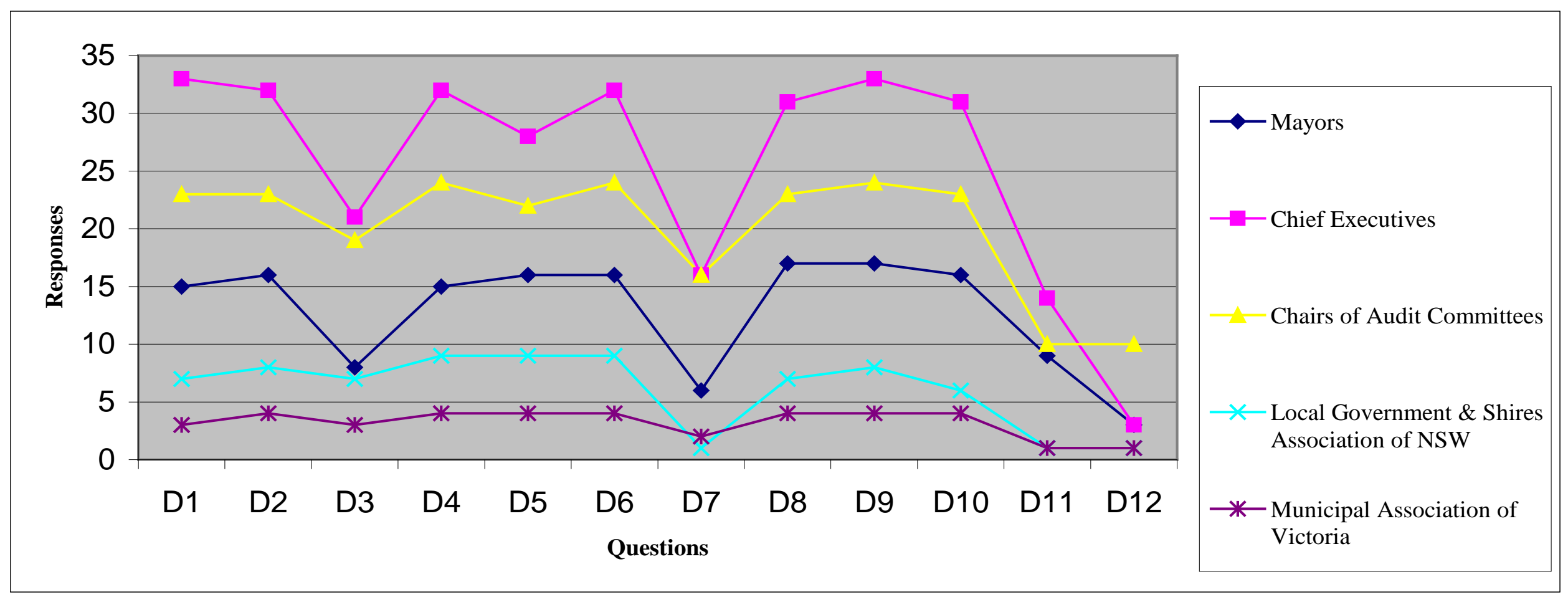


Table A7.13 Mean responses, questions D1-D12

\begin{tabular}{|c|c|c|c|c|c|c|c|c|c|c|c|c|}
\hline Questions & D1 & D2 & D3 & D4 & D5 & D6 & D7 & D8 & D9 & D10 & D11 & D12 \\
\hline Mayors & 6.80 & 6.38 & 5.75 & 5.53 & 6.69 & 5.94 & 5.17 & 6.12 & 6.24 & 5.88 & 5.78 & 6.00 \\
\hline Chief Executives & 6.52 & 6.19 & 5.76 & 5.69 & 6.04 & 6.03 & 6.00 & 6.16 & 6.00 & 5.84 & 5.86 & 5.33 \\
\hline Chairs of Audit Committees & 6.78 & 6.09 & 5.95 & 6.33 & 6.27 & 6.13 & 5.94 & 6.13 & 6.50 & 5.78 & 5.40 & 5.90 \\
\hline $\begin{array}{l}\text { Local Government and Shires Association } \\
\text { of New South Wales }\end{array}$ & 6.43 & 5.50 & 6.00 & 6.22 & 6.22 & 6.22 & 5.00 & 6.14 & 6.13 & 5.33 & 5.00 & 7.00 \\
\hline Municipal Association of Victoria & 6.67 & 4.50 & 4.67 & 3.50 & 4.50 & 4.00 & 3.50 & 4.50 & 5.00 & 4.50 & 5.00 & 4.00 \\
\hline
\end{tabular}

Notes: The mean and standard deviations in this table are the responses from mayors, chief executives and chairs of audit committees from a Likert 1 to 7 scale.

Table A7.14 Standard deviation responses, questions D1-D12

\begin{tabular}{|c|c|c|c|c|c|c|c|c|c|c|c|c|}
\hline Questions & D1 & D2 & D3 & D4 & D5 & D6 & D7 & D8 & D9 & $\begin{array}{c}\text { D1 } \\
\text { 0 }\end{array}$ & $\begin{array}{c}\text { D1 } \\
1\end{array}$ & $\begin{array}{c}\text { D1 } \\
2\end{array}$ \\
\hline & 0.4 & 0.8 & 0.9 & 1.3 & 0.4 & 0.8 & 1.0 & 0.8 & 0.7 & 0.7 & 1.1 & 0.8 \\
\hline \multirow[t]{2}{*}{ Mayors } & 0 & 6 & 7 & 1 & 6 & 3 & 7 & 3 & 3 & 8 & 3 & 2 \\
\hline & 0.7 & 0.6 & 0.9 & 1.1 & 0.8 & 0.8 & 0.7 & 0.8 & 1.0 & 0.9 & 0.9 & 0.9 \\
\hline \multirow[b]{3}{*}{ Chairs of Audit Committees } & 8 & 8 & 2 & 3 & 2 & 5 & 9 & 1 & 4 & 2 & 1 & 4 \\
\hline & 0.4 & 1.0 & 1.0 & 0.8 & 1.3 & 1.0 & 1.5 & 0.8 & 0.5 & 1.0 & 1.2 & 1.1 \\
\hline & 1 & 2 & 0 & 5 & 5 & 5 & 6 & 5 & 8 & 6 & 0 & 4 \\
\hline Local Government and Shires Association of New South & 0.7 & 1.1 & 0.9 & 0.7 & 0.7 & 1.0 & 0.0 & 0.8 & 1.0 & 1.3 & 0.0 & 0.0 \\
\hline \multirow[t]{2}{*}{ Wales } & 3 & 4 & 3 & 9 & 9 & 3 & 0 & 3 & 5 & 7 & 0 & 0 \\
\hline & 0.4 & 2.1 & 0.4 & 1.6 & 2.0 & 1.8 & 2.5 & 2.0 & 2.3 & 2.0 & 0.0 & 0.0 \\
\hline Municipal Association of Victoria & 7 & 8 & 7 & 6 & 6 & 7 & 0 & 6 & 5 & 6 & 0 & 0 \\
\hline
\end{tabular}

Notes: The mean and standard deviations in this table are the responses from mayors, chief executives and chairs of audit committees from a Likert 1 to 7 scale. 
Figure A7.2

Response rates - Victorian metropolitan and rural regional councils

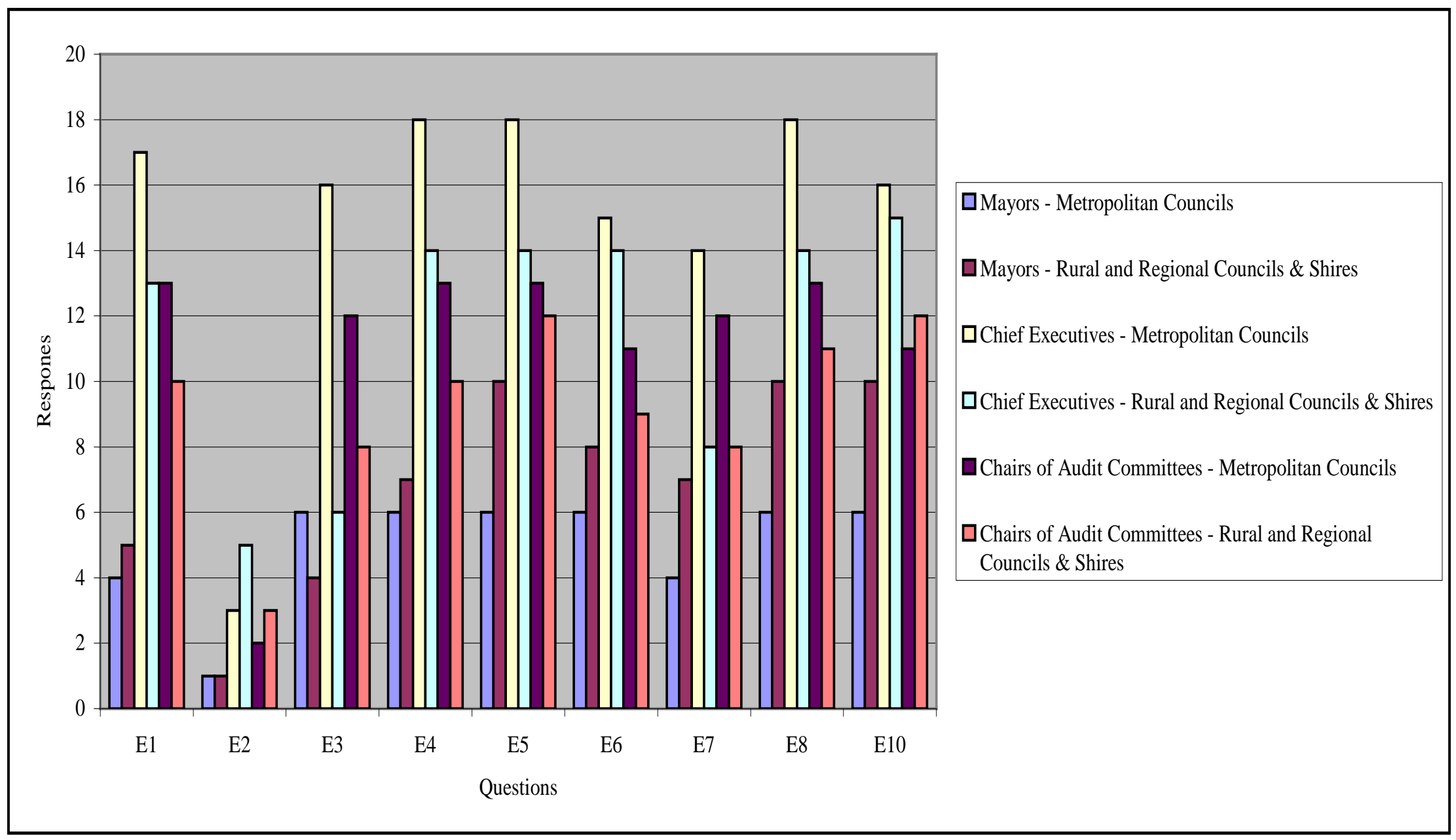

Source:

Results from the respondents. 
Table A7.15 Mean responses, questions D1-D12 - Victorian metropolitan and rural regional councils

\begin{tabular}{|c|c|c|c|c|c|c|c|c|c|c|c|c|}
\hline Questions & D1 & D2 & D3 & D4 & D5 & D6 & D7 & D8 & D9 & D10 & D11 & D12 \\
\hline Mayors - Metropolitan Councils & 7.00 & 6.50 & 6.00 & 5.40 & 6.83 & 5.83 & 5.00 & 6.50 & 6.33 & 6.00 & 5.67 & 7.00 \\
\hline Mayors - Rural and Regional Councils and Shires & 6.73 & 6.30 & 5.60 & 5.60 & 6.60 & 6.00 & 5.33 & 5.91 & 6.18 & 5.80 & 5.83 & 5.50 \\
\hline & & & & & & & & & & & & Note 1 \\
\hline Chief Executives - Metropolitan Councils & 6.67 & 6.44 & 5.85 & 5.89 & 6.07 & 6.06 & 6.00 & 6.29 & 6.44 & 6.24 & 6.43 & Nil \\
\hline Chief Executives - Rural and Regional Councils and Shires & 6.33 & 5.86 & 5.63 & 5.43 & 6.00 & 6.00 & 6.00 & 6.00 & 5.47 & 5.36 & 5.29 & 5.33 \\
\hline Chairs of Audit Committees - Metropolitan Councils & 6.85 & 6.17 & 6.09 & 6.75 & 6.92 & 6.58 & 5.73 & 6.50 & 6.67 & 6.00 & 5.86 & 6.60 \\
\hline Chairs of Audit Committees - Rural and Regional Councils and Shires & 6.70 & 6.00 & 5.75 & 5.92 & 5.50 & 5.67 & 6.40 & 5.73 & 6.33 & 5.58 & 4.33 & 5.20 \\
\hline
\end{tabular}

Notes: The mean and standard deviations in this table are the responses from mayors, chief executives and chairs of audit committees from a Likert 1 to 7 scale.

Note 1 There was no response from metropolitan chief executives to this question.

Table A7.16 Standard deviation responses, questions D1-D12 - Victorian metropolitan and rural regional councils

\begin{tabular}{|c|c|c|c|c|c|c|c|c|c|c|c|c|}
\hline Questions & D1 & D2 & D3 & D4 & D5 & D6 & D7 & D8 & D9 & D10 & D11 & D12 \\
\hline Mayors - Metropolitan Councils & 0.00 & 1.12 & 0.82 & 1.02 & 0.37 & 0.90 & 1.41 & 0.50 & 0.47 & 0.58 & 1.25 & 0.00 \\
\hline Mayors - Rural and Regional Councils and Shires & 0.45 & 0.64 & 1.02 & 1.43 & 0.49 & 0.77 & 0.47 & 0.90 & 0.83 & 0.87 & 1.07 & 0.50 \\
\hline & & & & & & & & & & & & $\begin{array}{c}\text { Note } \\
1\end{array}$ \\
\hline Chief Executives - Metropolitan Councils & 0.58 & 0.60 & 1.03 & 1.20 & 0.77 & 0.94 & 0.74 & 0.82 & 0.60 & 0.64 & 0.73 & Nil \\
\hline Chief Executives - Rural and Regional Councils and Shires & 2.28 & 2.30 & 1.96 & 2.45 & 2.02 & 2.19 & 1.82 & 2.20 & 2.40 & 2.28 & 1.51 & 0.94 \\
\hline Chairs of Audit Committees - Metropolitan Councils & 0.36 & 0.69 & 0.79 & 0.43 & 0.28 & 0.49 & 1.66 & 0.65 & 0.47 & 0.74 & 0.99 & 0.49 \\
\hline Chairs of Audit Committees - Rural and Regional Councils and Shires & 1.80 & 1.84 & 1.80 & 1.77 & 2.09 & 1.86 & 2.09 & 1.77 & 1.66 & 1.74 & 1.67 & 1.78 \\
\hline
\end{tabular}

Notes: The mean and standard deviations in this table are the responses from mayors, chief executives and chairs of audit committees from a Likert 1 to 7 scale.

Note 1 There was no response from metropolitan chief executives to this question. 
Table A7.17 Mean responses, questions E1-E10

\begin{tabular}{|l|c|c|c|c|c|c|c|c|c|c|}
\hline \multicolumn{1}{|c|}{ Questions } & E1 & E2 & E3 & E4 & E5 & E6 & E7 & E8 & E9 & E10 \\
\hline Mayors & 5.89 & 5.50 & 5.30 & 6.08 & 5.81 & 5.79 & 5.73 & 5.69 & 6.06 & 6.38 \\
\hline Chief Executives & 5.30 & 5.00 & 5.82 & 5.78 & 6.06 & 5.79 & 5.86 & 6.19 & 6.25 & 6.23 \\
\hline Chairs of Audit Committees & 5.61 & 5.00 & 5.30 & 6.13 & 5.96 & 6.05 & 5.95 & 6.33 & 6.04 & 6.30 \\
\hline $\begin{array}{l}\text { Local Government and Shires Association } \\
\text { of New South Wales }\end{array}$ & 4.60 & 3.50 & 5.43 & 6.00 & 4.86 & 6.00 & 5.00 & 6.11 & 5.44 & 6.43 \\
\hline Municipal Association of Victoria & 5.00 & 4.00 & 6.00 & 4.25 & 4.25 & 5.67 & 5.33 & 4.75 & 4.50 & 4.75 \\
\hline
\end{tabular}

Notes: The mean and standard deviations in this table are the responses from mayors, chief executives and chairs of audit committees from a Likert 1 to 7 scale.

Table A7.18 Standard deviation responses, questions E1-E10

\begin{tabular}{|l|c|c|c|c|c|c|c|c|c|c|}
\hline \multicolumn{1}{|c|}{ Questions } & E1 & E2 & E3 & E4 & E5 & E6 & E7 & E8 & E9 & E10 \\
\hline Mayors & 0.74 & 1.50 & 1.00 & 1.07 & 1.01 & 1.08 & 0.96 & 1.04 & 1.03 & 0.70 \\
\hline Chief Executives & 1.10 & 1.32 & 1.11 & 1.08 & 0.83 & 1.30 & 1.10 & 1.01 & 0.90 & 1.01 \\
\hline Chairs of Audit Committees & 1.17 & 1.67 & 1.58 & 0.99 & 0.87 & 1.12 & 0.86 & 0.90 & 0.92 & 0.86 \\
\hline $\begin{array}{l}\text { Local Government and Shires Association of } \\
\text { New South Wales }\end{array}$ & 1.02 & 1.12 & 1.68 & 0.63 & 1.64 & 0.82 & 0.00 & 0.99 & 1.57 & 0.49 \\
\hline Municipal Association of Victoria & 0.82 & 1.00 & 0.82 & 2.05 & 1.92 & 0.94 & 0.47 & 2.28 & 2.06 & 2.28 \\
\hline
\end{tabular}

Notes: The means and the standard deviations in this Table are the responses from the mayors, chief executives and the chairs of audit committees from a Likert 1 to 7 scale.

Table A7.19 Mean responses, questions E1-E10 - Victorian metropolitan and rural regional councils

\begin{tabular}{|l|c|c|c|c|c|c|c|c|c|c|}
\hline \multicolumn{1}{|c|}{ Questions } & E1 & E2 & E3 & E4 & E5 & E6 & E7 & E8 & E9 & E10 \\
\hline Mayors - Metropolitan Councils & 6.00 & 7.00 & 5.00 & 6.67 & 6.33 & 6.50 & 5.75 & 6.17 & 6.33 & 6.50 \\
\hline $\begin{array}{l}\text { Mayors - Rural and Regional } \\
\text { Councils and Shires }\end{array}$ & 5.80 & 4.00 & 5.75 & 5.57 & 5.50 & 5.25 & 5.71 & 5.40 & 5.90 & 6.30 \\
\hline Chief Executives - Metropolitan Councils & 5.53 & 5.00 & 5.88 & 6.22 & 6.22 & 5.93 & 6.21 & 6.56 & 6.44 & 6.63 \\
\hline $\begin{array}{l}\text { Chief Executives - Rural and Regional } \\
\text { Councils and Shires }\end{array}$ & 5.00 & 5.00 & 5.67 & 5.21 & 5.86 & 5.64 & 5.25 & 5.71 & 6.00 & 5.80 \\
\hline $\begin{array}{l}\text { Chairs of Audit Committees } \\
\text { Metropolitan Councils }\end{array}$ & 5.85 & 5.00 & 5.42 & 6.54 & 6.46 & 6.45 & 6.33 & 6.69 & 6.23 & 6.55 \\
\hline $\begin{array}{l}\text { Chairs of Audit Committees } \\
\text { Rural and Regional Councils and Shires }\end{array}$ & 5.30 & 5.00 & 5.13 & 5.60 & 5.42 & 5.56 & 5.38 & 5.91 & 5.83 & 6.08 \\
\hline
\end{tabular}

Notes: The mean and standard deviations in this table are the responses from mayors, chief executives and chairs of audit committees from a Likert 1 to 7 scale. 
Table A7.20

Standard deviation responses, questions E1-E10 Victorian metropolitan and rural regional councils

\begin{tabular}{|l|c|c|c|c|c|c|c|c|c|c|}
\hline \multicolumn{1}{|c|}{ Questions } & E1 & E2 & E3 & E4 & E5 & E6 & E7 & E8 & E9 & E10 \\
\hline Mayors - Metropolitan Councils & 0.71 & 0.00 & 0.58 & 0.47 & 0.47 & 0.50 & 1.09 & 1.07 & 0.94 & 0.50 \\
\hline $\begin{array}{l}\text { Mayors - Rural and Regional } \\
\text { Councils and Shires }\end{array}$ & 0.75 & 0.00 & 1.30 & 1.18 & 1.12 & 1.09 & 0.88 & 0.92 & 1.04 & 0.78 \\
\hline Chief Executives - Metropolitan Councils & 1.04 & 1.41 & 1.22 & 0.85 & 0.79 & 1.29 & 0.77 & 0.60 & 0.76 & 0.60 \\
\hline $\begin{array}{l}\text { Chief Executives - Rural and Regional } \\
\text { Councils and Shires }\end{array}$ & 2.40 & 1.60 & 2.46 & 2.45 & 2.34 & 2.19 & 2.18 & 2.41 & 2.35 & 2.16 \\
\hline $\begin{array}{l}\text { Chairs of Audit Committees } \\
\text { Metropolitan Councils }\end{array}$ & 1.10 & 2.00 & 1.71 & 0.63 & 0.50 & 0.66 & 0.62 & 0.61 & 0.70 & 0.66 \\
\hline $\begin{array}{l}\text { Chairs of Audit Committees } \\
\text { Rural and Regional Councils and Shires }\end{array}$ & 2.02 & 1.85 & 2.16 & 1.96 & 1.88 & 1.85 & 1.87 & 1.89 & 1.87 & 1.65 \\
\hline
\end{tabular}

Notes: The mean and standard deviations in this table are the responses from mayors, chief executives and chairs of audit committees from a Likert 1 to 7 scale. 


\section{Appendix 8 Qualitative research questions}

\section{i. Sources for qualitative research}

\begin{tabular}{|c|c|c|}
\hline Interviewee & Reference & Overview of the Council or Organisation \\
\hline Mayor A 2011 & $\begin{array}{l}\text { Section } 6.6 \text { in } \\
\text { Chapter } 6 .\end{array}$ & $\begin{array}{l}\text { This mayor was a member of the council's audit } \\
\text { committee in } 2009 \text { and } 2010 \text {. } \\
\text { This council was located in the outer northern } \\
\text { metropolitan suburbs of Melbourne. }\end{array}$ \\
\hline Councillor A 2011 & $\begin{array}{l}\text { Section } 6.6 \text { in } \\
\text { Chapter } 6 .\end{array}$ & $\begin{array}{l}\text { This councillor was a member of the council's audit } \\
\text { committee. } \\
\text { This metropolitan council was located } 13 \text { kilometres } \\
\text { east of the Melbourne central business district. }\end{array}$ \\
\hline Chief Executive A 2011 & $\begin{array}{l}\text { Section } 6.6 \text { in } \\
\text { Chapter } 6 .\end{array}$ & $\begin{array}{l}\text { This rural council was located about } 130 \text { kilometres } \\
\text { south-east of Melbourne and was predominantly a } \\
\text { coastal municipality. The two major industries are } \\
\text { tourism and agriculture. }\end{array}$ \\
\hline Chief Executive B 2011 & $\begin{array}{l}\text { Section } 6.6 \text { in } \\
\text { Chapter } 6 .\end{array}$ & $\begin{array}{l}\text { This metropolitan council was located to the south } \\
\text { east of Melbourne and it was the second largest } \\
\text { retail and commercial centre in the metropolitan } \\
\text { area. }\end{array}$ \\
\hline Corporate Service Director A 2010 & $\begin{array}{l}\text { Section } 6.6 \text { in } \\
\text { Chapter } 6 .\end{array}$ & $\begin{array}{l}\text { This interviewee was the delegate of the chief } \\
\text { executive. } \\
\text { This rural council was located } 120 \text { kilometres north } \\
\text { west of Melbourne and has a strong manufacturing } \\
\text { and engineering base. }\end{array}$ \\
\hline Corporate Service Director B 2011 & $\begin{array}{l}\text { Section } 6.6 \text { in } \\
\text { Chapter } 6 .\end{array}$ & $\begin{array}{l}\text { This interviewee was the delegate of the chief } \\
\text { executive. } \\
\text { This council was situated in the outer eastern } \\
\text { metropolitan area. The council has a large residential } \\
\text { population base, with local employment in business, } \\
\text { retail, chemical product manufacturing and food } \\
\text { manufacturing. }\end{array}$ \\
\hline
\end{tabular}




\begin{tabular}{|c|c|c|}
\hline Interviewee & Reference & Overview of the Council or Organisation \\
\hline Auditor A 2011 & $\begin{array}{l}\text { Section } 6.6 \text { in } \\
\text { Chapter } 6 .\end{array}$ & $\begin{array}{l}\text { The auditor was delegated to be interviewed on } \\
\text { behalf of the chief executive. } \\
\text { This shire council was located to the south east } \\
\text { of Melbourne was a mixture of urban areas, } \\
\text { resort towns, tourist development and rural } \\
\text { land. }\end{array}$ \\
\hline Audit Committee Chair A 2010 & $\begin{array}{l}\text { Section } 6.6 \text { in } \\
\text { Chapter } 6 .\end{array}$ & $\begin{array}{l}\text { This audit committee member currently serves } \\
\text { on two local government audit committee. He } \\
\text { previously served as chair on another three } \\
\text { local government audit committees. } \\
\text { He has extensive private sector audit and risk } \\
\text { experience and was an acknowledged expert in } \\
\text { the areas of information technology auditing. }\end{array}$ \\
\hline Audit Committee Chair B 2010 & $\begin{array}{l}\text { Section } 6.6 \text { in } \\
\text { Chapter } 6 .\end{array}$ & $\begin{array}{l}\text { This audit committee chair has extensive } \\
\text { financial and business advisory experience in } \\
\text { the financial services sector. He has been an } \\
\text { audit committee member in local government } \\
\text { for some years and was also a council member } \\
\text { of a university. }\end{array}$ \\
\hline Audit Committee Chair C 2011 & $\begin{array}{l}\text { Section } 6.6 \text { in } \\
\text { Chapter } 6 .\end{array}$ & $\begin{array}{l}\text { This audit committee member concurrently } \\
\text { serves on six local government audit } \\
\text { committees. } \\
\text { He has extensive public sector audit and risk } \\
\text { experience. }\end{array}$ \\
\hline
\end{tabular}

\section{ii. Qualitative research questions}

The objective of the qualitative research is to explore some of the possible reasons for the response rate to the questions from the quantitative research in the following table and the relevance of those questions for your council and audit committee. I would like to discuss with you the following questions:

i. From your perspective, was the question a relevant issue for your council's audit committee?

If yes, why?

If no, why not?

ii. What could be the contributing reasons for the low response rate to each of the questions in Table 1 and the accompanying low means and standard deviations?

iii. Do you consider that the council's ethical statements or the council's codes of conduct contribute to an environment which mitigates the council's risks and as such, contributes towards the effectiveness of the council's audit committee? 
If yes, why?

If no, why not?

iv. Do you consider that audit committee members are influenced by the views of mayors, chief executives and chairs of audit committees?

If yes, why?

If no, why not?

\section{General questions}

v. What do you consider to be the contributing factors for a successful audit committee in local government?

vi. What are the improvement opportunities for your council's audit committee?

vii. What are the practices at your audit committee, which you consider are being managed well?

viii. Is there anything else about your council's audit committee practices or processes, which you think are important or should be changed? 
Table A8.1 Outcomes from quantitative research

\begin{tabular}{|c|c|c|c|c|}
\hline Questions & $\begin{array}{c}\text { Sample } \\
\text { (n) }\end{array}$ & $\begin{array}{l}\text { Number of } \\
\text { Responses }\end{array}$ & Mean & $\begin{array}{l}\text { Standard } \\
\text { Deviation }\end{array}$ \\
\hline $\begin{array}{l}\text { Question C2 } \\
\text { Are audit committee members assisted by the council/shire to } \\
\text { periodically update their knowledge of local government activities } \\
\text { and risks? }\end{array}$ & 89 & 67 & 4.81 & 1.04 \\
\hline $\begin{array}{l}\text { Question C4 } \\
\text { Does the audit committee periodically visit the council's/shire's sites } \\
\text { and receive briefings from key officers? }\end{array}$ & 89 & 42 & 4.96 & 1.11 \\
\hline \multicolumn{5}{|l|}{ E. Managing the Audit Committee } \\
\hline $\begin{array}{l}\text { Question D3 } \\
\text { Does the audit committee have any extraordinary sessions to consider } \\
\text { important issues? }\end{array}$ & 89 & 58 & 5.63 & 0.86 \\
\hline $\begin{array}{l}\text { Question D7 } \\
\text { Do the audit committee members meet at least annually outside of } \\
\text { the audit committee with the council? }\end{array}$ & 89 & 41 & 5.12 & 1.18 \\
\hline $\begin{array}{l}\text { Question D11 } \\
\text { Does the audit committee directly receive communications from the } \\
\text { stakeholders of the council/shire regarding any allegations of } \\
\text { misconduct or corruption or matters of concern which they may have } \\
\text { with the council/shire? }\end{array}$ & 89 & 35 & 5.41 & 0.65 \\
\hline $\begin{array}{l}\text { Question D } 12 \\
\text { Does the audit committee review all whistleblower allegations and } \\
\text { oversee their investigation? }\end{array}$ & 89 & 18 & 5.65 & 0.58 \\
\hline \multicolumn{5}{|l|}{ E. Risk Assessment and Financial Reporting } \\
\hline $\begin{array}{l}\text { Question E3 } \\
\text { Are local government investigation reports from other council/shires } \\
\text { reviewed against the current management practices and processes in } \\
\text { your council/shire? }\end{array}$ & 89 & 62 & 5.57 & 1.24 \\
\hline $\begin{array}{l}\text { Question E7 } \\
\text { Does the audit committee review all unrecorded audit adjustments (if } \\
\text { any reported) with management and the external auditors and } \\
\text { understand why they were not recorded and reported? }\end{array}$ & 89 & 57 & 5.57 & 0.68 \\
\hline
\end{tabular}

